Universidad de Salamanca

Departamento de Derecho Administrativo,

Financiero y Procesal

Área de Derecho Financiero y Tributario

\title{
LA PROPIEDAD INTELECTUAL \\ EN EL DERECHO TRIBUTARIO CHILENO Y ESPAÑOL. \\ UN ESTUDIO COMPARADO
}

Marco Antonio Arellano Quiroz 



\section{ÍNDICE}

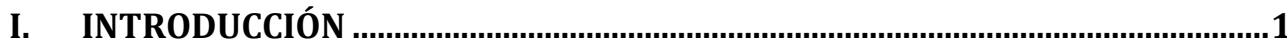

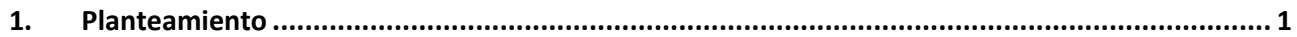

2. Metodología y orden de la exposición ..................................................................................... 4

\section{LA PROPIEDAD INTELECTUAL COMO PRESUPUESTO NECESARIO PARA EL} ESTUDIO DE SU TRIBUTACIÓN

\section{.. .9}

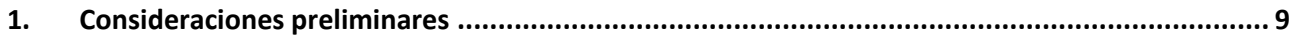

1.1. Evolución del concepto en la legislación positiva ........................................................... 9

1.2. Opciones para dar contenido a la propiedad intelectual, el modelo de OMPI .................... 17

2. Teorías sobre la naturaleza jurídica de la propiedad intelectual............................................. 23

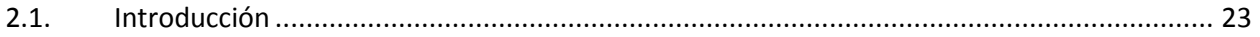

2.2. La propiedad intelectual antes de ser un privilegio ........................................................... 24

2.3. La propiedad intelectual como un privilegio ....................................................................... 26

2.4. La propiedad intelectual como propiedad ....................................................................... 30

2.4.1. Críticas a la concepción de la propiedad intelectual como propiedad ............................ 32

2.4.2. La propiedad intelectual como una propiedad especial ................................................. 33

2.5. Ausencia de derechos subjetivos en la propiedad intelectual ........................................... 34

2.6. Derecho subjetivo que protege la expresión de una idea y no la idea ................................ 35

2.7. La propiedad intelectual como derecho sobre bienes inmateriales .................................... 38

2.8. La propiedad intelectual como monopolio ................................................................. 40

2.9. La propiedad intelectual como un derecho autónomo. De los bienes intelectuales ............. 43

2.10. La propiedad intelectual como derecho de la personalidad ............................................... 44

2.10.1. La propiedad intelectual como derecho de la personalidad por OTTO GIERKE ............ 46

2.10.2. La propiedad intelectual como gestión de negocios ............................................... 47

2.10.3. La propiedad intelectual como prestación de un servicio o contrato de cambio ......... 48

2.10.4. Críticas a las teorías de la propiedad intelectual como derivada de la personalidad ... 49

2.11. La propiedad intelectual la tesis monista y dualista ......................................................... 50

2.11.1. La propiedad intelectual la tesis monista .............................................................. 52

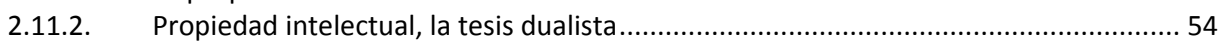

2.12. Propiedad intelectual, la postura monista pos dualista..................................................... 54

2.13. La propiedad intelectual como derecho humano ............................................................ 55

2.13.1. La propiedad intelectual como derecho humano en el contexto internacional ........... 58

2.13.2. La Observación General N 17 (2005) del Comité de Derechos Económicos, Sociales y

Culturales 61

2.13.3. La propiedad intelectual como derecho humano, nuestra opinión ............................64 64

2.14. La propiedad intelectual desde el análisis económico del derecho ..................................... 65

2.14.1. La eficiencia económica y el derecho de propiedad................................................ 68

2.14.2. La relación entre investigación, innovación y desarrollo como bases del desarrollo

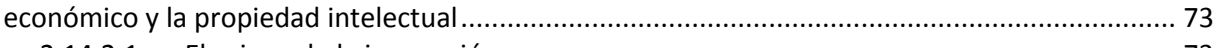

2.14.2.1. El origen de la innovación................................................................................ 73

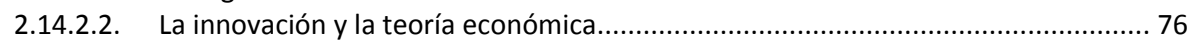

II.2.14.2.2.1 Primeras acepciones sobre la innovación .................................................. 79

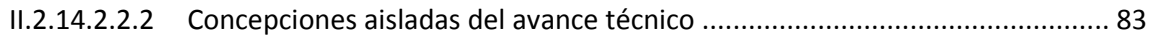

II.2.14.2.2.3 Los sistemas de innovación institucionales ................................................ 91

II.2.14.2.2.4 Últimas concepciones del avance técnico ................................................ 101

2.14.2.3. Nuestra opinión sobre el análisis económico del derecho ................................... 103 
3.1. La propiedad intelectual está en su integridad contenida en el Art. 20. 1. b) de la

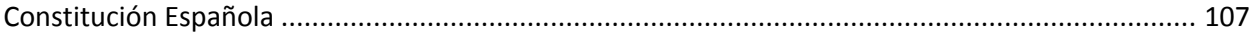

3.2. La propiedad intelectual está contenida en el Art. 33 de la CE........................................... 108

3.3. La propiedad intelectual está contenida parcialmente en el Art. 20. 1. b) y en el Art. 33 de la

CE $\quad 110$

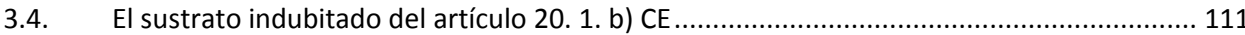

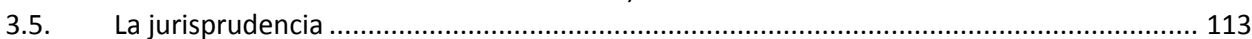

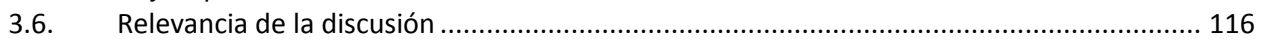

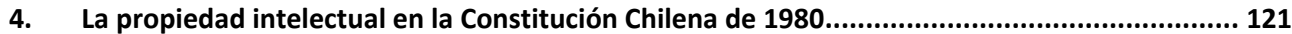

4.1. Breve resumen de la historia constitucional de Chile ..................................................... 121

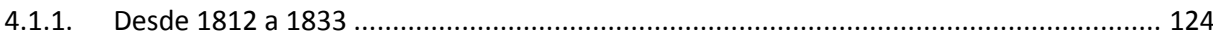

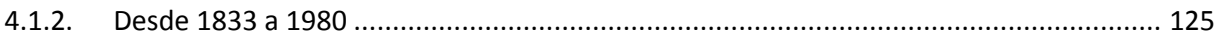

4.2. Naturaleza jurídica de la propiedad intelectual durante la historia constitucional de Chile

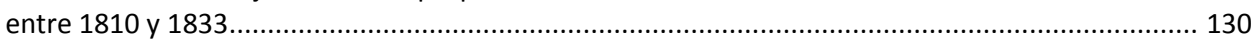
4.3. Naturaleza jurídica de la propiedad intelectual durante la historia constitucional de Chile

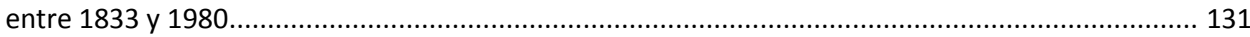

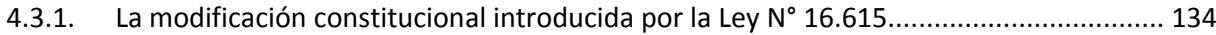

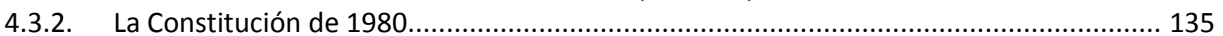

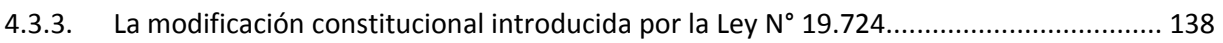

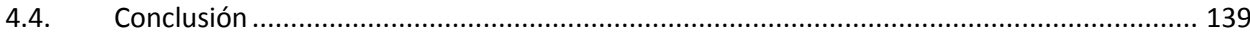

\section{TRIBUTACIÓN DE LA PROPIEDAD INTELECTUAL EN ESPAÑA Y CHILE 142}

1. La propiedad intelectual en la imposición directa e indirecta. Delimitación del objeto de estudio 142

2. En el ámbito español. 143

2.1. El Impuesto sobre Sociedades. Notas generales ........................................................ 144

2.2. La propiedad intelectual en el Impuesto sobre Sociedades............................................... 149

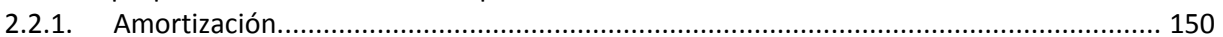

2.2.2. Amortización en la Ley del Impuesto sobre Sociedades ............................................ 154

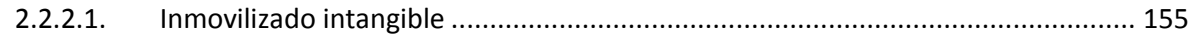

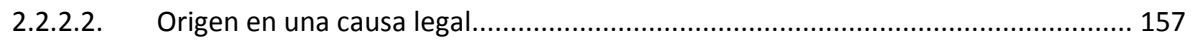

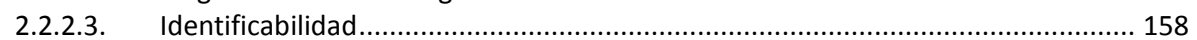

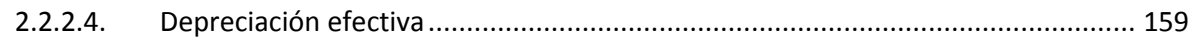

2.2.2.5. Demás requisitos establecidos en el reglamento .............................................. 161

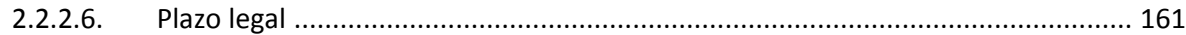

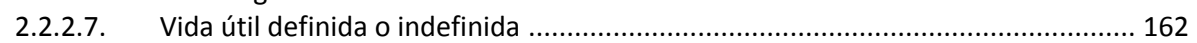

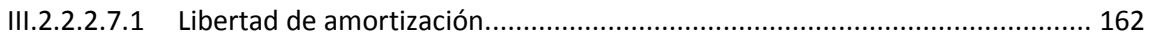

III.2.2.2.7.2 Amortización del inmovilizado intangible con vida útil definida ................... 163

2.2.2.8. Relación de la propiedad intelectual y la amortización de los gastos de I+D y del

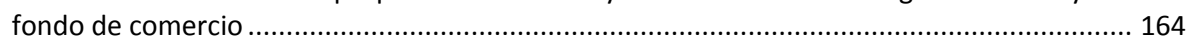

2.2.3. La propiedad intelectual como pérdida en el impuesto sobre sociedades ..................... 166

2.2.4. Reducción de ingresos procedentes de determinados derechos de propiedad intelectual.

El llamado Patent Box

2.2.4.1 Descripción del beneficio

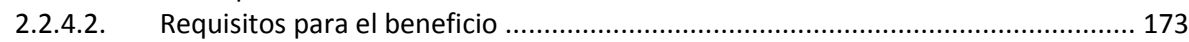

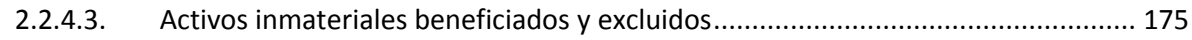

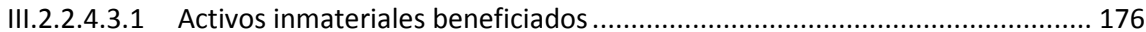

III.2.2.4.3.2 Activos inmateriales excluidos ................................................................. 185

2.2.4.4. Límite de la deducción por doble imposición internacional .................................. 186

2.2.4.5. Entidades en consolidación fiscal ................................................................. 187

2.2.5. La modificación del Impuesto sobre Sociedades de la Ley 35/2006 .............................. 187 
2.2.6. Bonificación por actividades exportadoras y de prestación de servicios públicos locales 189

2.2.6.1.

Rentas beneficiadas....

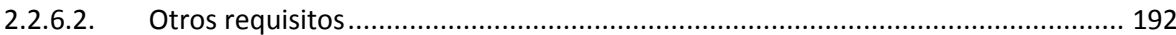

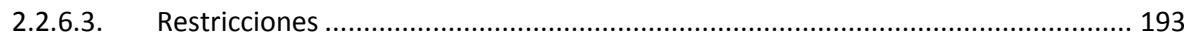

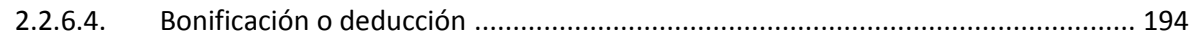

2.2.7. Deducción por actividades de investigación, desarrollo e innovación ........................... 195

2.2.7.1. Tributación de la investigación, desarrollo e innovación en general ...................... 195 III.2.2.7.1.1 Algunas consideraciones generales sobre la tributación de la investigación, desarrollo e innovación en el contexto internacional como antecedente para entender la deducción por este concepto

III.2.2.7.1.1.1 Depreciación de las expensas que no son capital en I+D+i ...................... 202

III.2.2.7.1.1.2 Depreciación de las expensas invertidas en bienes de capital para I+D+i 204

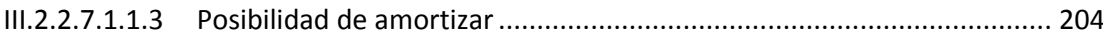

III.2.2.7.1.1.4 Existencia de un beneficio tributario expreso.......................................... 205

2.2.7.2. Una cuestión de denominación ...................................................................... 210

2.2.7.3. La I+D y la innovación científica y tecnológica.................................................... 214

2.2.7.4. Deducción por actividades de investigación, desarrollo e innovación en el art. 35

TRLIS $\quad 215$

III.2.2.7.4.1 Introducción

III.2.2.7.4.2 Historia de la deducción por actividades de investigación, desarrollo e

innovación 216

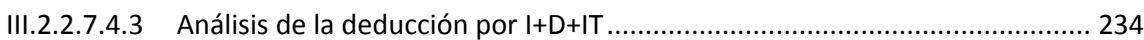

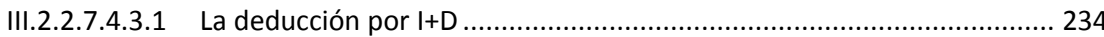

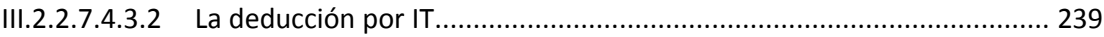

III.2.2.7.4.3.3 Cuestiones comunes a la deducción por I+D+IT..................................... 241

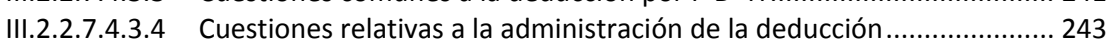

2.2.8. Deducción por producciones cinematográficas y producción de libros .......................... 245

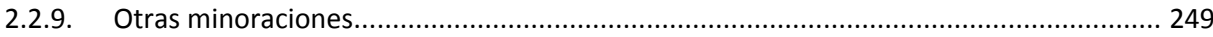

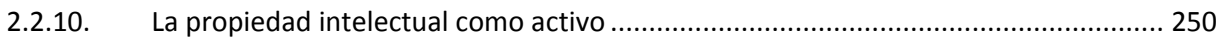

2.3. La propiedad intelectual en el Impuesto sobre la Renta de las Personas Físicas .................. 251

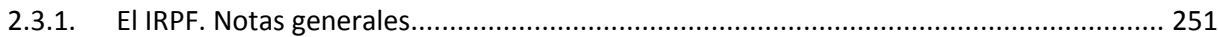

2.3.2. La propiedad intelectual como rendimiento del trabajo ............................................. 254

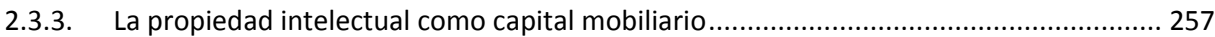

2.3.4. La propiedad intelectual como rendimiento de actividades económicas ....................... 260

2.4. La propiedad intelectual en el IVA ................................................................................... 261

2.4.1. El hecho imponible del IVA y la propiedad intelectual............................................... 261

2.4.2. Exenciones en favor de la propiedad intelectual propiamente tal................................ 264

2.4.3. El curioso artículo 50 de la Ley del IVA ....................................................................... 268

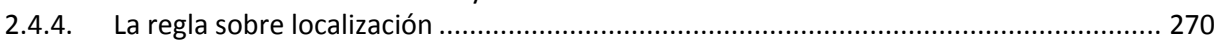

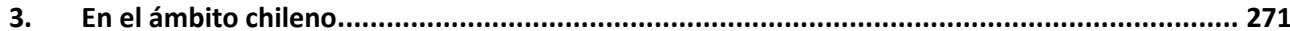

3.1. Decreto Ley $\mathrm{N}^{\circ} 824$, Ley de Impuesto a la Renta ............................................................ 272

3.1.1. Ingresos renta y no renta en el DL No 824............................................................ 273

3.1.2. El régimen de tributación especial de la propiedad intelectual hasta septiembre de 2014

274

3.1.2.1. Enajenación como verbo rector del régimen especial de la propiedad intelectual 276

3.1.2.2. Cuatro formas de tributar de la propiedad intelectual en el art. 17 de la Ley de la

Renta $\quad 277$

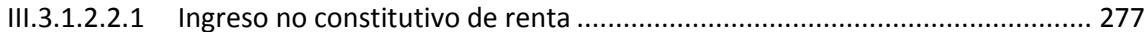

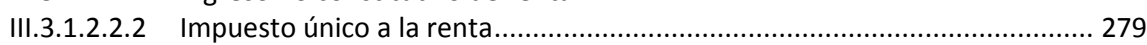

III.3.1.2.2.3 Renta del trabajo............................................................................... 280

III.3.1.2.2.4 Quien recibe las rentas es el autor o creador empresario unipersonal o empresa 280

3.1.2.3. Otras particularidades del régimen previsto en el art. 17 de la Ley de la Renta.... 281

III.3.1.2.3.1 Habitualidad. 281 


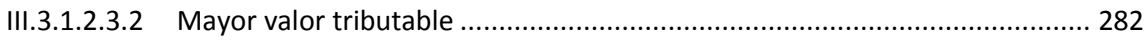

III.3.1.2.3.3 Resumen ................................................................................................ 282

3.1.3. El régimen de tributación especial de la propiedad intelectual desde septiembre de 2014 283

3.1.3.1. Enajenación como verbo rector del régimen especial de la propiedad intelectual 284

3.1.3.2. Tres formas de tributar de la propiedad intelectual en el art. 17 de la Ley de la

Renta 284

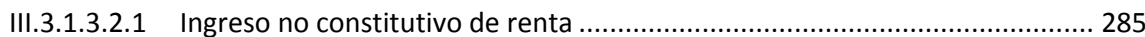

III.3.1.3.2.2 Desaparecimiento del impuesto único a la renta ........................................... 285

III.3.1.3.2.3 Régimen normal de tributación.............................................................. 286

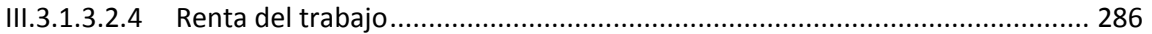

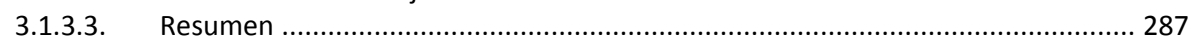

3.1.4. El régimen normal de tributación y la propiedad intelectual ....................................... 287

3.1.4.1. Localización ............................................................................................. 288

3.1.4.2. Gastos necesarios para producir la renta .......................................................... 288

III.3.1.4.2.1 Desembolsos en que ha incurrido la empresa en la investigación científica y tecnológica 289

III.3.1.4.2.2 Desembolsos consistentes en pagos por el uso o transferencia en Chile y en el extranjero 295

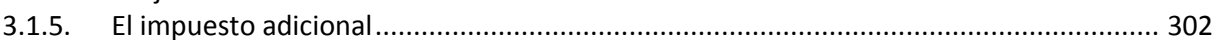

3.1.5.1. El hecho gravado con impuesto adicional ........................................................... 303

3.1.5.2. La propiedad intelectual como objeto del hecho gravado del art. 59 .................. 304

3.1.5.3. Indefinición sobre titularidad, dominio o derecho sobre los derechos de propiedad

intelectual 306

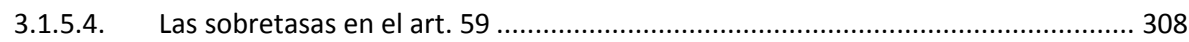

3.1.5.5. Retención y pago del impuesto ...................................................................... 309

3.1.5.6. El rol de las asesorías y el art. 59 ..................................................................... 310

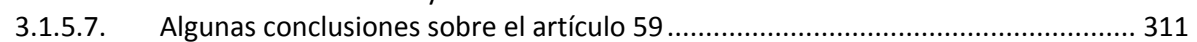

III.3.1.5.7.1 Confusión del Art. 59 al hablar de patentes .................................................. 311

III.3.1.5.7.2 Redundancia del art. 59 al hablar de derechos de edición ........................... 313

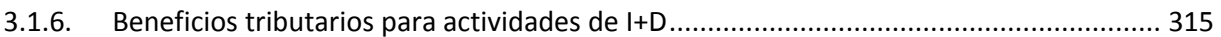

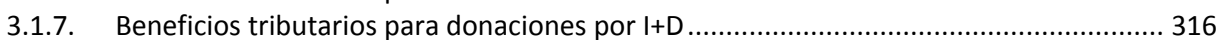

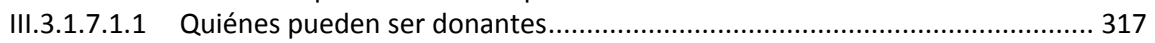

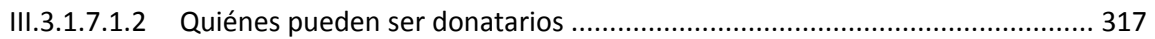

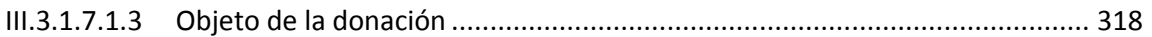

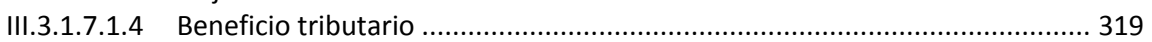

III.3.1.7.1.5 Propiedad intelectual .............................................................................. 319

3.1.7.2. Beneficios tributarios para inversión privada en I+D ......................................... 320

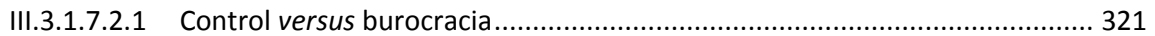

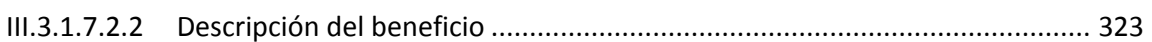

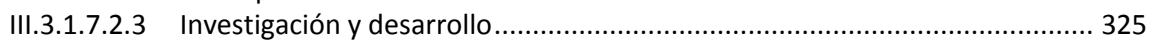

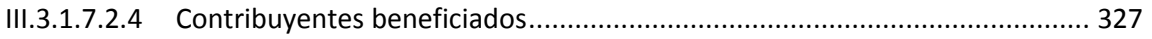

III.3.1.7.2.5 Conformación del beneficio .................................................................... 328

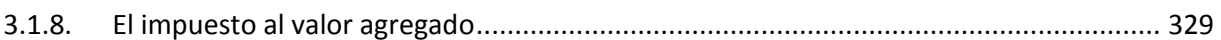

3.1.9. Necesidad de registro de la propiedad intelectual para fines impositivos ...................... 331

IV. VINCULACIÓN ENTRE ESPAÑA Y CHILE. ESPECIAL REFERENCIA AL ARTÍCULO XII DEL MODELO DE CONVENIO DE DOBLE IMPOSICIÓN DE LA OCDE 336

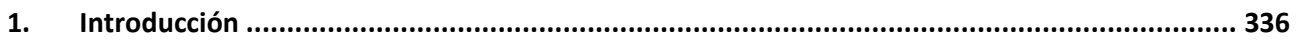

2. Ejemplo sobre alternativas de tributación de una licencia en Chile y España.......................... 337

2.1. Contribuyente residente fiscal en España ...................................................................... 338

2.1.1. Otorga licencias como persona natural ....................................................................... 338

2.1.2. Otorga licencias como sociedad de responsabilidad limitada.................................... 342 


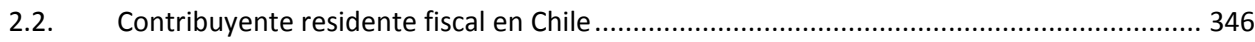

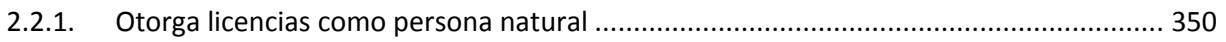

2.2.2. Otorga licencias como sociedad de responsabilidad limitada ...................................... 355

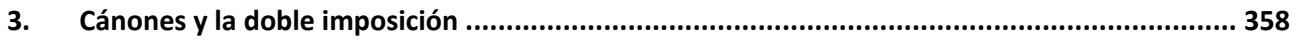

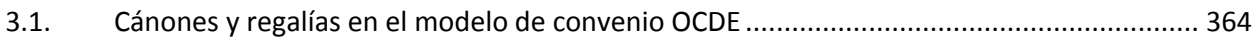

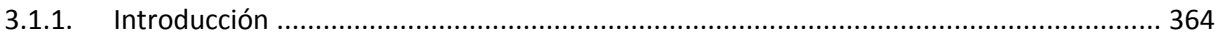

3.1.2. Armonización entre la definición de canon del Estado de la fuente y el convenio .......... 365

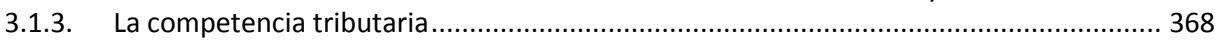

3.1.4. Cánones y su relación con otras rentas en los MC ..................................................... 369

3.1.4.1. Rentas del artículo 6 del MC OCDE. Rentas de inmuebles................................... 370

3.1.4.2. Rentas de los artículos 7, 10 y 11 del MC OCDE. Establecimiento permanente,

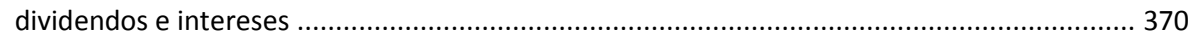

3.1.4.3. Rentas del artículo 13. Ganancias de capital .................................................... 371

3.1.4.4. Rentas del artículo 15 MC OCDE. Rentas del trabajo.......................................... 372

3.1.4.5. Artículo 17 del MC OCDE. Artistas y deportistas ................................................... 373

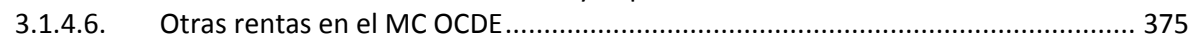

3.1.5. Análisis del concepto de canon o regalía ............................................................... 376

3.1.6. Elementos característicos de la definición del artículo 12.2 MC OCDE ........................... 378

3.1.7. Derechos y bienes específicos de la definición de regalía ............................................. 380

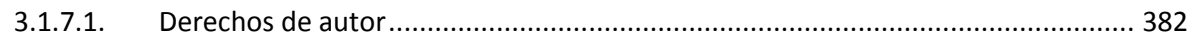

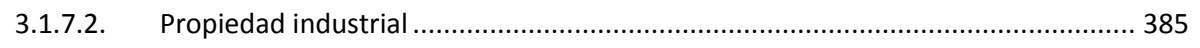

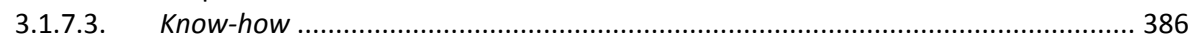

3.1.7.4. Equipos industriales, comerciales y científicos ................................................ 390

3.1.7.5. Prestaciones de servicios de asistencia técnica .................................................. 391

3.1.7.6. Supuestos confusos o de difícil calificación ...................................................... 392

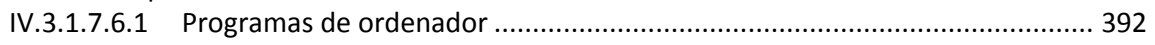

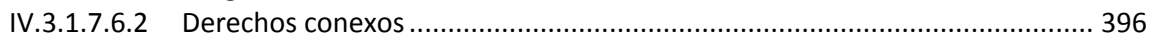

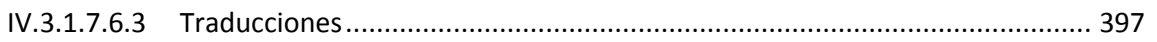

IV.3.1.7.6.4 Emisiones de televisión, imágenes, noticias y programas en general ............ 398

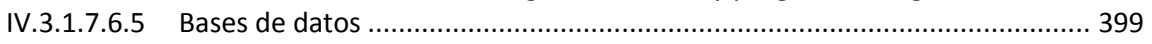

IV.3.1.7.6.6 Diseños, modelos, dibujos industriales, topografías de circuitos integrados y

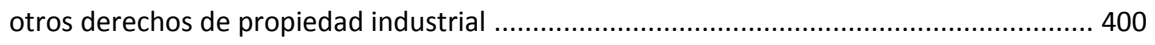

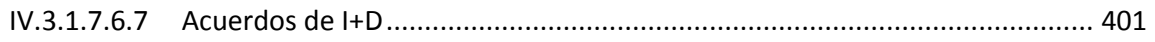

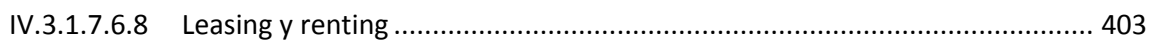

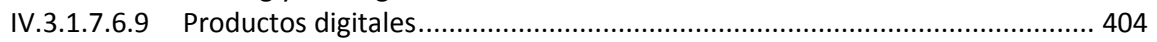

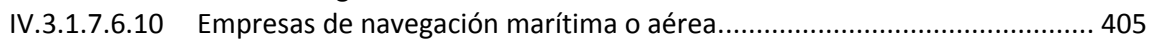

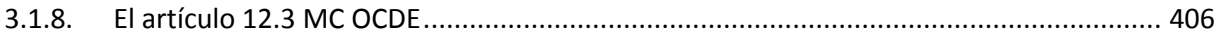

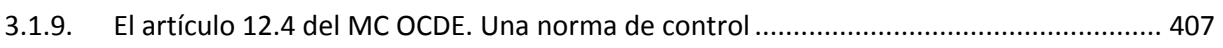

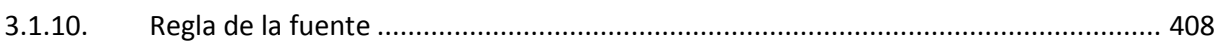

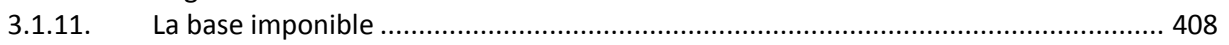

3.1.12. Los Ilamados cánones culturales ......................................................................... 409

3.1.13. El rol de la cláusula de nación más favorecida ...................................................... 410

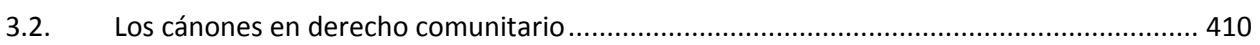

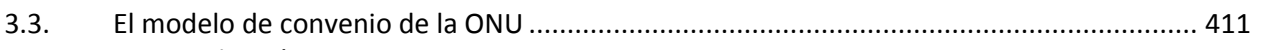

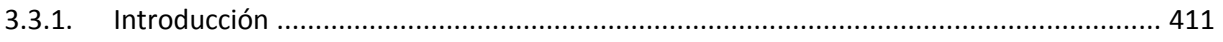

3.3.2. Principales diferencias entre el MC ONU y OCDE ....................................................... 413

3.3.3. Diferencias específicas en el tratamiento de los cánones entre el MC ONU y OCDE ...... 414

3.4. Cuadro comparativo entre los modelos ONU y OCDE versus el convenio España-Chile...... 416

3.5. El convenio de doble imposición entre España y Chile ................................................... 419

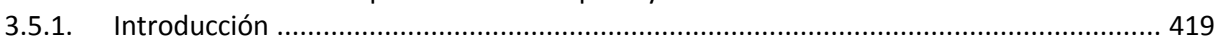

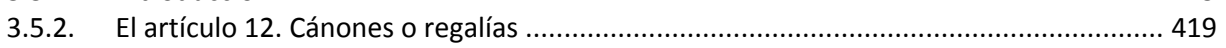

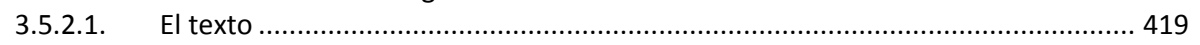

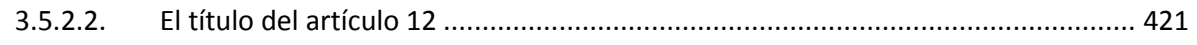

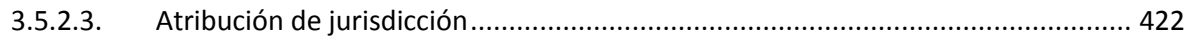

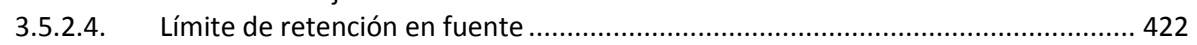

3.5.2.5. Bienes y derechos específicos en la definición de cánones o regalías ................... 423 


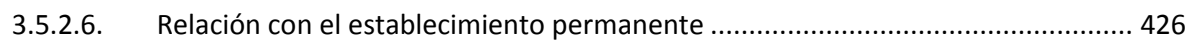

3.5.2.7. Determinación del Estado de procedencia ...................................................... 427

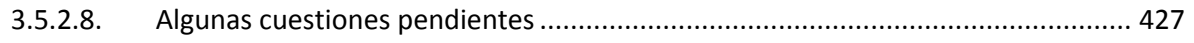

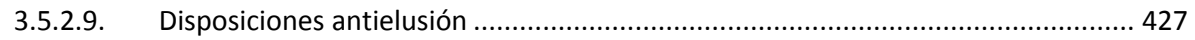

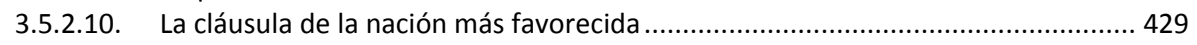

V. CONCLUSIONES ............................................................................................430

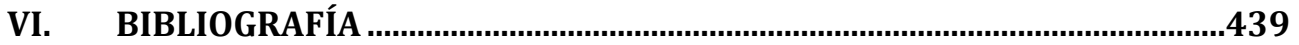




\section{ABREVIATURAS}

\begin{tabular}{|c|c|}
\hline ADPIC & $\begin{array}{l}\text { Acuerdo sobre los Aspectos de los Derechos de Propiedad Intelectual Relacionados } \\
\text { con el Comercio. Corresponde al Anexo 1C del Acuerdo de Marrakech por el que } \\
\text { se establece la Organización Mundial del Comercio }\end{array}$ \\
\hline ANBPI & Association des Bureaux pour la Protection de la Propriété Industrielle \\
\hline $\mathrm{BOE}$ & Boletín Oficial del Estado \\
\hline CDI & Convenio de doble imposición \\
\hline CE & Constitución Española \\
\hline cit. & citada \\
\hline $\mathrm{COB}$ & Convenio de Berna para la Protección de las Obras Literarias y Artísticas \\
\hline $\mathrm{CPR}$ & Constitución Política de la República \\
\hline CUP & Convenio de París para la Protección de la Propiedad Industrial \\
\hline CVDT & Convención de Viena sobre Derecho de los Tratados \\
\hline DGT & Dirección General de Tributos \\
\hline DL & Decreto Ley \\
\hline DUDH & Declaración Universal de Derechos Humanos de 1948 \\
\hline ECOSOC & Departamento de Asuntos Económicos y Sociales de las Naciones Unidas \\
\hline EP & Establecimiento permanente \\
\hline $\mathrm{I}+\mathrm{D}$ & Innovación y desarrollo \\
\hline $\mathrm{I}+\mathrm{D}+\mathrm{IT}$ & Innovación, desarrollo e innovación tecnológica \\
\hline INAPI & Instituto Nacional de la Propiedad Industrial \\
\hline IRNR & Impuesto a la Renta de no Residentes \\
\hline IRPF & Impuesto sobre la Renta de las Personas Físicas \\
\hline IS & Impuesto sobre Sociedades \\
\hline IT & Innovación tecnológica \\
\hline IVA & Impuesto al Valor Añadido (España) \\
\hline IVA & Impuesto al Valor Agregado (Chile) \\
\hline LGT & Ley General Tributaria \\
\hline LIR & Ley de Impuesto a la Renta \\
\hline LIRNR & Ley de Impuesto a la Renta de no Residentes \\
\hline LIS & Ley de Impuesto sobre Sociedades \\
\hline LIVA & Ley del Impuesto al Valor Añadido \\
\hline LMF & Ley de Medidas Fiscales \\
\hline LP & Ley de Patentes \\
\hline LPI & Ley de Propiedad Intelectual \\
\hline LPJDFP & Ley de Protección Jurisdiccional de los Derechos Fundamentales de las Personas \\
\hline LPJDI & Protección Jurídica del Diseño Industrial \\
\hline LPJTPS & Ley de Protección Jurídica de las Topografías de los Productos Semiconductores \\
\hline $\mathrm{MC}$ & Modelo de convenio \\
\hline MC OCDE & Modelo de Convenio Tributario sobre la Renta y el Patrimonio de la OCDE \\
\hline MC ONU & Modelo de Convenio ONU \\
\hline NMF & Nación más favorecida \\
\hline Ob. & Obra \\
\hline
\end{tabular}




\begin{tabular}{|l|l|}
\hline OCDE & Organización para la Cooperación y el Desarrollo \\
\hline OEPM & Oficina Española de Patentes y Marcas \\
\hline OEPM & Oficina Española de Patentes y Marcas \\
\hline OMC & Organización Mundial del Comercio \\
\hline OMPI & Organización Mundial de la Propiedad Intelectual \\
\hline ONU & Organización de las Naciones Unidas \\
\hline p. & Página \\
\hline PGC & Plan General de Contabilidad \\
\hline pp. & Páginas \\
\hline RDL & Real Decreto Legislativo \\
\hline RIS & Reglamento del Impuesto sobre Sociedades \\
\hline SII & Servicio de Impuestos Internos \\
\hline SRL & Sociedad de Responsabilidad Limitada \\
\hline supra & arriba \\
\hline TC & Tribunal Constitucional \\
\hline TLC & Tratado de libre comercio \\
\hline TRIPS & $\begin{array}{l}\text { Trade-Related Aspects of Intellectual Property Rights es el Anexo 1C del Acuerdo } \\
\text { de Marrakech por el que se establece la Organización Mundial del Comercio. } \\
\text { ADPIC por sus siglas en español. }\end{array}$ \\
\hline TRLIRNR & Texto refundido de la Ley de Impuesto a la Renta de no Residentes \\
\hline TRLIS & Texto refundido de la Ley de Impuesto sobre Sociedades \\
\hline
\end{tabular}




\section{INTRODUCCIÓN}

\section{Planteamiento}

Si analizamos la historia del conocimiento, "podemos ver que los dos últimos siglos representan el cincuenta por ciento de todo el avance del conocimiento en la historia de la humanidad (...) el crecimiento es sorprendente y nos podemos cuestionar si seremos capaces de asimilar la velocidad de nuestra propia evolución”" Es un hecho que no requiere prueba, que nunca en la historia de la humanidad se había acumulado tanto conocimiento. Si no podemos estar de acuerdo en el hecho que en los últimos doscientos años se ha producido más conocimiento que en todo el resto de la humanidad, sí tendremos que estarlo, en que este conocimiento ha sido usado principalmente en beneficio del hombre y que se traduce en gran parte, en lo que abstractamente conocemos como "ciencia y tecnología".

La RAE$^{2}$ entiende por ciencia el "Conjunto de conocimientos obtenidos mediante la observación y el razonamiento, sistemáticamente estructurados y de los que se deducen principios y leyes generales"; y, por tecnología el "Conjunto de teorías y de técnicas que permiten el aprovechamiento práctico del conocimiento científico".

Bajo estos conceptos, ciencia y tecnología dicen relación con una serie de conocimientos que tienen por objeto el mejor comprender de la realidad y el aprovechamiento práctico del conocimiento científico. Por cierto, que se trata de conocimientos que otorgan una ventaja que reporta beneficios económicos o técnicamente hablando "bienestar". La posibilidad de atribuirse este bienestar en términos personales o de rentabilizar sus beneficios, permitiendo la explotación de la tecnología por un tercero, revela en términos económicos, la presencia de un mercado para esa tecnología y en términos jurídicos, la existencia de un "bien".

Jurídicamente, bienes son aquellas cosas que prestan una utilidad al hombre y son susceptibles de apropiación. Las cosas entendidas como "[t]odo lo que tiene entidad, ya sea corporal o espiritual, natural o artificial, real o abstracta", , no son relevantes para el derecho, sino en cuanto se vuelven bienes.

\footnotetext{
1 Tall \& Cute Wordpress, citado en Curiosidades y Errores Históricos. www.erroreshistoricos.com/curiosidades-historicas/ciencia/621--evolucion-del-conocimiento-humanodurante-los-ultimos-30000-anos.html (14 Feb 2010).

2 RAE. Real Academia Española.

3 Definición de la RAE.
} 
El conocimiento generado por la ciencia, tecnología y artes, sin duda es una "cosa", de la misma manera, es también un "bien", puesto que presta utilidad al hombre y es susceptible de apropiación privada. Este conocimiento es altamente apreciado en la sociedad moderna, precisamente por su capacidad de producir bienestar, por ello, los países de una u otra forma buscan la manera de protegerlo, a través de diferentes leyes, como propiedad intelectual, copyright u otras. Además, lógicamente, buscan la forma de producirlo. Estos logros se alcanzan por medio de lo que conocemos como "innovación y desarrollo", "factor clave para aumentar la capacidad de innovación y productividad además de largos períodos de crecimiento económico" 5 .

Aceptado entonces que el conocimiento es un bien y que su existencia en la sociedad es deseable porque genera bienestar, nos encontramos en un entrecruce de ciencias. La economía intentará develar los misteriosos caminos que llevan a la creación del conocimiento y el derecho buscará los medios de reparto que de mejor forma representen la noción de justicia para una sociedad determinada. Esta conexión entre lo económico y lo jurídico, impone al orden jurídico conocer en detalle la realidad que busca regular, puesto que muchas veces la motivación de la norma estará dada por consideraciones de orden puramente económico. En el mismo sentido, el diseño jurídico de la protección que se otorgue incidirá, para bien o para mal, en la creación del conocimiento que se busca proteger.

A la vinculación entre lo económico y lo jurídico, para nuestro estudio, se agrega la incidencia de un tercer elemento, los impuestos. El tributo, además de su función recaudadora, puede estimular o desincentivar conductas, lo que incidirá en la dimensión económica y jurídica de la generación del conocimiento.

Nos encontramos frente a una realidad compleja, donde la regulación jurídica debe atender no sólo a la fuente ontológica del problema, como pudiese ser en el caso de la protección del derecho a la vida o la libertad de expresión, sino que la norma tendrá que considerar: la dimensión económica de la realidad que regula, los aspectos distributivos y atributivos que pretende conseguir y el componente impositivo.

La triple dimensión que hemos descrito es lo que ha motivado nuestro estudio, puesto que el análisis de la tributación de la propiedad intelectual, a nuestro juicio, va

\footnotetext{
4 Tradicionalmente abreviado como I+D.

5 Tax Incentives for Research and Development: Trends and Issues. Secretary-General of the OECD, 2002, p. 22.
} 
un poco más allá de la revisión de los principios clásicos del derecho tributario, como herramienta de recaudación fiscal, bajo criterios de justicia. En otras palabras, hablar de tributación de la propiedad intelectual, implica conocer su ajuste a los principios del derecho tributario en general, y además, su razón económica y naturaleza jurídica.

En este trabajo, principalmente, buscamos analizar cuál es la incidencia - si es que existe - de la naturaleza jurídica que posee la propiedad intelectual, en la valoración tributaria que se haga de un determinado hecho, sin dejar de considerar las razones económicas que pudieran existir. En otras palabras, buscamos conocer hasta qué punto, el legislador tributario considera la naturaleza jurídica y la justificación económica de la propiedad intelectual, a la hora de someterla a imposición y cuán incidentes son estos elementos, en la aplicación práctica e interpretación del tributo. Puede suceder, que bajo un determinado régimen, un hecho específico constituya propiedad intelectual y se encuentra gravado por ser tal, pero bajo otro régimen el mismo hecho específico, no constituya propiedad intelectual y no esté gravado o se encuentre exento.

La ardua discusión que ha existido desde los orígenes de la propiedad intelectual, que ha llegado a ser calificada de embriagante ${ }^{6}$, permite plantearse la duda sobre cómo ha sido este instituto recibido en los distintos países y si su calificación jurídica es un elemento relevante a la hora de revisar la situación de los royalties en un contexto de tributación nacional e internacional.

El desafío que enfrentamos, requiere partir por definir qué se entiende por propiedad intelectual, cuál es su naturaleza jurídica, establecer cómo es recibida y tratada en un determinado derecho interno, determinar cuál es la regulación que recibe en convenios internacionales sobre doble imposición asociados y finalmente, podrá verse si las normas han considerado o recogido la naturaleza jurídica que su propio sistema ha definido para la propiedad intelectual, a la hora de gravar sus rentas.

Por razones de extensión y de medios materiales y económicos, hacen muy ambicioso extender nuestro trabajo a una multiplicidad de países, motivo por el cual hemos decidido considerar únicamente a España y Chile. De manera que, nuestro estudio será un análisis comparativo entre estas dos realidades, lo que no quita, que pueda ser utilizado como base para incorporar otros países en futuras investigaciones.

6 PLAZA PENADES, JAVIER. El derecho de autor y su protección en el artículo 20, 1, b) de la Constitución, Tirant Monografías, Valencia, 1997, p. 103. 


\section{Metodología y orden de la exposición}

Si bien podríamos compartir el pensamiento de $\operatorname{AZCARATE}^{7}$ quien cree que al menos en germen, la propiedad intelectual ha existido desde siempre, las normas destinadas a la protección de las obras y creaciones del intelecto, las comenzamos a ver solamente durante el renacimiento ${ }^{8}$, en principio vinculadas a privilegios reales y con los años, conformando un derecho autónomo, llamado copyright, en el contexto anglosajón; derecho de autor o propiedad intelectual, en los países de tradición continental $^{9}$. Los quinientos años que han transcurrido desde este inicio tienen un momento de inflexión en el siglo XIX, con el florecimiento de tratados internacionales sobre la materia, que han llegado a tener escala planetaria, hablamos del Convenio de la Unión de París y del Convenio de la Unión de Berna ${ }^{10}$.

El desarrollo del derecho de la propiedad intelectual ha estado marcado por el surgir paralelo de legislación internacional y de normativa interna de los países, lo que ha dado como necesario resultado una influencia recíproca, generando una institucionalidad mundial, caracterizada porque, no obstante la existencia de diferentes formas de concebir y regular la propiedad intelectual entre los diferentes países, a la vez el sistema es capaz de comunicarse y dialogar a nivel mundial, para satisfacer las necesidades de protección de manera global, por ejemplo, bajo diferentes concepciones del sistema de patentes, existe un estándar común de clasificación que permite la debida ordenación e identificación de las invenciones.

Al igual que la propiedad intelectual, el desarrollo de un sistema internacional para evitar la doble tributación, se caracteriza por el crecimiento simultáneo de las legislaciones nacionales y la suscripción de tratados internacionales, si bien en este

AZCARATE G. Ensayo sobre la historia de la propiedad intelectual. Ed. Imprenta de Legislación, 1880 , p. 331.

8 La primera patente de que se tiene noticias, llamada "patente de monopolio" fue dada en 1491, en la República de Venecia, a favor de Pietro, quien aseguraba que sólo él o quienes él autorizada tenían derecho a imprimir su obra "Fénix". CARVAJAL M., JUAN CARLOS. Evolución de la propiedad intelectual, Instituto Tecnológico de Costa Rica. Disponible en www.tec-digital.itcr.ac.cr (10 Feb 2014).

9 Sobre la diferente naturaleza jurídica de estas dos visiones de la propiedad intelectual, puede verse GÓMEZ DÍEZ, JUSTO. La propiedad intelectual y el artículo 20.1 b) de la Constitución española, Revista de la Facultad de Derecho de la Universidad Complutense de Madrid, Anuario 84, p. 168.

10 El Convenio de la Unión de Paris, también conocido por su abreviación como CUP, data del 20 de marzo de 1883. El Convenio de la Unión de Berna, normalmente referido por su abreviación como CUB, data del 09 de septiembre de 1886. Si bien, originalmente estos tratados no contaron con un gran número de Estados adherentes, actualmente tiene alcance mundial con 174 Estados en el caso del CUP y 166 en el CUB. http://www.wipo.int/treaties/es/general (10 Feb 2014). 
caso, no existe un gran tratado multilateral como el CUP y CUB, hay un estándar internacional, dado por lo que se ha conocido como Modelos de Convenio de Doble Imposición $^{11}$, instrumentos que tienen por objeto servir de parámetro o borrador para la suscripción de tratados bilaterales, los que han tenido una influencia determinante en el texto que finalmente los países suscriben. Así las cosas, existe una equivalencia entre la evolución de la propiedad intelectual y la doble imposición internacional, en el sentido de estar marcadas por la proliferación simultánea de legislación nacional e internacional de manera más o menos paralela.

Los tratados internacionales se han conformado como una especie de traductor o intérprete entre los sistemas nacionales de propiedad intelectual y de impuestos, de manera de permitir la comunicación entre las regulaciones de los distintos Estados, para llegar a ello, todos los países deben por una parte modificar sus sistemas nacionales y transar, hasta donde les es posible, en el plano internacional.

Podemos ver como distintos sistemas de tributación y de protección de la propiedad intelectual se comunican recíprocamente para obtener un fin común, singularizado en un estándar más o menos uniforme de protección, en el caso de la propiedad intelectual y de carga tributaria, en el caso de la imposición. Sin embargo, como toda obra humana, los esfuerzos de armonización distan mucho de ser perfectos y normalmente, de manera inconsciente o consiente (porque no fue posible llegar a un acuerdo más profundo), existen espacios de interpretación, fronteras, bordes y diferentes puntos de vista, que tienen como necesaria consecuencia, distintas interpretaciones sobre un determinado hecho jurídico y sus efectos.

En este contexto, la diversidad de puntos de vista que existen sobre la naturaleza jurídica de la propiedad intelectual, que se extiende incluso a la indeterminación de su objeto, es un elemento clave a la hora de definir lo protegido y su correspondiente tributación, en la medida que conforme a la naturaleza jurídica que posea la propiedad intelectual en un Estado, un determinado hecho jurídico puede tener una calificación

11 La historia de los tratados de doble imposición es aún más reciente que la de la propiedad intelectual. En efecto, el modelo de convenio más difundido es el Modelo de Convenio de la OCDE, cuyo origen se remonta a sólo 90 años, bajo el auspicio de la Liga de las Naciones, publicándose el primer modelo en 1963. Según MAKHLOUF, GABRIEL. Ciot European Branch Conference, discurso de 07 de marzo de 2003, http://www.oecd.org/ctp/taxtreaties/cioteuropeanbranchconference.htm (10 Feb 2014). 
distinta a la que recibe en otro, por ejemplo, podría tratarse para una legislación de una renta del trabajo y para otra, de un canon.

No podríamos decir de antemano, que en la actualidad se estén dando casos de distinta calificación de un hecho jurídico, derivado de la diferente naturaleza normativa que se atribuye a la propiedad intelectual en una otra legislación, por ello es que nuestra investigación busca precisar si la naturaleza jurídica de la propiedad intelectual es influyente o determinante a la hora de hacer la calificación tributaria de un hecho y su consiguiente tributación. Para llegar a determinarlo, hemos estimado necesario partir por una aproximación teórica al asunto, para posteriormente, contrastar nuestras conclusiones con la realidad empírica de España y Chile.

En la tarea de la interpretación y aplicación de la propiedad intelectual y su tributación, es posible encontrar aspectos estructurales comunes, sin embargo ello no implica que se trate de una misma concepción o idéntica naturaleza jurídica; por el contrario, lo natural será que afianzados en los aspectos comunes, cada país mantenga las diferencias y la definición que por años se han creado en su derecho interno. Como es sabido, lo mismo sucede en el derecho tributario, puesto que los modelos de convenio y particularmente el modelo de la OCDE, ni siquiera están destinados a alterar el derecho interno, sino que es simplemente un comunicador entre diferentes jurisdicciones tributarias. En consecuencia, es evidente que en la tarea de interpretación y aplicación de estas normas, nos encontraremos con la necesidad de combinar al menos cuatro mundos: el derecho interno de la propiedad intelectual, el derecho tributario interno, la normativa internacional de derecho tributario y las disposiciones internacionales sobre propiedad intelectual. Encontraremos elementos que permitan fijar algunos conceptos con validez general, sin embargo ello no siempre será así, por lo que, en aquellos casos en que la frontera de la decisión no es clara, conocer y determinar la naturaleza jurídica que cada ordenamiento reconoce para la propiedad intelectual es una cuestión esencial a la hora de resolver, de ahí que el objetivo de nuestra investigación es determinar si esto se ha tomado en cuenta en el pasado o puede ser un aporte para que se considere en el futuro.

Por motivos de extensión de nuestro trabajo, hemos considerado tomar como referentes solamente dos países: España y Chile, los que resultan interesantes, puesto que, si bien ambos tienen un origen común en el derecho continental, han perfilado la 
naturaleza jurídica de sus respectivos sistemas de propiedad intelectual y tributación de manera diferente. Conocida es la influencia de España sobre Chile en materia jurídica, existiendo conexiones muy estrechas; no obstante eso, cada ordenamiento tiene su propia identidad, que sólo puede comprenderse plenamente cuando se descubren las fuentes de inspiración del legislador, el debate doctrinal y sus condicionantes históricos. Particularmente en la materia de nuestro estudio, tiene una relevancia decisoria comprender que en muchas ocasiones las soluciones fueron dictadas por condicionamientos externos a la ciencia del derecho, como la situación internacional, la teoría económica y el contexto del desarrollo económico de los países.

Ante la imprecisión del contenido sobre qué se entiende por propiedad intelectual, nuestro estudio debe comenzar definiendo qué comprendemos por tal, debemos establecer un marco conceptual en el cual situarnos, aunque éste no sea nuestro objetivo final. En el mismo momento, será necesario enfrentar nuestro primer problema: ¿cuál es la naturaleza jurídica de la propiedad intelectual?, para ello, nos referiremos a las distintas posiciones teóricas que se pueden dar sobre la materia. Un paso siguiente en este capítulo inicial, presupuesto necesario para poder apoyar la consecuente investigación, es determinar la naturaleza jurídica de nuestro objeto de estudio en los países que hemos tomado como muestra: España y Chile, partiendo desde la altura constitucional, a fin de conocer a cabalidad no sólo cómo se ha entendido en general el asunto en estas jurisdicciones, sino que cómo lo ha definido el legislador y el propio constituyente. Conjuntamente, el análisis se deberá extender a las explicaciones teóricas que la ciencia económica nos entrega, sobre la creación del conocimiento y su incidencia en la economía, puesto que, el fenómeno económico lo hemos considerado como una de tres variables que inciden en la tributación de la propiedad intelectual.

Habiendo abordado los límites de la propiedad intelectual y las explicaciones de la ciencia económica, nos corresponderá incorporar el tercer elemento que hemos estimado necesario para la cabal comprensión de nuestra investigación, la tributación. El análisis tributario lo enfrentaremos partiendo por la legislación de cada país, construyendo con estos elementos nuestro segundo capítulo.

En una tercera parte de la investigación, partiremos por el estudio del vehículo creado para servir de puente entre diferentes jurisdicciones tributarias, tal es el Modelo de Convenio Tributario sobre la Renta y el Patrimonio, más comúnmente conocido 
como el Modelo OCDE. Con ese referente, utilizado como base de comparación, concluiremos nuestro trabajo con el análisis del convenio tributario suscrito entre España y Chile.

Cerraremos la investigación con las conclusiones y la bibliografía. 


\section{LA PROPIEDAD INTELECTUAL COMO PRESUPUESTO NECESARIO PARA EL ESTUDIO DE SU TRIBUTACIÓN}

\section{Consideraciones preliminares}

\subsection{Evolución del concepto en la legislación positiva}

Todas las personas atribuyen un contenido a la idea de propiedad intelectual, lo que no significa que aquello que entiendan por tal se corresponda con alguna categoría de protección, ni mucho menos, con lo que una determinada legislación ha definido. La multiplicidad de contenidos que puede atribuirse a la propiedad intelectual parte por su propia concepción, de hecho, el uso de la palabra "propiedad" da cuenta de una vinculación al derecho de propiedad, pero esa es sólo una mira, porque a modo de ejemplo, GÓMEZ DÍEZ ${ }^{12}$ recalca su vinculación a un derecho "natural" y la visión del copyright, propia del derecho anglosajón, lo conforma como un derecho autónomo para autorizar o prohibir la reproducción del objeto protegido. De todas formas, en este momento, no son tan profundas las reflexiones que aspiramos efectuar, simplemente buscamos definir un límite material claro para el contenido de nuestro trabajo.

Una concepción amplia de propiedad intelectual comprenderá todas las creaciones del intelecto humano, ya sea que se trate de creaciones artísticas, científicas literarias, desarrollos tecnológicos u otros, se entenderá como alusiva a un derecho patrimonial exclusivo, otorgado por un Estado, por un cierto lapso de tiempo ${ }^{13}$.

Desde un punto de vista restrictivo, la propiedad intelectual puede ser entendida de diferentes maneras, tales como: equivalente a derecho autor ${ }^{14}$; sinónimo de derecho de autor $^{15}$; e incluso, como una propiedad especial ${ }^{16}$, tal como da cuenta MARCO MOLINA, quien nos indica que el objetivo de la ley española de Propiedad Intelectual

12 GÓMEZ DÍEZ, JUSTO. La propiedad intelectual y el artículo 20.1 b) de la Constitución española, Revista de la Facultad de Derecho de la Universidad Complutense de Madrid, Anuario 84, p. 168.

13 En esta perspectiva podemos ver las explicaciones de BERCOVITZ RODRÍGUEZ-CANO, RODRIGO. Manual de propiedad intelectual, Tirant Lo Blanch, Valencia, 2001, pp. 23 a 25.

14 Al hacer una búsqueda en internet por "derecho de autor", es fácil encontrar referencias a la "propiedad intelectual”. Por ejemplo, google nos mostró: “[E]n la legislación española el Real Decreto Legislativo 1/1996, de 12 de abril, por el que se aprueba el texto refundido de la [Ley de la Propiedad Intelectual] (...)", (15 Dic 2013).

15 ALCAZAR VARÓ, ENRIQUE y OTRO. Diccionario de Términos Jurídicos Inglés-Español, Editorial Ariel, Barcelona, 1993, p. 112. Los autores establecen que la palabra copyright puede ser traducida como propiedad intelectual o derechos de autor, haciendo sinónimos a estos conceptos.

16 MARCO MOLINA, JUANA. La propiedad intelectual en la legislación española, Marcial Pons, Madrid, 1995, p. 65. 
de 1879, fue "fundamentalmente la absoluta equiparación al derecho de propiedad ordinaria sobre bienes materiales".

Desde el punto de vista internacional, ya en el Convenio de Berna, comenzamos a ver con claridad la prudencia con que el texto trata la materia, evitando cualquier referencia a un perfilamiento asociado a una definición jurídica específica, como la propiedad, concepto que se había usado en el Convenio de París, de sólo tres años antes $^{17}$. El Convenio de Berna prefiere hablar de la protección de las obras literarias y artísticas, denotando con la palabra "protección" un compromiso de aseguramiento y respaldo institucionalizado, cualquiera sea el sistema que se utilice en el derecho interno de los Estados partes del tratado.

En cuanto al uso de la palabra "intelectual", en Berna también se aprecia la misma prudencia de que hemos hablado y solamente se usa en el artículo $2^{\circ}$, número 5), para destacar que las obras literarias y artísticas como enciclopedias y antologías, pueden ser objeto de protección por el tratado, en la medida que "(...) por la selección y disposición de las materias, constituyan creaciones intelectuales (...)”.

El otro gran referente mundial en la materia, el Convenio de París, a diferencia del Convenio de Berna, es más explícito en cuanto a su objeto, puesto que desde su título: "Convenio de París para la Protección de la Propiedad Industrial", deja en claro que se trata de "propiedad". Más aún, en el artículo $1^{\circ}$, número 3), expresamente, define "propiedad industrial"; no obstante, al hacerlo, deja en evidencia la multiplicidad de interpretaciones de que venimos hablando, puesto que se detiene a aclarar que el concepto de propiedad industrial es usado en su acepción más amplia, es decir, reconoce sus diferentes extensiones ${ }^{18}$ y opta por la más vasta.

En el caso del Modelo de Convenio Tributario sobre la Renta y el Patrimonio ${ }^{19}$ de la OCDE, como sabemos, el objetivo no es la propiedad intelectual en sí misma, sino las rentas que se pueden producir por su explotación como bien económico, por ello, el

17 Respectivamente, estos tratados datan de 1883 y 1886, tal como anotamos antes.

18 El artículo $1^{\circ}$, número 3) del CUP, señala: "La propiedad industrial se entiende en su acepción más amplia y se aplica no sólo a la industria y al comercio propiamente dichos, sino también al dominio de las industrias agrícolas y extractivas y a todos los productos fabricados o naturales, por ejemplo: vinos, granos, hojas de tabaco, frutos, animales, minerales, aguas minerales, cervezas, flores, harinas".

19 El Modelo de Convenio Tributario sobre la Renta y el Patrimonio de la OCDE ha tenido sucesivas modificaciones desde su primera versión en el año 1963, en este caso, hemos trabajado con la actualización del año 2010, en su versión en español. 
Convenio aborda el asunto desde las "regalías"20, en la medida que son la forma usual de obtener réditos de la propiedad intelectual. El artículo 12 del Modelo de Convenio de la OCDE, en su número 2), se detiene a definir "regalía", señalando que "significa las cantidades de cualquier clase pagadas por el uso, o la concesión de uso", de un listado de derechos e intereses jurídicos, como son: los derechos de autor sobre obras literarias, artísticas o científicas, incluidas las películas cinematográficas, patentes, marcas, diseños o modelos, planos, fórmulas o procedimientos secretos, o por informaciones relativas a experiencias industriales, comerciales o científicas. Cabe destacar, que se cuida de no incluir a la "propiedad intelectual" como género, sino que habla, entre otros, de derechos de autor y patentes; por otra parte, mezcla institutos que típicamente son propiedad intelectual, como el derecho de autor, con otros que no lo son, como las fórmulas y procedimientos secretos.

Como se aprecia, la indefinición terminológica que ronda a la propiedad intelectual, es transversal a todos los ámbitos en que ha sido objeto de regulación.

En el derecho español tampoco ha sido pacífica la existencia de la propiedad intelectual, de hecho, tal como recuerda MARCO MOLINA ${ }^{21}$, tras la influencia del derecho francés y con el claro objetivo de apartarse de la noción de privilegio, se dictaron en España, el Decreto $\mathrm{N}^{\circ} 265$ de las Cortes de Cádiz ${ }^{22}$, relativo a la conservación de la "propiedad" de los escritores; seguidamente, en 1823, se acentúa la idea de propiedad, en la "Ley Calatrava"23, sobre Propiedad de Obras Literarias. Sin embargo, esta claridad inicial, es eclipsada por el Reglamento de Imprentas de 1834, que en un intento por conciliar el sistema de los privilegios y la naciente idea de un derecho propietario ${ }^{24}$ establece su Título IV: De la Propiedad y Privilegios de los Autores y Traductores, mezclando la idea de propiedad y privilegio.

20 Las regalías corresponden a los pagos que se efectúan al titular por la cesión de la explotación de un derecho de propiedad intelectual. ALCAZAR VARÓ, en la obra citada supra, p. 671, traduce la expresión como royalties, lo que es coincidente con la versión en inglés del modelo de convenio de la OCDE.

21 Ob. supra cit., p. 20.

22 Decreto núm. 265 de las Cortes de Cádiz, de 10 de junio de 1813, titulado: Reglas para Conservar a los Escritores de la Propiedad de sus Obras.

23 Ley de Propiedad de Obras Literarias, de 05 de agosto de 1823, llamada así por cuanto fue firmada por don José María Calatrava, en calidad de Secretario del Despacho de Gracia y Justicia.

24 Si bien MARCO MOLINA. Ob. supra cit., p. 20, explica el asunto atribuyéndolo a la ambigüedad política que caracteriza la Regencia de María Cristina, para nuestros fines es un claro ejemplo de la 
Más adelante en la historia española, nos encontramos con la Ley sobre Propiedad Literaria de 1847 , la que según recuerda la autora citada ${ }^{25}$, venía a proteger las "obras del ingenio" 26 . En 1879, declarando la voluntad de acoger todo tipo de creaciones, se dicta la Ley de Propiedad Intelectual. En la actualidad la denominación utilizada es "propiedad intelectual", tal como da cuenta la RDL 1/1996, de 12 de abril, que aprueba el texto refundido de la Ley de Propiedad Intelectual ${ }^{27}$.

Si nos fijamos en la otra faz de la propiedad intelectual, la propiedad industrial, podemos ver que la situación ha sido más o menos similar, deambulando desde los "privilegios", a la "propiedad industrial", para terminar en una referencia directa al objeto protegido en la Ley de "Patentes", n 11 , de 20 de marzo de $1986^{28}$. Las primeras noticias sobre la materia, tal como dijimos, están asociadas a la idea de privilegio, así consta en Real Cédula, de 20 de mayo de $1788^{29}$, donde se observa la confusión existente entre el título de "inventor", propio del derecho de patentes, con el de "autor", típico de la propiedad intelectual, puesto que, al sujeto creador se le llama simultáneamente: inventor y autor ${ }^{30}$.

Un Real Decreto de 13 de junio de $1810^{31}$, establece el primer registro para “inventos", sin embargo estuvo asociado al Conservatorio de Artes y Oficios, por lo que

dificultad para delimitar los contornos de la propiedad intelectual y con mayor razón, de su naturaleza jurídica.

25 MARCO MOLINA. Ob. supra cit. p. 23.

26 Discurso de presentación del Proyecto de Ley. Diario de Sesiones del Senado de 1847, apéndice $1^{\circ}$, al núm. 17 , de 04 de febrero.

27 Actualmente existe en el Congreso Nacional un proyecto de ley en trámite, con el objetivo de modificar la Ley de Propiedad Industrial. Proyecto de Ley $N^{\circ}$ 81-1, de 21 de febrero de 2011. Disponible en Internet en:

http://www.congreso.es/public oficiales/L10/CONG/BOCG/A/BOCG-10-A-81-1.PDF. $\quad$ (15 Abr 2014).

28 En la página web de la Oficina de Patentes y Marcas de España, OEPM, existe una recopilación de las normas relativas a propiedad industrial en España desde 1788 hasta 1931, el listado incorpora 220 instrumentos jurídicos de distinta especie. No obstante haberlos examinado todos, sólo nos detendremos en aquellos que nos parecen más relevantes para destacar las dificultades que encierra la delimitación conceptual sobre qué se entiende por propiedad intelectual.

29 Novísima Recopilación. Ley $4^{\circ}$, Título 40, Libro $7^{\circ}$. Accesible electrónicamente en el archivo histórico electrónico de la Oficina Española de Patentes y Marcas, en http://historico.oepm.es/archivohistoricow3c/index.asp?idm=es\&page=compartiendo saberes, $\quad(10$ Ene 2014).

30 La Real Cédula, de 20 de mayo de 1788, se titulaba: "Real cédula mandando que los [inventores] de remedios para la salud revelen la composición de los medicamentos, y estableciendo la obligación de guardar secreto durante la vida del [autor] y 10 años más a favor de sus herederos"

31 El Real Decreto de 13 de junio de 1810, se titulaba: "Real Decreto mandando establecer en Madrid un Conservatorio de Artes y Oficios, como depósito de máquinas, modelos, instrumentos, dibujos, etc. de toda clase de artes y oficios, en el que se deberán colocar los originales de las máquinas que se inventen o perfeccionen en España”. Archivo histórico de la OEPM. Accesible electrónicamente en el 
se refería a "patentes" y a toda clase de "artes y oficios", mostrando nuevamente la coexistencia conceptual del derecho de autor con la propiedad industrial. Es en el Real Decreto de 16 de septiembre de 1811, donde comenzamos a apreciar una estructura semejante a una ley de patentes, con la existencia de un registro ${ }^{32}$. En el Decreto de las Cortes de 02 de octubre de $1820^{33}$, se mantiene la proximidad a la idea de "propiedad" que venía marcándose, con un matiz dado por el uso del sustantivo "protección”,34, al garantizar la "[protección] al que se crea inventor, perfeccionador o introductor".

En el año 1826, en el Real Decreto de 27 de marzo, podemos ver el artículo $2^{\circ}$, que mezcla las ideas de "propiedad" y "privilegio", al establecer que, "[p]ara asegurar al interesado la [propiedad] exclusiva se le expedirá una Real cédula de privilegio". Bajo el Real Decreto de 20 de noviembre de $1850^{35}$, que establece normas para la "concesión" de marcas de fábrica en España, se produce un nuevo giro, alejándose de las ideas de "privilegio" y "propiedad", para asumir el concepto de "concesión". En el año 1876, el Real Decreto de 17 de julio, contiene una referencia expresa al Convenio

archivo histórico electrónico de la Oficina Española de Patentes y Marcas, en $\underline{\mathrm{http}} / / /$ historico.oepm.es/archivohistoricow3c/index.asp?idm=es\&page=compartiendo saberes, $\quad(10$ Ene 2014).

32 El Real Decreto de 16 de septiembre de 1811, está señalado como: "Real decreto estableciendo las reglas por las que han de regirse en España los que inventen, perfeccionen o introduzcan nuevos artilugios en cualquier ramo de la industria". En este Real Decreto vemos como se comienza a instalar, sin titubeos, la idea de "propiedad" sobre las invenciones y la necesidad de su registro. Al efecto, en la exposición de motivos, sostiene: "Importando al estado que se divulguen los descubrimientos y mejoras útiles á la industria y á la agricultura, y no pudiendo exigirse de sus autores que cedan al público lo que es su propiedad particular, sino ofreciéndoles ventajas y pactando con ellos en favor de la nación". Más adelante en el artículo VII, número $2^{\circ}$, obliga a registrar como requisito de la constitución de una patente, al decir: "2 ${ }^{\circ}$ Depositar en la misma Secretaría bajo de cubierta sellada, una descripción exacta de los principios, medios y procedimientos que constituyen su descubrimiento, y los planos, secciones, dibujos y modelos relativos á él”. Archivo histórico de la OEPM. Accesible electrónicamente en el archivo histórico electrónico de la Oficina Española de Patentes y Marcas, en http://historico.oepm.es/archivohistoricow3c/index.asp?idm=es\&page=compartiendo saberes, $\quad$ (10 Ene 2014).

33 Archivo histórico de la OEPM. Accesible electrónicamente en el archivo histórico electrónico de la Oficina Española de Patentes y http://historico.oepm.es/archivohistoricow3c/index.asp?idm=es\&page=compartiendo saberes, $\quad(10$ Ene 2014).

34 Actualmente, el verbo protección es ampliamente usado en el ámbito internacional, porque permite asumir un compromiso de amparo a la propiedad intelectual, sin tener que especificar cuáles serán las vías por las que lo hará el derecho interno de cada país.

35 Archivo histórico de la OEPM. Accesible electrónicamente en el archivo histórico electrónico de la Oficina Española de Patentes y http://historico.oepm.es/archivohistoricow3c/index.asp?idm=es\&page=compartiendo saberes, $\quad$ (10 Ene 2014). 
de París y a la "propiedad" sobre marcas comerciales ${ }^{36}$. No obstante, un año más tarde, la idea de "concesión" vuelve a estar asociada a "privilegio", en la Real Orden de 15 de marzo de 1877 , cuyo punto $3^{\circ}$, se refiere al "concesionario del privilegio". Al año siguiente, la Ley 30 de julio de 1878, artículo $2^{\circ}$, utiliza la expresión "patente de invención", que termina por consolidarse en el ordenamiento español, junto a otras expresiones como: marca de fábrica, propiedad industrial y propiedad intelectual, tal como las conocemos en la actualidad ${ }^{37}$.

Cerrando el contexto español, debemos hacer presente que, las dificultades en la determinación de lo qué se entiende por propiedad intelectual no se acaban en el análisis o la indefinición normativa, así por ejemplo, BERCOVITZ RODRÍGUEZ-CANO ${ }^{38}$ nos precisa que "[1]a propiedad intelectual tienen pues tanto una acepción estricta, equivalente a derecho de autor, como una acepción amplia, correspondiente al título de la propia LPI, equivalente a todos los derechos que la misma ordena".

En el caso chileno, la propiedad intelectual aparece por primera vez en la Constitución de 1833, cuyo artículo 152 señalaba: "Todo autor o inventor tendrá la propiedad exclusiva de su descubrimiento, o producción por el tiempo que le concediere la ley; y si ésta exigiere su publicación, se dará al inventor la indemnización competente". Como se aprecia, al igual que los textos españoles de épocas semejantes,

36 Real Decreto de 17 de julio de 1876, titulado: "Real decreto resolviendo que la declaración firmada en París para la garantía recíproca de la propiedad de las marcas de fábrica en España y Francia se observe puntualmente en todas y cada una de sus partes". Archivo histórico de la OEPM. Accesible electrónicamente en el archivo histórico electrónico de la Oficina Española de Patentes y Marcas, en http://historico.oepm.es/archivohistoricow3c/index.asp? $\mathrm{idm}=$ es\&page=compartiendo saberes, $\quad$ (10 Ene 2014).

37 En la Real Orden de 14 de febrero de 1879, se habla de marcas de fábrica. En el Real decreto de 14 de mayo de 1880, se dispone poner "en vigor en las provincias de Ultramar la Ley de patentes de invención de 30 de julio de 1878”. En el ámbito internacional, el 20 de marzo de 1883, podemos ver el Convenio celebrado entre España, Bélgica, Brasil, Francia, Guatemala, Italia, Países Bajos, Portugal, Salvador, Servia y Suiza, constituyendo una unión internacional para la protección de la propiedad industrial, firmado en París el 20 de marzo de 1883. En 1885 el Código de Comercio, en el artículo 21, $\mathrm{N}^{\circ} 12$, se establece: "Los títulos de Propiedad Industrial, patentes de invención y marcas de fábrica, en la forma y modo que establezcan las leyes". Desde ahí en adelante, las referencias a propiedad industrial e intelectual son uniformes y constantes: en el Real Decreto de 2 de agosto de 1886, que crea "en el Ministerio de Fomento y bajo su dirección un Boletín oficial de la propiedad intelectual e industrial"; en la Ley sobre la propiedad industrial de 16 de mayo de 1902; la Real Orden de 17 de junio de 1903, que resuelve que "los dibujos y trabajos hechos con un fin industrial no son materia propia de la ley de propiedad intelectual"; en la Real Orden de 23 de octubre de 1928, que viene a dictar "las reglas que se indican relativas a los recursos que puedan presentarse en relación con una misma patente industrial"; y finalmente, en la Ley de Propiedad Industrial de 16 de septiembre de 1931 y en la Ley de Patentes $N^{\circ} 11 / 86$ de 20 de marzo.

38 BERCOVITZ RODRÍGUEZ-CANO, RODRIGO. Manual de Propiedad Intelectual, Tirant Lo Blanch, Valencia, 2001, pp. 19 y 20. 
existe en el constituyente chileno del año 1833, una total confusión sobre el contenido de qué entendía por propiedad intelectual, de hecho no usa la expresión propiedad intelectual y sólo sabemos que se refiere a ella, por la mención a "autor o inventor", que efectúa el artículo. Así pues, autor, inventor, descubrimiento y producción son usados como términos aparentemente capaces de calificarse recíprocamente, como que el autor y productor pudiesen hacer descubrimientos y producciones indistintamente, lo que nos da cuenta de una mezcla de conceptos. En el mismo sentido, existe indefinición en el contenido de los derechos que se confieren a autores e inventores, puesto que se les reconoce el derecho por el "descubrimiento o producción" ${ }^{39}$ y están ausentes las ideas de creación e invención o desarrollo, elementos típicos del derecho de autor y de la propiedad industrial, respectivamente. Al amparo de esta norma constitucional, se promulgó en Chile, la Ley de Propiedad Literaria y Artística de 24 de julio de 1834, según LARRAGUIBEL ZAVALA ${ }^{40}$, primera norma de propiedad literaria y artística en Chile. En ese caso, aunque el título de la norma, no alude al derecho de autor o propiedad intelectual, desde el punto de vista de la naturaleza jurídica del derecho que regula, es clara su connotación propietaria al hablar de propiedad literaria y artística. Reafirmando la existencia de una especie de propiedad, en el año 1857, el Código Civil, contempla en el artículo 584: "las producciones del talento y del ingenio son una propiedad de sus autores". Casi setenta años más tarde, un cambio legislativo se produce con el Decreto Ley ${ }^{41} \mathrm{~N}^{\circ} 345$, de 1925, sobre Propiedad Intelectual, que como refleja su título, asume sin titubeos la expresión "propiedad intelectual", en consonancia con lo que analizamos, era la tendencia española en el mismo momento histórico; ese año, también se promulgó la Constitución de 1925, cuyo capítulo III, bajo el título Garantías Constitucionales, en el art. $10 \mathrm{~N}^{\circ} 11$, asegura a todos los habitantes de la República "la propiedad exclusiva de todo descubrimiento o producción por el tiempo que concediere la ley. Si ésta exigiere su expropiación, se dará al autor o inventor la

39 Si bien el uso de los verbos descubrimiento y producción, se condicen con las ideas vigentes a la época, reflejadas en la legislación española, como vimos precedentemente, en el sentido que las patentes podían otorgarse por la sola introducción de un producto nuevo en el país, en consecuencia ausente de esfuerzo creativo en sí mismo, lo que extraña es que se prescinda de la idea de creación, elemento básico de todos los sistema de protección de propiedad intelectual.

40 LARRAGUiBEL ZAVAlA, SANTIAGO. El derecho de autor en la Constitución Política de la República de Chile. Revista Derecho y Jurisprudencia y Gaceta de los Tribunales, Tomo LXXX, N², mayo-agosto, Edit. Jurídica de Chile, 1983, pp. 67.

41 En Chile, la expresión Decreto Ley (DL) ha sido utilizada para designar una forma de legislación irregular que no cuenta con la aprobación del congreso nacional, propia de los gobiernos de facto, que en la práctica se han incorporado al sistema jurídico con rango de ley, terminado el gobierno autoritario que los dicta, no obstante mantienen su numeración y denominación de decreto ley. Se han dictado decretos leyes en tres períodos de 1924-1925; junio-octubre de 1932 y 1973-1981. 
indemnización competente", manteniendo de esta forma la idea de propiedad que subyace en el artículo $^{42}$, la que no varió en la Ley $\mathrm{N}^{\circ} 17.336^{43}$, de 1970 , sobre Propiedad Intelectual ${ }^{44}$, tendencia que se consolidó en la Constitución de 1980, cuyo artículo $19 \mathrm{~N}^{\circ} 24$, que si bien se enmarca dentro del contexto de la libertad de crear y difundir las artes, expresamente garantiza la propiedad sobre las obras y otros derechos y la propiedad industrial ${ }^{45}$.

En lo que a la propiedad industrial respecta, desde el punto de vista constitucional, son válidos todos los comentarios que hicimos para la propiedad intelectual, puesto que el asunto es tratado de manera conjunta en todos los textos constitucionales. Así lo que dijimos para la propiedad intelectual en el sentido que: originalmente en las Constituciones de 1833 y 1925 existe confusión sobre su contenido; no se usa la frase "propiedad intelectual" y sólo entendemos que se refiere a ella por la descripción del objeto a que se aplica, es plenamente válido para la propiedad industrial. De la misma manera, en la Constitución de 1980, el asunto se asienta con claridad en el artículo $19 \mathrm{~N}^{\circ} 25$, reconociendo a la propiedad industrial como una verdadera propiedad.

Las particularidades se presentan a nivel legislativo, no constitucional, en efecto el 9 de septiembre de 1840, se dictó un Decreto Ley sobre Patentes de Invención y por ley de 12 de noviembre de 1876, se crea un registro para inscribir marcas de fábrica o comercio, nacionales o extranjeras. Posteriormente, en el año 1925, encontramos el Decreto Ley $\mathrm{N}^{\circ} 588$, que será la primera Ley de Propiedad Industrial. Un poco más adelante, el Decreto Ley $N^{\circ} 958$ de 1931, estableció el texto definitivo de la Ley de

42 La norma está copiada de la Constitución de 1833, por lo que cabe reproducir en este punto los comentarios que hicimos en su momento sobre la indefinición que implica el uso de los verbos descubrimiento y producción.

43 Con modificaciones, esta es la ley vigente hasta nuestros días.

44 Desde el DL No 345 de 1925, hasta la Ley $N^{\circ} 17.336$ de 1970, sólo se registraron en el campo normativo dos hechos: la Ley $\mathrm{N}^{\circ} 9.549$ de 1950, que extendió el plazo de protección del derecho de autor a cincuenta años desde la muerte del autor; y, en 1970, Chile suscribió y ratificó el Convenio de Berna.

45 El artículo $19 \mathrm{~N}^{\circ} 25$, de la Constitución Chilena de 1980, garantiza a todas las personas: " $25^{\circ}$.- La libertad de crear y difundir las artes, así como el derecho del autor sobre sus creaciones intelectuales y artísticas de cualquier especie, por el tiempo que señale la ley y que no será inferior al de la vida del titular.

El derecho de autor comprende la propiedad de las obras y otros derechos, como la paternidad, la edición y la integridad de la obra, todo ello en conformidad a la ley.

Se garantiza, también, la propiedad industrial sobre las patentes de invención, marcas comerciales, modelos, procesos tecnológicos u otras creaciones análogas, por el tiempo que establezca la ley”. 
Propiedad Industrial, denominación que se mantiene por la Ley $\mathrm{N}^{\circ} 19.039$ de 1991, vigente hasta nuestros días ${ }^{46}$.

Como se aprecia, la división por la que optó el legislador nacional, apartando a la propiedad industrial de la intelectual, para concentrar en esta disciplina a las patentes de invención y marcas, se produce tempranamente en relación a España, puesto que desde 1840 se instaura la expresión "patentes de invención" y comienza a perfilarse la idea de propiedad, que acompañará a la propiedad industrial en Chile, hasta nuestros días.

\subsection{Opciones para dar contenido a la propiedad intelectual, el modelo de OMPI}

En el Convenio que establece la Organización Mundial de la Propiedad Intelectual $^{47}$, en el mismo nombre de la institución utiliza la expresión "propiedad intelectual", mostrando el perfil propietario con que se entendió la institución. Ahora bien, tal como el propio tratado señala, la propiedad intelectual está tomada como un género, que comprende tanto la protección de la propiedad industrial, como de las obras literarias y artísticas ${ }^{48}$.

En el artículo $2^{\circ}$, el tratado citado, plantea una definición de propiedad intelectual, que no es una verdadera definición, sino que se limita a enumerar aquellos institutos jurídicos que estima forman parte de la propiedad intelectual ${ }^{49}$. Con esta técnica, acorde con el lenguaje ambiguo del derecho internacional, se evita definir la

46 Actualmente existe en el Congreso Nacional un proyecto de ley en trámite, con el objetivo de modificar la Ley de Propiedad Industrial. Corresponde al Boletín N 8907-03, de 29 de abril de 2013. Disponible en Internet en: www.bcn.cl. (15 Abr 2014).

47 El tratado fue suscrito en Estocolmo el 14 de julio de 1967 y modificado el 28 de septiembre de 1979. http://www.wipo.int/export/sites/www/treaties/es/convention/pdf/trtdocs wo029.pdf ( 10 Mar 2013).

48 Así queda claro del preámbulo introductorio del tratado que señala: "Deseando modernizar y hacer más eficaz la administración de las Uniones instituidas en el campo de la protección de la propiedad industrial y de la protección de las obras literarias y artísticas, respetando al mismo tiempo plenamente la autonomía de cada una de las Uniones".

49 El artículo $2^{\circ}$ establece que se entenderá por: "viii) « Propiedad intelectual », los derechos relativos: - a las obras literarias, artísticas y científicas,

- a las interpretaciones de los artistas intérpretes y a las ejecuciones de los artistas ejecutantes, a los fonogramas y a las emisiones de radiodifusión,

- a las invenciones en todos los campos de la actividad humana,

- a los descubrimientos científicos,

- a los dibujos y modelos industriales,

- a las marcas de fábrica, de comercio y de servicio, así como a los nombres y denominaciones comerciales,

- a la protección contra la competencia desleal, y todos los demás derechos relativos a la actividad intelectual en los terrenos industrial, científico, literario y artístico". 
naturaleza jurídica de la propiedad intelectual, lo que es bueno, en tanto permite la suscripción del convenio al conciliar los intereses de las partes; sin embargo, es malo a la hora de establecer la naturaleza jurídica de la propiedad intelectual, que se presenta como un instituto con bordes difusos. En este contexto, no es clara la naturaleza jurídica de que se ha querido dotar a la institución, en tanto, al hablar de "propiedad intelectual" parece no quedar duda sobre su carácter de propiedad ${ }^{50}$; sin embargo no se le define como tal, sino que se enumera los derechos que se estiman "relativos a", sin hacer una afirmación definitiva. Finalmente, tampoco soluciona el problema, el análisis de los institutos que enumera, ya que mezcla: derechos de propiedad intelectual, como obras literarias y artísticas; propiedad industrial, como las invenciones; $\mathrm{y}$, otros que no son derechos, sino intereses protegidos, como la protección de la competencia desleal ${ }^{51}$.

La indefinición sobre la naturaleza jurídica de la propiedad intelectual con que da lugar el nacimiento de la OMPI, desde nuestra experiencia, era necesaria e insoslayable. Son tantos los intereses de cada parte negociadora, los puntos de vistas y las legítimas definiciones jurídicas que sustentan la posición de los negociadores, que sería muy difícil, sino imposible, buscar una precisión dogmática en la redacción de este tipo de instrumentos. Sin embargo, dentro de la indefinición característica, la OMPI ha ido decantando qué entiende por propiedad intelectual e industrial, pasando la propiedad intelectual a ser el género, que incluye al derecho de autor y la propiedad industrial. Obviamente, la OMPI utiliza en sus documentos oficiales un lenguaje muy cuidado, evita tomar posición en cuestiones espinosas como la que nos ocupa, para ello, se vale de declaraciones como: "Por 'propiedad intelectual' se entiende, [en términos generales], toda creación del intelecto humano. Los derechos de propiedad intelectual protegen los intereses de los creadores al ofrecerles [prerrogativas] en relación con sus creaciones" ${ }^{\$ 2}$. En cuanto al contenido de la propiedad intelectual, queda claro que lo amplio de la definición comprende tanto al derecho de autor como a la propiedad

50 Recibe tratamiento de propiedad en el título del tratado y en el preámbulo, tal como vimos previamente.

51 Existe discusión sobre el hecho que la competencia desleal y los secretos empresariales sean verdaderos derechos o simplemente se trata de intereses protegidos. Al respecto, puede verse a MORON LERMA, ESTHER. La tutela del secreto de empresa, desde una teoría general del bien jurídico, Tesis de Doctorado, Departamento de Ciencia Política y Dret Public, UAB, URN TDX0405102-104031, 2001.

52 OMPI. Principios básicos del derecho de autos y los derechos conexos, Publicación OMPI N 909(S), ISBN 987-92-805-1617-3. http://www.wipo.int/export/sites/www/freepublications/es/intproperty/909/wipo pub 909.pdf Mar 2013) 
industrial, sin embargo, desde el punto de vista de su naturaleza jurídica, lejos de aclarar su origen propietario, lo diluye, al decir que: "Los derechos de propiedad intelectual protegen" y "ofrecen prerrogativas"; es decir, previene que no se le debe considerar a la luz de las características propias de un derecho de propiedad, sino que evaluar la protección que brindan estos derechos, en función de las "prerrogativas" que ofrecen. Lógicamente la "protección" y las "prerrogativas", no tienen por qué coincidir con un derecho de propiedad.

A pesar de lo expuesto, rescatamos que la OMPI aclare que la propiedad intelectual se divide en dos ramas, a saber: "la propiedad industrial que, [por decirlo en pocas palabras], se refiere a las invenciones, y el derecho de autor, que se aplica a las obras literarias y artísticas" ${ }^{\mathrm{N}}$.

Siguiendo la línea marcada por el Convenio de la OMPI de 1967, esta institución internacional opta por precisar lo que engloba la propiedad industrial e intelectual, en vez de establecer una definición de estos institutos. Como parte de la propiedad industrial incorpora: "las patentes, que sirven para proteger las invenciones, y los diseños industriales, que son creaciones estéticas que determinan el aspecto de los productos industriales. La propiedad industrial abarca también las marcas de comercio, las marcas de servicio, los esquemas de trazado de circuitos integrados, los nombres y designaciones comerciales y las indicaciones geográficas, a los que viene a añadirse la protección contra la competencia desleal" ${ }^{54}$.

Bajo la misma premisa de enumerar las obras protegidas y no establecer una definición, OMPI explica que el derecho de autor "se aplica a las creaciones artísticas como los libros, las obras musicales, las pinturas, las esculturas, las películas y las obras realizadas por medios tecnológicos como los programas informáticos y las bases de datos electrónicas".

Por otra parte, OMPI se cuida de evitar precisiones, declarando que "faltando una definición jurídica aceptable a este respecto, existe consenso en el sentido que la combinación de sonido, texto e imágenes en formato digital, accesible mediante un programa informático, constituye una expresión original (...) con arreglo a la normativa

53 Ob. supra cit. p. 4.

54 Ob. supra cit. p. 5. 
de derecho de autor" ${ }^{55}$, es decir, deja abierta la discusión sobre el contenido y definición del derecho de autor.

Consistente con nuestro análisis hasta este momento, podemos afirmar que no existe un consenso sobre la denominación de lo que hemos llamado "propiedad intelectual", su naturaleza jurídica y tampoco, sobre cuál es su contenido específico. A este mismo problema se enfrentó PLAZA PENADES ${ }^{56}$, quien indica como la expresión "propiedad intelectual" es usada por influencia de la doctrina francesa y del célebre discurso del diputado LE CHAPELLIER ${ }^{57}$, para destacar la posición de los iusnaturalistas revolucionarios del siglo XVIII. De nuestra parte, creemos que la expresión se ha asentado porque despoja al concepto de la idea de privilegio y lo aproxima más a la de señorío sobre la obra; en todo caso, es un problema que tiene más que ver con las teorías sobre su naturaleza jurídica, que con los fines prácticos que buscamos a estas alturas.

PLAZA PENADES ${ }^{58}$ incorpora nuevos elementos en la determinación del contenido de la "propiedad intelectual", al explicar que se refiere a la totalidad de los derechos de un autor sobre su obra; es decir, aquellos de orden patrimonial y moral. También aclara, que la expresión es muy próxima a "Propriété Littéraire et Artistique" usada en el derecho francés, debiendo dársele el mismo contenido. En cuanto a la voz "derecho de autor", estudia su arraigo en Alemania e Italia, destacando que pone el acento en los derechos morales del autor, no obstante se refiere a la vez a los derechos patrimoniales y morales, por lo cual puede ser entendida como sinónimo de "propiedad intelectual". Desde otra perspectiva, se hace cargo de la expresión inglesa "Copyright" ${ }^{\prime 59}$, usada para referirse a la totalidad del derecho de autor, en sus dos facetas: patrimonial y moral. Además, recuerda a otros actores que habíamos olvidado, los derechos "afines, vecinos o conexos", los que tienen perfecta cabida dentro del

55 Ob. supra cit. p. 8.

56 PLAZA PENADES, JAVIER. El derecho de autor y su protección en el artículo 20, 1, b) de la Constitución, Tirant Monografías, Valencia, 1997, pp. 173 a 181.

57 El diputado francés inspira la ley francesa de su época sobre Propriété Littéraire et Artistique, llegando a ser célebre un discurso planteado en el congreso francés, donde reivindica que el derecho de autor es pura propiedad, diciendo: "la más sagrada, la más legítima, la más personal de todas las propiedades es la obra (...)".

58 Ob. supra cit., p. 177.

59 Si bien tienen un contenido mucho más restrictivo, puesto que se traduce solamente como derecho de copia, advierte el autor. 
derecho de autor y por lo tanto, son también llamados a atribuir contenido a la voz "propiedad intelectual".

Dentro de este contexto disperso de elementos, posiblemente, en un intento por encontrar una forma uniforme de denominar la institución, el autor citado, destaca las virtudes del sistema español, en cuanto a que la expresión "propiedad intelectual" abarca tanto al derecho de autor, como a los derechos vecinos, afines o conexos. Finalmente, advierte lo inútil de su intento, en el sentido que, aunque las expresiones “intellectual property" y "propriété intellectuel”60 comprendan a la vez, la "propiedad intelectual" en un sentido amplio ${ }^{61}$ y a la "propiedad industrial", ambas son "lo que nosotros conocemos como 'bienes inmateriales' o 'derechos intelectuales'".

A modo de conclusión, PLAZA PENADES ${ }^{62}$ plantea asimismo, que "propiedad intelectual" puede tener tres contenidos diversos: primero como referida a derecho de autor, comprendiendo tanto los derechos morales como patrimoniales ${ }^{63}$; segundo como alusivo a derechos de autor, incluyendo los derechos vecinos, afines o conexos ${ }^{64}$; y tercero, considerando tanto el derecho de autor, los derechos vecinos, afines o conexos y a la propiedad industrial. Este último, es a su juicio ${ }^{65}$, el sentido que le da el artículo $2^{\circ}$, punto 8, del Convenio de 1967, que establece la Organización Mundial de la Propiedad Intelectual (OMPI).

Por nuestra parte, el ejemplo del autor citado es ilustrativo de lo complejo que es buscar el contenido de la "propiedad intelectual", tanto es así, que vemos una cuarta posibilidad, entendiéndola como el género que enmarca todas las formas creativas y otros intereses o derechos, que convencional o legalmente se protejan por esta disciplina. En ese sentido se usa la expresión "Intellectual property rights" en el contexto de la $\mathrm{OMC}^{66}$, puesto que el Anexo 1C, del Acuerdo que Establece la Organización Mundial del Comercio ${ }^{67}$, se titula: "Acuerdo sobre los Aspectos de los

60 Que literalmente y sin dificultad, se traducen como propiedad intelectual.

61 Es decir, incluyendo al derecho de autor y los derechos vecinos, afines y conexos.

62 Ob. supra cit., p. 180.

63 Sería equivalente al sentido del artículo 2 de la Ley 22/1987, Texto refundido de la Ley de Propiedad Intelectual (TRLPI)

64 Sería equivalente al sentido del Libro I y II de la Ley 22/1987, Texto refundido de la Ley de Propiedad Intelectual (TRLPI).

65 Ob. supra cit., p. 181.

66 OMC. Organización Mundial del Comercio.

67 http://www.wto.org/spanish/docs_s/legal_s/legal_s.htm\#wtoagreement (15 Mar 2013). 
Derechos de Propiedad Intelectual relacionados con el Comercio"68. Asimismo, la Parte II de Convenio sobre los ADPIC, se titula "Normas Relativas a la Existencia, Alcance y Ejercicio de los Derechos de Propiedad Intelectual", a cuyo amparo, existen los siguientes subtítulos: 1 . Derecho de autor y derechos conexos; 2 . Marcas de fábrica o de comercio; 3. Indicaciones geográficas; 4. Dibujos y modelos industriales; 5. Patentes; 6. Esquemas de trazado (topografías) de los circuitos integrados; 7. Protección de la información no divulgada; 8 . Control de las prácticas anticompetitivas en las licencias contractuales". Como se aprecia, no sólo se incluye: al derecho de autor en sentido amplio (derechos morales, patrimoniales y vecinos, afines o conexos); institutos propios de la propiedad industrial, como patentes u otros; sino que, también figuran otros, que ni siquiera están mencionados en el Convenio de 1967 que establece la OMPI, como son: la protección de la información no divulgada y el control de las prácticas anticompetitivas en las licencias contractuales.

A efectos de nuestro trabajo, tomaremos la acepción más amplia de "propiedad intelectual" que hemos descrito, es decir, aquella que engloba las formas creativas y otros intereses o derechos, que convencional o legalmente se protejan por esta disciplina, ya sea que se les llame derechos de autor, propiedad intelectual, propiedad industrial, u otros. Desde esta perspectiva, la "propiedad intelectual" se subdivide en tres grupos: 1. Propiedad intelectual propiamente dicha, que es entendida como sinónimo de derecho de autor, comprendiendo la totalidad de los derechos que se pueden incorporar a su amparo, patrimoniales, morales, vecinos, afines o conexos; 2. Propiedad industrial, formada por marcas, patentes, modelos, dibujos, diseños, topografías de circuitos integrados y cualquier otro tipo de desarrollo que origine un quehacer industrial; 3. Otros derechos o intereses protegidos, incorporando aquí, algunas formas creativas que se discute su naturaleza, como son las indicaciones geográficas, software, conocimientos tradicionales, folklore, derechos de obtentores de nuevas variedades vegetales y otros institutos afines, como la protección de la información no divulgada, secretos empresariales, la protección contra la competencia desleal y los descubrimientos científicos.

68 Este acuerdo es conocido por su sigla ADPIC en español y TRIPS en inglés. 


\section{Teorías sobre la naturaleza jurídica de la propiedad intelectual}

\subsection{Introducción}

De cuando en cuando hay quienes dan con una forma de describir un problema que resulta genial, es lo que a nuestro juicio, hace PLAZA PENADES ${ }^{69}$, cuando hablando de la propiedad intelectual, dice: "el problema de la determinación de la naturaleza jurídica ha embriagado desde un principio la materia del derecho de autor" y posteriormente cita a F. RUFFINI, quien sostenía "que no existe en la ciencia jurídica otro campo en que las opiniones se encuentren tan divididas y sean tan diferentes, cuando no totalmente enfrentadas" ${ }^{\text {70 }}$. Así pues, tal como tuvimos oportunidad de apreciar previamente, no existe consenso sobre la denominación que deba usarse para lo que hemos llamado propiedad intelectual, su naturaleza jurídica y tampoco sobre cuál es su contenido específico, de ahí una de las dudas que motivó este estudio.

Sabemos que los convenios de doble imposición, diseñan un mecanismo de compatibilidad entre diferentes soberanías tributarias, para que una determinada renta tenga una calificación equivalente en los países involucrados y por esa vía, soporte un gravamen de manera coordinada. Este objetivo básico de los convenios, se ve frustrado cuando al interior de cada Estado, por las razones que sea, la calificación de la renta cambia, mutando con ello su régimen tributario y la proporcionalidad que previó el CDI.

Ante el incierto escenario sobre la naturaleza jurídica de la propiedad intelectual, más aún, sobre qué debemos entender por tal, nace la duda sobre si esta diferente calificación puede llegar a modificar el equilibrio previsto por un CDI, tal vez lo haga, como también puede suceder que la naturaleza jurídica de la propiedad intelectual sea irrelevante. Como sea, para contestar la pregunta, tenemos que partir por definir: cuál es la naturaleza jurídica y qué se entiende por propiedad intelectual en cada uno de los países que comparemos. Éste es el origen de la necesidad de iniciar el estudio enunciando las diferentes teorías para explicar la naturaleza jurídica de la propiedad intelectual, y junto a ello definir su contenido. Posteriormente, con esas enseñanzas

\footnotetext{
69 Ob. supra cit., p. 103.

70 Ob. supra cit., pp. 103 y siguientes. PLAZA PENADES, citando a F. RUFFINI, en: Visita guiada ao mundo do dereito de autor, separata de Revista da Ordem dos Abogados, Lisboa, 1974, pp. 38 y 39.
} 
como insumo, deberemos revisar la definición constitucional, considerando que, Chile y España han dedicado un espacio a la propiedad intelectual en el texto constitucional.

Para alcanzar nuestro objetivo partiremos con un análisis de las diferentes teorías sobre la naturaleza jurídica de la propiedad intelectual ${ }^{71}$, para posteriormente decantar en el ordenamiento español y chileno. Ya sabemos que para los fines de nuestro estudio, "propiedad intelectual" es el género que engloba la propiedad intelectual propiamente dicha (derecho de autor y conexos), la propiedad industrial (básicamente, patentes y marcas) y otros intereses o derechos protegidos convencional o legalmente por propiedad intelectual. Sin embargo, abordar la naturaleza jurídica de la propiedad intelectual pensando en todas y cada una de sus manifestaciones, es una labor que excede nuestras intenciones y nos desvía de destino; por ello, en esta parte, el análisis lo haremos desde la perspectiva de la propiedad intelectual, involucrando sólo el derecho de autor y de la propiedad industrial, considerando únicamente marcas y patentes.

\subsection{La propiedad intelectual antes de ser un privilegio}

No creemos errar al sostener la existencia de consenso en la doctrina, sobre el hecho que las primeras formas de protección de la propiedad intelectual nacen asociadas a la idea de privilegio. Antes de eso, en Roma no se conoció el derecho de autor como está configurado en nuestros días ${ }^{72}$ y en la Edad Media, lejos de aproximarse a la idea de un derecho erga hommes del autor sobre su obra, se exacerbó el concepto que toda obra se "crea para el disfrute y beneficio de la colectividad"73; así las cosas, considerando esa base, era muy difícil la configuración de un derecho autónomo que otorgase un señorío al autor sobre su obra, en beneficio propio. En cuanto al derecho de

71 Las complejidades para dar con la naturaleza jurídica de la propiedad intelectual, no terminan de quitar el sueño a los autores, existe un abanico de teorías a veces confusas y contrapuestas, por ello, vale anotar que probablemente la descripción más pedagógica del problema pueda encontrarse en DÍEZ-PICAZO, LUIS. Fundamentos del derecho civil patrimonial VI. Derechos reales. Civitas Colección, 2012, pp. 75 y 76.

72 PLAZA. Ob. supra cit., pp. 43 y sgtes. Comenta como en Roma la idea que el autor de una obra se paga con el prestigio que obtiene y no con el dinero, unido a la inexistencia de medios para reproducir las obras, se conforman como los elementos basales que explican la inexistencia de un derecho de autor. No obstante, citando a BOYTHA, G. La Justificación de la protección de los derechos de autor a la luz de su desarrollo histórico, RIDA, 1992, p. 54, recuerda los reclamos de Platón por las transcripciones que se hicieran de sus obras sin justificación. Este tipo de problemas fueron enfrentados por el derecho romano con las acciones comunes, sin desarrollar un sistema específico para ello, de manera que la actio furti que correspondía a la acción por el delito de hurto y la actio iniuriarum, que es la acción penal por injurias (según GARCÍA GARRIDO, MANUEL. Diccionario de jurisprudencia Romana, Dykinson, Madrid, 2000), se transformarían en los medios para otorgar una incipiente protección a los autores.

73 Ob. supra cit., p. 52. 
autor habrá "que esperar a que el progreso de la técnica haga posible la reproducción de objetos en cantidades considerables, para que se sienta con apremio la necesidad de tutela del autor" ${ }^{74}$. Respecto a la propiedad industrial, la situación es equivalente.

En esta época, ante la ausencia de una distinción entre derechos morales y patrimoniales, no hay mucho sentido para buscar diferencias entre la naturaleza jurídica de las creaciones literarias, artísticas, científicas o técnicas, que resultan ser más o menos lo mismo, la principal diferencia se da por cuanto las invenciones conllevan una ventajas competitiva para la industrial que las posee y explota, por lo que resulta interesante revisar la visión del análisis económico del derecho. En este sentido, SÁIZ GONZÁLEZ ${ }^{75}$ demuestra como los primeros sistemas que reconocen derechos sobre las invenciones, se basan en la propiedad colectiva. Es decir, no existe una atribución de los beneficios en la sociedad, representada en la tribu, emperador o rey (según la época); no se trata necesariamente que la "propiedad" del invento quede radicada en ellos, sino que, ante la ausencia de un mecanismo atributivo de derechos en favor del inventor, el invento en sí mismo es posible de ser explotado por toda la comunidad. Para el autor citado, esta característica, que parece tener ventajas, no las tiene, porque fomenta mantener el invento en secreto (para imponerse sobre la competencia), sin estimular la innovación, lo que da origen a la necesidad de estímulos para el fomento del desarrollo técnico; en demostración de ello, relata como Felipe II, el Prudente, ofreció 10.000 coronas para quien desarrollara un invento que permitiera medir la navegación en alta mar, premio que quedó vacante hasta el siglo XVIII.

Desde el punto de vista del derecho, lo relevante es que en este período no existe un planteamiento autónomo frente al asunto, no hay mecanismos específicos de protección y únicamente se observa la adaptación de las figuras del derecho común, como fue el caso de la actio furti y la actio iniuriarum en el derecho romano ${ }^{76}$.

Esta titularidad colectiva de que hablamos, la van a ejercer posteriormente en la edad media, los gremios y corporaciones, puesto que "el desarrollo de los gremios

\footnotetext{
74 Ob. supra cit., p. 52.

75 SÁIZ GONZÁLEZ, J. PATRICIO. Invención, patentes e innovación en la España Contemporánea, Publicación de la OEPM, Madrid, 1999, pp. 33 y sgtes.

76 LACRUZ BERDEJO, JOSÉ LUIS. Elementos de derecho civil: Derechos reales, Dykinson, Madrid, 2003, p. 341 .
} 
profesionales se basa en el control del conocimiento técnico"77, manteniendo en secreto al interior del gremio las invenciones y, en cuanto, la identidad del gremio le da su sello y se constituye en un activo para el grupo ${ }^{78}$, es decir, una verdadera marca comercial.

\subsection{La propiedad intelectual como un privilegio}

Los privilegios son invariablemente citados como el antecedente remoto de la propiedad industrial $^{79}$, sin embargo, ello no debe llevarnos a entender que se trata de un anticipo de la concepción de propiedad sobre una obra, de un germen de derecho con perfiles propietarios, puesto que, un privilegio se fundaba en la potestad del rey y tenía una justificación y efectos muy distintos a un derecho con contenido de propiedad.

SÁIZ GONZÁLEZ ${ }^{80}$ nos explica, como en el Antiguo Régimen la división social básica se da entre privilegiados y no privilegiados, prerrogativas que se obtienen por "gracia", es decir por voluntad y arbitrio del rey, generalmente asociadas a vínculos de sangre, en pago a la gesta, a la ayuda o a la contribución social, etc. Los privilegios se extienden a toda la actividad humana, a la posibilidad de comerciar, fabricar, etc., por lo que, la idea de vincularlos a la eventualidad de explotar comercialmente una obra ${ }^{81} \mathrm{o}$ un invento, resulta completamente coherente con el sistema imperante. Recordemos, que hasta ese momento, la concepción del derecho de autor o de explotación comercial de una obra, no estaba en el subconsciente de la sociedad; lo propio sucedía con los inventos, de los cuales si bien podría obtenerse una ventaja comercial, no había una relación con la noción de un "propietario inventor". De manera que, la idea de privilegio resulta una apacible conexión entre esa concepción y la posibilidad de atribuir derechos que permitieran aprovecharse de los beneficios.

Normalmente, se explica el aparecimiento de los privilegios como una respuesta a la invención de la imprenta, en tanto posibilitó la explotación comercial de las obras ${ }^{82}$, en tanto, la imprenta permitió "que las obras de los autores pudieran ser objeto de

\footnotetext{
SÁIZ. Ob. supra cit., pp. 40 y sgte.

En este sentido: LACRUZ y SÁIZ. Obs. supra cit., p. 341, 40 y sgte., respectivamente.

PLAZA. Ob. supra cit., pp. 53 y sgtes.

SÁIZ. Ob. supra cit., pp. 49 y sgtes.

81 Alternativa posible desde la invención de la imprenta a mediados del siglo XV.

82 En ese sentido: PLAZA. Ob. supra cit., pp. 51 y sgtes.
} 
tráfico y explotación comercial" ${ }^{\prime 3}$, sin embargo, el privilegio es una figura mucho más asentada y con consecuencias que le son muy propias. Al respecto, SÁIZ GONZÁLEZ $^{84}$ hablando de patentes, pone de manifiesto una cuestión que es igualmente aplicable al derecho de autor, consistente en que frente a la posibilidad de recibir el "real privilegio", es perfectamente coherente y necesario, exigir la demostración del funcionamiento y viabilidad ${ }^{85}$ del invento y también, requerir de una rentabilidad o provecho en el caso de las obras literarias o artísticas. Coincidente con esta visión, en el privilegio otorgado por el monarca a don MIGUEL DE CERVANTES SAAVEDRA, por su obra El ingenioso hidalgo de la Mancha, podemos leer: "Por cuanto de parte de vos Miguel de Cervantes, nos fue hecha relación que habíades compuesto un libro intitulado EL INGENIOSO HIDALGO DE LA MACHA, el cual os había costado mucho trabajo y [era muy útil y provechoso] (...)"86. Como se aprecia, el privilegio tienen toda una dogmática que lo justifica, donde no sólo es relevante el trabajo invertido por el autor o inventor, sino que también la utilidad y el provecho o aporte a la sociedad.

Las ciencias económica y jurídica, cada una por su parte, interpretan, explican y justifican los fenómenos sociales en que se desenvuelve la vida del ser humano, sin que propiedad intelectual sea la excepción, puesto que, es objeto de ambas ciencias, que buscan su razón de ser y justificación. Es posible advertir, tanto desde un punto de vista económico como jurídico, que la invención de la imprenta marca un momento de inflexión en la materia, lo que hacen presente: DANVILA Y COLLADO ${ }^{87}$ al decir que "[1]a imprenta ha producido para la propiedad intelectual, poco más o menos, los mismos efectos que la invención del arado produjo a la propiedad territorial”; SÁIZ GONZÁLEZ, cuando comenta: "El privilegio cumple la función de incentivar a los agentes económicos hacia la actividad inventiva $\mathrm{y}$, por tanto, a dar el paso previo hacia

83 Ob. supra cit., p. 53, citando a BOYTHA, G. La justificación de la protección de los derechos de autor a la luz de su desarrollo histórico, Revista Internacional de Derechos de Autor (RIDA), 1992, pp. 52 y sgtes.

${ }^{84}$ Ob. supra cit., pp. 49 y sgtes.

85 La posibilidad de exigir la demostración del funcionamiento y utilidad de la invención es una cuestión muy controvertida en el derecho de patentes. Desde el punto de vista económico, se piensa que exigirlo es una barrera de entrada puesto que pone de cargo del inventor los costes de su demostración. En la actualidad, no conocemos países que lo exijan como requisito de patentamiento en general, pero si lo hacen de manera puntual, como por ejemplo, en Chile se exige para permitir el patentamiento de los segundos usos médicos. Artículo 37, letra e), de la Ley $\mathrm{N}^{\circ} 19.039$ sobre Propiedad Industrial.

86 Extractado de PLAZA PENADES. Ob. supra cit., p. 57.

87 DANVILA Y COLLADO, MANUEL. La propiedad intelectual: Legislación española y extranjera. Imprenta de la Correspondencia de España, 1882, digitalizado en 2010, p. 44. 
la innovación y el crecimiento económico"88; y, PLAZA PENADES, al expresar: "[e]1lo justifica la aparición del privilegio de impresión, ya que mediante una concesión graciosa se otorgaba un monopolio a los impresores, para asegurar, por esta vía, el buen éxito de sus inversiones" ${ }^{\prime \prime}$.

En lo que no hay uniformidad es si los privilegios vinieron a proteger a autores, impresores o a ambos. Para LACRUZ BERDEJO"90, "la primera solución no viene determinada por la necesidad de tutela de los autores, sino de los impresores -en función de editores- que precisaban del monopolio de la obra impresa por ellos", a fin de asegurar la rentabilidad de la inversión en imprimir la obra, con ese fin recurrían al rey, a objeto de ser los únicos editores por un tiempo determinado, que les asegurara recuperar lo invertido. El derecho del autor, no obtenía un amparo de manera directa, sino a través del editor, salvo que la obra se hubiese impreso a expensas del propio autor. En el mismo sentido, se pronuncia PLAZA PENADES ${ }^{91}$, quien destaca que el privilegio evoluciona desde la protección del editor, hasta la consagración de la atribución de la titularidad del privilegio al autor.

Otras investigaciones sobre el asunto, han demostrado que desde un principio se concedieron privilegios a los autores e incluso que se les otorgaron más privilegios a ellos que a los editores, de lo que se deduce que el contenido patrimonial en beneficio del autor, estuvo siempre presente y no es un brote propio o exclusivo de la concepción del derecho de autor como derecho natural y propietario, que lo caracteriza desde la revolución francesa en adelante ${ }^{92}$.

88 SÁIZ. Ob. Cit., pp. 51.

89 Ob. supra cit., p. 55.

90 Ob. supra cit., p. 341.

91 Ob. supra cit., p. 54.

92 PLAZA PENADES. En ob. supra cit., p. 56, resume claramente la polémica doctrinal dada en Alemania en los años 60, al decir: "POHLMANN deseaba que se realizase una profunda revisión de las concepciones tradicionales sobre el desarrollo histórico de los derechos de autor. La postura hasta entonces dominante era la proveniente de KOHLER que situaba el origen de los derechos de autor en las teorías de la propiedad intelectual del siglo XVIII. Sin embargo, POHLMANN acometió una importante labor de búsqueda de documentos en diferentes archivos y encontró nuevos materiales que permitieron sostener que el número de privilegios de impresión concedidos a los autores fue mayor de los que hasta ahora se había conocido y que excedían considerablemente al número de privilegios concedidos a impresores y editores. Así, sobre este material, propuso una nueva construcción histórica de los derechos de autor en Alemania, sobre la base de defender la existencia de que el beneficiario del privilegio también fue, en bastantes ocasiones, el autor. Además no sólo confirmó las viejas investigaciones que reconocen que desde el renacimiento existió cierta protección de los intereses personales, sino que dio un paso más en este sentido al sostener que la parte o el aspecto patrimonial 
En nuestra opinión, las diferentes posiciones sobre el asunto son interesantes, pero se observa que los autores hacen un contrapunto personal sobre la materia, de manera de demostrar la superioridad de una posición sobre la otra. A nosotros nos parece más coherente seguir a SÁIZ GONZÁLEZ ${ }^{93}$, cuando dice no creer en la generación espontánea de los procesos, sino que su correspondencia a una línea ascendente que culmina en un hecho particular y más identificable, de manera que el origen de los cambios del siglo XVIII y principios del XIX, son el resultado del renacimiento y de una nueva concepción del mundo basada en la cultura, tendencia donde la propiedad intelectual se desarrolla sobre la base del avance de las teorías económicas, el análisis del capital y los factores de la producción, dentro de las reglas de lo que será el sistema económico capitalista. Desde esta perspectiva, tanto el editor como el autor, son parte de los medios de producción y coexisten en una interdependencia necesaria, siendo irrelevante cuál de ellos tiene el control del privilegio de impresión, puesto que el producto final, no podrá nacer sin la concurrencia de ambos. En consecuencia, no es importante si se dieron más o menos privilegios para el autor o el editor, lo relevante en este momento, es advertir que el sistema muta desde la ausencia total de reconocimiento, pasando por los privilegios, para llegar a un estado vinculado al derecho natural y la propiedad, en manos del autor de una obra.

Por su parte, al hablar en específico de privilegios e invenciones ${ }^{94}$, no podemos dejar de atender dos cuestiones esenciales, una de ellas es que el Estado, como partícipe de la invención, es el garante de la novedad" ${ }^{95}$, "por tanto, se convierte también en el que debe comprobar, mediante sus técnicos, la utilidad de la invención. En numerosas ocasiones, incluso tiene que ofrecer soporte y ayuda al inventor para que pueda materializar sus ideas" ${ }^{\prime 96}$; y, la otra, es que los privilegios no están conformados para estimular solamente la actividad creativa, la invención no se entiende como un

de los derechos de autor fueron reivindicados en los privilegios, siendo su contenido la facultad del autor de decidir sobre su publicación".

93 Ob. supra cit., p. 49.

94 Cuándo se otorgó el primer privilegio es aún una pregunta sin respuesta, sin embargo, tradicionalmente se menciona como primer privilegio, el otorgado por la República de Florencia al arquitecto Brunelleschi, por una barcaza con grúa para el transporte de mármol. La primera ley de patentes, se publicó en Venecia el 15 de marzo de 1474, donde por primera vez, se establecieron derechos exclusivos sobre la invención.

95 Por novedad entendemos el concepto de patentes, es decir, que el invento no haya existido previamente en el estado de la técnica.

96 Ob. supra cit., p. 50. 
desarrollo que "no tiene solución equivalente en el estado del arte" $"$, sino que, los privilegios están destinados a estimular la industria, por ello se pueden ver privilegios para inventos que no son nuevos, sino simplemente introducidos por primera vez en el país o la instalación de industrias que no existían antes ${ }^{98}$.

\subsection{La propiedad intelectual como propiedad}

Tal como anota LACRUZ BERDEJO 99 , “[en] general, a partir de la revolución francesa, la doctrina y los legisladores admiten la existencia de un derecho subjetivo natural del creador de la obra literaria o artística, el invento o la marca, que la Ley reconoce condicionado o no (según los casos y países) al cumplimiento de ciertas formalidades". Así pues, según venimos analizando, superado el Antiguo Régimen y a la luz de las nuevas ideas liberales, la concepción del derecho natural y los estudios sobre economía, se fue uniformando la idea que en la creación de las obras literarias y artísticas, inventos y marcas, existía la expresión personal de cada individuo sobre la cual se conservan derechos ejercitables erga homnes. En el mismo sentido y al igual como nosotros lo hiciéramos, para PLAZA PENADES ${ }^{100}$ no puede obviarse en este punto el discurso del diputado LE CHAPELLIER, que declara en el Congreso francés: "la más sagrada, la más legítima, la más personal de todas las propiedades es la obra (...)".

Para quienes la propiedad intelectual es propiedad, tiene su origen en el derecho natural y por tanto, su nacimiento y existencia está asociada indisolublemente a un creador, de la misma manera no admite limitaciones injustificadas ${ }^{101}$, su contenido y extensión están dados por el derecho de propiedad civil, entregando la totalidad de los facultades que se pueden tener sobre una cosa. En este sentido, no es admisible a este

97 Esa es tal vez, la definición más difundida de novedad, en materia de patentes.

98 En esto se aprecia claramente la mezcla que se va dando entre la teoría económica y el derecho, puesto que las patentes son usadas para estimular el desarrollo económico y la innovación, paradigma que había sido planteado por la ciencia económica como el medio para obtener el bienestar. Así pues, en Inglaterra, durante el siglo XVII se concedieron privilegios de invención para otorgar ventajas comerciales, amparándose en que eran "inventores" los que inauguraban una nueva forma de comercio; en la primera ley de patentes de los Estados Unidos de Norteamérica de 10 de abril de 1790, se contemplaron las "patentes de importación"; y, en España, SÁIZ. Ob. supra cit., p. 79, nos cuenta como entre 1770 y 1818, logró documentar 40 privilegios de invención o introducción. Con este último nombre se refiere a aquellos privilegios que dicen relación con la implementación de una nueva industrial que es "introducida" en España, que no es necesariamente un invento nuevo.

99 LACRUZ. Ob. supra cit., p. 342.

100 Ob. supra cit., p. 106.

101 Ob. supra cit., p. 106. 
derecho, más limitaciones que las comunes a cualquier propiedad. En la época, se busca despojar a los derechos del hombre de cualquier rasgo de privilegio, de manera que la propiedad se erige como un derecho que sólo cabe sea constatado ${ }^{102}$. Llevada esta concepción a la propiedad intelectual, no hay en ella bondad, beneficio o trato de favor de autoridad alguna, simplemente la expresión de un derecho esencial a la naturaleza humana.

La consagración de esta postura, subyace en la Declaración Universal de los Derechos del Hombre y del Ciudadano, efectuada en Francia, el 26 de agosto de 1789, donde se declara el derecho de propiedad (artículo $2^{\circ}$ ) y el derecho a "[l]a libre comunicación de pensamientos y de opiniones (...); en consecuencia, todo ciudadano puede hablar, [escribir e imprimir libremente] (...)"103; y, también, de una manera un poco más extensa, al incluir expresamente a autores e inventores, en la Constitución de los Estados Unidos de Norteamérica, que en 1787, en el artículo I, sección 8, cláusula 8, (en la llamada Cláusula del Progreso) estableció el derecho exclusivo sobre "sus respectivos escritos y descubrimientos" ${ }^{\text {"104 }}$. En el derecho español, a juicio de CHICO ORTÍZ, ${ }^{105}$ la consolidación de la propiedad intelectual como propiedad, se produce en España con la dictación del Código Civil de 1899, cuyo Título IV, Libro $2^{\circ}$, trata de las "propiedades especiales", de donde nace todo el amparo que la propiedad intelectual necesitaba, a lo que suma la propiedad en general, en tanto supletoria.

Refiriéndose específicamente a patentes de invención, MARTÍN ARESTI ${ }^{106}$ deja claro que su naturaleza jurídica ha sido estructuralmente asimilada al derecho de propiedad, "en cuanto esta constituye la situación de máximo poder jurídico que puede ostentar una persona respecto de un bien"107.

102 Ob. supra cit., pp. 106 y siguiente.

103 Accesible por medio de formato electrónico: http://www.fmmeducacion.com.ar/Historia/Documentoshist/1789derechos.htm (30 Mar 2013).

104 El objeto era fomentar el progreso de la Ciencia y las Artes útiles, asegurando a los autores e inventores, por un tiempo limitado, el derecho exclusivo sobre sus respectivos escritos y descubrimientos.

105 CHICO ORTÍZ, JOSÉ MARÍA. Principios y Problemas de la Propiedad Intelectual, Revista General de Legislación y Jurisprudencia, $\mathrm{N}^{\circ}$ 3, Madrid, 1984. p. 361.

106 MARTÍN ARESTI, PILAR. La Licencia Contractual de Patente, Edit. Aranzadi, Pamplona, 1997, p. 32.

107 Como se aprecia, lo que venimos diciendo de la propiedad intelectual en general, aplica tanto a la propiedad intelectual propiamente tal y a la propiedad industrial, de manera que, cuando menos hasta este momento, no cabe hacer distingos entre la concepción de la naturaleza jurídica que pudiese haber entre aquellas. 


\subsubsection{Críticas a la concepción de la propiedad intelectual como propiedad}

LACRUZ BERDEJO $^{108}$ advierte que a la concepción de la propiedad intelectual con carácter propietario se llegó por inercia, como una manera de preservar su carácter de erga omnes ${ }^{109}$, para luego, resumir las razones por la cuales no es posible considerar a la propiedad intelectual como una propiedad, al menos en el sentido civil tradicional. Al respecto, identifica: que la concepción propietaria solamente explica la faz pecuniaria del derecho, su explotación, pero no da cuenta de los derechos morales del autor; que el derecho de propiedad conforme se constituye en el Código Civil Español, únicamente permite su ejercicio sobre bienes corporales y la propiedad intelectual es un incorporal; y, que en la propiedad intelectual hay siempre "un quid de naturaleza espiritual" ${ }^{110}$, que la concepción propietaria no puede explicar.

Por su parte SALAZAR REYES-ZUMETA, ${ }^{111}$ agrega dos objeciones a la concepción propietaria de la propiedad intelectual, por un lado advierte que no se asemeja a la propiedad romanista, porque la transferencia del objeto material donde está fijada la obra, no transfiere la propiedad intelectual y además, porque no se consideran los derechos morales.

También son importantes las objeciones que recoge GARCÍA LÓPEZ ${ }^{112}$, al decir que la propiedad intelectual es distinta de la propiedad civil, respecto de: su nacimiento, por cuanto la propiedad nace por la adquisición del dominio mediante ocupación, donación, tradición u otro modo de adquirir del código civil y la propiedad intelectual nace del acto propio de creación de la obra; su contenido, por cuanto la propiedad carece del derecho moral, que es un atributo propio de la propiedad intelectual; la forma de transmitirla, ya que la propiedad intelectual no puede transmitirse en bloque, al contener facultades que son inalienables e irrenunciables para su autor, lo que no sucede con la propiedad común, que se transmitirse en su conjunto.

${ }^{108}$ LACRUZ. Ob. supra cit., p. 342.

109 En el mismo sentido de LACRUZ, encontramos a MARCO MOLINA, JUANA. Bases históricas y filosóficas y precedentes legislativos del derecho de autor, revista Anuario de Derecho Civil, 1994, pp. 121 y sgtes. Para ella, la capacidad de ejercerse erga omnes es clave para la conceptualización de la propiedad intelectual como propiedad.

${ }^{110}$ Ob. supra cit., p. 342.

111 SALAZAR REYES-ZUMETA, LEONEL. Aproximación Teórica a la Naturaleza Jurídica de los Bienes Inmateriales y del Derecho de Propiedad Intelectual, Rev. Propiedad Intelectual, $\mathrm{N}^{\circ} 13$, enerodiciembre, 2010, Mérida-Venezuela, pp. 20-71.

112 GARCÍA LÓPEZ, DANIEL. Aproximación crítica a la propiedad intelectual: la cultura como valor para la democracia. Revista Telemática de Filosofía del Derecho, nº 10, 2006/2007, ISSN 1575-7382, pp. 207-244. www.filosofiayderecho.com/rtfd (30 Mar 2013). 


\subsubsection{La propiedad intelectual como una propiedad especial}

Ante las críticas a la concepción propietaria, han surgido quienes, tal vez por las razones que hemos venido exponiendo, en el sentido que la propiedad garantiza el más amplio crisol de derechos que se puede tener sobre una cosa, por la flexibilidad de la concepción romanista de la propiedad, por mera nostalgia de la concepción de propiedad o por las razones que sea, mantienen la idea que la propiedad intelectual es una auténtica propiedad, salvo que dotada de características especiales, es decir, una "propiedad especial"113. En apoyo de esta posición, se argumenta como el más célebre de los defensores de la naturaleza propietaria de la propiedad intelectual, LE CHAPELLIER, admitía "su naturaleza completamente distinta a las otras propiedades" 114 .

Las características de la propiedad intelectual que la harían "especial", son aquellas vinculadas a su naturaleza inmaterial y temporalidad, puesto que la propiedad recae ${ }^{115}$ solamente sobre bienes corporales y además es perpetua. Adicionalmente, en el caso de las patentes, se trata de un derecho subjetivo patrimonial que nace por acto administrativo, lo que si bien no lo priva por completo de sus rasgos propietarios, lo pone "en una situación ambigua"" decir que "[1]os derechos de propiedad intelectual se [asemejan] a cualquier otro derecho de propiedad" "117, en la medida que el uso del verbo "asemejar", sugiere algo parecido a un derecho de propiedad, pero no igual.

Para CORTÉS GIRÓ, ${ }^{118}$ en la frase: "A la sociedad algo se le debe por haber transmitido al autor sus conocimientos", se resume la justificación de concebir a la propiedad intelectual como una propiedad especial, puesto que existirían intereses contrapuestos entre la sociedad y el propietario.

${ }^{113}$ En este sentido: LACRUZ. Ob. supra cit., p. 343; y, OTERO GARCÍA-CASTRILLÓN, CARMEN. Las Patentes en el Comercio Internacional, Edit. Dykinson, Madrid, 1997, p. 37.

114 PLAZA. Ob. supra cit., p. 111.

115 Al menos en el Código Civil Español.

${ }^{116}$ OTERO. Ob. supra cit., p. 37.

${ }^{117}$ Folleto de difusión, disponible en: http://www.wipo.int/freepublications/es/intproperty/450/wipo pub 450.pdf (02 May 2013).

118 CORTÉS GIRÓ, VICENTE. Derecho de Propiedad Intelectual, Editorial Marfil, Alcoy, 1957, pp. 16. 
Al analizar las teorías sobre la naturaleza jurídica de la propiedad intelectual, DÍEZ-PICAZO ${ }^{119}$ efectúa un análisis semejante, con la diferencia que se refiere a este grupo de teorías, como aquellas que entienden la propiedad intelectual como "un derecho patrimonial de naturaleza absoluta, idéntico o semejante al derecho de dominio".

\subsection{Ausencia de derechos subjetivos en la propiedad intelectual}

Al revisar la historia del derecho de autor, podemos observar como normalmente los escritores parten con el Estatuto de la Reina Ana, de 1710, sin embargo, desde muy antiguo existía preocupación por la vinculación de la obra y su creador ${ }^{120}$, de manera que, antes de las revoluciones Francesa y Americana es común que se estime que la retribución del autor viene dada por el prestigio social del mismo. Bajo esa línea de pensamiento, no hay un derecho subjetivo en exclusiva a favor del autor o creador ${ }^{121}$. Es con los monopolios que nacen de los privilegios, en donde comienza a verse un interés de los autores por reivindicar su creación ${ }^{122}$, en términos de buscar la atribución de derechos de comercialización exclusiva sobre sus obras.

Si bien, fue muy claro que entre las diferentes teorías sobre el derecho de autor, después de la Revolución Francesa, ganó la posición de atribuirle perfiles propietarios, ello no fue suficiente para desaparecer a quienes negaran este carácter a la propiedad intelectual y la proclamaran como un bien público. Bajo esta perspectiva, PLAZA PENADES $^{123}$, recuerda como PROUDHON ${ }^{124}$, en 1863 , negó al autor cualquier derecho sobre su creación, estimando que las obras son del dominio público. Fundados en antiguas concepciones y en la idea que la propiedad intelectual conforma monopolios que son dañinos para la economía, se planteó la ausencia de derechos subjetivos del

${ }^{119}$ DÍEZ-PICAZO. Ob. supra cit., pp. 77 y sgte.

${ }^{120}$ PLAZA. En ob. supra cit., p. 108, nos recuerda como en los pensamientos de Platón existía preocupación por las copias de sus escritos. Lo mismo podemos ver en el año 25 a.c., puesto que Marco Vitruvio, en su Libro Séptimo, De architectura, decía: “Ahora bien, así como hay que tributar merecidas alabanzas a éstos, incurren en nuestra severa condenación aquellos que, robando los escritos a los demás, los hacen pasar como propios. Y de la misma manera, los que no sólo utilizan los verdaderos pensamientos de los escritores, sino que se vanaglorian de violarlos, merecen reprensión, incluso un severo castigo como personas que han vivido de una manera impía".

${ }^{121}$ El vocablo "creador" lo usamos como sinónimo de inventor, para referirnos a patentes de invención.

${ }^{122}$ Lo vimos muy claramente al transcribir el privilegio reconocido a CERVANTES, por su obra: El Ingenioso Hidalgo de la Mancha.

123 PLAZA. Ob. supra cit., p. 107.

${ }^{124}$ PROUDHON, P. J. Les Majorats Littéraires, Examen d'un Project del Loi, Edit. Petrony, Lisboa, 1985, citado por PLAZA. Ob. supra cit., p. 107. 
autor o creador sobre sus obras e invenciones, resultando bienes $a b$ initio, comunes a todos los hombres.

Actualmente, el análisis económico muestra que entre la ausencia de un titular de los bienes -propietario, en términos jurídicos- y la asignación privada de los mismos, el último sistema favorece que "los agentes económicos tenga en cuenta costes sociales que de otra manera se olvidan"125. Es decir, económicamente es más rentable la propiedad privada de los derechos de autor, que mantenerlos como un bien de dominio público $^{126}$, lo que justifica desde el punto de vista del análisis económico del derecho, la existencia de derechos de propiedad intelectual como actualmente los conocemos, es decir, bajo formas de propiedad temporal privada ${ }^{127}$.

Se argumenta a este respecto que el pensamiento humano, dado su carácter inmaterial, carece de los atributos necesarios, del ser necesario, para ser apropiable, de manera que le pertenecen siempre a la comunidad, en la medida que en las obras y en los inventos hay un sustrato cultural, moral, religioso, político, etc., pues cada avance ha usado y se ha provisto de los medios y recursos con que cuentan la sociedad en un momento determinado, por lo que "las ideas que parecen nuevas son debidas, más que al esfuerzo individual del autor, al fondo común de la cultura de cada sociedad"128.

\subsection{Derecho subjetivo que protege la expresión de una idea y no la idea}

Como acertadamente advierte PLAZA PENADES ${ }^{129}$, lo verdaderamente significativo de la lucha entre partidarios y detractores del derecho de autor, en el sentido de entregar o no a los autores un derecho subjetivo que les permitiera el control sobre la explotación comercial de su obra, no fue sólo el triunfo de quienes defendían la existencia de un derecho de autor sobre su creación, argumentando que la obra es "propiedad de su creador", sino que, debe destacarse la precisión que nace de analizar el

125 SÁIZ. Ob. supra cit., p. 37.

${ }^{126}$ Notable sobre la materia es el artículo sobre la materia de ALCHIAN.A y DEMSETZ. H. El Paradigma de los Derechos de Apropiación, Hacienda Pública Española, Nº 68, 1981.

${ }^{127}$ En cuanto a la temporalidad, probablemente deberíamos haber hecho la salvedad: "con excepción de las marcas y la Indicaciones Geográficas", pero no tenemos claro si valga la diferencia, en la medida que respecto de las marcas si bien la propiedad es indefinida, deben renovarse periódicamente y además, en muchos lugares, debe usarse. En lo relativo a las Indicaciones Geográficas, la propiedad se radica en un colectivo comunal, lo que las hace incomparables con el resto de los derechos de propiedad intelectual.

128 PLAZA. Ob. supra cit., p. 108.

129 Ob. supra cit., p. 109. 
objeto protegido, puesto que se concluye, que lo protegido no son las ideas, en sí mismas inapropiables y a disposición de todos, sino que lo que ampara el derecho de autor, es la forma como las ideas se expresan ${ }^{130}$. Esta posición doctrinal, tomó escala planetaria y actualmente, está difundida de manera que es posible encontrarla por doquier, por ejemplo, en folletos de difusión del derecho de autor se dice: "El derecho de Autor protege la forma en que se expresan las ideas" ${ }^{\text {"131 }}$, y la propia OMPI, explica la extensión del derecho de autor y la escala universal de este principio, cuando señala: "La protección por derecho de autor abarca únicamente las expresiones pero no las ideas, procedimientos, métodos de operación o conceptos matemáticos en sí. Este principio queda confirmado en el Acuerdo sobre los Aspectos de los Derechos de Propiedad Intelectual relacionados con el Comercio (ADPIC) de la Organización Mundial del Comercio (OMC) y en el Tratado de la OMPI sobre Derecho de Autor"132.

En materia de patentes, si bien este paradigma no ha sido trasladado con nivel de principio, la verdad es que del análisis del sistema podemos advertir claramente su presencia. En efecto, la generalidad de las leyes de patentes exigen la novedad ${ }^{133}$ como requisito ineludible de patentamiento ${ }^{134}$. En general, se considera que una invención es nueva "cuando no está comprendida en el estado de la técnica" 135 . Lo importante es que aquello comprendido en el estado anterior de la técnica, carece de novedad y no puede ser objeto de patente, por constituir simple copia, carente de actividad creativa del inventor. Trasladando estas ideas al principio que lo protegido es la expresión de la idea y no ella en sí misma, es posible descubrir un símil que hace el asunto casi equivalente. Así pues, la sola existencia de un invento en el estado del arte no impide la creación de otros que funcionen sobre la base de la misma idea, necesidad o busquen solucionar el mismo problema técnico. Por ejemplo: el uso del principio activo X para el tratamiento del cáncer, no significa que no se pueda desarrollar el uso del principio activo X para el tratamiento de la hipertensión o el uso de otro principio activo para el tratamiento del cáncer; más claro aún, el uso del mismo principio activo X para el tratamiento del

\footnotetext{
${ }^{130}$ En este sentido, LATORRE. Ob. supra cit., p. 47.

${ }^{131}$ Folleto difundido por el Ministerio de Educación y Cultura de España, disponible en: http://www.mcu.es/propiedadInt/docs/MC/GuiaOMPI/Derechos_Autor_C.pdf (10 Abr 2013).

132 Disponible en el sitio web de OMPI, en preguntas frecuentes sobre derecho de autor en: http://www.wipo.int/copyright/es/faq/faqs.htm (10 Abr 2013).

133 A modo de ejemplo: la ley española la contempla en el artículo $4^{\circ}$ de la Ley $11 / 1986$, de Patentes; el legislador chileno la ubicó en el artículo 32 de la Ley $N^{\circ} 19.039$, sobre Propiedad Industrial.

134 En los países de fuente anglosajona, el equivalente es "novelty", cuyo contenido es semejante, pero no idéntico.

135 Artículo $6^{\circ}$ de la Ley 11/1986, de 20 de marzo, de Patentes.
} 
cáncer, cuando éste es obtenido por un método diferente que lo hace mucho más efectivo. Es decir, la patente de un principio activo para mejorar el cáncer, no significa la protección de todas las formas posibles en que esta idea se puede expresar ${ }^{136}$.

Los autores han tratado este asunto sin clasificarlo dentro de la naturaleza jurídica de la propiedad intelectual, sin embargo a nosotros nos parece de mucha relevancia, particularmente cuando hablamos de la tributación asociada, en cuanto las preguntas que surgen, pueden tener una solución en la observación de esta característica de la propiedad industrial, que al final del día, no es más que una descripción de su propia naturaleza, así por ejemplo: la licencia desde España a Chile, para el uso de una tecnología que permita la instalación de una chimenea solar, que además, por diferencias de presión mueve una turbina y produce energía eléctrica: ¿Conlleva verdaderamente un conocimiento protegido o protegible por patentes? ¿Estamos frente a una manifestación de propiedad intelectual que puede subsumirse en el concepto de cánones, en el sentido del MC de la OCDE? En principio, probablemente, estaremos frente a cánones, pero pudiese ser solamente asistencia técnica, para lo cual será un indicador potente saber si la idea basal del invento es protegible vía patente o se trata de un conocimiento del dominio público.

${ }^{136}$ Como manera de ejemplificar lo que decimos, es útil revisar las Directrices de Examen de Patentes de la OEPM, que en esto son muy semejantes a las de la EPO y han sido seguidas por Chile. Al efecto, las Directrices al enseñar la forma de analizar las reivindicaciones de patentes, ponen ejemplos de qué entienden por un invento nuevo, de los cuales se puede apreciar, cómo es que no se protegen las ideas contenidas en los inventos, sino la forma como ellas se expresan. Los ejemplos son, entre otros: "Ejemplo 1: una reivindicación relativa a una sustancia $\mathrm{X}$ destinada a ser utilizada como catalizador no será considerada una novedad en relación con la misma sustancia conocida como colorante, salvo que la utilización prevista implique una forma particular de esa sustancia (por ejemplo, por la presencia de ciertos aditivos) que la distinga de la forma ya conocida. Es decir, deben tomarse en consideración las características que sin indicarse explícitamente, estén implicadas implícitamente en su uso particular". Como se aprecia, la idea de usar la sustancia X como catalizador puede ser usada por un tercero, en la medida que aunque hagan lo mismo y sirvan para idéntico propósito, se le de una forma particular; 'Ejemplo 2: si una reivindicación hace referencia un 'molde de acero fundido', esto implica ciertas limitaciones del molde. Por ello, no quedaría cubierto por la reivindicación una bandeja de plástico para cubitos de hielo con un punto de fusión muy inferior al del acero, y la reivindicación respondería al criterio de novedad". En otras palabras, la idea de hacer cubitos de hielo, se puede alcanzar por múltiples vías, lo que implica que la idea no está protegida, sino que la forma de ejecutarla; 'Ejemplo 3: 'Una rueda para una bicicleta,' es muy distinta de una rueda para un vagón de ferrocarril, y por tanto, existiría novedad", podemos ver en este ejemplo, que la idea de rueda como artículo que gira, no estuvo protegida, sino que la manera como se expresó para hacer funcionar una bicicleta o un tren; "Ejemplo 4: 'Un motor eléctrico para impulsar un submarino", sería muy distinto de un motor eléctrico para un reloj de pulsea, y por tanto, existiría novedad", de manera que la idea de hacer girar un eje con energía eléctrica (motor eléctrico) no estuvo protegida en sí misma, sino de la forma como se expresó. 
PLAZA PENADES ${ }^{137}$ nos recuerda la sobresaliente explicación que da del asunto el profesor SÁNCHEZ ROMAN ${ }^{138}$, al decir: "que las ideas no son de nadie, sino de quien las dice -expresa- como nadie".

Si bien debemos coincidir en el sentido que esa característica de la propiedad intelectual no da con una posible descripción de su naturaleza jurídica ${ }^{139}$, estimamos que define completamente el contenido de la propiedad intelectual, puesto que, finalmente, se trata de la protección ofrecida por un derecho subjetivo que no ampara un bien inmaterial en sí mismo, sino la manera como éste se expresa.

\subsection{La propiedad intelectual como derecho sobre bienes inmateriales}

Esta teoría atribuida $\mathrm{KOHLER}^{140}$, parte de la base que el dominio civil, en términos romanos, aplica a las cosas materiales, no obstante la obra es una creación inmaterial, carente de corpus, por lo que el derecho de autor es un derecho absolutocomo la propiedad- pero se distingue de ella, en que recae sobre un bien incorporal. Para esta posición, las cosas son entes físicos sobre los que se ejerce un señorío físico, por otro lado están las creaciones intelectuales, desprovistas de materialidad, lo que "impide cualquier organización jurídica, pero unas y otras [las cosas materiales $e$ inmateriales] son entes autónomos sobre los que se refleja un poder jurídico, y por consiguiente el objeto jurídico es irreductible al sistema de cosas materiales" ${ }^{141}$.

En el mismo sentido, ASCARELLI ${ }^{142}$ planteó que "[n]inguna creación intelectual puede ser percibida independientemente de una exteriorización material en cosas o energías (...)", son precisamente las múltiples posibilidades de expresión de

137 PLAZA. Ob. supra cit., p. 109.

138 SÁNCHEZ ROMÁN, J. Derecho civil común y foral, Tomo III, S.F.

${ }^{139}$ Razón por la cual, posiblemente deberíamos haberle ubicado bajo otro título, no bajo el estudio de su naturaleza jurídico.

${ }^{140}$ LATORRE LATORRE, VIRGILIO. Protección penal del derecho de autor, Tirant lo Blanch, Valencia 1994, p. 38. En el mismo sentido, PLAZA, ob. supra cit., p. 119. La teoría se basa en la distinción planteada previamente por SCHOPENHAUER, FITCHE y HEGEL, quienes advirtieron la presencia de dos "propiedades" en la propiedad intelectual, la que se proyecta sobre el objeto material -soporte- que constituye la obra, y la propiedad que se proyecta sobre el contenido inmaterial que conforma la obra intelectual. Según PLAZA, ob. supra cit., p. 119 y sgtes: FITCHE diferenciaba "en un libro 'la corporalidad en sí, el papel impreso', de la creación espiritual" contenida en él; HEGEL, distingue "entre el ejemplar como objeto individual y la unidad de forma y contenido que es la obra"; y, SCHOPENAHUER, diferencia "entre propiedad de la cosa y propiedad espiritual o intelectual".

141 LATORRE. Ob. supra cit., p. 40.

142 ASCARELLI, TULIO. Teoría de la concorrenza dei beni inmateriali, Milán, 1956. Traducido por VERDERA Y TUELLS, EVELIO y SUÁREZ-LLANOS GÓMEZ, LUIS, en obra homónima, Ed. Bosh, Barcelona, 1970. 
este ser externo de una obra, las que imponen "la necesidad de una disciplina especial de la creación intelectual", independiente del derecho de propiedad común que recae sobre el objeto material que se ha exteriorizado.

Bajo este prisma, se ve a la propiedad intelectual investida del mismo poder y señorío que la propiedad civil, se trata de un poder jurídico "sobre un bien externo y autónomo al autor", ${ }^{143}$ "es un derecho absoluto sobre un bien inmaterial e incorpóreo" ${ }^{" 144}$. Se trata de la misma propiedad, con la sola diferencia que se ejerce sobre un objeto distinto, en el caso de la propiedad civil se ejerce sobre el corpus mechanicum y la propiedad intelectual sobre el corpus mysticum. Ahora bien, para evitar confusiones, es importante tener presente que esta teoría no se extendió a los derechos morales y patrimoniales, entendiendo a la propiedad intelectual como un bien inmaterial, compuesto únicamente por los derechos de contenido patrimonial, puesto que los derechos morales, serían inherentes al ser humano, a su personalidad y les correspondería un tratamiento autónomo y separado ${ }^{145}$.

En lo que a propiedad industrial se refiere, es importante destacar que esta posición intentó extenderse a todos los tipos de propiedad intelectual, es decir comprendió a lo que hemos llamado propiedad intelectual en sentido amplio, involucrando a la propiedad intelectual propiamente tal y a la propiedad industrial, quedando amparados marcas, patentes, modelos de utilidad, variedades vegetales, etc. Desde nuestra perspectiva, tal como hemos venido exponiendo, no había necesidad de distinguir entre todas éstas, la teoría acierta en su intento de dar una explicación unitaria a todos los derechos de propiedad intelectual, de hecho vemos en la propiedad industrial la misma posibilidad de distinguir entre el cuerpo material y espiritual de la invención, de la expresión de una marca o de cualquier otro derecho de propiedad industrial, ya que todos son producto de una actividad humana puramente creativa y se expresan, ya sea en una obra -como la propiedad intelectual propiamente tal- o en un documento que describe el proceso o la invención, antecedente sin el cual, la creación, al igual que un cuadro o un libro, permanecerá en el fuero interno de su creador, sin poder ser conocida o implementada por la sociedad.

\footnotetext{
${ }^{143}$ LATORRE. Ob. supra cit., p. 39.

${ }^{144}$ PLAZA. Ob. supra cit., p. 120.

${ }^{145}$ En este sentido: PLAZA y LATORRE. Ob. supra cit.
} 
Por nuestra parte, no estamos de acuerdo con la crítica que hace a esta teoría PLAZA PENADES ${ }^{146}$, en el sentido que su aproximación a la propiedad industrial implica desatender las facultades personales que caracterizan al derecho de autor, puesto que si estas facultades se desatienden es por una deficiencia en la estructura de la teoría en sí misma y no por su aproximación a la propiedad intelectual, en donde estas facultades personales o morales, también tienen cabida, aun cuando no hayan alcanzado el relieve o la incidencia que poseen en la propiedad intelectual.

Las críticas a esta construcción se han centrado en el hecho que es básicamente una teoría de la propiedad donde ha variado el objeto sobre el cual recae, de manera que se le atribuyen los mismos problemas que a la concepción propietaria de la propiedad intelectual a que nos hemos referido antes.

\subsection{La propiedad intelectual como monopolio}

Cuando hablamos de monopolio, resulta curioso ver como el diccionario de la Real Academia de la Lengua Española, incluye dentro de sus significados: "Cesión otorgada por la autoridad competente a una empresa para que esta aproveche con carácter exclusivo alguna industria o comercio", con directa alusión a un monopolio establecido por la ley u otra autoridad; y, "Situación de mercado en que la oferta de un producto se reduce a un solo vendedor", hipótesis en que la situación de monopolio se produce de manera natural, sin la intervención de un acto de autoridad.

Estos dos aspectos de un monopolio, son recogidos por LATORRE LATORRE $^{147}$, quien explica que la teoría viene del campo económico y se funda en el hecho que el titular es el único que está facultado para comercializar el objeto protegido por propiedad intelectual; cuando se trata de un monopolio legal, "la facultad alcanza a la impedición de que se haga por cualquier otro una oferta de productos idénticos"148. Esto explica por qué algunos autores como PLAZA PENADES, ${ }^{149}$ al titular esta teoría lo hacen como "[e]l derecho de autor como monopolio legal", en abierta alusión a que no se trata de una situación de monopolio natural, sino que de una posición a la que llega el autor por el amparo de la ley.

\footnotetext{
146 Ob. supra cit., p. 121.

${ }^{147}$ Ob. supra cit., p. 41.

148 Ob. supra cit., p. 41.

149 PLAZA. Ob. supra cit., p. 124.
} 
Existe uniformidad en señalar a FRANCESCHELLI, como el más ardiente defensor de esta teoría, para quien la estructura monopolística de la propiedad intelectual está dada desde las primeras formas de protección que se dieron después de la invención de la imprenta, caracterizadas por ser una condición de monopolio amparada por la ley, es decir "un monopolio legal", que permite evitar la comercialización de productos idénticos.

Básicamente, la observación que lleva a sostener esta corriente, se erige sobre la actividad que se desarrolla en torno a la propiedad intelectual, la creación en sí misma y la explotación comercial del objeto creado, pero prescinde de cualquier consideración sobre el objeto mismo y la vinculación de su creador con él, ya sea como dominio, bien inmaterial, atributo de su personalidad, derecho natural o cualquier otra.

PLAZA PENADES ${ }^{150}$ hace un resumen de las diferentes variantes que se han esculpido al amparo de la idea de monopolio y la propiedad intelectual. Parte con la "Teoría de la Clientela"151 que ve el asunto como una posición dinámica destinada a captar clientela por medio de aprovechar el monopolio temporal y legal que asegura la propiedad intelectual. Seguidamente, recuerda la posición de ROGUIN ${ }^{152}$ quien bajo el título "Monopolios de derecho privado", desarrolla dos epígrafes, "El derecho de autor" y "La teoría del monopolio"153, es allí donde plantea la "Teoría del derecho a la no imitación", para referirse a todos los derechos de propiedad intelectual, que a su juicio se caracterizan porque al titular se le otorga el derecho a impedir la imitación, "evitando de este modo que otros posean objetos semejantes a los del titular" ${ }^{\prime 154}$, es de esta posibilidad de evitar la copia, de donde ROGUIN deduce la existencia de un monopolio.

A nuestro juicio, esta última posición teórica, aun sin explicar completamente el fenómeno, se ajusta más a la realidad de marcas y patentes, puesto que ahí lo que se protege es precisamente la copia y la imitación, no obstante en el derecho de autor, la idea de imitación es muy poco realizable, puesto que la obra artística o literaria, simplemente se copia. De cualquier forma, el poder de evitar la imitación no es lo que caracteriza una posición monopólica, si bien ello puede ayudar, la condición de

${ }^{150}$ Ob. supra cit., p 124.

${ }^{151}$ Que atribuye a ROUBIER. M. P. Le Droit de le propieté industrielle. Ed. Sirey, vol I, París, 1952.

${ }^{152}$ ROGUIN, ERNEST. NAVARRO DE PALENCIA, JOSÉ MARÍA. Las reglas jurídicas: Estudio de ciencia jurídica pura. Reimp. de la EDCN. de Madrid, La España Moderna, 1904.

153 Ob. supra cit., pp. 359 y sgtes.

154 Ob. supra cit., p. 125. 
monopolio no nace solamente del sistema de propiedad intelectual y tiene mucho que ver con la realidad del mercado, así pues, dentro del propio sistema de propiedad intelectual puede haber competencia, de manera que, por ejemplo, analgésicos patentados puede haber más de uno, herramientas patentadas para la solución de un mismo problema técnico pueden haber simultáneamente muchas, libros que satisfagan una misma necesidad pueden existir innumerables, etc. En consecuencia, la idea de impedir la imitación no pasa de ser, un desarrollo más agudo u otra perspectiva al monopolio legal.

La bandera de esta teoría en España, a juicio de PLAZA PENADES, ${ }^{155}$ la ha llevado VALVERDE Y VALVERDE ${ }^{156}$, quien ve una doble faz en el asunto, la facultad que otorga la propiedad intelectual consistente en el derecho exclusivo a la reproducción de las obras y la autoridad para imponer a todos la obligación de no copiarlas, de manera que, se trataría de una condición de control de mercado que comprende un monopolio y no una propiedad sobre los bienes.

A las posiciones que argumentan la existencia de un monopolio se les atribuye un error conceptual, puesto que la propiedad intelectual parte con la libertad de creación, por lo mismo, es falso que un autor pueda crear condiciones monopolísticas a partir de su obra, ya que puesta la obra en el mercado, no puede impedir que otros autores realicen otras obras, "incluso sobre el mismo género, y que compitan en condiciones de igualdad en el mercado" ${ }^{157}$. Esto que es verdad en el derecho de autor, también lo es en la propiedad industrial, en efecto, podemos poner ejemplos de competencia tanto en derecho de autor como en marcas y patentes, a saber: existen diferentes libros de enseñanza básica con el mismo objetivo, diferentes diccionarios, incluso géneros enteros de novelas, como las últimas sagas sobre magos o vampiros, cuyos autores se han enfrentado competitivamente en el mercado, desde la edición del libro, hasta su realización en el cine; en cuanto a marcas y patentes, baste con pensar en tremendos competidores como las bebidas "cola" o como, para una misma necesidad pueden haber más de un instrumento patentado o los patentados, pueden tener que

\footnotetext{
155 Ob. supra cit., p. 125.

156 VALVERDE Y VALVERDE, Tratado de derecho civil español, Tomo II, Ed. Cuesta, Madrid, 1910, pp. 123 y sgtes.

157 PLAZA. Ob. supra cit., p. 128.
} 
competir con aquellos que ya han pasado al dominio público, como podría ser el walkman, CDs, MP3, MP4, etc.

Por lo anterior, a nuestro juicio, es más adecuado decir que la propiedad intelectual aumenta la competitividad de los bienes, por la vía de crear derechos para la comercialización exclusiva. En todo caso, de ello no desprenderíamos ninguna característica asociable a su naturaleza jurídica, puesto que compartimos la crítica, en contra de esta posición, que dice, que es incapaz de "trascender y superar una postura meramente descriptiva y aclarar: ¿por qué los derechos de autor (y en general, los derechos sobre las creaciones intelectuales) tienen una estructura 'monopolística'?"158.

\subsection{La propiedad intelectual como un derecho autónomo. De los bienes intelectuales}

De autoría del belga EDMUNDO PICARD ${ }^{159}$, quien probablemente cansado de intentar dar con la naturaleza jurídica de la propiedad intelectual -tarea nada fácil, como venimos viendo- decidió plantearla derechamente como una categoría independiente y autónoma. Es decir, algo semejante a las teorías eclécticas, que se esmeran en tomar todo de todos y no decir nada nuevo.

A pesar de nuestra crítica subjetiva, la teoría tiene la virtud de dar cobijo a todos los derechos que hemos catalogado al amparo de la propiedad intelectual, es decir propiedad intelectual propiamente tal y propiedad industrial, puesto que finalmente todas ellas poseen el rasgo común de ser creaciones intelectuales. El jurista propuso incorporar junto a las categorías tradicionales del derecho: derechos personales, reales y obligaciones; un cuarto grupo, llamado de "derechos intelectuales" ${ }^{160}$. Se trataría de los "jure in re intellectuali", o sea, "derecho de las cosas intelectuales"161 como complemento del derecho de las cosas materiales. Vio en ello, la ventaja de no alterar ni forzar las categorías tradicionales del derecho civil y la unificación de todas las disciplinas de la propiedad intelectual en una sola, de hecho critica la existencia de tan

158 Ob. Cit., p. 128. Cfr. BAYLOS. Ob. supra cit., p. 451.

159 Propuesta por el jurista PICARD, EDMUNDO, en sus obras: Pandectes Belges, Encyclopeadie de legislation de doctrine el jurisprudente belges, Bruselas, 1879 y Le droit pur, París, 1899.

${ }^{160}$ SALAZAR. Ob. supra cit., p. 59. En este sentido también, CANAVAL PALACIOS, JUAN PABLO. Manual de Propiedad Intelectual, Edit. Universidad del Rosario, Bogotá, 2008.

161 JENSEN, HENRI. Derechos intelectuales: de los autores, artistas, productores de fonogramas, Editorial Jurídica de Chile, 1970. 
amplia nomenclatura como propiedad industrial, artística, literaria, marcas, patentes, etc. Para el autor, "no hay relación ni asimilación posibles entre una cosa material, una res y una producción intelectual, es decir, una idea, un conjunto de ideas o una concepción del espíritu, por cuanto sus naturalezas son antípoda" ${ }^{162}$, la diferencia entre lo espiritual y lo material existirá siempre, por ello es más propio respetarla, creando una categoría de derechos, los derechos intelectuales, que respondan a esta realidad y atiendan a su génesis.

La crítica a esta propuesta, está dada por el hecho que al crear una cuarta categoría de bienes, termina resultando una construcción abstracta, desligada de su origen y razón de ser, en otras palabras, olvida a las facultades morales de la propiedad intelectual $^{163}$. Las facultades perpetuas del autor de reivindicar la paternidad, de oponerse a la deformación, modificación o mutilación cuando puedan causarle perjuicio a su honor o reputación, de conservar la obra inédita, modificarla antes de su circulación o retirarla después de puesta al público, son atributos globalmente aceptados, que el razonamiento expuesto no aborda.

\subsection{La propiedad intelectual como derecho de la personalidad}

LATORRE LATORRE ${ }^{164}$ hace una novelada introducción al tema, citando a RODRÍGUEZ ARIAS ${ }^{165}$, quien sostiene que "las teorías personalistas nacen ante el olvido por el legislador de la persona del autor, al ocuparse únicamente de la defensa de la obra intelectual". Para las teorías que se alojan bajo la idea de que la propiedad intelectual es un derecho de la personalidad, la obra sólo tiene sentido en cuanto se reconoce que su único origen posible es el autor, donde se proyecta su ser mismo, de manera que su personalidad queda plasmada en la obra, lo que le atribuye una connotación espiritual, una solemnidad especial, que la pone por sobre un simple bien inmaterial susceptible de explotación económica, todo lo cual, los lleva a sostener que si bien la obra es explotable, se trata de una dimensión económica subordinada a la connotación espiritual o personal que posee toda obra.

162 SALAZAR, ob. supra cit., p. 59, citando a LEDESMA, JULIO, quien cita a PICARD, en la definición de "Patente de invención", en la Enciclopedia Jurídica OMEBA, Tomo XXI, pp. 652-676, Edit. Bibliográfica, Buenos Aires, 1964.

163 PLAZAS, ARCADIO. Consideraciones introductorias al derecho de autor, Revista de Derecho y Jurisprudencia, Tomo LXXVII, Editorial Jurídica de Chile, Abril de 1980, pp. 33.

164 LATORRE. Ob. supra cit., p. 42.

${ }^{165}$ RODRÍGUEZ-ARIAS BUSTAMANTE, LINO. Naturaleza jurídica de los derechos intelectuales, Revista de Derecho Privado, Madrid, 1949, pp. 748. 
Tal como describen PLAZA PENADES ${ }^{166}$, LATORRE LATORRE ${ }^{167}$ y DÍEZ$\mathrm{PICAZO}^{168}$, el fundamento último de las teorías de la personalidad lo encontramos en la obra de $\mathrm{KANT}^{169}$, para quien la publicación de un libro implica un diálogo con el público, por medio del cual, el autor habla y por tanto, su personalidad está impregnada allí, de una manera ideal e indisoluble, puesto que el diálogo que el libro implica sólo puede producirse con el consentimiento de su autor, esto es lo que caracteriza y singulariza una obra y es lo que justifica que el discurso sólo pueda trascender con el consentimiento del autor, de aquí que lo importante de KANT, en este punto, es que plantea la coexistencia de una derecho real y uno personal, de manera simultánea sobre la obra, al decir: "Por una parte, el libro es un producto artificial corporal (corpus mechanicum), que puede ser copiado (por quien posea legítimamente un ejemplar del mismo), con lo cual hay aquí [un derecho real]; pero, por otra parte, el libro es también únicamente un discurso del editor al público, que éste no puede reproducir públicamente (praestatio operae) sin tener para ello un mandato del autor, [un derecho personal], y entonces el error consiste en que se confunden ambos" ${ }^{\text {"170 }}$.

LATORRE VIRGILIO, bajo el epígrafe "Teoría de la personalidad", hace una clasificación de ellas, donde ubica a las teorías "de la gestión de negocios", "de la prestación de un servicio o contrato de cambio" y "de la personalidad", con lo que confunde el género (teorías de la personalidad), con una especie de ellas (las de la personalidad), semejante a lo que venimos haciendo nosotros, al hablar de propiedad intelectual y propiedad intelectual propiamente tal.

En nuestro caso, como una manera de organizar el asunto, remarcaremos que como rasgo característico de esta tendencia, está el hecho de sostener que el derecho de autor es un derecho de la personalidad, cuyo objeto es la obra o creación intelectual, que emana de un ser humano y como tal, es parte integrante de la esfera de su personalidad, en consecuencia, es de la propia condición humana de su creador, de donde nace el derecho de autor y como tal la obra es parte de la personalidad del creador.

\footnotetext{
${ }^{166}$ PLAZA. Ob. supra cit., pp. 133 y sgtes.

${ }^{167}$ LATORRE. Ob. supra cit., pp. 42 y sgtes.

${ }^{168}$ DÍEZ-PICAZO y GULLÓN, ANTONIO. Sistema de derecho civil, Vol III, Tecnos, 2000, pp. 225 y sgtes.

169 Derivado de la posición de Kant, también son muchos los autores que le atribuyen haber sido el primero que habló de los intereses no patrimoniales entre el autor y su obra, según GARCÍA. Ob. supra cit., p. 218.

${ }^{170}$ Cita tomada de GARCÍA. Ob. supra cit., p. 218.
} 
Dentro de esta tendencia teoría se han desarrollado variadas posiciones que aportan puntos de vista particulares, siempre pensando en el derecho de autor como parte de la personalidad del creador, pero desde perspectivas diferentes, las que analizaremos seguidamente.

\subsubsection{La propiedad intelectual como derecho de la personalidad por OTTO GIERKE}

A OTTO GIERKE ${ }^{171}$ se le atribuye ${ }^{172}$ ser el máximo exponente de la teoría de la personalidad, él, si bien parte del punto común de entender que el derecho de autor es integrante de la personalidad, hace una interesante diferenciación entre un primer momento creativo de la obra, instante en el cual la entiende indisolublemente unida a su creador, puesto que es y permanece como un bien personal de su autor, de este hecho original de creación nace el derecho de autor, con la consecuencia manifiesta que cualquier otro derecho sobre la obra que detente otra persona, sólo puede venir de él. En esta concepción, es la divulgación de la obra, el momento en que ésta se separa de su autor, quien al hacerla parte de la sociedad, al revelar su contenido, permite que se transforme en "una entidad independiente de él"173; sin embargo a pesar de la publicación conserva su señorío sobre la consistencia íntima, interna y externa de su obra, puesto que es "plasmación de la personalidad del autor" ${ }^{174}$, de esta manera se justifica la duración de la protección por toda la vida del autor y la transmisibilidad, se entiende solamente como una alternativa legal para proteger a los herederos.

Un aspecto que debemos destacar de la posición de OTTO GIERKE, desarrollado por PLAZA PENADES ${ }^{175}$, es que las intensidades de la vinculación entre una obra y su creador, respecto de las distintas creaciones al amparo de la propiedad intelectual son diferentes, el grado de vinculación entre el autor y su creación varía. En las obras literarias y artísticas se aprecia una influencia mayor de la personalidad del autor, que imprime su sello individual, el de su personalidad. A este respecto, observamos que está asentada la idea de dar mayor jerarquía y dignidad al derecho de autor por sobre la propiedad industrial, específicamente marcas y patentes. Hay una

\footnotetext{
${ }^{171}$ Cfr. GIERKE, OTTO. Deutsches Privatrechts, Leipzig, Munich, 1936

172 Así lo dicen: PLAZA, LATORRE y DÍEZ-PICAZO. Obs. supra cit.

173 LATORRE. Ob. supra cit., p. 42.

${ }^{174}$ PLAZA. Ob. supra cit., p. 137.

175 Ob. supra cit., p.135.
} 
tendencia ${ }^{176}$ a estimar a la propiedad intelectual como poseedora de un toque supremo, un traspaso ideal del ser del autor a la obra, que la dota de toda la identidad y singularidad que define a cada ser humano, atributo del que carecería la propiedad industrial, reducida a simples experimentos de laboratorio, creaciones de taller y genios locos o únicamente, expresiones accidentales de acierto, en el caso de las marcas comerciales. Tan arraigada vemos esta posición que los derechos morales, han tenido su desarrollo únicamente vinculados al derecho de autor, en consecuencia que sin el talento, los conocimientos y frecuentemente, sin la genialidad del inventor, el invento no podría haber existido, observemos los grabados, dibujos, esculturas, bocetos de inventos de LEONARDO DA VINCI ¿Cuál de esos sería más digno o de más elevada investidura? ¿Cuál de aquellos sería menos de DA VINCI y más de la sociedad? ¿Cuál de esos es merecedor de más alta dignidad? Hay un reconocimiento subyacente a esta dignidad del inventor, en la ley y en la práctica del sistema de patentes, que se hace cargo de la figura del inventor y reivindica para él una posición jurídica, entregándole la paternidad del invento, en los hechos dentro de la solicitud de patente debe ir un "titular" y un "inventor" como requisito obligatorio de trámite. En consecuencia, a nuestro juicio, los intentos por entronizar al derecho de autor y atribuirle un ser y condiciones diferentes que a la propiedad industrial, yerran porque no hay una distinta dignidad entre unos y otros, razón por la cual, se equivoca también la posición de GIERKE, en cuanto la usa para jerarquizar entre las dos formas básicas de propiedad intelectual, la propiedad intelectual propiamente tal y la propiedad industrial.

\subsubsection{La propiedad intelectual como gestión de negocios}

Para la teoría "de la gestión de negocios", LATORRE LATORRE ${ }^{177}$ explica que parte de la obra de $\mathrm{KANT}^{178}$, en el sentido que el libro es el medio que permite al autor hablar, sólo el autor es quien puede hablar y lo hará cuando quiera hacerlo, no puede ser obligado a expresarse. La expresión de la obra pasa a ser una cuestión central, una vez que el autor ha querido divulgarla. El rol del editor es gestionar el poder que tiene el autor para divulgar o no su obra, en consecuencia, el derecho de autor es un derecho personal, por medio del cual el editor puede hablar en nombre del autor y es en esa relación que se basa la atribución del editor.

\footnotetext{
${ }^{176}$ No solo respecto de esta teoría, sino de todas las posiciones que explican la propiedad intelectual.

177 LATORRE. Ob. supra cit., p. 43.

${ }^{178}$ KANT, IMMANUEL. Principios metafísicos del derecho, Edit. Américalee, Buenos Aires, Argentina.
} 
La crítica a esta teoría la hizo RODRÍGUEZ ARIAS, siguiendo a VICENTE Y CARAVANTES $^{179}$ quien cree artificial centrarse en la relación con el editor para fundamentar su naturaleza jurídica, puesto que no hay ninguna vinculación entre la edición de una obra y su paternidad, la creación de la obra es autónoma y constituye una propiedad independiente de la edición de la misma. Desde nuestra perspectiva, la teoría es limitada en el sentido que sólo permite explicar la naturaleza del derecho de autor, dejando a fuera otras expresiones de la propiedad intelectual y a toda la propiedad industrial.

\subsubsection{La propiedad intelectual como prestación de un servicio o contrato de cambio}

En la teoría llamada "de la prestación de un servicio o contrato de cambio", su principal sostenedor, PIERRE PROUDHON ${ }^{180}$ sostenía que el derecho de autor es un contrato con la sociedad, en donde se retribuye con el derecho de autor, al creador, por su trabajo y esfuerzo empleado en la confección de la obra. La sociedad obtiene su parte al quedarse con el disfrute de la obra, en este sentido, el derecho de autor "es, sobre todo, un derecho de vinculación social”, ${ }^{181}$.

Esta teoría se ha criticado, porque el autor no es un trabajador al cual se le remunere por sus servicios, el autor es un creador, no presta servicios de autor para la sociedad. El derecho de autor no nace de la vinculación o contratación entre el autor y la sociedad, nace directamente del trabajo del autor como medio genuino y legítimo de ganar la propiedad por una parte y de expresarse por la otra.

179 VICENTE Y CARAVANTES, J. Exposición y examen de nuestras leyes y tratados sobre la propiedad literaria, Revista Legislación y Jurisprudencia, 1876, pp. 56, quien sostenía: "La concepción del autor encerrada en el texto material que constituye la obra, es sin duda una cosa incorporal, una abstracción. Comúnmente le da cuerpo y la consigna el manuscrito del escritor, pero este manuscrito es una primera copia trazada de la mano paternal y que sirve de tipo [á] todas las que han de seguir en breve, gracias [á] la actividad de las prensas. No constituye propiedad y no es de ningún modo necesaria a su existencia. Un orador improvisa un discurso; un profesor pronuncia de viva voz sus lecciones: estas dos obras intelectuales han sido creadas sin ningún manuscrito, sin que por eso deje de existir [menos] su derecho exclusivo, y el impresor que hiciera de ellas ediciones, sin consentimiento de sus autores, se apoderaría de lo que no era suyo. La obra, es pues, independiente del manuscrito. Confundirlos es un error muy grave", citado por EVANGELIO LLORCA, RAQUEL. El encargo de obra intelectual, Dykinson, 2006, p. 139.

180 PROUDHON, PIERRE JOSEPH. Les Majorats Litteraries, París, 1863. Este autor fue un filósofo político y revolucionario francés, uno de los padres del pensamiento anarquista y de su expresión económica, el mutualismo. En su posición sobre el derecho de autor, se puede ver claramente su influencia por clásicos como DESCARTES o ROUSSEAU, probablemente, de ahí su idea que el derecho de autor es un contrato con la sociedad.

${ }^{181}$ LATORRE. Ob. supra cit., p. 44. 


\subsubsection{Críticas a las teorías de la propiedad intelectual como derivada de la personalidad}

Además de las críticas particulares que se han formulado a las variaciones de las teorías de la personalidad, en general se les objeta que han dejado de lado los derechos de explotación, esenciales en el derecho de autor. Por reivindicar la faz personalista del derecho de autor, olvidan el contenido patrimonial del mismo. Enraizado con este problema, se advierte que el derecho de autor es finalmente un derecho a la explotación económica de la obra, por lo que, en sí mismo, como derecho, no posee nada de la personalidad del autor.

Otra crítica a estas teorías, es estar confundiendo el sujeto del derecho y el objeto, que son distintos, lo que les lleva a olvidar que si la obra ha podido ser tratada como un objeto, es precisamente porque posee también una existencia separada de su autor, se independiza, adquiere una identidad propia, razón por la cual, no puede arrastrar a la personalidad del autor.

La crítica más fundada a nuestro juicio, la hacen DÍEZ-PICAZO y GULLÓN ${ }^{182}$, quienes agudamente advierten, como se están confundiendo "derechos personalísimos" con "derechos de la personalidad".

Un derecho personalísimo se presenta cuando la situación de poder que el derecho garantiza, únicamente puede ser ejercida por su titular, como los alimentos en el derecho de familia o el ejercicio de los derechos de uso y habitación en plaza civil, en consecuencia la idea de personalísimo es de irremplazabilidad, infungibilidad, exclusividad, pero no de personalidad. Sin duda que todo derecho de la personalidad es personalísimo, pero no todo derecho personalísimo es un derecho de la personalidad, como sucede con el uso y la habitación, que siendo personalísimos no son de la personalidad. Estos autores sostienen que "la cualidad de 'personalísimo' no coincide con la idea de 'derecho de la personalidad'. La obra intelectual, la obra del ingenio no es un bien de la personalidad. Es algo creado por la persona, pero perfectamente distinto y separado de ella"183.

\footnotetext{
${ }^{182}$ DÍEZ-PICAZO y GULLÓN. Ob. supra cit., p. 226. En el mismo sentido, DÍEZ-PICAZO. Ob. supra cit., p. 76.

183 Ob. supra cit., p. 226.
} 


\subsection{La propiedad intelectual la tesis monista y dualista}

Por alguna razón, los seres humanos tendemos a explicarnos muchas cosas por la vía de efectuar comparaciones binarias: espíritu y cuerpo, bien y mal, yin y jang. La propiedad intelectual, al parecer, no quiso estar ausente de esta dualidad. Tal como vimos, KANT se encargó de plantear la existencia de un derecho personal en la propiedad intelectual y serán los filósofos FICHTE y HEGEL quienes se encargarán del "carácter incorporal del objeto del derecho de autor" ${ }^{\text {", }}$, para lo cual FITCHE propone la existencia de tres elementos en la propiedad de un libro: “a) El libro como bien corporal (papel impreso) cuya propiedad se transmite inmediatamente al comprador mediante su venta, puesto que, como objeto material, sólo es susceptible de apropiación por un único sujeto; b) El contenido del libro, las ideas o pensamientos que se convierten en propiedad compartida de autor y público desde que son publicadas; y, c) La forma en que el autor exterioriza o presenta ese pensamiento, de exclusiva propiedad de su autor" ${ }^{\prime 185}$. Serán estas corrientes filosóficas, recogidas por los juristas, las que dieron lugar a las teorías de personalidad y mostraron dos haces de la propiedad intelectual -si bien, claramente marcados, en el caso del derecho de autor, también presentes en la propiedad industrial. Desde este punto de vista, como si ya no hubiesen suficientes problemas con la naturaleza jurídica de la propiedad intelectual, frente a la clara concurrencia de una vertiente patrimonial y otra personal, se planteó un nuevo inconveniente, determinar si estas dos dimensiones son parte de un conjunto único, que se acrisola para generar fases de un mismo derecho o si se trata de dos derechos independientes. Estamos describiendo el nacimiento de lo que se ha conocido como monismo y dualismo, sustantivos que evocan la idea de un único derecho y de dos derechos independientes, respectivamente ${ }^{186}$, para definir la naturaleza jurídica de la propiedad intelectual.

Cabe destacar que advertida la existencia de un aspecto patrimonial y otro moral en la propiedad intelectual, la discusión que se plantea es si estas dos dimensiones

\footnotetext{
${ }^{184}$ GARCÍA. Ob. supra cit., p. 218.

185 Ob. supra cit., p. 218.

${ }^{186}$ Sobre monismo y dualismo tratan prácticamente todas las obras que consultamos, escritas desde el siglo XX. Para ver más, puede consultarse: PLAZA. Ob. supra cit., pp. 139 y sgtes; OTERO. Ob. supra cit., pp. 36 y sgtes; OLLERO TASSARA, ANDRÉS. Entre creación y propiedad el problemático carácter "fundamental" de los derechos de autor, X Jornadas de Estudio, Introducción a los derechos fundamentales, Dirección General del Servicio Jurídico del Estado, Ministerio de Justicia, Secretaría General Técnica, Centro de Publicaciones, España, 1988; BAYLOS CARROZA, Ob. supra cit., pp. 478 y sgtes; BERCOVITZ, Ob. supra cit., pp. 27 y sgtes.
} 
existen al amparo de un mismo derecho o son dos derechos independientes que coexistente, uno de contenido patrimonial y otro personal. No se trata del nacimiento de dos nuevas teorías que vienen a explicar la naturaleza jurídica de la propiedad intelectual, sino que, de alguna manera, lo que se busca es organizar las teorías que ya existían de manera que puedan explicar, la existencia de la dimensión patrimonial y personal, como elementos de la propiedad intelectual.

Para CÁMARA ÁGUILA ${ }^{187}$, monismo y dualismo tienen su origen en la doctrina alemana de finales del siglo XIX, refiriéndose a KHOLER y GIERKE.

Según la autora citada, KHOLER en su obra "Forschunguen aus dem Patentrecht" ${ }^{\prime 188}$, en el año 1888, planteó lo que se conoció como la teoría del "doble derecho"189, propiamente dualista, en la medida que sostiene que nos encontramos frente a dos derechos diferentes: uno de contenido patrimonial, destinado a proteger los intereses económicos del autor, es un derecho real y tiene su origen en la calidad de bien inmaterial de la obra; y otro, de contenido personal, que busca proteger cualidades morales del autor, cuya fuente es la personalidad del autor.

Por su lado GIERKE ${ }^{190}$, en "Deutsches privatrecht", en 1985, se distancia de KHOLER, para sostener una posición claramente monista, puesto que para él, el derecho de autor "pertenece a la categoría de los derechos de la personalidad, por ser la obra una parte integrante de la personalidad del autor"191. El autor entiende que estamos frente a la protección de la personalidad del autor, se trata de un único derecho relativo a la personalidad del creador de la obra y las facultades patrimoniales no son más que una consecuencia de la protección de la personalidad del creador.

DÍEZ-PICAZO ${ }^{192}$ se hace cargo de este planteamiento presentándolo como una tercera posición frente a las teorías de la personalidad y del derecho patrimonial,

${ }^{187}$ CÁMARA ÁGUILA, MARÍA DEL PILAR. El derecho moral de autor, Comares, Granada, 1998, p. 5.

${ }^{188}$ Ob. supra cit.

189 En alemán "Doppelrecht".

${ }^{190}$ CÁMARA. Ob. supra cit.

191 D' JESÚS PÉREZ, ANTONIO JOSÉ. Fundamentos de un sistema de gestión colectiva de derechos reprográficos, Universidad de los Andes, Facultad de Ciencias Jurídicas y Políticas, Postgrado de Especialización en Propiedad Intelectual, Mérida Venezuela, 2001, pp. 167. Disponible en Internet en: http://tesis.ula.ve/postgrado/tde arquivos/80/TDE-2012-06-11T04:38:19Z-2258/Publico/ (30 Mar. 2013).

${ }^{192}$ DÍEZ-PICAZO. Ob. supra cit., pp. 78 y sgtes. 
explicando que la crítica más potente que enfrenta, es "escindir una institución unitaria en dos derechos subjetivos diferentes, pues precisamente la característica esencial del derecho subjetivo consiste en su unidad" ${ }^{193}$.

Ante lo que venimos analizando, cabe iniciar el análisis del monismo y dualismo.

\subsubsection{La propiedad intelectual la tesis monista}

Para la concepción monista lo fundamental es que las facultades morales y patrimoniales del autor no están separadas, sino integradas en un conjunto único, donde es imposible diferenciar cuál de ellas obedece a una naturaleza patrimonial y cuál personal, puesto que se da "una mezcla inescindible de ambos elementos" "194. La propiedad intelectual es "un derecho unitario, aunque su contenido pueda ser heterogéneo"195. Algunas de estas posiciones hacen predominar el aspecto patrimonial, otras el personal, sin embargo ello no es relevante, lo sustancial es que serían dos grupos de facultades que protegen los intereses de autor y son inseparables.

En el análisis de estas teorías no puede saltarse a ULMER ${ }^{196}$, autor alemán que ejemplificó su posición con la célebre metáfora de un árbol, para él: "[e]l derecho de autor tienen tronco, raíces y ramas. Las raíces representan los intereses del autor (morales y patrimoniales); las ramas representan las distintas facultades que crecen del tronco común que es el derecho de autor. Por ello, todo forma un mismo bien, un mismo derecho y si se prescinde de una de las partes, el árbol muere" ${ }^{197}$.

Desde nuestra perspectiva, la metáfora es bella, pero no explica nada. En sí misma es falsa, porque el corte de las ramas puede, incluso, aumentar el vigor del árbol y el de las raíces, preservar su belleza en miniatura. Considerando lo que quiere demostrar el autor, tampoco prueba nada, ya que para todo el derecho puede hacerse una

193 Ob. supra cit., p. 78

${ }^{194}$ PLAZA. Ob. supra cit., p. 151.

195 Encontramos esta alusión al hecho que si bien el monismo parte de un único derecho, puede en él haber en él un contenido heterogéneo en BERCOVITZ RODRÍGUEZ-CANO, R., "Introducción a la regulación de los Derechos de autor", en Cuadernos de Derecho Judicial, CGPJ, 1995, p. 11, citado tanto en GARCÍA. OB. Cit., pp. 220, como en PLAZA. Ob. Cit., pp. 159.

${ }^{196}$ ULMER, E. One hundred years of the Berne Convention, International Review of Industrial Property and Copyright Law (IIC), vol 17, $\mathrm{n}^{\circ} 16,1986$.

197 PLAZA. Ob. supra cit., p. 154. En el mismo sentido refieren: GARCÍA. Ob. supra cit., p. 220; y, DESANTE GUANTER, J. La información como derecho, Ed. Nacional, Madrid, 1974, pp. 106 y sgtes. 
concepción unitaria como la propuesta, o es acaso, qué el dominio no se forma con las facultades de usar, gozas y disponer (que pueden ser las raíces) y dan derecho a arrendar, usufructuar o usar directamente aquello de lo que se es dueño (las facultades, que serían las ramas). La metáfora no habla más que de causa y efecto, pero no demuestra la posición monista del derecho, tal como pretende ${ }^{198}$.

El fundamento para defender la unidad del derecho de autor "es que, en la práctica, el ejercicio de las facultades morales se presenta intrínsecamente unido y entremezclado con el ejercicio de las facultades patrimonialistas y viceversa. Esto mismo es predicable en los casos de lesión del derecho de autor, donde una misma acción suele generar una lesión de intereses personales y patrimoniales" ${ }^{199}$. Si bien el razonamiento que hemos explicado es válido de manera general, debe tenerse presente, tal como acertadamente analiza el autor citado, ${ }^{200}$ que ULMER es alemán y en el derecho alemán, "tanto el derecho moral de autor como el derecho patrimonial nacen con la creación de la obra y, según el artículo 64 de la Ley alemana, ambos se extinguen tras setenta años post mortem auctoris"; es decir, al apoyo legislativo con que cuenta la teoría en Alemania no lo tendrá en aquellos países en donde los derechos morales tienen un régimen de vida y transmisión diferente a los derechos patrimoniales, como es el caso de España y Chile, donde los derechos morales son inalienables e imprescriptibles.

La forma más didáctica que hemos visto de clasificar las teorías monistas, lo hace en función de la preeminencia que se ponga en un determinado grupo de derechos, resultando dos conjuntos ${ }^{201}$ : a) Teorías patrimonialistas, en cuyo caso, el acento está en las facultades patrimoniales, por ello cuentan aquí las posiciones que ven al derecho de autor como derecho de propiedad general o especial y también las que lo consideran un monopolio legal; y, b) Teorías personalistas, que vienen a realzar los atributos personales del derecho de autor, entendiendo que el derecho moral de autor, prima por sobre su contenido patrimonial. Se incluyen aquí las teorías: de la Gestión de Negocios (KANT), del Contrato de Prestación de Servicios (RENOUARD) y de la Personalidad (GIERKE).

\footnotetext{
${ }^{198}$ De todas formas, nuestro objetivo, no es levantar críticas, sino que solamente describir las diferentes teorías como base de conocimiento necesario para nuestro estudio.

199 Ob. supra cit., p. 153.

${ }^{200}$ Ob. supra cit., pp. 153 y sgtes.

${ }^{201}$ Así lo hace GARCÍA. Ob. supra cit., p. 220.
} 


\subsubsection{Propiedad intelectual, la tesis dualista}

Quienes creen en la posición dualista, estiman que la propiedad intelectual se compone de dos derechos distintos, con orígenes diferentes y justificaciones separadas, se trata de dos atributos distintos, no obstante, relacionados.

Para el dualismo, el derecho de autor tiene una variante económica, donde se encuentran las facultades de orden patrimonial, "es un derecho real, equiparable al derecho de propiedad, cuyo contenido vendría determinado por las facultades patrimoniales que la ley concede a los autores"202 y que permiten la explotación comercial de la obra. También existen las facultades morales o personales, "equiparables a los derechos de personalidad, cuyo contenido estaría formado por las facultades morales que la Ley atribuye a los autores"203, es la conformación más espiritual del derecho y como tal, tienen un origen y fines diferentes a la vertiente patrimonial de la propiedad intelectual.

Esta teoría tuvo un gran exponente en KHOLER y la teoría del Doble Derecho, que hemos analizado antes.

\subsection{Propiedad intelectual, la postura monista pos dualista}

Parece ser que la idea de una propiedad intelectual conformada por dos derechos relacionados, por estrecha que sea esta vinculación, algo produce en los autores, que se resisten a aceptarla, por lo que tomando los aportes del dualismo que reconoció la existencia de los derechos patrimoniales y morales, junto a la tendencia de considerar de más importancia los derechos morales que los patrimoniales, encontraron los elementos necesarios para plantear con nuevos bríos, la última verdad, una nueva posición monista pos dualista, caracterizada por la preeminencia de los derechos morales, donde los derechos patrimoniales son meramente instrumentales y necesarios, únicamente, por requerimientos de la comercialización. Sobre este asunto, OLLERO TASSARA anota: "Una vez que el reconocimiento de esa dimensión personal se va consolidando, surge por motivos de coherencia doctrinal- la tendencia contraria: superar un dualismo que disloca el tronco común de todos los derechos del autor. Este nuevo «monismo» post dualista considera fuera de duda la operatividad práctica de los derechos «morales» y a

${ }^{202}$ BERCOVITZ. Ob. supra cit., p. 27.

${ }^{203}$ Ob. supra cit., p. 27. 
lo que aspira ahora -continuando, paradójicamente, la evolución cumplida por el dualismo- es a resaltar aún más su predominio, dado que son los más cercanos a la creatividad personal, fuente de todos los derechos del autor; mientras, a los derechos patrimoniales correspondería una dimensión instrumental, disponible -por los vericuetos del proceso de explotación- incluso para los no autores"204.

Es en el autor citado, en quien hemos visto la descripción de una postura monista pos dualista, título con el que designa, lo que a su juicio ha sido el asentamiento de la idea de un único derecho de propiedad intelectual (monista), desarrollado a partir de recoger los postulados de las posiciones dualistas. En este caso, se trataría de superar "un dualismo que disloca el tronco común de todos los derechos del autor. Este monismo pos dualista trata de resaltar aún más el predominio de los derechos 'morales', dado que son los más cercanos a la creatividad personal, fuente de todos los derechos de autor" 205 .

Para esta posición, la dimensión patrimonial de la propiedad intelectual es meramente utilitaria, necesaria debido a la estructura de comercialización, siempre secundaria en un contexto global de la propiedad intelectual. Obviamente, esta concepción monista pos dualista, viene a usar el molino de las doctrinas personalistas, por lo que tendrá que debatir en ese foro, si los derechos de autor son o no derechos de la personalidad. De todas formas, lo que en este momento interesa, es dejar en claro que la propiedad intelectual sería un único derecho, con su eje en las facultades morales, donde las patrimoniales son instrumentales.

\subsection{La propiedad intelectual como derecho humano}

Como sabemos desde la Ilustración, el nacimiento del Iusnaturalismo y la Revolución Francesa en 1789, se ha planteado la idea de la existencia de ciertos derechos inmanentes al ser humano, los llamados "derechos humanos", que son: "el conjunto de características y atributos propios del ser humano derivado de su dignidad, por lo que no pueden ser afectados o vulnerados. Sin ellos las personas no pueden

${ }^{204}$ OLLERO. Ob. supra cit., p. 550.

${ }^{205}$ Ob. supra cit., pp. 550 y sgtes. 
existir ni llevar una vida propiamente humana, por tanto, es imprescindible que los Estados y sus leyes los reconozcan, los difundan, protejan y garanticen”206.

Los derechos humanos, son una clasificación desde la perspectiva del ser humano, no se trata de una creación autónoma, sino de determinados derechos que son elevados a esta categoría, en esa medida, por ejemplo, el derecho de propiedad existe, sea o no considerado un derecho humano, con las características que le son propias, lo mismo pasa con el derecho a sindicalizarse y todos los derechos. Sobre esa base, se ha planteado la duda, sobre la naturaleza de la propiedad intelectual, en tanto derecho humano o no.

La doctrina se divide, según nos aclara DAVINIA OVETT ${ }^{207}$, al señalar que: “[p]or un lado están quienes defienden que la protección de los intereses morales y materiales de los autores no pueden compararse con la protección de los derechos de propiedad intelectual porque éstos no son derechos fundamentales e inalienables del ser humano". En esta posición encontramos a XAVIER SEUBA ${ }^{208}$, AUDREY CHAPMAN $^{209}$ y DAVINIA OVETT ${ }^{210}$.

Agrega DAVINIA OVETT, “[p]or otro lado, están quienes defienden que los derechos de propiedad intelectual están implícitos en el derecho a la protección de intereses morales y materiales de los autores y en el derecho a la propiedad consagrado en la Declaración Universal de Derechos Humanos". Junto a esta alternativa encontramos a VELÁZQUEZ VELÁZQUEZ ${ }^{211}$, YOLEIDA SERRANO ${ }^{212}$ y ADAMES PÉREZ ${ }^{213}$.

${ }^{206}$ Según definición del Congreso Nacional de Chile. Disponible en: http://www.bcn.cl/ecivica/ddhh (28 Mar 2013).

${ }^{207}$ OVETT, DAVINIA. Propiedad intelectual y derechos humanos: ¿queda ahora clara la diferencia?, en Informe Político $\mathrm{N}^{\circ}$ 3, 3D Trade - Human Rigths - Equitable Economy, 2006. Disponible en Internet en: http://www.3dthree.org/pdf 3D/3D CDESC DDHH PI.pdf. (28 Mar 2013).

${ }^{208}$ SEUBA, XAVIER. Derechos de propiedad intelectual y derechos humanos, estado de la cuestión y desarrollos recientes, Universidad Pomepeu Fabra de Barcelona. Disponible en Internet en http://www.descweb.org/files/cap12.pdf. (30 Mar 2013).

209 CHAPMAN, AUDREY. La propiedad intelectual como derecho humano. Boletín de Derecho de

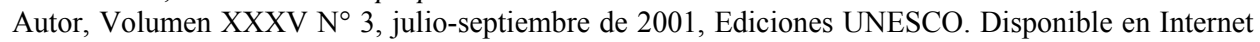
en: http://unesdoc.unesco.org/images/0012/001255/125505s.pdf. (30 Mar 2013).

210 Ob. supra cit., p. 7.

${ }^{211}$ Las referencias fueron tomadas de VELÁZQUEZ VELÁZQUEZ, SANTIAGO. Derechos humanos y derechos de propiedad intelectual, Revista Jurídica, Facultad de Ciencias Sociales y Políticas, Universidad Católica de Santiago de Guayaquil, pp. 28. Disponible en Internet en http://www.revistajuridicaonline.com/index.php?option $=$ com content\&task=view\&id=501\&Itemid $=5$ $\underline{0}$ (30 Mar 2013). 
Claro está, como todo en el derecho, el asunto no termina aquí, por lo que únicamente a modo de ejemplo, hay una tercera visión para la que "[e]l derecho de propiedad intelectual, es entonces un derecho humano en tanto su titular es una persona humana pero deja de serlo y se convierte en un derecho patrimonial cuando se titular es una empresa o alguno de sus representantes"214.

La polémica discurre entre quienes estiman que el carácter personal de la propiedad intelectual, en tanto indisolublemente ligada a su creador, emana de su propio ser y por tanto, debe ser reconocida como un derecho humano; y, aquellos que creen que, "[1]os derechos de propiedad intelectual carecen de las características fundamentales de los derechos humanos, ya que se establecen mediante leyes, tienen una duración limitada en el tiempo y pueden ser comprados, vendidos o revocados”215.

La discusión, si bien tiene un claro raigambre teórico, recrudece en la actualidad con el debate que se plantea entre países industrializados y en desarrollo sobre los efectos nocivos de la propiedad intelectual por grandes empresas transnacionales en el acceso a medicamentos, semillas, material educativo, aprovechamiento de recursos naturales y conocimientos tradicionales, todo ello en perjuicio del desarrollo sostenible de los países en desarrollo y menos adelantados ${ }^{216}$. El asunto se debate al más alto nivel en la OMPI, aunque allí, según nuestra manera de ver, las verdades jurídicas sólo sirvan para modelar las mayorías definidas por las fuerzas políticas. De todas formas, vale anotar, que la cuestión es levantada permanentemente por los países en desarrollo quienes estiman que no pueden "'subordinarse los derechos humanos -que son inalienables y universales- a la protección de la propiedad intelectual' ya que, de lo contrario, se pondrá en entredicho la capacidad que tienen los Estados para cumplir las obligaciones contraídas en materia de desarrollo y de derechos humanos"217; y, del otro lado, responden los países industrializados, ONGs y grupos de presión afines a ellos,

${ }^{212}$ SERRANO, YOLEIDA. Derechos Humanos y Propiedad Intelectual, Revista Razón y Palabra, № 81, noviembre $2012 \quad-\quad$ enero 2013. Disponible en Internet en http://www.razonypalabra.org.mx/N/N81/M81/15 Serrano M81.pdf. (30 Mar 2013).

213 ADAMES PÉREZ, JANET. La propiedad intelectual como derecho fundamental, Gaceta Judicial, 2009. Disponible

http://www.adopi.org.do/index.php?option=com content\&view=article\&id=82:la-propiedadintelectual-como-derecho-fundamental\&catid=43: articulos-de-interes\&Itemid=76. $(02$ Abr 2013).

${ }^{214}$ SERRANO. Ob. Cit., pp. 10.

${ }^{215}$ OVETT. Ob. Cit., pp. 2.

216 Sobre este asunto, pueden verse las obras citadas de: VELÁZQUEZ, SERRANO, CHAPMAN, SEUBA y ADAMES.

217 Ob. supra cit., p. 2. 
que hay "un derecho humano de protección de los intereses morales y materiales de los autores y los derechos de propiedad para reivindicar que los derechos de propiedad intelectual son derechos humanos y deben beneficiarse de normas más estrictas de protección de la propiedad intelectual”218.

En definitiva, lo cierto es que la discusión dista mucho de ser puramente teórica, como todo en esta materia está contaminada al máximo con intereses económicos y la idea que la creación y la innovación son las nuevas llaves del desarrollo y la prosperidad, de ahí la presión de las potencias económicas para incrementar los niveles de protección y del resto, por mantener esta protección lo más restringida posible ${ }^{219}$.

Bajo nuestros ojos, los argumentos teóricos para distanciar a la propiedad intelectual de los derechos humanos son contundentes, puesto que no posee las características fundamentales de los derechos humanos, en la medida que para nacer requiere de leyes que perfilen su contenido, sin las cuales no se sabría qué es lo protegido, cómo está protegido, cuánto tiempo dura la protección, si puede ser objeto compraventa, revocación, etc. Más esencialmente, debe considerarse que los derechos humanos son fundamentales, en tanto que la propiedad intelectual es instrumental y de ello se deriva, que los derechos humanos son inalienables e indisponibles, en cambio, la propiedad intelectual es cesible y comerciable. ${ }^{220}$

\subsubsection{La propiedad intelectual como derecho humano en el contexto internacional}

Considerando el asunto desde la visión del desarrollo de los derechos humanos en el contexto internacional, la propiedad intelectual ha sido vista en los siguientes instrumentos:

1) La consagración de esta postura, subyace en la Declaración Universal de los Derechos del Hombre y del Ciudadano, efectuada en Francia, el 26 de agosto de 1789 donde se declara el derecho de propiedad (artículo $2^{\circ}$ ) y el derecho a "La libre

\footnotetext{
${ }^{218}$ Ob. supra cit., p. 2.

219 El problema de la relación entre propiedad intelectual y desarrollo se viene plateando desde antaño, pero recrudeció con el Acuerdo sobre los ADPIC y el aumento de protección impuesto por los países desarrollados con motivo de convenios multi y bilaterales, tales como el NAFTA, llamados Tratados de Libre Comercio. El último convenio que busca aumentar la protección está en negociación, se denomina: "Trans Pacific Parnership". TPP por sus siglas en inglés.

220 SEUBA. Ob. Cit., pp. 6.
} 
comunicación de pensamientos y de opiniones (...); en consecuencia, todo ciudadano puede hablar, [escribir e imprimir libremente] (...),221.

2) En la Constitución de los Estados Unidos de Norteamérica, que en 1787, en el artículo I, sección 8 , cláusula 8 (en la llamada cláusula del progreso) estableció el derecho a "Fomentar el progreso de la Ciencia y las Artes útiles, asegurando a los autores e inventores, por un tiempo limitado, el derecho exclusivo sobre sus respectivos escritos y descubrimientos, ${ }^{, 22}$;

3) En la Declaración Americana de los Derechos y Deberes del Hombre de Bogotá de 1948, cuyo artículo XIII señala: "Toda persona tiene el derecho de participar en la vida cultural de la comunidad, gozar de las artes y disfrutar de los beneficios que resulten de los progresos intelectuales y especialmente de los descubrimientos científicos. Tiene asimismo derecho a la protección de los intereses morales y materiales que le correspondan por razón de los inventos, obras literarias, científicas y artísticas de que sea autor";

4) En la Declaración Universal de los Derechos Humanos, de 10 de Diciembre de 1948, que en su artículo 27 1, indica: "Toda persona tiene derecho a tomar parte libremente en la vida cultural de la comunidad, a gozar de las artes y a participar en el progreso científico y en los beneficios que de él resulten. 2. Toda persona tiene derecho a la protección de los intereses morales y materiales que le correspondan por razón de las producciones científicas, literarias o artísticas de que sea autora” ${ }^{223}$;

5) En la Convención Americana sobre Derechos Humanos o Pacto de San José de Costa Rica, de 1969, cuyo Capítulo III, Derechos Económicos, Sociales y Culturales, artículo 26, establece: "Los Estados Partes se comprometen a adoptar providencias, tanto a nivel interno como mediante la cooperación internacional, especialmente económica y técnica, para lograr progresivamente la plena efectividad de los derechos que se derivan de las normas económicas, sociales y sobre educación, ciencia y cultura, contenidas en la Carta de la Organización de los Estados Americanos, reformada por el Protocolo de

\footnotetext{
${ }^{221}$ Accesible en formato electrónico en: http://www.fmmeducacion.com.ar/Historia/Documentoshist/1789derechos.htm. (15 Mar 2013).

222 Accesible en formato electrónico en:

www.constitutioncenter.org. (15 Mar 2013).

223 Las referencias fueron tomadas de VELÁZQUEZ. Ob. supra cit., p. 28.
} 
Buenos Aires, en la medida de los recursos disponibles, por vía legislativa u otros medios apropiados";

6) En el Pacto Internacional de Derechos Económicos, Sociales y Culturales, suscrito al amparo de la Organización de Naciones Unidas, cuyo artículo 15, señala: "1. Los Estados Partes en el presente Pacto reconocen el derecho de toda persona a: a) Participar en la vida cultural; b) Gozar de los beneficios del progreso científico y de sus aplicaciones; c) Beneficiarse de la protección de los intereses morales y materiales que le correspondan por razón de las producciones científicas, literarias o artísticas de que sea autora";

7) En el apartado c) del párrafo 1 del artículo 14 del Protocolo Adicional a la Convención Americana sobre Derechos Humanos en Materia de Derechos Económicos, Sociales y Culturales, de 1988 ("Protocolo de San Salvador"); y, aunque no explícitamente, en el artículo 1, del Protocolo $\mathrm{N}^{0} 1$, del Convenio Europeo para la Protección de los Derechos Humanos y de las Libertades Fundamentales de 1952.

La naturaleza jurídica de los instrumentos que hemos mencionado es diferente, encontramos leyes, protocolos, tratados y una constitución, sin embargo lo importante de cada uno de los instrumentos mencionados es que ha ido, poco a poco, conformando la base de los derechos humanos tal como los conocemos en la actualidad, por lo tanto, son el referente obligado para definir si, actualmente, desde el punto de vista normativo internacional, la propiedad intelectual es un derecho humano.

Aun cuando algunos autores ${ }^{224}$ han querido ver en los documentos citados a la propiedad intelectual como derecho humano, la interpretación oficial de la mayoría de ellos, es la contraria. Efectivamente, para su análisis se pueden dividir en dos grupos, por una parte, los primeros referentes la Constitución de los Estados Unidos de 1787 y la Declaración Universal de los Derechos del Hombre y del Ciudadano, si bien en su momento entendían o podrían entender a la propiedad intelectual como parte del concepto de propiedad, recordemos que la connotación de "propiedad" se atribuyó a la propiedad intelectual, como una manera de despojarla de cualquier vinculación con los antiguos privilegios, a fin de conformar un derecho autónomo, sin ninguna vinculación a prerrogativa, dádiva o favor real. Así pues, a poco andar, su naturaleza jurídica de

\footnotetext{
${ }^{224}$ A modo de ejemplo: VELÁZQUEZ, SERRANO y ADAMES en las obras citadas.
} 
propiedad comenzó a ser discutida, por lo que en la actualidad, no podemos incluirla dentro de la protección a la propiedad general, tal como en apariencia, lo previeron la Declaración Universal de los Derechos del Hombre y del Ciudadano y la Constitución de los Estados Unidos de 1787, de lo que resulta que, conforme al tenor literal de estas normas, en el primer caso la propiedad intelectual queda más propiamente ligada a la libertad de expresión ${ }^{225}$ y en el segundo, se manifiesta como instrumental, un incentivo al progreso 226 .

Los restantes instrumentos que hemos citado, forman parte de un segundo grupo, donde tampoco hay una referencia expresa a la propiedad intelectual, sino que debe desprenderse de la mención que se efectúa a la protección del derecho a la "cultura" y del "derecho a la protección de los intereses morales y materiales". Bajo una redacción de ese tipo, que evita una mención expresa a la propiedad intelectual como derecho humano, donde solamente se deduce su presencia bajo el amparo de la protección de otros derechos como son la cultura y el derecho a la protección de los intereses morales y materiales, la propiedad intelectual pasa a ser un instrumento al servicio de estos derechos que la amparan, puesto que los países están obligados a la protección de la "cultura" y los intereses "morales y materiales", pero no de la propiedad intelectual. En otras palabras, pueden lograr la protección que se les pide, a través de la propiedad intelectual o de otros medios, como por ejemplo: privilegios de fabricación, premios, subvenciones, exenciones de impuestos, secreto comercial u otros ${ }^{227}$.

\subsubsection{La Observación General $N^{\circ} 17$ (2005) del Comité de Derechos Económicos, Sociales y Culturales}

La discusión sobre la naturaleza de la propiedad intelectual como derecho humano, que a ratos amenaza con eternizarse, a nuestro juicio está destinada a permanecer hasta tanto los teóricos de la economía, sigan sustentando que la propiedad intelectual es la clave del desarrollo. En fin, el asunto ha intentado ser interpretado incluso por los órganos oficiales de la Organización de las Naciones Unidas, donde el Comité de Derechos Económicos Sociales y Culturales ${ }^{228}$, a través de la Observación

\footnotetext{
${ }^{225}$ Al decir: "todo ciudadano puede hablar, escribir e imprimir libremente (...)".

${ }^{226} \mathrm{Al}$ decir: "Fomentar el progreso de la Ciencia y las Artes útiles, asegurando (...)".

${ }^{227}$ Ejemplos sacados de SAÍZ. Ob. supra cit., p. 34.

${ }^{228}$ El Comité de Derechos Económicos, Sociales y Culturales (CESCR) es el órgano de expertos independientes que supervisa la aplicación del Pacto Internacional de Derechos Económicos, Sociales y Culturales por sus Estados Partes. Se estableció en virtud de la resolución 1985/17 (1985). Esto en:
} 
General $\mathrm{N}^{\circ} 17$ (2005), intentó explicar la diferencia entre derechos de propiedad intelectual y derechos humanos, a la luz de lo dispuesto en el apartado c) del párrafo 1 del artículo 15, del Pacto Internacional de Derechos Económicos, Sociales y Culturales, que reconoce el derecho a toda persona de "a beneficiarse de la protección de los intereses morales y materiales que le correspondan por razón de las producciones científicas, literarias o artísticas de que sea autor(a),229.

En la discusión, no puede perderse de vista la casi identidad entre la redacción del apartado 2 del artículo 27 de la Declaración Universal de Derechos Humanos que dice: "Toda persona tiene derecho a la protección de los intereses morales y materiales que le correspondan por razón de las producciones científicas, literarias o artísticas de que sea autora", puesto que implícitamente, lo dicho para uno aplica al otro, en el mismo sentido, tampoco puede obviarse la similitud de la protección conferida por los instrumentos citados, con aquella reconocida en los restantes instrumentos internacionales que mencionamos anteriormente.

El objetivo de la Observación General $\mathrm{N}^{\circ} 17$ (2005) fue aclarar la diferencia entre derechos de propiedad intelectual y derechos humanos ${ }^{230}$, lo que hace explícitamente diciendo que el derecho garantizado en el apartado c) del párrafo 1 del artículo 15, a que hemos hecho referencia, no es un derecho humano y que los derechos

http://www2.ohchr.org/spanish/bodies/cescr/index.htm. (01 Abr 2013).

El Pacto de Derechos Económicos, Sociales y Culturales es (ICESCR, por su sigla en inglés) es un tratado multilateral general que tiene por objeto la protección de derechos económicos, sociales y culturales. Adoptado por la Asamblea General de las Naciones Unidas en 1966, entró en vigor en 1976. En él, las partes asumen la obligación de trabajar por los derechos económicos, sociales y culturales de las personas, incluidos los derechos laborales y los derechos a la salud, la educación y un nivel de vida adecuado. Esto en:

http://es.wikipedia.org/wiki/Pacto Internacional de Derechos Econ $\% \mathrm{C} 3 \% \mathrm{~B} 3$ micos, Sociales y Cul turales. (01 Abr 2013).

229 Al respecto OVETT. Ob. supra cit., p. 2, relata que la "Observación General es el resultado de un largo proceso que se remonta al año 2000, cuando se celebró el día de debate general del Comité de Derechos Económicos, Sociales y Culturales sobre el apartado c) del párrafo 1 del artículo 15 del Pacto Internacional de Derechos Económicos, Sociales y Culturales, al que siguió una declaración sobre la propiedad intelectual y los derechos humanos en 2001, y la elaboración de la Observación General $\mathrm{n}^{\mathrm{o}} 17$ entre 2003 y 2005. En el proceso de redacción de la Observación General, los defensores de los derechos humanos y los expertos en propiedad intelectual a favor del desarrollo hicieron hincapié en la necesidad de que en el texto se explicara la diferencia entre propiedad intelectual y derechos humanos, al tiempo que también se abordaban los efectos negativos de las normas de propiedad intelectual en el acceso a los medicamentos, las semillas, el material educativo, el desarrollo sostenible y los conocimientos tradicionales".

${ }^{230}$ Ob. supra cit., p. 1. 
de propiedad intelectual que reconocen las legislaciones tienen un contenido y una extensión diferentes ${ }^{231}$.

La Observación General ha sido fuertemente criticada por: estimarse que desmarca la protección de los intereses morales y materiales de los autores, del apartado a) del párrafo 1 del artículo 15 , donde se contiene el acceso a la cultura, sin lo cual no puede interpretarse $\mathrm{e}^{232}$; estimarse que "da alas a la tendencia expansiva de la protección de la propiedad intelectual" ${ }^{, 233}$; poseer un lenguaje confuso que impide saber si está hablando de la propiedad intelectual como derecho humano o como el derecho aprovecharse de sus beneficios ${ }^{234}$; considerarse que las afirmaciones sobre prohibición a la discriminación en el goce de los derechos, puede dar pie a la sobreprotección de la propiedad intelectual ${ }^{235}$; establecer un enfoque sobre las violaciones que puede llevar a la sobreprotección en perjuicio de los “compromisos contraídos en la esfera del desarrollo y los derechos humanos, en particular los derechos a la alimentación, la salud y la educación, así como los derechos a participar en la vida cultural y a gozar de los beneficios del progreso científico y de sus aplicaciones"236.

${ }^{231}$ En lo más relevante para nuestros fines, la Observación General $N^{\circ} 17$, señala: "El derecho de toda persona a beneficiarse de la protección de los intereses morales y materiales que le correspondan por razón de las producciones científicas, literarias o artísticas de que sea autora es un derecho humano, que deriva de la dignidad y la valía inherentes a toda persona. Este hecho distingue el derecho consagrado en el apartado c) del párrafo 1 del artículo 15 y otros derechos humanos de la mayoría de los derechos legales reconocidos en los sistemas de propiedad intelectual. Los primeros son derechos fundamentales, inalienables y universales del individuo y, en ciertas circunstancias, de grupos de individuos y de comunidades. Los derechos humanos son fundamentales porque son inherentes a la persona humana como tal, mientras que los derechos de propiedad intelectual son ante todo medios que utilizan los Estados para estimular la inventiva y la creatividad, alentar la difusión de producciones creativas e innovadoras, así como el desarrollo de las identidades culturales, y preservar la integridad de las producciones científicas, literarias y artísticas para beneficio de la sociedad en su conjunto.

2. En contraste con los derechos humanos, los derechos de propiedad intelectual son generalmente de índole temporal y es posible revocarlos, autorizar su ejercicio o cederlos a terceros. Mientras que en la mayoría de los sistemas de propiedad intelectual los derechos de propiedad intelectual, a menudo con excepción de los derechos morales, pueden ser transmitidos y son de alcance y duración limitados y susceptibles de transacción, enmienda e incluso renuncia, los derechos humanos son la expresión imperecedera de un título fundamental de la persona humana. Mientras que el derecho humano a beneficiarse de la protección de los intereses morales y materiales resultantes de las producciones científicas, literarias o artísticas propias protege la vinculación personal entre los autores y sus creaciones y entre los pueblos, comunidades y otros grupos y su patrimonio cultural colectivo (...). Además, el alcance de la protección de los intereses morales y materiales del autor prevista en el apartado c) del párrafo 1 del artículo 15 no coincide necesariamente con lo que se denomina derechos de propiedad intelectual en la legislación nacional o en los acuerdos internacionales".

${ }^{232}$ SEUBA. Ob. supra cit., p. 8.

${ }^{233}$ Ob. supra cit., p. 8.

${ }^{234}$ Ob. supra cit., p. 10.

${ }^{235}$ Ob. supra cit., p. 11

${ }^{236}$ OVETT. Ob. supra cit., p. 7. 


\subsubsection{La propiedad intelectual como derecho humano, nuestra opinión}

Como hemos podido apreciar, desde el punto de vista doctrinario hay quienes sostienen que la propiedad intelectual es un derecho humano, sin embargo en el ámbito internacional, que es donde los derechos humanos han visto su nacimiento y desarrollo, no es posible sostener que en los instrumentos internacionales sobre la materia se considere, indubitadamente, a la propiedad intelectual como un derecho humano.

El reconocimiento de la propiedad intelectual ha tenido un desarrollo extenso desde el Convenio de París para la Protección de la Propiedad Industrial, el Convenio de Berna para la Protección de las Obras Literarias y Artísticas, en su última versión revisada en 1971, la Convención Internacional sobre la Protección de los Artistas Intérpretes o Ejecutantes, los Productores de Fonogramas y los Organismos de Radiodifusión (Convención de Roma), el Tratado de la OMPI sobre Derecho de Autor, el Tratado de la OMPI sobre Interpretaciones o Ejecuciones y Fonogramas, el Convenio sobre la Diversidad Biológica, la Convención Universal sobre Derechos de Autor y el Acuerdo sobre los Aspectos de los Derechos de Propiedad Intelectual Relacionados con el Comercio (ADPIC) de la OMC, sin embargo no ha sido posible incorporarla de manera explícita en los acuerdos sobre derechos humanos ${ }^{237}$. Lo primero que salta de esta observación, es una obviedad que ya apuntamos, no hay consenso sobre que sea un derecho humano y de contrario, tampoco hay acuerdo que no sea un derecho humano. Entonces: ¿Por qué preocupa tanto el problema? Desde nuestro punto de vista, es fiel reflejo de la influencia que están teniendo las decisiones económicas en el ámbito internacional, verdaderamente que intrínsecamente el ser humano toma en consideración cuestiones económicas para todas sus decisiones, pero en el caso específico de la propiedad intelectual, su vinculación con la educación, la innovación y el desarrollo, han esculpido las decisiones en la materia, al menos desde la Revolución Francesa e Industrial, hasta nuestros días.

Actualmente, sostener que la propiedad intelectual es un derecho humano, puede servir para alterar la balanza argumentando la necesidad de más propiedad intelectual para su protección ${ }^{238}$. Declarar que la propiedad intelectual no es un derecho humano y no tiene ninguna vinculación con ellos, puede implicar que la protección de otros

\footnotetext{
${ }^{237}$ Sobre las dificultades de incorporar a la propiedad intelectual en los convenios sobre derechos humanos, puede verse: OVETT. Ob. supra cit., pp. 2 - 4.

${ }^{238}$ OVETT. Ob. Cit., pp. 2.
} 
derechos puede menoscabarla en su base. De esta forma, la comunidad internacional, como todo grupo social, ha ido encontrando una media, una postura equidistante para la propiedad intelectual, que se traduce en su amparo al nivel de derecho humano, bajo el cobijo del acceso a la cultura y la protección de los intereses patrimoniales y morales de los autores y creadores, soslayando de esta manera la orfandad al excluirla de la jerarquía de derecho humano y a la vez, evitando los inconvenientes de un reconocimiento original como derecho humano.

Para nosotros, la realidad actual es una medida de equilibrio, que está compensada por intereses cruzados sustentados en la idea que la propiedad intelectual es la llave del bienestar, por lo cual, el asunto no variará en el futuro.

\subsection{La propiedad intelectual desde el análisis económico del derecho}

Tal como hemos venido advirtiendo, la propiedad intelectual ha estado fuertemente influida, sino determinada, por razones económicas, asunto que el derecho no reconocía, sino que la doctrina insistía en buscar las explicaciones de la propiedad intelectual, únicamente en cuestiones jurídicas. Al respecto, RICHARD POSNER, nos recuerda como en los años 80 , "todavía era necesario justificar tanto a juristas como a un gran número de economistas y autoridades políticas la adopción de un enfoque económico en el ámbito del derecho (...) [a]ctualmente se admite que para llevar a cabo un análisis y una evaluación adecuada del derecho de propiedad intelectual debe adoptarse una perspectiva económica (...)”239.

A nuestro juicio, al menos en los últimos cien años, toda la evolución del sistema internacional de protección de la propiedad intelectual se ha ido produciendo como reacción a nuevos postulados económicos, por ejemplo: SMITH (1723-1790), plantea las bases de la economía de libre mercado y la relación entre comercio y crecimiento económico (donde la propiedad intelectual es una mercadería); y, RICARDO $^{240}$ (1772-1823), postularon la existencia de las ventajas comparativas y los beneficios del comercio internacional (la propiedad intelectual otorga ventajas y es transable internacionalmente); es decir, en ese momento histórico está asentada la

${ }^{239}$ LANDES, WILLIAM M. y POSNER, RICHARD A. La estructura económica del Derecho de propiedad intelectual e industrial, traducción de SÁNCHEZ ÁLVARES, VÍCTOR MANUEL, Fundación Cultural del Notariado, Madrid, 2006, p. 10.

${ }^{240}$ Otros clásicos como BENTHAM y MILL, también se preocuparon del tema. LANDES y POSNER. Ob. supra cit., p. 8. 
importancia de la propiedad intelectual como objeto económico y coincidentemente, es el mismo instante en que se desprende de la idea de privilegio y es llevada al más alto grado de protección, considerándola como propiedad en la Declaración Universal de Derechos Humanos y del Ciudadano (Francia 1789) e incorporándola en la Constitución de los Estados Unidos de Norteamérica (1787).

Buscando otro ejemplo, podemos ver como, CHRISTOPHER FREEMAN publica el libro The economics of industrial innovation ${ }^{241}$ en 1974, obra que es republicada en 1982 y 1997, donde plantea la idea neoshumpeteriana o evolucionista, que viene a realzar la importancia del análisis económico en la innovación, así pues en 1998, con la publicación de The economics of thecnical change ${ }^{242}$, vino a cerrar un capítulo, destacando la relación entre la ciencia (conocimiento y por ende bienes culturales) como un factor endógeno al proceso innovador e indicando como contribuyen las fuentes internas y externas a la empresa (y al país) en los procesos de innovación ${ }^{243}$, concurrentemente en el año 1994, se firman los Acuerdos de Marrakech, se establece la Organización Mundial del Comercio y se suscribe el Acuerdo sobre los ADPIC, desde ahí se inicia una cruzada de los países industrializados por elevar los estándares de protección de la propiedad intelectual vía tratados multi o bilaterales.

Estamos lejos de querer suscribir o plantear afirmar que la regulación de la propiedad intelectual está determinada por el desarrollo de la teoría económica o que exista alguna relación temporal entre ellas, lo que buscamos destacar es un asunto mucho más simple, tal es que, el asentamiento de una determinada idea económica tiene una incidencia en la regulación jurídica que se ha dado a la propiedad intelectual. Por cierto que cada norma jurídica obedece a un patrón complejo de ideas, cultura, historia, idiosincrasia, religión, etc., que se dan en una sociedad determinada en un momento histórico específico; no obstante, desde nuestro punto de vista, en la propiedad intelectual en general y la propiedad industrial en particular, la incidencia de la visión económica viene siendo un asunto fundamental, tendencia que se incrementado desde el

${ }^{241}$ FREEMAN, CHRISTOPHER. The economics of industrial innovation, Routledge, Tercera Edición, 1997.

242 Capítulo 2, del libro Trade, growth and technical change, Editado por Daniel Archibugi y Jonathan Michie, publicado por Cambridge University Press, 1998, pp. 16 y sgtes.

243 FREEMAN, CHRISTOPHER. The economics of thecnical change, en Trade, growth and technical change, editado por Daniel Archibugi y Jonathan Michie, publicado por Cambridge University Press, 1998, apartados tercero y cuarto. 
Convenio de la Unión de París y continúa creciendo después del Acuerdo sobre los ADPIC.

El análisis económico del derecho, como sabemos, es "la aplicación de las categorías e instrumentos de la teoría microeconómica neoclásica y sus modelos econométricos en la explicación y evaluación de las instituciones y realidades jurídicas ${ }^{\text {244 }}$ o más simplemente, la aplicación del método de la economía al derecho, para explicar la realidad jurídica.

Al observar la relevancia que ha tenido la teoría económica en la propiedad intelectual, por un lado y advertir que existe toda una teoría sobre la incidencia de la economía en la norma jurídica, a nuestro juicio, actualmente, sólo es posible una visión completa de la propiedad intelectual cuando se acepta su relevancia como bien económico y la importancia que ha tenido la coyuntura económica en el resultado normativo que actualmente exhibe. Por nuestros días, es bien posible que la explicación de una determinada norma jurídica o decisión judicial, no la encontremos en la naturaleza jurídica, en el derecho positivo o en fuentes del derecho, sino que derechamente en justificaciones de orden económico o político económico, puesto que es finalmente la política la que impone sus transacciones al derecho. Al respecto, vale anotar lo que dice RICHARD POSNER: "Por lo que hace al papel positivo del análisis económico del derecho -el intento de explicar las reglas y los resultados legales tal como son, en lugar de cambiarlos para volverlos mejores-, veremos (...) que muchas áreas del derecho, sobre todo, pero no únicamente, los grandes campos del derecho común de la propiedad, los cuasidelitos ${ }^{245}$, los delitos y los contratos, ostentan la marca del razonamiento económico. Es cierto que pocas opiniones judiciales contienen referencias explicitas a los conceptos económicos. Pero es frecuente que las bases verdaderas de la decisión estén ocultas antes que iluminadas por la retórica característica de las opiniones" ${ }^{246}$.

Desde el análisis económico del derecho, son dos los puntos claves que han influido en el establecimiento de la propiedad intelectual, como actualmente la

${ }^{244}$ Diccionario Jurídico en línea: Diccionariojurídico.mx. Disponible en: http://www.diccionariojuridico.mx/?pag=vertermino\&id=136 (05 Abr 2013).

245 Cuasidelito, es la expresión utilizada por el derecho continental, para referirse a los delitos cometidos con culpa.

${ }^{246}$ POSNER, RICHARD A. El análisis económico del derecho, traducción de SUAREZ, EDUARDO, Fondo de Cultura Económica, Segunda Edición, México, 2007, pp. 58. 
conocemos. El primero de ellos, es la constatación sobre el hecho que económicamente la mayor eficiencia se alcanza por la vía de asignar derechos de propiedad. El segundo, la relación entre investigación, innovación y desarrollo, como bases del desenvolvimiento económico y la propiedad intelectual.

\subsubsection{La eficiencia económica y el derecho de propiedad}

Para la economía, la propiedad tiene una significación distinta que para el derecho. Para LANDES y POSNER el "derecho de propiedad consiste en la facultad jurídicamente protegida de excluir a otras personas de la utilización de un recurso"247. Bajo esta definición, el problema económico de las necesidades múltiples y los recursos escasos tiene una vinculación directa con la propiedad, en la medida que permite excluir a otros del disfrute de ciertos bienes que satisfacen necesidades.

Tal como nos recuerda SÁIZ, "en la [H]istoria de las [D]octrinas [E]conómicas no hay una elaboración teórica sobre el tema de los derechos de propiedad hasta que $\mathrm{Z}$. Marshall (...) y A.C. Pigou, se ocupan de ello"248. ARTHUR CECIL PIGOU fue el gran teórico del derecho de propiedad, hasta que RONALD COASE criticó su posición y planteó lo que GEORGE STIGLER, llamó “Teorema de COASE". Para ARTHUR PIGOU, es la búsqueda del interés personal de cada cual, el que lleva al bienestar económico, sin embargo existen las "externalidades", que producen divergencias entre el bienestar económico que se generaría de la búsqueda del bienestar de cada cual, es decir hay diferencia entre el producto social neto y el particular. Para la corrección de estas diferencias, de manera que aumente el bienestar general y la renta nacional, debe intervenir el Estado. Las externalidades negativas pueden ser corregidas con un impuesto y las positivas estimuladas con un subsidio. En palabras de SÁIZ ${ }^{249}$ : "La solución teórica a la que llegó PIGOU fue la intervención institucional y legal para gravar a los que resultaran beneficiados y recompensar o subvencionar a los perjudicados".

MIRÓ ROCASOLANO ${ }^{250}$ grafica el asunto, citando el ejemplo de ARTHUR PIGOU sobre una locomotora que despide chispas a bosques cercanos, puesto que la

\footnotetext{
${ }^{247}$ LANDES y POSNER. Ob. supra cit., p. 22.

${ }^{248}$ SÁIZ. Ob. supra cit., p. 34.

${ }^{249}$ SÁIZ. Ob. supra cit., p. 35.

${ }^{250}$ MIRÓ ROCASOLANO, PABLO. El teorema de Coase y sus implicaciones según el problema del coste social, en Contribuciones a la Economía de La Economía de Mercado, virtudes e
} 
locomotora causa daño, se le debería exigir un impuesto para palear esos daños o indemnizar a quienes se incendien sus bosques, por esta vía se llegará a una eficiencia óptima, puesto que la locomotora para evitar el pago del impuesto buscará alternativas para no lanzar chispas o el rendimiento del impuesto repararía el daño.

RONAL COASE ${ }^{251}$ contraviene la posición de ARTHUR PIGOU ${ }^{252}$, fundado en el derecho de propiedad, puesto que piensa que si los derechos de propiedad están bien establecidos, no es necesaria la intervención del Estado para enfrentar las externalidades. Él muestra que cuando los costos de transacción son bajos, "para alcanzar niveles óptimos de uso e inversión de los recursos, la sociedad únicamente necesita que se delimiten derechos contractuales cuyo cumplimiento se asegure legalmente (...) ${ }^{, 253}$, bajo esta premisa, rechaza la necesidad de intervención y entiende que se debe permitir la externalidad cuando los costos de transacción son menores de lo que se persigue con el intercambio. Así, únicamente, "si el beneficio que se pudiera obtener eliminando la externalidad fuera mayor que el daño que se produce al eliminar la actividad generadora de la misma, tiene sentido la intervención, aunque en tal caso es mejor llegar a ese óptimo mediante negociación” ${ }^{, 54}$. Dejando a los agentes del mercado actuar, con bajos costos de transacción y con reglas claras, se producirá el óptimo rendimiento de la economía. MIRÓ ROCASOLANO lo explica continuando con el ejemplo del tren y el bosque, al decir: "un impuesto sobre la locomotora puede evitar un daño (externalidad), que bien puede causar un mayor perjuicio a la colectividad si se reducen los servicios que presta el tren y éstos tienen más valor de la madera que se queme por las chispas. Hay que ver el efecto total en base a un análisis coste-beneficio, en un sistema general: ¿Qué es más perjudicial?, ¿Qué se queme la madera del bosque o que el tren deje de prestar servicios para que no se queme la madera (afectando por

inconvenientes. Disponible en: http://www.eumed.net/cursecon/colaboraciones/index.htm (05 Abr 2013).

${ }^{251}$ COASE plantea su teoría en el artículo The problem of social cost, publicado en 1960.

${ }^{252}$ Según explica MIRÓ ROCASOLANO. Ob. supra cit., RONALD COASE discute a ARTHUR PIGOU, básicamente, con los siguientes argumentos: 1) la recaudación del impuesto no tiene por qué llegar a los afectados, en cuyo caso se perderá; 2) la subvenciones tienen muy poca aplicación práctica; 3) si bien un impuesto puede disminuir una externalidad negativa, no siempre será deseable que eso suceda; 4) plantear el asunto sólo en términos de impuesto desconoce la naturaleza recíproca del problema, es decir que en el ejemplo del tren están involucrados el propietario del tren y el dueño de los bosques. Para RONALD COASE incluso si el impuesto gravara al tren y al dueño del bosque, la solución sería ineficiente, lo que resolvería el problema es la negociación recíproca entre las partes, para lo cual necesitan reglas claras sobre la propiedad y el cumplimiento de lo negociado.

${ }^{253}$ LANDES y POSNER. Ob. Cit., pp. 24.

${ }^{254}$ MIRÓ. Ob. supra cit. 
tanto a los usuarios del tren)? Es por eso, que no siempre es deseable ni la intervención ni la responsabilidad por daños",255.

Para LANDES y POSNER $^{256}$ la propiedad es necesaria porque produce dos tipos de beneficios económicos: estáticos y dinámicos. Los beneficios estáticos se producen porque si la propiedad fuese pública, todos concurrirían a ella, se sobreexplotaría y perdería su valor para toda la sociedad; en cambio, al ser privada el propietario se encarga de explotarla hasta su máximo posible y de mantenerla útil. Los beneficios dinámicos, dicen relación con la actividad del propietario para mejorar su propiedad, lo que no haría si la propiedad fuese pública. Además, en el caso de la propiedad intelectual, hacen presente que al igual que la propiedad sobre bienes físicos, puede generar beneficios estáticos al eliminar las externalidades de congestión, lo que se produce porque en ausencia de propiedad intelectual, efectivamente ésta podría sobreexplotarse, el ejemplo que sugieren es el de Mickey Mouse, que si no estuviese protegido y controlada estrictamente la forma y cantidad de Mickey Mouses que llegan al mercado, podría haber sido sobreexplotado, hartando al consumidor, perdiendo completamente su valor ${ }^{257}$.

Hasta este punto, lo relevante para nuestro estudio es constatar que tanto en el análisis de ARTHUR PIGOU como en el de RONALD COASE, la norma jurídica y el diseño que ella haga del derecho de propiedad, tienen necesariamente un efecto en el plano económico, lo que también permite sostener que la visión económica modelará la definición de propiedad en un determinado momento.

Esta misma constatación ya la hizo SÁIZ GONZÁLEZ, al revelar que una de las cosas que más llamó su atención al estudiar el análisis económico del derecho de propiedad, fue el llamado uniforme que hacen los economistas teóricos a analizar la historia, pues el efecto más importante que se puede ver de los cambios que ha sufrido

255 Ob. supra cit.

${ }^{256}$ LANDES y POSNER. Ob. supra cit., pp. 22 y sgtes.

257 Ob. supra cit., pp. 291 y sgtes.

Obviamente que el análisis económico del derecho, si bien fue planteado por RICHARD POSNER, no ha terminado en él. SÁIZ. Ob. supra cit., p. 36, nos recuerda a muchos otros autores que han seguido investigando sobre las implicancias económicas de la propiedad, mencionando A: DEMSETZ. H. Hacia una teoría de los derechos de propiedad, Hacienda Pública Española, № 68, 1981, p. 289; ALCHIAN, A. Reflexiones económicas en torno a los derechos de propiedad, N 68, 1981, pp. 325 a 334; y, FURUBOTN E. y PEJOVICH S. Los derechos de propiedad, pp. 296 a 297. 
el derecho de propiedad (en el sentido económico) ${ }^{258}$ es "la reducción de costes de transacción a la hora de negociar (el análisis de la propiedad sobre el invento nos develará, como veremos, que la patente parece ser la fórmula de menores costes)". En otras palabras, para los economistas, la evolución del derecho de propiedad intelectual se ha venido dando hasta llegar a la conformación que reduce al máximo los costes de transacción, que es el sistema de patentes.

Al analizar las diferente teorías sobre la propiedad intelectual y su historia, hemos tenido oportunidad de revisar las diferentes formas de apropiación de las ideas que se han desarrollado en la historia, desde la formula romana de la protección del honor y el plagio, la propiedad pública o estatal en la edad media, la propiedad colectiva en los gremios, el secreto, premios y beneficios, los privilegios y la fórmula más reciente de propiedad intelectual como propiedad intelectual propiamente tal $\mathrm{y}$ propiedad industrial, por lo que, no cabe que hagamos un nuevo análisis, más aún, cuando hemos anticipado que la propiedad privada sobre las ideas es la fórmula que económicamente se estima más eficiente ${ }^{259}$. Sobre este asunto, compartimos con SÁIZ GONZÁLEZ ${ }^{260}$ que el capitalismo nunca ha dudado que las personas son dueñas de sus ideas, el problema es: ¿Qué tipo de propiedad privada es más eficiente en términos económicos y por qué? Para el autor ${ }^{261}$, las posibilidades son las siguientes: 1) la propiedad estatal y comunal; 2) propiedad privada no exclusiva; 3) propiedad privada total y exclusiva; 4) propiedad privada exclusiva temporal; y, 5) propiedad privada semiexclusiva y temporal.

Los economistas han ido descartando las diferentes formas de propiedad hasta llegar a aceptar al sistema de patentes como aquél que produce los mayores beneficios, lo que, obviamente, ha ido recogiendo el sistema jurídico. Las razones por las cuales un sistema de propiedad es mejor que otro, las veremos seguidamente.

La propiedad estatal o colectiva produce los mayores costes sociales, en la medida que el bien es público, todos pueden usarlo sin pagar al inventor que no podrá

\footnotetext{
${ }^{258}$ Recordemos que el sentido que se da al término propiedad es el de un economista, es decir, como la posibilidad de excluir a tercero del uso público de un bien. Por lo que, el traspaso desde la protección del derecho de autor, por la vía del plagio, los privilegios, el derecho de propiedad común y el derecho de autor, es un ejemplo de cambio del derecho de propiedad para estos efectos.

259 Al menos para las economías de mercado, como es el caso de España y Chile, que finalmente son el objeto de nuestro estudio.

${ }^{260}$ SÁIZ. Ob. supra cit., p. 44.

${ }^{261}$ SÁIZ. Ob. Cit., p. 44.
} 
recuperar su inversión, ni tendrá estímulo para inventar, por otro lado nadie estará interesado en invertir en la conservación del bien público. La propiedad privada no exclusiva, tal como dice SÁIZ GONZÁLEZ ${ }^{262}$, es simplemente una contradicción, en ese caso, se piensa que el inventor es el dueño de su invención, por lo que puede mantenerla en secreta y transarla, pero no tiene la facultad de evitar que otros la copien. Una vez que se reproduzca la invención por un tercero, será él quien intente transarla, de manera que, los costos de transacción se elevarán y el costo social será el retraimiento de las invenciones ${ }^{263}$. La propiedad privada total y exclusiva, conlleva que la propiedad es como los bienes físicos, es decir, perpetua y heredable. Dar este tipo de control sobre el derecho de autor, implica que usar hoy una obra de HOMERO, podría implicar un pago a sus herederos y pedir licencia para su uso, lo que elevaría los costos de producción de obras nuevas y paradójicamente disminuiría la creación de obras ${ }^{264}$. Respecto de las patentes, el efecto es igualmente perjudicial, una tecnología para siempre bajo el control de una única persona, implica que los costos de transacción se harían enormes, más aún cuando se trate de tecnologías dependientes de otras previas, baste imaginar la cantidad de licencias que se necesitarían para construir un automóvil, sobre el motor, airbags, bombillas, sistema de ignición, etc. La propiedad privada exclusiva temporal, el sistema actual, caracterizado por unos derechos de propiedad (facultad de excluir en términos económicos) limitados en el tiempo, para posteriormente pasar al dominio público (disponible para cualquiera). Aquí el autor o inventor se beneficia al ser el único que puede comercializar mientras dure la protección y la sociedad recibe el aporte que implica la difusión de la creación o invención. Por su parte, la transacción se puede producir directamente con el autor o inventor durante la vigencia de la protección o con terceros después de extinguida la protección, de manera que los costos de transacción se reducen y tanto la sociedad como el autor e inventor se benefician. El centro del problema en este modelo, son los plazos de protección, de hecho, paradójicamente, plazos de protección demasiado largos tenderán a producir los efectos de la propiedad perpetua afectando negativamente a la creación e innovación ${ }^{265}$. Finalmente, la propiedad privada semiexclusiva y temporal, es una variante de la anterior, donde el propietario es obligado a transar sus derechos durante la vigencia de

\footnotetext{
${ }^{262}$ SÁIZ. Ob. Cit., p. 45.

${ }^{263}$ SÁIZ. Ob. Cit., p. 45.

${ }^{264}$ LANDES y POSNER. Ob. Cit., p. 96.

${ }^{265}$ LANDES y POSNER. Ob. supra cit., pp. 96 y 97. Estiman que el plazo óptimo de protección en el derecho de autor son entre veinte y veinticinco años.
} 
la protección, en derecho de autor cabrían aquí los usos justos amparados bajo la doctrina del fair use ${ }^{266}$ y en patentes, las licencias obligatorias.

Como podemos apreciar hasta el momento, la teoría económica es clara en señalar que la propiedad intelectual es el sistema de explotación de las ideas más eficiente y el que reduce los costes de transacción de mayor manera, en comparación con los métodos que han existido históricamente. Solamente hemos observado discrepancia en los plazos de protección, particularmente, en derechos de autor, donde LANDES y POSNER, postulan plazos de entre veinte y veinticinco años, no obstante en la actualidad estos plazos llegan a toda la vida del autor, más setenta años.

\subsubsection{La relación entre investigación, innovación y desarrollo como bases del desarrollo económico y la propiedad intelectual}

Tener o no un sistema de propiedad intelectual y en el evento de tenerlo, definir cuál es el más eficiente, es un asunto que sin duda tiene repercusiones en la cantidad de bienestar que proporcionarán a la sociedad los bienes regulados, lo que no implica que haya necesidad de regular el acceso a todos los bienes. Es decir, la pregunta que cabe es por qué ha habido tanto empeño en la regulación de la propiedad intelectual, al punto de haberse transformado en una disciplina de escala planetaria y cuál es la relevancia de la innovación en ello. Aunque nos haremos cargo de estas preguntas seguidamente, debemos anticipar, que la innovación es actualmente entendida como el motor del desarrollo económico y de ahí la importancia de la propiedad intelectual, en tanto herramienta de protección y estímulo de la innovación ${ }^{267}$.

\subsubsection{El origen de la innovación}

Será de gran utilidad, conocer las diferentes teorías que intentan explicar el origen de las invenciones, en tanto unas y otras son a la vez presupuesto o antecedente de las teorías económicas sobre el avance técnico. La pregunta es: ¿Cómo o por qué se originan las invenciones? Las podemos suponer autónomas, surgiendo de una especie de instinto de los hombres por crear o en una línea de pensamiento económica,

\footnotetext{
${ }^{266}$ Sobre fair use, se puede ver: Ob. supra cit., pp. 155 y sgtes.

${ }^{267}$ HYWEL G, JONES. En Introducción a las teorías modernas del crecimiento económico, Antoni Bosch, Barcelona, 1979, pp. 3, recuerda como MISHAN ha acuñado la expresión "La manía del crecimiento", para referirse a la idea generalizada de la necesidad del crecimiento económico como promotor de bienestar.
} 
dependientes de las fuerzas que regulan el mercado. PALMA MARTOS ${ }^{268}$ hace un excelente recorrido por cinco de las principales teorías sobre la materia.

Teoría heroica o trascendentalista. Esta corriente supone que la invención viene dada por el toque ocasional y genial de una persona determinada, que derivada de aquél, logra conocer la verdad esencial. Para este enfoque, la invención termina allí, el resto del proceso de innovación, la aplicación práctica de esta verdad esencial, hasta llevarla al mercado, es un simple acto de "habilidad al alcance de cualquier técnico competente" 269 .

Teoría mecanisista. Intenta explicar el asunto, sosteniendo que la invención es una mezcla, combinación o alianza desconocida de elementos hasta ese momento conocidos. El invento surge entonces de la actividad más o menos preestablecida y mecánica que desarrolla el inventor, siendo él un mero instrumento del proceso.

Teoría de la síntesis acumulativa. En este caso, bajo la influencia de la teoría sicológica de la Gestalt, se distingue entre los actos de habilidad y los inventos, donde los primeros nacen de la intuición normal de cualquier individuo adiestrado y los segundos, se generan por la intuición de personas superiores bajo circunstancias especiales. Para esta posición, "pueden reconocerse cuatro pasos distintos en el proceso de invención: la percepción de un patrón poco satisfactorio (percepción del problema), la preparación (arreglo) del escenario, el acto primario de intuición (acto de intuición) y la revisión y el desarrollo críticos (revisión crítica)"270. Esta teoría a diferencia de las anteriores, ve la innovación como un proceso donde pueden caber tanto la ciencia pura, invenciones o el proceso de innovación, en otras palabras, se extiende de manera transversal desde la creación misma del conocimiento nuevo, hasta su desarrollo y aplicación comercial. Sobre este punto PALMA MARTOS, anota: "Ruttan señala que podríamos designar cualquier cosa nueva de cualquier área con el término innovación y si fuera precisa una mayor precisión esta innovación podría adjetivarse ("innovación

268 PALMA MARTOS, LUIS. Teoría Económica, Innovación Tecnológica y estructura de mercado, Editorial de la Universidad de Sevilla, Sevilla, 1989. Tesis Doctoral.

${ }^{269}$ PALMA. Ob. Ci., pp. 69.

${ }^{270}$ PALMA. Ob. supra cit., p. 68. Advierte el autor, que la terminología entre paréntesis es usada por RUTTAN. 
técnica"). La invención se convierte así en un subconjunto especial de la innovación técnica para el que pueden obtenerse patentes" 271272.

Teoría del empujón tecnológico ${ }^{273}$. Bajo esta mirada, se concibe a la innovación como impulsada por la invención, se describe un proceso lineal ciencia básica / tecnología / producción, identificándose al equipo investigador de la empresa como iniciador del proceso que terminará en una innovación, en el evento de encontrarle una aplicación comercial a la invención. Dos cuestiones son relevantes en esta teoría: a) Las empresas más grandes concentrarán los equipos investigadores y tendrán una ventaja sobre las PYMES; b) La velocidad del avance tecnológico, siempre estará determinada por su base, es decir: la ciencia básica.

Como podemos comenzar a apreciar, asumir cualquiera de estas teorías, al igual como pasaba con los derechos de propiedad, tendrá consecuencias diferentes en la regulación jurídica y de ahí en sus consecuencias físcales, a modo de ejemplo, considerar la teoría del empujón tecnológico, implica que el diseño de una deducción para incentivar la innovación, debería ir especialmente hacia centros de investigación y extensión que permitan el acceso a la ciencia básica y la difusión de las invenciones hasta las PYMES.

Teoría del tirón de la demanda ${ }^{274}$. En este caso, el centro de la innovación gira desde la oferta (donde ponían el acento las teorías anteriores) hacia la demanda. La demanda cambia derivado de las fluctuaciones en los niveles de rentas de los consumidores, cuando la demanda aumenta los consumidores pueden exigir bienes más específicos para la satisfacción de sus necesidades, cuestión a la que reaccionan los empresarios poniendo en marcha el proceso de innovación y activando sus equipos de investigación. Este enfoque presenta una relación entre los departamentos de

\footnotetext{
${ }^{271}$ Ob. supra cit., p. 73.

${ }^{272}$ Es interesante ver, como esta teoría se aproxima a la idea de coexistencia entre investigación, desarrollo e innovación tecnológica, al estilo del artículo 35 de la Ley de Impuesto sobre Sociedades, Real Decreto Legislativo 4/2004, de 05 de marzo, en el caso español, que es el artículo que contiene las deducciones para incentivar determinadas actividades. Es decir, en la misma línea del pensamiento económico de PIGOU, que tal como vimos, proponía estímulos o beneficios para las actividades que poseen externalidades positivas. En resumen, es claro que para el legislador español, la innovación es una actividad que genera bienestar a la sociedad, por ello busca estimularla.

273 Ob. supra cit., pp. 75 a 80 y sgtes.

274 Ob. supra cit., pp. 87 y sgtes.
} 
producción - comercialización e investigación, de manera completamente opuesta a la teoría del Empujón Tecnológico.

Continuando con nuestro intento por demostrar que asumir una determinada teoría económica afecta la regulación jurídica, bajo la teoría del tirón de la demanda, una norma de incentivo a la innovación tendría un centro completamente distinto que bajo la teoría del empujón tecnológico. En este caso, si bien siguen siendo beneficiadas las grandes compañías que tienen potentes y efectivos equipos de investigación ${ }^{275}$; por otro lado, presenta a la innovación como una cuestión de identificación de posibilidades de inversión -constituidas por aquellos negocios destinados a satisfacer las necesidades que la demanda está requiriendo- de manera que, el objetivo promocional debería ser facilitar el proceso de inversión para generar los bienes que satisfagan las nuevas necesidades que el público puede pagar.

\subsubsection{La innovación y la teoría económica}

El análisis del proceso de innovación ${ }^{276}$ dista mucho de ser una cuestión simple, "reflexionar sobre el cambio tecnológico es enfrentarnos a uno de los problemas más complejos que podemos encontrar y presenta múltiples facetas: la investigación científica, la difusión de la tecnología, la selección de técnicas (...) Podemos por ello decir que hablar del cambio tecnológico es hablar del mundo de la ciencia, del mundo económico e incluso del mundo de la política" ${ }^{277}$, esto en la visión de un economista como SÁNCHEZ CHÓLIZ, no obstante es una posición coincidente con lo que venimos planteando, en el sentido que la innovación y su relación con la propiedad intelectual es un fenómeno complejo, donde confluyen muchos factores, así pues junto a la ciencia, la economía y la política, antes mencionadas, podemos agregar la norma jurídica y la definición que asuma de la propiedad intelectual, como privilegio, propiedad, intereses protegidos u otro. La distinción para nuestro estudio dista mucho de ser trivial, ya que la norma tributaria de gravamen o promoción ${ }^{278}$, como toda norma, será siempre

${ }^{275}$ Circunstancia que la norma de incentivo debería respetar y estimular o cuando menos no empeorar.

276 Salvo que explícitamente digamos otra cosa, el término "innovación" lo estamos usando como genérico que involucra a la innovación propiamente tal, la investigación y el desarrollo. Es decir, lo que se conoce como $\mathrm{I}+\mathrm{D}+\mathrm{i}$.

277 SÁNCHEZ CHÓLIZ, JULIO. Algunas reflexiones sobre la medida del cambio tecnológico, en El cambio tecnológico hacia el nuevo mileno. Debates y nuevas teorías, obra coordinada por MALGESINI, GRACIELA, Economía Crítica, Madrid, 1992, p. 251.

${ }^{278}$ Ya sea que, desde el punto de vista económico, se use para promocionar externalidades positivas o para desincentivar externalidades negativas. 
interpretable y en ese plano, para determinar el real sentido y alcance de ella, el intérprete deberá estar, entre otros, a su objetivo y los principios que la inspiran, de manera que la justificación teórica de una disposición puede resultar determinante a la hora de aplicarla, aun cuando frecuentemente esto no se exprese en las sentencias, sin duda son elementos relevantes que los jueces siempre toman en cuenta, porque la concepción que tengan de la materia que resuelven, quiéranlo o no, modela su forma de pensamiento.

Por lo anterior, creemos que es indispensable "explicar la generación de tecnología en términos económicos, así como evaluar los posible senderos por los que puede transitar a lo largo de un determinado proceso de desarrollo"279, ya que, "cada período histórico y cada país dentro de dicho período, se diferencia en razón de la distinta configuración de sus normas de innovación, de producción, de consumo, de acumulación, de financiación, de relación social, de intervención y de inserción en la economía internacional"280 y en función de eso, en mayor o menor medida, pero siempre teniéndolo en cuenta, se toman las decisiones que han terminado en el diseño de una determinada estructura de protección de las ideas, que hoy conocemos como propiedad intelectual y de su consecuente tributación, ya sea como contribución a los gastos fiscales o utilizando el sistema impositivo para beneficiar la creación de externalidades positivas o disminuir las negativas, de ahí la importancia que asignamos a esta parte de nuestro estudio.

Ciertamente, no buscamos conocer los misterios económicos que la innovación y el desarrollo puedan tener, ni mucho menos nos planteamos explicar su comportamiento por medio de modelos o métodos matemáticos, sino que simplemente intentaremos precisar su contenido, como presupuesto indispensable para conocer aquello que el legislador ha querido regular y paralelamente, las más de las veces, incentivar ${ }^{281}$. En ese sentido, para JONES HYWELL ${ }^{282}$, el término "modelo" está reservado para elaboraciones lógicas y abstractas sobre una teoría (que contiene elementos de una economía real) en particular o "inicial" capaz de generar una "predicción teórica en base

${ }^{279}$ GOMEZ URANGA, MIKEL; SÁNCHEZ PADRÓN, MIGUEL y DE LA PUERTA, ENRIQUE. El cambio tecnológico hacia el nuevo milenio. Debates y nuevas teorías, Economía Crítica, Madrid, 1992, p. 12.

${ }^{280}$ Ob. supra cit., p. 12.

${ }^{281}$ Baste con ver como son de frecuentes las normas de estímulo tributario para la creación de I+D+i.

${ }^{282}$ HYWELL G., JONES. Introducción a las teorías modernas del crecimiento económico, Antoni Bosch, editor, Barcelona, 1979, pp. 2 y sgtes. 
a unos postulados iniciales"283, objetivo que ni remotamente pretendemos. Buscamos conocer la realidad de la teoría económica, como hecho susceptible de ser normativizado por el derecho. Así pues, sin lugar a dudas, que la tecnología de la visión marxista, donde "las condiciones o formas de producción constituyen el determinante fundamental de las estructuras sociales, las cuales, a su vez, engendran las actitudes, las acciones y las civilizaciones" 284 , es muy distinta de la posición neoclásica donde "la innovación resulta crítica no sólo para aquellos que desean acelerar o sostener el ritmo de crecimiento económico en este y en otros países, sino también para quienes, alarmados únicamente por la cantidad de bienes, desean modificar el rumbo del progreso económico o concentrar su atención en la mejora de la calidad de vida" ${ }^{285}$. Con este simple ejemplo, podemos ver lo complejo que puede llegar a ser, depurar el problema práctico que se presenta en tanto las diferentes visiones económicas pueden enfrentarnos a contenidos completamente distintos para una misma palabra y lo que es más difícil de manejar, para un mismo hecho.

En cuanto al análisis económico del tema, creemos que considerando la atención o participación que la innovación ha tenido en el pensamiento o teoría económica, se pueden distinguir claramente tres períodos, que más o menos coinciden con los llamados economistas clásicos, neoclásicos y teorías modernas del crecimiento económico.

Nos interesa destacar que nuestra clasificación no tiene por qué tener una correspondencia exacta con la evolución de la teoría económica y que tampoco es perfecta, ni tan depurada como para poseer cortes históricos que permitan ubicar a cada autor o período con una categorización que le identifique plenamente, por lo demás creemos que eso estaría fuera de nuestros objetivos, lo que buscamos es una distinción entre los puntos de inflexión más importantes, donde el pensamiento económico marca un cambio de tendencia o altera su visión anterior sobre la función de la innovación y en consecuencia del rol que le puede caber en ello a la propiedad intelectual y la

\footnotetext{
283 Ob. supra cit.

${ }^{284}$ Explicación dada por GIL GÓMEZ, HERMENEGILDO y PORTILLA SOGORB, JOSÉ, en Economía, Contabilidad y Finanzas, de la Universidad Politécnica de Valencia, pp. 2. Disponible en Internet en: http://users.alliedmods.net/ faluco/apuntespak/4A/Economia-ApuntesProfesores.pdf (10 Abr 2013).

285 AZEVEDO, ADALBERTO. El nacimiento de la tecnología relacionado con la ciencia, PP. 20. Disponible en Internet en: http://www.slideshare.net/ProfessorAdalbertoAzevedo/freeman1974123 (10 Abr 2013).
} 
consecuente tributación asociada, así por ejemplo, todos los autores tuvieron en vista la innovación ${ }^{286}$, incluso casos como THOMAS MALTHUS ${ }^{287}$, con su particular visión de la economía, ve como causa del atraso económico, el hecho que la producción se vea favorecida por "la acumulación de capital, la fertilidad del suelo y las [invenciones] que economizan mano de obra" ${ }^{288}$. En lo concreto, hemos distinguido tres etapas: primeras observaciones sobre el avance técnico; concepciones aisladas del avance técnico; y, los sistemas de innovación institucionales ${ }^{289}$.

\section{II.2.14.2.2.1 Primeras acepciones sobre la innovación}

Generalmente se identifica el nacimiento del concepto de innovación con JOSEPH ALOIS SHUMPETER, particularmente con su obra Capitalismo, socialismo y democracia, especialmente con su capítulo VII, El proceso de destrucción creadora. En este sentido se puede observar a TULIO ROSEMBUJ ${ }^{290}$ o RALPH LANDAU ${ }^{291}$, lo que por cierto no pretendemos desconocer, pero en nuestro caso, creemos conveniente hacer un muy breve repaso a fin de determinar, qué rol jugaba la tecnología, si es que alguno tenía, en las teorías económicas clásicas.

La afirmación de PALMA MARTOS: "El avance técnico como fenómeno económico es un hecho más o menos reciente, que podemos datar aproximadamente a finales de la segunda guerra mundial. En la actualidad muchos textos de Economía

${ }^{286}$ FREEMAN CHRISTOPHER. La teoría económica de la innovación industrial. Alianza Editorial, 1974, p. 20, ejemplifica esto, de la siguiente manera: "El famoso primer capítulo de La riqueza de las naciones de Adam Smith entra inmediatamente a estudiar los 'adelantos de la maquinaria' y la forma en que la división del trabajo fomenta invenciones especializadas. El modelo de Marx para la economía capitalista asigna un papel central a la innovación técnica en los bienes de capital: 'la burguesía no puede existir sin revolucionar constantemente los medios de producción'. Marshall no dudo en señalar el 'conocimiento' como el motor principal del progreso en la economía. Un típico libro de texto de antes de la guerra, afirma en el capítulo sobre 'progreso económico': 'Nuestro breve panorama de la expansión económica durante los últimos 150 años aproximadamente, parece demostrar que la fuerza principal la constituyó el progreso de la técnica' (Bentham. 1938, pág., 319) En nuestros días Samuelson ha llegado a una conclusión casi idéntica".

${ }^{287}$ MALTUS, THOMAS. El libro titulado Ensayo sobre el principio de la población, 1798, es la obra que lo hizo célebre, en ella afirmaba que la población crecer en progresión geométrica y los alimentos en progresión aritmética, por lo que en algún momento la población será mayor que el alimento necesario para la subsistencia.

${ }^{288}$ HIDALGO CAPITÁN, LUIS ANTONIO. El pensamiento económico sobre el desarrollo. De los mercantilistas al PNUD, Universidad de Huelva, 1998, p. 26. Disponible en Internet en: http://www.uhu.es/antonio.hidalgo/documentos/pesd.pdf (15 Abr 2013).

289 Para nuestro estudio "avance técnico" e "innovación" son tenidos como sinónimos, en el sentido que implican el aporte de nuevas tecnología en la economía.

${ }^{290}$ ROSEMBUJ, TULIO. Intangibles. La fiscalidad del capital intelectual. El Fisco, Barcelona, 2003, pp. 25 y sgtes.

${ }^{291}$ LANDAU, RALPH. How competitiveness can be achieved: fostering economic growth and productivity. Technology and Economics, National Academy Press, Washington, D.C., 1991. 
tratan a la tecnología como algo que viene dado por el entorno y se determina, por lo tanto, fuera del sistema económico"292, nos enfrenta a la evolución que ha sufrido o está sufriendo nuestro tema, volviendo a poner de relieve la importancia de precisar el contenido de estos conceptos a la hora de interpretar las disposiciones normativas. En efecto, aunque su tesis fue escrita en 1989, el autor sólo identifica a la tecnología como un elemento "dado por el entorno", señalando además que únicamente "de modo ocasional se incluye" 293 en la literatura especializada "un capítulo o alguna referencia sobre la tecnología como variable endógena"294. Más adelante tendremos ocasión de ver cómo es que existen abundantes modelos en uno y otro sentido, los que pueden influenciar el análisis del concepto jurídico de la innovación, con perspectivas sustancialmente diversas; sin embargo, de momento, remontémonos a los orígenes de nuestro tema.

Siguiendo a PALMA MARTOS, menciona a RENÉ DESCARTES en su Discurso del método ${ }^{295}$, como el primero en reconocer los efectos benéficos del avance técnico sobre la economía. Más adelante el autor da cuenta como ADAM SMITH en 1776, en La riqueza de las naciones ${ }^{296}$, ya reconoce la importancia de la "introducción de máquinas nuevas y cada vez más complejas en los procesos productivos". PALMA MARTOS, también da cuenta como es que ADAM SMITH identifica "los dos ingredientes que configuran el avance técnico como actividad económica: se realiza al objeto de lograr una ventaja -como por ejemplo un trabajo más cómodo- y requiere una inversión en dinero" ${ }^{297}$. Claro está que las observaciones sobre ADAM SMITH son verdaderas, toda vez que, recordemos, el centro del crecimiento económico estaba dado para él, por la división y especialización del trabajo, que permitiría la introducción de maquinaria cada vez más compleja en los procesos productivos, aumentando de esta forma el rendimiento del trabajo y con ello del capital.

\footnotetext{
${ }^{292}$ PALMA. Ob. supra cit., p. 23.

${ }^{293}$ Ob. supra cit., p. 23.

294 Ob. supra cit., p. 23.

295 Como sabemos RENÉ DESCARTES, en su obra El discurso del método, 1637, propone un método científico basado en la duda, llama a obtener conclusiones propias obtenidas a través de métodos racionales. Él propone que el progreso de la ciencia reporta múltiples beneficios materiales y morales. Vinculado a la innovación, establecer que el progreso científico necesita la comunicación de las experiencias de otras personas, por lo que es un esfuerzo conjunto.

296 SMITH, ADAM. Investigación sobre la naturaleza y causas de la riqueza de las naciones, El Otriba, Argentina. Disponible en: http://www.amawebs.com/storage/docs/n59bb37dgon.pdf (12 Abr 2013).

${ }^{297}$ PALMA. Ob. supra cit., p. 25.
} 
Por su parte, THOMAS MALTHUS y DAVID RICARDO "estuvieron también interesados en el impacto del avance técnico, sobre todo en lo referente a mejoras en las máquinas y la sustitución del trabajo"298. JOSEPH SCHUMPETER nos explica la importancia de la innovación para DAVID RICARDO, de esta forma: "En él, se considera una empresa, con una determinada cantidad de capital y con un número dado de obreros, que decide incrementar su mecanización. Para ello, destina un grupo de sus trabajadores a la tarea de construir una máquina que, una vez instalada, permitirá prescindir de una parte de dicho grupo. Después de esto, puede ocurrir que los beneficios sigan siendo los mismos (cuando la competencia haya hecho desaparecer las ganancias temporales que de la innovación se derivan), pero los ingresos brutos habrán disminuido en una cantidad exactamente igual al total de los salarios que se pagaban a los obreros que ahora han sido dejados en libertad"299; volveremos sobre la visión ricardiana de la innovación, especialmente por su explicación de las ganancias temporales. De momento, debemos destacar y recordar que es DAVID RICARDO quien plantea la importancia de la especialización de los países en la producción de bienes respecto de los que posean ventajas comparativas, lo que permitirá la especialización tecnológica de cada cual y el reparto de los beneficios de la innovación, junto a ello, nos recuerda que nuestros esfuerzos por entender el fenómeno de la innovación, tendrán siempre que manejar una delicada ecuación determinada por la noción de rendimientos decrecientes.

Para Karl Marx en El capital $^{300}$, la tecnología toma una fuerza que nunca antes tuvo, los beneficios en la economía se obtienen de la explotación del trabajo, que capitalistas reinvierten en equipo (capital) con el objeto de incrementar sus ganancias. En este punto, se puede apreciar como la tesis marxsista, de la sustitución del capital variable (salarios de los obreros) por el capital fijo (maquinarias), es perfectamente coincidente con la posición ricardiana antes descrita. La diferencia viene dada, porque este proceso se realiza de manera incesante, prediciendo la formación de las grandes compañías multinacionales que serían el anticipo a la lucha de clases y el quiebre del sistema capitalista.

\footnotetext{
${ }^{298}$ Ob. supra cit., p. 25.

299 SCHUMPETER, JOSEPH A. 10 Grandes economistas: de Marx a Keynes, Alianza Editorial, 1983, p. 30.

${ }^{300}$ MARX, KARL. El capital, Verlag con Otto Meissner, Hamburgo, 1867.
} 
En la visión marxsista "la competencia por parte de otros capitalistas ejerce presión para mantenerse al corriente de la última tecnología. Aquí podemos vislumbrar ya la teoría de la competencia a través de la innovación que desarrollo posteriormente J.A. Schumpeter" ${ }^{301}$, quien por cierto, explica de manera preclara la teoría marxsista, resumiéndola a dos puntos esenciales: $1^{0}$ "Las condiciones o formas de la producción constituyen el determinante fundamental de las estructuras sociales, las cuales, a su vez, engendran las actitudes, las acciones y las civilizaciones. Marx aclaraba el significado de esta tesis mediante su célebre fórmula de que el molino movido por el brazo crea las sociedades feudales y el molino de vapor las sociedades capitalistas"; y $2^{\circ}$ "Las formas de producción tienen su lógica propia: es decir, se transforman de acuerdo con necesidades inherentes a ellas mismas" ${ }^{302}$, en otras palabras, no requieren de ningún impulso exterior.

Como se puede apreciar en la dimensión marxsista, la tecnología aparece con toda su fuerza como el fenómeno que mueve a la economía y determina el comportamiento de la sociedad, posee un motor interno que la impulsará por sí sola hasta producir el quiebre del sistema capitalista.

Refiriéndonos a JOHN KEYNES, su economía frecuentemente descrita como una economía de crisis, evoluciona entre las dos grandes guerras mundiales y tiene por objeto sacar a Inglaterra de la depresión, por lo que es claro que sus esfuerzos no se centran en explicar el fenómeno del cambio tecnológico, sino que se concentra en estudios macroeconómicos y en la política monetaria como herramienta de política económica; sin embargo, en el escrito póstumo que su contemporáneo JOSEPH SCHUMPETER $^{303}$ le dedica, recuerda el siguiente pasaje de la obra de JOHN KEYNES: "Rápidamente habían ido desapareciendo las condiciones en que la iniciativa empresarial había sido suficiente para asegurar éxito tras éxito, aprovechando el rápido crecimiento de las poblaciones y las numerosas oportunidades de inversión que incesantemente volvían a presentarse gracias a [las innovaciones tecnológicas] y a la conquista de una serie de fuentes de materias primas y de recursos alimenticios". Esto explica porque la teoría keynesiana se centró en el análisis de los factores que condicionan el ingreso y la ocupación, además para nuestro análisis, revela que entiende

\footnotetext{
${ }^{301}$ PALMA. Ob. Cit., pp. 27 y sgtes.

${ }^{302}$ SCHUMPETER. 10 Grandes economistas: de Marx a Keynes, Ob. supra cit., p. 30 y sgtes.

${ }^{303}$ Ob. supra cit.
} 
a la innovación tecnológica como capaz de producir las incesantes oportunidades de inversión que habían permitido el desarrollo de la economía.

Finalmente, no podemos decir que, en esa época los avances técnicos hayan sido apreciados por los economistas que hemos escogido y no por otros, lo que sucede es que no dieron al fenómeno una perspectiva sistemática. De hecho, tal vez, lo más destacable del avance tecnológico en esa época, es que se trata como un fenómeno aislado, asociado a inventores solitarios o al azar, no resulta visible bajo la perspectiva de una actividad organizada, ni mucho menos tiene forma de empresa. En este período la innovación no recibe un tratamiento autónomo y atención directa, los aumentos de la renta y la producción, para estos autores, siempre están asociados mayores cantidades de los factores de la producción, trabajo y capital, de manera que el progreso técnico está incardinado dentro de ellos, pasando desapercibido.

\section{II.2.14.2.2.2 Concepciones aisladas del avance técnico}

Es SHUMPETER en sus obras La teoría del desarrollo económico, 1912, Ciclos económicos, 1939 y Capitalismo, socialismo y democracia, 1942, a quien debemos la primera aproximación sistemática a la innovación tecnológica como fenómeno económico. En sus dos primeros libros el autor centra su atención en el empresario, quien es la figura protagonista del desarrollo económico, pero se debe tener presente que no lo es por su capacidad para combinar trabajo y capital, sino por ser aquella persona que crea nuevas combinaciones de los factores de producción, puede introducir una nueva función de producción en la economía, satisface necesidades que hasta el momento no estaban cubiertas o es tan audaz, que es capaz de influir en los consumidores generando nuevas necesidades que antes no existían, se puede tratar de un invento nuevo o de la simple aplicación de uno ya existente. Explicando la visión shumpeteriana, PALMA MARTOS nos dice: "Así en la definición de Schumpeter el acto de invención y la actividad del empresario no son la misma cosa, ya que el inventor y el empresario no tienen que ser la misma persona. Ahora bien el invento se realiza desde una perspectiva económica, mediante la actividad innovadora que es llevada a cabo por el empresario" ${ }^{304}$.

\footnotetext{
${ }^{304}$ PALMA. Ob. supra cit., p. 30.
} 
El empresario se ve estimulado por la búsqueda de un beneficio adicional que le reporta su anticipación en el mercado, creando condiciones de monopolio, sin embargo se trata de una posición efímera, no permanente, que puede ser fácilmente destruida por la imitación, a tal punto que si la imitación es contemporánea a la creación o muy rápida, los beneficios del innovador desaparecen. Por esto, en el modelo schumpeteriano se critica la competencia perfecta, ya que anularía el incentivo del empresario, condenado el sistema al estancamiento. De todas formas, para él, la economía no tiende a un estado estacionario, sino que está en constante evolución.

Es en la obra Capitalismo, socialismo y democracia ${ }^{305}$, donde SCHUMPETER centra su atención en la innovación, allí él reconoce la existencia del "proceso de destrucción creadora" en la economía, que resulta ser "más importante que la competencia basada en los precios y en realidad justifica, de acuerdo con Schumpeter, ciertas prácticas monopolísticas y los beneficios que éstas llevan aparejados" ${ }^{306}$. En otras palabras, cada vez que el empresario decide innovar se enfrenta a prácticas monopolísticas y su centro debe ser retardar lo más posible la aparición de los imitadores, quienes con su competencia, socavarán el margen de ganancia superior que se ha obtenido con la aparición preferente en el mercado. El permanente estado de evolución de la economía, determina con certeza que la posición dominante es temporal, que los imitadores aparecerán y que el innovador perderá su ventaja, siendo forzado a intentar la implantación de una nueva innovación y así repetir su ciclo. Este riesgo de temporalidad en la posición monopólica, además del alto costo de las invenciones, hacen que el autor destaque el papel de las grandes empresas en este proceso, más que el del empresario individual.

De lo que hemos expuesto, se puede mostrar como en una visión schumpeteriana, el centro del desarrollo económico está dado por la actividad innovativa, ya sea de producto o proceso, además se aprecia la justificación y la indisoluble ligazón del desarrollo técnico a la existencia de grandes empresas, lo que dará como efecto normativo una visión laxa en la legislación antitrust. Para los fines de nuestro estudio, en una visión shumpeteriana, podríamos confirmar la legitimidad teórica de gravar los rendimientos obtenidos por la propiedad intelectual y la validez de

\footnotetext{
305 SCHUMPETER, JOSEPH. Capitalismo, socialismo y democracia. Versión castellana por ATANASIO SÁNCHEZ, Editorial Claridad, 1946.

${ }^{306}$ PALMA. Ob. supra cit., p. 32.
} 
la promoción de la innovación, pero también tendríamos que aceptar una distribución regresiva del gasto en innovación y desarrollo, en favor de las grandes empresas, puesto que son indispensables dentro del sistema y no podríamos discriminarlas a la hora de promocionar la actividad.

No podemos dejar de detenernos en la distinción planteada por JOSEPH SCHUMPETER entre “invención” e “innovación”, que recuerda CHIRSTOPHER FREEMAN al definir un invento como, "una idea, un esbozo, o un modelo para un dispositivo, producto, procesos o sistemas nuevo o perfeccionado" ${ }^{307}$. La distinción entre invención e innovación shumpeteriana, la desarrolla PALMA MARTOS, explicando que invención "es el descubrimiento de las posibilidades de aplicación productiva de un conocimiento que pertenece al saber científico o técnico. La innovación es la introducción de nuevas combinaciones de los factores productivos. Constituye una ruptura voluntaria del equilibrio productivo en base a la aplicación de nuevas técnicas que permiten dar un 'salto ${ }^{, 308}$ y colocar a la empresa en mejor situación de competencia" ${ }^{309}$.

La visión de innovación de SCHUMPETER tiene otra particularidad, ya que para él, "recordando que la producción, en sentido económico, no es más que combinación de servicios productivos, podemos expresar lo mismo diciendo que la innovación combina los factores de una forma nueva, o que consiste en llevar a cabo nuevas combinaciones, aunque, tomadas en sentido literal, las últimas expresiones también incluirán lo que ahora no pretendemos incluir; es decir, aquellas adaptaciones corrientes de los coeficientes de producción que son parte de la marcha ordinaria de la rutina económica dentro de las funciones de producción dadas" ${ }^{310}$. Aunque en este punto no parece que el autor niegue el carácter de innovación a los esfuerzos rutinarios dentro de una empresa, es más claro cuando nos dice: "[E]ntenderemos por innovación un cambio en alguna función de producción de primer orden de magnitud, y no de

\footnotetext{
${ }^{307}$ FREEMAN. Ob. supra cit., p. 26.

308 PALMA. Ob. supra cit., p. 50. El autor explica que "salto" es lo que JOSEPH SHUMPETER llamó la "destrucción creadora", "pues en él se elimina capital ya invertido y se invierte nuevo capital, en busca de rápidos beneficios. Los empresarios suelen servirse de los inventos cuyo origen está fuera del ámbito económico, en el campo científico y tecnológico".

${ }^{309}$ Ob. supra cit., p. 50.

310 SCHUMPETER, JOSEPH A. Ciclos económicos, 1939, Traducción de JORDI PASCUAL, Prensas Universitarias de Zaragoza, Zaragoza, 2002, p. 66.
} 
segundo ni aun mayor" ${ }^{\prime 311}$. Dentro de esta visión de innovación, "de primer orden", extrema, rupturista; curiosamente, las invenciones tienen poco que hacer, llegan a la economía dadas, totalmente desarrolladas y no son en ningún caso objeto del fenómeno económico, le interesarán a la economía sólo cuando han sido puestas en práctica. Las innovaciones son en este sentido "el modo de producción capitalista, caracterizado por la introducción de innovaciones" ${ }^{1312}$. Dentro de este proceso capitalista, JOSEPH SCHUMPETER conceptualiza a la innovación diciendo: "[E]ste concepto cubre los cinco casos siguientes: 1) La introducción de un nuevo bien - esto es, uno con el que no se hayan familiarizado los consumidores- o de una nueva calidad de un bien. 2) La introducción de un nuevo método de producción, esto es, de uno no probado por la experiencia en la rama de la manufactura de que se trate, que no precisa fundarse en un descubrimiento nuevo desde el punto de vista científico, y puede consistir simplemente en una forma nueva de manejar comercialmente una mercancía. 3) La apertura de un nuevo mercado, esto es, un mercado en el cual no haya entrado la rama especial de la manufactura del país de que se trate, a pesar de que existiera anteriormente dicho mercado. 4) La conquista de una nueva fuente de aprovisionamiento de materias primas o de bienes semimanufacturados, haya o no existido anteriormente, como en los demás casos. 5) La creación de una nueva organización de cualquier industria, como la de una posición de monopolio (por ejemplo, por la formación de un trust) o bien la anulación de una posición de monopolio existente con anterioridad" ${ }^{1313}$.

De las cinco formas de innovación descritas por el autor, podemos ver efectos concretos en nuestro estudio, respecto de las dos primeras, las que se encuentran contempladas en la actual norma de incentivo para innovación y desarrollo, del artículo 35 de la LIS, puesto que el 35.3.a. de la LIS ${ }^{314}$, expresamente excluye: "las actividades que no impliquen una novedad científica o tecnológica significativa”. Así, poco a poco,

${ }^{311}$ Cita tomada de JAVIER BRAÑA y otros. El Estado y el cambio tecnológico en la industrialización tardía. Un análisis del caso español. Fondo de Cultura Económica, México D.F., 1984, Ediciones F.C.E., España, 1984, pp. 255 y sgtes. JAVIER BRAÑA, también anota que JOSEPH SHUMPETER se convertirá en foco de frecuentes críticas, por olvidar las innovaciones incrementales o menores.

312 HEERTJE, ARNOLD. Economía y progreso técnico, F.C.E., México, 1984, p. 118. Citado por PALMA, Ob. supra cit., p. 52.

${ }^{313}$ Es interesante en este punto, advertir que para PALMA. Ob. supra cit., pp. 53 y 55, el hecho que su investigación se centre en las "innovaciones que pudiéramos considerar tecnológicas", lo reduce sólo a las dos primeras hipótesis de SCHUMPETER, esto es la introducción de nuevos productos y procesos. Se ve como la obra de PALMA MARTOS, escrita en 1989, tenía un concepto de innovación tecnológica centrado en la novedad y materialidad de la innovación, por ello no incorpora el tercer supuesto, que puede ser de mucha importancia, por ejemplo, para las economías subdesarrolladas dependientes de la importación tecnológica.

314 Ley española del Impuesto sobre Sociedades, Real Decreto Legislativo 4/2004, de 05 de marzo. 
vamos viendo la influencia de la relación entre determinadas visiones económicas sobre la innovación, la propiedad intelectual y el desarrollo normativo de esta última.

En 1974, CHRISTOPHER FREEMAN, en perfecta armonía con lo expuesto precedentemente, advierte que todos los economistas hasta la fecha han dado "su respetuosa aprobación del cambio tecnológico" ${ }^{315}$, sin embargo pocos se han preocupado de él. En este sentido, desconoce las explicaciones técnicas que JOHN JEWKES intenta dar a este fenómeno, "sobre la base de tres factores: ignorancia de las Ciencias Naturales y de la tecnología por parte de los economistas; su concentración en los problemas del ciclo económico; y la falta de estadísticas" ${ }^{\text {} 316, ~ d i c i e n d o ~ q u e ~ l o s ~}$ economistas de esta época (desde los años 50 a 1974, fecha de la obra) han sido "víctimas de sus propios supuestos y compromisos respecto de sistemas aceptados de doctrina" ${ }^{317}$. Seguidamente, explica como estos "sistemas aceptados de doctrina", consideran a la tecnología y al conocimiento como fuera de los modelos económicos, es decir como "variables exógenas" ${ }^{1318}$. A su juicio, aun aquellos autores que se centraron en los problemas del crecimiento económico, relegaron al avance tecnológico a ser considerado como un factor "residual" ${ }^{319}$, que comprendía, junto a otros factores del crecimiento tal como la educación, a la tecnología.

En esta época, la idea del progreso técnico se incorpora dentro de los modelos tradicionales, al respecto HYWELL ${ }^{320}$ hace un recorrido explicando los modelos más representativos. En el modelo de JOHN HICKS, también conocido como "teoría de los salarios", se plantea la influencia del progreso técnico donde la relación capital-trabajo es constante, por lo que el avance técnico influye en ellos permitiendo clasificar los inventos como "ahorradores de trabajo", "ahorradores de capital" y "neutros". Un segundo modelo es el "modelo de Harrod" para el que, "[u]n avance será neutral cuando no afecta el valor del coeficiente de capital, para un tipo de interés constante" y "[u]n flujo de inventos será neutral, cuando no afecte la distribución del producto nacional total entre el trabajo (en su acepción más amplia) y el capital, siempre que el tipo de

\footnotetext{
315 FREEMAN. Ob. supra cit., p. 20.

${ }^{316}$ Ob. supra cit., p. 21.

${ }^{317}$ Ob. supra cit., p. 21.

318 Ob. supra cit., p. 21.

319 Ob. supra cit., p. 21.

${ }^{320}$ HYWELL. Ob. supra cit., pp. 197 y sgtes.
} 
interés se mantenga constante" ${ }^{\text {321 }}$, es decir la diferencia entre estos dos modelos es que mientras en el modelo de Harrod, la función de producción se compara con la misma relación capital-producto, en el de JOHN HICKS se comparan puntos con idénticas relaciones de capital-trabajo. Finalmente, el autor citado, se hace cargo del modelo neoclásico del desarrollo económico, al que incorpora la variable del avance técnico, sin obtener conclusiones definitivas para ninguno de sus intentos, salvo decir que "no se altera sustancialmente la visión armoniosa, aunque proporciona conclusiones que, aparentemente, están más de acuerdo con los hechos estilizados ${ }^{322}$ de la realidad económica"323.

Las críticas a los modelos exógenos no se han hecho esperar, se les ataca estableciendo que no es aceptable entender que el progreso técnico se produce sin costes, que sea una verdadera donación celestial un "maná caído del cielo", no puede pensarse que sería completamente gratis si no tuviese que recogerse. También se critica que el progreso técnico haya sido conceptualizado sin provenir de ninguna parte, completamente independiente de los demás factores de la producción, es decir el progreso técnico se reduce a un factor que simplemente existe, conjuntamente no es posible medir los factores que intervienen en el progreso técnico real. También se argumenta, que estos modelos al unir el progreso técnico con la función de producción, hacen que cualquier desplazamiento en la función de producción sea parte de lo que se considera progreso técnico, de manera que se hace imposible distinguir otras cuestiones que son necesarias de diferenciar como "distinguir entre las acusas que permiten una producción mayor con la misma cantidad de factores, o la misma cantidad de producción con menos cantidad de uno o más factores" ${ }^{\$ 24}$.

En estas críticas de JONES HYWELL, podemos comenzar a ver un embrión de cambio, puesto que son transversales a los modelos que entienden a la innovación como un elemento exógeno a la economía, lo que da pie al aparecimiento de modelos, que retoman la idea que se subyace en la visión clásica, de la innovación como un elemento endógeno a la economía.

\footnotetext{
${ }^{321}$ Ob. supra cit., p. 202, citando a ROY HARROD.

${ }^{322}$ Nicholas Kaldor en el artículo A model of economic growth, 1957, describió lo que llamó los "hechos estilizados", que corresponden a seis afirmaciones sobre los elementos que un modelo de crecimiento económico que una economía industrial madura debería reflejar.

${ }^{323}$ HYWELL. Ob. supra cit., p. 217.

${ }^{324}$ HYWELL. Ob. supra cit., p. 220.
} 
ROBERT SOLOW ${ }^{325}$ es otro autor en el que nos detendremos en este período. No obstante, en este segundo período fueron muchos los autores que reconocieron la importancia que el avance técnico tiene en el crecimiento económico e intentaron medirlo a través de métodos matemáticos, de hecho, es un período caracterizado por ello. Sin embargo, son difíciles de clasificar, porque cada cual va desarrollando su propio modelo, poniendo el acento en una cuestión u otra, sin que encontremos un tratamiento global del problema. Además, la propia dificultad que implica definir el cambio tecnológico, que a juicio de JACOB SCHMOOKLER, "es la 'tierra incógnita' de la economía moderna (...) ni siquiera hemos llegado a un acuerdo sobre los términos a utilizar" ${ }^{326}$, hace aún más compleja una clasificación de todos ellos. De cualquier forma, el análisis de los modelos econométricos escapa al objetivo de nuestro trabajo. Sin embargo, la detención en ROBERT SOLOW es importante, porque "concluyó que el $90 \%$ del crecimiento de la producción por trabajador en USA durante el período 1909-49, era debido al efecto del factor residual, $A$, que se tomaba como medida del progreso técnico" ${ }^{327}$. Por cierto que la obra de ROBERT SOLOW ha sido discutida, sosteniendo que casi todo el crecimiento de los Estados Unidos entre 1945 y 1965 puede explicarse por el crecimiento de los factores productivos convencionales, pero eso no es lo que interesa para nuestros fines. De todas formas, la obra de ROBERT SOLOW debe destacarse, porque marca el principio de una época, tal es el comienzo del desarrollo de modelos con el progreso tecnológico incorporado como un elemento endógeno.

Desde nuestros intereses, podemos ver la visión analizada, por si sola justificaría el gravamen de los rendimientos de la propiedad intelectual (puesto que sería la razón de ser del crecimiento económico) y también la inversión promocional del Estado en innovación y desarrollo, avalada por el aumento de bienestar que los ciudadanos recibirían del crecimiento económico. Sin embargo, el mayor aporte del modelo de Solow, es hacer evidente otros elementos del progreso técnico que en adelante no podrán ser ignorados. Para el autor, el avance técnico tiene una tasa de crecimiento

\footnotetext{
${ }^{325}$ La ubicación de SOLOW en este período es por su aporte a él, no debemos confundirnos con las contribuciones que en 1987 le valieron el Premio Nobel.

${ }^{326}$ Citado por HYWELL. Ob. supra cit., p. 189.

327 En la ecuación de SOLOW, " $A$ " representa, lo que se ha llamado "residuo de Solow", en este "residuo" están comprendidos una serie de elementos, distintos a los factores clásicos que explicaban el crecimiento hasta esa época (trabajo y capital), y que para él implican "cualquier tipo de desplazamiento en la función de producción”. Citado por HYWELL, Ob. supra cit., p. 218.
} 
constante, pero "sólo afecta a los bienes de capital" 328 , de manera que la innovación vendría incorporada en la maquinaria y desde allí contribuiría a la economía, de esta forma, en la economía existirían una serie de máquinas de diferentes edades, la que aportarían innovación en función de su antigüedad, con ello se calcula un "índice de capital eficaz" nacido de la ponderación del aporte de las diferentes máquinas de la economía. Desde este punto de partida, el objetivo fue plantear un sistema "generacional", que se transformará en un cuarto grupo de sistemas (teníamos los clásicos, endógenos y exógenos) caracterizados por la visión del progreso técnico como un elemento dinámico que afecta los ciclos de la economía, para JONES HYWELL, "en dichos modelos, la inversión nueva no sólo se suma al stock de capital productivo, sino que también disminuye la edad media del stock de capital, y, por lo tanto, lo moderniza, en el sentido de que incrementa la proporción del stock de capital que incorpora tecnología reciente ${ }^{, 329}$.

Siguiendo a JONES HYWELL, entre los enfoques endógenos, cabría comentar los esfuerzos de NICHOLAS KALDOR por incorporar la función de progreso técnico, en donde el progreso depende de la acumulación de capital y viceversa. En esta función se suponen incluidos "los efectos del progreso técnico y la acumulación de capital, que en caso de la función de producción agregada ortodoxa eran conceptualmente separables”330. También desarrollaron modelos endógenos KENNEDY-WEIZSÄCKER y KENNETH ARROW, con dos nuevos puntos de vista. Para KENNEDY nos encontramos con la "frontera de posibilidades de invención" ${ }^{331}$, que se representa en su modelo, para explicar que los empresarios se enfrentan a la necesidad de escoger entre tasas altas de aumento de eficiencia del capital o del trabajo, ya que uno y otro se encuentran siempre en una relación de interdependencia en el sentido que el aumento en la tasa de eficiencia del capital hace suponer una disminución en el aumento de la tasa de eficiencia del trabajo. En este sentido, la opción tecnológica del empresario siempre supone que estos pretendían "maximizar la tasa instantánea de reducción del coste medio, dados los precios de los factores, lo que equivale a maximizar la tasa corriente de progreso técnico" ${ }^{332}$. En el caso de KENNETH ARROW, planteó "la hipótesis de que la adquisición del conocimiento o 'aprendizaje', era un producto de la experiencia.

\footnotetext{
328 Ob. supra cit., p. 224.

329 Ob. supra cit., p. 224.

${ }^{330}$ Ob. supra cit., p. 237.

331 Ob. supra cit., p. 239.

332 Ob. supra cit., p. 241.
} 
Por lo tanto, los aumentos de la productividad podían originarse en la acumulación de experiencia adquirida en la producción" ${ }^{333}$, su modelo de Learning by doing, toma como índice de la experiencia, la inversión bruta acumulativa de la empresa, de manera que, cada inversión nueva contiene a la anterior y así la experiencia (proceso de aprendizaje) pasa a formar parte del modelo. En este modelo, dos son los efectos que tienen especial significación jurídica, el proceso de aprendizaje se va dando de manera acumulativa generando la experiencia, produciendo importantes externalidades, en términos que "un acto de inversión beneficia a los futuros inversores, pero este beneficio no recibe pago alguno en el mercado" ${ }^{134}$ y la divergencia entre el producto privado y el social, donde los inversores sólo se pueden apropiar de una parte de la inversión y el resto se traslada a la sociedad en su conjunto, lo que lleva a la conclusión que los mercados competitivos generan una inversión menor que la que sería socialmente óptima.

\section{II.2.14.2.2.3 Los sistemas de innovación institucionales}

La distinción entre los diferentes modelos económicos que explican el rol del avance técnico en la economía, normalmente se ha hecho por economistas, con fines económicos, sin embargo como nos mueven fines jurídicos, nos parece que la clasificación que proponemos recoge el hecho que queremos destacar, tal es que la evolución del entendimiento del avance técnico como fenómeno económico, social y susceptible de normativizar, se ha ido desarrollando hasta descubrir o advertir una cantidad creciente de factores que en él intervienen, conformado un entramado complejo que involucra múltiples variables, que se explican a través de modelos ortodoxos de la economía, endógenos, exógenos, generacionales y también de modelos más reciente multisectoriales, mucho más complicados ${ }^{335}$, lo que ha desembocado no en el "último modelo", sino en decisiones de Estado, con el establecimiento de "sistemas institucionales de innovación", es decir la conformación de autoridades organizadas cuyo objetivo es el desarrollo económico por la vía de la innovación.

A nuestro juicio desde la obra de CHRISTOPHER FREEMAN La teoría económica de la innovación industrial ${ }^{336}$, publicada en 1975, hasta nuestros días, se ha dado un período caracterizado por el entendimiento y estudio del avance técnico como

\footnotetext{
${ }^{333}$ Ob. supra cit., p. 246.

334 Ob. supra cit., p. 247.

335 HYWELL. Ob. supra cit., p. 281. El autor anota entre los modelos multisectoriales: "La trayectoria de crecimiento" de VON NEUMANN; y, el "Teorema de la autopista" de KOOPMANS, entre otros.

336 FREEMAN. Ob. supra cit.
} 
un proceso y el análisis detallado de una serie de factores que influyen en el desarrollo tecnológico, como su relación con el derecho de autor, patentes de invención, asimetrías de información, incertidumbre, riesgos tecnológicos, dispersión, educación, creación de redes tecnológicas, etc. En este sentido, en algún momento quisimos llamar a este período "complejo", pero desistimos por la connotación de dificultad asociada a la palabra, puesto que para nosotros, en este período el estudio del rol de la innovación involucra otros aspectos que antes no consideraba, se transforma en una visión amplia y acabada, pero no por ello más compleja.

En este escenario "complejo" o de "sistemas de innovación institucionales", donde aparece una actividad del Estado vinculada directamente a la innovación ${ }^{337}$, tienen más importancia, preguntas cómo las siguientes: ¿Es la propiedad intelectual productora de rendimientos gravables por el derecho tributario?, ¿Es posible y necesario fomentar utilizando la vía tributaria el proceso de innovación, sin generar efectos regresivos con la inversión o sin que el coste sea mayor que el beneficio?, ¿Cómo se hizo esto en el plano internacional? No podemos desconocer que las dos primeras no son preguntas que estemos llamados a contestar en este trabajo y mucho menos pretendemos hacerlo, pero creemos necesario para nuestros fines, conocer cuál es el escenario que el derecho interviene con sus normas.

Hemos visto como la innovación tiene dos facetas muy marcadas, que en adelante distinguirán a todos los estudios económicos sobre la materia, se le puede ver: actuando en el proceso de crecimiento económico y estudiándola en sí misma, como proceso de investigación, invención, desarrollo e implantación de los adelantos en el sistema productivo. Estas dos visiones, se alinean con la tradicional división entre macro y micro economía. Para nuestro estudio esta división es respetable y reconocible, pero no esencial, a nosotros nos interesa tanto la una como la otra, en tanto aporten elementos necesarios de considerar en el ámbito tributario. De momento, lo más relevante es cómo esta división ha ido enriqueciendo el horizonte de conocimientos sobre la materia, hasta generar una nueva perspectiva sobre el avance técnico.

\footnotetext{
${ }^{337}$ No es que antes no la hubiese habido, sino que ahora aparece respaldada por un sistema institucional y por una teoría económica, considerando en el asunto múltiples elementos que antes no se tuvieron en cuenta.
} 
CHRISTOPHER FREEMAN, como antes dijimos, es un autor de detención obligada en este momento. En su obra La teoría económica de la innovación industrial $^{338}$, el autor partiendo de la realidad empírica ${ }^{339}$ sobre la investigación, invención e innovación en plantas químicas, de refinamiento de petróleo, energía nuclear, sustancias sintéticas y electrónica, intenta demostrar como "las características que distinguen a la $\mathrm{R}$ y $\mathrm{D}$ modernas son su escala, contenido científico y grado de especialización profesional" ${ }^{340}$. A su juicio, la investigación y desarrollo ha pasado de ser una actividad de inventores aislados a una verdadera empresa, departamento o unidad económica autónoma, generándose departamentos de $\mathrm{I}+\mathrm{D}$ al interior de las empresas, centros públicos de investigación -autónomos o universitarios - etc. El centro de la posición del autor, es el desaparecimiento de la investigación y desarrollo como el trabajo solitario e instantáneo del inventor, para pasar a ser una actividad de conjunto propia de empresas o unidades especializadas y que se desenvuelve, normalmente, a través de una serie de investigaciones sucesivas e incrementales, en un período más o menos largo, donde no sólo interviene el -ahora existente- departamento de $\mathrm{I}+\mathrm{D}$ de la empresa, sino también los de producción y marketing. Él no desconoce la labor del inventor solitario que sigue existiendo, pero lo resumen de la siguiente manera: "indudablemente el equilibrio ha quedado alterado, y es esta especialización de la función de R y D la que justifica expresiones como la 'revolución de la investigación' para describir el fenómeno que ha tenido lugar en el seno de la industria del siglo $\mathrm{XX}^{\prime 341}$. Se ha producido la absoluta profesionalización de la investigación y desarrollo, apareciendo las denominadas redes "de 'Investigación y Desarrollo Experimental' (Research and Experimental Development) (...) 'R y D' (...) 'NIOKR' en la URSS"”42. Finalmente, queremos destacar dos cosas que FREEMAN estima fundamentales en la existencia sostenida de innovación, por un lado la existencia de una relación cada vez más estrecha entre los nuevos instrumentos científicos y el desarrollo de nuevas tecnología, y por otra parte, para él, la empresa que no pueda desarrollar un producto de

\footnotetext{
338 Ob. supra cit.

${ }^{339}$ El autor trabaja con base en datos históricos y estadísticos reales, cuestión que no es novedad en economía, sin embargo quisimos destacar en contraposición a los modelos económicos entendidos como construcciones abstractas con fundamentación matemática.

${ }^{340}$ FREEMAN. Ob. supra cit., p. 29. Nótese como en 1975, no es claro para el traductor del libro el significado en el lenguaje meta de la expresión R\&D, puesto que lo traduce de manera literal "R y D", en consecuencia, que hoy se traduciría como I+D. Esto da cuenta del cambio que sufría la visión del rol del avance técnico en la economía, dando inicio a lo que es nuestro tercer período de análisis.

${ }^{341}$ Ob. supra cit., p. 25.

342 Ob. supra cit., p. 25.
} 
'nueva generación' con bastante rapidez, antes de que los líderes tecnológicos hagan el cambio, terminará fuera del mercado porque nadie querrá sus productos.

En este escenario, las empresas deben tener acceso a un nivel mínimo de investigación y desarrollo defensivo que les permitan incorporar nuevos productos cuando lo haga la competencia, a esto llama CHRISTOPHER FREEMAN el "umbral"343.

Es muy interesante ver cómo el asunto evoluciona incorporando dentro del concepto de avance técnico, pequeños desarrollos "defensivos", es decir puede tratarse de tecnología, conocimiento u obras que están disponibles hace mucho tiempo en el mercado, pero que una determinada empresa o comunidad no ha podido tener acceso a ellas, la idea de aprendizaje permanente se hace presente aquí con la potencia para sustentar el desarrollo económico. Relacionando estas ideas con nuestra materia, a modo de ejemplo, bajo la perspectiva descrita se permitiría justificar la mantención de un incentivo para I+D no sólo en la investigación básica, investigación nueva, adquisición de intangibles como patentes, entre otros, sino que también en la adquisición de activos fijos, especialmente instrumental, que no sea nuevo en términos de innovación, es decir, material existente en el estado del arte. Otro ejemplo, lo podemos ver al pensar bajo estas ideas el concepto de know how, a la hora de interpretar los convenios de doble imposición, puesto que perfectamente podríamos despojarlo de la connotación de secreto y asemejarlo a las asesorías técnicas.

Siguiendo a JOOST HEIJS ${ }^{344}$, podemos repasar lo que venimos analizando, en el sentido que en un primer momento la consideración de la teoría económica a la tecnología, simplemente la toma como información -exógena al sistema económicodesenvuelta en un modelo lineal de cambio tecnológico, supone que la transferencia tecnológica es un proceso automático, sin costes, regulado por la "mano invisible", donde la influencia o estrategias competitivas de otras empresas o países, la demanda o los niveles de educación, en nada intervienen en el avance técnico. El punto de partida es para estos modelos el equilibrio, que en el caso de los bienes tecnológicos no se cumple, debido a tres fallos de mercado: incertidumbre, externalidades y ventajas de

\footnotetext{
343 Ob. supra cit., pp. 157 y sgtes.

${ }^{344}$ HEIJS, JOOST. Política económica e innovación. Evaluación de la financiación pública de I+D en España, Publicaciones del Consejo Económico y Social, Colección Estudios N 117, España, 2001.
} 
escala, pudiéndose producir superabundancia o escasez de inversión en el mercado tecnológico. Por ello, las políticas de I+D se concentraban en "la generación o creación de innovaciones mediante la creación de centros de investigación, el apoyo a la I+D básica para tecnologías claves, o la financiación directa de las actividades empresariales $^{\prime 345}$. En los años 80 se desarrolla una concepción del crecimiento endógeno, donde "la producción endógena de conocimientos o progreso técnico sustituye a los efectos de estimulación del crecimientos procedentes de los factores de producción capital y trabajo" ${ }^{134}$, en esta posición se intenta poner dentro de los modelos económicos de crecimiento, al cambio tecnológico y al capital humano, en tanto cuanto son entendidos como los factores determinantes del crecimiento, de suerte que el avance técnico es el elemento central, entendido ahora como un proceso, que incluye no sólo la investigación, sino también el desarrollo hasta la comercialización. En este marco, la educación y formación son elementos indispensables que generan externalidades sin las que el avance técnico no se puede sostener en el tiempo. Sobre este punto FREEMAN se habían anticipado a decir: "Ahora bien, no sería nada disparatado considerar la educación, la investigación y el desarrollo experimental como los factores básicos en el proceso de crecimiento y relegar la inversión de capital al puesto de factor intermedio" $^{347}$.

Como hemos venido exponiendo, existe multiplicidad de estudios, análisis y modelos que aparecen desde los años 80, fundados en la nueva visión del crecimiento, intentan corroborar sus hipótesis o plantear otras nuevas, tomando cada etapa o instante del proceso innovador, se han estudiado los efectos de la productividad del trabajo, la incidencia del tamaño de las empresas, el comportamiento del avance técnico por áreas de la tecnología (mecánica, química, etc.), los ciclos de la innovación, el papel de las patentes en los procesos de invención, la transferencia internacional de tecnología, la importancia de las llamadas innovaciones menores (también llamadas “incrementales"), la alternativa de desarrollar o adquirir la tecnología, la importancia de la capacidad de imitar, los procesos educativos, la importancia de la disponibilidad de las obras, se desarrolló la teoría del fair use, etc. Todo esto, a nuestro juicio, ha dado paso a la formación de los modelos complejos, evolucionistas y generacionales, que matizan el escenario en nuestros días, dando forma a la necesidad de plantear respuestas

\footnotetext{
${ }^{345}$ Ob. supra cit., p. 18.

346 Ob. supra cit., p. 31.

347 AZEVEDO. Ob. supra cit., p. 17.
} 
institucionales de los desafíos de la innovación. Resumir las características de estos últimos modelos es tarea de especialistas que sin duda ya la hicieron de mejor forman los profesores RALPH LANDAU y CHRISTOPHER FREEMAN ${ }^{348}$, por eso nos basaremos en dos artículos de ellos, para mostrar algunos de los múltiples factores que se consideran en el análisis hoy en día y terminar nuestro análisis.

En cuanto a los aspectos macroeconómicos se encargó principalmente el artículo de RALPH LANDAU, quien discrepa de las teorías del crecimiento exógeno. Partiendo del modelo neoclásico, toma datos de los EE.UU., eliminando el supuesto clásico de que los factores de la producción (trabajo y capital) son homogéneos y utilizando una serie de indicadores, consigue considerar en sus mediciones la calidad del trabajo y capital (no sólo su cantidad), con ello los resultados de sus medidas, muestran cómo afecta el aumento de la calidad de los bienes, equipos y también del capital humano utilizados para la producción. Los datos obtenidos, sugieren que el cambio en la calidad explica gran parte del crecimiento de los EE.UU. entre 1947 y 1985. El aumento en la calidad lógicamente proviene del avance técnico.

Las principales observaciones sobre "las nuevas investigaciones en la economía del crecimiento de los países industrializados" ${ }^{149}$, resumidamente, son las siguientes: capital y cambio tecnológico son complementarios, existiendo una relación entre ellos para generar crecimiento, resulta claro que la tecnología es un elemento endógeno a la economía, que interactúa con los demás factores de la producción y con la economía en su conjunto; la calidad del capital se mejora de manera constante, a través de la sustitución del capital antiguo por uno nuevo que incorpora mejor tecnología, "por tanto, la productividad de la economía aumentaría incluso si la inversión neta fuera cero"${ }^{350}$; una vez que se ha ingresado al mercado con una innovación temprana, para los competidores es muy difícil superar las economías de escala y curvas de aprendizaje; los factores tecnología, capital y trabajo, deben ser considerados como "piezas de un

\footnotetext{
${ }^{348}$ Economía de la Innovación. Las visiones de Ralph Landau y Christopher Freeman. Es un artículo que consiste en la traducción de dos publicaciones de estos profesores. Disponible en Internet en: http://213.229.166.39/upload/documentos/200505120014 6 0.pdf (15 Abr 2013). De RALPH LANDAU se traduce: Competitividad, crecimiento económico y productividad; y de CHRISTOPHER FREEMAN: La economía del cambio tecnológico. Economía de la Innovación. Los títulos originales son: How Competitiveness can be Achieved: Fosterind Economic Growth and Productivity, publicado en Technology and economics, National Academy Press, Washington, D.C., 1991 y The Economics of Technical Change, publicado en Archibugi, D. y J. Michie (eds), Trade, Growth and Technical Change, Cambridge University Press, 1998, respectivamente.

349 LANDAU. Ob. supra cit., pp. 21 y sgtes.

${ }^{350}$ Ob. supra cit., p. 21.
} 
mismo proceso - una silla de tres patas: capital físico, intangible y humano-" ${ }^{351}$ que resulta ser la base del crecimiento; por capital intangible no debe entenderse sólo "las actividades de $\mathrm{I}+\mathrm{D}$, sino que también incluye ingeniería de diseño, producción experimental, formación de los trabajadores, desarrollo de mercados, pérdidas en las operaciones iniciales y en la penetración en el mercado, precauciones legales y aseguramiento" ${ }^{352}$; el clima de riesgo es básico para la inversión, que se ve afectada por factores como "las políticas macroeconómicas, la predictibilidad y la volatilidad de las políticas, los sistemas e instituciones legales, el comportamiento del ahorro, el sistema educativo, las instituciones financieras y las políticas de ciencia y tecnología" ${ }^{353}$; el clima legal, la excesiva rigurosidad de los tribunales, la gran lentitud de los juicios y el aumento de indemnizaciones por daños, pueden perjudicar seriamente a la industria innovadora, especialmente industrias como la química, farmacéutica o aeronáutica ${ }^{354}$; la formación del capital físico, sugiere que existe una estrecha relación entre la inversión en capital por trabajador y las tasas de crecimiento, por lo que la educación toma un lugar importantísimo en la innovación, ya se trate de la educación general o institucionalizada, como de la capacitación específica al interior de la empresa. Las deficiencias en educación, hacen imposible el avance técnico ${ }^{355}$.

En lo referente a los elementos microeconómicos, son abordados por el artículo de CHRISTOPHER FREEMAN ${ }^{356}$, quien plantea un grupo de conclusiones sobre la materia, para él: el carácter endógeno de la tecnología se hace presente también en la empresa, la innovación es un proceso interactivo, en el que la empresa adquiere los conocimientos de fuente interna o externa; la innovación se presenta como un proceso complejo, en el cual para cada industria y para cada innovación confluyen características particulares que le son propias; los conocimientos científicos generados exógenamente son muy importantes, existe una fuerte interdependencia entre la ciencia pura y la tecnología. En las innovaciones radicales los inputs del conocimiento científico puro, son muy importantes, en las innovaciones incrementales, pierden relevancia; la combinación interna de las funciones de investigación, diseño, producción y comercialización puede ser incluso más importante que la propia innovación; la

\footnotetext{
${ }^{351}$ Ob. supra cit., p. 21.

352 Ob. supra cit., p. 21.

${ }^{353}$ Ob. supra cit., p. 21.

${ }^{354}$ Ob. supra cit., p. 21.

355 Ob. supra cit., p. 21.

${ }^{356}$ FREEMAN. Ob. supra cit., pp. 53 y sgtes.
} 
tecnología se puede encontrar en muchos sitios dentro o fuera de la empresa ${ }^{357}$, en ocasiones es mejor adquirirla que producirla, de ahí la relevancia, de la transferencia nacional e internacional de tecnología de los acuerdos de cooperación contratos de licencias, etc.; el sistema educativo es básico no sólo en la enseñanza primaria, secundaria, universitaria, al interior de la empresa, sino que también preparando a los empresarios e ingenieros para entender la innovación como un proceso competitivo y tomar decisiones a su altura; el entendimiento de la innovación como un proceso, requiere entenderlo también en términos económicos, por lo que se deben considerar también las reducciones de costes, mejoras de producto, mejoras financieras, etc., innovación en términos económicos pone el acento en los costos, gastos y formas de comercialización, no sólo en el invento; la importancia creciente de los servicios por sobre los bienes materiales y de una "industria del conocimiento" 358.

Especial atención merece la visión de CHRISTOPHER FREEMAN sobre las innovaciones radicales e incrementales ${ }^{359}$, puesto que deja claro, algo que ya mencionamos previamente, que la asociación de conceptos como $\mathrm{I}+\mathrm{D}$, desarrollo, innovación, investigación y otros, con la idea de inventos, adelantos o creaciones rupturistas, nunca antes existentes y asociados a una genialidad absoluta, no es la única forma de innovación económicamente relevante y socialmente beneficiosa. Esto será especialmente relevante en el derecho de autor, puesto que demuestra que no siempre deben estar disponibles las últimas obras para la educación, sino que a veces es suficiente con que entren al dominio público algunas obras ya conocidas. Destaca, que se ha descubierto una importancia creciente en innovaciones menores, nacidas del propio proceso de producción, de mejoras o adaptaciones a las existentes, etc. Sobre este punto, nos dice que "[1]as dificultades para definir la novedad son inmensas, tal y como constantemente demuestran los sistemas de patentes. De todos modos, es necesario realizar algunas distinciones (...) porque los dos tipos de innovación tienen una combinación muy diferente de inputs de conocimiento y tienen consecuencias muy diferentes para la economía y las empresas que las realizan". Lo que CHRISTOPHER FREEMAN parece querer destacar, es que puede existir una novedad absoluta y

\footnotetext{
357 Ob. supra cit., pp. 53 y sgtes.

358 FREEMAN, sobre este punto relata como más del treinta por ciento de la economía de los Estados Unidos, estaba ya en 1962 empleada en tareas dedicadas a manejar y distribuir información más que bienes físicos.

359 Ob. supra cit., pp. 65 y sgtes.
} 
universal y otra menor, menos exigente o más relativa, no necesariamente universal, perspectiva coherente con lo que hemos venido analizando hasta este momento, porque la innovación económicamente relevante no tiene que ver con la originalidad del invento, sino con su introducción en el mercado y su habilidad para la producción, podría tratarse de un invento viejo o de una idea conocida, pero no comercializados antes y perfectamente útiles en la actualidad.

CHRISTOPHER FREEMAN realizan nuevas observaciones sobre las teorías del Tirón de la Demanda y el Empujón de la Tecnología, que a diferencia de los análisis anteriores, donde las teorías son independientes, en sus investigaciones de los años ochenta y noventa, las analizan bajo la visión endógena concluyendo que la innovación no está liderada por la demanda ni por la tecnología, "sino por una compleja interacción que vincula a los usuarios potenciales con los nuevos desarrollos de la ciencia y la tecnología" ${ }^{360}$, lo que es coincidente con la visión de JONES HYWELL, cuando dice: “[L]a conclusión que parece más acertada es la de suponer que la mejor aproximación a la realidad es una mezcla de progreso técnico exógeno y endógeno" ${ }^{, 361}$.

En cuanto a la difusión de las innovaciones, CHRISTOPHER FREEMAN compara los primeros modelos de los años cincuenta, que asumían que las tecnologías no cambiaban, se difundían de una forma y en un entorno que permanecía sin variaciones, contrastando con la posición actual, declarando que sus conclusiones no pueden resumirse de mejor manera que la hecha por KLINE y ROSEMBERG ${ }^{362}$, al decir: "Es un serio error tratar la innovación como si fuera una cosa homogénea y bien definida cuya entrada en la economía se pudiera identificar en un momento preciso (...) el hecho es que las innovaciones más importantes atraviesan cambios drásticos a lo largo de sus vidas, cambios que pueden -y a menudo lo hacen- transformar completamente su importancia económica. Las mejoras subsiguientes a una invención tras su primera introducción podrían ser mucho más importantes económicamente que la disponibilidad de la invención en su forma original (...) considerar las características del teléfono en 1880, del automóvil en 1900, o del avión cuando los hermanos Wright realizaron su primer vuelo en 1903. En esa forma eran, con mucho, una novedad débil y

\footnotetext{
${ }^{360}$ Ob. supra cit., p. 70.

361 HYWELL. Ob. supra cit., p. 249.

${ }^{362}$ KLINE, S., y ROSENBERG, N., 1985. An overview of the process of innovation. En R. Laudau y N. Rosenberg eds., The positive Sun Strategy. National Academy of Sciences, Washington D.C.
} 
económicamente inviable" ${ }^{1363}$. No obstante, el autor también agrega estudios empíricos sobre productos que no han variado prácticamente nada, o más bien nada, durante su difusión, como algunos farmacéuticos. Lo verdaderamente concluyente, parece ser que la innovación varía enormemente dependiendo del producto, lo que lógicamente agregará un punto de complejidad a los estudios sobre la materia.

La visión sobre la participación de la innovación en la economía, es por estos días tan amplia, que CHRISTOPHER FREEMAN dedica un espacio especial de su artículo a lo que llama: "cambio institucional, trayectorias y paradigmas", a cuyo amparo presenta un importante asunto, elegido por nosotros para caracterizar el estado actual de la cuestión. Para él, dado que las empresas dependen de vínculos externos no sólo para implementar sus innovaciones, sino también para adquirir los conocimientos y habilidades necesarias para llegar a desarrollarlas, se evidencia la influencia del "sistema nacional de innovación" que comprende las instituciones de soporte a la I+D, pero también, las relaciones de colaboración entre empresas, vínculos productores y usuarios, sistemas de incentivo, sistema tributario, apropiabilidad (secreto empresarial, libre competencia y patentes), relaciones laborales y un amplio conjunto de instituciones públicas y privadas.

El cambio institucional es también incidente en otros aspectos: una innovación radical implica cambios no sólo en la organización de producción, sino también en los mercados, para demostrarlo los ejemplos se reproducen, tales como: la cadena de montaje, la comida rápida, los supermercados, Internet, etc., (esto puede suceder con innovaciones de producto, proceso o ambas); conecta inmediatamente al problema de cómo surgen procesos ordenados de cambio técnico dentro de la diversidad y la incertidumbre asociada a la invención e innovación; requiere procesos de armonización, regulación, estandarización y rutinas, para evitar la inestabilidad y conseguir economías de escalas; y, es indispensable poder diseñar sistemas que permitan orientar a los ingenieros y empresarios, visualizar las probables sendas futuras del crecimiento.

Otro asunto vinculado al cambio institucional, es el aparecimiento de una interrelación entre lo nacional e internacional al momento de la estandarización de tecnologías, lo cual se atribuyen a diferentes razones, como conectividad de los

${ }^{363}$ Citado por FREEMAN. Ob. supra cit., p. 73. 
sistemas, aceptación y aprendizaje del consumidor, economías de escala u otras. La gran incógnita que siempre se presentará en este momento, es saber cuándo y cuál tecnología está lo suficientemente madura como para estandarizarla, lo que se resuelve "no mediante la racionalidad óptima, sino a través de la competencia oligopolística, la negociación política y el conflicto nacional o internacional" ${ }^{364}$.

En otro aspecto sobre lo mismo, el autor se hace cargo de un asunto de mucha importancia para nuestro estudio, el rol del sistema de patentes, en cuanto incide en la decisión de estimular la innovación y la difusión. Describe el autor, que el sistema de patentes tiene dos extremos que conforman una ecuación difícil de calcular, por un lado sin duda es un incentivo a la innovación mediante la garantía de un monopolio temporal, pero no es menos cierto que en el otro extremo, un período demasiado largo de protección puede desestimular futuras invenciones o retrasar la difusión. Lógicamente, el problema se trasladará como certeza matemática a nuestro estudio, a modo de ejemplo: el plazo de protección de una patente determina también la calificación de una tecnología como "patentada" y limita la consideración de pagos por “el uso o cesión del uso" de una "patente", que exige el MC OCDE para dar lugar a la existencia de cánones. En todo caso, para FREEMAN "el dilema de diseñar un sistema de apropiabilidad 'óptimo' nunca ha sido resuelto" ${ }^{365}$.

Finalmente, RALPH LANDAU se hace cargo de la incidencia del sistema gubernamental y el sistema financiero, señalando que deben ser capaces de liderar estrategias de largo plazo y tomar decisiones difíciles, incentivar las inversiones a largo plazo, incentivar los estudios de ciencia e ingeniería, facilitar los doctorados en estas áreas e incorporar capital de riesgo a tasas de financiamiento adecuadas.

\section{II.2.14.2.2.4 Últimas concepciones del avance técnico}

La evolución de la investigación sobre el rol de la innovación en la economía ha tomado ritmo muy intenso en los últimos años, que se refleja en la visión de los autores que hemos estudiado, ya que, si bien RAPLPH LANDAU, en el año 1989, seguía preocupado de incorporar a la innovación como un factor endógeno, afirmando que "si el cambio tecnológico no es exógeno, la incorporación de la tecnología y el aprendizaje por la práctica -fenómeno reconocido por los economistas neoclásicos- interactúan con

${ }^{364}$ Ob. supra cit., p. 79.

365 Ob. supra cit., p. 79. 
la inversión en capital, aumentando las tasa de crecimiento, y la inversión en capital se hace fundamental para alcanzar el equilibrio más alto y aproximarse a la frontera tecnológica de la economía a mayor velocidad. Este es el proceso de evolución por el que se establece la no convexidad del proceso de producción y se produce un crecimiento que no cesa" ${ }^{366}$, sólo nueve años más tarde, CHRISTOPHER FREEMAN está mucho más allá, al decir: "[e]stos y otros modelos de simulación han demostrado la posibilidad de modelar aspectos del comportamiento económico que se ignoraban previamente (innovaciones y su difusión, diversos regímenes de apropiabilidad, heterogeneidad de los agentes, aprendizaje por la interacción, mejoras de calidad, eficiencia dinámica, etc.). Sin embargo, la diversidad de los agentes, industrial y circunstancias nacionales, la complejidad de sus interacciones y la falta de una suficiente comprensión de algunas relaciones clave significan que estos modelos evolucionarios, aunque más ricos y realistas que sus predecesores en muchos aspectos, necesitan ser complementados y contrastados constantemente con el tipo de investigación empírica e histórica que ha sido el sello de la tradición neoschumpeteriana" 367 .

Si bien lo que vimos como el último período del entendimiento del rol de la innovación en la economía, que llamamos "sistemas institucionales de innovación", caracterizado por el uso de concepciones endógenas, exógenas o ambas, la aceptación de la innovación como un proceso y el análisis detallado de los sistemas de $\mathrm{I}+\mathrm{D}$, sigue plenamente vigente, hoy han aparecido, desde el punto de vista económico, los modelos generacionales, interactivos y evolucionistas, que ponen el acento en el entendimiento del rol de la innovación como un fenómeno complejo que afecta la integridad del ciclo económico.

Siguiendo a JOOST HEIJS, podemos ver que, actualmente, ya no se discute si la tecnología es endógena, exógena o si debemos verla como un proceso, esto está completamente decantado. La idea actual, es que la sola generación de inventos no es suficiente para el crecimiento económico, pone el énfasis en desarrollar la capacidad innovadora, es decir, la habilidad de la empresa para llevar las nuevas tecnologías al mercado. El carácter complejo de la innovación, su alto costo, las necesidades de educación, cultura, artes, infraestructura, existencia de una base tecnológica, la difusión,

\footnotetext{
${ }^{366}$ LANDAU. Ob. supra cit., p. 31.

${ }^{367}$ FREEMAN. Ob. supra cit., p. 33.
} 
resistencia al cambio y otros, enfrentan a la empresa y a la sociedad en su conjunto, a la necesidad de mantener una interrelación con todos los sectores económicos, especialmente al interior del sistema productor de tecnología -ahora, departamento de $\mathrm{I}+\mathrm{D}+\mathrm{i}$ y producción- como respecto de los consumidores.

\subsubsection{Nuestra opinión sobre el análisis económico del derecho}

Actualmente los autores nos muestran en pensamiento económico sobre la tecnología, destacando su consideración como un elemento endógeno dentro de la economía o enfatizándola como una teoría generacional, evolucionista o interactiva. Desde un punto de vista jurídico, no vemos en estas posiciones nada contradictorio, por el contrario complementario, nos parece que la evolución del pensamiento económico ha sido normal, dentro de una dinámica creciente, ha utilizado y aprendido de las que llamamos "primeras acepciones del avance técnico", que hicieron los economistas clásicos, desechando y demostrado errores teóricos de otras posturas como las marxsistas, aprovechado las observaciones más desarrolladas de las teorías de la innovación endógena y actualmente, con los conocimientos adquiridos, observan el fenómeno de la innovación con muchos más antecedentes que permiten reconocer en detalle sus peculiares características. En definitiva, creemos que la teoría económica se puede considerar "como una secuencia de modelos conceptuales que pretenden expresar de forma simplificada diferentes aspectos de una realidad siempre más complicada".

Podríamos decir, que cada cual ha ido poniendo su granito de arena, a modo de ejemplo: ADAM SMITH aporta la especificación del trabajo; JOSEPH SHUMPETER el análisis de la innovación como fenómeno económico o la diferenciación entre "invención" e "innovación"; ROBERT SOLOW ilustra sobre el "residuo" y desvía la atención de toda la ciencia económica al estudio del avance técnico; CHRISTOPHER FREEMAN demuestra un proceso organizado y coherente que da origen a la innovación; KENNETH ARROW exhibe su idea del "learning by doing"; muchos autores han desarrollado diferentes modelos de crecimiento exógeno -incluyendo a ARROW-; también vemos innumerables nuevos aportes, en cuanto a la incidencia de la educación, economías de escala, importancia de innovaciones incrementales, necesidad del énfasis en la gestión de la empresa, dificultades para llevar la tecnología al mercado, entre otros. Cada uno, quien más quien menos, presenta una visión propia y particular de comprender y regular el avance técnico, que implicará consecuencias prácticas 
imposibles de ignorar para el derecho y que deberemos tener en cuenta a la hora de intentar normar el comportamiento del avance técnico y a la hora de juzgar sobre sus implicancias y manifestaciones en la propiedad intelectual.

La división que hemos hecho del pensamiento económico muestra la importancia creciente que se da a la innovación como motor de la economía, la aceptación definitiva de la propiedad intelectual como método para reducir los costes de transacción y generar el mayor beneficio social, de lo que desprende la indisoluble ligazón que el pensamiento actual encuentra entre estas dos ramas, aparentemente separadas. De hecho, la evidencia muestra como los legisladores chileno y español, en el diseño de sus políticas de $\mathrm{I}+\mathrm{D}$, han abandonado completamente la visión de la investigación y desarrollo como un hecho aislado, para asumirlo como un proceso que involucra todo el ciclo productivo, lo mismo se puede decir, de su visión sobre la regulación de la propiedad intelectual como motor de desarrollo.

\section{La propiedad intelectual en la Constitución Española de 1978}

Antes de iniciar el trabajo siempre tuve la impresión que determinar la dimensión constitucional de una determinada institución era tarea fácil, en mi ingenuidad bastaba con leer una constitución e identificar si se hacía cargo de una materia o no, otra cosa, a mi juicio, era determinar con qué profundidad se aborda un determinado asunto, donde siempre vi la verdadera dificultad. Pues bien, la búsqueda de la propiedad intelectual en la Constitución Española me trajo de vuelta a la realidad, donde la verdad depende de cada quien y las letras, incluidas las mías, resultan serviles más resueltas a prestar su ayuda al espíritu que a la razón. Lo que quiero decir, es que los autores han escrito con resuelta voluntad para encontrar a la propiedad intelectual en la Constitución Española y no dudo del convencimiento de cada quien, pero las posiciones son tan contrapuestas que no parecen guiadas por un hilo interpretativo uniforme, fundado en la lógica reglada de un sistema legal, más bien parecen defensas justificadas de lo que convicciones previas del autor esperaban encontrar, de manera que tanto ven en la Constitución a la propiedad intelectual en toda su dimensión espiritual, vinculada a las teorías personalistas; como en su condición de activo material - duramente como propiedad- relacionada con las posiciones patrimonialistas sobre la naturaleza jurídica de la propiedad intelectual. 
Los artículos de la Constitución Española de 1978, en los que se instala a la propiedad intelectual, según los diversos autores, son: art. 20. 1, "Se reconocen y protegen los derechos: (...) b) A la producción y creación literaria, artística, científica y técnica"; art. 33. 1. "Se reconoce el derecho a la propiedad privada y a la herencia (...)"; y, art. 149. 1. "El Estado tiene la competencia exclusiva sobre las siguientes materias: (...) $9^{\circ}$ Legislación sobre propiedad intelectual e industrial".

Como puede verse de una simple lectura, ninguna de las disposiciones transcritas se hace cargo del contenido sustantivo de la propiedad intelectual e industrial, lo que si puede decirse sin duda, es que la propiedad industrial e intelectual son institutos jurídicos conocidos para el constituyente, puesto que en el art. 149. 1. $9^{\circ}$, clara, derechamente y sin eufemismos, reservar al Estado, la competencia para regular estos tipos de propiedad. En el mismo sentido, la clasificación es coincidente con la escogida para nuestro estudio, es decir, el constituyente entiende que la propiedad intelectual en general se divide en propiedad intelectual propiamente tal (derecho de autor y afines o conexos, centralmente) y propiedad industrial (marcas y patentes, básicamente).

Más adelante expondremos sobre las diversas teorías que intentan ubicar a la propiedad intelectual dentro del texto constitucional, desafortunadamente, a nuestro entender, todas ellas tienen sus fortalezas y debilidades, lo que impide asumir alguna de ellas con parámetros de verdad.

Hay quienes ven a la propiedad intelectual en el art. 20.1. b), otros en el 33 y no faltan quienes la ven en ambos. Si el asunto tiene o no importancia en la tributación asociada, es una cuestión que caerá por su propio peso, que tendremos oportunidad de ver más adelante; sin embargo, de momento no podemos pasar por alto, que desde la perspectiva constitucional, ubicar en un lugar u otro a la propiedad intelectual, tiene consecuencias no solamente respeto de la definición de su naturaleza jurídica, sino desde la propia Constitución, puesto que si la ubicamos en el artículo 20. 1. b), tal como advierte ROMERO COLOMA ${ }^{368}$ y otros $^{369}$, será parte de la sección primera del capítulo

${ }^{368}$ ROMERO COLOMA, AURELIA MARÍA. La protección constitucional de los derechos de los artistas, Actualidad Administrativa, Sección Doctrina, Edit. La Ley, 2000, Ref. LVII, p. 1113, tomo 3.

369 PLAZA. Ob. supra cit., pp. 237 y sgtes; CASTRO BONILLA, ALEJANDRA. La protección constitucional del derecho de autor en España, Noticias Jurídicas, diciembre de 2002. Disponible en internet en: 
II, del título I, con lo que su naturaleza sería de aquellos derechos que la CE califica de "fundamentales", en cuya virtud les confiere una protección reforzada. De ser así, la propiedad intelectual gozaría de la protección de todo derecho fundamental, por lo que sólo podría ser regulada por ley orgánica constitucional, que "en todo caso deberá respetar su contenido esencial”370, en función de lo dispuesto por los artículos 53 1, 53. 2 y 81.1 de la CE y además, cualquier ciudadano podría recabar tutela ante "los Tribunales ordinarios por un procedimiento basado en los principios de preferencia y sumariedad y en su caso, a través del recurso de amparo ante el Tribunal Constitucional" ${ }^{\text {371 }}$.

Sobre este asunto, por alguna razón, la literatura es frondosa en abordarlo desde la perspectiva del derecho de autor, no obstante olvida que el artículo 20. 1. b), da cuenta de "la producción y creación literaria, artística, [científica y técnica]"372, de manera que, si es posible que exista la duda sobre la presencia de la propiedad intelectual al referirse el artículo a la "producción y creación literaria, artística, científica (...)", igualmente puede darse cuando hablamos de la "producción y creación (...) científica y técnica", ya que los adjetivos "científica" y "técnica", aluden a propiedad industrial, específicamente a patentes. Además, lo mismo podría decirse del derecho de marcas, cuya producción y creación, fácilmente es insinuada por cualquiera de los sustantivos señalados. Antes estas dudas, para nosotros, lo que se dice del derecho de autor, en principio lo entendemos aplicable a la propiedad industrial en general, sin perjuicio de detenernos, si se justifica, en las diferencias con la propiedad industrial.

Entre las teorías que explican la presencia de la propiedad intelectual en la Constitución de 1978, encontramos cuatro grupos: las que entienden que la propiedad intelectual está en plenitud en el artículo 20.1. b) CE; aquellas que estiman que en el artículo 20.1. b), está presente únicamente la dimensión personal del derecho de autor; las que ven la propiedad intelectual íntegramente en el artículo 33; y, aunque no lo hemos visto planteado de manera autónoma, consideramos que hay un grupo de autores

http://noticias.juridicas.com/articulos/05-Derecho\%20Constitucional/200212275512281010243310.html (20 Abr 2013).

GÓMEZ DÍEZ, JUSTO JOSÉ, La propiedad intelectual y el artículo 20.1 b) de la Constitución española, Revista de la Facultad de Derecho de la Universidad Complutense, Anuario Nº 84, p. 177.

370 Art. 53. 1. CE.

${ }^{371}$ Art. 53. 2. CE.

${ }^{372}$ Art. 20. 1. b) CE. 
o al menos de argumentos, que permiten sostener que la propiedad intelectual no está presente de manera directa en la CE.

\subsection{La propiedad intelectual está en su integridad contenida en el Art. 20. 1. b) de la Constitución Española}

Una línea doctrinal ha sostenido que en el artículo 20. 1. b) de la CE, se contiene la propiedad intelectual en su integridad, es decir el artículo haría referencia tanto a la dimensión moral como patrimonial de la propiedad intelectual. Las razones van desde el derecho internacional, al derecho nacional y las veremos seguidamente ${ }^{373}$.

Las evidencias en el plano internacional las encuentran en la propia Declaración Universal de Derechos Humanos de 1948, cuyo artículo 27.2, declara que "[t]oda persona tiene el derecho a la protección de los intereses morales y materiales que se correspondan por razón de las producciones literarias, científicas o artísticas de las que sea autor", enunciado desde el cual, elevan a la propiedad intelectual, en cuanto titularidad de su autor, al más alto estándar de protección, el reconocimiento como derecho humano, lugar desde el que le corresponde el amparo como "derecho fundamental" a la luz de la $\mathrm{CE}^{374}$. A lo anterior, se contra argumenta diciendo que no hay en la DUDH ninguna especificación sobre la forma de protección o la ubicación que ésta debe recibir en el derecho interno y además, durante la redacción del artículo 27 de la DUDH, se discutió que no era necesario proteger al derecho de autor en ese precepto, puesto que estaba garantizado como propiedad privada, por lo que la dimensión del derecho de autor sería un asunto resuelto en la $\mathrm{DUDH}^{375}$.

El tenor literal de la norma es usado en favor de esta posición, al sostener que el sentido de los adjetivos: "literaria, artística y científica", sólo puede ser de obras y con ello la referencia al derecho de autor es directa $^{376}$. Conjuntamente, sostienen que la redacción ambigua del artículo 20. 1. b), que se ha prestado para tantas interpretaciones, tiene una razón que deja claro su sentido, puesto que su origen está en el artículo original del proyecto de constitución, donde la disposición se redactaba como un 20.2, de manera autónoma, para garantizar "la protección de los derechos inherentes a la

\footnotetext{
${ }^{373}$ En esta línea doctrinaria se ubica CREMADES, JAVIER. Aspectos constitucionales del derecho de autor, Diario La Ley, Sección Doctrina. Ref - 126. Tomo 2. Editorial La Ley, 1996, p. 1.

374 PLAZA. Ob. supra cit., p. 247; y, LATORRE. Ob. supra cit., p. 69.

375 Ob. supra cit., p. 248.

${ }^{376}$ Ob. supra cit., p. 248, citando a RODRÍGUEZ TAPIA.
} 
producción literaria, artística y científica", resultando manifiesta la voluntad del constituyente de proteger al derecho de autor como derecho fundamental; sin embargo, solamente por una cuestión de diseño y organización de la norma, el artículo 20 se organizó de la manera que lo conocemos, sin que haya habido nunca intención de variar su contenido.

Otro argumento es más de orden teleológico, puesto que predica que la norma del 20 1. b) hace sentido en la medida que se entienda que la libertad de creación debe materializarse en una obra, cuyo titular es un autor que debe "poder disponer y explotarla según su voluntad", puesto que "no existen autores sin obras", ${ }^{377}$ es decir que no es suficiente con tener la libertad para crear, sino se está garantizando el contenido de esa creación.

En cuanto a la principal crítica que se hace a esta posición es que la Ley de Propiedad Intelectual de 1987, no tiene carácter orgánico constitucional, en circunstancias que si se atendiese a su ubicación, sería un "derecho fundamental" -en términos de la CE- debiendo tener el carácter de orgánica constitucional por aplicación del artículo 81.1 de la $\mathrm{CE}^{378}$.

\subsection{La propiedad intelectual está contenida en el Art. 33 de la CE}

Partiendo desde la constatación que existe una diferencia entre el "derecho a ser autor", entendido como el ejercicio de la "capacidad potencial para crear una obra literaria, artística, científica o técnica"379, y el "derecho de autor", considerado como el conjunto de facultades que se reconocen al creador y que tienen por objeto directo la obra creada, en el art. 20. 1. b) CE, sólo tendría cabida con rango de derecho fundamental, la "libertad intelectual o de pensamiento"380. Es decir, lo que estaría consagrado como derecho fundamental es la posibilidad de convertirse en autor para quien pueda, quiera y tenga las habilidades para hacerlo, sin censura previa, independientemente a que lo haga. La protección que recibe la creación en sí misma, vendría dada por el derecho de autor, que se puede componer con un crisol distinto de

\footnotetext{
377 LATORRE. Ob. supra cit., p. 69.

${ }^{378}$ En este sentido PLAZA. Ob. supra cit., p. 251.

379 ARROYO ZAPATERO, LUIS y GARCÍA RIVAS, NICOLÁS. Protección penal de la propiedad intelectual, en Estudios de derecho penal económico, Colección Estudios, Universidad de Castilla-La Mancha, 1994, p. 162.

380 ARROYO y GARCÍA. Ob. supra cit., p. 163.
} 
facultades, según la legislación lo defina, en el sentido que puede entregar o no determinadas facultades al autor y en determinado plazo. La propiedad intelectual toma una dimensión más utilitaria, destinada a proteger los intereses del autor, más que un derecho fundamental, consagrado en el artículo $33 \mathrm{CE}$ bajo el amparo de la propiedad ordinaria y en el art. 21. 1. b) CE, estaría únicamente el derecho a crear libremente. Un argumento para confirmar esta posición, es la posibilidad de sucesión intestada que posee el Estado, puesto que de tratarse de un derecho fundamental, eso no sería posible ${ }^{381}$.

Otras evidencias en favor de esta teoría, son el carácter de ley ordinaria que posee la Ley de Propiedad Intelectual de 1987, puesto que tal como explicamos antes, de tratarse de un derecho fundamental, debería tener el rango de ley orgánica ${ }^{382}$ y como no lo tiene, es porque no se ha entendido que deba ser un derecho fundamental y por tanto, no corresponde que esté en el artículo 21. De otra parte, también se dice que "el derecho a la producción y creación no incluyen los derechos sobre lo producido o creado"383. Finalmente, también se da una argumentación que vimos al hablar de la naturaleza jurídica de la propiedad intelectual, consistente en que si bien la propiedad intelectual contiene facultades personalísimas, no es un derecho de la personalidad, puesto que tanto las obras como las invenciones, aunque pueda sostenerse que emanan del fuero interno de una persona, no son parte de su personalidad, teniendo una existencia diferente y separada de ella. En esta línea de pensamiento están BERCOVITZ RODRÍGUEZ-CANO y CARMONA SALGADO ${ }^{384}$.

El gran inconveniente de esta teoría -que cabe considerar si influye en la tributación- es que de aceptar que la propiedad intelectual está únicamente protegida en el artículo $33 \mathrm{CE}$, implica hacerse cargo del hecho que la propiedad intelectual es una propiedad distinta de la propiedad ordinaria, por lo que su dimensión vinculada a la persona -como los derechos morales- al no poder entenderse subsumidos en la protección de la propiedad ordinaria, quedan en el desamparo ${ }^{385}$.

\footnotetext{
${ }^{381}$ Ob. supra cit., p. 163.

382 Conforme a LATORRE. Ob. supra cit., p. 65, este argumento sería de BERCOVITZ RODRÍGUEZCANO; sin embargo, también lo hemos visto planteado en el mismo sentido en PLAZA, Ob. supra cit., pp. 251 y sgtes.

383 Ob. supra cit., p. 65.

${ }^{384}$ Citados por LATORRE. Ob. supra cit., pp. 65 a 67.

385 Según PLAZA. Ob. supra cit., p. 246, ésta es la posición de BAYLOS.
} 


\subsection{La propiedad intelectual está contenida parcialmente en el Art. 20. 1. b) y en el Art. 33 de la CE}

Esta posición podríamos decir que es la típica postura "ecléctica" que tan comúnmente vemos en el derecho. Efectivamente, hay quienes piensan que el derecho de autor está contenido de una doble forma en la CE. Por una parte, las facultades vinculadas a la persona estarían en el artículo. 20 1. b) y por otra, aquellas de orden patrimonial se contendrían en el artículo $33 \mathrm{CE}$.

La dimensión personal de la propiedad intelectual gozaría del mismo grado de protección que otros derechos de la personalidad como el honor, la intimidad y la propia imagen $^{386}$. Por su lado, la dimensión patrimonial al ubicarse junto a la propiedad ordinaria, reconocería allí su lugar natural, puesto que como sabemos, la propiedad ordinaria es incluso supletoria de la propiedad intelectual ${ }^{387}$. En esta corriente se encuentran autores como ARROYO y GARCÍA ${ }^{388}$, JUFRESA PATAU, ROLDÁN BARBERO $^{389}$, PLAZA PENADES ${ }^{390}$ y PÉREZ DE CASTRO ${ }^{391}$.

El manto de dudas cae sobre esta teoría, lanzado por quienes piensan que la propiedad intelectual es unitaria, por lo que no debe ser dividida o seccionada, para encontrar su justificación en tan disímiles preceptos; no obstante, compartimos con PLAZA PENADES ${ }^{392}$ que esta objeción es menor, puesto que no se ve impedimento para que una concepción así sea posible. Las verdaderas objeciones las encontramos en la falta de evidencia sobre la intención del 20. 1. b), en el sentido que su voluntad fuese constitucionalizar la propiedad intelectual, ya sea en su dimensión personal o patrimonial, a lo que se suma que, en el evento de ser cierto sólo para la dimensión personal, tal como se pretende, no podría determinarse cuáles de los derechos que se integran en esta dimensión fueron los que se quisieron elevar al rango constitucional ${ }^{393}$, así por ejemplo: el derecho al acceso al ejemplar único tiene reconocimiento en España,

\footnotetext{
386 Ob. supra cit., p. 252.

387 En este sentido GÓMEZ DÍEZ, JUSTO JOSÉ. La propiedad intelectual y el artículo 20.1 b) de la Constitución española, Revista de la Facultad de Derecho de la Universidad Complutense, Anuario 84 , pp. 165 y sgtes.

388 ARROYO y GARCÍA. Ob. supra cit., p. 163.

389 Referidos por LATORRE. Ob. supra cit., pp. 70 y 71.

390 PLAZA. Ob. supra cit., p. 272.

391 PÉREZ DE CASTRO, NAZARETH. El derecho de propiedad sobre obras de arte y el derecho del autor respecto de la obra, Actualidad Civil N³, 1987, p. 224.

392 PLAZA. Ob. supra cit., p. 254.

${ }^{393}$ En este sentido PLAZA. Ob. supra cit., p. 251.
} 
pero no en otros países (en Chile no lo tiene). Entonces, cabría preguntarse: ¿Qué tan derecho moral es? o ¿Es más bien una concesión del legislador en favor del autor? De ser una mera concesión legislativa, ¿Cómo se justificaría proteger esta facultad al nivel de derecho fundamental? Diferenciar entre los distintos tipos de derechos morales, "obliga a replantearse si es posible dar una solución en bloque; es decir, entender que todo el derecho moral de autor se protege en el artículo 20. 1. b) CE o, si, por el contrario, resulta deseable concebir el derecho a la creación intelectual como un derecho específico, con un ámbito y fundamento propio, que puede proyectarse sobre algunos derechos morales, pero su ámbito no incluye a todos ellos”. Tal vez, de esta idea planteada por PLAZA PENADES ${ }^{394}$, nazca una cuarta generación de teorías que buscan explicar la presencia de la propiedad intelectual en la CE.

Una última cuestión que hay que plantear, es que esta teoría explicaría al derecho de autor, pero no a la propiedad industrial, cuya dimensión personal se yergue posiblemente con menos fuerza que el derecho de autor, pero existe. Así las cosas: ¿Cómo podría justificarse un tratamiento distinto para uno y otro tipo de propiedad intelectual?, si el texto constitucional no plantea diferencia alguna.

\subsection{El sustrato indubitado del artículo 20. 1. b) CE}

Existe una "postura restrictiva o mínima",395, conformada por aquello que nadie duda forma parte del artículo 20. 1. b) de la CE, consiste en el derecho a la creación y producción intelectual. Esta postura planteada por PLAZA PENADES la desarrolla para el derecho de autor, en consecuencia, cabe la duda si este contenido mínimo, caracterizado por la facultad de crear y producir sin censura, ni más restricciones que las que pudiesen imponer otros derechos fundamentales, contiene o no a la propiedad industrial. Nuestra posición es que no existe ninguna razón para distinguir o fraccionar la aplicación del derecho a la creación y producción, ya que no se divisan razones para distinguir entre la protección que el constituyente ha querido prodigarle a quien pueda escribir una obra o desarrollar un invento.

\footnotetext{
${ }^{394}$ Ob. supra cit., p. 273.

395 Ob. supra cit., p. 266.
} 
Esta "postura restrictiva o mínima" no está libre de interrogantes, tal como ha dejado de manifiesto URÍAS MARTÍNEZ ${ }^{396}$, al advertir que si bien no cabe duda sobre que la Constitución garantiza el derecho a producir y crear como un derecho fundamental, ello plantea la duda sobre cómo afecta al régimen de propiedad intelectual. Las posiciones a nuestro juicio son tres: no la afecta en nada, son asuntos independientes; afecta a los derechos morales tras de la obra, básicamente los que dicen relación con la posibilidad de controlar la obra, pero no afecta a los derechos patrimoniales; y, afecta transversalmente a toda la propiedad intelectual.

Para nosotros, el derecho a producir y crear es un derecho independiente vinculado más a la vida en común, a la protección del pacto político que se contiene en una constitución, como tal es un derecho con existencia independiente relacionado con la esencia del ser humano en su condición de criatura social y no tiene por qué amalgamarse con otros derechos, no obstante tengan un objeto en común. Por su parte, la propiedad intelectual en sus dos dimensiones personal y patrimonial, tiene más que ver con expresiones del ser humano o con la apropiación de beneficios pecuniarios o personales -como el honor- se presenta como un derecho instrumental y no tan inherente al ser humano, pudiendo serlo, lo que no desconocemos, pero no es su única dimensión. Como derecho independiente puede tener su propio perfil de derecho humano, fundamental o esencial, como quiera llamársele y no necesita de otros derechos, ni menos de presencia literal en las constituciones, no lo exigen los tratados internacionales y no hay razón jurídica para pretenderlo. En otras palabras, la propiedad intelectual no requiere de otros derechos humanos, ni del tenor literal de las constituciones, para reclamar su carácter de derecho fundamental, en esa medida si la $\mathrm{CE}$, olvidó, no quiso o no estuvieron las condiciones políticas para darle un reconocimiento expreso como derecho fundamental, eso no varía su esencia de tal y no requiere de sociedades con el derecho a crear o producir. Otra cosa será determinar hasta donde llega la dimensión de derecho fundamental de la propiedad intelectual, búsqueda que seguramente llevaría a interminables debates.

\footnotetext{
${ }^{396}$ URÍAS MARTÍNEZ, JOAQUÍN. El derecho a la producción y creación literaria, artística, científica y técnica, en Comentarios a la Constitución Española, XXX Aniversario, Fundación Wolters Kluwer, 2009 , p. 509.
} 


\subsection{La jurisprudencia}

Todos los autores que abordan el problema de la naturaleza jurídica de la propiedad intelectual después de 1987, hacen referencia a las sentencias del Tribunal Supremo y del Tribunal Constitucional, sobre el "Caso Serrano", STS RJ 1985/6320 de 09 de diciembre de 1985 y STC 35/1987 de 18 de marzo, normalmente criticándolas, por no tomar posición en favor de una u otra de las teorías que hemos enunciado, como si las sentencias tuviesen la obligación de resolver problemas teóricos, en vez del caso concreto sometido al conocimiento del tribunal ${ }^{397}$.

Las sentencias señaladas tratan sobre el mismo caso que previamente había sido resuelto por el Tribunal Supremo a través de sentencia de 21 de junio de 1965 (RJ 1965\3670), en que fueron parte las mismas personas y se discutieron los mismos hechos, relacionados con una escultura llamada "Viaje a la luna en el fondo del mar", que realizó el escultor Pablo Serrano, por un encargo de la sociedad Industrias Turísticas SA, cuyo objeto era ser instalada en el hall del hotel de su propiedad, llamado Las Tres Carabelas, ubicado en Torremolinos. El precio acordado se pagó, la obra se efectuó con materiales y mano de obra de Industrias Turísticas SA y se exhibió por corto tiempo, puesto que para la propietaria tenía diferencias con el boceto original y no armonizaba con la decoración del hotel. Se le ofreció al escultor instalarla en otro lugar y ante la negativa de éste, se ordenó desmontarla, guardándola en una bodega. El Sr. Serrano se negó a que fuese instalada en otro lugar y demandó fundado en su derecho moral de autor, específicamente argumentó la paternidad, que le permitía impedir que se deforme o mutile e incluso retirarla de la circulación, demandó también daños y perjuicios. El propietario de la obra se opuso en calidad de dueño, alegando que como tal, tenía el derecho a disponer de la obra y que no se había pactado con el artista, nada que le impidiera desmontar la obra.

El pleito en 1965 se resolvió a favor de la empresa propietaria, lo que se justifica, básicamente porque a la fecha estaba vigente al Ley de Propiedad Intelectual de 1879, que no contemplaba los derechos morales de autor ${ }^{398}$.

\footnotetext{
${ }^{397}$ El caso Serrano, está tratado en extenso en PLAZA. Ob. Cit., pp. 205 y sgtes.

${ }^{398}$ En el pleito también se discutieron otras cuestiones que afectaban al fondo, como la aplicación al caso del artículo 6 Bis, del CUB, pero no lo mencionamos porque no es el centro de nuestro análisis en este momento.
} 
Con la llegada de la Constitución de 1978 y la Ley de Protección Jurisdiccional de los Derechos Fundamentales de las Personas ${ }^{399}$ de 27 de diciembre del mismo año, el escultor demandante estimó que no le afectaba el principio de cosa juzgada respecto de la sentencia de 1965, afirmando que desde el momento en que la escultura permanecía guardada al momento de entrada en vigencia de la Norma Suprema y continúa guardada a la época de la demanda, se están viendo vulnerados sus derechos fundamentales, cuales son los de creación y producción artística del artículo 20.1. b) CE y el derecho al honor del artículo 18. 1. CE. También entiende el demandante, que el derecho de autor está contenido en el Art. 20. 1. b) CE, de donde nace su derecho moral de paternidad, asistiéndole la facultad de recrear obra, modificarla e incluso retirarla, utilizando para ello la nueva legislación.

La pretensión del Sr. Serrano, fue desestimada en las dos instancias judiciales por incompetencia de jurisdicción, por inadecuación de procedimiento, llegando al Tribunal Supremo vía casación, donde se confirmó la resolución. El Tribunal Supremo consideró que "no ha existido respecto de la situación legal existente en el año 1965 ninguna variación legal en el plano jurisdiccional, pues el 'derecho a la creación y producción' no está incluido en la Ley que la parte demandante afirma ha sido infringida: de 28 de diciembre de 1987 (LPJDFP)"400 , puesto que "el procedimiento que dicha Ley establece no es extensible a todos los derechos fundamentales, sino a los expresamente citados en el apartado $2^{\circ}$ del artículo $1^{\circ}$ y los comprendidos en su Disposición Final. Y en ninguno de esos preceptos aparece expresamente citado el derecho a la creación y producción literaria, artística, científica y técnica"401.

No obstante lo anterior, lo relevante para nuestro estudio, no es lo que sucedió con el juicio con la parte procesal, sino que la sentencia utilizando lo que podríamos llamar "prudencia de juez", para referirse a la búsqueda que hacen los jueces para intentar contribuir a la resolución de fondo del caso concreto, aun cuando no tengan argumentos legales, hizo observaciones sobre el fondo del asunto, las que PLAZA PENADES, muy acertadamente, califica de haber sido hechas obiter dictum ${ }^{402}$. El

\footnotetext{
${ }^{399}$ Cuya sigla es LPJDFP.

400 PLAZA. Ob. supra cit., p. 215.

${ }^{401}$ Ob. supra cit., pp. 215 y 216.

402 Ob. supra cit., pp. 214.
} 
Tribunal Supremo vio en la norma del Art. 20. 1. b) $\mathrm{CE}^{403}$, un derecho de orden general a producir o crear obras, destinado a proteger a todos quienes potencialmente quieran ser autores o creadores, de manera que lo viene a proteger es la facultad de crear sin interferencias o censura de ninguna especie, sin embargo el resultado de la creación, lo creado, no está incluido aquí, sino que es objeto de propiedad intelectual. El Tribunal Supremo, expresamente, se hace cargo de la naturaleza jurídica del derecho de autor, diciendo que no es un derecho de la personalidad, porque no es consustancial o esencial a la persona, ya que se puede ser persona sin ser autor.

En resumen, para el Tribunal Supremo en el Art. 20. 1. b) CE, hay un derecho personal, no personalísimo, que garantiza la libertad para crear o producir propiedad intelectual y no está la propiedad intelectual en sí misma.

En cuanto al Tribunal Constitucional, PLAZA PENADES ${ }^{404}$ se detiene en el análisis de la sentencia STC 35/1987 de 18 de marzo, que tiene la particularidad de versar sobre los mismos hechos, es decir después de haber sido resuelto el asunto a nivel del Tribunal Supremo en 1965 y posteriormente, en 1985, la demandante insistió por vía de amparo, pretendiendo que se vulneraban sus derechos fundamentales de autor, consagrados en el artículo 20.1. b) CE. Es decir, para el demandante subyacen en

${ }^{403}$ El texto completo del considerando respectivo dice: "Que el derecho que se alega como perjudicado en este caso, se pone en relación con el artículo veinte de la Constitución, apartado uno, letra b), a cuyo tenor «se reconocen y protegen los derechos... a la producción y creación... artística», precepto que está incluido en la Sección primera (De los derechos fundamentales y de las libertades públicas), del Capítulo segundo (Derechos y libertades) del Título primero (De los derechos y deberes fundamentales); siendo de observar que lo que se consagra como fundamental, es un derecho genérico e impersonal, a producir o crear obras artísticas, pues no toda persona crea o produce arte, viniendo a proclamar la protección de una facultad; cuando se produce o crea, entonces lo que se protege es el resultado, que hace surgir un derecho especial, el derecho de autor, que no es un derecho de la personalidad porque asimismo carece de la nota indispensable de la esencialidad, pues no es consustancial o esencial a la persona, en cuanto que no toda persona es autor; y, conlleva la necesidad de la exteriorización, puesto que se crea o produce arte, para ser exteriorizado, lo que implica el nacimiento de otro derecho en favor de aquéllos a los que se exterioriza -público, adquirente, receptores- el primero de los cuales tiene por objeto un «bien inmaterial», mientras que en el segundo es un «bien material»; lo cual plantea una serie de problemas de coordinación de ambos derechos, que supone la de los respectivos intereses que entran en juego que surgen, no con la persona, sino como consecuencia de una actividad de ésta, cuya solución es difícil, que se intentó resolver en Derecho comparado sin resultados plenamente satisfactorios y a veces chocantes con las soluciones prácticas de la aplicación jurídica, que en ESPAÑA se acometió con el reciente intento de que se tiene noticia, de elaboración de un Proyecto de Ley, en tramitación; pero que la Constitución no sólo no resuelve, sino que ni siquiera intentó resolver instaurando una nueva normativa, pues, tiene buen cuidado, respecto de éste y de los demás derechos que consagra, en dejar las peculiaridades de cada uno de ellos, a la regulación especial que les corresponda, según se establece en el apartado cuarto del artículo veinte al hablar de «los preceptos de las leyes que lo desarrollen», y en el apartado primero del artículo cincuenta y tres, donde se añade que «sólo por ley, que, en todo caso deberá respetar su contenido esencial, podrá regularse el ejercicio de tales derechos»".

${ }^{404}$ Ob. supra cit., pp. 222 y sgtes. 
esta norma, de manera conjunta, el derecho de autor y el derecho general a la producción y creación literaria, artística, científica y técnica. En cuanto a los hechos, consideró que existía una situación permanente, porque la obra permanecía desmantelada. El Tribunal Constitucional desestimó el recurso sin hacer ningún pronunciamiento sobre el fondo del asunto, ya que consideró que estaba presentado fuera de plazo, por lo que a nuestro juicio, no cabe pensar que el Tribunal Constitucional haya emitido juicio alguno sobre el fondo del asunto ${ }^{405}$.

\subsection{Relevancia de la discusión}

Desde nuestro punto de vista, los esfuerzos por introducir a la propiedad intelectual a nivel constitucional son desmedidos e innecesarios, en efecto, el reconocimiento constitucional como "derecho fundamental" no requiere de norma expresa que lo declare. De nuestro análisis, vemos que hay un excesivo celo científico por elevar a la propiedad intelectual propiamente tal (derecho de autor) al más alto estándar de protección jurídica, el alzamiento como "derecho fundamental"; sin embargo, resulta curioso que los esfuerzos olviden a la propiedad industrial y la releguen a una condición secundaria, lo que nos plantea una duda que hemos mencionado anteriormente: ¿Cuál es la razón por la que el autor pudiera tener una protección diferente al inventor o al creador de una marca?, ¿Es acaso que goza de una mayor dignidad el autor o existe una esfuerzo creativo superior? o ¿Es que la condición de bien "cultural" está limitada a la literatura y las artes plásticas? Resulta ser entonces que los conocimientos científicos, matemáticos y técnicos no forman parte de la "cultura" o tal vez, se estima que son menos dignos de protección, que las obras y las artes.

${ }^{405}$ De todas formas es interesante ver el razonamiento en que se fundó el demandante para pretender esta acción tantos años después de ocurridos los hechos, al respecto la STC 35/1987 hace un excelente resumen de ellos, al decir: "El art. 20.1. b) de la Constitución, no sólo contiene un derecho de libertad respecto a toda injerencia, proceda de poderes públicos o personas privadas, en el proceso espiritual que concluye en una obra literaria, artística, científica o técnica y en la difusión de ésta, sino que constitucionaliza el núcleo esencial del derecho del autor a la protección de sus intereses morales y materiales, que incluyen la paternidad de la obra y la facultad de oposición a las deformaciones, mutilaciones y modificaciones o a cualquier atentado a la obra que cause perjuicio al honor y reputación del artista; el citado art. 20.1. b) es invocable en concurrencia con el 18.1 de la Constitución.

La destrucción del ejemplar único de una obra de arte, decidida por su propietario a espaldas del autor, constituye, en primer término, la mutilación extrema de la obra artística $\mathrm{y}$, en segundo lugar, supone un atentado al honor y reputación de su autor, que vulneran los derechos reconocidos en los arts. 20.1 b) y 18.1 de la Constitución". 
No encontramos respuesta para las interrogantes que planteamos, puesto que no vemos diferencia entre la protección debida a uno u otro tipo de propiedad intelectual, razón por la cual, creemos que es una decisión consiente del constituyente no elevar a rango constitucional a la propiedad intelectual, para evitar cualquier tipo de diferencia o arbitrio entre los derechos derivados de la propiedad intelectual o industrial. En esta misma línea de pensamiento está nuestra experiencia, son tantas las variantes, las implicancias y los puntos de vista, que muchas veces se requiere de mucho tiempo y de sucesivos pasos para que sea posible normatizar un determinado punto de vista. La Constitución Española, elaborada bajo un régimen autoritario, es buen ejemplo de los límites que pueden tener los redactores, la necesidad que la redacción sea aceptada por el mayor número de personas, impone fronteras que no están marcadas, que constituyen un hilo invisible que no se expresa en actas, debates, ni conclusiones, pero constriñe las posibilidades del redactor.

A nuestro juicio, el artículo 27. 2) de la DUDH, que dice: "Toda persona tiene derecho a la protección de los intereses morales y materiales que le correspondan por razón de las producciones literarias, artísticas y científicas de las que sea autor", tiene perfecta cabida en la $\mathrm{CE}$, desde el momento que el art. 10. 2. CE manda interpretar la Constitución considerando el 27. 2) de la DUDH, al decir: "Las normas relativas a los derechos fundamentales y a las libertades que la Constitución reconoce se interpretarán de conformidad con la Declaración Universal de Derechos Humanos y los tratados y acuerdos internacionales sobre las mismas materias ratificados por España". Vistas así las cosas, el derecho de autor tanto en su variante moral como material (protección de los intereses morales y materiales) es elemento interpretativo de la $\mathrm{CE}$, de manera que, “[s]in perjuicio de que, por su situación en el contexto constitucional, le llamemos derecho fundamental o, conforme a la Declaración de 1948, derecho humano, es uno de aquellos derechos que, sin prejuicios de escuela, hay que llamar derecho innato, ius nativum o derechos "inherentes" (artículo 10.1. de la Constitución)"406.

Esta consideración de derecho fundamental, no impone a ningún Estado la obligación de darle protección por un sistema específico, de manera que, bien podremos encontrar a la propiedad intelectual en el 20. 1. b) o en el $33 \mathrm{CE}$, al amparo del derecho

${ }^{406}$ DESANTES GUANTER, JOSÉ MARÍA. El derecho de autor en la Constitución española de 1978, Cuadernos constitucionales de la Cátedra Fadrique Furió Ceriol, ISSN 1133-7087, No 3, 1993 , p. 5. Disponible en Internet en: http://dialnet.unirioja.es/servlet/articulo?codigo=229791 (12 Abr 2013). 
de propiedad, tampoco impone la protección reforzada que poseen los derechos del Título I "De los derechos y deberes fundamentales" de la Carta Magna, por lo que no se justifican esfuerzos interpretativos para incorporarla dentro de la Constitución, no obstante pueda de ello derivarse una protección más laxa que la de otros derechos. De manera que, la concepción de la propiedad intelectual en el derecho español, puede ser "como un derecho ius privatista, tutelado como propiedad especial que incluso encuentra su protección en el propio Código Civil Español (art. 428 y 429) (...) Pero no por ser una propiedad es un derecho meramente patrimonial, sino que la especialidad de tal derecho exige el reconocimiento de las facultades morales que dejan intrínseco el rango de derecho humano" 407 que posee.

Asentado que no vemos la necesidad de constitucionalizar la propiedad intelectual, compartimos la visión de URÍAS MARTÍNEZ ${ }^{408}$, en el sentido que el art. 20. 1. b) CE, garantiza "la libertad plena en el momento de reflexión y elaboración creativa. De hecho, la íntima vinculación entre el proceso creativo y la esencia misma de la personalidad hacen que cualquier determinación de la manera en que se ha de elaborar una obra afecte a la dignidad misma de la persona y su capacidad de autodeterminación". A nuestro entender, es más útil la consagración del derecho a la producción y creación así definido, en la medida que no es expreso en la DUDH, que se limita en el art. 27.1 a asegurar el derecho a "participar libremente en la vida cultural", en vez de incorporar al derecho de autor, que tiene su sitio claramente definido en el art.

\subsection{DUDH.}

Nada malo vemos en la división de la protección del derecho de autor por un lado y la libertad de producción y creación por otro, puesto que concordamos con UMA SUTHERSANEM, en el sentido que "la existencia y el ejercicio de algunos derechos presupone la existencia de otros. Los derechos de propiedad van acompañados de los derechos de libertad, que van a su vez, acompañados de los derechos sociales" ${ }^{409}$.

En principio, al analizar los argumentos de quienes ven al derecho de autor en el Art. 20 .1. d) CE, resultan tan razonables en función de la unidad del derecho de autor y

\footnotetext{
${ }^{407}$ CASTRO. Ob. supra cit., p. 2.

${ }^{408}$ URÍAS. Ob. supra cit., p. 20.

409 SUTHERSANEN, UMA. El derecho de autor como motor de la libertad de expresión: una perspectiva inglesa, en Derecho de Autor y Libertad de Expresión, Actas de las Jornadas de Estudio ALAI, junio 2006, Barcelona, p. 126.
} 
de la necesaria conexión entre el derecho a crear y la titularidad de la obra creada, que parece ser imposible el conflicto con otros derechos, se ve una unión necesaria e indisoluble. Sin embargo, a poco andar, van apareciendo los ejemplos que justifican plenamente la separación entre la libertad de creación y la propiedad intelectual, puesto que, efectivamente, estos derechos pueden necesitarse de manera recíproca, pero también contraponerse con otros derechos, fundamentales o no, conjunta o separadamente.

En un caso se planteó ante el Tribunal Constitucional, el recurso de amparo $\mathrm{N}^{\circ}$ $740 / 1984,{ }^{410}$ demandaba el recurrente porque a su juicio al denegarle la facultad de darse de alta en cualquier Colegio de Arquitectos de España, se estaban vulnerando sus derechos fundamentales, contenidos en los arts. 20.1. b), 17.1 y 25.1 de la CE. El TC resolvió que el reconocimiento y protección que la norma tiene del "derecho a la producción y creación literaria, artística, científica y técnica no puede enlazarse del modo que pretende el demandante al ejercicio de la profesión de Arquitecto. En efecto, el contenido y manifestaciones del art. 20 de la CE hace referencia a los variados ámbitos en que se manifiesta la libertad de pensamiento y de expresión, sin que pueda reconducirse a tal esfera el ejercicio de una profesión, y menos una profesión titulada, que la propia Constitución reserva, en cuanto su ejercicio, a la Ley”. Si pensamos de contrario, las alegaciones del requirente habrían sido posibles si estimamos que los planos arquitectónicos están protegidos por derecho de autor, considerado como inescindible de la libertad de creación del Art. 20. 1. b) CE.

En otro caso, se recurrió ante el Tribunal Constitucional, en recurso de amparo $\mathrm{N}^{\circ} 720 / 1989^{411}$, por un profesor universitario quien estimaba vulnerados sus derechos fundamentales a la libertad de cátedra y al derecho de autor respecto de sus apuntes y documentos de clases. El TC se pronunció, en lo que es relevante para fundar nuestra opinión, diciendo: "Para ponderar la consistencia constitucional de la demanda, debe tenerse en cuenta, en primer término, que, como consecuencia de su incorporación al ordenamiento jurídico, todo derecho «puede experimentar limitaciones o restricciones en su ejercicio, derivadas de su conexión con otros derechos o bienes constitucionalmente protegidos y que habrán de estimarse válidas en tanto no rebasen su contenido esencial, haciéndolo impracticable, obstruyéndolo más allá de lo razonable o

\footnotetext{
${ }^{410}$ El asunto se resolvió por Auto TC $130 / 1985$ de 27 de febrero de 1985.

${ }^{411}$ El asunto se resolvió por Auto TC 457/1989 de 18 de septiembre de 1989.
} 
despojándolo de la necesaria protección» (STC 53/1986, de 5 de mayo). En particular, el derecho a la libertad de cátedra, entendido como «el derecho de quienes llevan a cabo personalmente la función de enseñar, a desarrollarla con libertad dentro de los límites del puesto docente que ocupan» está sujeto a «límites necesarios que resultan de su propia naturaleza, con independencia de los que se producen por su articulación con otros derechos o de los que, respetando siempre su contenido esencial, pueda establecer el legislador» (STC 5/1981, fundamento jurídico 7. º".

En el caso planteado en el Recurso de Amparo N 2.319/1991412, se ventiló un conflicto entre el derecho de autor y el derecho a la libre producción y creación, los hechos consistieron en que doña María del Sagrario Anunciación Dovale Ferreira, titular de una farmacia en La Coruña, recibió por años cartas de amor que nunca contestó. A finales de 1986, el autor de las cartas (demandado) publicó un libro titulado "El Amor Universal", en el que se contenían las cartas y datos de la vida personal de la destinataria. Doña María del Sagrario, desde la publicación del libro sufrió todo tipo de comentarios al ser reconocida por la información del mismo. El Juzgado $\mathrm{N}^{\circ} 2$ de La Coruña, la Audiencia Provincial y el Tribunal Supremo, estimaron que la obra supone una intromisión ilegítima en el derecho a la intimidad personal, dando una serie de motivos por los cuales el libro no puede ser considerado una "obra de ficción realizada de forma epistolar", sin que se le pueda estimar dentro de la cobertura del 20 de la CE. Es decir, el derecho a la intimidad de la demandante eclipsó el derecho a la libre producción y creación literaria del demandado y éste se impuso sobre el derecho de autor, puesto que también se ordenó el retiro de circulación de la obra. A nuestro juicio, es a consecuencia que el autor no pudo crear libremente lo que quiso, lesionando el derecho a la intimidad de la demandante, lo que justifica que lo creado esté sometido a limitaciones y se haya ordenado su retiro. De manera que, el derecho a la libre creación literaria y el de autor, pueden entrar en conflicto.

En sentencia STC 78/1995, el Tribunal Constitucional, declaró que en los casos de "conflicto entre las libertades reconocidas en el art. $20 \mathrm{CE}$, de expresión e información, por un lado, y otros derechos y bienes jurídicamente protegidos, no cabe considerar que sean absolutos los derechos y libertades contenidos en la Constitución, pero, tampoco puede atribuirse ese carácter absoluto a las limitaciones a que han de

${ }^{412}$ El asunto se resolvió por Auto TC 152/1993 de 24 de mayo de 1993. 
someterse esos derechos y libertades". De esta forma, ve el TC la necesidad de un balance entre los diferentes derechos e intereses protegidos por el ordenamiento jurídico, lo que llevado al análisis conjunto del derecho a la libre creación y producción y el derecho de autor, hace posible buscar un balance entre ellos y evita la imperiosa necesidad de entenderlos unificados o consagrados juntos, a nivel constitucional.

\section{La propiedad intelectual en la Constitución Chilena de 1980}

Aunque no estaba dentro de nuestros objetivos abordar la historia constitucional de Chile, al revisarla nos dimos cuenta de lo esclarecedor que puede ser para entender la definición actual que tomó la Constitución de 1980, actualmente vigente, por lo que nos detendremos brevemente en ella.

\subsection{Breve resumen de la historia constitucional de Chile}

Un primer asunto que es indispensable tener presente, es que Chile, hasta comienzos del siglo XIX, formaba parte de las colonias que el Reino de España mantenía en América. Normativamente rigió en Chile el "derecho indiano"413, cuya principal fuente eran las disposiciones dictadas por la Corona Española.

Respecto de la propiedad intelectual, JOSÉ MARÍA OTS CAPDEQUÍ4 ${ }^{414}$ sostiene que no hay en el derecho indiano "normas jurídicas reguladoras de esta materia a lo largo del período colonial. Pero se contienen numerosos testimonios históricos de expedientes instruidos a instancias de particulares, por virtud de los cuales se concede permiso para la impresión y venta exclusiva de algún libro en los territorios de las Indias por el plazo de tiempo que se señala, o para la explotación también con carácter exclusivo y por el tiempo que concretamente se fija, de algún invento de aplicación industrial que detalladamente se describe", sin embargo para el autor, el volumen de los documentos que existen en la Colección Balmonte del archivo señalado, es insuficiente para determinar la existencia de disposiciones específicas en el derecho indiano. Desde nuestro punto de vista, el relato es consistente con la época de los privilegios característico del Antiguo Régimen, ya que tal como estudiamos anteriormente, encontramos ejemplos de privilegios de patentes que se dieron por la Corona Española para su explotación en los territorios de ultramar.

413 Tomó este nombre porque se suponía que regiría para "Las Indias".

${ }^{414}$ Citado en Enciclopedia Jurídica Omeba, Tomo XXII, Driskill SA, Buenos Aires, 1990, p. 638. 
Conforme a la tendencia independentista de la época, el 18 de septiembre de 1810, se forma en Chile la primera Junta de Gobierno, marcando el inicio de la independencia. La Junta de 1810, dicta el Reglamento para el Arreglo de la Autoridad Ejecutiva Provisoria de Chile de 1811, considerado como uno de los primeros ensayos constitucionales del país, de marcada tendencia leal al Rey de España. El 4 de septiembre de 1811, toma el mando José Miguel Carrera, a través de un golpe de estado, derogando el reglamento de 1811 y dictando el Reglamento Constitucional Provisorio de 1812. En el clima de tensión propio de los procesos independentistas de la época, Carrera es destituido, dictándose el Reglamento para el Gobierno Provisorio de 1814. Después, viene un profundo conflicto entre patriotas y realistas, triunfan las fuerzas y la idea independentista, declarándose la independencia por Bernardo O’Higgins Riquelme el 12 de febrero de 1818. Se establece la Constitución de 1818.

No obstante el texto constitucional de 1818, el país no logra superar la inestabilidad tras la lucha por la independencia, sancionándose la Constitución de 1822, que lejos de contribuir, es vista como intento O'Higgins para seguir en el poder, quien termina abdicando como Director Supremo, el 28 de enero de 1823. Posteriormente, se designa Director Supremo a Ramón Freire Serrano, quien promulga la Constitución de 1823. La Constitución de 1823, de fuerte tinte conservador, autoritario y moralista, conocida como la "constitución moralista", sólo sobrevive hasta el año 1826, siendo derogada por resultar impracticable. Le suceden una serie de estudios que dieron origen al Ensayo Federal de 1826, que buscaba el establecimiento de un régimen federal, que fue imposible de implantar, dando paso al gobierno interino de don Francisco Antonio Pinto, que instituye la Constitución de 1828, reconocida por su acabada elaboración, no obstante incapaz de responder a la realidad social y cultural del país. En la siguiente elección, resulta vencedor don Francisco Antonio Pinto, pero se frustra el nombramiento del vicepresidente, lo que provoca una guerra civil que finaliza en 1830, con el triunfo de Diego Portales en la Batalla de Lircay.

Diego Portales, aunque nunca fue presidente de Chile fue una figura de la mayor relevancia. Él consiguió la promulgación de una nueva Ley Fundamental, la Constitución de 1833, que rigió hasta 1925, estabilizó el país, dando paso a lo que se conoció como "el siglo de Portales". Termina así una etapa de inestabilidad política y ajustes institucionales originados en el proceso independentista. 
La Constitución de 1833, también da inicio a lo que se conoce como "República Autoritaria -o también de los Decenios, porque los presidentes electos gobernaron en total diez años cada uno-, que puso en manos del primer mandatario amplios poderes, a través de la Constitución de 1833. Se dotó al Ejecutivo con el estado de sitio y las facultades extraordinarias, los medios indispensables para imponer la normalidad a despecho de agitaciones y desórdenes. Los resultados de tales disposiciones se tradujeron en exilio, censura a la prensa y persecución a los adversarios políticos, no obstante que en materia de libertades, entre otras, se garantizaban la igualdad ante la ley, la inviolabilidad de las propiedades, la libertad de imprenta y la seguridad personal. $^{, 415}$.

Después de una serie de gobiernos, en la presidencia de Arturo Alessandri Palma se sanciona la Constitución de 1925, que rige hasta el golpe de estado del año 1973.

El 11 de septiembre de 1973, se destituyó al presidente Salvador Allende (elegido en 1970), estableciéndose una Junta Militar, que nombra una comisión encargada del estudio de una nueva constitución, en el ínterin, se dictan las llamadas Actas Constitucionales, el proceso culmina con la promulgación de la Constitución de $1980^{416}$.

Según hemos venido estudiando, no es común la preocupación de la propiedad intelectual a nivel constitucional, de hecho, como también hemos analizado, en el caso español los autores se debaten por constitucionalizar a la propiedad intelectual, ante la ausencia de normativa expresa al respecto. Desde esa visión, la situación chilena es particular, puesto que la propiedad intelectual aparece, claramente, por primera vez, en la Constitución de 1833 y se mantiene hasta la actualidad.

Recordemos que las postrimerías del siglo XVIII y los inicios del XIX, es la época de abolición del antiguo régimen y la instauración del nuevo régimen, caracterizado por la consolidación de las libertades y del sistema capitalista, por lo que si bien los autores chilenos, tradicionalmente, tal como hemos mencionado, ubican a la propiedad intelectual por primera vez, en la Constitución de 1833, estimamos relevante

415 Extracto obtenido de la página de Internet. Disponible en Internet en:

http://www.profesorenlinea.cl/chilehistoria/Republica_conservadora.htm (15 Abr 2013).

416 Las fechas y relación históricas, las hemos extraído del texto Breve historia constitucional de Chile, disponible en la Biblioteca del Congreso Nacional de Chile, en:

http://www.bcn.cl/lc/cpolitica/resena_const (15 Abr 2013). 
revisar no sólo si aparece de manera expresa, sino también si hubiese podido estar subsumida, al menos embrionariamente en la libertad de prensa y el derecho de propiedad, lo que nos llevó a identificar dos períodos, desde 1812 a 1833, donde se ubican las primeras normas de rango constitucional y la presencia de la propiedad intelectual en ella, no es clara o al menos es discutible. En un segundo período la regulación se vuelve expresa y aparece también la normativización a nivel legal, por mandato de los propios textos constitucionales.

\subsubsection{Desde 1812 a 1833}

En éste período no hay una regulación expresa de la propiedad intelectual como tal y solamente podríamos ubicarla al amparo de la libertad de imprenta y derecho de propiedad, sin embargo ello no pasa de ser una especulación, puesto que no encontramos referencia en este sentido, en la escasa literatura jurídica de la época. Las normas que podrían contener a la propiedad intelectual o que cuando menos guardan relación con ella, son las siguientes ${ }^{417}$ :

1) El Reglamento Constitucional de 1812 , en el artículo $23^{\circ}$, señala: "La imprenta gozará de una libertad legal; y para que ésta no degenere en licencia nociva a la religión, costumbres y honor de los ciudadanos y del país, se prescribirán reglas por el Senado";

2) En la Constitución de 1818, el artículo 9, impone que: "No puede el Estado privar a persona alguna de la propiedad y libre uso de sus bienes, si no lo exige la defensa de la patria, y aún en este caso, con la indispensable condición de un rateo proporcionado a las facultades de cada individuo, y nunca con tropelías e insultos". Después, el artículo 11, indica: “Todo hombre tiene libertad para publicar sus ideas y examinar los objetos que están a su alcance, con tal que no ofenda a los derechos particulares de los individuos de la sociedad, a la tranquilidad pública y Constitución del Estado, conservación de la religión cristiana, pureza de su moral y sagrados dogmas; y en su consecuencia, se debe permitir la libertad de imprenta, conforme al reglamento que para ello formará el Senado o Congreso";

3) La Constitución de 1922, señala en los artículos 114 y 115, como límites al poder ejecutivo: "No puede por sí conceder privilegios exclusivos" y "A nadie le privará

\footnotetext{
${ }^{417}$ Los textos constitucionales son accesibles en Internet en: www.bcn.cl, http://www.bcn.cl/lc/cpolitica/resena_const (14 Abr 2013).
} 
de sus posesiones y propiedades; y cuando algún caso raro de utilidad o necesidad común lo exija, será indemnizado el valor, a justa tasación de hombres buenos";

4) El texto de la Constitución de 1823, a nuestro juicio, es la primera referencia expresa a la propiedad intelectual, al decir en el artículo 253: "La sabiduría y los talentos literarios útiles a la Patria, serán premiados de este fondo, pero con la precisa y notoria calidad de probidad de costumbres y moralidad de opiniones". Además establece un título, el XXII, "Del uso de la imprenta", destinado a regular el derecho a la libertad de imprenta, prescribiendo en el artículo 262: "La imprenta será libre, protegida y premiada en cuanto contribuya a formar la moral y buenas costumbres; al examen, y descubrimientos útiles de cuantos objetos pueden estar al alcance humano; a manifestar de un modo fundado las virtudes cívicas y defectos de los funcionarios en ejercicio; y a los placeres honestos y decorosos", sin embargo en los artículos siguientes del título en referencia, se establece el "tribunal de libertad de imprenta" destinado a revisar todo escrito que haya de publicarse, para "advertir a su autor las proposiciones censurables";

5) La Constitución de 1828, vuelve a concentrarse en las libertades y el dominio, con las siguientes normas: art. 10: "La Nación asegura a todo hombre, como derechos imprescriptibles e inviolables, la libertad, la seguridad, la propiedad, el derecho de petición, y la facultad de Publicar sus opiniones"; art. 17: "Ningún ciudadano podrá ser privado de los bienes que posee, o de aquellos a que tiene legítimo derecho, ni de una parte de ellos por pequeña que sea, sino en virtud de sentencia judicial. Cuando el servicio público exigiese la propiedad de alguno, será justamente pagado de su valor, e indemnizado de los perjuicios en caso de retenérsela"; art. 18: "Todo hombre puede publicar por la imprenta sus pensamientos y opiniones. Los abusos cometidos por este medio, serán juzgados en virtud de una ley particular y calificados por un tribunal de jurados".

\subsubsection{Desde 1833 a $1980^{418}$}

Desde la Carga Magna de 1833, el tratamiento de la propiedad intelectual ha sido preocupación constante de todas las constituciones que se sucedieron hasta la actualidad. En este período también se desarrolla la normativización legislativa de la

\footnotetext{
${ }^{418}$ La Constitución de 1980, con modificaciones, se encuentra vigente hasta la actualidad.
} 
materia, siguiendo el mandato constitucional que unánimemente dispone al legislador regular el asunto.

Las normas constitucionales y legales de este período, según su orden cronológico, son las siguientes:

1) En la Constitución de 1833, la regulación de la propiedad intelectual es expresa e innegable, puesto que su art. $143(152)^{419}$, señalaba: "Todo autor o inventor tendrá la propiedad exclusiva de su descubrimiento, o producción por el tiempo que le concediere la ley; y si ésta exigiere su publicación, se dará al inventor la indemnización competente". También debe considerarse el art. $12,(10)^{420} \mathrm{~N}^{\circ} 5$, que aseguraba la "inviolabilidad de todas las propiedades, sin distinción de las que pertenezcan a particulares o comunidades, y sin que nadie pueda ser privado de la de su dominio, ni de una parte de ella por pequeña que sea, o del derecho que a ella tuviere, sino en virtud de sentencia judicial; salvo el caso en que la utilidad del Estado, calificada por una ley, exija el uso o enajenación de alguna; lo que tendrá lugar dándose previamente al dueño la indemnización que se ajustare con él, o se avaluare a juicio de hombres buenos". Estas normas son importantes, porque al decir de HUNEEUS ZEGERS ${ }^{421}$, desde el momento en que el art. 143 (152), entrega al autor o inventor la propiedad exclusiva de su desarrollo o creación por el tiempo que fije la ley y si ésta exigiera la publicación, se dará al inventor la indemnización correspondiente, éste es el mecanismo por el que se puede afectar la propiedad de las patentes y no es aplica el artículo 10 (12) $\mathrm{N}^{\circ} 5$, donde se contempla limitación del dominio por causa de utilidad pública, calificada por ley ${ }^{422}{ }^{423}$, estas observaciones que pudieran parecer inconexas con la naturaleza jurídica de la propiedad intelectual, son un elemento importante para demostrar como desde todos los ángulos, la propiedad intelectual ha sido siempre considerada como propiedad.

\footnotetext{
419 El número del artículo cambio en el tiempo, pero el contenido no varió.

${ }^{420}$ El número del artículo cambio en el tiempo, pero el contenido no varió.

${ }^{421}$ HUNEEUS ZEGERS, JORGE. La Constitución ante el Congreso (sobre la Constitución de 1833), publicada entre 1879 y 1880 .

422 Citado por LARRAGUIBEL ZAVALA, SANTIAGO. Tratado sobre la propiedad industrial, Editorial Jurídica Conosur, Santiago de Chile, 1995, p. 145.

${ }^{423}$ El análisis de HUNEEUS, se efectúa en su obra publicada en 1891, por lo que atendida su data, contribuye en favor de nuestra tesis, sobre el hecho que en Chile el tratamiento de la propiedad intelectual como propiedad especial, se venía produciendo desde los albores de la República, aun cunado los textos constitucionales no le dieran un espacio expreso hasta 1833.
} 
Bajo la Constitución de 1833, se dictaron las siguientes leyes, que conformaron la regulación fundamental de la materia:

a) El 01 de enero de 1857, entró a regir el Código Civil Chileno, cuyo artículo 584 no deja duda del perfil propietario que se imprime a la propiedad intelectual, al establecer: "Las producciones del talento y del ingenio son una propiedad de sus autores. Esta especie de propiedad se regirá por leyes especiales".

b) La Ley de Propiedad Literaria de 24 de julio de 1834, que se transforma en la primera ley chilena sobre propiedad intelectual propiamente tal, dividiendo la regulación entre derecho de autor ${ }^{424}$ y propiedad industrial.

c) La Ley sobre Privilegios Exclusivos de 1840. Bajo el rótulo de privilegios exclusivos, lo que trató es de patentes de invención.

d) La Ley de Marcas de Fábrica y de Comercio de 12 de noviembre de 1874. Posteriormente, la propiedad industrial unificará bajo su alero al derecho de patentes y marcario.

e) Por DL N $\mathrm{N}^{\circ}$ 43, de 14 de octubre de 1924, se creó el Ministerio de Agricultura y Colonización, cuyo artículo $4^{\circ}$, numeral 10, le entregó: "Todo lo relativo a la propiedad comercial, industrial y artística".

f) Por DL $\mathrm{N}^{\circ}$ 90, de 12 de noviembre de 1924, se creó la Oficina de Propiedad Industrial dependiente del recién creado Ministerio de Agricultura y Colonización.

g) El DL N 358, de 17 de marzo de 1925, viene a ordenar que los servicios de propiedad industrial y comercial, a que se refieren el DL $\mathrm{N}^{\circ} 90$, antes citado, serán de competencia de una nueva repartición pública denominada Oficina de la Propiedad Industrial. Utiliza la expresión "patente". Estableció la regulación de detalle y definió lo que podía o no patentarse. Además, derogó el DL $\mathrm{N}^{\circ} 90$ de 1924; el DL sobre Privilegios Exclusivos de 1840; la Ley de Marcas de 1874; y, las referencias a la propiedad artística del DL No 43 de $1924^{425}$.

h) Finalmente el DL $N^{\circ} 345$, de 17 de marzo de 1925, reemplazó a la Ley de Propiedad Literaria de julio de 1834.

\footnotetext{
${ }^{424}$ Que llamó "propiedad literaria”. Corresponde a lo que nosotros hemos identificado como propiedad intelectual propiamente tal.

${ }^{425}$ LARRAGUIBEL. Ob. supra cit., p. 144.
} 
2) La Constitución de 18 de septiembre de 1925, en el art. 10, $\mathrm{N}^{\circ} 11$, asegura a los autores e inventores: "La propiedad exclusiva de todo descubrimiento o producción, por el tiempo que concediera la ley. Si ésta exigiera su expropiación, se dará al autor o inventor la indemnización competente"; y, en art. 10, $\mathrm{N}^{\circ} 10$, garantiza "la inviolabilidad de todas las propiedades, sin distinción alguna", permitiendo su privación sólo por sentencia judicial o por expropiación por causa de utilidad pública, calificada por una ley.

Bajo la Constitución de 1925, se dictaron las siguientes leyes, que normaron en detalle la materia:

a) El DL N 588, de 29 de septiembre de 1925, sobre Organización de los Servicios de la Propiedad Industrial, creando una entidad independiente denominada Oficina de la Propiedad Industrial y estableciendo la normativa sustantiva.

b) El DL N 958, de junio de 1931, sobre Propiedad Industrial, reemplazó al DL No 588, encargó la materia al Departamento de Industrias Fabriles y complementó la regulación de fondo.

3) En el año 1967, a través de la Ley Constitucional $\mathrm{N}^{\circ} 16.615$, se introdujo una reforma a la Constitución de 1925 , reemplazando el numeral $10^{\circ}$ del art. 10, de manera que ahora la Constitución asegura: "La inviolabilidad de todas las propiedades, sin distinción alguna (...) El ejercicio del derecho de propiedad está sometido a las limitaciones o reglas que exijan el mantenimiento y el progreso del orden social, y, en tal sentido, podrá la ley imponerle obligaciones o servidumbres de utilidad pública en favor de los intereses generales del Estado, de la salud de los ciudadanos y de la salubridad pública”.

Bajo la reforma constitucional referida, sucedió lo siguiente:

a) Se promulgó la Ley $\mathrm{N}^{\circ} 17.336$, de 02 de octubre de 1970, sobre Propiedad Intelectual, que con modificaciones rige hasta el día de hoy.

b) Si bien no se dictó una ley, hay un hecho que debemos destacar puesto que el Gobierno de Salvador Allende, fundado en el art. $4^{\circ}$ del Decreto Supremo $\mathrm{N}^{\circ}$ 1.262, del año 1953, del Ministerio de Economía y Comercio -Ley Orgánica de la Superintendencia de Abastecimiento y Precios de la época-, que facultaba "al 
Presidente de la República para declarar de utilidad pública los establecimientos dedicados a la producción y distribución de artículos de primera necesidad y expropiarlos a solicitud de la Superintendencia de Abastecimientos y Precios”426, inició un proceso de expropiación de empresas que comprendía todos los bienes necesarios para la marcha de la empresa, por lo que "la expropiación comprendía las marcas comerciales, patentes de invención y otros derechos de propiedad que tuviera la empresa" ${ }^{, 427}$.

4) La Constitución de 1980, viene a reforzar el derecho de propiedad en general y especialmente a la propiedad intelectual, al establecer en su art. 19, que asegura a todas las personas: $\mathrm{N}^{\circ} 25$ "La libertad de crear y difundir las artes, así como el derecho del autor sobre sus creaciones intelectuales y artísticas de cualquier especie, por el tiempo que señale la ley y que no será inferior al de la vida del titular. El derecho de autor comprende la propiedad de las obras y otros derechos, como la paternidad, la edición y la integridad de la obra, todo ello en conformidad a la ley.

Se garantiza, también, la propiedad industrial sobre las patentes de invención, marcas comerciales, modelos, procesos tecnológicos u otras creaciones análogas, por el tiempo que establezca la ley.

Será aplicable a la propiedad de las creaciones intelectuales y artísticas y a la propiedad industrial lo prescrito en los incisos segundo, tercero, cuarto y quinto del número anterior”. En los incisos segundo, tercero, cuarto y quinto del número anterior, está la garantía del derecho de propiedad, la regulación de sus limitaciones y el procedimiento de expropiación, que sólo puede llevarse a cabo previa declaración de utilidad pública calificada por ley.

Al cobijo de la Constitución de 1980, nació la siguiente normativa:

- En los años 1985, 1990, 1992, 2003 y 2010, se modificó la Ley $\mathrm{N}^{\circ} 17.336$ de 02 de octubre de 1970, sobre Propiedad Intelectual, vigente con las modificaciones introducidas hasta el día de hoy.

\footnotetext{
${ }^{426}$ Ob. supra cit., p. 157.

${ }^{427}$ Ob. supra cit., p. 157.
} 
- En el año 1991, se dictó la Ley N 19.039, sobre Propiedad Industrial, que vino a reemplazar el DL $\mathrm{N}^{\circ} 958$ y con las modificaciones introducidas los años 2006, 2007 y 2012, se encuentra vigente hasta la actualidad.

\subsection{Naturaleza jurídica de la propiedad intelectual durante la historia constitucional de Chile entre 1810 y 1833}

Durante el período comprendido entre 1810 y 1833, que corresponde al inicio de la vida independiente de la República de Chile, los esfuerzos se centran en organizar la naciente república, por lo que es razonable que no tengamos una referencia clara a la propiedad intelectual a nivel constitucional, pudiendo sostenerse dos hipótesis. Por una parte, más adelante veremos como la propiedad intelectual ha tenido un perfil propietario fuertemente arraigado en la legislación y la doctrina, lo que coincide con el momento histórico y las ideas que predominaban en Europa después de la Revolución Francesa de 1879, donde se intentaba despojar a la propiedad intelectual de cualquier rasgo de privilegio, para como conceptualizarla como la "más sagrada de las propiedades", tal como vimos, declamaba el diputado LE CHAPELLIER. Desde ese punto de vista, si consideramos que la concepción de una institución no es algo que se cambie en una sociedad de un momento a otro y que la Constitución de 1833, conceptualizó a la propiedad intelectual como un tipo de propiedad, es posible sostener que estuviese entendida como tal, en los embriones constitucionales de 1812, 1818, 1822 y 1828, en cuanto consistentemente garantizan el derecho de propiedad y la libertad para publicar.

Otro punto de vista lo encontramos en el texto de la Constitución de 1823, cuyo art. 253, al referirse a la "sabiduría y los talentos literarios útiles a la Patria", sin duda se hace cargo de las creaciones intelectuales, pero se aleja de una concepción propietaria de las mismas, al parecer optando por un sistema de propiedad pública, en donde el incentivo para el autor sería una retribución que se otorgaría desde un fondo creado al efecto. Nuestro convencimiento no va en la dirección de apoyar esta teoría, puesto que la Constitución de 1823 tuvo una corta vida, siendo reemplazada en 1828, donde los artículos 10, 17 y 18, vuelven a hacerse cargo de la propiedad y libertad para "publicar sus opiniones", conforme a lo que venía siendo una constante en los textos constitucionales precedentes. 


\subsection{Naturaleza jurídica de la propiedad intelectual durante la historia constitucional de Chile entre 1833 y 1980}

A partir de la Constitución de 1833, la propiedad intelectual ha tenido un espacio en todos los textos constitucionales chilenos, siempre tratada desde la perspectiva de la propiedad común, específicamente entendida como una propiedad especial, siendo muy pocos los autores que han emitido opinión en un sentido diverso. De la misma manera, en la tradición chilena, en cuanto a la naturaleza jurídica propietaria, no se distingue entre derecho de autor y propiedad industrial, teniendo ambas la misma conceptualización como propiedad especial, amparadas bajo la expresión genérica de propiedad intelectual.

JOSÉ VICTORINO LASTARRIA, en una obra publicada en 1855, se hace cargo de la naturaleza jurídica de la propiedad intelectual, pero no para discutir su condición de propiedad, que asume completamente, sino para argumentar que el hecho de tratarse de un derecho temporal y no perpetuo se justifica "si se trata de un proceso industrial, pero no en el caso de la propiedad literaria" 428 . Por otra parte, el autor citado, hablando sobre la novedad de patentes recuerda que se trata de una idea recogida de la legislación francesa y que nuestro sistema "lo admite expresamente" ${ }^{429}$, lo que viene a confirmar el perfil propietario que caracterizaba a la institución, puesto que a la sazón era la opción defendida por la doctrina y legislación francesas.

El Código Civil chileno de 1857 , ni por un minuto se aleja de la tendencia que hemos descrito, sino que, de alguna manera, viene a perfeccionar el sistema aclarando lo que, tal como vimos al inicio de nuestro trabajo, podía ser un obstáculo para las teorías sobre la naturaleza propietaria de la propiedad intelectual, nos referimos a la circunstancia que el dominio recae sobre bienes corporales y la propiedad intelectual recae sobre un derecho o bien incorporal. A este respecto, el Código Civil ${ }^{430}$ en su art. 583, señaló que sobre: "las cosas incorporales hay también una especie de propiedad" y el art. 584, remató la concepción, al decir que: “[1]as producciones del talento o del ingenio son una propiedad de sus autores. Esta especie de propiedad se regirá por leyes especiales". El Código Civil vino a salvar la objeción teórica, respecto a que la

\footnotetext{
428 Ob. supra cit., p. 135.

${ }^{429}$ Ob. supra cit., p. 136.

${ }^{430}$ En esto el Código Civil está vigente sin modificaciones hasta nuestros días.
} 
propiedad sólo recaía sobre bienes corporales y dejó en claro que la propiedad intelectual es un tipo de propiedad sólo que tiene características especiales. En este mismo sentido, LARRAGUIBEL ZAVALA recuerda que respecto de los artículos 582, 583 y 584, don Andrés Bello, redactor del Código Civil, se apartó de su modelo francés con el objetivo de "clarificar que los descubrimientos y producciones son una propiedad de sus autores" $" 431$.

Los autores que conocemos de esa época confirman la idea de propiedad de que venimos hablando, ROBUSTIANO VERA ${ }^{432}$, en el año 1894, sostenía que "los productos de inteligencia o del arte constituyen el patrimonio del hombre que consagra su vida entera al cultivo de la ciencia y a la manifestación de la belleza". Para él, se trata de una propiedad más sagrada que la de la tierra, porque es creación del hombre, en cambio la tierra en si misma tiene existencia previa a su asignación en dominio. HUNEEUS ZEGERS ${ }^{433}$, por su parte, también se hace cargo del art. 10 (12), $\mathrm{N}^{\circ} 5^{\circ}$ de la Constitución de 1833, para dejar en claro que al referirse la norma a "[1]a inviolabilidad de todas las propiedades", incluye la propiedad intelectual, de manera que la entiende plenamente como una forma de propiedad.

Una particularidad histórica que es constante en las Constituciones chilenas es entregar al legislador la regulación de detalle de los asuntos sobre propiedad intelectual, cometido que durante la vigencia de la Constitución de 1833, si bien se cumple, no se ve en el legislador la misma claridad que el constituyente. En efecto, no obstante que la Constitución dice derechamente que "[t]odo autor o inventor tendrá [la propiedad] $(\ldots)^{, 434}$, a lo que cabe agregar el aparente consenso en la doctrina sobre el régimen propietario, el legislador se aprecia aún confundido con las diferentes doctrinas de la época, mostrándose titubeante en la nomenclatura y en el contenido sustantivo que daba a los derechos que pretendía regular, así por ejemplo, la regulación de patentes de 1840, se designó como: "Privilegios exclusivos. Lei sobre la materia", retomando la idea de privilegio superada por el constituyente y la doctrina. Lo mismo sucede al revisar el contenido sustantivo de la ley, donde encontramos que se brinda protección a la

\footnotetext{
${ }^{431}$ Ob. supra cit., p. 137.

${ }^{432}$ VERA ROBUSTIANO. Código Civil de la República de Chile, Tomo III, Impr. Gutemberg, 1894, p. 432.

${ }^{433}$ HUNEEUS. Ob. supra cit., pp. 369.

${ }^{434}$ Constitución de 1833, art. 152.
} 
“introducción de artes, industrias o máquinas inventadas en otras naciones" ${ }^{435}$, instituto que busca la llegada al país de tecnologías que pueden ser dominio público, pero que no están disponibles en el país, que si bien se justifica desde el punto de vista económico, desde el momento que se trata de proteger tecnologías que ya están inventadas, es completamente contradictorio con el principio de la novedad que caracteriza a un sistema de patentes. En apoyo de lo que venimos exponiendo, también observamos que en el plano del derecho de autor, la Ley de 1834, se denominó: "Propiedad Literaria. Lei sobre la materia", tomando la opción más restringida, al referirse solamente a la "propiedad literaria" y olvidando a la pintura, escultura y cualquier otra forma creativa, en circunstancias que por aquellos años, ya era un asunto resuelto el hecho que el derecho de autor tiene un contenido mucho más amplio que la sola propiedad literaria.

Avanzando en el tiempo, en 1890, encontramos a JACINTO CHACÓN ${ }^{436}$, quien, ahora vigente el Código Civil, al preguntase si "[1] as cosas incorporales i los productos del espíritu, ¿son susceptibles de propiedad?”, explica que las cosas que no tienen cuerpo no son susceptibles de posesión ni de dominio, sin embargo las cosas incorporales y los productos del espíritu, producen renta y goce al igual que las cosas corporales, por lo que son susceptibles de una propiedad, bajo estos parámetros, sin duda el autor declara: "[l]a propiedad del autor sobre su obra existe, sin duda, sobre el libro o el cuadro artístico que da a luz, pero está principalmente radicada sobre el tipo ideal que él ha creado i de que son meros efectos el libro i cuadro publicados"437. En la jurisprudencia, OTERO ESPINOZA ${ }^{438}$ da cuenta como en el año 1879, se aplicó la Ley de Marcas de Fábrica y de Comercio de 1874, en relación con el artículo 584 del Código Civil, en donde se reconoce que las producciones del talento o del ingenio son una propiedad de sus autores.

Sin dudar de la naturaleza propietaria de la propiedad intelectual en la Constitución de 1833, encontramos a LARRAGUIBEL ZAVALA ${ }^{439}$, que incluso

\footnotetext{
${ }^{435}$ Ley sobre Privilegios Exclusivos de 1840, art. $8^{\circ}$. Se trata de un período de protección de patentes para la introducción en Chile de tecnología que existía en el extranjero, pero no en el país.

${ }^{436}$ CHACÓN, JACINTO. Exposición razonada. Estudio comparativo del Código Civil Chileno, Imprenta Nacional, Santiago de Chile, 1890, pp. 44.

437 Ob. supra cit., p. 44.

438 OTERO ESPINOZA, FRANKLIN. Concordancias y jurisprudencia del Código Civil Chileno, Casa Zamorano y Caperán, Santiago de Chile, 1920, pp. 27.

439 LARRAGUIBEL ZAVALA, SANTIAGO. El derecho de autor en la Constitución Política de la República de Chile, Revista Derecho y Jurisprudencia y Gaceta de los Tribunales, Tomo LXXX, N², mayo-agosto, Edit. Jurídica de Chile, 1983, pp. 67.
} 
enfatiza, cuando anota "[r]eafirmando esta especie de propiedad, nuestro Código Civil (...)". Sin embargo, el autor es un escritor contemporáneo, por lo que creemos más autorizadas las opiniones de aquellos que escribieron bajo la Constitución de 1833, a los que nos referimos previamente. Como referencia, en España en 1904 encontramos a MANRESA Y NAVARRO, que tampoco duda en tratar a la propiedad intelectual como "propiedad particularísima" 440 o "esta forma especial de propiedad".

La llegada de la Constitución de 1925, no cambió el criterio interpretativo sobre la naturaleza propietaria de la propiedad intelectual, ni la unidad de la propiedad intelectual propiamente tal y la propiedad industrial, al amparo del género "propiedad intelectual", así lo podemos observar de la sola lectura del texto del art. $10 \mathrm{~N}^{\circ} 10$, antes transcrito, en cuanto garantiza su "propiedad exclusiva".

Quienes escribieron regidos por la Constitución de 1925, continuaron asumiendo el perfil propietario de la propiedad intelectual, opinión que tuvieron los dos más insignes civilistas chilenos don LUIS CLARO SOLAR y ARTURO ALESSANDRI RODRÍGUEZ. CLARO SOLAR ${ }^{441}$ no sólo ratifica la naturaleza de propiedad, sino que se detiene para desestimar la teoría de la propiedad industrial como contrato entre el Estado y el inventor. ALESSANDRI RODRÍGUEZ ${ }^{42}$ dedica un subtítulo especial a la "Garantía constitucional" para referirse a "[1]os titulares de la propiedad de las creaciones intelectuales y artísticas y de la propiedad industrial”.

\subsubsection{La modificación constitucional introducida por la Ley $\mathbf{N}^{\circ} \mathbf{1 6 . 6 1 5}$}

Un hecho que determinó la historia de Chile en el siglo XX, está íntimamente relacionado con la naturaleza propietaria de la propiedad intelectual en Chile y con la modificación introducida a la Constitución de 1925, por la Ley Constitucional $\mathrm{N}^{\circ}$ 16.615, del año 1967, puesto que flexibilizó la posibilidad de afectar, gravar o expropiar la propiedad privada, lo que unido al DS $\mathrm{N}^{\circ} 1.262$, del año 1953, permitió al Gobierno del Presidente Salvador Allende, iniciar el proceso de expropiaciones que caracterizó su

${ }^{440}$ MANRESA Y NAVARRO, JOSÉ MARÍA. Comentarios al Código Civil Español, Tomo III, Madrid, 1904, p. 615.

${ }^{441}$ CLARO SOLAR, LUIS. Explicaciones de derecho civil chileno y comparado, Tomo VI, Edit. Roma, 1930, p. 599.

442 ALESSANDRI RODRÍGUEZ, ARTURO; SOMARRIVA U, MANUEL; VADANOVIC H, ANTONIO. Tratado de los derechos reales, Editorial Jurídica de Chile, Tomo I, 1993, p. 328. No obstante la obra está fechada en 1993, se trata de una reedición que originalmente fue escrita durante la vigencia de la Constitución de 1925. 
mandato, tal como explicamos previamente. La conexión con nuestro tema es que aun en este contexto de decidido reformismo, no se dudó del perfil propietario de la propiedad intelectual y el control de marcas y patentes por parte del Estado de Chile, se efectúo usando las disposiciones citadas por la vía de la expropiación, tal como recuerda LARRAGUIBEL ZAVALA ${ }^{443}$ al señalar que la Ley $N^{\circ} 17.450$, "nacionalizó y declaró incorporadas de pleno y exclusivo dominio de la Nación las empresas de la Gran Minería del Cobre, las patentes de invención y marcas comerciales" que utilizaban esas empresas. A nuestro entender, los hechos apoyan la hipótesis que en Chile la propiedad intelectual, siempre ha sido entendida y cobijada como una forma especial de propiedad, de manera que supletoriamente y en todo aquello que no se modifique por ley especial, aplican las normas comunes de la Constitución y el Código Civil para la propiedad.

Una voz disidente en este período es citada por LARRAGUIBEL ZAVALA ${ }^{444}$, quien se hace cargo de que, ZULOAGA VILLALÓN ${ }^{445}$ reprocha al Código Civil, cuando su artículo 582 entrega el calificativo de "propiedad" a la propiedad intelectual, argumentando que de "propiedad intelectual" no tiene más que el nombre. Sin embargo, a nuestro entender ZULOAGA VILLALÓN, discrepa con la posición tomada por el Código Civil, pero no discute el hecho que el Código le esté dando ese tratamiento, es decir no plantea que por una interpretación diversa se pueda llegar a sostener que el legislador no quiso hablar de "propiedad" sino que de "derechos" o cualquier otra alternativa, sino que establece que ontológicamente se trata de "derechos intelectuales" y no de una propiedad.

\subsubsection{La Constitución de 1980}

El constituyente de 1980 fue especialmente sensible con la regulación del derecho de propiedad, recibiendo el tratamiento más detallado que ha conocido la historia constitucional de Chile, no varió la constante de entender a la propiedad intelectual como una forma de propiedad, no obstante a nuestro juicio, en lo literal introdujo un cierto grado de duda o al menos en apariencia, perdió la severidad con que declaraban "propiedad" al derecho de autor, los textos constitucionales precedentes. En efecto, cuando el art. $19 \mathrm{~N}^{\circ} 25$, deja de hablar de "la propiedad exclusiva" como lo hacía la Constitución de 1925, para girar el centro discursivo de la norma iniciando el

${ }^{443}$ LARRAGUIBEL. Ob. supra cit., p. 157.

${ }^{444}$ Ob. supra cit., p. 154.

445 ZULOAGA VILLALÓN, ANTONIO. Derecho industrial y agrícola, 1943, pp. 387 a 393. 
texto con el "derecho [de] autor" ${ }^{446}$, parece estar abandonando la concepción puramente propietaria y girando hacia la idea de derecho de autor, probablemente más ligado a la dimensión personal del mismo; sin embargo, el cambio de giro es más aparente que real desde el punto de vista literal, porque la norma nunca llega a hablar del "derecho de autor" -como acabamos de decir- sino que del "derecho [del] autor", de manera que al usar el posesivo "del", deja en claro que el derecho del autor puede ser la propiedad y que no está hablando del "derecho de autor" como sustantivo ${ }^{447}$. De todas formas, la explicación más convincente para el asunto la encontramos en la Historia de la Constitución, que ha sido preparada por la Biblioteca del Congreso Nacional ${ }^{448}$, donde queda claro que la Comisión Constituyente nunca tuvo intención de alterar la naturaleza

${ }^{446}$ El texto original del art. 19 № 25, de la CPR de 1980 decía: "La Constitución asegura a todas las personas:", $\mathrm{N}^{\circ} 25^{\circ}$ : "El derecho del autor sobre sus creaciones intelectuales y artísticas de cualquier especie, por el tiempo que señale la ley y que no será inferior al de la vida del titular. El derecho de autor comprende la propiedad de las obras y otros derechos, como la paternidad, la edición y la integridad de la obra, todo ello en conformidad a la ley. Se garantiza, también, la propiedad industrial sobre las patentes de invención, marcas comerciales, modelos, procesos tecnológicos u otras creaciones análogas, por el tiempo que establezca la ley. Será aplicable a la propiedad de las creaciones intelectuales y artísticas y a la propiedad industrial lo prescrito en los incisos segundo, tercero, cuarto y quinto del número anterior, $\mathrm{y}$ ".

${ }^{447} \mathrm{El}$ art. $19 \mathrm{~N}^{\circ} \mathrm{s} 24$ incisos segundo, tercero, cuarto y quinto; y, 25, de la Constitución Chilena de 1980 señalan: $24^{\circ}$ : "El derecho de propiedad en sus diversas especies sobre toda clase de bienes corporales o incorporales.

Sólo la ley puede establecer el modo de adquirir la propiedad, de usar, gozar y disponer de ella y las limitaciones y obligaciones que deriven de su función social. Esta comprende cuanto exijan los intereses generales de la Nación, la seguridad nacional, la utilidad y la salubridad públicas y la conservación del patrimonio ambiental.

Nadie puede, en caso alguno, ser privado de su propiedad, del bien sobre que recae o de alguno de los atributos o facultades esenciales del dominio, sino en virtud de ley general o especial que autorice la expropiación por causa de utilidad pública o de interés nacional, calificada por el legislador. El expropiado podrá reclamar de la legalidad del acto expropiatorio ante los tribunales ordinarios y tendrá siempre derecho a indemnización por el daño patrimonial efectivamente causado, la que se fijará de común acuerdo o en sentencia dictada conforme a derecho por dichos tribunales.

A falta de acuerdo, la indemnización deberá ser pagada en dinero efectivo al contado.

La toma de posesión material del bien expropiado tendrá lugar previo pago del total de la indemnización, la que, a falta de acuerdo, será determinada provisionalmente por peritos en la forma que señale la ley. En caso de reclamo acerca de la procedencia de la expropiación, el juez podrá, con el mérito de los antecedentes que se invoquen, decretar la suspensión de la toma de posesión."

$\mathrm{N}^{\circ} 25^{\circ}$ : "La libertad de crear y difundir las artes, así como el derecho del autor sobre sus creaciones intelectuales y artísticas de cualquier especie, por el tiempo que señale la ley y que no será inferior al de la vida del titular.

El derecho de autor comprende la propiedad de las obras y otros derechos, como la paternidad, la edición y la integridad de la obra, todo ello en conformidad a la ley.

Se garantiza, también, la propiedad industrial sobre las patentes de invención, marcas comerciales, modelos, procesos tecnológicos u otras creaciones análogas, por el tiempo que establezca la ley.

Será aplicable a la propiedad de las creaciones intelectuales y artísticas y a la propiedad industrial lo prescrito en los incisos segundo, tercero, cuarto y quinto del número anterior".

448 En www.bcn.cl está disponible un documento llamado: Historia de la ley. Constitución Política de la República de Chile de 1980. Artículo $19 N^{\circ} 25$, Derecho de autor. La historia del artículo $19 \mathrm{~N}^{\circ} 25$ de la Constitución Política, se terminó de construir con fecha 22 de septiembre del año 2008. Su contenido ha sido recogido de las siguientes fuentes: Actas Oficiales de la Comisión Constituyente; Actas del Consejo de Estado; y, Antecedentes de la Ley $N^{\circ} 19.742$. 
jurídica de la propiedad intelectual, sino que su preocupación fue que todos los aspectos de ella fuesen alcanzados por la protección constitucional, de suerte que, lejos de pretender diluir el carácter propietario que históricamente se le ha dado a la propiedad intelectual, se quiso ampliar el espectro de protección de la misma.

Al revisar la Historia de la Constitución podemos encontrar frondosa evidencia de lo que venimos exponiendo, la que resulta tan clara como el párrafo que a continuación transcribimos: "El señor SILVA BASCUÑAN señala que el debate de la sesión pasada está reflejado en la redacción que propuso. En esa oportunidad, agrega, incluso se distinguió, respecto del ciudadano que era autor o inventor de una creación intelectual o de un avance industrial, valores que no eran directa y puramente patrimoniales que debían ser protegidos además de la propiedad. La filosofía de la norma propuesta, que recoge el debate de la sesión precedente, reside en que la protección para el autor se encuentra en todo el orden de valores inherentes al resultado de su creación, no sólo en el de la propiedad. Por eso, considerando que en todo sentido aquí se está consagrando un derecho considerándolo desde el punto de vista individual del beneficiario de la creación una vez producida, allí, en esa protección que requiere el autor o inventor de parte de la colectividad, no están comprendidos sólo valores de orden patrimonial o de otro orden que puedan expresarse únicamente en términos de propiedad. Se recordaron en el debate precedente muchísimos valores que no eran inherentes a la propiedad y que tienen que ser defendidos, incluso, en cuanto la persona haya perdido la propiedad. Son valores de dignidad, de honor, de prestigio, de academia, etcétera, que son de carácter individual y no puramente patrimonial"449.

A través de toda la Historia de la Constitución, encontramos referencias que dejan en claro la voluntad del constituyente de no permitir ningún eslabón de la propiedad intelectual sin protección, como cuando dice: “(...) a esta Comisión le pareció que era necesario elevar el derecho moral del autor a rango constitucional, y muchos miembros opinaron en ese sentido"450. No cabe duda que la Constitución de 1980, no buscó alterar la naturaleza propietaria de la propiedad intelectual, sino dejar en claro que todas las dimensiones de ella encontraban acogida en la protección constitucional, no obstante este loable esfuerzo, desde nuestra perspectiva ello no era necesario desde el momento que la propiedad intelectual tal como se entiende en Chile,

449 Ob. supra cit., p. 7.

${ }^{450}$ Ob. supra cit., p. 8. 
comprende a la propiedad intelectual propiamente tal (derecho de autor y derechos conexos), tanto en su dimensión material como moral. De todas formas, estimamos que no debe buscarse más explicación en el asunto, la solución correcta es entender que para el constituyente no hay dentro de la propiedad intelectual facetas o aspectos más o menos importantes, en el sentido de existir algunos aspectos que no merezcan protección constitucional, con la particularidad, que se buscó poner énfasis en aclarar que los derechos morales de autor tienen raigambre constitucional.

Otras interpretaciones, además de no contar con sustento en la Historia de la Constitución, pueden llevar a pensar que la división del primer inciso del art. $19 \mathrm{~N}^{\circ} 25$ CPR de 1980, en el sentido de distinguir entre propiedad intelectual e industrial, implica prodigarles una protección diferente o más aún, únicamente proteger la dimensión personal del derecho de autor y no de la propiedad industrial. No creemos que esa interpretación sea aceptable, puesto que como vimos, preocupaba a la Comisión Constituyente, toda la dimensión espiritual de la propiedad intelectual, valores como la "dignidad, de honor, de prestigio, de academia, etcétera, que son de carácter individual y no puramente patrimonial" 451 , por lo que su detención en el derecho moral del autor, debe entenderse porque es el más desarrollado normativamente; sin embargo, en la propiedad industrial hay también un derecho moral, aun cuando no posea el perfeccionamiento que ha tenido en el caso de los autores. En efecto, dignidad, honor, prestigio, reputación, son valores transversales, en esa medida, podemos aceptar que el derecho moral en la propiedad industrial, no tenga cabida para impedir la deformación de la invención -entendida por ejemplo como nuevas aplicaciones- o las variaciones en la creación de una marca comercial, para adaptarla al paso del tiempo, pero no podríamos pensar que no existe, puesto que hay dimensiones del derecho moral que son transversales a toda la propiedad intelectual, como la paternidad o el derecho a mantener la obra, creación o invención sin divulgar.

\subsubsection{La modificación constitucional introducida por la Ley $\mathbf{N}^{\circ} 19.724$}

En el año 2001, se introdujo una modificación a la Constitución de 1980, cuyo tenor literal da una primera impresión, que se asemeja más al art. 10. 1. b) CE, es decir de una disposición destinada a proteger libertad de creación, por sobre la propiedad intelectual en sí misma. El art. $19 \mathrm{~N}^{\circ} 25$, actualmente garantiza: "La libertad de crear y

${ }^{451}$ Ob. supra cit. 
difundir las artes, así como el derecho del autor (...)”, con lo que la libertad de crear y difundir las artes, pasa a tomar un rol preeminente en la disposición, incorporando un elemento que nunca antes estuvo presente en toda la historia constitucional chilena, al menos no directamente unido a la protección de la propiedad intelectual. Esta nueva redacción fue incorporada a través de una reforma constitucional, implementada por la Ley $N^{\circ} 19.742$, de 25 de agosto de 2001, sobre Reforma Constitucional que Elimina la Censura Cinematográfica Sustituyéndola por un Sistema de Calificación y que Consagra el Derecho a la Libre Creación Artística. El cambio, originalmente, estuvo orientado a modificar el art. $19 \mathrm{~N}^{\circ} 12$, donde se alojan la libertad de opinión e información, dado principalmente el eje original de la reforma, destinado a eliminar la censura cinematográfica y reemplazarla por un sistema de calificación previa, lo que motivó también abordar la libertad de creación y difusión artística, dando origen a la modificación, tal como ahora la analizamos.

Es necesario tener en claro, que no hay antecedente alguno de que haya existido el ánimo de efectuar alteración alguna al régimen de la propiedad intelectual, solamente por una cuestión de armonía se ubicó el derecho a la creación y difusión artística en el art. $19 \mathrm{~N}^{\circ}$ 25, lo que se refleja, ya, en el Mensaje Presidencial del Proyecto de Ley, que para justificar el mismo, se hace la siguiente pregunta: “¿No es acaso natural, entonces, si se ha consagrado constitucionalmente el derecho de propiedad sobre las obras artísticas, extender también una garantía constitucional a aquello que es previo y que hace posible la existencia de obras, cual es el derecho a la libre creación?" ${ }^{, 452}$.

\subsection{Conclusión}

El Código Civil chileno, promulgado en 1857, se apartó de su guía el Código Civil francés, para en el art. 583, establecer que la propiedad sobre los bienes incorporables era algo perfectamente posible, diciendo que "Sobre las cosas incorporales hay también una especie de propiedad"; además, pedagógicamente, pone un ejemplo y agrega que "Así, el usufructuario tiene la propiedad se su derecho de usufructo". En el mismo sentido, vimos como ya en el año 1890, JACINTO CHACÓN $^{453}$ enfrentaba la pregunta sobre si las cosas incorporales eran susceptibles de propiedad, contestando que en el derecho chileno es perfectamente posible. No es del

\footnotetext{
${ }^{452}$ Historia de la Constitución. Ob. supra cit., p. 38.

${ }^{453}$ CHACÓN. Ob. supra cit., p. 43.
} 
caso insistir como es de asentado en el derecho nacional la posibilidad de ejercer propiedad sobre los bienes incorporales y particularmente, como la propiedad intelectual es entendida desde los albores de la República como una propiedad especial, puesto que se ha demostrado suficientemente.

Para nosotros la propiedad intelectual goza de los mismos atributos de la propiedad en general y se caracteriza de igual forma, no hay inconveniente en que sea temporal, ni varía su condición con el hecho que una parte de ella atienda preferentemente a una condición más espiritual que material, desde esa perspectiva diríamos que el propietario tan dueño es de la dimensión material, como del derecho moral que caracteriza a la propiedad intelectual.

En consecuencia, vemos una interpretación uniforme sobre la materia y una acogida pacífica de la propiedad intelectual, como propiedad, en el sistema jurídico nacional. De nuestro estudio solamente nos llama la atención la preocupación que han tenido por el tema, los gobiernos históricamente catalogados como autoritarios, si se observa, en todos ellos, desde lo que se conoció como la República Autoritaria (18301860), pasando por la República Parlamentaria (1924-1925), el Gobierno del General Carlos Ibáñez del Campo (1927-1931) y el Gobierno Militar (1973-1990), ha habido fuertes y sustanciales modificaciones al régimen jurídico de la propiedad intelectual, siempre optando por el derecho de propiedad civil como marco teórico, probablemente por la autoridad que impone este derecho en sí mismo, lo que no pasa de ser una especulación; sin embargo, refleja la preocupación por la propiedad intelectual que han tenido estos gobiernos. El asunto mirado desde la perspectiva del análisis económico del derecho, permite ver como paulatinamente la propiedad intelectual es entendida como herramienta de desarrollo económico y también, como no se duda de su naturaleza propietaria, en efecto, incluso durante el Gobierno del Presidente Allende, cuando se expropia la gran minería del cobre, junto a sus marcas y patentes; es decir, aun cuando gira el titular y la función de la propiedad intelectual, pasando de ser una propiedad privada pública, ésta sigue siendo vista como propiedad.

Probablemente este asentamiento sobre la propiedad civil viene de antaño, aunque a veces se discuta, olvidando que la innovación está disponible para todos, los países industrializados y los que no lo son, de manera que el camino al liderazgo está en el esfuerzo creativo, no en la copia, ni evitar la protección del esfuerzo ajeno. Así pues, 
a veces luchamos contra ideas más enraizadas en el subconsciente de lo que creemos, es lo que pensamos cuando leímos el siguiente párrafo de JACINTO CHACÓN, en 1890: “(...) atendido el estado de inferioridad intelectual en que se halla Chile [i] ${ }^{454}$ la América latina, respecto de Europa [i] Estados Unidos, no nos conviene celebrar con estas naciones tratados que garanticen la propiedad literaria, porque, la libertad de publicación, nos permite asimilarnos las producciones del espíritu de aquellos centros de las ciencias, artes [i] letras antiguas [i] modernas" ${ }^{, 455}$.

${ }^{454}$ El uso de la "i" en vez de "y", es textual. Corresponde al castellano utilizado en Chile a la época de la cita.

${ }^{455}$ Ob. supra cit., p. 44. 


\section{TRIBUTACIÓN DE LA PROPIEDAD INTELECTUAL EN ESPAÑA Y CHILE}

\section{La propiedad intelectual en la imposición directa e indirecta. Delimitación del objeto de estudio}

En el desarrollo lógico de nuestro trabajo hemos estimado relevante analizar cuáles son las particularidades a que está sometida la tributación de la propiedad intelectual tanto en Chile como en España, puesto que son los referentes de nuestro análisis. En este punto, es necesario considerar que los tributos que nos interesan, son aquellos vinculados al rendimiento o provecho económico que se pueda obtener de la propiedad intelectual, el que se puede producir básicamente por tres vías: la primera, la explotación de la propiedad intelectual conservado el dominio de la misma, como cuando existen cánones (regalías o royalties) ${ }^{456}$ o más genéricamente hablando, una remuneración por el uso de la propiedad que se ha permitido a un tercero; la segunda, se produce cuando la propiedad intelectual es considerada en sí misma como un bien económico, es el caso de la venta, dación en pago, aporte a una sociedad, etc.; y, la tercera se presenta cuando la propiedad intelectual forma parte de la explotación de una empresa, verbi gratia si al producir un bien se le incorpora determinada tecnología o al editar un libro, el editor es titular de todos los derechos de autor, de manera que el rendimiento de la propiedad intelectual se mezcla y confunde con el de la empresa.

También tenemos que considerar que la propiedad intelectual siempre está sometida a prestaciones en favor de las oficinas de registro, caracterizadas por la exigencia de tasas o derechos que normalmente tienen la condición de habilitantes para conseguir la publicidad registral, estas contribuciones poseen su propia historia y no serán objeto de nuestro estudio, puesto que su naturaleza jurídica es discutida y son marginales en términos cuantitativos, comparados con los niveles a los que puede llegar la imposición directa (a la renta) e indirecta (valor agregado), así pues desde el punto de vista de la obtención de rentas, su incidencia fundamental es que constituyen un gasto propio de la constitución del activo fiscal (propiedad intelectual) y desde ese punto de

${ }^{456}$ Actualmente, en el derecho español, la expresión "royalty" se utiliza como sinónimo de "canon". En el derecho chileno, las expresiones regalía y royalty son aceptadas, al menos coloquialmente. 
vista disminuye la utilidad de la empresa y con ello la renta gravable. En todo caso, a fin de evitar distraernos innecesariamente hemos decidido excluirlas de nuestro análisis ${ }^{457}$.

\section{En el ámbito español}

Como es sabido, en el caso español los impuestos sobre la renta se encuentran distribuidos en tres normas diferentes, a saber: Real Decreto Legislativo 4/2004, de 5 de marzo, por el que se aprueba el texto refundido de la Ley del Impuesto sobre Sociedades ${ }^{458}$; Ley 35/2006, de 28 de noviembre, del Impuesto sobre la Renta de las Personas Físicas ${ }^{459}$; y, Real Decreto Legislativo 5/2004, de 5 de marzo, por el que se aprueba el texto refundido de la Ley del Impuesto sobre la Renta de no Residentes ${ }^{460}$. En cambio, en el caso chileno, toda la imposición directa se encuentra bajo el amparo de una normativa única, el Decreto Ley $N^{\circ} 824$ sobre Impuesto a la Renta ${ }^{461}$, ello sumado al hecho que al interior del DL $\mathrm{N}^{\circ} 824$, los impuestos se encuentran integrados o parcialmente integrados ${ }^{462}$ y a que, la propiedad intelectual tiene un régimen tributario especial, hay una gran diferencia para efectos de análisis, puesto que en España será necesario diferenciar entre la naturaleza de quien recibe la renta (persona jurídica o

${ }^{457}$ Sobre tasas para la propiedad industrial en España, puede verse a LÓPEZ ESPADAFOR, CARLOS MARÍA, Régimen Fiscal de la Propiedad Industrial, Tirant lo Blanch, Valencia, 1998, pp. 22 y sgtes.

458 Texto accesible en: http://www.boe.es/buscar/pdf/2006/BOE-A-2006-20764-consolidado.pdf (17 Abr 2013).

459 Texto accesible en: http://www.boe.es/buscar/act.php?id=BOE-A-2004-4456 (17 Abr 2013).

${ }^{460}$ Texto accesible en: http://www.boe.es/buscar/pdf/2004/BOE-A-2004-4527-consolidado.pdf (17 Abr 2013).

461 Texto accesible en: http://www.leychile.cl/Navegar?idNorma=6368 (17 Abr 2013).

${ }^{462}$ El 2 de abril de 2014, ingresó al Congreso Nacional chileno, el Boletín $N^{\circ}$ 9290-05, que contiene el proyecto de ley sobre "Reforma tributaria que modifica el sistema de tributación de la renta e introduce diversos ajustes en el sistema tributario". Aprobado el 10 de septiembre de 2014, modifica, entre otros el impuesto a renta y al IVA, erigiéndose como la reforma más profunda del sistema tributario chileno en los últimos cuarenta años. A la fecha de escribir esta nota en septiembre del año dos mil catorce, el proyecto está cumpliendo los trámites necesarios para ser promulgado como ley de la República. Hasta la reforma, el sistema estaba integrado en un único impuesto de manera que lo pagado a nivel de empresas (impuesto de sociedades en el caso español) se registraba en un registro conocido como FUT (Fondo de utilidades tributables) y no pagaba ningún otro impuesto hasta que se retirse desde la empresa, al patrimonio de una persona natural. Al momento de efectuarse el retiro, esos montos iban al Impuesto Global Complementario (IRPF en el caso español), teniendo derecho a reconocer un crédito en contra del impuesto a pagar, por el monto total de lo pagado a nivel de empresas. Desde septiembre de 2014, comienza la eliminación del FUT, de manera que si bien el sistema continúa estando igualmente integrado, no puede postergarse la tributación, puesto que las utilidades se entienden jurídicamente retiradas aunque físicamente esto no se haya realizado. De ahí que el FUT se vuelve innecesario, porque todas las utilidades se deben declara como retiradas, cada año. Junto a este sistema, subsiste una variación del FUT, que por razones políticas no se llamó FUT, sino "sistema parcialmente integrado" (la razón política a que nos referimos, fue que la bandera de lucha política de la reforma era la eliminación del FUT, al que se culpaba de ser fuente de evasión, por ello, no podía mantenerse). La particularidad del sistema parcialmente integrado, es que permite postergar la tributación igual que el FUT, pero a la hora de retirar reduce el monto del impuesto que puede ser usado como crédito a nivel de los impuestos personales. 
persona natural) y en Chile, hay que distinguir por la naturaleza de la renta, si proviene de régimen general o de la propiedad intelectual, pues en este último caso, tiene un tratamiento preferente.

\subsection{El Impuesto sobre Sociedades. Notas generales}

En el Real Decreto Legislativo 4/2004, de 5 de marzo, por el que se aprueba el texto refundido de la Ley del Impuesto sobre Sociedades ${ }^{463}$, encontramos el Impuesto sobre Sociedades, referencia con la que, en el derecho español se denomina al gravamen que soportan los rendimientos obtenidos por personas jurídicas -aunque a veces no lo sean- dedicadas a la actividad industrial o comercial. La clasificación de los impuestos puede hacerse desde diferentes perspectivas, y probablemente nunca será perfecta, de manera que, una alternativa razonable de entender la dinámica tributaria española, es advertir que podríamos dividir a los contribuyentes entre residentes y no residentes. Los no residentes están sometidos al Impuesto sobre la Renta de no Residentes, por su parte los residentes, pueden estar gravados por el Impuesto sobre Sociedades o por el Impuesto sobre la Renta de las Personas Físicas, bajo esta perspectiva el IS, viene a centrarse en las personas jurídicas y demás personas jurídicas de acuerdo con las normas de la Ley ${ }^{464}$, en contraposición al IRPF cuyo objetivo son las ganancias de las personas físicas. Vale anotar que en Chile la clasificación es más o menos igual, con la particularidad que todos los impuestos sobre la renta cohabitan bajo una única ley, divididos por categorías (primera categoría para empresas; segunda categoría para personas naturales) y que, la clasificación en primera o segunda categoría se hace en función de la naturaleza de la actividad y no de la calidad del contribuyente, en esa medida, un contribuyente persona natural que es empresario unipersonal tributará en primera categoría por las rentas que obtenga como empresa.

El hecho imponible está regulado en el art. 4. 1 TRLIS, constituido por "la obtención de renta, cualquiera que fuese su fuente u origen, por el sujeto pasivo". Definición bastante lógica, por no decir obvia, puesto que se trata precisamente de lo que describe, de gravar las "rentas". En todo caso, lo bueno hubiese sido que dijese qué es "renta", porque está declarando que no debe distinguirse la fuente de la renta para

\footnotetext{
${ }^{463}$ El RDL 4/2004, de 05 de marzo, ha tenido sucesivas modificaciones, la última actualización se conforma con un texto consolidado de 8 de marzo de 2014. Disponible en Internet en: http://www.boe.es/buscar/pdf/2004/BOE-A-2004-4456-consolidado.pdf (10 Abr 2014).

${ }_{464}$ Artículo 1.1 Ley de IS.
} 
efectos de su gravamen, en vez de definir el hecho imponible. De todas formas, también es conveniente que exista una definición amplia, para evitar la permanente búsqueda de los rendimientos no gravados ${ }^{465}$. El legislador también incluye aquí la imputación de las bases imponibles de entidades en régimen de transparencia fiscal nacional e internacional, que a nuestro juicio es curioso, puesto que eso no constituye el hecho imponible, que sigue siendo la obtención de renta.

El período de imposición está señalado en función del ejercicio económico del sujeto pasivo, sin que pueda exceder de doce meses, el devengo es el último día del período correspondiente. La imputación de ingresos se prevé sobre base de "devengado" $" 466$ por regla general, permitiendo el uso del criterio del "percibido"467, siempre que lo autorice la administración tributaria.

El sujeto pasivo del impuesto, lo encontramos regulado en el art. 7 TRLIS, en una lata enumeración que se inicia con "[1]as personas jurídicas, excepto las sociedades civiles", lo que da debida cuenta de la clasificación de impuestos que hicimos supra, puesto que el IS se concentra en las personas jurídicas por contraposición de las personas naturales. De todas formas, no todos los sujetos pasivos del IS deben ser personas jurídicas, como sucede con los fondos de inversión, los fondos de garantía de inversiones, las uniones temporales de empresas, los fondos de pensiones o las comunidades titulares de montes vecinales de mano común ${ }^{468}$.

El sujeto pasivo debe ser residente ${ }^{469}$ en territorio español y estará sometido a imposición por las rentas sobre el principio de renta mundial ${ }^{470}$. Algunos sujetos pasivos están exentos del impuesto, los que se clasifican en dos grupos: quienes tienen una exención total, donde cuentan: el Estado, las comunidades autónomas y las entidades locales, organismos autónomos del Estado, el Banco de España, Fondos de garantía de depósitos, Fondos de garantía de inversiones, entidades públicas encargadas de la Seguridad Social y otros entes públicos señalados en la Ley 6/1997, de 14 de abril; y,

${ }^{465}$ MARTÍN QUERALT, JUAN. Curso de derecho tributario y financiero, Tecnos, Madrid, 2000, p. 570. El autor opina en el mismo sentido.

${ }^{466}$ Ob. supra cit. p. 571. El autor define devengado como: “(...) esto es, al momento en que nace el derecho a percibirlos o a exigirlos, con independencia del momento en que unos y otros se hacen efectivos".

${ }^{467}$ Esto es, cuando efectivamente se han cobrado.

468 Ob. supra cit., p. 572.

469 Art. 7. 2 RDL 4/2004, TRLIS.

470 Art. 7. 2 RDL 4/2004, TRLIS. 
aquellos que gozan de una exención parcial, como son: las entidades e instituciones sin ánimo de lucro, como son organizaciones sindicales, profesionales, políticas y otras, que se enumeran expresamente.

La base imposible está sancionada en los arts. 10 y sgtes. TRLIS, constituida por “el importe de la renta en el período impositivo (...)”, compensación de bases imponibles negativas de períodos impositivos anteriores". Compartimos con MARTÍN QUERALT ${ }^{472}$, que la referencia a la minoración por bases imponibles negativas es innecesaria, tiene sentido, sólo en cuanto se refiere a períodos impositivos anteriores, puesto que la expresión "renta" dentro de su esencia supone la suma de los ingresos y el descuento de los gastos para producirla, ello aunque no se encuentre definida por la Ley.

El cálculo de la base imponible se determina por estimación directa como regla general, admitiéndose por excepción la estimación objetiva y subsidiariamente el método indirecto. Claro está que el régimen de estimación objetiva nos lleva a la interminable discusión sobre la relación del resultado contable y la base imponible tributaria, cuestión que escapa a nuestro análisis, de manera que, al igual que MARTÍN QUERALT $^{473}$, nos limitaremos a hacer una secuencia cronológica del proceso. El punto de partida será la información contable, para la cual se dispone del Plan General de Contabilidad $^{474}$. Lo central es obtener el resultado contable dado por la diferencia entre ingresos y gastos necesarios para obtenerlos, lo que constituye una operación matemática de sumas, restas y actualizaciones. El componente aportado por la norma tributaria se produce inmediatamente determinado el resultado contable, cuando el beneficio contable debe ajustarse, "al alza o a la baja, mediante la aplicación de las reglas que correspondan en cada caso, de entre las contenidas en la Ley" ${ }^{\text {"475, }}$, es lo que en Chile se conoce, pedagógicamente, como "renta líquida imponible", puesto que al fin y al cabo, la renta depurada desde lo financiero, para fines de imposición. La regulación de esos ajustes, está principalmente concentrada en los artículos 11 y sgtes de la LIS, donde encontraremos correcciones por: amortizaciones, pérdida del valor de los

\footnotetext{
471 Art. 7. 2 RDL 4/2004, TRLIS.

${ }^{472}$ Ob. supra cit., p. 573.

473 Ob. supra cit., p. 574.

474 Actualmente contenido en Real Decreto 1514/2007, de 16 de noviembre, por el que se aprueba el Plan General de Contabilidad.

${ }^{475}$ Ob. supra cit., p 574.
} 
elementos patrimoniales, provisión para riesgos y gastos, gastos no deducibles, supuestos de transmisiones lucrativas, entre otras. Como ejemplo y sólo para clarificar, aumentan el resultado contable: las amortizaciones libres que deben ser ajustadas a la legal, las dotaciones por insolvencia que tienen que respetar los estándares de insolvencia fijados por la ley, donaciones que no cumplen los requisitos legales, etc. Por su lado, disminuyen el resultado contable: los mismos conceptos anteriores, cuando se efectúan dentro de los límites legales. En otras palabras, una donación de orden cultural efectuada en conformidad a la Ley, disminuye el resultado contable, pero la misma donación realizada al hijo del socio mayoritario de la empresa para viajar de vacaciones, aumenta el resultado contable.

El resultado del proceso de ajuste de la contabilidad a las exigencias legales nos dará la base imponible del IS ${ }^{476}$, monto sobre el cual aplicando el tipo impositivo que corresponda obtendremos la "cuota íntegra".

La deuda tributaria, se hace presente en los arts. 28 y sgtes. TRLIS, cuyo punto de partida es la cuota íntegra, que luego de las deducciones y bonificaciones que permita la propia Ley, resultará en el monto del impuesto a pagar. El tipo del impuesto está definido en un 35 por 100, no obstante, en la misma disposición se prevén tipos de 40, 25, 20, 20, 1 por 100 y hasta un caso de tipo cero. Cabe hacer presente que la Disposición Adicional Novena del RDL 4/2004, de 5 de marzo, modificó algunos de estos tipos impositivos, de manera que la tributación general está actualmente en 30 por 100, y el tipo de 40 por 100 se redujo a 30 por 100 .

Obtenida la cuota íntegra, corresponde minorarla aplicando las deducciones a que pudiere haber lugar ${ }^{477}$, para lo cual la LIS, tiene una pródiga pluma, habiendo creado un listado tan prolífero de deducciones que lleva a pensar que el fin del impuesto no es recaudar, sino que redirigir las rentas hacia las actividades que busca promocionar. Como sea, en cuanto a deducciones, encontramos:

a) Deducciones que pretenden evitar la doble imposición. Aquí figuran: la deducción para evitar la doble imposición interna: dividendos y plusvalías de fuente interna; la deducción para evitar la doble imposición internacional: impuesto soportado por el

\footnotetext{
${ }^{476}$ La "renta líquida imponible" o RLI, en Chile.

${ }^{477}$ Sobre las deducciones, puede verse: ob. supra cit., pp. 576.
} 
sujeto pasivo; y, deducción para evitar la doble imposición internacional: dividendos y participaciones en beneficios;

b) Bonificaciones. Donde cuentan: la bonificación por rentas obtenidas en Ceuta y Melilla; la bonificación por actividades exportadoras y de prestación de servicios públicos locales; la deducciones para incentivar la realización de determinadas actividades; la deducción por actividades de investigación y desarrollo e innovación tecnológica; deducción por inversión de beneficios; la deducción por inversiones en bienes de interés cultural, producciones cinematográficas, edición de libros, sistemas de navegación y localización de vehículos, adaptación de vehículos para discapacitados y guarderías para hijos de trabajadores; la deducciones por inversiones medioambientales; la deducción por gastos de formación profesional; la deducción por creación de empleo para trabajadores con discapacidad; la deducción por reinversión de beneficios extraordinarios; y la deducción por creación de empleo.

Finalmente, en el artículo 46, le LIS establece las deducciones por retenciones, ingresos a cuenta y pagos fraccionados, que a nuestro entender, obedecen a una naturaleza distinta de las anteriores, puesto que ya no tienen por objeto evitar la doble imposición o promocionar ciertas actividades, sino que únicamente compensar el monto del impuesto pagado por diferentes vías.

La LIS, también se hace cargo de ciertos regímenes tributarios especiales, establecidos por la naturaleza de los sujetos pasivos afectados o por razón de la naturaleza de los hechos, actos u operaciones que se efectúen, tales como: el régimen de las agrupaciones de interés económico españolas; entidades de arrendamiento de viviendas; sociedades y fondos de capital de riesgo; régimen de entidades de deportistas; régimen de la minería, entre otros. Cabe destacar la existencia de un régimen de consolidación fiscal, destinado a grupos fiscales que podrán optar por dejar de tributar en el régimen individual de que se trate y optar por un sistema de tributación conjunta de todo el grupo.

Finalmente, la LIS posee normas sobre la gestión del impuesto, que resultan bastante esperables, tales como, la obligación de llevar contabilidad, de declarar, la autoliquidación, etc., y el reconocimiento de la autoridad y rol de la Administración Tributaria. 


\subsection{La propiedad intelectual en el Impuesto sobre Sociedades}

Partiendo de la base que no existe inconveniente legal para que una persona jurídica, específicamente una sociedad de cualquier naturaleza, sea titular de los derechos de explotación de la propiedad intelectual o derechamente propietaria de la misma, tampoco hay impedimento a que obtenga ganancias derivadas de aquella, las que formarán parte de los rendimientos normales de la sociedad y estarán sometidas al régimen común de tributación para este tipo de contribuyentes. De manera que, la renta obtenida por la sociedad y reflejada en su contabilidad de acuerdo a las normas del Código de Comercio, estarán gravadas con un tipo del 35 por ciento ${ }^{478}$, y de ser el caso, tendrán el derecho a las minoraciones que prevé la ley.

En el RDL 4/2004, TRLIS, encontramos referencias expresas a la propiedad intelectual en seis artículos, que analizaremos más adelante, tales son: art. 11, números 1,2 y 4, referidos a amortizaciones; art. 12, números 1,6 y 7 , relativos a pérdidas; art. 23, que contiene una reducción de ingresos por activo intangible; art. 34, regulando una bonificación por actividades exportadoras y de prestación de servicios públicos locales; art. 35 , donde se ubica una deducción por actividades de $\mathrm{I}+\mathrm{D}+\mathrm{i}$; art. 38 , que viene a regular una deducción por bienes de interés cultural.

La propiedad intelectual no tiene en el Impuesto sobre Sociedades un tratamiento especial, está integrada dentro del impuesto, muchas veces subsumida en el concepto más general de "inmovilizado inmaterial", de manera que la atención que le presta el legislador viene dada por su naturaleza intangible y las dificultades que ello supone $^{479}$. En este contexto, los rendimientos que de ella se obtengan, tributarán conforme al régimen general que en la ley se prevé, cualquiera sea la fuente de explotación de la propiedad intelectual como se produzcan. Partiendo de esta base, viene al caso analizar la implicancia de las disposiciones que se refieren específicamente a la propiedad intelectual en el Impuesto sobre Sociedades.

478 Art. 28. 1. RDL 4/2004, TRLIS.

${ }^{479}$ Los intangibles siempre representan una complicación para la fiscalidad, atendidas las dificultades en su valorización, las complejidades para determinar su incidencia en el proceso productivo y la indeterminación sobre su depreciación y deterioro. 


\subsubsection{Amortización}

La amortización puede ser vista desde el punto de vista económico y contable ${ }^{480}$, financieramente es "el reintegro de un capital propio o ajeno, habitualmente distribuyendo pagos en el tiempo" ${ }^{481}$, sin embargo no es desde esta perspectiva que el término está tomado en la Ley de Impuesto sobre Sociedades, sino que como un concepto tributario-contable.

Desde el punto de vista fiscal, la amortización está asociada con el costo que implica para la producción, el deterioro de los bienes con que se produce. En este sentido, FERNÁNDEZ IPARRAGUIRRE destaca que: "La amortización tiene por objeto reflejar la pérdida de valor por la utilización del inmovilizado mediante su incorporación a los costes de la empresa”,482. Para este autor, la amortización es sinónimo de depreciación y explica que "es un coste del ejercicio, y se procederá a su reflejo contable exista o no beneficio en el ejercicio, ya que la pérdida de valor, básicamente por su utilización en el proceso productivo, se produce con independencia de los resultados obtenidos" ${ }^{\$ 43}$. La consideración fiscal del asunto, viene por una cuestión obvia, mientras mayor sea la amortización, más aumentan los gastos y disminuye la utilidad, reduciendo la base imponible del impuesto. Esto motiva al legislador tributario a reglar este fenómeno, para evitar la evasión por medio de aumentar la depreciación y erosionar la base del tributo.

La amortización de los intangibles probablemente no es pacífica en ningún Estado y España no ha sido la excepción, puesto que fue un asunto discutido en la antigua ley del Impuesto sobre Sociedades, Ley 61/1978 y lo sigue siendo en la actual, contenida en el Real Decreto Legislativo 4/2004. En este sentido, podemos observar como COLAO SÁNCHEZ ${ }^{484}$, comentando la antigua Ley del Impuesto sobre Sociedades, ponía de manifiesto cómo es que, ya en las causas de la amortización existía controversia, él estima que el artículo 44 del Decreto 2631/1982 $2^{485}$, contiene las

\footnotetext{
${ }^{480}$ En este sentido FERNÁNDEZ IPARRAGUIRRE, JOSÉ LUIS y CASADO MAYORDOMO, MANUEL. Contabilidad financiera para directivos, ESIC Editorial, Madrid, 2008, p. 81.

${ }^{481}$ Diccionario económico. Disponible en Internet en: http://www.expansion.com/diccionario-economico/amortizacion-financiera.html (10 Ene 2014).

482 Ob. supra cit., p. 76.

483 Ob. supra cit., p. 76.

${ }^{484}$ COLAO SÁNCHEZ, PEDRO. La “amortización” del inmovilizado inmaterial en el Impuesto sobre Sociedades: algunas cuestiones, Revista Impuestos №21, 1993, pp. 276 a 299.

${ }^{485}$ Reglamento de la Ley de Impuesto sobre Sociedades.
} 
causas que pueden originar la depreciación ${ }^{486}$, tales son: "la utilización física, la acción del progreso técnico y el simple paso del tiempo"487 ${ }^{488}$, de las cuales, discute que el progreso técnico pueda ser considerado como fuente de amortización, en la medida que no tiene una vinculación con la función de producción. Para él se trata de una acción "generalmente inopinada" 489 , se produce por factores externos en los que la actividad productiva de la empresa no interviene, desvinculados del proceso de producción, en consecuencia la obsolescencia viene a afectar el proceso productivo, pero no es parte de él; hace que los bienes generados por la empresa no puedan venderse, pero no se trata de la incapacidad para producirlos generada por el deterioro o desgaste del aparato productivo, que es lo que caracteriza a la depreciación ${ }^{490}$.

En el mismo sentido anterior, COLAO SÁNCHEZ si bien no discute la posibilidad de amortización del inmovilizado inmaterial ${ }^{491}$, que por lo demás es aceptado sin reparos por la ciencia financiera, tal como podemos ver en FERNANDÉZ ${ }^{492}$ quien expresamente hace referencia a la amortización del "inmovilizado técnico intangible (propiedad industrial, concesiones, software...)", advierte que a su juicio, estamos más bien ante un caso de imputación de costes. En efecto, estima que el inmovilizado inmaterial colabora con la producción, agrega valor, pero no se desgasta con ella, es decir no existe una depreciación asociada a su uso, lo que es especialmente cierto a propósito de la propiedad intelectual, ya que por mucho

${ }^{486}$ El artículo 44 del Decreto 2631/1982, decía: “Elementos amortizables.

1. Serán susceptibles de amortización los elementos integrados en el inmovilizado material que se deprecien necesariamente por su utilización física, por la acción del progreso técnico o por el simple paso del tiempo".

487 Ob. supra cit., p. 277.

${ }^{488}$ Ob. supra cit., p. 277. Para el autor, de aquí se puede establecer una clasificación de la depreciación en tres tipos "funcional, económica y física".

489 Ob. supra cit., p. 277.

490 Si bien estas observaciones fueron hechas por COLAO SÁNCHEZ para el Reglamento del Impuesto sobre Sociedades de 1982, actualmente derogado, son igualmente aplicables a la situación actual, puesto que el artículo 11. 1. de la actual Ley del Impuesto sobre Sociedades contenida en el Real Decreto Legislativo 4/2004, dice:

1. Serán deducibles las cantidades que, en concepto de amortización del inmovilizado material, intangible y de las inversiones inmobiliarias, correspondan a la depreciación efectiva que sufran los distintos elementos por funcionamiento, uso, disfrute u obsolescencia", en donde respecto de la obsolescencia, cabría hacer las mismas observaciones que se hicieron para el progreso técnico.

${ }^{491}$ Ob. supra cit., pp. 281 y sgtes.

492 FERNÁNDEZ. Ob. supra cit., p. 77. 
imprimir una obra o utilizar el conocimiento de una patente, estos derechos no se desgastan ni deterioran ${ }^{493}$.

El atributo del inmovilizado inmaterial de no envejecer ni deteriorarse, al incorporarse al proceso productivo, unido a las dificultades sobre su valoración especialmente difícil en el caso de la propiedad intelectual- hace que sea muy controvertido determinar cuál sería un parámetro adecuado de amortización, por cierto que teóricamente hay casos en que podría calcularse con precisión, como cuando se tiene derecho al inmovilizado inmaterial por un período corto de tiempo y fijo ${ }^{494} \mathrm{o}$ asociado a un número definido de unidades producidas. De estas complicaciones nacen las suspicacias de legisladores y agencias tributarias, quienes rodean la amortización, depreciación y costeo del inmovilizado inmaterial, de resguardos de todo tipo; ello, explicaba la exigencia del RIS de 1984, "para que el inmovilizado inmaterial sea "amortizable", que tenga "una vigencia temporal limitada, sin posibilidad de prórrogas sucesivas".

El hecho que al inmovilizado inmaterial no podamos atribuirle un desgaste asociado al coste de los bienes producidos, no desmerece que en sí mismo posea un costo, que debe ser tenido como tal dentro del resultado operacional de la producción, lo que nos lleva a compartir la posición de COLAO SÁNCHEZ ${ }^{495}$, en el sentido que está mal aplicada la amortización, puesto que implica una disminución de la estimación del valor patrimonial del activo (inmovilizado inmaterial), que no es real, al suponer una depreciación del mismo producida por el desgaste en el proceso productivo, en tanto que no ha habido tal desgaste, ni menos disminución de valor. De esta manera, se demuestra que el sistema de amortización, en este caso, viene a desfigurar la realidad financiera. Lo que realmente existe es simplemente una imputación de costes, es decir el reflejo del coste de adquisición o producción del inmovilizado inmaterial que debe ser contabilizado como tal, rebajando el margen de utilidad de las unidades producidas por la empresa.

${ }^{493}$ En el mismo sentido se pronuncian GONZÁLEZ POVEDA, Impuesto sobre Sociedades, Ediciones pirámide SA, Madrid, 1988, p. 188; ORTEGA, Reglamento del Impuesto sobre Sociedades. Ingresos y Gastos, Asociación para el Progreso de la Dirección, Madrid, 1983, p. 127; y COLMENAR VALDÉS, Política de Amortizaciones, Revista Impuestos, Tomo I/86, pp 545, todos citados por COLAO. Ob. supra cit., p. 282.

${ }^{494}$ Ob. supra cit., p. 282, trata este ejemplo en el mismo sentido.

495 Ob. supra cit., p. 283. 
En todo caso, debemos dejar establecido que bien sea que se haga el descuento por considerarlo una amortización o una minoración de los costes de producción, en la medida que sea una resta efectiva y matemáticamente equivalente, no debería molestarnos que se haga por una u otra vía. El problema es cuando derivado del diferente tratamiento que suele tener la amortización, puede resultar que no pueda descontarse el gasto del inmovilizado inmaterial, que como ya hemos anticipado, es más frecuente de lo esperado, por la sensibilidad que genera el asunto en los legisladores tributarios, v. g., vimos como el antiguo Reglamento de la Ley del Impuesto sobre Sociedades limitaba la posibilidad de amortizar a aquellos inmovilizados inmateriales que tuviesen un plazo definido de término, de donde se desprende, que los que no posean esta característica no podrán ser amortizados.

Desgraciadamente, cuando de activos inmateriales y especialmente cuando de propiedad intelectual se trata, estamos siempre rodeados de resguardos y medidas de control tomados por parte de las administraciones y legislaciones tributarias, que frecuentemente derivan en injusticias, siempre en perjuicio del contribuyente.

Ahora bien, hablando de propiedad intelectual la solución no es única, atendidos los diferentes roles y formas que ésta puede tomar dentro de la empresa. Si se trata de una patente adquirida a un tercero ${ }^{496}$ o de un contrato de edición limitado a un cierto número de ejemplares, al tener un valor efectivo y una vida útil determinada, a nuestro juicio, es plenamente aplicable la discusión sobre el hecho de si estamos propiamente frente a amortización o imputación de costes. De otra parte, si resulta ser una patente obtenida por un proceso de I+D impulsado por la propia empresa, los gastos serán de investigación y desarrollo, debiendo imputarse como gastos, salvados los casos en que la ley permite activarlos, materia regulada en el art. 35 de la LIS. También podría suceder que se tratase de un programa informático desarrollado por empleados de la empresa y cuyo costo se haya absorbido completamente en el proceso productivo, por ejemplo, porque únicamente significó el pago de un sueldo, caso en el cual, únicamente cabría hablar de amortización y la pregunta sería cómo valorizar este activo.

${ }^{496}$ Considerando que conforme a la Ley 11/1986, de 20 de marzo, de Patentes, siempre tendrá un plazo fijo de duración. 
El asunto es y seguirá siendo intrincado y sin duda el eterno juego del gato y el ratón que caracteriza a las administraciones de impuesto y a los contribuyentes, tendrá en estos derroteros alegres partidas.

\subsubsection{Amortización en la Ley del Impuesto sobre Sociedades}

Superando con creces el desarrollo que daba al tema la Ley 61/1978, el actual RDL 4/2004 LIS, se hace cargo del asunto con mucho más detalle, aliviando la tarea que antes estuvo entregada al reglamento de la ley del ramo.

Como vimos al amparo de la Ley 61/1978, su reglamento limitaba la posibilidad de amortizar el inmovilizado inmaterial a aquellos que tuviesen una vida útil efectiva de duración, restricción que parecía tener su origen en el celo de la administración más que en una justificación sistémica. En la actual LIS, se distingue claramente entre una regla general que contiene a todos los inmovilizados inmateriales y aquellos que tienen una duración limitada, de manera que en el caso de la propiedad intelectual, dependiendo del derecho de que se trate podremos estar en uno u otro caso.

La LIS no se refiere expresamente a la propiedad intelectual, tampoco lo hacía la antigua LIS de 1978, salvo que su reglamento se refería únicamente a la propiedad industrial $^{497}$, de manera que tenemos que entenderla comprendida dentro de los inmovilizados intangibles (o inmateriales) a los que expresamente se refiere el artículo 11 de la actual LIS 43/1995, que bajo el rótulo de "amortizaciones" comprende a las cantidades que en concepto de "inmovilizado intangible" correspondan a depreciación efectiva. Es decir, permite la amortización de aquella parte del inmovilizado intangible que haya sido consumida como producto de la depreciación en un período determinado.

La ley española, tampoco hace un listado de los requisitos necesarios para hacer procedente la amortización, por lo que con fines de estudio, hemos decidido intentar sistematizarlos, identificando los siguientes: debe tratarse de un inmovilizado intangible; tiene que tener un origen en una causa legal; debe ser un activo que cumpla con el requisito de identificabilidad; hay que considerar una depreciación efectiva; cumplir con los requisitos de detalle establecidos en el reglamento; amortizar dentro de

497 Art. 66. c) del antiguo RLIS, Decreto 2631/1982, decía: "Los elementos de la propiedad industrial tales como patentes, marcas y nombres comerciales, procedimientos de fabricación, modelos y dibujos, obtenidos mediante contraprestación y cuya utilización exclusiva figure reconocida legalmente por un plazo limitado e improrrogable". 
plazo legal; distinguir cuando se trata de inmovilizados intangibles de vita útil definida $\mathrm{o}$ indefinida.

\subsubsection{Inmovilizado intangible}

Tal como dijimos la Ley del Impuesto sobre Sociedades, no define que entiende por "inmovilizado intangible" (o inmaterial), de manera que atendida la obligada relación con la esta materia con la contabilidad, es indiscutido que se puede determinar su contenido por referencia al Plan General de Contabilidad. Tal como dice GAY SALUDAS ${ }^{498}$, es archisabido que el inmovilizado intangible comprende: los gastos de investigación y desarrollo, concesiones administrativas, propiedad industrial, fondo de comercio, derechos de traspaso, aplicaciones informáticas y derechos sobre bienes en régimen de arrendamiento financiero. Sin embargo, el PGC establecido por Real Decreto 1514/2007, de 16 de noviembre, no dice exactamente lo mismo, sino que enumera como inmovilizados intangibles: gastos de investigación y desarrollo, propiedad industrial, fondo de comercio, derechos de traspaso, programas de ordenador y otros inmovilizados intangibles ${ }^{499}$. Lo particular de estas aproximaciones al contenido del inmovilizado inmaterial con relación a nuestro estudio, es que únicamente se refieren a la propiedad industrial, olvidando completamente a la propiedad intelectual propiamente tal, a nuestro juicio, puede haber una explicación en el hecho que "la influencia contable en el terreno de la fiscalidad se ha convertido en una realidad aplastante" ${ }^{, 500}$, ya que revisado el PGC, se aprecia una mano experta en contabilidad e inexperta en derecho de la propiedad intelectual, puesto que no alcanzamos a entender por qué la propiedad industrial es reconocida expresa y directamente como un activo intangible, de hecho se le señala con un título propio "propiedad industrial" explica en que consiste, pero no sucede lo mismo con la propiedad intelectual

498 GAY SALUDAS, JOSÉ MARÍA. El inmovilizado inmaterial en el contexto del nuevo impuesto sobre sociedades: normas de valoración contables "versus" fiscales, Revista del Profesional de Contabilidad, 1995, pp. 431 y sgtes. El autor incorpora dentro del inmovilizado inmaterial a los anticipos para inmovilizaciones inmateriales, sin embargo ellos no figuran en el Plan General de Contabilidad, de todas formas, a los fines de nuestro estudio, lo que interesa es la referencia a la propiedad industrial.

499 Real Decreto 1514/2007, de 16 de noviembre, que aprueba el Plan General de Contabilidad, Segunda Parte, Normas de Registro y Valoración, regla 6 , Normas particulares sobre inmovilizado intangible.

500 Ob. supra cit., p. 434.

${ }^{501}$ Real Decreto 1514/2007, de 16 de noviembre, que aprueba el Plan General de Contabilidad, Segunda Parte, Normas de Registro y Valoración, regla $6^{\mathrm{a}}$, Normas particulares sobre inmovilizado intangible, letra b) "Propiedad industrial". 
propiamente tal, que está subsumida dentro de "Otros inmovilizados intangibles" $"$. En este mismo sentido podemos ver a GAY y $\mathrm{COLAO}^{503}$ quienes haciéndose cargo de la actual normativa contenida en la LIS y de la antigua contenida en el Reglamento de la LIS de 1978, las que adolecen de la misma característica de hablar únicamente de "propiedad industrial", concluyen sin dudar, que se debe entender tanto propiedad industrial como intelectual propiamente tal, conclusión que compartimos, porque no encontramos argumento alguno que permita diferenciar entre estos institutos, a la hora de analizarlos como activos empresariales.

Hasta aquí parecía no cabernos duda que tanto la Ley del Impuesto sobre Sociedades como el PGC, entendieron a la toda la propiedad intelectual como un inmovilizado intangible, permitiendo su amortización, en el caso de la ley porque no distingue al respecto y en el del PGC, al amparo de la referencia expresa a la "Propiedad industrial" ${ }^{, 504}$ como un grupo de inmovilizados intangibles y por medio de la inclusión de la propiedad intelectual en el título "Otros inmovilizados intangibles". Sin embargo, tal como venimos latamente advirtiendo, la autoridad manifiesta su permanente recelo con la amortización de los intangibles y en la especie, a nivel de reglamento, prohíbe la amortización de determinados inmovilizados intangible relacionados con la propiedad intelectual, al decir: "En ningún caso se reconocerán como inmovilizados intangibles los gastos ocasionados con motivo del establecimiento, las marcas, cabeceras de periódicos o revistas, los sellos o denominaciones editoriales, las listas de clientes u otras partidas similares, que se hayan generado internamente" ${ }^{\Perp 505}$. La norma es confusa, puesto que establece como requisito común que los activos "se hayan generado internamente", lo que podría ser razonable si se trata de simples ordenaciones, listados u otros que no demanden costo adicional y estén completamente subsumidos dentro de la labor productiva de la empresa, en consideración a que no tendrían un costo de producción determinable, pero no podemos decir lo mismo de las marcas, sellos, denominaciones editoriales u otros, que pudiesen tener un alto costo de creación, perfectamente

502 Afortunadamente, a nuestro entender, la imprecisión no es relevante, puesto que tal como venimos afirmando, para determinar el régimen de amortización de la propiedad intelectual debemos estar más a la situación concreta de cada derecho que a su rótulo bautismal; al fin y al cabo, si bien lo hace bajo una lógica que no entendemos, el PGC se hace cargo tanto de la propiedad intelectual propiamente tal como de la propiedad industrial.

${ }^{503}$ GAY. Ob. supra cit., y, COLAO. Ob. supra cit. Páginas 431 y 286, respectivamente.

${ }^{504}$ Real Decreto 1514/2007, de 16 de noviembre, que aprueba el Plan General de Contabilidad, Segunda Parte, Normas de Registro y Valoración, regla $6^{\mathrm{a}}$, Normas particulares sobre inmovilizado intangible.

505 Real Decreto 1514/2007, de 16 de noviembre, que aprueba el Plan General de Contabilidad, Segunda Parte, Normas de Registro y Valoración, regla $5^{\text {a }}$, Inmovilizado intangible. 
identificable, aunque se haya hecho al interior de la empresa, de hecho, en el caso de las marcas, en tasas y agentes pueden haber montos significativos.

A todo evento, el avance de la legislación española, al permitir la amortización de la propiedad industrial e intelectual, los gastos de $\mathrm{I}+\mathrm{D}^{506}$ y del fondo de comercio ${ }^{507}$, demuestra la decisión de abordar el asunto en su integridad, por lo que un próximo avance normativo estará llamado a precisar las cuestiones pendientes.

En conclusión, para tener derecho a amortización un derecho de propiedad intelectual debe estar considerado como un inmovilizado intangible y no haber sido expresamente excluido.

\subsubsection{Origen en una causa legal}

El artículo 11 de la LIS 43/1995, establece que el origen de la amortización o en otras palabras, el derecho a amortizar, se produce por la "depreciación efectiva que sufran los distintos elementos por funcionamiento, uso, disfrute u obsolescencia”. Es decir, funcionamiento, uso, disfrute u obsolescencia son las causas aceptadas por el legislador para motivar la amortización. La LIS no distinguió entre el inmovilizado material e intangible, de manera que cualquiera de las causas enumeradas permitirá amortizar, sin embargo conviene tener presente que el "funcionamiento" como causa de amortización de la propiedad intelectual no parece aceptable. Lo que podríamos llamar "funcionamiento", en este caso, consiste únicamente en la aplicación de la idea protegida, que como tal, no podríamos pensarse tiene un "funcionamiento" y de tenerlo, en ningún caso significaría desgaste o depreciación alguna. Algo parecido sucede con el "uso" y "disfrute", como causas de depreciación de la propiedad intelectual, en el entendido que naturalmente su explotación no implica desgaste, perjuicio o deterioro. De todas maneras la situación no es igual a la anterior, puesto que en aquellos casos en que se tenga derecho a la explotación por un tiempo limitado o vinculadas cantidades específicas de producción, se puede cuantificar un agotamiento o depreciación del derecho a medida de su uso o disfrute. Es por todo esto, que compartimos con COLAO

\footnotetext{
506 A pesar que respecto de los gastos de I+D debemos celebrar su inclusión en la normativa, pero no los efectos de ésta, ya que son tan restrictivos los requisitos impuestos para su amortización a nivel del PGC, que tal vez, deberíamos considerarlo una mera hipnosis.

${ }^{507}$ Real Decreto 1514/2007, de 16 de noviembre, que aprueba el Plan General de Contabilidad, Segunda Parte, Normas de Registro y Valoración, regla $6^{\mathrm{a}}$, Normas particulares sobre inmovilizado intangible.
} 
SÁNCHEZ, cuando analizando el asunto ${ }^{508}$, concluye que la propiedad industrial está afectada por una causal externa que es el progreso técnico, de donde nace la obsolescencia, verdadera causa de la depreciación de la propiedad intelectual. Para demostrar que la obsolescencia puede producirse de igual forma en la propiedad industrial e intelectual, proponemos pensar en los programas de ordenador se vuelven rápidamente obsolescentes, y considerar que los libros, música y tendencias artísticas también tienen su momento de moda y luego decrece el interés por ellos.

\subsubsection{Identificabilidad}

El PGC exige al bien susceptible de amortización, ser un activo para la empresa, puesto que sólo los activos tienen la propiedad de poder representar un valor económico para la empresa, por tanto, son susceptibles de un deterioro que da origen a amortización. No obstante, el PGC va más allá, no se conforma con que la propiedad intelectual deba cumplir estas características para estimarla un activo depreciable; además, le exige cumplir "el criterio de identificabilidad"509. La propiedad intelectual será "identificable", cuando sea: "separable, esto es, susceptible de ser separado de la empresa y vendido, cedido, entregado para su explotación, arrendado o intercambiado" o cuando "surja de derechos legales o contractuales, con independencia de que tales derechos sean transferibles o separables de la empresa o de otros derechos $u$ obligaciones" $" 510$.

Esta norma, aparentemente tiene su justificación como una disposición antielusión. Busca asegurar que los bienes inmateriales amortizables, sean verdaderos activos de la empresa y no estén constituidos por meras especulaciones o estimaciones de la empresa sobre los derechos que posee y su valor.

El hecho que la identificabilidad no sea un requisito establecido en la LIS, sino que solamente en el PGC, puede llevar a pensar que de no haberse efectuado la deducción de la amortización a nivel contable por no cumplir con el requisito de la identificabilidad, sería posible considerarla fiscalmente. En otras palabras, atendido a que la identificabilidad no es una exigencia legal, el gasto contable no considerado por

\footnotetext{
${ }^{508}$ COLAO. Ob. Cit., pp. 277.

509 Real Decreto 1514/2007, de 16 de Noviembre, que aprueba el Plan General de Contabilidad, Segunda Parte, Normas de Registro y Valoración, regla $5^{\mathrm{a}}$, Inmovilizado intangible.

510 Ob. supra cit.
} 
no cumplirse con el requisito de identificabilidad, sería un gasto fiscalmente deducible, por lo que el sujeto puede realizar un ajuste negativo reduciendo su base imponible en el importe correspondiente.

Si bien nosotros mismos estamos planteando la teoría anotada, no compartimos que jurídicamente pueda llegarse a esta conclusión, puesto que una cuestión de simple suma y resta, dice que lo amortizable es aquello que tiene un valor para la empresa, es decir un activo, lo que es coincidente con el art. 11. 1 de la LIS, que deja en claro que para proceder a la deducción por amortización, debe sufrirse una depreciación por funcionamiento, uso, disfrute u obsolescencia de los "elementos" de la empresa. En otras palabras, la norma está exigiendo lo que es lógico, la existencia de una entidad identificable en la empresa, susceptible de ser denominada activo, ya sea que tenga un contenido material o inmaterial, eso sí, debe poseer una cierta esencia y unidad, lo que se condice con el requisito de identificabilidad que hemos analizado. Así las cosas, exista o no el requisito de la identificabilidad en el PGC, la exigencia para con un activo intangible debería ser relativamente equivalente.

\subsubsection{Depreciación efectiva}

El artículo 11. 1 de la LIS exige que la depreciación sea efectiva y entiende por tal, la que se estime conforme a alguno de los métodos establecidos por el mismo artículo $^{511}$ que regula tres métodos: amortización según tabla, cuando se corresponda a

${ }^{511}$ El Art. 11. 1 de la LIS, señala en lo pertinente: "Se considerará que la depreciación es efectiva cuando:

a) Sea el resultado de aplicar los coeficientes de amortización lineal establecidos en las tablas de amortización oficialmente aprobadas.

b) Sea el resultado de aplicar un porcentaje constante sobre el valor pendiente de amortización.

El porcentaje constante se determinará ponderando el coeficiente de amortización lineal obtenido a partir del período de amortización según tablas de amortización oficialmente aprobadas, por los siguientes coeficientes:

$1 .^{\circ} 1,5$, si el elemento tiene un período de amortización inferior a cinco años.

2. 2 , si el elemento tiene un período de amortización igual o superior a cinco años e inferior a ocho años.

$3 .^{\circ} 2,5$, si el elemento tiene un período de amortización igual o superior a ocho años.

El porcentaje constante no podrá ser inferior al 11 por ciento.

Los edificios, mobiliario y enseres no podrán acogerse a la amortización mediante porcentaje constante.

c) Sea el resultado de aplicar el método de los números dígitos.

La suma de dígitos se determinará en función del período de amortización establecido en las tablas de amortización oficialmente aprobadas.

Los edificios, mobiliario y enseres no podrán acogerse a la amortización mediante números dígitos.

d) Se ajuste a un plan formulado por el sujeto pasivo y aceptado por la Administración tributaria.

e) El sujeto pasivo justifique su importe". 
coeficientes de amortización lineal oficialmente aprobados ${ }^{512}$; amortización según porcentaje constante, es decir a un porcentaje de depreciación constante sobre el valor residual de amortización ${ }^{513} ; \mathrm{y}$, amortización de número dígito, según la cual el ritmo de la amortización puede variar de manera descendiente o ascendiente. Además, existe la posibilidad que el sujeto pasivo presente su propio plan de amortización a la administración tributaria, que debe ser previamente aceptado por ésta.

La LIS hace aplicable todos los métodos de amortización que ella misma acepta de manera general a la propiedad intelectual, sin hacer distinciones, sin embargo, a nuestro entender, los métodos que más se condicen con la esencia de la propiedad intelectual son: el de amortización constante, puesto que supone que el activo se desgasta a un ritmo uniforme durante todo su uso, fórmula razonable, considerando que normalmente la pérdida de valor de la propiedad intelectual sobreviene de un momento a otro con su obsolescencia, sin que pueda establecerse un parámetro de desgaste durante su vida útil, lo que hace prudente distribuir su amortización durante toda su vida útil a un ritmo constante; $\mathrm{y}$, el plan de amortización, aplicable, por ejemplo, en aquellos casos en que la titularidad del derecho de propiedad intelectual que se explota esté asociado a un número de unidades producidas, en la medida que en ese caso, se conoce exactamente cuánto incide en el costo de cada unidad.

El último requisito establecido por el art. 11. 1 de la LIS es bastante obvio, puesto que implica que el sujeto pasivo debe justificar el importe de la amortización. Ahora bien, es natural que los activos de la empresa vayan perdiendo su valor económico, pero no es un certeza matemática; sin embargo, la depreciación es un fenómeno tan natural que lo razonable parece ser entender que debe justificarse el método de amortización, no ella en sí misma.

\footnotetext{
${ }^{512}$ Una explicación clara sobre el funcionamiento de las tablas de amortización, está disponible en Internet, en: http://www.fiscal-impuestos.com/2-base-imponible-i-amortizaciones.html (28 Abr 2013). Allí se señala: "Dichas tablas establecen para cada elemento patrimonial un coeficiente de amortización lineal máximo y un periodo máximo de amortización (del que se deriva el coeficiente de amortización lineal de carácter mínimo). Se entiende, por tanto, cumplido el requisito de depreciación efectiva cuando se aplique cualquiera de estos dos coeficientes o cualquier otro comprendido entre ellos".

${ }^{513}$ Una explicación clara sobre el funcionamiento de las tablas de amortización, está disponible en Internet, en: http://www.fiscal-impuestos.com/2-base-imponible-i-amortizaciones.html (28 Abr 2013). Allí se señala: "Tal y como su propio nombre indica, se trata de aplicar un porcentaje constante sobre la base. de amortización de cada ejercicio, constituida esta, por el valor pendiente de amortización o valor contable del elemento patrimonial".
} 


\subsubsection{Demás requisitos establecidos en el reglamento}

El RLIS establece una serie de requisitos que deben cumplirse para hacer procedente la depreciación: el valor amortizable es el precio de adquisición o coste de producción, excluido, en su caso, el valor residual; no es amortizable la parte del precio de adquisición correspondiente al valor del suelo, hipótesis que será bien poco frecuente cuando se trata de propiedad intelectual, salvo que se haya adquirido la integridad de una empresa, incluidas marcas, patentes e instalaciones; cuando se trata de elementos patrimoniales de naturaleza análoga o sometidos a un similar grado de utilización, es posible su amortización como un conjunto, en el caso de la propiedad intelectual esto es posible de encontrar en los proyectos de investigación y en general en todos los proyectos nuevos que implican el uso de propiedad intelectual ${ }^{514}$; debe aplicarse un único método de amortización ${ }^{515}$; en caso de fusión, escisión, total y parcial, y aportación, se mantendrá el método de amortización que originalmente se venía aplicando $^{516} ; \mathrm{y}$, el régimen de amortización continuarán aplicándose hasta la extinción de la vida útil de los mismos.

\subsubsection{Plazo legal}

La amortización es posible desde que la propiedad intelectual esté en condiciones de producir ingresos y su período de amortización es aquél en que razonablemente se espera que produzca ingresos ${ }^{517}$.

Cuando la vida útil sea inferior a diez años, el límite anual máximo se calculará atendiendo a dicha duración.

\footnotetext{
${ }^{514} \mathrm{El}$ art. 1. 3. del RIS, establece una norma especial para las "instalaciones técnicas", que puede resultar aplicable a la propiedad intelectual. Señala: "Las instalaciones técnicas podrán constituir un único elemento susceptible de amortización. Se considerarán instalaciones técnicas las unidades complejas de uso especializado en el proceso productivo que comprenden edificaciones, maquinaria, material, piezas o elementos, incluidos los sistemas informáticos que, aun siendo separables por su naturaleza, están ligados de forma definitiva para su funcionamiento y sometidos al mismo ritmo de amortización, así como los repuestos o recambios válidos exclusivamente para este tipo de instalaciones".

515 El art. 1. 5. del RIS, establece una excepción, cuando señala: "No obstante, en casos excepcionales que se indicarán y se justificarán en la memoria de las cuentas anuales, podrá aplicarse un método de amortización distinto del que se venía aplicando, dentro de los previstos en este capítulo".

${ }^{516} \mathrm{El}$ art. 1. 6. del RIS, establece una excepción, al decir: excepto si el sujeto pasivo prefiere aplicar a los mismos su propio método de amortización, para lo cual deberá formular un plan de amortización, en los términos previstos en el artículo 5 de este Reglamento.

517 Art. 1. 4. del RIS.
} 


\subsubsection{Vida útil definida 0 indefinida}

Al amparo de la antigua LIS de 1978, el Reglamento sólo permitía la amortización cuando los derechos de propiedad intelectual tuviesen un plazo fijo de duración, que además fuese improrrogable ${ }^{518}$, de no existir este plazo no había amortización posible.

Por su parte, el PGC distingue si la vida útil de la propiedad intelectual ${ }^{519}$ es definida o indefinida. Un activo es de vida útil definida o indefinida, dependiendo si hay o no un límite previsible del periodo a lo largo del cual se espera que el activo genere entradas de flujos netos de efectivo para la empresa ${ }^{520}$. Si la vida útil es definida procede su amortización, de otra manera la amortización no es procedente, sin perjuicio de evaluar cada período si el activo se deterioró completamente o si su vida útil se volvió definida, en cuyo caso procederá su amortización. En este punto, si bien podría decirse que debemos estar atentos a las diferencias entre el régimen contable y el fiscal, puesto que la restricción de tener un plazo de duración definido no existe fiscalmente. Así, por ejemplo, en el caso de las marcas comerciales al ser renovables indefinidamente poseen un plazo indefinido de extinción, en esa medida, contablemente, según el PGC, no procedería su amortización, pero fiscalmente sí procede, por lo que correspondería hacer la deducción para fines de impositivos.

De todas formas, conviene recordar como GAY SALUDAS hace presente que en la nueva LIS "se admite la deducibilidad con el límite anual máximo de la décima parte de su importe de las dotaciones para las amortizaciones de los elementos patrimoniales del inmovilizado inmaterial que no tuviesen fecha cierta de extinción"521.

\section{III.2.2.2.7.1 Libertad de amortización}

El art. 11. 2 de la LIS, prevé la posibilidad de amortizar libremente la propiedad intelectual: en el caso de las sociedades anónimas laborales y de las sociedades limitadas laborales, siempre que la propiedad intelectual haya estado afecta a la

\footnotetext{
${ }_{518}^{518}$ Art. 66 RIS de 1978.

519 La norma no se refiere específicamente a propiedad intelectual sino que a "inmovilizado intangible", no obstante, ya hemos dejado en claro que bajo esa expresión se incluye a los derechos de propiedad intelectual.

${ }^{520}$ Real Decreto 1514/2007, de 16 de noviembre, que aprueba el Plan General de Contabilidad, Segunda Parte, Normas de Registro y Valoración, regla $5^{\mathrm{a}}$, Inmovilizado intangible.

${ }^{521}$ GAY. Ob. supra cit., p. 437.
} 
realización de sus actividades y fuese adquirida durante los cinco primeros años a partir de la fecha de su calificación como tales; cuando esté destinada a las actividades de investigación y desarrollo, incluyendo los edificios destinados a estos fines, por partes iguales, durante un período de 10 años; vinculada a gastos de investigación y desarrollo que hayan sido activados como inmovilizado intangible, excluidos los bienes que se acojan a libertad de amortización ${ }^{522}$.

Finalmente, sobre este punto, es necesario hacer presente que los montos utilizados como amortización bajo el sistema bajo el régimen de libertad de amortización, incrementarán la base imponible con ocasión de la amortización o transmisión de los elementos que disfrutaron de ella ${ }^{523}$.

\section{III.2.2.2.7.2 Amortización del inmovilizado intangible con vida útil definida}

La LIS, en el art. 11.4, da normas especiales para el inmovilizado intangible con vida útil definida, que obviamente y tal como venimos analizando son aplicables a la propiedad intelectual. Las normas consisten en limitar el período de amortización a diez años, aun cuando la propiedad tenga una duración superior (podrían ser veinte años en el caso de una patente o toda la vida del autor, en el caso del derecho de autor), para lo cual exige dos requisitos: que la propiedad intelectual se haya adquirido por medio de un título oneroso y que las entidades adquirente y transmitente no formen parte de un grupo de sociedades según los criterios del artículo 42 del Código de Comercio ${ }^{524}$.

Por último, el art. 11. 4. de la LIS, cierra con una disposición que establece que en caso de no darse las condiciones citadas, la amortización "será deducible sólo si se acredita una pérdida irreversible del mismo". Esta disposición, no obstante su ubicación bajo el título referido a "inmovilizado intangible con vida útil definida", creemos que debe entenderse como una norma de aplicación general, puesto que la pérdida de un activo, es siempre motivo de costo para la empresa. En el caso de la propiedad

\footnotetext{
${ }^{522}$ Finalmente, la LIS también otorga el beneficio de libertad de amortización a un caso bastante puntual que se refiere a: "Los elementos del inmovilizado material o intangible de las entidades que tengan la calificación de explotaciones asociativas prioritarias de acuerdo con lo dispuesto en la Ley 19/1995, de 4 de julio, de modernización de las explotaciones agrarias, adquiridos durante los cinco primeros años a partir de la fecha de su reconocimiento como explotación prioritaria".

523 Art. 1. 4. del RIS.

${ }^{524} \mathrm{Si}$ las sociedades forman parte del mismo grupo, la ley prevé una norma de control que implica estimar el precio a valor de mercado. En efecto, sostiene el art. 11. 6 de la LIS: "Si, por el contrario, ambas sociedades forman parte de un grupo, la deducción se aplicará respecto del precio de adquisición del inmovilizado satisfecho por la entidad transmitente cuando lo hubiera adquirido de personas o entidades no vinculadas".
} 
intelectual esta pérdida puede producirse por variadas causas, como caducidad, nulidad, abandono, obsolescencia, etc.

\subsubsection{Relación de la propiedad intelectual y la amortización de los gastos de I+D y del fondo de comercio}

Antes tuvimos la oportunidad de precisar como dentro del inmovilizado intangible se comprende no sólo la propiedad intelectual, sino también otros rubros que pueden resultar de interés para nuestro estudio, como son los gastos de $\mathrm{I}+\mathrm{D}$ y el fondo de comercio.

Los gastos por $\mathrm{I}+\mathrm{D}^{525}$ no son inmovilizado desde la perspectiva fiscal ${ }^{526}$, son puramente gasto, por lo que procede reconocerlos como tales en el ejercicio en que se hicieron. Sin embargo, sucede como analizamos previamente, que el art. 11. 2. d) de la LIS, permite su amortización cuando se han activado como inmovilizado intangible, en un plazo máximo de cinco años, para lo cual establece una serie de requisitos ${ }^{527}$ que analizaremos al hablar de la deducción de gastos por I+D.

Una nota particular respecto de los gastos de I+D asociados a la propiedad intelectual, como es evidente, es que pueden llevar a una investigación exitosa incluso a título de propiedad industrial, ya sea patente, modelo, diseño, programa informático, etc., pero también pueden terminar en un fracaso. Cuando la investigación no prospera compartimos con COLAO SÁNCHEZ, que "son pura y simplemente gasto que o bien se imputan como tales, de forma inmediata o de forma plurianual" ${ }^{, 528}$, lo que no debe causar sorpresa, atendida su naturaleza de gastos. Lo singular se produce cuando la investigación tiene éxito y es producto de un proyecto de desarrollo efectuado por la propia empresa, en ese caso "habrán de imputarse a la cuenta Propiedad Industrial, amortizándose según la naturaleza de ésta" ${ }^{329}$. Es decir, variará su forma de amortización de haberse permitido su activación e imputación en cinco años, para pasar al régimen de la propiedad intelectual.

${ }^{525}$ Cabe hacer presente que los gastos de I+D no estaban tratados en la LIS de 1978, sino que eran una innovación de la disposición $2^{\mathrm{a}}$ del Reglamento de 21 de enero de 1992, del que han pasado al actual artículo 35 de la nueva LIS.

${ }^{526}$ COLAO y GAY se pronuncian en el mismo sentido de entender que los gastos de I+D son puramente gasto. Obs. supra cit., pp. 286 y 435, respectivamente.

527 Ver, art. 33 LIS.

${ }^{528}$ COLAO. Ob. supra cit., pp. 296.

${ }^{529}$ GAY. Ob. supra cit., p. 435. 
En cuanto al fondo de comercio $^{530}$, tal como todos los inmovilizados intangibles que venimos analizando no estaba abordado por la LIS de 1978, no obstante en este caso, el Reglamento se hacía cargo de ellos para, expresamente, declararlos no amortizables, situación que cambió en la actual LIS, a cuyo alero estimamos que es perfectamente amortizable ${ }^{531}$, a pesar de no serlo contablemente ${ }^{532}$. En efecto, para el PGC, el fondo de comercio es un inmovilizado inmaterial y la LIS, tal como hemos analizado, permite la amortización de aquellos sin hacer distinciones. A todo evento, lo relevante para nuestro análisis no es el fondo de comercio en sí mismo, sino que podría estar conformado por derechos de propiedad intelectual ${ }^{533}$, incluso por algunos que no tiene protección legal o que se discute su amparo al cobijo de la propiedad intelectual como pudiesen ser el nombre comercial, secretos empresariales, rótulos de comercio, listas de clientes, derechos de llaves u otros, que al amparo del fondo de comercio pudiesen tener un valor apreciable y por esta vía amortizable, obviamente cuando se den los requisitos generales para la amortización de este inmovilizado intangible ${ }^{534}$.

${ }^{530}$ LABATUT SERER, GREGORIO. Deducibilidad fiscal del fondo de comercio en los ejercicios 2012 y 2013, en el caso de sociedades y empresario individual. Disponible en Internet en: http://gregoriolabatut.blogcanalprofesional.es/deducibilidad-fiscal-del-fondo-de-comercio-en-losejercios-2012-y-2013-en-el-caso-de-sociedades-y-empresario-individual/ (2 May 2013). Allí se define el fondo de comercio como: "la parte del precio de adquisición de la participación en el capital de otra sociedad que excede del valor razonable del patrimonio neto de la misma, y que se produce con motivo de una adquisición, fusión o consolidación de sociedades"; y también como: "es la diferencia inasignable que se produce cuando se adquiere el control sobre otra sociedad pagando por esa inversión un importe superior que el valor razonable de sus activos y pasivos (patrimonio neto)".

531 En el mismo sentido GAY. Ob. supra cit., p. 437.

${ }^{532}$ LABATUT. Ob. supra cit., s/p.

${ }^{533}$ ROSEMBUJ. Ob. supra cit., pp. 76 y sgtes. El autor trata este asunto en detalle, explicando cuáles intangibles pueden formar parte del fondo de comercio.

${ }^{534}$ Respecto del fondo de comercio, también conviene hacer presente que el art. 12.6 y 7. de la LIS, que permite la corrección del valor, de la pérdida por deterioro del valor de los elementos patrimoniales, acepta la deducción "del precio de adquisición originario del inmovilizado intangible correspondiente a fondos de comercio, con el límite anual máximo de la veinteava parte de su importe, siempre que se cumplan los siguientes requisitos:

a) Que se haya puesto de manifiesto en virtud de una adquisición a título oneroso.

b) Que la entidad adquirente y transmitente no formen parte de un grupo de sociedades según los criterios establecidos en el artículo 42 del Código de Comercio, con independencia de la residencia y de la obligación de formular cuentas anuales consolidadas. Si ambas entidades forman parte de un grupo, la deducción se aplicará respecto del precio de adquisición del fondo de comercio satisfecho por la entidad transmitente cuando lo hubiera adquirido de personas o entidades no vinculadas.

c) Que se haya dotado una reserva indisponible, al menos, por el importe fiscalmente deducible, en los términos establecidos en la legislación mercantil. Caso de no poderse dotar dicha reserva, la deducción está condicionada a que se dote la misma con cargo a los primeros beneficios de ejercicios siguientes.

Esta deducción no está condicionada a su imputación contable en la cuenta de pérdidas y ganancias. Las cantidades deducidas minorarán, a efectos fiscales, el valor del fondo de comercio.

7. Cuando se cumplan los requisitos previstos en los párrafos a) y b) del apartado anterior será deducible con el límite anual máximo de la décima parte de su importe el inmovilizado intangible con vida útil indefinida. Esta deducción no está condicionada a su imputación contable en la cuenta de 


\subsubsection{La propiedad intelectual como pérdida en el impuesto sobre sociedades}

Es universalmente aceptado que la renta ${ }^{535}$ gravable se obtiene de los ingresos menos los gastos y pérdidas, motivo por el cual, todas las leyes sobre el impuesto a la renta establecen normas de control para evitar que los contribuyentes abulten los gastos o las pérdidas.

La propiedad intelectual puede actuar disminuyendo la utilidad de la empresa, a nuestro juicio, por tres vías: cuando ha sido activada, si bien nunca será un gasto porque es un activo, disminuirá el resultado por vía de amortización; cuando es costo o gasto, por ejemplo, cuando se adquiere para ser embebida en el producto que será comercializado, como sucede con el pago de un euro como licencia por cada lápiz producido que lleva la imagen de Mickey Mouse; y, como pérdida, caso en el cual, la destrucción o total menoscabo de ella, hacen que pierda toda utilidad para la empresa.

Cuando la propiedad intelectual es entendida como una pérdida se mezclan ciertos conceptos, puesto que a nuestro modo de ver, debido a que normalmente estará activada, de producirse su "pérdida irreversible" $" 536$, cabe su amortización conforme al art. 11.4 de la LIS. Ahora bien, en lo concreto, para la determinación del resultado empresarial, debe usarse la contabilidad y puede haber habido pérdidas, que expresan "contablemente el deterioro no sistemático y reversible del valor de un elemento del activo, sufrido como resultado de uno o más eventos ocurridos" ${ }^{, 37}$. De manera que ahí hay una diferencia importante, puesto que la amortización es un fenómeno sistemático y la pérdida no.

Contablemente las pérdidas ${ }^{538}$ tomarán el nombre de "pérdidas por deterioro de

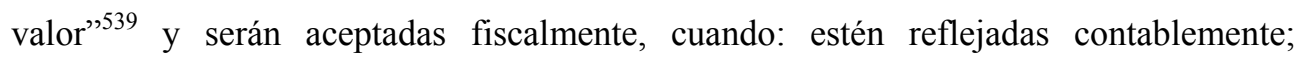

pérdidas y ganancias. Las cantidades deducidas minorarán, a efectos fiscales, el valor del inmovilizado".

535 Este es en definitiva el hecho gravado conforme al art. 4 LIS.

${ }^{536}$ Art. 11. 6 LIS.

537 GONZÁLEZ ORTIZ, DIEGO. Correcciones de valor: pérdidas de valor de elementos patrimoniales y provisión para riesgos y gastos, Universitat Jaume I. Castellón. Disponible en Internet en: https://aulavirtual.uji.es/pluginfile.php/809755/mod resource/content/0/Isoc - T3 Perdidas de valor_y provisiones.pdf (15 May 2013).

538 Respecto de qué es una pérdida, siguiendo la definición del PGC, GONZÁLEZ. Ob. supra cit., p. 2, hace una muy buena descripción de ellas, al decir: "De acuerdo con la regla de valoración $10^{\mathrm{a}}$, apartado 2, del PGC, cuando el valor neto realizable de las existencias, es decir, el importe que se puede obtener por la enajenación de un activo en el mercado, sea inferior a su precio de adquisición o a su coste de producción, se deben realizar las oportunas correcciones valorativas, reconociéndolas como un gasto en la cuenta de pérdidas y ganancias. Así, si la pérdida fuera reversible, la pérdida se 
justificadas $^{540}$; imputarse fiscalmente al período impositivo objeto de liquidación ${ }^{541}$; y, que la deducción no esté limitada por la norma fiscal, como sucede, a modo de ejemplo, con los gastos que enumera el art. 14 LIS. De no darse todos estos requisitos, la pérdida será fiscalmente rechazada y deberá adicionarse al resultado de manera extracontable para fines impositivos. Si se cumplen todos los requisitos señalados la pérdida será completamente deducible. Lo curioso para nuestro estudio no es que el legislador se haya tomado la molestia de normar el origen y deducibilidad de las pérdidas, puesto que el aumento de las pérdidas siempre lleva consigo la rebaja de la base imponible y con ello de la cuota tributable, sino que se haya detenido en dos casos especiales de pérdida, uno directamente relacionado con nuestro estudio y el otro tangencialmente, hablamos de las pérdidas por fondos documentales y por el fondo de comercio, respectivamente. Estos casos son también particulares, puesto que como es sabido, el legislador tributario no innova respecto de las disposiciones contables en materia de pérdidas por deterioro de existencias, asumiendo que las pérdidas deducibles según la norma contable, también lo son a nivel fiscal.

En el caso de los fondos editoriales, fonográficos y audiovisuales, el art. 12 de la LIS, exige además de los requisitos comunes antes vistos, dos requisitos adicionales: las pérdidas solamente pueden ser deducidas por las entidades que realicen la correspondiente actividad productora y que hayan transcurrido dos años desde la puesta en el mercado de las respectivas producciones ${ }^{542}$. Claro que, tal como GONZÁLEZ ORTÍZ se encarga de destacar, es posible para "las entidades productoras deducir la pérdida contabilizada antes del transcurso del plazo de dos años, siempre que se pruebe su efectivo deterioro" ${ }^{, 543}$.

En cuanto al fondo de comercio, si bien al igual que la propiedad intelectual es un inmovilizado inmaterial y como tal tiene un tratamiento equivalente, tal como dijimos al hablar de la amortización de los gastos de $\mathrm{I}+\mathrm{D}$ y del fondo de comercio, lo que puede resultar relevante para nuestro estudio, es solamente que podría estar

abonará a cuentas del grupo 39 «Deterioro de valor de las existencias», mientras que si la pérdida fuera irreversible minorarán el valor de las existencias finales".

539 Tomaron este nombre en el PGC de 2007.

540 Nóminas, recibos, escritura pública, sentencias judiciales, etc.

${ }^{541}$ Según GONZÁLEZ. Ob. supra cit., p. 2, es posible "deducir gastos imputables fiscalmente a un período impositivo anterior siempre que ello no determina una menor tributación de la que hubiera resultado por aplicación de los criterios fiscales de imputación temporal”.

542 Art. 12. 1. LIS.

${ }^{543}$ Ob. supra cit., p. 2. 
conformado por derechos de propiedad intelectual e incluso por algunos activos semejantes que pueden no tener protección legal, los que podrían incidir en la valoración del mismo y en la determinación de la existencia de un resultado de ganancia o pérdida a su respecto. En el evento que la propiedad intelectual no esté contabilizada de manera separada y sea un elemento que motiva la cuantificación del fondo de comercio, estará sometida al régimen éste, sin tener una existencia independiente.

El fondo de comercio no es amortizable contablemente, pero se admite la dotación de una pérdida por deterioro correspondiente a la depreciación de la participación imputable a ese fondo de comercio, siempre que se ponga de manifiesto como consecuencia de una disminución en el valor de la sociedad adquirida. Sin embargo, desde el punto de vista fiscal, el fondo de comercio es amortizable, conforme se cumplan con los requisitos establecidos en el art. 11. 4. LIS $^{544}$

\subsubsection{Reducción de ingresos procedentes de determinados derechos de propiedad intelectual. El llamado Patent Box}

El art. 23 TRLIS establece un mecanismo de trato preferente para la tributación de determinados ingresos provenientes de la explotación de algunos activos de propiedad intelectual, con el objetivo de favorecer la internacionalización de las sociedades innovadoras y de reducir la dependencia tecnológica del exterior de las empresas españolas.

Para el Ministerio de Economía y Competitividad de España, el sistema tiene por objeto, "ayudar a crear sinergias entre empresas generadoras de conocimiento, y empresas cuyo 'core business' (línea de negocio) sea la explotación y comercialización de productos. Fomenta el interés general en que las empresas españolas compartan conocimiento y se transfiera tecnología, en el contexto empresarial de "win-win

\footnotetext{
544 Los requisitos para la deducibilidad, son:

- Que se haya puesto de manifiesto en virtud de una adquisición onerosa.

- Que adquirente y transmitente no formen parte de un grupo mercantil (art 42 Código de Comercio).

- Dotación o compromiso de dotación de reserva indisponible para periodos con beneficios.

Hasta el ejercicio 2011, tributariamente el fondo de comercio era deducible en un $5 \%$ anual. En el año 2011 y para los ejercicios 2011, 2012 y 2013, el art. 12. 5. TRLIS (Texto refundido de la Ley de impuesto sobre sociedades), limitó al $1 \%$ la deducción en el caso de fondos de comercio en la adquisición de entidades no residentes.

Mediante Real Decreto 12/2012, la limitación de deducción al $1 \%$, se extendió a los ejercicios 2012 y 2013, y se amplió su ámbito de aplicación a cualquier fondo de comercio, esto es, tanto del generado en adquisiciones de cualquier tipo de negocios (art. 12.6 TRLIS), como en operaciones de restructuración empresarial (art. 89.3 TRLIS).
} 
situation" (ambas partes ganan), que para la Dirección General de Innovación y Competitividad redundará en la competitividad del sector empresarial español y en el crecimiento económico global, además de rentabilizar los apoyos públicos creados al respecto" ${ }^{, 545}$.

Este sistema tiene su antecedente en la Directiva Europea sobre "Intereses y Cánones" (2003/49/CE), que entendió que en el contexto de un mercado único, "las transacciones entre sociedades de diferentes Estados miembros no deberían estar sujetas a condiciones fiscales menos favorables que las que se aplican a las mismas transacciones cuando éstas tienen lugar entre sociedades del mismo Estado miembro" 546 , condición que, a juicio de la Directiva, no se estaba cumpliendo en lo que respecta a los pagos de intereses y cánones. La Directiva estimó que la supresión de los impuestos sobre los pagos de intereses y cánones en el Estado miembro en el que se generan, recaudados mediante retención a cuenta o por medio de la estimación de la base imponible, cuando se trata de operaciones entre sociedades vinculadas de diferentes Estados miembros o entre establecimientos permanentes, era la forma más efectiva de conseguir la buscada neutralidad fiscal.

La Directiva validó el sistema que ya poseía Irlanda desde $1973^{547}$ y que se ha ido extendiendo por la Unión Europea con diferentes denominaciones, tales como: Holanda (Innovation Box), Luxemburgo (LITL), Bélgica (Patent Income Deduction), España (Patent Box); Irlanda (Depreciation regime of Intangible Assets) ${ }^{548}$. En este contexto, España a través de correo electrónico de 14 de agosto de $2007^{549}$, en cumplimiento del artículo 88, apartado 3, del Tratado CE, notificó a la Comisión Europea su voluntad de implementar el beneficio fiscal que estamos analizando. La Comisión Europea se pronunció por medio del Oficio Bruselas, 13.II.2008, C (2008)

\footnotetext{
545 Presentación del Ministerio de Economía y Competitividad de España, denominada: Deducción por proyectos de $I+D+I T$ e informes motivados, patent box y novedades, Madrid 14 de junio, 2012. Disponible en Internet en:

http://www.ucam.edu/investigacion/transferencia-tecnologica/ucaminnova/financiacion/ incentivosfiscales-y-bonificaciones-por-i-d-i/Jornada14-06-2012Ministerio\%20deducciones\%20I-d.pdf (10 May 2013).

546 DIRECTIVA 2003/49/CE, del Consejo. Considerando (1).

${ }^{547}$ Fuente: http://www.clarkemodet.cl/Boletin/patent_box/espana_necesita_el_patent_box_.aspx, visitado en mayo de 2013.

${ }^{548}$ Fuente: http://www.iplusf.com/?ids=736, visitado en mayo de 2013 .

${ }^{549}$ Fuente: Oficio Bruselas, 13.II.2008, C(2008)467 final. Asunto: Ayuda de Estado n N 480/2007 España. Reducción del impuesto sobre activos intangibles.
} 
467 final, señalando que no venía inconveniente en que España implementara el sistema que proponía, puesto que no vulneraba el Tratado CE.

El sistema se volvió realidad por medio de la disposición adicional octava, apartado octavo, de la Ley 16/2007, de 4 de julio, de reforma y adaptación de la legislación mercantil en materia contable para su armonización internacional con base en la normativa de la Unión Europea, que vino a reformar el art. 23 TRLIS.

\subsubsection{Descripción del beneficio}

El beneficio del art. 23 TRLIS ${ }^{550}$ consiste en una reducción en un cuarenta por ciento de la base imponible generada por los ingresos brutos ${ }^{551}$ producidos por la cesión

${ }^{550}$ El Art. 23 TRLIS, en lo pertinente, señala: “1. Las rentas procedentes de la cesión del derecho de uso o de explotación de patentes, dibujos o modelos, planos, fórmulas o procedimientos secretos, de derechos sobre informaciones relativas a experiencias industriales, comerciales o científicas, se integrarán en la base imponible en un 40 por ciento de su importe, cuando se cumplan los siguientes requisitos:

a) Que la entidad cedente haya creado los activos objeto de cesión, al menos, en un 25 por ciento de su coste.

b) Que el cesionario utilice los derechos de uso o de explotación en el desarrollo de una actividad económica y que los resultados de esa utilización no se materialicen en la entrega de bienes o prestación de servicios por el cesionario que generen gastos fiscalmente deducibles en la entidad cedente, siempre que, en este último caso, dicha entidad esté vinculada con el cesionario.

c) Que el cesionario no resida en un país o territorio de nula tributación o considerado como paraíso fiscal, salvo que esté situado en un Estado Miembro de la Unión Europea y el sujeto pasivo acredite que la operativa responde a motivos económicos válidos.

d) Cuando un mismo contrato de cesión incluya prestaciones accesorias de servicios, deberá diferenciarse en dicho contrato la contraprestación correspondiente a los mismos.

e) Que la entidad disponga de los registros contables necesarios para poder determinar los ingresos y gastos, directos e indirectos, correspondientes a los activos objeto de cesión.

Lo dispuesto en este apartado también resultará de aplicación en el caso de transmisión de los activos intangibles referidos en el mismo, cuando dicha transmisión se realice entre entidades que no formen parte de un grupo de sociedades según los criterios establecidos en el artículo 42 del Código de Comercio, con independencia de la residencia y de la obligación de formular cuentas anuales consolidadas.

2. En el caso de cesión de activos intangibles, a los efectos de lo dispuesto en el apartado anterior, se entenderá por rentas la diferencia positiva entre los ingresos del ejercicio procedentes de la cesión del derecho de uso o de explotación de los activos, y las cantidades que sean deducidas en el mismo por aplicación de los artículos 11.4 o 12.7 de esta Ley, por deterioros, y por aquellos gastos del ejercicio directamente relacionados con el activo cedido.

No obstante, en el caso de activos intangibles no reconocidos en el balance de la entidad, se entenderá por rentas el 80 por ciento de los ingresos procedentes de la cesión de aquellos.

3. Esta reducción deberá tenerse en cuenta a efectos de la determinación del importe de la cuota íntegra a que se refiere el artículo 31.1.b) de esta Ley.

4. Tratándose de entidades que tributen en el régimen de consolidación fiscal, las operaciones que den lugar a la aplicación de lo dispuesto en este artículo estarán sometidas a las obligaciones de documentación a que se refiere el apartado 2 del artículo 16 de esta Ley.

5. En ningún caso darán derecho a la reducción las rentas procedentes de la cesión del derecho de uso o de explotación, o de la transmisión, de marcas, obras literarias, artísticas o científicas, incluidas las películas cinematográficas, de derechos personales susceptibles de cesión, como los derechos de imagen, de programas informáticos, equipos industriales, comerciales o científicos, ni de cualquier otro derecho o activo distinto de los señalados en el apartado 1". Según modificación introducida por 
a terceros de patentes y otros activos intangibles, expresamente señalados por la norma y que hayan sido creados por la empresa. Es decir, se trata de una deducción en la base imponible del impuesto, de manera que si la venta se efectuó por 100, solamente se considerarán 40, a efectos del Impuesto sobre Sociedades.

El beneficio tenía un tope, que implicaba que la reducción podrá aplicarse hasta el año en que la facturación supere el costo del desarrollo del intangible multiplicado por seis, según el RDL 4/2004, el que fue eliminado por la Ley 14/2013, de 27 de septiembre, de Apoyo a los Emprendedores y su Internacionalización. El límite contenido en la disposición del art. 23. 2. TRLIS, decía: "La reducción o se aplicará a partir del período impositivo siguiente a aquel en que los ingresos procedentes de la cesión de cada activo (...) superen el costo del activo creado, multiplicado por seis".

Es interesante señalar que este beneficio se extendió incluso a aquellos casos en que los activos intangibles no estén reconocidos en el balance, bajo la sanción que lo que se considerará renta no será el 40 por ciento de los ingresos, como es la regla general sino que el 80 por ciento ${ }^{552}$.

No existe norma alguna que establezca que por el hecho de aprovechar este beneficio se excluya la posibilidad de utilizar el descuento por actividades de $\mathrm{I}+\mathrm{D}+\mathrm{i}$ de que hablaremos más adelante. Esta disposición es compatible con las ventajas fiscales de que haya podido disfrutarse previamente, por el desarrollo de actividades de $\mathrm{I}+\mathrm{D}+\mathrm{i}$. Hay una plena compatibilidad con todas las deducciones, aunque tiene un carácter no acumulable, tampoco necesita serlo, porque como lo que hace es dejar de colacionar una utilidad a la base del impuesto, opera aun con una base imponible negativa ${ }^{553}$.

el apartado dos del artículo 26 de la Ley 14/2013, de 27 de septiembre, de apoyo a los emprendedores y su internacionalización.

551 A diferencia de lo que ocurre en otros países como: Holanda, Bélgica o Luxemburgo, donde el beneficio se aplica sobre la renta neta (ingresos menos gastos). Según Deloitte, Madrid, diciembre de 2012, p. 8. Disponible en Internet en: http://www.espaitec.uji.es/cmsupload/prensa/121210 Presentacion $\quad$ Instituto Ceramica 2 20121211094335.pdf (15 May 2013).

552 Art. 23. 2 TRLIS.

${ }^{553}$ En este sentido: una presentación del Ministerio de Economía y Competitividad de España, denominada: Deducción por proyectos de $I+D+I T$ e informes motivados, patent box y novedades, ob. supra cit., p. 39; una presentación de MADRID NETWORK, denominada: Nota sobre la reducción de ingresos a efectos tributarios por cesión a terceros de activos intangibles creados por la empresa. Disponible en Internet en:

https://www.yumpu.com/es/document/view/14585174/documento-madrid-network (30 Mar 2014); 
La ventaja para una empresa puede ser alta, aunque como veremos, implica que se deshaga de su innovación y obtenga una gran utilidad por ella, de otra manera el beneficio decrece. Para cuantificar los montos y hacernos una idea de su proporción, pensemos en una empresa que tributa a un tipo de treinta y cinco por ciento, las rentas provenientes de esta operación tributarían sobre un cuarenta por ciento por el treinta y cinco por ciento, lo que equivale a decir que pagarán un catorce por ciento. Lógicamente, que el cálculo es diferente a la situación vigente hasta la Ley 14/2013, de 27 de septiembre, que contemplaba el tope del séxtuplo del coste. A estos efectos, teniendo en cuenta lo que hemos hablado antes sobre los criterios contables versus los tributarios, encontramos un interesante ejemplo de coordinación sobre un caso concreto vinculado a la deducción que estudiamos, en la Consulta Vinculante V1299-08, considera "válidos los criterios fijados por la norma contable" ${ }^{, 554}$, procedimiento que por lo demás, es el "habitual con arreglo al ordenamiento jurídico español" que los criterios fijados por el PGC serán aplicables en la especie, resultando una homologación entre el criterio financiero y el fiscal, al menos a estos efectos.

SALUDES, FLORENTINO. Patent box, La estrategia fiscal de los activos intangibles. Presentación disponible en Internet en: www.iies.es/attachment/333494 (30 Mar 2014).

${ }^{554}$ La Consulta Vinculante V1299-08, en lo pertinente, dijo: "En aplicación de este precepto, puesto que la normativa fiscal no establece un concepto específico de activo intangible, se consideran válidos los criterios fijados en la norma contable. En este sentido, el Plan General de Contabilidad (PGC), aprobado por Real Decreto 1514/2007, de 16 de noviembre, define como activo 'los bienes, derechos y otros recursos controlados económicamente por la empresa, resultantes de sucesos pasados, de los que se espera que la empresa obtenga beneficios o rendimientos económicos en el futuro'.

Asimismo, las normas de registro y valoración $5^{\mathrm{a}}$ y $6^{\mathrm{a}}$ recogidas en la segunda parte del PGC recogen los criterios de reconocimiento y valoración del inmovilizado intangible, entre los que se incluyen los gastos de investigación y desarrollo. Precisamente, para estos gastos, la norma prevé como regla general su consideración como gasto del ejercicio, sin perjuicio de que puedan activarse como inmovilizado intangible si se cumplen las siguientes condiciones: - Estar específicamente individualizados por proyectos y su coste claramente establecido para que pueda ser distribuido en el tiempo.

- Tener motivos fundados del éxito técnico y de la rentabilidad económico-comercial del proyecto o proyectos de que se trate.

Por tanto, los gastos de investigación y desarrollo podrán figurar contabilizados como gastos del ejercicio o proceder a su activación por la entidad que los lleve a cabo de acuerdo con los criterios contables señalados. Este hecho, sin embargo, no afecta a su calificación como activos intangibles en la medida en que se cumple la definición de activo anteriormente señalada.

En consecuencia, dentro del coste de los activos intangibles cedidos a los que hace referencia el artículo 23 del TRLIS se incluirán los gastos de investigación y desarrollo incurridos para la obtención del activo, sin que resulte necesario que figuren activados en el balance de la entidad, en cumplimiento de los requisitos sobre registro contable establecidos en el PGC". Disponible en: http://petete.meh.es/Scripts/know3.exe/tributos/CONSUVIN/texto.htm?NDoc $=11740 \&$ Consulta $=. E N$ + +NUM-CONSULTA+(V1299-08)\&Pos $=0 \& U D=1$ (20 Mar 2014).

555 Oficio Bruselas, 13.II.2008, C (2008) 467 final. Ob. supra cit., p. 2. 


\subsubsection{Requisitos para el beneficio}

El Art. 23. 1. TRLIS que venimos analizando, establece las condiciones para la procedencia del beneficio, que son los siguientes:

a) Existencia de ingresos procedentes de la cesión del derecho de uso o explotación de un activo intangible de los expresamente señalados por la Ley ${ }^{556}$. Es indispensable que existan ingresos producto de la operación, puesto que, como hemos explicado, el beneficio consiste en la "no imputación" de la mitad de estos ingresos, no se trata de una devolución de impuesto, ni de un subsidio, por lo que si la transferencia se hace a título gratuito, esta ayuda fiscal será improcedente. Los ingresos deben provenir de cesión, no de la transmisión, ni de la asistencia técnica ${ }^{557}$.

b) Quien efectúa la cesión debe haber creado los activos cedidos al menos en un 25 por ciento de su coste ${ }^{558}$. Tiene que haber existido una actividad innovadora anterior, que dio origen al activo. No es indispensable que esté "activado" en términos contables, sino que se trate de un activo. La norma no distingue dónde deba efectuarse la investigación y desarrollo, como tampoco exige que se haya hecho directamente por el titular del derecho, exige que el cedente los haya creado y sea su titular al momento de cederlos ${ }^{559}$. En consecuencia, el desarrollo puede hacerse en España o en el extranjero, directamente por la empresa o encomendándoselo a un tercero;

c) El cesionario debe utilizar los derechos cedidos en el desarrollo de una actividad económica;

d) La producción efectuada con los derechos cedidos no puede vincularse a gastos fiscalmente aceptados de la entidad cedente, si están relacionadas ${ }^{560}$. El Oficio Bruselas, antes citado, explica que: "Los resultados del uso de los derechos cedidos no pueden materializarse en la entrega de bienes o prestación de servicios por el

556 Art. 23. 1. a) TRLIS.

${ }^{557}$ Presentación del Ministerio de Economía y Competitividad de España. Ob. supra cit., p. 40. Se establece que se acepta el arrendamiento operativo, pero no el financiero.

558 Art. 23. 1. a) TRLIS.

559 Esto queda claro al analizar el Oficio Bruselas, 13.II.2008, C(2008)467 final, Ob. Cit., pp. 2, que explicando que significa que la entidad cedente haya creado los activos objeto de cesión. señala: "Esto significa que la entidad cedente ha asumido los riesgos y beneficios derivados de la creación del activo intangible. Esto no significa, sin embargo, que los activos deban ser desarrollados material o físicamente por la propia empresa. Es perfectamente admisible externalizar y encargar a terceros la elaboración o creación de esos activos. No existe distinción territorial alguna de tal manera que el desarrollo efectivo de los activos intangibles puede ser efectuado por la propia empresa en España o en el extranjero o encomendado a terceros independientemente de si están establecidos en España o en otros países".

${ }^{560}$ Art. 23. 1. b) TRLIS. 
cesionario, que generen gastos fiscalmente deducibles en la entidad cedente, si ésta está vinculada con el cesionario" ${ }^{, 561}$. Tanto este requisito, como el anterior, tienen por objeto evitar que la vinculación entre las empresas se preste para la evasión fiscal, efectuando una cesión ficticia, que adicionalmente generará gastos fiscalmente $\operatorname{aceptados}^{562}$

e) El cesionario no debe residir en un país o territorio de nula tributación o considerado como paraíso fiscal, salvo que esté situado en un Estado Miembro de la Unión Europea y el sujeto pasivo acredite que la operativa responde a motivos económicos válidos. ${ }^{563}$. Los paraísos fiscales se establecen por Real Decreto, con la importante excepción que una jurisdicción puede estar en el Real Decreto, pero dejará de ser considerada como paraíso fiscal, cuando exista con España un convenio sobre intercambio de información en materia tributaria o un tratado para evitar la doble imposición con cláusula de intercambio de información ${ }^{564}$;

f) En el evento que en el contrato de cesión se incluyan prestaciones accesorias de servicios, debe diferenciarse lo correspondiente a la cesión y al servicio ${ }^{565}$. Sobre este requisito la Dirección General de Tributos ha interpretado que no es suficiente con que la diferenciación esté hecha en los asientos contables, puesto que debe figurar "en el contrato" 566 , tal como dice la norma;

g) La entidad que aprovecha el beneficio, debe disponer de los registros contables necesarios para poder determinar los ingresos y gastos, directos e indirectos,

${ }^{561}$ Oficio Bruselas, 13.II.2008, C (2008) 467 final. Ob. Cit., pp. 2.

${ }^{562}$ En este sentido explica el Oficio Bruselas, 13.II.2008, C (2008) 467 final. Ob. Cit., pp. 2.

${ }^{563}$ Art. 23. 1. c) TRLIS.

${ }^{564}$ Por el Real Decreto 1080/1991, de 5 de julio, se establecen los países o territorios a que se refieren los Art. 2. 3. No 4, de la Ley 17/1991, de 27 de mayo, de Medidas Fiscales Urgentes y Art. 62 de la Ley 31/1990, de 27 de diciembre, de Presupuestos Generales del Estado para 1991. El Art. 2, dice: "los países y territorios a los que se refiere el artículo 1 que firmen con España un acuerdo de intercambio de información en materia tributaria o un convenio para evitar la doble imposición con cláusula de intercambio de información dejarán de tener la consideración de paraísos fiscales en el momento en que dichos convenios o acuerdos entren en vigor".

565 Art. 23. 1. d) TRLIS.

${ }^{566}$ En la Consulta Vinculante 0252-09, la consultante plantea que registra en "su contabilidad analíticamente, diferenciando los distintos tipos de ingreso objeto del contrato (royalties obtenidos por la cesión de patente, prestaciones accesorias de servicios, fabricación de medicamentos) por lo que puede acreditarse la cantidad percibida por cada concepto", esperando que por ello se entienda cumplido el requisito del art. 23. 1. c) TRLIS; sin embargo, la DGT le contesta que: "Tal y como establece el citado artículo 23 del TRLIS cuando un mismo contrato de cesión incluya prestaciones accesorias de servicios, como ocurre en el caso planteado, deberá diferenciarse en dicho contrato tanto dichas prestaciones como la contraprestación correspondiente a las mismas. Dado que los contratos suscritos o que se van a suscribir por el consultante no diferencian las contraprestaciones correspondientes a la prestación de servicios accesorios que se realizan, los ingresos derivados de dichos contratos no podrán beneficiarse de la reducción contemplada en el artículo 23 del TRLIS”. 
correspondientes a los activos objeto de cesión ${ }^{567}$. Este requisito es una cuestión de toda evidencia en cualquier sistema tributario basado en la contabilidad, por lo demás se trata de la información que servirá de "base para que la propia empresa pueda identificar y calcular tanto los ingresos como gastos vinculados con los activos intangibles" ${ }^{\circ 68}$.

\subsubsection{Activos inmateriales beneficiados y excluidos}

Es importante dejar en claro, que el beneficio no está disponible para cualquier derecho de propiedad intelectual, ni para cualquier inmovilizado intangible. La ley hace una enumeración positiva y negativa de los mismos, señalando aquellos que hacen procedente el beneficio ${ }^{569}$ y los que excluye ${ }^{570}$ de su aplicación.

La reducción fiscal está claramente conceptualizada para beneficiar la actividad inventiva que tenga por objeto desarrollar un conocimiento que origine un quehacer industrial, lo que se deduce del hecho que se extiende taxativamente a los ingresos procedentes de la cesión del derecho de uso o de explotación de patentes, dibujos o modelos, planos, fórmulas o procedimientos secretos y derechos sobre informaciones relativas a experiencias industriales, comerciales o científicas, todos institutos directamente vinculados con el desarrollo del conocimiento científico aplicable en la industria. De este grupo, sólo conocemos con certeza cuál es el contenido de patentes, dibujos y modelos, puesto que se trata de institutos expresamente regulados por la legislación española ${ }^{571}$, de existencia registral y reconocimiento previo cumplimiento de un procedimiento normado; lo que no sucede con el resto de los activos mencionados, que tienen un contenido cuya precisión es, al menos, difícil de conseguir.

Analizaremos brevemente los activos incluidos y excluidos, puesto que su estudio en detalle lo haremos en el capítulo siguiente de nuestro trabajo.

\footnotetext{
567 Art. 23. 1. e) TRLIS.

${ }^{568}$ Oficio Bruselas, 13.II.2008, C (2008) 467 final. Ob. supra cit., p. 3.

${ }^{569}$ Art. 23. 1. TRLIS.

570 Art. 23. 5. TRLIS.

${ }^{571}$ Ley 11/1986, de 20 de marzo, de Patentes y su Reglamento, y Real Decreto Ley de 26 de julio de 1929, Estatuto sobre Propiedad Industrial.
} 


\section{III.2.2.4.3.1 Activos inmateriales beneficiados}

Pueden acogerse a la exención los ingresos procedentes de la cesión del derecho de uso o explotación, de: patentes, dibujos y modelos, planos, fórmulas o procedimientos secretos. Se incluyen los ingresos procedentes de derechos sobre informaciones relativas a experiencias industriales, comerciales o científicas ${ }^{572}$. Es necesario tener presente que la enumeración es taxativa.

El rendimiento que está beneficiado con el descuento legal es el que procede de la cesión del uso o explotación de los derechos que se poseen sobre alguno de los activos inmateriales que hemos mencionado, cuya determinación no representa problemas porque corresponde pura y simplemente al precio pagado. Los derechos objetos de cesión, pueden ser enajenados en su integridad o explotados a través de licencias o contratos que mantienen el control del derecho en el cedente. Es a partir de estas posibilidades de explotación y de la contraprestación que recibe el cedente ${ }^{573}$ que nace la base de cálculo para la aplicación del beneficio. Así las cosas, el margen de interpretación de la norma no se puede dar allí, puesto que representa un monto puro y simple, sino que las dificultades estarán en la definición del contenido de cada uno de los activos intangibles cuya cesión admiten el beneficio, por ello nos referiremos a cada uno de ellos brevemente.

\section{- Las Patentes}

Las patentes están reguladas en la Ley 11/1986, de 20 de marzo, de Patentes, sin embargo, la Ley no definió que es una patente, sino que en su art. 4.1, dice: "Son patentables aquellas invenciones nuevas que impliquen actividad inventiva y sean susceptibles de aplicación industrial". Por su parte, una invención es una solución a un problema de la técnica que origina un quehacer industrial.

En consecuencia, aquellas soluciones a un problema de la técnica que tengan actividad inventiva y origen un quehacer industrial, serán posibles de patentar, para lo cual deben cumplir un estricto procedimiento que culmina con el otorgamiento de un registro de patente. En este sentido, antes del registro únicamente puede existir una

\footnotetext{
572 Oficio Bruselas, 13.II.2008, C (2008) 467 final. Ob. supra cit., p. 2

573 Cuando se trata de licencias en el derecho español, se suele hablar de "canon", para referirse al precio de la licencia.
} 
solicitud de patente y la norma exige una "patente", por lo que para seguir el tenor literal de la disposición será necesario esperar a obtener la patente para poder cederla y aprovechar el beneficio, esa es nuestra opinión, puesto que otros como REY QUIROGA, sacan cuentas más alegres y sostiene que no es necesaria la existencia del registro de patente para poder aprovechar el beneficio ${ }^{574}$, posición con la que discrepamos, básicamente, porque si el legislador hubiese querido dar un contenido así de amplio al concepto lo habría hecho, tal como hizo al usar la expresión "derechos sobre informaciones relativas a experiencias industriales, comerciales o científicas" ubicada en la misma oración y porque implicaría dar un contenido excesivamente amplio al concepto, ya que al fin y al cabo, sería el contribuyente quién definiría qué entiende por patente.

Sin perjuicio de lo anterior, lo que creemos que si puede cederse sin que exista registro de patente, es el know how ganado con el desarrollo de la tecnología que permitió la innovación, pero su amparo lo encontramos en aquella frase que dice "derechos sobre informaciones relativas a experiencias industriales, comerciales o científicas" del apartado 1. del art. 23 LIS y no en la expresión "patentes", de la misma disposición legal.

Los arts. 4. 5. y 5 de la Ley de Patentes, establecen un listado sobre lo que no se considera invención y de aquellas cosas, que siendo invenciones, no son patentables ${ }^{575}$.

574 QUIROGA, REY. Guía sobre el régimen fiscal especial de Patent Box Español. Fiscalistas. Presentación disponible en Internet en: http://www.reyquiroga.com/Noticias/2012/Guia_patent_box.pdf (20 May 2013).

575 El Art. 4.5 LP, establece: "No se considerarán invenciones en el sentido de los apartados anteriores, en particular:

a) Los descubrimientos, las teorías científicas y los métodos matemáticos.

b) Las obras literarias, artísticas o cualquier otra creación estética, así como las obras científicas.

c) Los planes, reglas y métodos para el ejercicio de actividades intelectuales, para juegos o para actividades económico-comerciales, así como los programas de ordenadores.

d) Las formas de presentar informaciones.

El Art. 5 LP, indica: "No podrán ser objeto de patente:

1. Las invenciones cuya explotación comercial sea contraria al orden público o a las buenas costumbres, sin poderse considerar como tal a la explotación de una invención por el mero hecho de que esté prohibida por una disposición legal o reglamentaria.

En particular, no se considerarán patentables en virtud de lo dispuesto en el párrafo anterior:

a) Los procedimientos de clonación de seres humanos.

b) Los procedimientos de modificación de la identidad genética germinal del ser humano.

c) Las utilizaciones de embriones humanos con fines industriales o comerciales.

d) Los procedimientos de modificación de la identidad genética de los animales que supongan para estos sufrimientos sin utilidad médica o veterinaria sustancial para el hombre o el animal, y los animales resultantes de tales procedimientos. 
Estas últimas, al no poder llegar a ser patentes, no podrán servirse del beneficio, lo que a nuestro juicio no implica, que no pueda cederse el know how vinculado a investigaciones o trabajos sobre las materias excluidas de patentabilidad, puesto que el art. 23. 1. LIS, se refiere a "derechos sobre informaciones relativas a experiencias industriales, comerciales o científicas", sin exigir la vinculación a un conocimiento patentado o patentable.

Las patentes tienen una duración temporal limitada, normalmente 20 años desde la solicitud, por lo que una vez vencidas el título de patente estará caducado y no podría sostenerse que estemos frente a una "patente" para efectos del Art. 23 LIS, que analizamos. Atendida la temporalidad de la patente, también nos cabe la duda de qué sucede si la patente vence antes de completar el séxtuplo del coste, que constituye el límite para la aplicación del beneficio, ¿Puede continuarse con la imputación hasta completar el séxtuplo? o vencida la patente se extingue el beneficio. El asunto no está resuelto por la norma, por lo que sería una buena causal para requerir una consulta vinculante.

2. Las variedades vegetales y las razas animales. Serán, sin embargo, patentables las invenciones que tengan por objeto vegetales o animales si la viabilidad técnica de la invención no se limita a una variedad vegetal o a una raza animal determinada.

3. Los procedimientos esencialmente biológicos de obtención de vegetales o de animales. A estos efectos se considerarán esencialmente biológicos aquellos procedimientos que consistan íntegramente en fenómenos naturales como el cruce o la selección.

Lo dispuesto en el párrafo anterior no afectará a la patentabilidad de las invenciones cuyo objeto sea un procedimiento microbiológico o cualquier otro procedimiento técnico o un producto obtenido por dichos procedimientos.

4. El cuerpo humano, en los diferentes estadios de su constitución y desarrollo, así como el simple descubrimiento de uno de sus elementos, incluida la secuencia o la secuencia parcial de un gen.

Sin embargo, un elemento aislado del cuerpo humano u obtenido de otro modo mediante un procedimiento técnico, incluida la secuencia total o parcial de un gen, podrá considerarse como una invención patentable, aun en el caso de que la estructura de dicho elemento sea idéntica a la de un elemento natural.

La aplicación industrial de una secuencia total o parcial de un gen deberá figurar explícitamente en la solicitud de patente". 
- $\quad$ Los modelos de utilidad ${ }^{576}$

Los modelos de utilidad, son para Ley 11/1986, de Patentes, "aquellas invenciones que, siendo nuevas e implicando una actividad inventiva, consisten en dar a un objeto una configuración, estructura o constitución de la que resulte alguna ventaja prácticamente apreciable para su uso o fabricación" ${ }^{\text {577 }}$. Los modelos de utilidad son conocidos como invenciones menores, en alusión a un menor nivel de desarrollo y complejidad respecto a una patente, normalmente se trata de productos como utensilios, herramientas, accesorios, etc. Los requisitos sustantivos son: el modelo de utilidad debe tener una ventaja o resultado útil ${ }^{578}$ y ser novedoso, no obstante que la evaluación de la novedad se efectúa solamente a nivel nacional en España ${ }^{579}$.

En cuanto al régimen jurídico de los modelos de utilidad, es estructuralmente el mismo que una patente, se diferencian porque tienen un menor tiempo de protección (diez años desde la solicitud ${ }^{580}$ ) y su procedimiento de registro es simple, por lo tanto, lo dicho para las patentes es aplicable a los modelos de utilidad.

${ }^{576}$ La Ley 11/1986 de Patentes, norma a las patentes y a los modelos de utilidad, por lo que puede entenderse que el art. 23 LIS al hablar de "patentes" se refiere a la ley de patentes y por tanto, incluye tanto a las patentes y a los modelos de utilidad; sin embargo, también podría pensarse que la norma del art. 23 LIS, únicamente se refiere a los títulos de patente de invención y no a los modelos de utilidad, en cuyo caso, estos últimos no podrían ser objeto del beneficio. A nuestro juicio, los modelos de utilidad cumplen con la motivación de este estímulo, puesto que están directamente destinados a proteger una actividad inventiva que tiene aplicación en la industria, por lo que no habrían razones para entenderlos excluidos del beneficio. En el mismo sentido, la totalidad de los documentos que hemos consultado y previamente mencionado, en ningún caso excluyen o advierten la posibilidad que los modelos de utilidad hayan estado fuera de la idea matriz del legislador. Por ello, hemos compartido la opinión de MADRID NETWORK, Ob. supra cit., p. 2, que se hace cargo de los modelos de utilidad asumiendo que están incluidos en la disposición del art. 23 LIS.

577 Art. 143. 1. LP.

${ }^{578}$ Art. 143. 1. LP.

579 Art. 146 LP.

580 Art. 152 LP. 
- $\quad$ Los dibujos o modelos ${ }^{581}$

El art. 23 de LIS, habla de "dibujos o modelos", con lo que se está refiriendo a los diseños industriales, que corresponde al género para esas dos especies (dibujos y modelos) de propiedad industrial, regulados en la Ley 20/2003, de 7 de julio, de Protección Jurídica del Diseño Industrial ${ }^{582}$, que expresa que "a efectos de esta ley se entenderá por: a) Diseño: la apariencia de la totalidad o de una parte de un producto, que se derive de las características de, en particular, las líneas, contornos, colores, forma, textura o materiales del producto en sí o de su ornamentación”,583.

De la lectura podemos advertir una diferencia terminológica, mientras el art. 23 LIS, se refiere a "patentes ${ }^{584}$, dibujos o modelos...", la Ley 20/2003, donde se contiene la regulación sustantiva de los "dibujos" "585 y "modelos", se denomina "de Protección Jurídica del Diseño Industrial”. Esta posible confusión la previó el legislador, no obstante la desestimó, lo que queda claro al leer el siguiente párrafo de la exposición de motivos de la ley citada, que dice: "[L]a distinción entre modelos y dibujos industriales, correspondiente a los diseños tridimensionales y bidimensionales respectivamente, no

${ }^{581}$ Las denominaciones en este punto pueden ser confusas, no obstante el objeto al que se refieren es el mismo. En este sentido, un ejemplo del diferente manejo conceptual que se da al interior de la UE, lo encontramos en Internet en:

http://www.protectia.eu/blog/disenos-industriales/registro-de-diseno-industrial-diferencia-entremodelos-y-dibujo-industrial/ (20 May 2013). Allí se señala: "En el caso de registros comunitarios tramitados en la OAMI (agencia europea responsable del registro de marcas, dibujos y modelos válidos en los 27 Estados de la UE) se habla de modelos y dibujos industriales, en España, por ejemplo, la OEPM (oficina española de patentes y marcas) habla de diseños industriales y en el caso de la OMPI (Organización Mundial de la Propiedad Intelectual) vuelve a hablarse de modelos y diseños".

${ }^{582}$ La definición más comúnmente usada de "diseño industrial", dice que corresponde a: "todo tipo de innovación formal referida a las características de apariencia del producto o de su ornamentación. Es decir, todo objeto que pueda servir de tipo para la fabricación de un producto y que pueda describirse por su estructura, configuración, ornamentación o representación".

583 Art. 1. 2. a) de la Ley 20/2003, de 7 de julio, de Protección Jurídica del Diseño Industrial.

${ }^{584}$ Recordemos que a propósito de la expresión "patentes" se presentó un problema similar al que analizados, puesto que nos cabe la duda si por "patentes" se entiende patentes y modelos de utilidad o solamente las primeras.

${ }^{585}$ En el sitio web www.protectia.ue se aloja una buena explicación de qué se entiende por modelo industrial y dibujo industrial.

Modelo industrial "es un objeto espacial, tridimensional, que ocupa un lugar en el espacio. En este ámbito, el producto toma cuerpo en la misma forma que se les da. Por tanto su geometría espacial es su característica principal. Dentro de esta categoría entrarían por citar algunos ejemplos el mobiliario (mesas, sillas, armarios), el menaje (vasos, platos, floreros, etc.), la marroquinería (bolsos, cinturones, etc.), etc.".

El dibujo industrial se sitúa en un plano y consiste en cierta combinación de líneas o colores y carece de una existencia propia, consiste en una creación inseparable de un producto al que se le aplica con fines de ornamentación (estampados, encajes, alfombras, tapices, porcelanas, cerámicas, etc.) con el propósito de aumentar su belleza, individualidad, o valor respecto a otros objetos semejantes sin aumentar su utilidad". 
se traduce realmente en un tratamiento legal diferenciado, y además el término modelo se aplica también a una figura distinta, los modelos de utilidad. Por ello se ha preferido utilizar el término diseño industrial, que es el empleado en el lenguaje común para designar la forma proyectada para los objetos de uso que serán fabricados en serie. El mantenimiento de la terminología tradicional en la versión española de los convenios internacionales vigentes y de la legislación comunitaria [no debería plantear ningún problema de interpretación] (...)”.

Las condiciones de registro de los diseños industriales, a decir de la exposición de motivos de la Ley 20/2003 son "puramente objetivas: la cobertura legal alcanza a los diseños dotados de novedad y singularidad según los criterios adoptados por la directiva comunitaria. En aplicación de estos criterios se registran los diseños que producen en el usuario informado una impresión de conjunto diferente a la de los demás diseños, y que, en el momento en que se solicita la protección, no hayan podido llegar a ser conocidos en el curso normal de los negocios por los círculos especializados en el sector de que se trate que operan en la Comunidad Europea”. El registro puede alcanzar a diseños puramente ornamentales y también a los que tenga una utilidad, salvo que sus "características vengan exclusivamente impuestas por su función técnica" ${ }^{586}$, en ese caso pueden dar lugar a un modelo o una patente. Así las cosas, en un diseño lo que se protege es la forma externa, separada de la función, no obstante pueda corresponder a un aparato funcional; por eso, el diseño en sí mismo es una expresión que protege las características de la apariencia siempre que sea novedosa, singular y no haya sido accesible $^{587}$ al público antes de su registro ${ }^{588}$.

El registro del diseño se concede por períodos de cinco años, renovables hasta veinticinco $^{589}$. El registro otorga a su titular el derecho a la utilización exclusiva del diseño y a impedir la utilización del diseño por terceros, junto a acciones penales de protección $^{590}$.

\footnotetext{
${ }^{586}$ Exposición de motivos de la Ley 20/2003.

${ }^{587} \mathrm{La}$ "accesibilidad al público" tiene que ver con que el diseño no se haya publicado, expuesto o comercializado.

${ }^{588}$ Sin perjuicio de que exista un plazo de gracia de 12 meses, "durante el cual la divulgación del diseño realizada por el autor, su causahabiente, o un tercero como consecuencia de la información facilitada por ellos, no perjudica la posibilidad de registro por su legítimo titular". Exposición de motivos Ley 20/2003.

589 Art. 43 de la Ley 20/2003, de 7 de julio, de Protección Jurídica del Diseño Industrial (LPJDI).

${ }^{590}$ Art. 52 y 53 LPJDI.
} 
- Topografías de productos semiconductores

Un producto semiconductor está caracterizado principalmente por su topografía, la estructura y disposición de los elementos, permiten las funciones para las que es creado. Las distintas capas que componen el circuito integrado, dan lugar a su diseño o "topográfica" como normalmente se le conoce, son lo que les aporta valor y motiva a su protección. El esfuerzo creativo en su diseño se protege por medio de la Ley 11/1988, de 3 de mayo, de Protección Jurídica de las Topografías de los Productos Semiconductores ${ }^{591}$.

La protección de un producto semiconductor está condicionada a la obtención de un registro, lo que se logra por un procedimiento rápido, de simple depósito, a cargo de la Oficina Española de Patentes y Marcas. La duración de la protección tiene límites establecidos en la ley ${ }^{592}$. En el evento de existir un registro, el plazo es de diez años desde la correcta presentación de la solicitud.

${ }^{591}$ El Art. 1 de la Ley 11/1988, de 3 de mayo, de Protección Jurídica de las Topografías de los Productos Semiconductores. Contiene una definición de producto semiconductor y de topografía de producto semiconductor, al señalar: "1. Producto semiconductor, la forma final o intermedia de cualquier producto:

a) constituido por un sustrato que incluya una capa de material semiconductor,

b) que tenga una o más capas suplementarias de materiales conductores, aislantes o semiconductores, dispuestas en función de una estructura tridimensional predeterminada, y

c) destinado a desempeñar, exclusivamente o junto con otras funciones, una función electrónica.

2. Topografía de un producto semiconductor, una serie de imágenes interconectadas, sea cual fuere la manera en que estén fijadas o codificadas:

a) que representen la estructura tridimensional de las capas que componen el producto semiconductor,

b) en la cual cada imagen tenga la estructura o parte de la estructura de una de las superficies del producto semiconductor en cualquiera de sus fases de fabricación".

592 El art. 7 de la Ley 11/1988, de 3 de mayo, de Protección Jurídica de las Topografías de los Productos Semiconductores, establece: " 1 . Los derechos exclusivos contemplados en el artículo 2 nacerán en la primera en el tiempo, de las fechas siguientes:

a) En la que la topografía ha sido objeto de explotación comercial por primera vez en cualquier lugar del mundo.

b) En la que se haya presentado la solicitud de registro en debida forma.

2. Los derechos exclusivos expirarán transcurridos diez años, contados a partir de la primera en el tiempo de las siguientes fechas:

a) El fin del año en el que la topografía ha sido objeto de explotación comercial por primera vez en cualquier lugar del mundo.

b) El fin del año en el que se haya presentado la solicitud de registro en debida forma.

No obstante, quedará sin efecto todo registro relativo a una topografía que no haya sido objeto de explotación comercial en ningún lugar del mundo en el plazo de quince años, contados a partir de la fecha de su primera fijación o codificación". 
- Planos, fórmulas, procedimientos secretos, informaciones

El art. 23 LIS, establece un último grupo de institutos cuya cesión puede dar origen a la reducción de ingresos que el mismo artículo trata, son los "planos, fórmulas o procedimientos secretos, de derechos sobre informaciones relativas a experiencias industriales, comerciales o científicas". Este conjunto de conceptos, no tiene un contenido del todo claro, planos y procedimientos secretos son los más preciso de todos ellos, sin embargo no parece razonable interpretarlos de un modo literal, en el sentido que no es suficiente que se trate de la venta de un plano o un procedimiento secreto cualquiera, sino que deben estar vinculados a una innovación y a un real quehacer industrial.

En la búsqueda de encontrar un contenido más específico a estos conceptos, la Comisión Europea ${ }^{593}$, sistematiza el objeto del beneficio como: patentes; dibujos y modelos; planos; fórmulas o procedimientos secretos, incluyendo en este último grupo los ingresos procedentes de derechos sobre informaciones relativas a experiencias industriales, comerciales o científicas. En otros casos, los autores engloban "planos, fórmulas o procedimientos secretos, de derechos sobre informaciones relativas a experiencias industriales, comerciales o científicas", dentro de concepto general de know-how ${ }^{594}$. Para nosotros la referencia al know-how es útil, puesto es un concepto conocido, con un desarrollo que se ha extendido a la doctrina y particularmente, en el contexto del MC OCDE, lo que permite aumentar la certeza de su contenido ${ }^{595}$, si bien sabemos lo complejo que esto puede ser. A todo evento, nunca debemos perder de vista que el legislador no habló de know-how, por lo que no puede confiarse sólo en la doctrina para entender cumplidas las exigencias del art. 23 LIS y considerar al knowhow bajo su amparo.

Desde otro punto de vista, la referencia al know-how, tampoco salva los problemas interpretativos que presenta la frase del art. 23 LIS que venimos analizando, sino que simplemente los cambia, ya que, éste en sí mismo es un concepto cuyo

\footnotetext{
${ }^{593}$ Oficio Bruselas, 13.II.2008, C (2008) 467 final. Ob. Cit., pp. 1.

${ }^{594}$ QUIROGA. Ob. Cit., pp. 2. MADRID NETWORK. Ob, Cit., pp. 4.

${ }^{595}$ Además, que desarrollaremos el concepto en detalle en el próximo capítulo de nuestro estudio.
} 
contenido no es preciso ${ }^{596}$. Una de las definiciones más difundidas del know-how, es la de la Association des Bureaux pour la Protection de la Propriété Industrielle (ANBPI), que lo conceptualiza como: "el conjunto no divulgado de informaciones técnicas, patentables o no, que son necesarias para la reproducción industrial, directamente y en las mismas condiciones, de un producto o de un procedimiento; puesto que procede de la experiencia, el know-how representa lo que un industrial no puede conocer por el solo examen del producto y el mero conocimiento del progreso de la técnica".

Los conocimientos técnicos de la empresa, no están patentados, si se mantienen en reserva, ya sea que se trate de experiencias industriales, comerciales o científicas, caben dentro de la descripción del art. 23 LIS; sin embargo al tratarse de experiencias y conocimiento, es muy fácil confundirlos con asesorías técnicas, lo que pone una dosis adicional de incertidumbre a la definición exacta del objeto beneficiado por la reducción que nos ocupa. Por lo tanto, "la calificación jurídica que se haga del concreto elemento de propiedad industrial o de la actividad efectivamente realizada resulta esencial para determinar la posibilidad de acoger las rentas a la reducción fiscal”597.

La diferenciación entre know-how y prestación de servicios, afortunadamente ya ha sido abordada por la DGT, siguiendo parámetros uniformemente aceptados para distinguirlos $^{598}$, lo que permite aportar claridad a su contenido. La DGT ha dejado claro

${ }^{596}$ A modo de ejemplo, podemos encontrar un desarrollo del concepto de know-how en: las consultas a la DGT, la interpretación del MC CDE, el Manual de Frascati, el Manual de Camberra, el Manual de Oslo y en la doctrina.

${ }^{597}$ MADRID NETWORK. Ob. supra cit., p. 4.

598 En la Consulta Vinculante 0787-09, una empresa preguntaba si estarían beneficiados con la reducción del art. 23 LIS, los ingresos derivados de los acuerdos para la puesta en práctica de conocimientos tecnológicos (que la empresa poseía) en la instalación de plantas industriales para la elaboración de cobre.

Para la DGT, debe seguirse la "la jurisprudencia del Tribunal Supremo (entre otras, STS de 30 de mayo de 2002; de 19 de diciembre de 2002 o de 2 de octubre de 1999), resultando imprescindible distinguir los contratos de cesión o licencia de know-how (saber hacer) de los contratos de asistencia técnica, siendo ambos dos modalidades diferenciadas del contrato de transferencia de tecnología". Por una parte, "en virtud de los contratos de cesión o licencia de know-how-, una de las partes se obliga a comunicar a la otra parte sus conocimientos y experiencias específicos, no revelados al público, de manera que pueda utilizarlos por su cuenta, sin que el cedente o licenciante intervenga en el uso que el cesionario o licenciatario haga de la información suministrada", por la otra, "por asistencia técnica se entiende la ayuda especializada que el comerciante o industrial recibe de un tercero para la mejor realización de la actividad que le incumbe. La asistencia técnica puede tener lugar a través de muy diversas prestaciones; (...) puede consistir en la asunción de una fase (o de parte de una fase) del proceso por quien la presta (...)". Lo más característico de la asistencia técnica es que "una de las partes se obliga, apoyada en los conocimientos usuales de su profesión, a hacer ella misma una obra o a prestar algún servicio para la otra parte, quedando por tanto sometida a una obligación de resultado". En el caso, la DGT observó que el consultante estaba asumiendo una obligación de resultado en la instalación de las plantas industriales, por lo que consideró que estaba frente a una prestación de 
que el elemento central para distinguir entre la transferencia de know how y los servicios de asistencia técnica, se encuentra en determinar si el prestador del servicio asume o no una obligación de resultado en la aplicación del conocimiento transferido. En esa medida, si se trata de la sola transferencia del conocimiento adquirido por la experiencia del cedente, estamos frente a la transferencia del know-how; de otra parte, si la cesión del conocimiento implica la actividad material del cedente y la asunción de un determinado resultado esperado, se trata de una prestación de servicios de asistencia técnica que no está beneficiada con el art. 23 LIS.

\section{III.2.2.4.3.2 Activos inmateriales excluidos}

La lista de bienes respecto de los cuales los rendimientos de su cesión pueden acogerse a la reducción del art. 23 LIS, tal como ya hemos dicho, es exhaustiva, de manera que de no tratarse de un bien allí enumerado, simplemente el beneficio no opera. No obstante, la LIS en el art. 23. 5, ha querido ser reiterativa, estableciendo un listado de ejemplos de bienes cuya cesión en ningún caso dará derecho a la reducción. Esta enumeración podría entenderse innecesaria, puesto aquello que no forma parte de la descripción del beneficio, conforme al principio de legalidad, no puede entenderse comprendido en él; sin embargo, desde nuestra perspectiva la enumeración es beneficiosa, porque permite conformar la estructura del beneficio, cuyo centro se cierra en función de estimular aquellas actividades innovativas que originen un quehacer industrial.

Desde el inicio de este trabajo hemos venido analizando lo difícil que es encontrar los bordes de la propiedad intelectual y de los institutos que la componen,

servicios de asistencia técnica y no a la transferencia del know-how, de manera que, la operación no estaba beneficiada con la reducción del art. 23 LIS.

En la Consulta Vinculante 2100-09, el consultante dice tener como actividad principal la cesión de uso, especialmente en régimen de franquicia de diferentes tipos de bienes, entre ellos patentes y otros intangibles. Consulta si los ingresos de su actividad están beneficiados con la franquicia del Art. 23 LIS. En este caso, si bien la DGT no responde la consulta, deja claro que su criterio para distinguir es la asunción de responsabilidad por parte del prestador del servicio, al decir: "En relación con las diferentes fuentes de ingresos derivados, entre otros, de la prestación a los franquiciados, todos ellos residentes en España, de determinados servicios, así como de la enseñanza de determinadas técnicas y metodología, cabe señalar que no existe información suficiente para determinar si las diferentes prestaciones realizadas por la consultante pueden calificarse como cesión de know-how o como prestación de asistencia técnica, en la medida en que no existe información acerca de si la consultante queda o no sometida a una obligación de resultado respecto de los franquiciados, por lo que este Centro Directivo no puede pronunciarse sobre si procede o no la aplicación de la reducción prevista en el artículo 23 del TRLIS respecto de dichos ingresos". 
circunstancia que se acentuará cuando entremos a analizar el contenido y extensión de la propiedad intelectual en el contexto de la tributación internacional, todo lo cual demuestra la utilidad del apartado quinto del art. 23 LIS, en cuanto deja en claro que, aquellos activos de propiedad intelectual que no estén directamente relacionados con la actividad fabril, no están alcanzados por la norma.

La disposición del art. 23. 5. LIS, enumera como activos cuya cesión nunca dará derecho a la reducción a: "marcas, obras literarias, artísticas o científicas, incluidas las películas cinematográficas, de derechos personales susceptibles de cesión, como los derechos de imagen, de programas informáticos, equipos industriales, comerciales o científicos, ni de cualquier otro derecho o activo distinto de los señalados en el apartado $1,, 599$.

\subsubsection{Límite de la deducción por doble imposición internacional}

El art. 23. 3. LIS, refiriéndose a la reducción que venimos analizando, dice: "Esta reducción deberá tenerse en cuenta a efectos de la determinación del importe de la cuota íntegra a que se refiere el art. 31. 1. b) de esta Ley". Con esta fórmula enigmática, lo que está haciendo la disposición es poner un límite a la deducción por doble imposición internacional y a la vez, permitir que se haga efectiva la reducción en el caso de rentas obtenidas en el extranjero que hayan pagado impuesto en la fuente.

El art. 31 LIS, prevé que cuando en la base imponible del sujeto pasivo se integren rentas obtenidas y gravadas en el extranjero, se deducirá de la cuota íntegra, cuando sea el caso, el importe de la cuota íntegra que en España correspondería pagar por las mencionadas rentas si se hubieran obtenido en territorio español. De suerte que, como en España, a consecuencia de la reducción, el importe de la cuota íntegra está aminorado en un cincuenta por ciento, la deducción del impuesto extranjero aplicada en la declaración del Impuesto sobre Sociedades no podrá exceder del quince por ciento de la renta obtenida o lo que es lo mismo, del cincuenta por ciento del tipo español de treinta por ciento.

${ }^{599}$ En el apartado 1., están los activos que dan derecho a la reducción, de aquí que se deduce que el apartado 1. debe ser interpretado como de numerus clausus. 


\subsubsection{Entidades en consolidación fiscal}

El art. 23. 4. LIS, se hace cargo de las entidades que tributen en régimen de consolidación fiscal y los efectos que la deducción produce en esas circunstancias, admitiendo su aplicación, al señalar: "Tratándose de entidades que tributen en el régimen de consolidación fiscal, las operaciones que den lugar a la aplicación de lo dispuesto en este artículo estarán sometidas a las obligaciones de documentación a que se refiere el apartado 2 del artículo 16 de esta Ley" ${ }^{\prime 600}$. Claro está que no lo dice asertivamente, no obstante, desde el momento que las somete a las obligaciones de control de documentación, acepta que en el evento que se pueda demostrar y acreditar la operación, la deducción es procedente.

Las consecuencias de esta norma son de un gran beneficio para los grupos empresariales, puesto que de no existir, podría haberse pensado que el beneficio no se aplicaba en operaciones entre relacionados y de hecho habría desaparecido por el efecto contable de la consolidación fiscal. Con la norma descrita se logra que el grupo aproveche la integridad de los gastos que demandó el desarrollo que originó el derecho que se cede y los ingresos se incorporaren en el cedente sólo por su mitad. De manera que, si la cesión se hace a terceros ajenos o a miembros del grupo fiscal, igualmente se aprovechará el beneficio. La DGT ha tenido la oportunidad de pronunciarse aceptando este procedimiento en Consulta Vinculante V0579-0 $09^{601}$.

\subsubsection{La modificación del Impuesto sobre Sociedades de la Ley 35/2006}

El Real Decreto Legislativo 4/2004, de 5 de marzo, por el que se aprueba el texto refundido de la Ley del Impuesto sobre Sociedades, dio inicio a un proceso de modificaciones en el régimen del Impuesto sobre Sociedades, en lo que a nosotros interesa, comenzó a apreciarse la voluntad del legislador de reducir las tasas de

${ }^{600}$ Art. 23. 3. LIS.

${ }^{601}$ En la Consulta V-0579-09, la consultante es una empresa dedicada a la fabricación de calzados, que plantea que su actual departamento de desarrollo se independice formando una empresa diferente, la que tendrá por objeto hacer los desarrollos y posteriormente se los cedería a la consultante. Los signos distintivos no variarán, pero la nueva entidad llevará una "contabilidad por proyecto, de forma que podrán identificarse todos los gastos e ingresos, directos e indirectos, correspondientes a cada modelo de calzado concreto". Ante la consulta la DGT es clara en señalar que la aplicación del Art. 23 LIS es procedente, al decir: "En particular, en caso de que las entidades cedente y cesionaria formen parte de un grupo que haya optado por tributar en régimen de consolidación fiscal, el artículo 23.4 del TRLIS, en su nueva redacción, prevé que los ingresos y gastos derivados de la correspondiente cesión no sean objeto de las eliminaciones intra-grupo previstas en los artículos 71 y 72 del TRLIS, con el fin de que la sociedad cedente pueda aplicar en el mismo ejercicio de la cesión la reducción del $50 \%$ del artículo 23 del TRLIS". 
bonificaciones, lo que puede apreciarse en la Disposición adicional novena, que contiene un calendario de reducción de los tipos impositivos desde el 2007 al 2013, para la bonificación de actividades exportadoras y en la Disposición adicional décima, que contiene otro calendario de reducción para otras deducciones.

La Ley 35/2006, de 28 de noviembre, del Impuesto sobre la Renta de las Personas Físicas y de modificación parcial de las leyes de los Impuestos sobre Sociedades, sobre la Renta de no Residentes y sobre el Patrimonio, tuvo por objeto introducir modificaciones en el sistema tributario español, dentro de las cuales, en lo que a nuestro estudio implica, destaca la voluntad del legislador de eliminar progresivamente casi la totalidad de las deducciones para incentivar la realización de determinadas actividades ${ }^{602}$, del Capítulo IV, Arts. 35 a 44 del TRLIS, de manera que en el año 2011 habrían desaparecido la mayor parte de ellas y las restantes en los años 2012 y 2014. El objetivo declarado en el Preámbulo de la Ley es no distorsionar la libertad de movimiento de capitales, bienes y servicios.

La derogación de las deducciones para incentivar ciertas actividades, afecta derechamente al objeto de nuestro estudio, puesto que muchas de ellas están relacionadas con activos intangibles y específicamente con la propiedad intelectual, en esa medida surge la necesidad de preguntarse si es necesario entrar al estudio de ellas o si debemos pasarlas por alto, atendida su corta o nula expectativa de supervivencia. Estimamos que si bien con menor grado de atención, igualmente es conveniente que estudiemos el contenido de cada una ellas, puesto que, como sabemos, toda esta parte de nuestro estudio es instrumental, tiene por objeto adquirir las herramientas para efectuar una correcta evaluación de qué se ha entendido por propiedad intelectual en cada país, lo que implica también comparar las variaciones que pueden haber existido -en el evento que existan- en la propiedad intelectual, en diferentes contextos impositivos. En consecuencia, a fin de determinar si la naturaleza jurídica de la propiedad intelectual ha sido un factor relevante a considerar, decidimos arremeter con el estudio de las deducciones. De esta manera, avanzado que sea el estudio, podríamos encontrar referencias a las deducciones en comento, puedan resultar de utilidad para entender el contexto general sobre el que trabajamos o que simplemente se trate de consideraciones importantes a la hora de efectuar conclusiones.

602 Originalmente sólo iban a subsistir la Deducción por creación de empleo para trabajadores minusválidos, del Art. 41 TRLIS y la Deducción por inversión de beneficios extraordinarios. 


\subsubsection{Bonificación ${ }^{603}$ por actividades exportadoras y de prestación de servicios públicos locales}

En el texto del Art. 34 TRLIS se establece una bonificación por actividades exportadoras, consistente en un descuento del $99 \%$, de la parte de la cuota íntegra derivada de las rentas procedentes de la actividad exportadora ${ }^{604}$ de producciones cinematográficas o audiovisuales y manifestaciones editoriales de carácter didáctico, con tal que se reinviertan, conforme lo dispone la propia ley. Sin embargo, la propia Ley en su Disposición adicional novena, en consonancia con lo que venimos advirtiendo sobre la idea del legislador de eliminar bonificaciones y deducciones, estableció una tabla de disminución de la alícuota del impuesto, de manera que al año 2011 el descuento era del 38\% y desde el 2012 del 25\% ${ }^{605}$. Finalmente, por aplicación de la Ley 35/2006, de 28 de noviembre, del Impuesto sobre la Renta de las Personas Físicas y de modificación parcial de las leyes de los Impuestos sobre Sociedades, sobre la Renta de no Residentes y sobre el Patrimonio, se derogó el Art. 34. 1. que contiene el beneficio que nos ocupa, con efectos para los períodos impositivos que se inicien a partir de 01 de enero de 2014. Por lo que, en lo que a la bonificación por actividades exportadoras vinculadas a la propiedad intelectual, se mantiene la premisa del legislador de derogar los beneficios que le favorecen, lo que se hará efectivo a contar del 2014, de manera que el 2013 con tasa del 13\% sería el último ejercicio en que se podría disfrutar de la bonificación.

${ }^{603}$ Es primera vez durante nuestro estudio que topamos con la voz "bonificación", por lo que estimamos apropiado hacer una pequeña aclaración sobre su contenido. Técnicamente unas bonificaciones son "aquellos institutos sustractivos que operan sobre una porción de la cuota tributaria y que son expresión de una norma promocional, de carácter derogatorio, que genera posiciones preferentes en sujetos afectados por su incidencia, y que en esencia, constituyen un auténtico gasto fiscal". Según la definición de VELARDE ARAMAYO, MARÍA SILVIA, en Beneficios y Minoraciones en Derecho Tributario, Marcial Pons, Madrid, 1997, pp. 106.

${ }^{604}$ De haber existido subvenciones en el proceso productivo estas deben ser descontadas previo a la determinación del beneficio.

${ }^{605}$ El legislador formuló la disminución de las tasas de la manera más intrincada que pudo, puesto que en vez de fijar la tasa para cada año, estableció un factor para multiplicar por la tasa que originalmente planteaba en 99\%. De manera que la Disposición adicional novena TRLIS Real Decreto Legislativo 4/ 2004, de 05 de marzo, establece que la "bonificación regulada en el apartado 1 del artículo 34 de esta Ley se determinará multiplicando el porcentaje de bonificación establecido en dicho apartado por el coeficiente siguiente:

0.875, en los períodos impositivos iniciados a partir de 1 de enero de 2007.

0.750 , en los períodos impositivos iniciados a partir de 1 de enero de 2008 .

0.625 , en los períodos impositivos iniciados a partir de 1 de enero de 2009 .

0.500, en los períodos impositivos iniciados a partir de 1 de enero de 2010.

0.375 , en los períodos impositivos iniciados a partir de 1 de enero de 2011 .

0.250 , en los períodos impositivos iniciados a partir de 1 de enero de 2012.

0.125 , en los períodos impositivos iniciados a partir de 1 de enero de 2013 .

El porcentaje de bonificación que resulte se redondeará en la unidad superior. 


\subsubsection{Rentas beneficiadas}

Las rentas beneficiadas son las procedentes de la actividad exportadora relativa a producciones cinematográficas o audiovisuales españolas, de libros, fascículos y elementos cuyo contenido sea normalmente homogéneo o editado conjuntamente con aquéllos, así como de cualquier manifestación editorial de carácter didáctico. Como fácilmente advertimos se trata típicamente de propiedad intelectual propiamente tal, por lo que la voluntad del legislador de promocionar la actividad cinematográfica y editorial es evidente.

Las producciones contempladas por la norma se pueden clasificar en tres $\operatorname{grupos}^{606}$ :

- $\quad$ Producciones cinematográficas y audiovisuales;

- Libros, fascículos y elementos cuyo contenido sea normalmente homogéneo y editado conjuntamente con aquéllos;

- Cualquier manifestación editorial de carácter didáctico.

Al hablar de producciones cinematográficas y audiovisuales, debemos considerar que el Real Decreto Legislativo 1/1996, de 12 de abril, por el que se aprueba el texto refundido de la Ley de Propiedad Intelectual (LPI), en su art. 86, establece un régimen jurídico uniforme, para las obras cinematográficas y demás obras audiovisuales, "entendiendo por tales las creaciones expresadas mediante una serie de imágenes asociadas, con o sin sonorización incorporada, que estén destinadas esencialmente a ser mostradas a través de aparatos de proyección o por cualquier otro medio de comunicación pública de la imagen y del sonido, con independencia de la naturaleza de los soportes materiales de dichas obras" ${ }^{\$ 607}$. Desde el punto de vista empresarial es fácil advertir la complejidad que implica la producción de una obra audiovisual, sin embargo no solemos detenernos a pensar las dificultades que puede involucrar desde la perspectiva jurídica, que parte con los derechos de autor comprometidos en el guion, la música, los ejecutantes, los derechos del propio productos, etc. ${ }^{608}$. En este contexto la labor del productor y de la producción en general,

${ }^{606}$ Esta clasificación la obtuvimos de GARCÍA-ROZADO GONZÁLEZ, BEGOÑA Y OTROS. Guía impuesto sobre sociedades, CISS, Valencia, 2008, p. 629.

${ }^{607}$ Art. 86 LPI

${ }^{608}$ Una relación narrada de estos problemas, dice: "La producción de una obra audiovisual comercial (...) supone con frecuencia, (...) una compleja y muy variable cadena de transmisiones de derechos de 
desde la fase de ideas hasta la comercialización de la obra, pasa a ser el centro neurálgico y no es difícil darse cuenta como la intención del legislador seguramente va más allá de la sola estimulación de la industria cultural, sino que también de protección y apoyo económico a una industrial de suyo compleja, posición que se confirma al analizar la Consulta Vinculante V-0254/2006, que reconoce el derecho a la bonificación tanto al coproductor como para el coproductor financiero, con lo que claramente se protege a la actividad creativa (efectuada por el coproductor material) y al apoyo financiero (dado por el coproductor financiero) ${ }^{609}$.

Libros, fascículos y elementos cuyo contenido sea normalmente homogéneo y editado conjuntamente con aquéllos, son el segundo grupo de bienes cuya exportación da derecho a la bonificación. En este caso, hay que tener en cuenta que La Ley 9/75 de 12 de marzo, define al Libro como: “(...) publicaciones unitarias editadas en uno o varios volúmenes, fascículos o entregas, cuyo contenido sea normalmente homogéneo. Asimismo el régimen de esta Ley alcanza a los materiales complementarios de carácter visual, audiovisual o sonoro que sean editados conjuntamente con el libro, así como cualquier otra manifestación editorial de carácter didáctico", cuyo contenido conceptual hace que tenga sentido la frase "elementos cuyo contenido conceptual sea normalmente homogéneo" que de otra forma no lo tendría. En este caso, el objetivo de la bonificación se perfila claramente por la promoción de la industria cultural y editorial en general.

propiedad intelectual que puede iniciarse en el autor de obras preexistentes que no estén en dominio público (novela, obra de teatro, cómic, otra obra audiovisual...), y ha de confluir necesariamente en el productor, que organiza y financia la producción, y organiza la su explotación de la obra. Si la obra audiovisual no se basa en obras preexistentes, la cadena se inicia en los autores de su guion original. Si está basada en obras preexistentes, el productor tras adquirir en derecho de adaptación audiovisual de las mismas, ha de encargar a un guionista la adaptación y adquirir también los derechos sobre el guion adaptado. Con los derechos sobre el guion, ha de contratar a un variable (y con frecuencia elevado) número de actores y de técnicos, alguno de los cuales serán autores de la obra audiovisual (el director, y según la normativa de cada país, posiblemente alguno más), otras personas tendrán derechos conexos sobre sus interpretaciones y ejecuciones (los actores e intérpretes de la música de la banda sonora). Otras aunque no sean autoras de la obra audiovisual, son autoras de sus propias contribuciones (figurinistas, directores de arte, compositores de música no compuesta específicamente para la obra audiovisual...). Nótese que en esta cadena pueden participar también editores de obras literarias (que pueden haber adquirido los derechos de transformación audiovisual del autor), productores de fonogramas (si preexisten a la obra audiovisual, p.ej.), editores musicales, productores audiovisuales (si se trata, por ejemplo, de un "remake"...)". Disponible en Internet en www.eoi.es (20 May 2013).

${ }^{609}$ Vale la pena tener presente que en la producción de una obra audiovisual interviene todo el cúmulo complejo de acciones a que nos hemos referido, puesto que no debe prestarse para confusión el hecho que el Art. 88 LPI, restrinja el contrato de producción estrictamente a los contratos de cesión de derechos de los autores al productor, puesto que tal como hemos analizado, la interpretación de la norma es mucho más amplia que eso. 
Cualquier manifestación editorial de carácter didáctico, es el último grupo de bienes contemplados en el art. 34. 1. TRLIS. Respecto de este grupo, no podemos pasar por alto la precisión efectuada por la Consulta Vinculante V-0570/2007 $7^{610}$, que dejó en claro que el beneficio tiene que ver con la actividad de edición del material y no con la simple impresión o encuadernación, dando cuenta que el legislador pensó en algo más que el mero beneficio de una industria, sino que exigió una actividad de edición, como fenómeno complejo en que "el autor o sus derechohabientes ceden al editor, mediante compensación económica, el derecho de reproducir su obra y el de distribuirla" ${ }^{\$ 11}$ y el editor "realiza estas operaciones por su cuenta y riesgo en las condiciones pactadas y con sujeción a lo dispuesto en esta Ley”612.

\subsubsection{Otros requisitos}

Todos los requisitos que establece la ley son copulativos, resulta entonces que para tener derecho a la bonificación es necesario:

- Obtener rentas, ya que la bonificación no opera en ausencia de cuota, en la medida que tiene por objeto descontar de la "cuota íntegra";

- Que las rentas provengan de la actividad exportadora de las producciones, manifestaciones editoriales o bienes que señala el art. 34. 1. TRLIS;

- Que las producciones y ediciones sean realizadas por el productor en términos de propiedad $^{613}$;

- Que los beneficios correspondientes se reinviertan en el mismo período impositivo al que se refiere la bonificación o en el siguiente;

- Que la reinversión se haga en elementos afectos a la realización de las citadas actividades o en cualquiera de los activos indicados en: el art. 37 TRLIS, sobre Deducción por actividades de exportación ${ }^{614}$; art. 38 relativo a la Deducción por

\footnotetext{
${ }^{610}$ La Consulta vinculante, en lo pertinente, establece: "De acuerdo con todo lo anterior, el sujeto pasivo tendrá una bonificación del 99 por ciento de la parte de cuota íntegra que corresponda a las rentas procedentes de la actividad exportadora de los libros que edite. Por el contrario, en el caso planteado la consultante no realiza una actividad editorial sino la impresión y encuadernación por encargo de empresas extranjeras, lo cual la excluye del derecho a la bonificación establecida en el artículo 34.1 del TRLIS".

611 Art. 58 LPI.

612 Art. 58 LPI.

${ }^{613}$ Este requisito lo desprendemos de la doctrina de la DGT, emanada de las Consultas vinculantes que hemos analizado.

${ }^{614}$ Actualmente derogado.
} 
inversiones en bienes de interés cultural y otros ${ }^{615}$; y, art. 39 sobre Deducciones por inversiones medioambientales ${ }^{616}$;

\subsubsection{Restricciones}

La bonificación en comento posee algunos requisitos negativos, que para efectos de orden denominamos como restricciones, son los siguientes:

- No se incluye en el cálculo la cuota íntegra derivada de las subvenciones concedidas para la realización de las actividades beneficiadas;

- Los elementos en los que se materialice la reinversión no disfrutarán nuevamente de la deducción;

- $\quad$ Las reinversiones efectuadas no deben haberse beneficiado con las deducciones previstas en los artículos 37 y 38 TRLIR;

Todos estos requisitos tienen que ver con evitar una duplicación o aprovechamiento excesivo del beneficio, son verdaderas normas de control o restricciones estructurales, en la medida que buscan evitar excesos en la aplicación de la minoración, pero no se trata de exigencias que vengan a perfilar la bonificación en su esencia. Lo mismo sucede con la Disposición transitoria vigésima tercera de la Ley 35/2006, sobre estableció un Régimen Transitorio de la Bonificación por Actividades Exportadoras, consistente en asegurar que las reinversiones podrán efectuarse después del 2014, cuando la norma esté derogada, ya que de otra manera se hacía ilusoria la posibilidad de reinvertir en el ejercicio siguiente, como prevé la disposición del art. 34 TRLIS $^{617}$.

${ }^{615}$ Actualmente incluida en el proceso de eliminación progresiva de todas las Deducciones para incentivar determinadas actividades, de los arts. 35 y sgtes. TRLIS, al año 2013, sólo pervive la deducción por el monto del 1\%, vinculada a la edición de libros (Conforme a la Disposición adicional décima de la Ley 35/2006, de 28 de noviembre, del Impuesto sobre la Renta de las Personas Físicas y de modificación parcial de las leyes de los Impuestos sobre Sociedades, sobre la Renta de no Residentes y sobre el Patrimonio).

${ }^{616}$ Cabe reiterar los comentarios anteriores con la precisión que pervive con tasa de $8 \%$, únicamente para inversiones de bienes del activo material destinado a la protección del medio ambiente.

${ }^{617}$ La disposición citada, señala: "La bonificación establecida en el apartado 1 del artículo 34 de esta ley, aplicada en períodos impositivos iniciados antes de 1 de enero de 2014, según su redacción vigente en dichos períodos, estará condicionada al cumplimiento de los requisitos exigidos en dicho artículo, aun cuando la reinversión tenga lugar en un período impositivo iniciado a partir de esa fecha. 


\subsubsection{Bonificación o deducción}

No llama la atención que la bonificación que venimos analizando del art. 34 TRLIS, se ubique bajo el Capítulo III Bonificaciones, sin embargo sí lo hace el hecho que el capítulo inmediatamente siguiente, Capítulo IV Deducciones para Incentivar la Realización de Determinadas Actividades, tenga como sujeto las deducciones. A nuestro juicio, en la Ley de Impuesto sobre Sociedades, encontramos una falta de prolijidad en la nomenclatura para señalar determinados institutos minorativos. Para nuestro entender, resulta técnicamente más apropiado hablar de "reducciones" y "deducciones" (incluidas las deducciones técnicas) para referirnos a las intervenciones del legislador que obedeciendo al principio de capacidad contributiva y equidad de la imposición, tienen por objeto subjetivar el gravamen, frenar la progresividad, discriminar determinadas rentas y corregir problemas derivados de la transferencia de capacidad contributiva.

Por su lado, las bonificaciones son institutos típicamente destinados a actuar en cuota y cuyo objetivo es la promoción e incentivo de determinados comportamientos, usualmente económicos. Las bonificaciones suponen una minoración de la cuota íntegra consistente en aplicar un porcentaje sobre la misma derivada de las rentas bonificadas. Además, los casos de insuficiencia de cuota íntegra no se podrán trasladar para su cómputo en ejercicios futuros, y operan sobre dicha cuota, sin minoración de las deducciones por doble imposición.

Enfrentados entonces a la idea de bonificación como instituto destinado a tener una función promocional y a la deducción viniendo a corregir cuestiones estructurales del impuesto, nos resulta sin sentido que el Capítulo IV se llame de las "deducciones" cuando verdaderamente son bonificaciones, lo que además era completamente innecesario, puesto que el capítulo anterior, es precisamente de las bonificaciones. De esta manera el título del Capítulo IV es innecesario y habría sido más propio que los arts. 35 y sgtes. TRLIS fuesen la continuación natural del Capítulo III, donde propiamente deberían estar, atendida su naturaleza de bonificación y no confundir con un nuevo bautismo, que aparentemente lo desprende de sus fines promocionales ${ }^{618}$.

${ }^{618}$ Por lo demás, los fines promocionales del Capítulo IV del TRLIS, no sólo emanan de su propia naturaleza, sino que vienen siendo expresamente reconocidos por el legislador desde el RDL 4/2004, que estableció el TRLIS, cuya expresión de motivos claramente deja en clara la voluntad de reducir 


\subsubsection{Deducción por actividades de investigación, desarrollo e innovación}

Previo al inicio de nuestro estudio sobre la deducción por actividades de investigación, desarrollo e innovación, será necesario detenernos en un asunto un poco más amplio y que dice relación con la tributación de la innovación y el desarrollo en general, puesto que es en ese contexto donde se ubica la deducción y es lo que justifica el análisis del subtítulo siguiente.

\subsubsection{Tributación de la investigación, desarrollo e innovación en general}

La tributación de las actividades de investigación, desarrollo e innovación si se efectúan por un contribuyente dedicado a la investigación, desarrollo e innovación, no presenta ninguna particularidad, puesto que se trata precisamente de su giro empresarial. Supongamos una empresa en área biotecnológica que se dedica a desarrollar vacunas, las patenta y luego las licencia a terceros. Todos los gastos de producción vinculados a la investigación son propios del giro y cualquier sistema tributario debe aceptarlos, en el mismo sentido, los ingresos por el licenciamiento conforman sus haberes, de los que descontados los gastos, se obtendrá la renta tributable. Este esquema tan simple, tratándose de un contribuyente dedicado al giro de investigación, desarrollo e innovación, es el mismo de cualquier actividad empresarial, luego, surge la pregunta: ¿Por qué se requiere de un régimen especial de tributación para la investigación, desarrollo e innovación?

Al iniciar nuestra investigación fue difícil perseverar en la idea de estudiar todas las perspectivas desde las que es posible observar a la propiedad intelectual, básicamente creíamos que era una pérdida de tiempo analizar todas las teorías que explican la naturaleza jurídica de la propiedad intelectual, parecía ser que con entender que coexisten al interior de ella una veta patrimonial y otra más espiritual vinculada a la personalidad del autor o creador (los derechos morales) era suficiente para estudiar los derroteros que podía tomar su tributación. Afortunadamente, no cedimos e impulsamos nuestro estudio hasta agotarlo, ya que la perspectiva del análisis económico del derecho, a nuestro perecer juicio, es la que mejor explica el comportamiento de los Estados al generar regímenes tributarios diferenciados para la investigación y el desarrollo, comprendida la propiedad intelectual asociada a ello y además, frecuentemente,

las tasas de los beneficios promocionales establecidos en la ley, lo que se concreta en la Disposición adicional novena y Disposición adicional décima. 
establecer un sistema de favor para su estímulo, puesto que la motivación que los impulsa es siempre el desarrollo de la economía, junto a la evidencia empírica e histórica que la investigación, desarrollo e innovación $(\mathrm{I}+\mathrm{D}+\mathrm{i})^{619}$ dan origen a largos ciclos de bienestar económico.

Actualmente es indiscutido el reconocimiento que posee la innovación y el desarrollo como elemento promotor de la economía y con ello de bienestar social, lo que ha provocado el desarrollo selectivo de la tributación de las actividades de investigación, desarrollo e innovación, puesto que se les reconoce como acciones beneficiosas para la economía. Al amparo de los mismos fundamentos, se han creado estímulos fiscales para su promoción, respecto de los cuales, no obstante ha sido imposible establecer con certeza las bondades de su existencia, los países perseveran en mantenerlos. Por lo anterior, es difícil leer un estudio sobre los efectos económicos de la

${ }^{619}$ No hay acuerdo para definir las fronteras de qué se entiende por $\mathrm{I}+\mathrm{D}+\mathrm{i}$. Originalmente, se utilizó solamente la expresión $\mathrm{I}+\mathrm{D}$, proveniente del inglés R\&D (research and development), con ella se designaba a cualquier investigación y desarrollo de una manera muy amplia, entendiendo por tal, toda actividad destinada a la creación de conocimiento y su aplicación, comprendiendo el conocimiento que era de dominio público, pero desconocido para la empresa. Posteriormente, se ha distinguido, entre investigación, desarrollo e innovación $(\mathrm{I}+\mathrm{D}+\mathrm{i})$, donde la investigación y el desarrollo no requieren que el conocimiento sea nuevo en el arte, sino que sea nuevo para quien lo aplica. Por su parte, la expresión innovación se reservó para el trabajo en materias inexistentes en el estado de la técnica. Actualmente, se ha incorporado la expresión "innovación tecnológica", cuyo contenido en cuanto innovación es el que hemos descrito, adicionándosele el adjetivo "tecnológica" para acentuar la idea que no es cualquier innovación la que merece ser promovida.

Lo relevante para nuestro estudio es que actualmente existe una diversidad de aproximaciones a estos conceptos que conforman un escenario de lo más variopinto, por lo que es un verdadero desafío conciliar que entienden por tales economistas, "patentólogos", especialistas en propiedad intelectual y tributaristas, lo que complica enormemente el desarrollo fiscal de su tributación e incentivos.

En cuanto a nuestro convencimiento, creemos que existe una diferenciación clara entre la investigación y el desarrollo, respecto de la innovación, caracterizada, como expusimos en el párrafo precedente, porque las personas pueden efectuar investigación y desarrollo sin trabajar sobre un conocimiento nuevo en el estado del arte, sino que simplemente algo que es desconocido para ellos, como la empresa de sillas de madera que primero investiga nuevos materiales y posteriormente desarrolla y lleva al mercado una silla de fierro (nueva para esa empresa). Desde el punto de vista jurídico es un comportamiento legítimo, desde el punto de vista económico es beneficioso y contribuye al bienestar, desde el punto vista político, implica progreso y desarrollo. Luego, si la justificación es bajo el análisis económico del derecho, producir bienestar, estamos frente a una actividad que podría someterse a un régimen tributario particular (que atienda a sus particularidades) y es posible de beneficiar con un estímulo fiscal. En la misma línea de pensamiento, la innovación es básicamente el mismo comportamiento que hemos descrito, sólo que sus efectos se potencian, tanto porque puede implicar ganancias exponenciales, como porque su riesgo es mucho más alto, sin embargo su rasgo característico no es ese, sino que el hecho de buscar un conocimiento nuevo en el estado del arte. Siguiendo nuestro ejemplo, la empresa de sillas, investiga y desarrolla un polímero fotosensible que les permite cambiar de color según la iluminación que reciban, lógicamente, se trata de una característica que no existía previamente en los polímeros conocidos hasta ese momento. 
$\mathrm{I}+\mathrm{D}^{620}$, de su tributación o de su estímulo por la vía de impuestos, sin encontrar que se inicie con declaraciones como éstas:

- Tanto Estados Unidos como la Unión Europea, han estado preocupados por el rendimiento tecnológico de sus países durante el siglo XX. Esta preocupación fue modelada por los logros de Japón en la postguerra, ya que disfrutó de altas tasas de crecimiento hasta los noventas. El fenómeno económico del Tigre entre los ochentas y noventas ${ }^{621}$;

- A través del mundo industrializado y de las economías emergentes del Sudeste Asiático, ha habido un crecimiento expansivo en relación a su Producto Interno Bruto (PIB), que se atribuye principalmente a las actividades de investigación y desarrollo ${ }^{622}$;

- Finalmente, la ciencia básica es la piedra angular del modelo de desarrollo tecnológico que se propone. Es generalmente aceptado que el apropiado rol del gobierno es un apoyo básico y fundamental para la investigación en las universidades y también para enriquecer las ciencias básicas ${ }^{623}$.

Aceptado entonces el supuesto de los beneficios que produce la innovación y el desarrollo para el bienestar económico de los países, la idea de reconocer esta realidad y en ciertos casos estimularla por la vía fiscal no ha tardado en posicionarse, extendiéndose de tal manera, que parece haber una verdadera disciplina sobre el estudio de la tributación de la investigación y el desarrollo, junto a las medidas fiscales para su estímulo, que intenta identificar el objeto $^{624}$, método $^{625}$, características $^{626}$ y particularidades ${ }^{627}$ de su tributación.

${ }^{620}$ R\&D son las siglas en inglés para referirse a "research" "development" (investigación y desarrollo, respectivamente).

${ }^{621}$ BLOOM, NICHOLAS Y OTROS. Do R\&D credits work? Evidence from a Panel of Countries 19791997, Journal of Public Economics 85, 2002, pp. 2 y sgtes. El texto ha sido traducido y adaptado de su versión original en inglés.

${ }^{622}$ BLOOM, NICHOLAS Y OTROS. How has Tax Affected Changing Cost of R\&D? Evidence from Eight Countries, Working Papers Series W 97/3, The Institute for Fiscal Studies and University College London, marzo de 1997, pp. 1 y sgtes. El texto ha sido traducido y adaptado de su versión original en inglés.

${ }^{623}$ LINK, ALBERT. Fiscal Measures to Promote R\&D and Innovation - Trends and Issues, en R\&D Tax Provisions, OECD Working Papers, $\mathrm{N}^{\circ}$ 96, Paris 1996, p. 30.

${ }^{624}$ Por objeto nos referimos a preguntas como: ¿Qué es o cuáles son la innovación y el desarrollo beneficiosos? ¿Cuáles dentro de los beneficiosos escogió un determinado legislador, para otorgarle un tratamiento diferente o de favor? ¿Por qué los legisladores benefician determinadas figuras que nada tienen que ver con la innovación y el desarrollo? ¿Qué contenido y qué relación tienen otras expresiones vecinas como investigación e innovación tecnológica? 
Los asuntos que normalmente se contemplan a la hora de estudiar la tributación de la innovación y el desarrollo son: tasa de depreciación general, tasa depreciación del capital; posibilidad de amortizar y en qué plazo; existencia de un crédito o beneficio contra impuestos; situación de algunas actividades o tipos de empresa ${ }^{628}$. En el contexto de la legislación española, podemos ver como estos asuntos son también preocupación del legislador fiscal, puesto que tal como vimos, existen normas expresas que abordan la posibilidad de depreciar y amortizar los gastos e inversiones efectuadas en $\mathrm{I}+\mathrm{D}+\mathrm{i}$, que ya han sido objeto de nuestro estudio, por lo que cabe tenerlo presente y abordar el análisis del incentivo fiscal diseñado para el estímulo de la investigación, desarrollo e innovación. Tenemos claro que no es nuestro objeto particularmente este tipo de incentivos fiscales, ni ningún otro, no obstante la extensión del mismo difundido prácticamente por todo el mundo y el hecho que su eje sea siempre e ineludiblemente la propiedad intelectual, hace que no podamos pasar por alto su existencia y análisis, además de considerar necesario detenernos en su configuración teórica, puesto que sin duda son elementos que los jueces considerarán a la hora de resolver.

\section{III.2.2.7.1.1 Algunas consideraciones generales sobre la tributación de la investigación, desarrollo e innovación en el contexto internacional como antecedente para entender la deducción por este concepto}

Tal como venimos analizando no cabe duda de la importancia que se asigna en el mundo contemporáneo a la propiedad intelectual, ya sea por el valor que se le atribuye en sí misma, como por sus indiscutidos atributos benéficos en favor del bienestar social. Propiedad intelectual puede o no ser sinónimo de $\mathrm{I}+\mathrm{D}+\mathrm{i}$, dependiendo las perspectivas son figuras próximas, pero nunca sinónimas, de manera que muchos inventos son patentables y no tienen ningún valor económico; en otros casos, podemos

${ }^{625}$ Por método entendemos los mecanismos matemáticos que se utilizan para cuantificar la base y la cuota, ya sea de manera normal o aplicando algún trato preferente. Por ejemplo, en el caso de los estímulos fiscales para la I+D, podemos apreciar que se utilizan mecanismos de base fija o progresiva, con límites o sin ellos y que pueden actuar en base o en cuota.

${ }^{626}$ Cuando hablamos de características, nos referimos a las particularidades que posee cada modelo de tributación, como: si se acepta amortización y qué tipo de amortización; qué tipos de gastos pueden ser deducidos; a qué tasa se tributa; si existen tasas o tratamientos diferenciados por actividad o tipo de empresa, etc.

${ }^{627} \mathrm{Al}$ referirnos a particularidades hemos querido singularizar otros elementos secundarios que pueden estar modelando un sistema como: si está integrado dentro de una política general; si existe un tratamiento diferenciado o especial para conglomerados o grupos empresariales de investigación, si hay alguna diferencia cuándo la investigación se hace directamente o con universidad o entes públicos, etc.

${ }^{628}$ Clasificación basada de la Secretaría General de la OCDE. $R \& D$ Tax Provisions, OCDE WORKING PAPERS, Vol. IV, N 96, Paris, 1996, pp. 4 y sgtes. 
estar frente a investigaciones y desarrollos que no son patentables, no obstante tienen un gran potencial económico y son perfectamente beneficiosas para la economía. Lo que no puede discutirse es que hay una estrecha vinculación entre investigación, desarrollo e innovación y propiedad intelectual en general ${ }^{629}$ y que ambas se entienden como una cuestión deseable promover desde la perspectiva de su desarrollo y protección, de ahí que puede observarse la convergencia de ambas (propiedad intelectual e $\mathrm{I}+\mathrm{D}+\mathrm{i}$ ) en muchos aspectos, de hecho, la propiedad intelectual es normalmente instrumento de protección del esfuerzo innovador, por lo mismo es posible apreciar un tratamiento tributario que de una u otra manera involucra a ambas.

Bajo el punto de vista que hemos expuesto, se entiende por qué proliferan disposiciones tributarias que tienen por objeto las actividades de $\mathrm{I}+\mathrm{D}+\mathrm{i}$ y su vinculación con la propiedad intelectual. En este contexto, para establecer con claridad el objeto de estudio es útil observar cómo se han sistematizado los patrones comunes que presentan los esquemas de incentivos para la investigación, desarrollo e innovación, implementados por los diferentes países, trabajo que abordaremos más adelante, basados principalmente en documentos de la $\mathrm{OCDE}^{630}$, abordando cuatro aspectos fundamentales: depreciación de las expensas que no son de capital en $\mathrm{I}+\mathrm{D}+\mathrm{i}$; depreciación de las expensas invertidas en bienes de capital para $\mathrm{I}+\mathrm{D}+\mathrm{i}$; posibilidad de amortizar; y, existencia de un beneficio tributario expreso ${ }^{631}$.

${ }^{629}$ La vinculación no es únicamente con la propiedad industrial, donde parece darse con más naturalidad, sino que también con la propiedad intelectual propiamente tal (derecho de autor), puesto que por ejemplo, manuales de aplicación, folletos explicativos, estudios y análisis teóricos de un desarrollo y tecnología, pueden estar protegidos también por propiedad intelectual.

${ }^{630} \mathrm{Si}$ bien seguimos los documentos OCDE que oportunamente citaremos, atendidos los rasgos comunes que se presentan entre los diferentes países, es frecuente encontrar tablas comparativas basadas en los mismos conceptos, a modo de ejemplo, puede verse CAGO RODRÍGUEZ, ALBERTO. De los incentivos fiscales a las actividades de $I+D$, Hacienda Pública Española, Monografías $\mathrm{N}^{\circ} 2,1992$, $\mathrm{p}$. 155; y, ÁLVAREZ VILLAMARÍN, JOSÉ CARLOS, La deducción para inversiones en I+D en el impuesto sobre sociedades: alternativas de reforma, Revista de Derecho Financiero y de Hacienda Pública, Vol. 43, N²25 (226), 1993, pp. 697 y sgtes.

${ }^{631}$ Obviamente esta no es la única forma de tipificar los incentivos por I+D, hay otras, a modo de ejemplo el modelo que plantea GAGO, es muy claro sobre la materia. El autor, establece una tipología de los incentivos, de la siguiente manera: “a) En base. La primera diferencia consiste en si los sistemas fiscales tienen o no un tratamiento específico para los gastos de I+D. Con independencia de esta distinción formal, las soluciones más frecuentes son:

a1) Gastos corrientes I+D

- Reducción plena en el año de la realización.

- Reducción plena opcional, combinada con capitalización y amortización, normalmente por cinco años.

- Reducción plena sólo para gastos corrientes cualificados.

- Cómputo en base vía amortización, normalmente a cinco años.

a2) Gastos $I+D$ en activos intangibles 
A la hora de diseñar un incentivo tributario son muchas las consideraciones que deben tomarse, sin embargo en el caso de la $\mathrm{I}+\mathrm{D}+\mathrm{i}$, destacan algunas que por su importancia pueden inspirar a todo el diseño. Basados en LHUILLERY ${ }^{632}$, los principales problemas envueltos en el diseño de los incentivos por $\mathrm{I}+\mathrm{D}+\mathrm{i}$, son ${ }^{633}$ mantención de la equidad, problemas de neutralidad, control de ciclos económicos, evitar el desplazamiento de la inversión, no traslaparse con otros beneficios, compatibilizar con la totalidad del sistema económico, definir lo que se busca estimular con claridad y compatibilizar con la totalidad del sistema tributario. Someramente daremos un vistazo a cada uno de ellos.

La mantención de la equidad, implica que el diseño del incentivo puede favorecer a unos u otros de manera diferente, alterando la proporcionalidad como razón de justicia en la tributación. Por ejemplo, en un sistema proporcional, si la inversión es constante a ritmo de 1.000 por año para una empresa y otra organiza su inversión y gasta 100 el primer año y 200 el segundo, la primera no tendrá derecho al beneficio y la segunda sí.

- Reducción plena en el año de adquisición.

- Reducción plena opcional, combinada con amortización según vida legal.

- Amortización según vida legal.

a3)Gastos I+D en activos fijos

- Amortización acelerada, normalmente entre dos y cinco años.

- Amortización normal.

b) En cuota.- La solución más frecuente es la inexistencia de inventivos en cuota, si bien los créditos fiscales siguen siendo utilizados en algunos Sistemas Fiscales en condiciones muy diversas. Por lo tanto:

- Crédito fiscal a porcentaje (máximo 200\%) del importe bruto o neto (gastos-subvenciones) de la cantidad invertida, con sin límite global sobre la cuota.

- Crédito fiscal a porcentaje del exceso sobre le promedio de la inversión realizada en ejercicios anteriores (uno a tres años).

- Inexistencia de crédito fiscal en cuota".

GAGO RODRÍGUEZ, ALBERTO. Imposición e innovación tecnológica: la reforma de los incentivos fiscales a las actividades de I+D, Hacienda Pública Española, Monografías N²/1992, 1992, p. 153.

${ }^{632}$ LHUILLERY, STÉPHANE. Problems Involved in Designing and Implementing R\&D Tax Incentive schemes, OCDE Working Papers Vol. IV, R\&D Tax Provisions, No 96, Paris, 1996, pp. 38 y sgtes. Sobre los efectos de los incentivos por I+D+i, puede verse: BLOOM, NICHOLAS Y OTROS. How has Tax Affected Changing Cost of R\&D? Evidence from Eight Countries. Ob. supra cit., pp. 1 y sgtes; WARDA JACEK. Measuring the Value of $R \& D$ Tax Provisions, en R\&D Tax Provisions, OECD Working Papers, No 96, Paris 1996, pp. 9 y sgtes; BILliNGS, ANTHONY Y OTRO. Would H.R. 463 Improve the Competitiveness of U.S. R\&D Tax Incentives? Tax Notes, Vol. 99, $\mathrm{N}^{\circ} 10$, June, 2003, pp. 1509 y sgtes; ALLISTAIR, CHRISTOPHER. Innovation + Incentives: VCs Find Partner in Quebec, Venture Capital Journal, Wellesley Hills, May 1, 2002, pp. 1 y sgtes.

${ }^{633}$ Debe aclararse que son aplicables en la especie todos los problemas que pueden existir para la creación de un beneficio tributario, sólo que nosotros nos hemos detenido en los que resultan más visibles atendida la naturaleza específica del beneficio de que hablamos. 
Los problemas de neutralidad, vienen dados porque el incentivo debe estimular la inversión en $\mathrm{I}+\mathrm{D}+\mathrm{i}$, pero no puede llegar a distorsionar la estructura de los gastos, de manera que todas empresas gasten en un único tipo de insumos o rubros. A pesar que en ciertos casos esto se hace deliberadamente como cuando se dirige el incentivo por actividad, tamaño u otro discriminador.

El control de ciclos económicos, implica no olvidar que el beneficio está llamado a operar dentro de los ciclos económicos, de manera que aunque no puede predecirlos, debe tenerlos en cuenta, para que sea lo más armónico posible con ellos, estimulando cuando el ciclo está en su fase decreciente y reduciendo su presencia cuando está en su fase ascendente.

Evitar el desplazamiento de la inversión, conlleva supervisar la posibilidad de desplazamiento de las inversiones únicamente para aprovechar el beneficio y proscribir que se beneficien acciones que no sean real $\mathrm{I}+\mathrm{D}+\mathrm{i}$.

Considerar el traslape con otros beneficios, quiere decir que el diseño debe considerar que deliberadamente o de manera inadvertida se puede estar usando más de un instrumento de beneficio, como puede suceder si existiendo un beneficio para la adquisición de activo fijo, se vuelve a beneficiar por la vía de la inversión en $\mathrm{I}+\mathrm{D}+\mathrm{i}$.

Compatibilizar con la totalidad del sistema económico, implica evaluar, medir y considerar que la creación del incentivo se instala dentro de un sistema general más amplio, con consideraciones económicas, políticas, legales, sociales, medioambientales, etc., de manera que no puede venir a agredirlos ${ }^{634}$. Así por ejemplo, en el evento de una política expansiva de patentamiento, la opción debería ser beneficiar con mayor intensidad los proyectos que obtengan una patente, en cambio en una realidad de creación de ciencia básica, probablemente la inversión en premiar la obtención de patentes sea completamente innecesaria.

Definir con claridad lo que se busca estimular, tal vez sea el problema fundamental a la hora de establecer un beneficio por $\mathrm{I}+\mathrm{D}+\mathrm{i}$, y dentro de ello, qué busca

\footnotetext{
${ }^{634}$ Sobre los incentivos por $\mathrm{I}+\mathrm{D}+\mathrm{i}$, como herramientas de política, se puede ver: LINK. Ob. supra cit., $\mathrm{p}$. 23 y sgtes. Respecto de los costos que puede tener para la economía en general el establecimiento de estos beneficios, ver: BLOOM Y OTROS. How has tax affected the changing cost of R\&D? Evidence from eight countries, ob. supra cit., pp. 25 y sgtes.
} 
promocionarse, qué investigación, cuál desarrollo y qué tipo de innovación u otros. Sobre la definición de qué es la $\mathrm{I}+\mathrm{D}+\mathrm{i}$ se han escrito innumerables páginas y continuarán escribiéndose con desenfreno. Ahora bien, como esta definición perfila el contenido del incentivo, se vuelve sin duda en el asunto de mayor complejidad que se pueda enfrentar en esta materia. Desde el punto de vista teórico puede suceder que: únicamente se usen los conceptos y no se definan, en cuyo caso será la jurisprudencia administrativa y judicial la que los dote de contenido; se establezca una definición autónoma basada en la descripción de los $\operatorname{conceptos}^{635}$; se desarrolle un listado de actividades que se consideran $\mathrm{I}+\mathrm{D}+\mathrm{i}$ y de cuáles no son $\mathrm{I}+\mathrm{D}+\mathrm{i}^{636}$; se use una definición preestablecida como la contenida en el Manual de FRASCATI ${ }^{637}$; se tome una definición prestablecida y se la amplíe o reduzca ${ }^{638}$; se defina de manera positiva y negativa a la vez, diciendo que es y que no es $\mathrm{I}+\mathrm{D}+\mathrm{i}^{639}$; se establezcan criterios o conceptos adicionales ${ }^{640}$; el caso a nuestro juicio más pintoresco, es la posibilidad de pedir informes previos vinculantes a la administración tributaria, que es la que termina dando contenido a cada concepto ${ }^{641}$.

Compatibilizar con la totalidad del sistema tributario, significa que el beneficio usado, debe estar de acuerdo con el conjunto del sistema tributario, ya sea que esté destinado a operar como una exención ${ }^{642}$, en base, en cuota o posteriormente como un reintegro, devolución o pago a cuenta.

\section{III.2 2.7.1.1.1 Depreciación de las expensas que no son capital en $\mathrm{I}+\mathrm{D}+\mathrm{i}$}

Una primera clasificación advierte que entre los países que aceptan los gastos o la depreciación dentro del ejercicio fiscal en que se produjeron, distinguen entre aquellas expensas por bienes de capital y las que no tienen ésta característica. Ahora bien, en uno u otro caso, el hecho que se acepten los gastos o la depreciación en el ejercicio fiscal en que se incurrieron, no justifica un tratamiento diferente bajo ningún respecto, tal como explicamos antes, es lo que subyace en el concepto de "renta", puesto

\footnotetext{
${ }^{635}$ Esta es la situación francesa.

${ }^{636}$ España utiliza este sistema.

${ }^{637}$ El Manual de Frascati, es un documento desarrollado por la OCDE en 1994.

${ }^{638}$ Así lo hace Canadá.

${ }^{639}$ Este también es el caso español.

${ }^{640}$ Es la situación de España que introdujo el concepto de "innovación técnica" y de los Estados Unidos de Norteamérica que incorporó la idea de "experimental development".

${ }^{641}$ En este sentido el art. 35. 4. b) TRLIS.

${ }^{642}$ LHUILLERY. Ob. supra cit, p. 52, señala como Bélgica, Malasia, Singapur y Taiwán, tienen un sistema de exención.
} 
que el impuesto no grava los "ingresos", sino la "renta", lo que implica esencialmente ingresos menos gastos. De esta manera, a la luz de la Ley del Impuesto sobre Sociedades, la determinación de la renta (ingreso menos gastos) se puede efectuar por el método de estimación directa u objetiva (art. 10 TRLIS), en el primer caso se usa la contabilidad (que supone el ingreso menos los gastos) para efectuar los ajustes que establece la ley de renta y en el segundo, se hace una estimación sobre supuestos reveladores de renta, sin considerar que todo el flujo recibido es renta, sino que descontando un estimado por gastos. Siendo así de absoluto el concepto de renta, no debería ser objeto de análisis que se permita descontar o depreciar las expensas efectuadas en investigación, desarrollo e innovación, sin embargo lo es, por dos razones.

La primera razón ya la hemos anticipado. Es del caso que para evitar la erosión de la base imponible, las legislaciones se cuidan de impedir la imputación de gastos ficticios, con entidades relacionadas o innecesarios para producir la renta ${ }^{643}$, en ese escenario, ante la ausencia de una norma expresa que permita la imputación o depreciación de las expensas efectuadas en inmateriales que no son capital (tales como: pagos a expertos, contratación de servicios, retribuciones por investigación, etc.), en el contexto de una empresa productiva y que no se dedica únicamente a la $\mathrm{I}+\mathrm{D}+\mathrm{i}$, fácilmente podrían ser estimados como ficticios o innecesarios para producir la renta, lo que obligaría a hacer un ajuste extracontable y sumarlos a la base imponible para calcular la base del impuesto. En el mismo sentido, frecuentemente la actividad de I $+\mathrm{D}+\mathrm{i}$ se realiza con una empresa vinculada, lo que dará lugar a suspicacias sobre la posibilidad de que se estén trasladando rentas por esta vía. De ahí entonces la utilidad de contar con una disposición expresa que no cuestione las expensas efectuadas en $\mathrm{I}+\mathrm{D}+\mathrm{i}$. La extensión de la disposición la verá cada legislación, puesto que podrá aplicarse a todos o determinados gastos, pagados a determinadas entidades, etc., según los objetivos que busque el legislador.

Bajo nuestra mirada, toda vez que las expensas se refieran actividades de $\mathrm{I}+\mathrm{D}+\mathrm{i}$, deberían ser estimados gastos y permitirse su deducción, ya que no existe la actividad de $\mathrm{I}+\mathrm{D}+\mathrm{i}$ estéril para la economía, por lejana que sea el área en que se desenvuelva respecto de la actividad del que la ejecuta, no obstante sabemos que esto no pasa de ser

${ }^{643}$ En el caso español, a modo de ejemplo en el TRLIS, en el art. 15. 5, se exige para aceptar la deducción de un servicio entre entidades vinculadas, que "los servicios prestados produzcan o puedan producir una ventaja o utilidad a su destinatario". 
una mirada romántica de la innovación, imposible de ver bajo la luz refractaria que alumbra la vista de las administraciones tributarias.

La segunda razón por la que resulta significativo este análisis, es porque puede anidarse en la posibilidad de depreciación un beneficio promocional. En efecto, conforme al razonamiento que venimos sosteniendo, es natural aceptar la depreciación del cien por cien de las expensas efectuadas en $\mathrm{I}+\mathrm{D}+\mathrm{i}$, verificadas en un período impositivo determinado, pero no podría justificarse bajo el razonamiento expuesto, cuando lo que se acepta es el 101 por 100, habiendo casos en que se ha admitido incluso el 150 por cien ${ }^{644}$. Estimamos que en estos últimos casos, existe pura y simplemente un estímulo con el objeto de promocionar las acciones de $\mathrm{I}+\mathrm{D}+\mathrm{i}$.

III.2.2.7.1.1.2 Depreciación de las expensas invertidas en bienes de capital para $\mathrm{I}+\mathrm{D}+\mathrm{i}$

Una segunda clasificación derivada de la anterior, se detiene en observar que los gastos se efectúan en bienes de capital tienen un tratamiento independiente. La situación es más o menos la misma que en el caso anterior, igualmente las legislaciones buscan resguardar que estos bienes de capital sean realmente necesarios para la obtención de la renta y no resulten superfluos, se trate de una forma de beneficiar a las personas naturales tras de la entidad empresarial, sean utilizados para transferir rentas, etc. Así pues, la particularidad puede estar dada por un lado, por aceptar la imputación del gasto aun cuando no esté directamente relacionado con el giro y por otro, por permitir su depreciación en más de un ejercicio (como bien de capital que es), ya sea por el sistema normalmente aceptado para todos los bienes de capital, (según la legislación de que se trate) o por otro método $a d$ hoc ${ }^{645}$.

\section{III.2.2.7.1.1.3 Posibilidad de amortizar}

Otra particularidad que suele abordarse es la posibilidad de amortizar las expensas efectuadas en $\mathrm{I}+\mathrm{D}+\mathrm{i}$. En tanto la amortización, contablemente, no es más que

${ }^{644}$ OCDE. R\&D Tax Provisions. Ob. supra cit., pp. 7. Allí se presenta una tabla comparativa donde se explica que Australia aplicó una tasa de depreciación de 150\%; Austria de 105\%; Dinamarca de $125 \%$, en contraposición a casi la totalidad de los países OCDE de la época del estudio (1996) que reconocen el $100 \%$.

${ }^{645}$ Ob. supra cit., p. 7. En la tabla comparativa que se presenta, se muestra como los diferentes países utilizan diversas alternativas de depreciación, por ejemplo a la época del estudio: Australia permitía la depreciación lineal por tres años; Austria e Italia, acelerada; Países Bajos, Noruega y Suiza, diferenciaban según el tipo de inversión, entre otros. 
la expresión matemática de la fórmula para ir descontando período a período el gasto que representa el desgaste de los bienes ${ }^{646}$, sucede igual que en los casos de depreciación en relación a que una mayor amortización representa la erosión de la base imponible del impuesto y que por lo tanto, las legislaciones deben evitarlo, es el mismo asunto sobre el que discurrimos en los dos casos anteriores. De esta manera, también podemos decir lo mismo sobre el hecho que se pueda aceptar la amortización de expensas en $\mathrm{I}+\mathrm{D}+\mathrm{i}$ que no estén directamente relacionadas con el giro del contribuyente que las efectúa, no obstante lo más característico se revela al advertir que aquél contribuyente que por razones del ciclo de su empresa, por tratarse de gastos de organización y puesta en marcha o por lo que sea, carece de utilidades a las que pudiese imputar los gastos del ejercicio, en nada lo beneficiaría el poder depreciar las expensas en $\mathrm{I}+\mathrm{D}+\mathrm{i}$, ya sea que se trate de capital o no. Bajo esa hipótesis, el mayor gasto efectuado en $\mathrm{I}+\mathrm{D}+\mathrm{i}$, únicamente contribuirá a aumentar la pérdida del ejercicio y no produciría ningún beneficio para el contribuyente que las hiciese.

Por lo expuesto, normalmente, los países permiten que estos gastos se activen, resultando en la posibilidad de reconocerlos a través del tiempo, en ejercicios futuros en diferentes plazos cuando la empresa genere utilidades ${ }^{647}$, lo que constituye un verdadero beneficio tributario, cuya naturaleza promocional no podemos discutir.

\section{III.2.2.7.1.1.4 Existencia de un beneficio tributario expreso}

Al hablar de la existencia de un beneficio tributario expreso, hemos querido hacer presente la idea que nos haremos cargo de una ventaja o tratamiento de favor con fines extrafiscales, a diferencia de los casos anteriores de depreciación y amortización que hemos revisado, que constituyen situaciones limítrofes entre, por un lado la operación de la técnica normal del tributo, puesto que tal como analizamos a nadie debería sorprender la posibilidad de depreciar y amortizar, y por otro lado, la existencia de un beneficio anidado allí, como el caso de una depreciación superior al 100\% y aceptar los gastos que no se relacionan directamente con el giro.

${ }^{646}$ HERNAZ MARTÍN, ANTONIO. Estudio contable y fiscal de las amortizaciones, Gaceta Fiscal $\mathrm{N}^{\circ}$ 158, 1997, pp. 62 y sgtes. Los elementos de la definición planteada se basan en lo expuesto por este artículo.

${ }^{647}$ OCDE. R\&D Tax Provisions. Ob. supra cit., p. 7. En la tabla comparativa que se presenta, sobre un total de 16 países, únicamente Italia y Japón no tenían una norma que permitiese la amortización. 
Los países han ido desarrollando sistemas de beneficio tributario para incentivar la $\mathrm{I}+\mathrm{D}+\mathrm{i}$, ya sea por la vía de reducciones, deducciones o bonificaciones, ejemplo de ello, es la deducción del art. 35 TRLIS en el caso español. Estos mecanismos se han implementado sobre ciertas bases similares, que fueron sistematizadas por LHUILLERY $^{648}$, quien al hablar de los "Esquemas de incentivos para I+D", advierte la existencia de dos tipos de estímulos: los llamados "mecanismos de volumen"649 que son aquellos que dan un incentivo proporcional a la inversión; y, los sistemas incrementales, que se caracterizan por otorgar el beneficio en la medida que se produzca un aumento en la inversión en I+D. Sobre la base de esa diferenciación fundamental entre beneficios proporcionales y progresivos, siguiendo a LHUILLERY, planteamos la existencia de cuatro mecanismos para el incentivo de la $\mathrm{I}+\mathrm{D}+\mathrm{i}$, que operan al interior del beneficio, con diferentes objetivos: disminuir los riesgos de pérdida de recaudación asociados a las políticas de incentivos; asegurar que el esquema de beneficio favorezca también a los contribuyentes que no tienen una obligación tributaria que permita imputar el beneficio; incorporar ciertos criterios de estímulo focalizado; y, efectuar correcciones técnicas o de política sobre la orientación específica que se busca para el incentivo.

Los riesgos de pérdida de recaudación asociados a las políticas de incentivo de $\mathrm{I}+\mathrm{D}+\mathrm{i}$, existen por la tendencia del contribuyente a alterar su decisión de inversión y también sus libros contables para aprovechar al máximo un beneficio tributario. Para contrarrestar esta tendencia LHUILLERY ${ }^{650}$, identificó que los países usan tres métodos: el establecimiento de un "techo" ${ }^{651}$, que puede ser un monto fijo o variable, ya sea que varíe en función de la inversión o de otros factores como el tipo de industria que se desea promocionar; la fijación de un período de "allanamiento" 652 , es un segundo mecanismo que consiste en tomar períodos ya sea de dos o más años previos para calcular la base del beneficio; la tercera alternativa es la creación de "créditos negativos" ${ }^{\prime 653}$, consistentes en un verdadero sistema al revés, en el sentido que va en el sentido contrario que de los incentivos, en este caso si el contribuyente disminuye su nivel de inversión en $\mathrm{I}+\mathrm{D}+\mathrm{i}$, tiene un débito del que hacerse cargo, variantes de este

${ }^{648}$ LHUILLERY. Ob. supra cit., pp. 38 y sgtes.

${ }^{649}$ Ob. supra cit., p. 39.

${ }^{650}$ Ob. supra cit., p. 40.

${ }^{651}$ Ob. supra cit., p. 40. Para la autora es un "ceiling”, la traducción a "techo" es nuestra.

652 Ob. supra cit., p. 40. Para la autora es un "smoot", la traducción a "allanamiento" es nuestra.

${ }^{653}$ Ob. supra cit., p. 40. Para la autora es un "negative credits", la traducción a "créditos negativos" es nuestra. 
sistema es un "crédito negativo" que se paga año a año y un "crédito negativo" amortizable, que tiene la virtud de poder llevarse a resultado a lo largo de los años y por esa vía incluso revertirse, bajo la condición que se vuelva a invertir en $\mathrm{I}+\mathrm{D}+\mathrm{i}$.

También es común que los países busquen asegurar que el esquema de beneficio favorezca también a los contribuyentes que no tienen una obligación tributaria que permita imputar el beneficio. Puede suceder que un contribuyente no pueda beneficiarse con el incentivo propuesto por carecer de base o cuota contra la cual imputarlo (dependiendo de si el beneficio está diseñado para operar en base o en cuota), en cuyo caso no será favorecido aunque haya efectivamente invertido en $\mathrm{I}+\mathrm{D}+\mathrm{i}$. En estos casos, las posibilidades son: el establecimiento de un reembolso, es decir el beneficio ya no opera reduciendo la base o la cuota, sino que permite pedir una devolución en dinero; la fijación de un tanto alzado indexado según el monto de la facturación ${ }^{654}$ inversión; e incluso diseños más complejos, como el caso de los Países Bajos donde el referente para el otorgamiento del reembolso no son todas las expensas en $\mathrm{I}+\mathrm{D}+\mathrm{i}$, sino que los costos de mano de obra. La posibilidad de activar los gastos en $\mathrm{I}+\mathrm{D}+\mathrm{i}$ e imputarlos a largo de extensos períodos de tiempo, es un buen ejemplo de este tipo de mecanismo.

En otros casos, el diseño del incentivo se estructura de manera que se focaliza en una determinada actividad como biotecnología, software, ingeniería estructural, etc., en grupo de empresas, como PYMEs, laboratorios, universidades, entidades de investigación y desarrollo, o incluso, lugares o regiones, como el País Vasco o la Patagonia Argentina.

Finalmente, en el incentivo encontramos normas que tienen por objeto efectuar correcciones técnicas o de política sobre la orientación específica que se busca para el mismo, dentro de las cuales, para el caso de los incentivos para $\mathrm{I}+\mathrm{D}+\mathrm{i}$, podemos mencionar casos en que la corrección es puramente técnica, otros en que obedece a cuestiones de política y otros en que el ajuste se justifica en la sistematización. Los ejemplos los veremos en los párrafos siguientes.

\footnotetext{
${ }^{654}$ Ob. supra cit., p. 41. Menciona el caso de los Estados Unidos de Norteamérica, donde el sistema exige otorga al contribuyente una suma a monto alzado, siempre que haya invertido en I+D+i más del 3\% de su facturación.
} 
En cuanto a correcciones puramente técnicas. Como sabemos que estos beneficios pueden actuar en combinación con otros ${ }^{655}$, tales como: subsidios ${ }^{656}$; subvenciones ${ }^{657}$; financiamiento en condiciones preferentes; contrataciones con el gobierno en condiciones preferentes ${ }^{658}$; premios e incentivos ${ }^{659}$, se debe evaluar cuidadosamente la existencia conjunta de estos beneficios, de manera que de permitirse sea una consecuencia querida por el diseño promocional instaurado y no un resultado accidental o indeseado. De manera que en algunos casos, técnicamente debe efectuarse una corrección para evitar que el beneficio se duplique, como puede ser excluir de los montos para el cálculo del benefício los dineros que se hayan recibido a título de subvención, puesto que al fin y al cabo, representan una inversión estatal y no del sujeto pasivo $^{660}$. De existir complementación con otras medidas, debe ser algo previsto y analizado por el sistema, no accidental, puesto que podría suceder que una empresa se beneficie doblemente de manera indeseada por el sistema.

Además podemos recordar que si bien técnicamente las minoraciones tributarias con fines promocionales, como es el caso, tienen su lugar operando en cuota, por la vía de las bonificaciones, no tiene por qué ser siempre así, en algunos casos pueden estar anidadas en otras lugares del tributo, como es el caso de la depreciación de los gastos superior al $100 \%{ }^{661} \mathrm{y}$ de las exenciones, que pueden estar técnicamente injustificadas, pero políticamente sustentadas ${ }^{662}$. El beneficio incluso puede estar instalado en la misma definición de $\mathrm{I}+\mathrm{D}+\mathrm{i}$, como sucede en TRLIS, que declara como actividad de I+D "diseño y elaboración de un muestrario para el lanzamiento de nuevos productos"

${ }^{655}$ Ob. supra cit., pp. 41 y 42.

${ }^{656}$ Ob. supra cit., p. 42. Menciona: Canadá, materiales de biotecnología; semiconductores; Francia, computadores, entre otros.

${ }^{657}$ Sobre subvenciones y deducciones para $\mathrm{I}+\mathrm{D}+\mathrm{i}$, ver: USATEGUI DÍAZ DE OTAROLA. Subvenciones versus deducciones fiscales en la adopción de innovaciones, Hacienda Pública Española, $\mathrm{N}^{\circ} 116-3$, 1990, pp. 195 y sgtes.

${ }^{658}$ LHUILLERY. Ob. supra cit., p. 42. Menciona los ejemplos de Francia y los Estados Unidos de Norteamérica y los contratos en el sector defensa.

${ }^{659}$ Ob. supra cit., p. 42. Menciona el ejemplo de Reino Unido, que favorece a las empresas que efectúen $\mathrm{I}+\mathrm{D}+\mathrm{i}$ y que tengan menos de 50 empleados.

${ }^{660}$ En este sentido el art. 35. 2. b) inciso final TRLIS.

${ }^{661}$ OCDE. R\&D Tax Provisions. Ob. supra cit., p. 7, figura el caso de Australia con un 150\%. En este caso, lógicamente que el $50 \%$ que excede del $100 \%$ es puramente un subsidio, puesto que supera el desembolso efectuado por el sujeto pasivo.

${ }^{662}$ Por ejemplo, podría establecerse exentos los ingresos obtenidos por actividades de $\mathrm{I}+\mathrm{D}+\mathrm{i}$ obtenidos por pueblos originarios, definiendo $\mathrm{I}+\mathrm{D}+\mathrm{i}$ de manera que incluya cualquier mejora incremental respecto del estado del arte conocido por la comunidad.

${ }^{663}$ Art. 35 TRLIS. 
muestrario que de no estar expresamente incluido en la ley, jamás habría sido posible de considerar como I+D.

Respecto de las correcciones que obedecen a cuestiones de política. El lugar dónde debe efectuarse la actividad de $\mathrm{I}+\mathrm{D}+\mathrm{i}$, no obedece a ninguna razón constitutiva del incentivo, pero puede tener mucha importancia estratégica o política. En algunos casos se exige que la actividad se desarrolle por la propia empresa y en otros no, pero es más frecuente que se exija que debe llevarse a cabo dentro del país que otorga el beneficio y no puede ejecutarse en el extranjero. Uno u otro camino, es una decisión que debe resolverse en función de las ventajas comparativas y competitivas de cada país, por ejemplo, en Chile, siendo el primer país productor de cobre del mundo y careciendo casi por completo de petróleo, comparativamente parece más rentable invertir en el desarrollo de procesos de lixiviación de cobre que en extracción limpia de petróleo. En el mismo sentido, en ocasiones los países deciden no producir determinada tecnología y fomentan su importación.

Las correcciones que se relacionan con sistematización. Frente a la sistematización del proceso de investigación y desarrollo, ya sea que se trabaje sobre un conocimiento nuevo en el estado del arte o sobre uno existente, las etapas son las mismas: investigación básica, investigación aplicada, desarrollo de productos $\mathrm{y}$ aplicación de productos ${ }^{664}$ (entendiendo producto como un concepto amplio que implica cualquier resultado, producto propiamente tal, proceso o servicio). Una cuestión central entonces, es definir la extensión del beneficio, puesto que optarse por favorecer sólo la investigación o el desarrollo, favorecer únicamente los trabajos que sean innovativos o incorporar conceptos nuevos como en el caso de España y la "innovación tecnológica". Cualquiera sea el caso, será necesario precisar hasta dónde se extenderá el beneficio, a la investigación básica, aplicada, desarrollo del productos, hasta la aplicación del producto. Incluso conocemos casos en que se ha ido más allá, como en el TRLIS que favorece incluso la realización de un muestrario para el lanzamiento de nuevos productos.

${ }^{664}$ COSÍN OCHAITA, RAFAEL. El nuevo régimen fiscal de las actividades de investigación y desarrollo, Gaceta Fiscal $N^{\circ} 144,1996$, p. 57. En el mismo sentido se puede ver el "Manual de Frascati" de la OCDE. 


\subsubsection{Una cuestión de denominación}

Si bien el legislador español habla derechamente de investigación, desarrollo e innovación tecnológica, no usa la sigla $\mathrm{I}+\mathrm{D}+\mathrm{i}$, ni tampoco $\mathrm{I}+\mathrm{D}+\mathrm{IT}$ u otra como I+D+TPP, lo que pone de manifiesto la pregunta sobre si el uso de esas siglas coincide o no con lo que se regula como investigación, desarrollo e innovación.

Tendremos oportunidad de constatar como en España a nivel legislativo, en el preámbulo de muchas de las leyes sobre la materia se usa la expresión ${ }^{665} \mathrm{I}+\mathrm{D}+\mathrm{i}$, también en importantes documentos internacionales como la Sentencia del Tribunal de Justicia de las Comunidades Europeas, de 13 de marzo de 2008, relativa a la deducción española por investigación, desarrollo e innovación, habla de I+D+IT, lo que plantea la duda sobre el contenido de una u otra abreviación. Tampoco, podemos pasar por alto, que desde el punto de vista de la propiedad industrial, en el ámbito del derecho de patentes, la novedad es un concepto muy claramente definido y que únicamente podría asociarse a la idea de "innovación", lo que unido a la relevancia que tienen las patentes en la materia que nos ocupa, puede llevar a asociaciones y confusiones. La novedad de patentes tal como está definida en el art. 6 de la Ley 11/1986, de Patentes y en el punto 6.4.1 de las Directrices de Examen de Patentes de la OEPM ${ }^{666}$, es una cuestión objetiva y de identidades, de manera que "una invención, tal como se define por una reivindicación, carece de novedad si cada elemento o cada etapa, incluyendo cualquier característica implícita para el experto en la materia, está explícita o implícitamente divulgado en el estado de la técnica". Si seguimos esa línea de pensamiento y entendemos que a la novedad, en tanto conocimiento nuevo, sólo se puede llegar previa investigación y desarrollo, tenemos que su espacio natural es la innovación, puesto que tanto la investigación y el desarrollo se pueden dar respecto de conocimiento nuevo o existente, en cambio el toque distintivo de la innovación sería precisamente que actúa sobre lo previamente ignorado, es decir, lo nuevo.

Visto el asunto con ojos de experto en patentes, la innovación como culmine del proceso de investigación y desarrollo sobre conocimiento nuevo, debería ser aquello que requiere de mayor protección y desde el punto de vista del derecho de patentes es así, en la medida que la novedad es requisito esencial de las patentes. En ese orden de ideas,

${ }_{665}$ Preámbulo de la Ley 2/2012, de Economía Sostenible.

${ }^{666}$ Disponibles en www.oepm.es (10 Jun 2013). 
frente al esfuerzo más significativo y el interés más potente, una noción de justicia proporcional nos indicaría que es el elemento que merece mayor protección y que desde el punto de vista de una deducción debería ser merecedor del mayor estímulo, sin embargo no es lo que vemos en la deducción del art. 35 TRLIS, donde la solución es exactamente la opuesta $^{667}$.

Esta aparente contradicción, a nuestro entender, tiene su explicación en el análisis económico del derecho, puesto que estos conceptos han sido desarrollados para medir los efectos del avance técnico en la economía, básicamente por lo que se conoce como los Manuales de FRASCATI y OSLO ${ }^{668}$, que corresponden a planteamientos estandarizados para recoger información sobre el avance técnico, de manera que al tener un sustrato común la información sea comparable y parametrizable. Aclara la situación tener presente que los manuales han sido construidos para analizar el comportamiento de la economía, por lo que no obedecen a criterios dogmáticos sino que prácticos y además, trabajan sobre una base dinámica conformada por todo el proceso de investigación, desarrollo e innovación, como realidad fáctica beneficiosa para la economía. El Manual de FRASCATI, define la Investigación y el Desarrollo experimental, de manera que "comprende el trabajo creativo llevado a cabo en forma sistemática para incrementar el volumen de los conocimientos humanos, culturales y el uso de esos conocimientos, para derivar nuevas aplicaciones" ${ }^{\prime 669}$. Posteriormente, el Manual eleva a la máxima relevancia a la novedad como criterio que permite distinguir la presencia de $\mathrm{I}+\mathrm{D}$ frente a actividades similares, pero claramente no se trata de la novedad de patentes, puesto que la califica y exige la presencia de "un elemento apreciable de novedad y la resolución de una incertidumbre científica y/o tecnológica" ${ }^{~} 670$, es decir, ya no se trata de una novedad objetiva de mera comparación como la típica de patentes, sino que de un criterio valorativo "apreciable" que además debe contribuir a la resolución de una incertidumbre científica, elemento completamente inexistente en la novedad de patentes. Más luces podemos encontrar cuando el Manual explica que: "La noción de novedad debe seguir sirviendo de criterio fundamental para la definición de las fronteras entre la I+D y las actividades científicas afines (rutinarias). Tales actividades no pueden considerarse I+D más que cuando forman parte de un

\footnotetext{
${ }^{667}$ Actualmente la tasa de deducción para investigación y desarrollo está en un 30\% y para innovación en un $12 \%$.

${ }^{668}$ Disponibles en Internet en: www.oecd.org (10 Jun 2013).

${ }^{669}$ Manual de FRASCATI, edición 1993. Capítulo 2, 2.1, 57, p.11.

${ }^{670}$ Ob. supra cit., Capítulo 2.3, 2.3.1, 79, p. 14.
} 
proyecto específico de investigación o están destinadas a un proyecto específico de investigación" ${ }^{\text {671 }}$, puesto que muestra como concibe a la I+D como una actividad sistémica, lo que es consistente con su objetivo de medir la incidencia de ésta como elemento relevante en el proceso económico y que la novedad como una cuestión vinculada al proceso de investigación, desarrollo e innovación, apreciada no desde la perspectiva de la creación en sí misma, sino desde el punto de vista del agente económico. Esta diferente visión de lo que constituye novedad, la distingue de la novedad de patentes, liberándola de su dignidad de elemento rector del sistema de patentes, evaluable a escala planetaria, en una relación entre la invención y el estado del arte, completamente desvinculada de la efectividad o viabilidad técnica de la invención y mucho más alejada aún de sus posibilidades de éxito comercial.

En cuanto a la innovación, el Manual de FRASCATI, utiliza tanto la expresión "innovación" como "innovación tecnológica" $" 672$ y explica que abarca los nuevos productos y nuevos procesos, así como los cambios tecnológicos significativos en productos y procesos ${ }^{673}$, orientación que comparte de manera casi idéntica el Manual de Oslo $^{674}$, no obstante este último, es más específico cuando señala: "La innovación tecnológica de producto es la implementación/comercialización de un producto con características mejoradas de desempeño con el fin de brindar objetivamente servicios nuevos o mejorados al consumidor. La innovación tecnológica de proceso es la implementación/adopción de métodos de producción o de suministro nuevos o mejorados ${ }^{2675}$. Bajo estas luces vemos dos elementos característicos y diferenciadores de la noción de innovación de patentes con la que se maneja en los Manuales, por una parte la inclusión de "los cambios tecnológicos significativos" y por otra "la implementación/comercialización”.

Respecto del primero, la existencia de cambios tecnológicos significativos no es una cuestión evaluable para las patentes, potencialmente puede ser relevante, pero los requisitos son novedad, nivel inventivo y aplicación industrial, de manera que un cambio tecnológico menor, puede tener novedad y ser sorprendente al punto de otorgar altura inventiva al invento. En cuanto a la necesidad de implementación y

\footnotetext{
${ }^{671}$ Ob. supra cit., Capítulo 2.3, 2.3.1, 80, d), p. 15.

${ }^{672}$ A modo de ejemplo, ver ob. supra cit., Anexo II, punto 29, p. 21.

${ }^{673}$ Ob. supra cit., Anexo II, punto 29, p. 21

${ }^{674}$ Manual de Oslo, 1996, Capítulo 3, 129. 1., p. 8.

${ }^{675}$ Ob. supra cit., 1996, Capítulo 1, 24., p. 16.
} 
comercialización o adopción son elementos completamente ausentes de la evaluación de patentes, que se traduce en un análisis abstracto y de escritorio.

Con lo expuesto, a nuestro juicio, queda claro como la referencia a investigación, desarrollo e innovación y particularmente la novedad como elemento distintivo de ellos, tiene un contenido diferente desde la perspectiva económica, que desde el derecho de la propiedad intelectual, lo que se refleja particularmente en el contenido que se ha dado a la expresión "innovación", puesto que desde el punto de vista económico las exigencias de implementación y aplicación, junto a la perspectiva laxa de novedad, la transforman en el segmento de menor relevancia dentro del proceso de investigación, desarrollo e innovación y eso justifica que sea la que tiene la menor relevancia dentro del diseño de un estímulo fiscal, de contrario con lo que sucede en el derecho de la propiedad intelectual, donde hablar de innovación es sinónimo de novedad y con ello, se le dota de toda la dignidad que puede tener el desarrollo de conocimiento nuevo a escala planetaria.

Lo que venimos exponiendo justifica nuestra detención en este punto, dejar en claro, que no deben entenderse como sinónimos la novedad de patentes y la exigencia de novedad en el plano de un incentivo a la investigación, desarrollo e innovación, de la misma manera que, debe ponerse cuidado al usar las expresiones $\mathrm{I}+\mathrm{D}, \mathrm{I}+\mathrm{D}+\mathrm{i}, \mathrm{I}+\mathrm{D}+\mathrm{I}$, I+D+IT u otras. Estimamos que la opción del Tribunal Europeo de usar I+D+IT es la más apropiada para la realidad española, puesto que el art. 35 TRLIS, es eso lo que hace, desarrolla un beneficio en favor de la investigación, desarrollo e innovación tecnológica, definiendo que entiende por "innovación tecnológica", lo que no tiene por qué ser coincidente con una u otra visión teórica de la "innovación”. Respecto de $\mathrm{I}+\mathrm{D}+\mathrm{i}$, creemos que es la mejor forma de graficar la perspectiva económica del proceso, disminuyendo la relevancia de la innovación frente a la investigación y el desarrollo. La abreviación $\mathrm{I}+\mathrm{D}+\mathrm{I}$ parece más cercana a la idea jurídica, puesto que mantienen a la innovación en mayúscula, sin reducir su importancia. Otras formas de abreviación como $\mathrm{I}+\mathrm{D}+\mathrm{PTT}$ creemos que no presentan conflicto, puesto que al ser poco usadas, inmediatamente transmiten el mensaje de un asunto particular que debe ser evaluado en su mérito. 
En cuanto a nuestra opción, creemos que para hacer mención al art. 35 de la LIS, debería usarse $\mathrm{I}+\mathrm{D}+\mathrm{IT}$, por las razones indicadas y en los demás casos, la expresión $\mathrm{I}+\mathrm{D}+\mathrm{i}$, por cuanto su aplicación se encuentra ampliamente generalizada.

\subsubsection{La I+D y la innovación científica y tecnológica}

El título de "La I+D y la innovación científica y tecnológica", está tomado del Manual de FRASCATI ${ }^{676}$, lo que hemos hecho expresa y voluntariamente para destacar como distingue entre innovación científica y tecnológica, a diferencia de la deducción del art. 35 TRLIS, que se refiere únicamente a innovación tecnológica. No es que tras de esto hayan sustanciales diferencias, sino que lo importante es advertir cómo es que estos conceptos poseen bordes imprecisos, resbalosos, sobre los que cuesta caminar, por lo que ante la ausencia de un contenido estandarizado los legisladores están llamados a pormenorizar el desarrollo cuando se introducen en estas materias.

Para FRASCATI, la innovación que puede ser científica o tecnológica, consiste en un conjunto de actividades que se desarrollan en el tiempo y tiene por objeto "la transformación de una idea en: en producto nuevo o mejorado introducido en el mercado; o en un proceso o fabricación nuevo en la industria o en el comercio; o en un nuevo enfoque de un servicio social" ${ }^{\text {677 }}$. La innovación se produce en el momento en que se ha introducido el producto en el mercado (innovación de producto) o se ha aplicado a un proceso productivo (innovación de proceso). La vinculación de la innovación con el mercado y sus efectos en la economía se erige entonces como una cuestión fundamental para el concepto de FRASCATI, lo que la aleja por completo de la significación que posee para la propiedad industrial que prescinde de este rasgo, le es irrelevante su introducción en el mercado y no da cabida a aquello que diga relación con aplicaciones sociales $^{678}$.

La $\mathrm{I}+\mathrm{D}$ es tan solo una fase o actividad dentro del proceso innovativo, cuya esencia es ser "fuente original de ideas creadoras"679 y también está destinada a resolver

\footnotetext{
${ }^{676}$ MANUAL DE FRASCATI. Ob. supra cit., Cap. I, p. 15.

677 Ob. supra cit., Cap. I, p. 15.

${ }^{678}$ Obviamente que al decir que la innovación no tiene aplicaciones sociales, no estamos pensando en la propiedad intelectual propiamente tal, donde puede existir innovación y tener implicancias sociales, sino que nos referimos a aquellos métodos, ideas o concepciones que pueden derivar en una mejor administración de la sociedad, que carecen de protección por vía de propiedad industrial.

${ }^{679}$ Ob. supra cit., Cap. I, p. 15.
} 
los problemas técnicos que pueden surgir dentro del proceso innovativo, de manera que no es una forma de innovación, sino que es una parte de ella.

Para FRASCATI ${ }^{680}$ la innovación está compuesta de diferentes etapas, dentro de las cuales está la I+D y además:

- Reglaje de herramientas e ingeniería industrial;

- Inicio de la fabricación y desarrollo previo a la producción;

- Comercialización de productos nuevos, donde se cubren las actividades asociadas a su lanzamiento;

- Adquisición de tecnología no incorporada en forma de know-how, patentes, licencias, marcas, diseños, modelos y servicios de contenido tecnológico;

- Adquisición de tecnología incorporada, como son maquinaria y herramientas que poseen tecnología necesaria para la innovación;

- Diseño, donde se integran, planos, dibujos, procesos, especificaciones técnicas, características de desarrollo, fabricación y comercialización.

Para el Manual de FRASCATI, cuando se trata de programas públicos de I+D puede la innovación llegar a tener una importante etapa destinada a la demostración, a fin de definir la política y promover su uso.

\subsubsection{Deducción por actividades de investigación, desarrollo e innovación en el art. 35 TRLIS}

\section{III.2.2.7.4.1 Introducción}

Al analizar a la propiedad intelectual desde el punto de vista del análisis económico del derecho, tuvimos oportunidad de revisar como desde la mitad del siglo $\mathrm{XX}$ en adelante, se ha asentado la idea que la investigación, desarrollo e innovación producen largos ciclos de impulso económico y bienestar social. Tal como también vimos, apoya esta idea la existencia de numerosos estudios y abundante evidencia empírica, de ahí la búsqueda permanente para estimularla. No volveremos sobre estas ideas, sino que en este momento lo que interesa es advertir que de ahí nace la necesidad de implementar sistemas de estímulo tributario para la $\mathrm{I}+\mathrm{D}+\mathrm{i}$, sin embargo en este momento se produce lo que hemos denominado el efecto "aspirina", en alusión a que la aspirina durante siglos se usó con fines benéficos, pero en la absoluta ignorancia sobre

${ }^{680}$ Ob. supra cit., Cap. I, p. 15. 
cómo funcionaba. En el caso de los estímulos a la $\mathrm{I}+\mathrm{D}+\mathrm{i}$, la situación es la misma, hay muchos estudios sobre cada uno de los beneficios que se han diseñado, pero al final del día, las mediciones de los mismos son incapaces de demostrar que efectivamente estén logrando los efectos benéficos prometidos o en la proporción esperada ${ }^{681}$, realidad teórica que, nuestro modesto entender, en el caso español se dimensiona en el compartimiento errático del legislador en esta materia, puesto que desde el año 1978 con la promulgación de la LIS, se contempló un tratamiento de favor para las inversiones en $\mathrm{I}+\mathrm{D}+\mathrm{i}$, el que ha sido sometido a incesantes cambios, revelando la incertidumbre sobre la consistencia del diseño y los objetivos esperados. En todo caso, debemos dejar en claro que nuestra observación no es una crítica a la realidad española, sino un simple ejemplo de lo que venimos afirmando, puesto que ya hemos visto la diversidad de formas que toman los incentivos en el ámbito internacional, demostrando que a nivel global la situación no es distinta.

\section{III.2.2.7.4.2 Historia de la deducción por actividades de investigación, desarrollo e innovación}

En el año 1978 se promulga la Ley 61/78 del Impuesto sobre Sociedades, que tomamos como punto de partida para nuestro análisis ${ }^{682}$, no obstante que los conceptos de investigación y desarrollo no nacieron con esta ley, pero es el antecedente de la TRLIS, que ahora nos ocupa. Desde ese momento hasta el actual art. 35 TRLIS, han existido múltiples modificaciones, que dan cuenta de un proceso de ensayo y error, en el cual el legislador reconoce las virtudes de la investigación, desarrollo e innovación, pero no alcanza a tener el convencimiento de cuál es la mejor manera de alcanzarlos, tampoco tiene certeza sobre la estimación de sus resultados y permanentemente se envuelve en transacciones políticas que finalmente distorsionan la frontera de la norma que diseña.

En el año 1978, nos encontramos con el apartado cuarto del art. 26 LIS, que dentro del contexto general de una deducción por inversiones, beneficia a "las

\footnotetext{
${ }^{681}$ En este sentido numerosos de los estudios que hemos citado, como los artículos de: GAGO, USATEGUI, BILLINGS, ALISTAIR, BLOOM, WARDA, LINK, LHUILLERY. Y también otros como: VAN REENEN, JOHN. Methodologies for evaluating the impact of $R \& D$ tax credits, R\&D Tax Provisions, OECD Vol. IV, N 96, Paris, 1996, p. 34 y sgtes; USATEGUI, JOSÉ MARÍA, Incentivos fiscales a la innovación, Economía Pública, N 3, 1989, p. 67 y sgtes; y, NEUMAN, MANFRED. Fiscalidad y cambio tecnológico, Hacienda Pública Española, Nº 131 - 4, 1994, p. 179 y sgtes, dan cuenta de lo que venimos diciendo, sobre lo difícil que es sostener con certeza la efectividad o ineficacia de los incentivos fiscales a $\mathrm{I}+\mathrm{D}+\mathrm{i}$.

${ }^{682}$ Partimos desde la LIS y no desde antes, porque estamos analizando esa norma.
} 
cantidades destinadas a llevar a cabo programas de investigación o desarrollo de nuevos productos o procedimientos industriales y siempre que se contabilicen como tales inversiones". Como podemos ver, la disposición es de una austeridad franciscana, en lo que se refleja poca conciencia sobre la realidad que afectaría la norma e incertidumbre en el diseño en general y particularmente en sus efectos. La simpleza de la disposición muestra la falta de conciencia sobre la realidad que se estaba normando, se arriesgan los conceptos de investigación y desarrollo, sin definirlos, no es posible ver la línea divisoria con la innovación y tampoco es posible establecer que se está entendiendo al exigir que los programas sean "nuevos", de manera que de su sola lectura se puede apreciar que es una norma que tendría serias dificultades en su aplicación práctica, como de hecho las tuvo. Así pues, tan consiente parece estar el legislador de la época, que en la Disposición Adicional Segunda, número tercero, autorizó a las Leyes de Presupuestos, para que pudiesen modificar "por razones de política económica" el art. 26 LIS, de que estamos tratando. Al parecer, el legislador apostaba por definir de manera empírica los deslindes del beneficio que diseñaba, puesto que de otra forma no se entiende la necesidad de una facultad tan potente, planteada $a b$ initio.

Los problemas que describimos poseía la norma analizada, no tardaron en hacerse presente, fue así como al promulgarse las Leyes 1/79 y 42/79 sobre Presupuestos Generales del Estado del año 1979 y 1980, respectivamente, la primera contempló un nuevo régimen transitorio para determinadas inversiones en activos fijos nuevos, que originasen aumentos de trabajadores y la segunda, amplía a todas las deducciones por "inversiones" el nuevo régimen previsto en la Ley 1/79. Es decir, se estableció un régimen de favor para las inversiones en activo fijo, no obstante como las inversiones en $\mathrm{I}+\mathrm{D}$, no se trataban junto a las inversiones en activo fijo, resultó que hubo de entenderse que las inversiones en activo fijo tenían un tratamiento y aquellas en I+D, otro. Tal como relata SAÉZ DE IBARRA Y TRUEBA ${ }^{683}$, la situación se mantuvo y consolidó en la Ley 74/80 de Presupuestos Generales del Estado para 1981, en la medida que la reglamentación de las deducciones de que hablamos ${ }^{684}$, ni las propias leyes, aclararon qué se entendía por "investigación y desarrollo", por lo que saltaba la

${ }^{683}$ SÁEZ DE IBARRA Y TRUEBA, IGNACIO. Los gastos de investigación y desarrollo: Concepto y tratamiento fiscal, Cuadernos de Formación Inspección de Tributos, $\mathrm{N}^{\circ} 3$, Escuela de Hacienda Pública Española, 1988, p. 4 y 5.

${ }^{684}$ Real Decreto 3.031/79, de diciembre, por el que se regula el régimen fiscal de inversión empresarial. Real Decreto 2.226/1982, de agosto, por el que se desarrollaron las modificaciones introducidas en la LIS. 
duda que si la compra de un activo fijo para I+D podía beneficiarse del régimen general que se resultaba más favorable. Por otra parte, como para no simplificar el asunto, el RD 3.061/79, se tomó la molestia de decir: “(...) en ningún caso dará derecho a tal deducción la adquisición de los activos inmateriales antes citados", con lo que instaló la duda, en el sentido que el beneficio para las inversiones en I+D sólo era procedente cuando se invertía en un intangible.

En la Ley 44/81 de Presupuestos Generales del Estado para 1982, a diferencia de los dos años anteriores, se abordó el tema de la deducción aplicable por $\mathrm{I}+\mathrm{D}$, mejorando expresamente su condición, pero sin llegar a igualarse al régimen general de adquisición de activos fijos nuevos, lo que mantuvo la incertidumbre sobre la real voluntad del legislador al respecto. En este momento, es muy revelador lo que anota SAÉZ DE IBARRA Y TRUEBA ${ }^{685}$, en aquella época, al decir, en referencia a la I+D: "Volvemos, por consiguiente, a la indefinición del término como causa determinante de la posible aplicación de un régimen más o menos favorable para este tipo de gastos o inversiones. Lo más curioso del caso es que, suponiendo el carácter material de las inversiones en $\mathrm{I}+\mathrm{D}$, el régimen hasta ahora contemplado, que deja ineficaz el beneficio, va a dar un vuelco a partir del Real Decreto/Ley $8 / 83$ y de la Ley 27/84, bajo cuyo amparo la consideración del beneficio como 'autónomo' y separado del artículo 26 de la L.I.S. puede dar lugar a que lo que sea 'papel mojado' sea precisamente el tratamiento fiscal que las Leyes Presupuestarias van a ir dando al concepto de I+D",686. En otras palabras, la regulación reglamentaria que debiera ser la vía para actuar más rápidamente y corregir el incordio surgido, lejos de contribuir a la solución lo hizo al problema.

El Real Decreto 2.631/82, Reglamento del Impuesto sobre Sociedades, no mejora el problema, puesto que no se atreve a definir que entiende por $\mathrm{I}+\mathrm{D}$ e incluso al comentar sus efectos en conjunto con la Ley 27/84, SÁEZ DE IBARRA Y TRUEBA ${ }^{687}$ dice que "puede abrir para el contribuyente avispado fórmulas insospechadas que le

${ }^{685}$ SÁEZ DE IBARRA Y TRUEBA. Ob. supra cit., p. 5.

${ }^{686}$ La norma del Art. 35 de la Ley 27/84 sobre reconversión y reindustrialización, decía: "1. Los gastos de investigación y desarrollo realizados por las empresas podrán reducir la cuota íntegra del Impuesto sobre Sociedades, en el año en que se produzcan, en la cuantía de 15 por 100 de los gastos en intangibles y del 30 por 100 de la adquisición de los activos fijos aplicados al proceso de investigación y desarrollo.

2. Existirá libertad de amortización durante cinco años para las inversiones en maquinarias y bienes de equipos destinados a actividades de investigación y desarrollo, así como las inversiones en intangibles unidas a los programas y proyectos realizados, y durante siete años para los edificios asignados a tales actividades".

${ }^{687}$ Ob. supra cit., p. 6. 
permitan reducir su tributación efectiva por esta vía", a lo que agrega que "una consideración literal y amplia del mencionado artículo 35 de la Ley 27/84 puede dar un vuelco total al tratamiento fiscal de los gastos en I+D". Todo ello, muestra como por aquellos años, la interpretación del beneficio era una cuestión para nada pacífica, que tampoco consiguió aclarase con la Ley 5/83 de Medidas Urgentes en Materia Presupuestaria, Financiera y Tributaria, ni con la Ley 9/83 de Presupuestos Generales del Estado para 1983, que nuevamente, tal como cada año anterior, vuelven a contener disposiciones sobre el asunto. La modificaciones son incesantes, puesto que la Ley 44/83 de Presupuestos Generales del Estado para 1984, se hace cargo de la materia, estableciendo una regulación más extensa de todas las deducciones por inversión, lo que no quiere decir que se haya hecho cargo de una definición de $\mathrm{I}+\mathrm{D}$, ni de las cuestiones interpretativas que se habían presentado hasta la fecha, sino que se limitó a aumentar el monto de la deducción y a generar un nuevo problema, puesto que el art. 31.2 al de mencionar las "Inversiones", parece ampliar el contenido de la I+D a intangibles y tangibles, lo que conlleva un elemento que se adiciona la polémica que venía de unos años antes, sobre si el concepto de I+D incluía solamente a los intangibles. No obstante, el foco principal de conflicto, se presentó porque el art. 31.5 de la Ley 44/83, como trató de manera conjunta todas las deducciones por inversión, al definir la deducción adicional por inversión dijo que "incluye expresamente para su cómputo a las inversiones en $\mathrm{I}+\mathrm{D}{ }^{, 688}$ y además aumentó la tasa del beneficio en un $10 \%$, con ello desde un punto de vista orgánico, sumado al hecho que venía planteándose la idea que la Ley 27/84 era una norma autónoma (desvinculada de la normativa general), fue posible plantear la teoría de que era posible utilizar de manera conjunta la normativa general de deducción fijada por la Ley 44/83 y adicionalmente la deducción asentada de manera autónoma por la Ley 27/84. El asunto se resolvió por aplicación del principio de non bis in ídem ${ }^{689}$, aplicando una norma con preferencia sobre la otra, pero eso no es lo relevante para nuestro estudio, sino que por la vía de la revisión normativa que vamos efectuando, estamos dando contenido a la afirmación que originalmente hicimos sobre el comportamiento errático de los legisladores en estas materias.

\footnotetext{
${ }^{688}$ Ob. supra cit., p. 7.

${ }^{689}$ Principio que se traduce como: "no dos veces por lo mismo". Enciclopedia Jurídica. Disponible en Internet en: http://www.enciclopedia-juridica.biz14.com/d/non-bis-in-idem/non-bis-in-idem.htm (10 Abr 2014).
} 
Llegado el turno de la Ley de Presupuestos Generales del Estado de 1985, Ley 50/84, vuelve a intervenir el tipo de la deducción, dando paso a una nueva redacción que elimina la referencia a "productos" contenida en la disposición que le precedía, lo que transforma el asunto en un nuevo galimatías, está vez llamado a descubrir la razón de la eliminación, en un contexto en que los productos son el ejemplo paradigmático de innovación.

Por otra parte, el Real Decreto Ley $2 / 85^{690}$, vino a establecer un régimen preferente de libertad de amortización para los elementos del activo fijo material nuevo, adquiridos desde su publicación y durante 1985, junto a una norma supletoria que permitía la desgravación en cuatro años, pero olvidando que estaba vigente la Ley 27/84, de que ya hemos hablado, que contemplaba un régimen de libertad de amortización en cinco o siete años para los bienes relacionados a $\mathrm{I}+\mathrm{D}$, de manera que a la época no se ve consenso en el propio legislador sobre el régimen que cabe, sin duda que para el contribuyente de la época, ante la multiplicidad de alternativas, lejos de sentirse beneficiado ha de haberse sentido perjudicado.

Avanzando en el tiempo las Leyes de Presupuestos Generales del Estado para los años 1986 y 1987, contribuyeron a aumentar la confusión, puesto que aparentemente el legislador quiso superar el lapsus que lo afectó en la Ley 50/84 al eliminar la referencia a "productos" y la reincorporó, claro que le adicionó la particularidad que del beneficio (la deducción) se excluye "cualquier tipo de gastos en tales conceptos no activables", lo que permitió a SÁEZ DE IBARRA Y TRUEBA ${ }^{691}$ plantearse preguntas como: “¿qué es lo que se ha querido excluir del beneficio?, ¿los gastos accesorios a conceptos activables?, ¿la totalidad de los conceptos 'no activables' cuando en esta materia está ordenada su activación sin perjuicio de su amortización más o menos rápida?", entre otras. En un claro intento por corregir la estela de confusión que venía dejando, en la Ley 33/87, el legislador eliminó la referencia a que se tratase de “conceptos no activables", en los hechos copió el artículo anterior y eliminó el final que decía: "excluyéndose cualquier tipo de gastos en tales conceptos no activables".

\footnotetext{
${ }^{690}$ BOE, 09 de mayo de 1985.

${ }^{691}$ SÁEZ DE IBARRA Y TRUEBA. Ob. supra cit., p. 8.
} 
A estas alturas, parece ser que la idea es diseñar una suerte de tornillo sin fin, que vuelve indefinidamente una y otra vez sobre sí mismo, dando la sensación de avance perpetuo, no obstante estar siempre en el mismo lugar ${ }^{692}$.

En la Ley de presupuestos del año 1986, en medio de la confusión que hemos descrito, al menos no hubo nuevos cambios al régimen de deducciones por inversiones en el marco de la LIS, ni de la Ley 27/84 sobre Reconversión Empresarial. En la Ley 3/1987 de Presupuestos para el año 1988, se modificó la tasa de la deducción reduciéndola a un 10\% y volvió a desaparecer la expresión: "excluyéndose cualquier tipo de gasto en tales conceptos no activables" ${ }^{\prime 693}$.

La siguiente novedad, no se hizo esperar, en la Ley 37/88 de Presupuestos para 1989, el legislador español estimó que llevaba mucho tiempo sin complicar el asunto e innovó en la relación existente entre la Ley 27/84 sobre reconversión e industrialización y la LIS, de manera que metió la mano justamente en el punto que había mantenido por años la polémica sobre: si el beneficio de la Ley 27/84 era autónomo y complementario o derogatorio de la deducción regulada en el art. 26 LIS; si tenían derecho a él todas las empresas o sólo las que estaban en reconversión; si las leyes presupuestarias posteriores al año 1984, al referirse únicamente al art. 26 LIS habían derogado tácitamente la norma

${ }^{692}$ Una perspectiva más cercana de la confusión que se vivió en la época, con la dictación de la Ley 27/84 sobre Reconversión Empresarial y las dificultades que planteó su existencia, sin aclarar su compatibilidad con el régimen general del art. 26 LIS de la época, creemos que puede verse al leer algunos extractos de lo escrito en la época por SÁEZ DE IBARRA Y TRUEBA. Ob. supra cit., p. 9 a 11. Dice el autor: “Así pues, parece lógico interpretar que la deducción del artículo 35 de la Ley 27/84 es independiente y autónoma de la general prevista en el artículo 26 de la L.I.S., según redacción dada por las sucesivas L.P y habida cuenta de que la deducción general sí es aplicable al Capítulo III, puede interpretarse que la Ley de Presupuestos para 1984 derogó el límite del $40 \%$ establecido en el artículo 8.e de la Ley 27/84 elevó nuevamente dicho límite hasta el momento de la entrada en vigor de la L.P. 1958 y que a partir de ese momento el mencionado límite está o no derogado según que se interprete o no que las inversiones del plan de reconversión constituyen "normativa" del tributo, a efectos de poder trasladar un límite más elevado. Parece lógico pensar que así sea y suponiendo que la deducción del artículo 35 sea autónoma e independiente del artículo 26 de a le L.I.S ¿es compatible con éste? ¿Pueden aplicarse, por tanto, las dos?"; en otra parte, dice que con "la promulgación de la Ley de Presupuestos para 1984 transcurrieron unos pocos días sin que la norma presupuestaria, que daba redacción íntegra al artículo 26 de la L.I.S. recogiese la circunstancia de modificación del límite aplicable a este caso y sólo la del tipo máximo por lo que, moviéndose dentro del ámbito del artículo 26 de la L.I.S al que da redacción íntegra la Ley Presupuestaria, puede llegar a entenderse que la vigencia de dicho límite del 40 \% duró sólo desde el 04 de diciembre de 1983 hasta el 31 de diciembre de 1983. Empieza ya, por tanto, aquí la confusión de normas", cierra su publicación atribuyendo la problemática fiscal de los gastos de I $+\mathrm{D}$ a: la falta de definición de los términos, coexistencia de normas generales y específicas, ausencia de desarrollo reglamentario del art. 35 de la 27/84, falta de claridad de la Ley 27/84, en su relación con las normas de los arts. 14 y 16 de la LGT.

${ }^{693}$ De manera que el art. 26, Uno, letra e) LIS, que en el año 1987 decía: "Programas de investigación y desarrollo de nuevos productos o procedimientos industriales, excluyéndose cualquier tipo de gastos en tales conceptos no activables", para 1988, vino, así: "Programas de investigación y desarrollo de nuevos productos o procedimientos industriales". 
de la Ley 27/84, etc. La solución legislativa fue modificar el art. 26 LIS, eliminando la letra e), del apartado Uno, que contenía la deducción por inversiones en programas de I $+\mathrm{D}$, reemplazándola por un apartado Dos, del mismo artículo, que no es más que una copia del art. 35 de la Ley 27/84. Lo curioso de la técnica legislativa es que nunca derogó el art. 35 de la Ley 27/84, sólo incorporó su texto en parte, en el art. 26 LIS. En otras palabras, parece claro que buscó zanjar las polémicas a que hemos hecho referencia y eliminar la coexistencia de dos deducciones con el mismo fin, una en la Ley de impuesto sobre sociedades y la otra en la ley de reconversión e industrialización, sin embargo, al no derogar la disposición art. 35 de la Ley 27/84, podía entenderse que ésta permanece vigente y que sólo se modificó el art. 26 LIS $^{694}$, con lo cual, ante la duda, el zanje que aparentemente pretendió hacer el legislador quedó en completo entredicho. Cabe hacer presente, que si aceptamos que subsistió un único beneficio, debemos anotar que sobrevivió bastante jibarizado o al menos con una fuerte anemia y vocación de extinción, ya que: desde ahora deja de tratarse de dos beneficios en el art. 26, apartado Uno, letra e) y el del Art. 35 de la Ley 27/84, pasando a ser un único estímulo en el art. 26, apartado Dos, LIS; la deducción se deja de aplicar en cuota íntegra, pasando a restarse de la cuota líquida; queda completamente limitada al tope del $20 \%$ de la cuota líquida del año (límite que antes no tenía la deducción de la Ley 27/84); y, pierde la posibilidad de trasladarse a ejercicios futuros en caso de ausencia de $\operatorname{cuota}^{695}$.

En la Ley 31/1991, de Presupuestos Generales del Estado para 1992, nuevamente se arremete con el incentivo por $\mathrm{I}+\mathrm{D}$, esta vez para girar el esquema teórico que hasta el momento la había sustentado, pasando de ser un sistema de base proporcional (15\% para inversiones en intangibles y $30 \%$ para activos fijos), a uno progresivo, basado en el crecimiento de los gastos en $\mathrm{I}+\mathrm{D}$ en el ejercicio sobre el promedio de dos años anteriores, de manea que de aumentarse los gastos en un importe superior a dicho valor promedio, los porcentajes de deducción también suben a un 30\% para intangibles y un $45 \%$ para activos fijos.

${ }^{694}$ GONZÁLEZ GONZÁLEZ, LOURDES. Régimen fiscal de las actividades de investigación y desarrollo, Impuestos, Revista de doctrina, legislación y jurisprudencia, Tomo II, 1989, p. 130. Aunque la autora no es de esta postura, advierte que es una interpretación posible para la modificación planteada.

${ }^{695}$ Ob. supra cit., pp. 128 a 130. 
Para GONZÁLEZ GONZÁLEZ ${ }^{696}$ la deducción por I+D, en su redacción resulta escuálida y desconcertante, lo que explica diciendo: "Escuálida porque la LIS de 1978 se limita a ordenar una deducción en cuota para las 'cantidades destinadas a llevar a cabo programas de investigación o desarrollo de nuevos productos o procedimientos industriales'. No cabe una oferta más vaga". Sin duda la visión de GONZÁLEZ GONZÁLEZ refleja lo que es imposible de negar, todo el sistema hace agua puesto que no tiene definido su objeto, lo que sorprende es por qué tras sucesivas modificaciones el legislador no aborda el tema, pues bien, la tarea la asume el Real Decreto 1.622/1992, de 29 de diciembre del mismo año, no obstante para consolidar la tradición, lo hizo de la manera más alambicada que le fue posible, lo que podemos ver en el siguiente comentario de GONZÁLEZ GONZÁLEZ ${ }^{697}$, que dice: "Hábilmente se ha aprovechado el nuevo modelo de cálculo de la deducción establecido en la ley de Presupuestos de 1992 para presentar este Real decreto como 'su' reglamento, aunque nos parece que su intención, en cuanto que esclarecedora de ciertas ideas, va más allá”. Efectivamente, el Real Decreto fue más allá, abordando materias que nuestro juicio están en el dominio legal y para ello, básicamente usó el PGC, ciñéndose a la cuenta 210, "Gastos de investigación y desarrollo".

A nivel legislativo, la tormenta dio paso a la quietud en los años que siguieron a la reforma de la Ley 31/1991, de presupuestos para 1992, puesto que no hubo nuevas intervenciones, sin embargo hubo borrascas significativas en el plano judicial, puesto que el Real Decreto 1622/1992, antes citado, corriendo con colores propios, discriminó en favor de la actividad de I+D realizada por el sujeto pasivo, en perjuicio de la efectuada por terceros ${ }^{698}$, "produciéndose el hecho de que nadie iba a disfrutar del beneficio fiscal, unos por encargar la I+D a terceros y no realizarla ellos mismos, y otros por realizarla para terceros y no para ellos mismos" ${ }^{\text {699 }}$, excepto en el caso de ciertos proyectos que involucraban a universidades españolas o europeas, según se establecida en el Real Decreto.

${ }^{696}$ GONZÁLEZ GONZÁLEZ, MARÍA JOSÉ. Los gastos de investigación y desarrollo en el impuesto sobre sociedades. El Real Decreto $N^{\circ} 1.622 / 1922$, Carta Tributaria, Monografías, $N^{\circ} 179,1993$, pp. 2.

${ }^{697}$ Ob. supra cit., p. 2.

${ }^{698}$ El Real Decreto 1622/1922, estableció en su art. $2^{\circ}$, “2. No tendrán la consideración de gastos de investigación y desarrollo: (...) c) Los efectuados en las actividades de investigación y desarrollo realizadas para terceros".

${ }^{699}$ GALENDE DEL CANTO, JESÚS. La fiscalidad de los gastos de investigación y desarrollo: situación actual y propuesta de reforma, Revista Contabilidad y Tributación, Editorial Estudios Financieros, $\mathrm{N}^{\circ} 322,1995$, p. 10. 
Es del caso que el Tribunal Supremo, Sala de lo Contencioso, en Sentencia STS 7092/1994, de 03 de noviembre de 1994, resolvió declarar nulo el art. 2. 2. c), donde se establecía la exclusión de los gastos realizados a través de terceros, con lo que se volvieron válidas, para los fines de la deducción por $\mathrm{I}+\mathrm{D}$, las expensas en favor de terceros, con tal que cumplan las demás exigencias legales ${ }^{700}$. La intervención de los Tribunales de Justicia, perfilando y moldeando el contenido de la norma de incentivo a la $\mathrm{I}+\mathrm{D}$, es muy relevante, porque confirma lo que venimos exponiendo respecto del nudo gordiano que, para bien o para mal, vienen conformando las sucesivas modificaciones legales de que hemos hablado ${ }^{701}$.

La próxima detención corresponde hacerla en el año 1995, puesto que la Ley 43/1995 del Impuesto sobre Sociedades, sistematizó el asunto, trasladándolo desde el art. 26 al 33, donde bajo el título Deducción por la realización de actividades de investigación y desarrollo, alojó las dos deducciones que venían de la Ley 27/84 sobre Reconversión Empresarial y de la Ley 61/78 de Impuesto sobre Sociedades, las que como vimos, habían sido fusionadas, en el art. 26, apartado Dos, de la Ley 61/78, por la Ley 31/1991 de Presupuestos para 1992. Además, elevó a nivel legislativo las definiciones sobre investigación y desarrollo que se habían efectuado en el RD 1622/1992, dando de esta manera por primera vez, un tratamiento global a la deducción. Claro está que de paso modificó nuevamente la tasa de la deducción, aunque mantuvo el sistema progresivo instaurado en el año $1992^{702}$.

En el año 1996, apartándose de la tradición de establecer las reformas a través de las leyes de presupuestos, en la Ley 13/96, sobre Medidas Fiscales, el legislador introduce el numeral 4, al art. 33, que tiene por objeto permitir la deducción por I+D, correspondientes a actividades realizadas en el exterior, "cuando la actividad de investigación y desarrollo principal se efectúe en España y no sobrepase el 25 por 100 del importe total invertido". Con esta disposición, el legislador comienza a asumir una discusión, que tal como analizamos ya venía dándose, en el sentido que el beneficio

\footnotetext{
${ }^{700}$ Ob. supra cit., p. 10.

${ }^{701}$ Cabe destacar que el TS reconoció algo que ya se venía estableciendo en la ciencia económica y que son los beneficios de la cooperación en $\mathrm{I}+\mathrm{D}$, al respecto, existe un interesante estudio específico del caso español, tal es: BAYONA SÁEZ, CRISTINA Y OTROS. Motivaciones empresariales para cooperar en I+: Un análisis empírico con empresas españolas, Documento de Trabajo, Universidad Pública de Navarra, DT 36/99 , Departamento de Gestión de Empresas, 1999.

${ }^{702}$ Sobre la situación en ese momento, puede verse PERAIRE SAUS, JUAN MIGUEL. Gastos en investigación y desarrollo (I+D), Tribuna Fiscal, N 96, CISS, 1998, pp. 81 y sgtes.
} 
debería favorecer tanto a las actividades efectuadas en España como en el extranjero. Como ya estamos acostumbrados, esta aparición normativa será paulatinamente desarrollada en el futuro.

Fue en el año 1999, cuando España acomete con una nueva modificación de las deducciones por $\mathrm{I}+\mathrm{D}$, esta vez bastante significativa, lo que hace dando otra redacción al art. 33 LIS $^{703}$, por medio de la Ley 55/1999, sobre Medidas Fiscales. En esta oportunidad, si bien se mantiene la estructura que se ha venido consolidando, también se adicionan elementos y conceptos nuevos ${ }^{704}$, conformando una estructura que desde ahora muestra peculiaridades.

Conforme a lo anterior, se puede destacar que se aumentan los tipos de la deducción y se establece una deducción adicional del $10 \%$ para gastos por $\mathrm{I}+\mathrm{D}$ vinculados a personal y a proyectos vinculados Universidades y Organismos Públicos de Investigación. También, se incorpora como actividad de investigación y desarrollo al "software avanzado",705, que por primera vez tiene un rol preponderante ${ }^{706}$. Aparece un nuevo concepto la "Innovación tecnológica", que a nuestro juicio es lo más significativo de esta reforma, puesto que pone de manifiesto la atención del legislador sobre la

${ }^{703}$ Un análisis extenso de la norma puede verse en: MORILLO MÉNDEZ, ANTONIO. La deducción por gastos de investigación, desarrollo e innovación tecnológica en el Impuesto sobre Sociedades, Impuestos, Revista de doctrina, legislación y jurisprudencia, Tomo II, 2001, pp. 28 y sgtes; PERAIRE SAUS, JUAN MIGUEL. La nueva regulación de la deducción por gastos en $I+D$ e innovación tecnológica, Revista Tributario y Financiero, Tribuna Fiscal, N 117, 2000, pp. 75 y sgtes; TOBES PORTILLO, PALOMA. Incentivos fiscales a la investigación desarrollo e innovación, EIF, Documentos, $N^{\circ}$ 17/03; BONET SÁNCHEZ, MARÍA PILAR. Incentivos fiscales a la I+D+i en el impuesto sobre sociedades, Revista Valenciana de Economía y Hacienda, N 5, 2002, pp. 10.

${ }^{704}$ Como no podía ser de otra manera, todos los nuevos conceptos introducidos fueron cuestionados y plantearon dudas sobre su aplicación práctica, sin embargo, estimamos que desde esta modificación, superados los problemas de la coexistencia de beneficios en normas independientes y con la posibilidad de las consultas vinculantes, el panorama en el mediano plazo debería haber sido de mucha más claridad para todos los contribuyentes.

705 Sobre la incorporación del Software avanzado, puede verse: RUIZ ZAPATERO, JOSÉ LUIS. Deducción por actividades de investigación científica e innovación tecnológica relacionada con el software, Revista de Contabilidad y Tributación, $N^{\circ} 36$, Estudios Financieros, $\mathrm{N}^{\circ} 207,2000$, pp. 15 y sgtes.

${ }^{706}$ En el caso del software desde el inicio se planteó la duda sobre si la regulación establecida en el Art. 33, número 2, párrafo tercero, en beneficio de éste, debía ser entendida como autónoma, lo que implicaba exigir rigurosamente a todo software que fuese avanzado, es decir, que supusiese "un conocimiento científico y tecnológico significativo mediante el desarrollo de nuevos teoremas y algoritmos o mediante la creación de sistemas operativos y lenguajes nuevos" o si estos requisitos debían interpretarse conforme los conceptos tradicionales de I+D. Las consecuencias de esta diferente interpretación eran que la primera implica asumir estándares tal altos, que probablemente sólo los cumplirían lenguajes completamente nuevos y diferentes desde cero, como puede ser Linux versus Windows. De manera que se imponía una interpretación sistemática de la norma, que visualizase el artículo como un conjunto normativo integrado. Sobre este asunto puede verse: RUIZ ZAPATERO. Ob. Cit., pp. 16. 
evolución que venía sufriendo la ciencia económica sobre el crecimiento económico y el rol de la innovación, especialmente visibles en la Nueva Teoría del Crecimiento Económico (SCOTT, 1989) ${ }^{707}$, lo que una vez más vuelve a confirmar como el análisis económico del derecho es una fuente de explicaciones para muchas cosas en estas materias. De manera que, desde ahora, coexisten dos deducciones una vinculada a investigación y desarrollo, alojada en el numeral 1. del art. 33 y otra relativa a innovación, instalada en el numeral 3. del mismo art. 33 LIS $^{708}$. Adicionalmente, se establece la posibilidad que el sujeto pasivo requiera a la administración un Acuerdo Previo de Valoración de los gastos correspondientes a proyectos de investigación, desarrollo e innovación tecnológica. Asimismo, nace una deducción adicional del $15 \%$ para gastos por innovación, vinculados a Universidades y Organismos Públicos de Investigación y de $10 \%$ para aquellos relacionados con ciertas áreas de la investigación, tales como: tecnología avanzada en forma de patentes, licencias, "know how", etc. Por primera vez instaura la facultad del sujeto pasivo para plantear consultas vinculantes a la administración, lo que debe ser visto como un "acuse recibo" del legislador, sobre lo que hemos venido comentando respecto de lo difícil que era al final del día, darle contenido a la deducción por I+D.

No tardó en llegar el año 2001 y con él la Ley 24/2001, sobre Medidas Fiscales, Administrativas y de Orden Social, disposición a la que el legislador trasladó su vocación de cambio, para la que antes utilizaba la Ley de presupuestos. En fin, la LMF 24/2001, si bien mantuvo el texto que venía de la Ley 55/1999, lo reorganizó dándole una nueva estructura y orden, no obstante lo más significativo estuvo en el art. 33, apartado 1 . letra b) y letra c) $2^{\circ}$, puesto que allí nació una nueva deducción del $10 \%$, esta vez por inversiones en elementos del inmovilizado material e inmaterial ${ }^{709}$, excluidos los inmuebles y terrenos. En otras palabas, subsistiendo las antiguas deducciones por $\mathrm{I}+\mathrm{D}$ y por innovación tecnológica, se le sumó otra por inversiones en elementos del inmovilizado material e inmaterial. Esta nueva deducción llamada a

${ }^{707}$ Citado en un contexto similar al que estamos explicando, por GAGO RODRÍGUEZ, ALBERTO. Imposición e innovación tecnológica: la reforma de los incentivos fiscales a las actividades de $I+D$, Hacienda Pública Española, Monografías N² 2/1992, 1992, p. 153.

708 Sobre la incorporación del concepto de "innovación” y sus consecuencias, puede verse a MARTÍN FERNÁNDEZ, JAVIER. Las actividades de investigación y desarrollo e innovación tecnológica en el Impuesto sobre Sociedades: a propósito de la reciente doctrina administrativas y de las modificaciones legislativas para el ejercicio 2002, Quincena Fiscal, Revista de Actualidad Fiscal, $\mathrm{N}^{\circ}$ 4, Aranzadi, 2002, pp. 9 y sgtes.

${ }^{709}$ Ob. supra cit., p. 27. 
coexistir con las anteriores nace, como todo en esta materia, llena de dudas, tales como: ¿Se refiere al inmovilizado adquirido y al construido o solamente a uno de ellos? ¿Deben reducirse en 65 por 100 las subvenciones recibidas para la adquisición del inmovilizado? El precepto afirma su compatibilidad con la deducción por $\mathrm{I}+\mathrm{D}$, pero ¿Qué sucede con la libertad de amortización la deducción?

En el año 2002, la Ley 53/2002 sobre Medidas Fiscales, Administrativas y de Orden Social, se ocupó del diseño y elaboración de muestrarios, que se había prestado para numerosas consultas. Efectivamente, fue razonable que así fuese, ya que los muestrarios difícilmente caben dentro de la idea de $\mathrm{I}+\mathrm{D}+\mathrm{i}$, por lo que su incorporación como actividad beneficiada por la deducción tiene que ver solamente con la promoción comercial, de manera que no obedece a los criterios dogmáticos que orientan a la deducción en general, así pues, como es de esperar, cuando las cosas no tienen un principio inspirador confunden y se pierde su objetivo. La mención a los muestrarios se prestó para numerosas consultas, que al perecer el legislador quiso resolver, puesto que “siguiendo la línea que ha mantenido la Dirección General de Tributos en sus múltiples respuestas a las consultas planteadas al respecto, incorpora un nuevo párrafo al artículo 33.1. a) de la $\operatorname{LIS}^{, 710}$, destinado a aclarar que se entiende por el lanzamiento de un nuevo producto la introducción del mismo al mercado y que un producto es considerado nuevo cuando su "novedad sea esencial y no meramente formal". El lector ya se habrá dado cuenta que la precisión entre novedad "esencial" y "meramente formal", no pasa de ser una monserga, que será motivo de nuevos desafíos interpretativos. En este momento, también debemos hacer presente que respecto del software, la deducción por I+D se complementó con aquella diseñada para el fomento de las tecnologías de la información y de la comunicación del art. 33 bis LIS.

El año 2003 es el momento en que las modificaciones muestran frenesí de locura, anotándose cinco cambios al mecanismo de incentivo de $\mathrm{I}+\mathrm{D}+\mathrm{i}$. La primera a través de la Ley 7/2003 sobre Sociedades de Responsabilidad Limitada, cuya disposición adicional primera, incorporó una medida razonable en términos de dar certeza al contribuyente, sin embargo desconcertante al preguntarse por qué no se hizo en la Ley 53/2002, promulgada sólo cuatro meses antes. La citada Ley 7/2003, modificó el apartado 4, del art. 33 de la Ley 43/1995, para dar cabida a los "Informes motivados"

710 TOBES PORTILLO, PALOMA. Incentivos fiscales a la investigación, desarrollo e innovación, Crónica Tributaria, $\mathrm{N}^{\circ} 109,2003$, p. 154. 
documentos que pueden ser emitidos por el Ministerio de Ciencia y Tecnología o por organismos adscritos al mismo y que tienen por objeto acreditar el cumplimiento de los requisitos científicos y tecnológicos que la propia ley exige para tener derecho a la deducción $^{711}$.

La segunda acción normativa, cabe reconocerlo es técnicamente muy apropiada, puesto que por medio del Real Decreto 1432/2003 de noviembre de 2003, se reguló la emisión por el Ministerio de Ciencia y Tecnología de informes motivados relativos al cumplimiento de requisitos científicos tecnológicos, a efectos de la aplicación e interpretación de deducciones fiscales por actividades de investigación y desarrollo e innovación tecnológica, documento cuyo preámbulo deja en claro que "una de las principales medidas de apoyo a la $\mathrm{I}+\mathrm{D}+\mathrm{i}$ es la constituida por los beneficios fiscales a los que pueden acogerse las empresas mediante la deducción en la cuota del Impuesto sobre Sociedades (...)", reconociendo además, algo que hemos venido repitiendo hasta el cansancio, al decir: "para que las medidas antes expuestas produzcan el efecto deseado con toda la intensidad posible, resulta necesario ofrecer a los agentes

711 El apartado 4, queda de la siguiente manera: "4. Aplicación e interpretación de la deducción: a) Para la aplicación de la deducción regulada en este artículo, los sujetos pasivos podrán aportar informe motivado emitido por el Ministerio de Ciencia y Tecnología, o por un organismo adscrito al mismo, relativo al cumplimiento de los requisitos científicos y tecnológicos exigidos en el párrafo a) del apartado 1 de este artículo para calificar las actividades del sujeto pasivo como investigación y desarrollo, o en el párrafo a) de su apartado 2, para calificarlas como innovación, teniendo en cuenta en ambos casos lo establecido en el apartado 3. Dicho informe tendrá carácter vinculante para la Administración tributaria.

b) El sujeto pasivo podrá presentar consultas sobre la interpretación y aplicación de la presente deducción, cuya contestación tendrá carácter vinculante para la Administración tributaria, en los términos previstos en el artículo 107 de la Ley 230/1963, de 28 de diciembre, General Tributaria.

A estos efectos, los sujetos pasivos podrán aportar informe motivado emitido por el Ministerio de Ciencia y Tecnología, o por un organismo adscrito al mismo, relativo al cumplimiento de los requisitos científicos y tecnológicos exigidos en el párrafo a) del apartado 1 de este artículo para calificar las actividades del sujeto pasivo como investigación y desarrollo, o en el párrafo a) de su apartado 2, para calificarlas como innovación tecnológica, teniendo en cuenta en ambos casos lo establecido en el apartado 3. Dicho informe tendrá carácter vinculante para la Administración tributaria.

c) Igualmente, a efectos de aplicar la presente deducción, el sujeto pasivo podrá solicitar a la Administración tributaria la adopción de acuerdos previos de valoración de los gastos e inversiones correspondientes a proyectos de investigación y desarrollo o de innovación tecnológica, conforme a lo previsto en el artículo 9 de la Ley 1/1998, de 26 de febrero, de Derechos y Garantías de los Contribuyentes.

A estos efectos, los sujetos pasivos podrán aportar informe motivado emitido por el Ministerio de Ciencia y Tecnología, o por un organismo adscrito al mismo, relativo al cumplimiento de los requisitos científicos y tecnológicos exigidos en el párrafo a) del apartado 1 de este artículo para calificar las actividades del sujeto pasivo como investigación y desarrollo, o en el párrafo a) de su apartado 2, para calificarlas como innovación tecnológica, teniendo en cuenta en ambos casos lo establecido en el apartado 3, así como a la identificación de los gastos e inversiones que puedan ser imputados a dichas actividades. Dicho informe tendrá carácter vinculante para la Administración tributaria". 
económicos un entorno de seguridad jurídica que les permita conocer si las actividades que planean llevar a cabo merecerán o no la calificación requerida para aplicar los incentivos fiscales considerados". Ahora bien, al revisar el Real Decreto nos parecen indiscutidas las observaciones de GONZÁLEZ Y CHAMORRO, quienes dieron por cierta la importancia de la innovación en la economía, aborda específicamente su financiación, advirtiendo que se trata de un "problema rico en matices y perplejidades, en el que entran en juego y se entrecruzan criterios y principios (...) Cuestiones todas íntimamente relacionadas con la opción por la financiación pública, generadora de mayor igualdad y burocracia (Europa), o por la financiación privada (Estados Unidos y

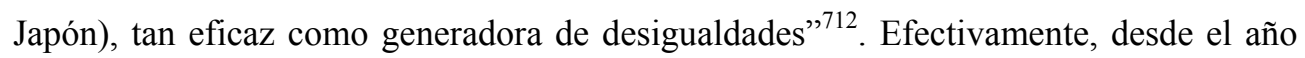
1978, en que iniciamos nuestro estudio, hasta el momento, hemos visto un desarrollo exponencial de la norma, pero a la vez un crecimiento de temores, resguardos, medidas y garantías de parte del legislador, que lo muestran en un estado de permanente desconfianza frente al contribuyente y hacen difícil la aplicación de lo que propone. El RD 1432/2003, se presenta como una herramienta para producir certeza jurídica, que paradójicamente, bajo nuestro crisol, por la misma senda viaja a la conquista de la burocracia $^{713}$.

La tercera intervención normativa, la encontramos en el RDL 2/2003, sobre Medidas de Reforma Económica, que vio la luz cuatro días más tardes que la Ley 7/2003. En este caso, se extiende el ámbito objetivo de la deducción, de modo que también podrá aplicarse a la generación de "software avanzado" que facilite el acceso de personas discapacitadas a los servicios de la sociedad de la información. El fin de la norma es loable, pero creemos que su aplicación es demasiado restringida, en la medida, que si no se modifica lo que se entiende por "software avanzado", bastante poco relevante es que se extienda al software para personas con discapacidad, más aún que de ser "software avanzado", ya se encontraba amparado por la disposición, independiente de que se destinase para personas con discapacidad o no.

La cuarta intervención normativa, tiene una razón de ser en el art. $86 \mathrm{CE}$, puesto que corresponde a la Ley 36/2003, de Medidas de Reforma Económica, que tenía por

712 GONZÁLEZ, EUSEBIO Y CHAMORRO, JOSÉ ANTONIO. Incentivos fiscales a las actividades de $I+D$ en defensa, CESEDEN, Ministerio de Defensa, $N^{\circ} 280,2003$, p. 83.

713 Sólo como ejemplo de lo que queremos demostrar, el RD 1432/2003, tiene trece formas distintas, de entre las que hay que escoger y llenar para obtener un informe motivado. 
objeto ratificar el RDL antes citado, lo que hizo manteniendo íntegramente el texto concebido por este último.

La quinta iniciativa normativa del año 2003, es la Ley 62/2003, de medidas fiscales administrativas y de orden social, que hizo ciertas modificaciones de tasas, aumentándolas: a $20 \%$ en el caso de los gastos de personal en investigadores cualificados y proyectos de investigación contratados con organismos públicos; y, a $50 \%$ para la deducción en el evento que el monto de la inversión sea superior al promedio de los últimos dos años.

En el año 2004 el RDL 4/2004, de 5 de marzo, por el que se aprueba el texto refundido de la Ley del Impuesto sobre Sociedades, vino a contribuir a la seguridad jurídica y el orden legislativo, puesto que como es fácil de advertir, particularmente en la materia que venimos analizando, las sucesivas modificaciones a la Ley 43/1995, de Impuesto sobre Sociedades, habían terminado por desmenuzar la norma del art. 33, repartiéndolo en puzle de disposiciones. El RDL según declara en su preámbulo, "se circunscribe a la mera formulación de un texto único y no incluye una autorización para regularizar, aclarar y armonizar los textos legales que han de ser refundidos", no obstante, está ahí su virtud, tal es, aportar un texto íntegro de la tan manoseada deducción que nos ocupa.

El texto refundido del RDL, trajo algo de tranquilidad, ya que la próxima modificación del texto de la deducción, ahora alojado en el art. 35 TRLIS, no la veremos sino hasta fines de 2005 , lo que es todo un logro, comparando con la velocidad de las modificaciones que le preceden. Ese año, la Ley 23/2005, de 18 de noviembre, de Reformas en Materia Tributaria para el Impulso a la Productividad, hizo un cambio menor en la disposición con el objeto de incluir en el concepto de innovación tecnológica a los muestrarios textiles.

Desde este momento, a nuestro juicio, el azaroso camino recorrido por la deducción parece comenzar a rendir sus frutos, resultando una construcción técnicamente perfilada, lo que se refleja en una reducción dramática de la necesidad legislativa por reformarla. En efecto, durante los años venideros las discusiones han rondado a la deducción por $\mathrm{I}+\mathrm{D}+\mathrm{i}$, sin llegar a alcanzarla, de manera que el art. 35 TRLIS, se ha mantenido casi sin alteraciones, no obstante que las opiniones sobre el 
asunto están lejos de desaparecer o de dar con un resultado consensuado, más bien parece ser que se han vuelto verdad las afirmaciones de GONZÁLEZ Y CHAMORRO, cuando discurrían sobre la relevancia de la innovación en la economía y el rol de los tributos en su dinámica, diciendo: "En el punto de equilibrio en que actualmente nos encontramos de 'liberalismo económico dirigido', se pretende, por una parte, que el Estado haga lo que se los particulares no quieren hacer (principio de subsidiariedad) y, por otra, que el estado aliente o estimule a hacer a los particulares aquellos que éstos no harían sin estímulos o incentivos (dirigismo económico). Sobre todo esto se puede naturalmente discutir, pero va a ser difícil demostrar que el que piense de manera distinta está en un error" ${ }^{\text {714. }}$.

De lo que hablamos es del hecho que las discusiones sobre la necesidad de un incentivo para $\mathrm{I}+\mathrm{D}+\mathrm{i}$, la forma de estructurarlo, su incidencia en la economía, entre otras, se han seguido dando, lo que podría haber justificado más modificaciones del texto, pero eso no ha sucedido, tanto es así, que en la propia legislación encontramos rastros de lo polémico que sigue siendo el asunto y no obstante ello, la norma pervive. Diversas son las materias en las que subsisten las diferencias y que podrían fundar cambios normativos, de partida el propio rol de la innovación en la economía no es una cuestión sellada, la necesidad de tener un incentivo, dónde ubicarlo, sus límites, etc., lo curioso es que muchas de esos asuntos han estado bordeando la deducción por $\mathrm{I}+\mathrm{D}+\mathrm{i}$, sin alcanzar a tocarla.

Así pues, ya desde los años 80, venía una tendencia mundial hacia tipos impositivos más reducidos, de manera que: "La razón primordial detrás de estas, a menudo dramáticas, reducciones fiscales era el deseo de conseguir sistemas tributarios lo más neutrales posibles, y minimizar el efecto de los impuestos en el proceso de decisión económica. El movimiento de reforma fiscal era una consecuencia más de la filosofía de liberalización de mercados; con la reforma fiscal se esperaba generar una mayor eficiencia económica (...) que a su vez se traduciría en un crecimiento económico más elevado"715. Esta posición es recogida por el legislador Español, quien a la zaga del inglés, se hace cargo del asunto en la Ley 35/2006, de 28 de noviembre, del

\footnotetext{
${ }_{714}^{714}$ Ob. supra cit., p. 90.

715 BROWN, CHUCK Y SANDFORD, CEDRIC. Reforma fiscal e incentivos: Un estudio práctico del Reino Unido, Cuestiones Claves sobre la Reforma Fiscal, CEDRIC SANDFORD, IEF, Madrid, 1999, p. 214.
} 
Impuesto sobre la Renta de las Personas Físicas y de modificación parcial de las leyes de los Impuestos sobre Sociedades, sobre la Renta de no Residentes y sobre el Patrimonio, al decir en su preámbulo: "La creciente globalización de la economía está introduciendo una importante preocupación por la productividad y el crecimiento económico, va acompañada de nuevas tendencias en la fiscalidad internacional, en las que se destacan la reducción de los tipos nominales (...) En segundo lugar, se establecer que la reducción del tipo impositivo vaya acompañada de la progresiva eliminación de determinadas bonificaciones y deducciones que provocan distorsiones, manteniendo las deducciones que persigan eliminar la doble imposición (...)”.

$\mathrm{Si}$ a lo anterior unimos lo que ya hemos demostrado latamente, respecto a que no existe evidencia empírica que los beneficios tributarios para $\mathrm{I}+\mathrm{D}+\mathrm{i}$ sean verdaderamente efectivos, tendríamos un escenario claro para cambios normativos sobre la materia, no obstante, frente a la duda, el legislador prefiere declarar que su aplicación se mantiene otros cinco años, conservando su estructura, limitándose a reducir "los porcentajes de deducción en la misma proporción en que se minoran los tipos de gravamen"716.

Como vemos la Ley 35/2006, es una parada singular, puesto que haciéndose cargo del asunto en el preámbulo, a la hora de decidir, optó en la Disposición adicional vigésima tercera, por dar un mandato a los Ministros de Economía y Hacienda, asistido por el Ministro de Industria, Turismo y Comercio, para que presenten al Gobierno un estudio sobre la eficacia de las diferentes ayudas a las actividades de $\mathrm{I}+\mathrm{D}+\mathrm{i}$. De manera que, no obstante haber antecedentes suficientes para dudar de la necesidad de la norma o de sus efectos y hacerse cargo específicamente del asunto en el preámbulo de la ley, al momento de decidir, el legislador optó por mantener la deducción por cinco años, reducir las tasas (que fue un requerimiento de proporcionalidad por la modificación de la tasa de la LIS y no una cuestión sistémica), dejar incólume a la disposición del art. 35 de la Ley 35/2006 y ordenar al Gobierno estudiar el asunto.

La siguiente modificación se produce a través de la Ley 4/2008, de 23 de diciembre, por la que se suprime el gravamen del Impuesto sobre el Patrimonio, se generaliza el sistema de devolución mensual en el Impuesto sobre el Valor Añadido, y se introducen otras modificaciones en la normativa tributaria. La etiología de esta

${ }^{716}$ Preámbulo Ley 35/2006. 
modificación es completamente diferente a todo lo que hemos analizado hasta el momento, puesto que tal como da expresa cuenta el preámbulo de la Ley, el Tribunal de Justicia de las Comunidades Europeas, por sentencia de 13 de marzo de 2008, había determinado la deducción por actividades de I+D+IT, tal como estaba planteada era contraria al ordenamiento comunitario "al ser menos favorable para los gastos realizados en el extranjero que para los efectuados en España" ${ }^{\text {"717 }}$, lo que obligó a la modificación legislativa del derecho interno español.

No obstante lo anterior, como estamos analizando la historia de la deducción por $\mathrm{I}+\mathrm{D}+\mathrm{IT}$, vale tener presente que la imputación efectuada en contra de España por la Comisión Europea, se refería básicamente a dos puntos: el tope a la deducción por gastos efectuados en el extranjero, de un $25 \%$ de la inversión y la deducción adicional por los gastos correspondientes a proyectos contratados con universidades y organismos públicos, en ambos casos para I+D e IT, respectivamente. La imputación consistía en que el RDL 4/2004, de 5 de marzo, que definió el texto refundido de la ley de impuesto sobre sociedades, mantuvo las condiciones señaladas, en el art. 35, numerales: 1. b), párrafo cuarto; 1 . c), $1^{\circ}$, párrafo quinto; $\left.2, \mathrm{~b}\right), 1^{\circ}$ y 2. b), párrafo tercero, del TRLIS. La sentencia es del 13 de marzo de 2008 y la Ley 4/2008, de 23 de diciembre del mismo año, de manera que su objetivo en cuanto a la deducción por I+D+IT es claro y definido, dar cumplimiento a lo resuelto por el Tribunal Europeo, lo que puede apreciarse de la sola lectura del nuevo artículo 35, puesto que aun cuando se trata de un artículo íntegramente nuevo, es idéntico al que le precedía, con la sola modificación en las disposiciones objetadas por el Tribunal Europeo, además de haber reducido la tasa de la deducción por IT, de un 12 a un 10 por 100 .

Finalmente, a pesar que como hemos visto, no hay evidencia empírica de las ventajas de los incentivos fiscales por $\mathrm{I}+\mathrm{D}+\mathrm{i}$ y de la intención manifiesta del legislador, expresada en la Ley 35/2006, de llegar a una condición de neutralidad fiscal, donde los inventivos no existan o sólo estén en su mínima expresión, a nuestro juicio, el inconsciente colectivo sobre la potencia de la $\mathrm{I}+\mathrm{D}+\mathrm{i}$ en la economía y el bienestar social, hacen imposible para el legislador abandonarlos, de manera que se observa una clara tendencia a su perpetuación, así pues, la última intervención en la materia está conectada con el mandato de la Disposición adicional vigésima tercera de la Ley

\footnotetext{
${ }^{717}$ Preámbulo de la Ley 4/2008.
} 
35/2006, que ordenaba al Ministerio de Economía y Hacienda, asistido por el Ministerio de Industria, Turismo y Comercio, efectuar un estudio sobre la eficacia de las diferentes ayudas e incentivos a las actividades de I+D+IT. Llegado el año 2011, la Ley 2/2011, de Economía Sostenible, ha mantenido la situación del art. 35 del TRLIS, sin modificaciones, salvo en cuanto volvió a subir el porcentaje de la deducción por IT de un 10 a un 12 por 100 .

\section{III.2.2.7.4.3 Análisis de la deducción por I+D+IT}

Con motivo de su desarrollo histórico, prácticamente ya hemos analizado a fondo la deducción, por lo que ahora intentaremos solamente sistematizar su contenido fijado por el art. 35 TRLIS.

Conforme hemos venido analizando, ha quedado demostrado como la disposición del art. 35 TRLIS, ha sido el objeto de una evolución de más treinta años, lo que permite que actualmente posea una redacción estructurada, claramente dividida en cuatro grupos de cuestiones: la deducción por I+D, la deducción por IT, aquellas comunes a la I+D e IT y las relativas a la administración de la deducción, sobre cada una de ellas entraremos al análisis seguidamente

\section{III.2.2.7.4.3.1 La deducción por I+D}

La deducción por I+D, ubicada en el apartado primero del art. 35 TRLIS, es el segmento más antiguo del artículo, que ha acompañado a la LIS desde su promulgación en el año 1978.

El objetivo de la deducción, tal como hemos visto, es básicamente instrumental, pretende ser un estímulo o aliciente para fomentar la actividad de investigación y desarrollo. Se conforma como una deducción en la cuota, es decir opera rebajando directamente el monto del impuesto que el contribuyente debe pagar, cuando éste ya está calculado. Hasta aquí y considerando que la tasa actual, parece ser un asunto sin dificultades que se resuelve por un simple cálculo aritmético, sin embargo su ejecución práctica siempre ha sido de muy difícil desempeño, derivado de las dificultades para establecer que se entiende por $\mathrm{I}+\mathrm{D}+\mathrm{i}$, lo que llevó al legislador originalmente a plantear una definición y posteriormente a establecer las Consultas Vinculantes y los Acuerdos 
Previos de Valoración como mecanismos que permitieran certeza jurídica a los contribuyentes.

a) Definición de investigación y desarrollo

El art. 35 TRLIS, apartado primero, define por separado investigación y desarrollo $^{718}$, entendiendo por "investigación a la indagación original planificada que persiga descubrir nuevos conocimientos y una superior comprensión en el ámbito científico y tecnológico, y desarrollo a la aplicación de los resultados de la investigación o de cualquier otro tipo de conocimiento científico para la fabricación de nuevos materiales o productos o para el diseño de nuevos procesos o sistemas de producción, así como para la mejora tecnológica sustancial de materiales, productos, procesos o sistemas preexistentes". El rasgo característico de las definiciones es la exigencia de novedad, sin embargo, paradójicamente esta misma particularidad es la que hace impreciso su contenido, puesto que no se define qué se entiende por novedad. Al efecto, como hemos visto, para el derecho de la propiedad intelectual tiene una connotación de universalidad, es nuevo lo que nunca ha existido en ninguna parte, para el derecho de patentes además de universalidad es un examen de identidades y para los manuales de FRASCATI y OSLO es una cuestión relativa, vinculada al desenvolvimiento de la economía, a la empresa que hace el desarrollo y cuya evaluación es subjetiva. Desde esta perspectiva y considerando los casos específicos que desarrollan más adelante en el art. 35 LIS, creemos que se confirma nuestra visión, en el sentido que estas definiciones han sido establecidas bajo una perspectiva instrumental, entendiendo a la I+D como una actividad que contribuye al desarrollo económico, prescindiendo de otras connotaciones teóricas que pudiesen sugerir una definición más próxima a la concepción de la $\mathrm{I}+\mathrm{D}$ como vinculada a la propiedad intelectual y desde ahí a la dimensión moral de la misma, en el sentido que lo que se viene a proteger, cuando estamos frente a la novedad, es la expresión creativa única que caracteriza al ser humano.

La aproximación a la perspectiva de I+D de los Manuales de FRASCATI y OSLO, aparece muy claramente al continuar la lectura del art. 35 TRLIS, puesto que en esa parte, el artículo viene a complementar la definición, estableciendo positivamente

\footnotetext{
718 Parece natural que investigación y desarrollo tengan un tratamiento separado de la innovación, ya sea porque la idea de innovación se ha perfilado con posterioridad, como por el hecho que dentro de la evolución de la disposición, esta última tuvo un aparecimiento más tardío.
} 
cono situaciones de $\mathrm{I}+\mathrm{D}$ determinadas circunstancias que en ausencia de una calificación expresa pudiesen estimarse que no lo son o prestarse para dudas.

El artículo trata tres casos, el prototipo, los muestrarios y el software avanzado $^{719}$. Dentro de éstos, si bien son todos casos discutibles, el más paradigmático son los muestrarios, puesto que al carecer de novedad, fácilmente puede interpretarse que se trata de una hipótesis que nada tiene que ver con $\mathrm{I}+\mathrm{D}$, posición que entre otros sustenta PERAIRE SAUS ${ }^{720}$. Sin embargo, si entendemos que pueden existir "cambios estéticos capaces de producir un efecto importante sobre la atracción que ejercen los productos en el consumidor, y por ende en el rendimiento de la empresa en cuestión"721, perspectiva que sostiene el Manual de OSLO, cambia radicalmente la aproximación a los muestrarios que pasan a tener un rol determinante en aquellos desarrollos donde un cambio estético es lo relevante ${ }^{722}$. Con menor intensidad, sucede lo mismo a propósito de los prototipos, que expresamente están considerados como parte del proceso de $\mathrm{I}+\mathrm{D}$ en el Manual de FRASCATI ${ }^{723}$. En el caso del software en comparación con los Manuales se exigen más requisitos en el art. 35 TRLIS, para considerarlo una actividad de $\mathrm{I}+\mathrm{D}$, puesto que requiere que se trata de un "software avanzado", que implique un avance significativo, nuevos teoremas, algoritmos o lenguajes, en tanto para FRASCATI, “el paso a una versión más potente, la introducción o modificación de un

719 Art. 35. 1. a), párrafos segundo, tercero y cuarto: "Se considerará también actividad de investigación y desarrollo la materialización de los nuevos productos o procesos en un plano, esquema o diseño, así como la creación de un primer prototipo no comercializable y los proyectos de demostración inicial o proyectos piloto, siempre que éstos no puedan convertirse o utilizarse para aplicaciones industriales o para su explotación comercial.

Asimismo, se considerará actividad de investigación y desarrollo el diseño y elaboración del muestrario para el lanzamiento de nuevos productos. A estos efectos, se entenderá como lanzamiento de un nuevo producto su introducción en el mercado y como nuevo producto, aquel cuya novedad sea esencial y no meramente formal o accidental.

También se considerará actividad de investigación y desarrollo la concepción de software avanzado, siempre que suponga un progreso científico o tecnológico significativo mediante el desarrollo de nuevos teoremas y algoritmos o mediante la creación de sistemas operativos y lenguajes nuevos, o siempre que esté destinado a facilitar a las personas discapacitadas el acceso a los servicios de la sociedad de la información. No se incluyen las actividades habituales o rutinarias relacionadas con el software".

${ }^{720}$ PERAIRE. Ob. supra cit., p. 84.

${ }^{721}$ MANUAL DE OSLO. Ob. supra cit., Cap. II, p. 27.

${ }^{722}$ Sobre este asunto, cabe recordar lo que analizamos bajo el subtítulo: "La I+D y la innovación científica y tecnológica”, en el sentido que para el Manual de FRASCATI, la comercialización de productos nuevos, donde se incluyen las actividades para su lanzamiento, constituye parte de lo que entiende por innovación.

${ }^{723}$ MANUAL DE FRASCATI. Ob. supra cit., Cap. I, pp. 21 y 22. El Manual distingue como parte del proceso de $\mathrm{I}+\mathrm{D}$ al prototipo, planta piloto, diseño industrial y plano, ingeniería industrial y utillaje y parcialmente la producción a título experimental. No considera como I+D a los servicios de postventa y detección de averías, trabajos relacionados con patentes y licencias, ensayos rutinarios, recogida de datos y servicios públicos de inspección y control, aplicación de normas de reglamentación. 
programa o de un sistema ya existentes, pueden clasificarse en $\mathrm{I}+\mathrm{D}$ si se trata de progresos científicos y/o tecnológicos que desembocan en un enriquecimiento de conocimientos".

b) Base de la deducción

La base de la deducción está constituida por tres grupos de expensas: los gastos de investigación y desarrollo; las inversiones en elementos de inmovilizado material e intangible excluidos los inmuebles y terrenos; y, las amortizaciones de los bienes afectos a las citadas actividades. Para todas ellas se exige, que estén directamente relacionadas con las actividades de $\mathrm{I}+\mathrm{D}$ y que se apliquen efectivamente a la realización de éstas, debiendo estar contabilizados por cada proyecto, es decir, deben estar desagregados del movimiento general de la empresa ${ }^{724}$.

Por razones obvias, para evitar un doble beneficio, la ley dispone que cuando existan subvenciones se reducirá la base imponible en un 65 por 100, en la parte que corresponda a las subvenciones, ello debido a que respecto del dinero recibido por subvenciones un 65 por 100, será la subvención en sí misma y un 35 por 100, el impuesto, de manera que al reducir en un 65 por 100 la base, evita aprovechar para la deducción lo recibido a título de subvención.

Un punto muy discutido, que dio origen al pronunciamiento del Tribunal de las Comunidades Europeas, es el lugar dónde deben efectuarse los gastos. Por años se distinguió exigiendo que los gastos se efectuasen en España, para permitir la deducción de los gastos en el extranjero con un límite del 25 por 100 de la inversión, sin embargo después del pronunciamiento del Tribunal, que ya tratamos previamente, se exige que los gastos se efectúen en España o en cualquier Estado miembro de la Unión Europea o del Espacio Económico Europeo, ya sea que se realicen por encargo del sujeto pasivo, individualmente o en colaboración con otras entidad sin hacer distinción por límite. Desde el punto de vista de la creación de $\mathrm{I}+\mathrm{D}$, la postura sigue siendo discutible, puesto que la ganancia en conocimiento se produce en cualquier lugar que se efectúe el gasto.

${ }^{724}$ SÁNCHEZ DE IBARRA Y TRUEBA. Ob. supra cit., pp. 1 y sgtes. Si bien todos los documentos que hemos citado en esta materia se refieren a la deducción por I+D+IT, este tiene la virtud de abordar específicamente los gastos y hacer un análisis comparado con otros países. 
La limitación está dada por la exigencia de estimar que las inversiones se entenderán realizadas cuando los elementos patrimoniales sean puestos en condiciones de funcionamiento.

c) Porcentajes de deducción

Tal como vimos al analizar los tipos de deducción por I+D, una clasificación las distingue entre deducción de base fija y progresiva ${ }^{725}$. España optó por utilizar ambos sistemas. La base fija es, actualmente, de un 30 por 100 de los gastos efectuados en el período impositivo por este concepto. El porcentaje sube de manera progresiva a 50 por 100 , en el año en que los gastos por I+D sean superiores a la media de los efectuados en los dos años anteriores, pero sólo respecto de los gastos que superen la media.

d) Deducciones adicionales

Existen dos deducciones adicionales, una por personal calificado y la otra por la adquisición de inmovilizado material o inmaterial. La primera, consiste en una deducción adicional del 20 por 100 del total de los gastos de personal, siempre que se trate de investigadores calificados dedicados exclusivamente a las actividades de I+D.

En el segundo caso, se trata de una deducción del 10 por 100, de las inversiones en elementos de inmovilizado material e intangible (excluidos los inmuebles y terrenos), siempre que se cumpla con la misma exigencia del caso anterior, es decir que estén dedicados completamente a las actividades de investigación y desarrollo.

La ley se detiene para hacer compatible la deducción adicional por inversiones en inmovilizado, con la deducción por reinversión de beneficios extraordinarios del art. 46 de la Ley, además de declararla incompatible con las restantes deducciones previstas en otros artículos del Capítulo IV, sobre deducciones para incentivar la realización de determinadas actividades.

\footnotetext{
${ }^{725}$ ÁLVAREZ. Ob. supra cit., p. 697 y sgtes. Realiza un estudio sobre las técnicas de incentivo en I+D.
} 
Finalmente, debe tenerse presente que para gozar de la deducción, los elementos activos en que se materialice la inversión deberán permanecer en el patrimonio del sujeto pasivo ${ }^{726}$.

\section{III.2.2.7.4.3.2 La deducción por IT}

Después de la deducción por I+D, alojada en el mismo artículo 35 TRLIS, encontramos a una deducción que aborda específicamente a la innovación tecnológica como objeto digno de promoción por la vía fiscal. La geografía de esta parte del artículo es casi igual a la regulación por I+D y también caben los mismos comentarios, de manera que, sólo nos detendremos en aquello que puede haber diferencias significativas.

a) Concepto de innovación tecnológica

El TRLIS optó por una definición de innovación tecnológica que la conceptualiza, como una actividad incremental, menor en relación a la I+D y por lo mismo la beneficia en un porcentaje inferior.

Para el art. 35 TRLIS, se "considerará innovación tecnológica la actividad cuyo resultado sea un avance tecnológico en la obtención de nuevos productos o procesos de producción o mejoras sustanciales de los ya existentes. Se considerarán nuevos aquellos productos o procesos cuyas características o aplicaciones, desde el punto de vista tecnológico, difieran sustancialmente de las existentes con anterioridad".

La primera parte de la definición es bastante ortodoxa en el sentido que exige novedad y un avance tecnológico, sin embargo, desde el momento que exige la existencia de "diferencias sustanciales", introduce un elemento subjetivo, que muestra un claro giro hacia la visión económica de la innovación, tal como sucedía con la I+D. De todas formas, la opción no está del todo en línea con FRASCATI, puesto que tal como analizamos en su oportunidad, para el Manual la innovación científica y tecnológica es un proceso complejo que comprende a la $\mathrm{I}+\mathrm{D}$, en cambio en la definición legal, no resulta nada claro que se consideren de esa manera, por el contrario, tal como

\footnotetext{
${ }^{726}$ Excepto en los casos previstos en el art. 35. 1. c) $2^{\circ}$, párrafo final, en cuanto establece: “(...) salvo pérdidas justificadas, hasta que cumplan su finalidad específica en las actividades de investigación y desarrollo, excepto que su vida útil conforme al método de amortización, admitido en el párrafo a) del apartado 1 del artículo 11, que se aplique, fuese inferior".
} 
dijimos, la innovación más bien se ve como un estado de innovación y desarrollo menor, que implica un esfuerzo y desarrollo técnico más reducido que la I+D.

Al igual que en el caso de la $\mathrm{I}+\mathrm{D}$, respecto de lo cual, caben los mismos comentarios que hicimos en su momento, la norma extiende la protección a los prototipos y muestrarios ${ }^{727}$, además se agregan los muestrarios textiles, de la industria del calzado, del curtido, de la marroquinería, del juguete, del mueble y de la madera, a los que se exige muy en la línea del Manual de FRASCATI ${ }^{728}$, "que no puedan convertirse o utilizarse para aplicaciones industriales o para su explotación comercial ${ }^{729}$.

b) Base de la deducción

En este caso la base de la deducción o no es tan amplia como para la I+D, donde se aceptaban todos los gastos vinculados al proyecto. La reducción del espectro de la deducción es armónica con la concepción restringida de la innovación que desarrolla el legislador, puesto que constituye un resguardo frente a contribuyentes voraces, limitando los gastos a los del período, que correspondan a los siguientes conceptos:

“1. Actividades de diagnóstico tecnológico tendentes a la identificación, la definición y la orientación de soluciones tecnológicas avanzadas, con independencia de los resultados en que culminen.

2..$^{\circ}$ Diseño industrial e ingeniería de procesos de producción, que incluirán la concepción y la elaboración de los planos, dibujos y soportes destinados a definir los elementos descriptivos, especificaciones técnicas y características de funcionamiento necesarios para la fabricación, prueba, instalación y utilización de un producto, así como la elaboración de muestrarios textiles, de la industria del calzado, del curtido, de la marroquinería, del juguete, del mueble y de la madera.

3. Adquisición de tecnología avanzada en forma de patentes, licencias, «knowhow» y diseños. No darán derecho a la deducción las cantidades satisfechas a personas

\footnotetext{
${ }^{727}$ No incluye el software avanzado, lo que es razonable, puesto que difícilmente cabría en la definición de innovación tecnológica que establece el Art. 35 TRLIS

${ }^{728}$ MANUAL DE FRASCATI. Ob. Cit., Cap. I, pp. 21 y 22.

${ }^{729}$ Art. 35. 2. a) TRLIS.
} 
o entidades vinculadas al sujeto pasivo. La base correspondiente a este concepto no podrá superar la cuantía de un millón de euros.

4. ${ }^{\circ}$ Obtención del certificado de cumplimiento de las normas de aseguramiento de la calidad de la serie ISO 9000, GMP o similares, sin incluir aquellos gastos correspondientes a la implantación de dichas normas" ${ }^{\$ 30}$.

Como puede observarse, se trata de gastos vinculados a actividades más lejanas de una concepción ideológica de la innovación y el desarrollo, desaparecen todos los gastos vinculados a investigación pura, trabajos de laboratorios, se observa un alejamiento de la investigación básica y aplicada, centrando la deducción alrededor del desarrollo experimental y de aplicaciones concretas, aun cuando se trata de actividades de escasa altura científica como la elaboración de muestrarios textiles, de la industria del calzado, del curtido, de la marroquinería, del juguete, del mueble y de la madera.

Posteriormente el artículo se hace cargo -de manera casi idéntica a como lo hizo en el caso de la I+D- de exigir: que los gastos deben está directamente relacionados con las actividades de IT; que los gastos deben efectuarse en España o en cualquier Estado miembro de la Unión Europea o del Espacio Económico Europeo; que se realicen por encargo del sujeto pasivo, individualmente o en colaboración con otras entidades; y, que se deduzca de la base el 65 por 100 de las subvenciones recibidas.

\section{III.2.2.7.4.3.3 Cuestiones comunes a la deducción por I+D+IT}

Dentro de la estructura de la deducción, desde el punto 3. del art. 35, en adelante, se tratan cuestiones comunes, aplicables tanto a la I+D como a la IT. Lo primero que hace es definir las actividades no deben entenderse como parte de I+D+IT, lo que podría haber hecho después de la definición de I+D e IT, respectivamente, asunto que si bien sería gramaticalmente más claro, se entiende la ubicación actual, puesto que emana de las sucesivas modificaciones que ha sufrido la deducción que le dieron su actual forma, en consecuencia, a estas alturas del partido, se gana más manteniendo la estructura de un artículo asentado en el medioambiente que norma, que pretendiendo dogmatismos o purezas estéticas.

\footnotetext{
${ }^{730}$ art. 35.2.b) TRLIS.
} 
La norma se detiene para no considerar actividades de investigación y desarrollo ni de innovación tecnológica:

a) "Las actividades que no impliquen una novedad científica o tecnológica significativa".

Esta sola oración introduce una complicación interpretativa de proporciones épicas, puesto que la "novedad" es un análisis objetivo, algo es nuevo o no lo es. La adición de la exigencia de que sea "significativa" transforma la cuestión, en algo parecido al "nivel inventivo" o alguna de las formas de conceptualizar este requisito típico de patentes, como el llamado "efecto sorprendente" o los métodos del "salto técnico", del "problema solución"731, etc. Por ello, parece más claro, prescindir de ideas preconcebidas por asentadas que estén en otras ramas del derecho y encontrar el contenido de esta oración, no en su tenor literal, sino en lo que agrega la continuación del mismo párrafo. Así las cosas, da contenido pensar que se busca excluir los esfuerzos rutinarios, el trabajo diario y los cambios inherentes a la actividad fabril de que se trate $^{732}$, lo que es concordante con el contexto lógico en que se ha elaborado la deducción. De todas formas, la norma se cuida de dejar a salvo, los muestrarios ya que expresamente dice que no se excluyen, lo que no sorprende, puesto que es coherente con la definición de $\mathrm{I}+\mathrm{D}$, donde están expresamente incluidos.

b) "Las actividades de producción industrial y provisión de servicios o de distribución de bienes y servicios".

Este punto muestra un alejamiento de la idea de innovación del Manual de FRASCATI, ya que tal como vimos en su oportunidad, el reglaje de herramientas y la ingeniería industrial, junto al inicio de la fabricación y desarrollo previo son parte de la innovación científica y tecnológica, que aquí aparecen expresamente excluidas. En

\footnotetext{
731 Los mencionados son algunos de los métodos utilizados para poder dar vida al requisito de las patentes de "nivel inventivo" o "inventive step" según sea la concepción continental o del common law. Superada la novedad, el nivel inventivo busca encontrar en la diferenciación del estado del arte, el esfuerzo del inventor en una magnitud tal que permita reconocerle la ventaja que implica el otorgamiento de una patente de invención.

732 Continúa art. 35, 4., letra a), diciendo: "En particular, los esfuerzos rutinarios para mejorar la calidad de productos o procesos, la adaptación de un producto o proceso de producción ya existente a los requisitos específicos impuestos por un cliente, los cambios periódicos o de temporada, excepto los muestrarios textiles y de la industria del calzado, del curtido, de la marroquinería, del juguete, del mueble y de la madera, así como las modificaciones estéticas o menores de productos ya existentes para diferenciarlos de otros similares".
} 
particular, la planificación de la actividad productiva: la preparación y el inicio de la producción, incluyendo el reglaje de herramientas y aquellas otras actividades distintas de las descritas en la letra b) del apartado anterior; la incorporación o modificación de instalaciones, máquinas, equipos y sistemas para la producción que no estén afectados a actividades calificadas como de investigación y desarrollo o de innovación; la solución de problemas técnicos de procesos productivos interrumpidos; el control de calidad y la normalización de productos y procesos; la prospección en materia de ciencias sociales y los estudios de mercado; el establecimiento de redes o instalaciones para la comercialización; el adiestramiento y la formación del personal relacionada con dichas actividades. $^{733}$

c) "La exploración, sondeo o prospección de minerales e hidrocarburos".

La exclusión de estas actividades no parece ser necesaria puesto que no caben dentro de la definición de I+D+IT, básicamente por no tener nada de nuevo y ser acciones rutinarias, sin embargo el legislador estimó necesario excluirlas.

\section{III.2 2.7.4.3.4 Cuestiones relativas a la administración de la deducción}

La Ley estableció algunas reglas, específicamente, sobre la administración de la deducción, lo que se condice con la importancia que asigna al asunto, que pasaremos a revisar, someramente.

\section{a) Informes motivados}

Los informes motivados nacen de una solicitud efectuada por el contribuyente al Ministerio de Ciencia e Innovación, o por un organismo adscrito a éste, normalmente previa a la inversión, no obstante la disposición no distingue por lo que puede ser en cualquier momento. El objetivo es evitar los problemas que implica la definición de las actividades y gastos están beneficiados con la deducción, de manera de evitar los

\footnotetext{
${ }^{733} \mathrm{El}$ art. 35, 4., letra b), menciona las actividades excluidas y: "En particular, la planificación de la actividad productiva: la preparación y el inicio de la producción, incluyendo el reglaje de herramientas y aquellas otras actividades distintas de las descritas en la letra b) del apartado anterior; la incorporación o modificación de instalaciones, máquinas, equipos y sistemas para la producción que no estén afectados a actividades calificadas como de investigación y desarrollo o de innovación; la solución de problemas técnicos de procesos productivos interrumpidos; el control de calidad y la normalización de productos y procesos; la prospección en materia de ciencias sociales y los estudios de mercado; el establecimiento de redes o instalaciones para la comercialización; el adiestramiento y la formación del personal relacionada con dichas actividades".
} 
problemas de que hemos venido hablando, que nacen de la dificultad que presenta definir el contenido de que se entiende por I+D+IT. Se trata entonces de la calificación de las actividades de I+D+IT y sus gastos asociados, de forma de otorgar al contribuyente certidumbre y seguridad jurídicas.

El sistema, sin duda, constituye un avance y aunque no es una innovación del legislador tributario, es una institución que brinda una adecuada respuesta a los problemas que presentaba otorgar contenido a la $\mathrm{I}+\mathrm{D}+\mathrm{IT}$ y que podía llevar a la propia deducción a perder toda su efectividad.

Lo característico de los informes es que una vez emitidos son vinculantes para la administración tributaria ${ }^{734}$.

b) Consultas y acuerdos previos de valoración

El art. 35. 4. b) TRLIS establece el derecho del contribuyente de presentar consultas sobre la interpretación y aplicación de la deducción, lo que no debería presentar novedad, puesto que no existiendo la norma de todas formas las consultas son procedentes en virtud de los artículos 88 y 89 de la Ley 58/2003, Ley General Tributaria. En este sentido, no es claro si hacer expreso el derecho a las consultas sirve para reafirmar su procedencia o para interpretar a contrario sensu, que en aquellos casos en que no se otorgue el derecho expresamente, éste no es procedente ${ }^{735}$.

El art. 35. 4. c) TRLIS otorga el derecho a solicitar acuerdos previos de valoración de los gastos e inversiones correspondientes a proyectos de investigación y desarrollo o de innovación. Éstos deben ser solicitados de manera previa ${ }^{736}$.

${ }^{734}$ Los informes motivados están contenidos en el art. 35. 4. a) TRLIS, que dice: "Para la aplicación de la deducción regulada en este artículo, los sujetos pasivos podrán aportar informe motivado emitido por el Ministerio de Ciencia e Innovación, o por un organismo adscrito a éste, relativo al cumplimiento de los requisitos científicos y tecnológicos exigidos en la letra a) del apartado 1 de este artículo para calificar las actividades del sujeto pasivo como investigación y desarrollo, o en la letra a) de su apartado 2, para calificarlas como innovación, teniendo en cuenta en ambos casos lo establecido en el apartado 3. Dicho informe tendrá carácter vinculante para la Administración tributaria”.

735 Las consultas están contenidas en el art. 35. 4. b) TRLIS, que dice: "El sujeto pasivo podrá presentar consultas sobre la interpretación y aplicación de la presente deducción, cuya contestación tendrá carácter vinculante para la Administración tributaria, en los términos previstos en los artículos 88 y 89 de la Ley 58/2003, de 17 de diciembre, General Tributaria".

${ }^{736}$ Los acuerdos previos de valoración están contenidos en el art. 35. 4. c) TRLIS, que dice: "Igualmente, a efectos de aplicar la presente deducción, el sujeto pasivo podrá solicitar a la Administración 
Tanto las consultas como los informes previos de valoración, se diferencian de los informes motivados en que se solicitan a la propia Administración Tributaria, lo que a nuestro juicio les resta imparcialidad, no obstante morigera nuestra crítica, el hecho que puedan presentarse como antecedente los informes motivados que se vuelven vinculantes para la Administración Tributaria.

c) Desarrollo reglamentario

El último punto que regula la disposición del art. 35 TRLIS, que latamente venimos analizando, es otorgar la facultad para que reglamentariamente se puedan “concretar los supuestos de hecho que determinan la aplicación de las deducciones",737, disposición respecto de la cual puede agradecerse su flexibilidad, no obstante debe permitírsenos dudar de su efectividad; por dos razones: por una parte, una disposición de esta naturaleza siempre estará al borde de violar el principio de reserva de ley; y, por otra, porque la experiencia demuestra que particularmente en esta materia, los caminos cortos se vuelven largos y los arreglos rápidos a nivel reglamentario, terminan en arduos conflictos interpretativos con llevan a modificaciones legales, más que a soluciones. De todas formas, si la atribución se usa con prudencia, posiblemente podrá obtenerse de ella todo su rendimiento.

\subsubsection{Deducción por producciones cinematográficas y producción de libros}

Siguiendo el orden cronológico del TRLIS nos corresponde entrar al análisis del art. 38, donde encontramos, a las deducciones por producciones cinematográficas y producción de libros, de nuestro interés, puesto que afectan a dos categorías de protección de la propiedad intelectual; sin embargo, tenemos que considerar que estas deducciones están destinadas a desaparecer desde el año 2006, cuando la Disposición derogatoria segunda de la Ley 35/2006, pretendiendo la neutralidad fiscal, dispuso la eliminación periódica de las deducciones contenidas en los diferentes apartados del art. 38 TRLIS. La supervivencia, originalmente estuvo asegurada hasta el año 2013, desapareciendo completamente en el período impositivo que se iniciare el 1 de enero de 2014.

tributaria la adopción de acuerdos previos de valoración de los gastos e inversiones correspondientes a proyectos de investigación y desarrollo o de innovación".

737 Art. 35. 4. TRLIS. 
Con posterioridad, la Disposición derogatoria 2.4 de la Ley 35/2006, ha sido modificada en tres oportunidades: primero por el RDL 3/2009, que prolongó la vigencia de la deducción del apartado dos, relativo a las producciones cinematográficas, para la hacerlo aplicable a las deducciones pendientes de aplicación al comienzo del primer período impositivo que se inicie a partir del 1 de enero de 2012; segundo por el RDL 8/2011, que copiando la redacción del RDL 3/2009, prolongó su aplicación hasta el año 2013; y, tercero, por la Ley 16/2013, de 29 de octubre, por la que se Establecen Determinadas Medidas en Materia de Fiscalidad Medioambiental y se Adoptan otras Medidas Tributarias y Financieras, que fijó la vigencia indefinida de la deducción por inversiones en producciones cinematográficas y series audiovisuales, y se amplió su base, incluyendo los gastos incurridos en la producción de las copias y en la publicidad, que corran a cargo del productor.

En atención a lo expuesto, no tiene sentido detenernos en la deducción del apartado tercero del art. 38 TRLIS, sobre edición de libros, ya que se ha derogado con efecto para los períodos impositivos que se inicien a partir del 1 de enero de 2014738.

La deducción por inversiones cinematográficas, si bien está regulada en el art. 38. 2 TRLIS, tiene una madrina en la Ley 5/2007, de 28 de diciembre, del Cine, que ha asegurado, en un primer momento la mantención de los tipos de la deducción y, actualmente, mediante la intervención de la Ley 16/2013, de 29 de octubre, volverla permanente, yendo en contra de la tendencia que veníamos viendo, de hacer desaparecer las deducciones.

La permanencia de la deducción por inversiones cinematográficas, confirma aquello en lo que venimos insistiendo, sobre la vocación de eternidad que van tomando estos beneficios, lo que a nuestro modo de ver, también da cuenta de una cierta manera, del convencimiento sobre el beneficio de estos institutos.

El objeto de la deducción. La deducción está destinada a beneficiar la producción de largometrajes cinematográficos y de series audiovisuales ${ }^{739}$ de ficción,

${ }^{738}$ Disposición derogatoria segunda, apartado cuarto, Ley 35/2006.

${ }^{739}$ La definición de obra audiovisual, la encontramos en artículo 86 del RDL 1/1996, de 12 de abril, Ley de Propiedad Intelectual, al decir, que son "[L]as creaciones expresadas mediante una serie e imágenes asociadas, con o sin sonorización incorporada, que estén destinadas esencialmente a ser mostradas a través de aparatos de proyección o por cualquier otro medio de comunicación pública de la imagen y del sonido, con dependencia de la naturaleza de los soportes materiales de dichas obras". 
animación o documental, que permitan la confección de un soporte físico previo a su producción industrial seriada. Es decir, no es suficiente con la producción de la obra, sino que además se exige que sea posible su fijación en un soporte físico y conjuntamente, exige que se haga una producción seriada de la misma, lo que va más allá de ser un mero requisito formal, puesto que, tal como veremos la obra debe ser explotada al menos por tres años para poder aprovechar plenamente el beneficio.

La producción cinematográfica debe ser española, lo que no está definido en la LIS, pero si en la Ley del Cine, que da tal consideración a las obras realizadas por una empresa de producción española o de otro Estado miembro de la Unión Europea establecido en España. Esta calidad debe ser certificada por el Instituto de la Cinematografía y de las Artes Audiovisuales, organismo dependiente del Ministerio de Cultura $^{740}$.

El sujeto pasivo de la deducción. Los sujetos pasivos con derecho a la deducción pueden ser el productor o el coproductor financiero de la obra. Claro está que deben ser contribuyentes del IS.

El productor es quien tiene los derechos de propiedad de la obra, encontrándose el concepto de productor ${ }^{741}$. Para PÉREZ BUSTAMANTE742, son dos los elementos que identifican al productor: "iniciativa y responsabilidad, elementos que no siempre

${ }^{740}$ El art. 5 de la Ley 5/2007, del Cine, exige para el otorgamiento del certificado, que:

- Que el elenco de autores de la producción, entendiendo por tales el director, el guionista, el director de fotografía y el compositor de la música, este formado al menos en un 75 por 100, por personas con nacionalidad española o de cualesquiera de los otros Estados miembros de la Unión Europea, de los Estados parte en el Acuerdo sobre el Espacio Económico Europeo, o que posean tarjeta o autorización de residencia en vigor en España o en cualesquiera dichos estados. En todo caso se exigirá que el director de la película cumpla siempre este requisito;

- Que los actores y otros artistas que participan en la producción estén representados al menos en un 75 por 100 por personas que cumplan los requisitos establecidos en la letra anterior;

- Que el personal creativo de carácter técnico así como el resto del personal técnico que participen en la producción estén representados al menos en un 75 por 100 por personas que cumplan los requisitos establecidos en la letra anterior;

- Que la obra se realice preferentemente en su versión original en alguna de las lenguas oficiales del estado español;

- Que el rodaje, salvo exigencias del guion, la posproducción en estudio y los trabajos de laboratorio se realicen en territorio español o de otros estados miembros de la Unión Europea.

${ }^{741}$ Productor de una grabación audiovisual, según el art. 120.2 RDL 1/1996, de 12 de abril, Ley de Propiedad Intelectual, es "la persona natural o jurídica que tenga la iniciativa y asuma la responsabilidad de dicha grabación audiovisual"

742 PÉREZ BUSTAMANTE, DAVID. Fiscalidad de las Inversiones Cinematográficas en la Nueva Ley del Cine, Revista Aranzadi de Derecho del Deporte y el Entretenimiento, $n^{\circ}$ 25, 2009. Disponible en Internet en: http://www.uria.com/es/publicaciones/articulos-juridicos.html $? \mathrm{id}=2186 \& \mathrm{pub}=$ Publicacion\&tipo=es (10 Abr 2014). 
fáciles de identificar en la práctica". Ahora bien, que se conozcan sus características no dice que sea fácil de identificar, lo que nos va llevar siempre a la evaluación caso a caso, a las particularidades del contrato y la realidad de las funciones asumidas ${ }^{743}$.

A pesar de no haber definido quién es el productor, la LIS se detuvo para referirse al "coproductor financiero", considerando como tal a la entidad que participe en la producción de las películas exclusivamente mediante la aportación de recursos financieros en cuantía que no sea inferior al 10 por ciento ni superior al 25 por ciento del coste total de la producción, a cambio de participar en los ingresos derivados de su explotación.

La base de la deducción. Existen dos bases diferenciadas, según el beneficio aproveche al productor o al coproductor financiero. Para el productor, a contar del 1 de enero de 2014 y gracias a la Ley 16/2013, antes citada, la base estará constituida por el coste total de la obra ${ }^{744}$, incluidos los gastos por obtención de copias, publicidad y promoción a cargo del productor hasta el límite del 40 por ciento del coste de producción, menos la parte financiada por el coproductor financiero. Para el coproductor financiero la base de la deducción será el importe de la obra que financie excluidas subvenciones.

El tipo de deducción. Los porcentajes están fijados en un 18 por ciento para el productor y en un 5 por ciento para el coproductor financiero, pero este último, tiene un límite del 5\% de las rentas obtenidas por la inversión.

Límite de la deducción. La deducción está limitada por lo dispuesto en el artículo 44 LIS, que establece las normas comunes para todas las deducciones previstas en el Capítulo IV, Título VI de la Ley del Impuesto. Siguiendo esas normas, esta deducción debe ser aplicada después de las deducciones para evitar la doble imposición interna e internacional y bonificaciones establecidas en los capítulos II y III del Título VI. El monto total de la misma, unida a todas las deducciones del período,

743 Ob. supra cit. El autor destaca una cosa que vale tener presente: "[T]ambién nos encontraremos ante un supuesto complejo en aquellas ocasiones en las que la iniciativa y responsabilidad sea asumida por un grupo de personas. La calificación como productor en tales supuestos se deberá realizar caso por caso a través del análisis de las relaciones contractuales existentes entre los potenciales productores".

${ }^{744}$ La Resolución Vinculante V0643/2005, señala que el coste de la producción, "esto es, la totalidad del importe derivado de la adquisición de bienes y servicios necesarios para la producción del obra, que tengan la consideración contable de coste de producción, cualquiera que haya sido la fuente de financiación". 
contempladas en el Capítulo IV, no podrán exceder, en conjunto, del 35 por ciento de la cuota íntegra del impuesto, minorada en las deducciones para evitar la doble imposición interna e internacional y las bonificaciones.

Otros requisitos o características. Los montos que excedan los límites señalados pueden arrastrarse a ejercicios futuros, por los 10 años inmediatos y sucesivos. La obra cinematográfica debe mantenerse en funcionamiento durante 3 años, de tal forma que si se transmiten los derechos de emisión y demás inherentes a la condición de productor se pierde la deducción.

Finalmente, es del caso hacer presente, que la bonificación por actividades exportadoras regulada en el artículo 34 LIS, pudiese ser aplicable en este caso, puesto que beneficia a la actividad exportadora de producciones cinematográficas, siempre que los beneficios correspondientes se reinviertan en el mismo período impositivo al que se refiere la bonificación o en el siguiente, en la adquisición de elementos afectos a la realización de las citadas actividades. El monto de la bonificación alcanza al 99 por ciento aplicado sobre la parte de cuota íntegra que corresponda a las rentas procedentes de la exportación de las producciones cinematográficas.

Respecto de esta bonificación y nuestro tema de estudio, no vemos muchas consecuencias conceptuales, puesto que su justificación se ve bastante estrecha, su único objeto es estimular una industrial muy puntual y respecto de una actividad igual de específica, como es la exportación. Finalmente, Compartimos con PÉREZ BUSTAMANTE, cuando señala que "su utilización práctica es compleja ya que requiere, además de la existencia de un beneficio, que el mencionado proceda de la exportación así como una obligatoria reinversión del mismo"745.

\subsubsection{Otras minoraciones}

Pudiera darse el caso que atendido el tipo de bien inmaterial fuesen aplicables a la propiedad intelectual otros beneficios o minoraciones, como por ejemplo: la deducción por reinversión de beneficios extraordinarios o la amortización acelerada que favorece a las empresas de reducida dimensión.

${ }^{745}$ PÉREZ. Ob. supra cit. 
Efectivamente, dentro de los elementos patrimoniales que al transmitirse ${ }^{746}$ son susceptibles de generar rentas que constituyan la base de la deducción prevista en el art. 42 TRLIS, Deducción por Reinversión de Beneficios Extraordinarios ${ }^{747}$, están los que hayan pertenecido al inmovilizado intangible, donde sin duda clasifica la propiedad intelectual, cualquiera sea la posición que se tome sobre la naturaleza jurídica de la misma. Por su parte, el art. 42. 3 TRLIS, considera como un bien dentro de los cuales se puede invertir para tener derecho a la deducción por reinversión a los pertenecientes al inmovilizado intangible. En esa medida, la propiedad intelectual puede ser objeto de la deducción, sin ningún inconveniente, aun cuando no se le haya mencionado como tal en la disposición, tal como lo analiza LÓPEZ ESPADAFOR ${ }^{748}$.

En el Capítulo XII de la TRLIS, sobre Incentivos Fiscales para las Empresas de Reducida Dimensión, el art. 112 prevé un sistema de amortización acelerado, que viene a auxiliar a las empresas de reducida dimensión. El mecanismo originalmente alojado en el art. 125 LIS, que "hasta el año 1997 sólo resultaba aplicable a la amortización de activos fijos materiales nuevos, a partir de 1998 se ha ampliado a los activos inmateriales, pudiendo así alcanzar a manifestaciones de propiedad industrial" ${ }^{\text {"79 }}$. En este sentido, la ley declara "que los elementos del inmovilizado intangible, (...) podrán amortizarse en función del coeficiente que resulte de multiplicar por 2 el coeficiente de amortización lineal máximo previsto en las tablas de amortización oficialmente aprobadas ${ }^{750}$.

\subsubsection{La propiedad intelectual como activo}

Como venimos advirtiendo, para nuestro estudio hemos revisado todas las oportunidades en que el legislador se refiere expresamente a la propiedad intelectual, esto se debe a que creemos que es en esos momentos donde podremos encontrar la mayor cantidad de elementos que nos permitan aproximarnos a la concepción más

\footnotetext{
${ }^{746}$ Es útil advertir que en Chile existe la costumbre de referirse a "transferencia" cuando se trata de actos entre vivos y "transmisión" en el caso de la sucesión por causa de muerte, lo que no sucede en España, donde la expresión "transmitirse" corresponde al desplazamiento del dominio por acto entre vivos.

${ }^{747}$ Sobre la deducción por beneficios extraordinarios puede verse, entre otros: GARCÍA-ROSADO GONZÁLEZ, BEGOÑA. Impuesto sobre sociedades: Guía, Edit. CISS, 2008, pp. 684 y sgtes; y, FERNÁNDEZ DE SOTO BLASS, MARÍA LUISA. Practicum del Derecho Tributario Español, Edit. Dykinson, Madrid, 2005, pp. 352 y sgtes.

${ }^{748}$ LÓPEZ. Ob. supra cit., p. 76. El autor establece que es posible aplicar la deducción a propósito de la propiedad industrial, no obstante, hay que tener presente que él trabajó con el art. 21, Ley 43/1995 LIS, que básicamente contiene la misma deducción que el actual art. 42 TRLIS.

749 Ob. supra cit., p. 79.

${ }^{750}$ ART. 112, párrafo primero, TRLIS.
} 
profunda que tiene el legislador tributario sobre la propiedad intelectual y determinar más exactamente, cómo la entiende y dimensiona. Por ello, nos conformamos con los ejemplos analizados y con insistir que, finalmente, la propiedad intelectual poco a poco ha ido conquistando su lugar como un activo más dentro de la empresa y por tanto, cuando el legislador no distinga no debieran existir razones para darle un trato diferente, en comparación con otros activos.

\subsection{La propiedad intelectual en el Impuesto sobre la Renta de las Personas Físicas}

\subsubsection{El IRPF. Notas generales}

Por Ley 35/2006, de 28 de noviembre, se establece el Impuesto sobre la Renta de las Personas Físicas ${ }^{751}$. El impuesto sobre la Renta de las Personas Físicas, es la contrapartida a nivel de impuestos directos del Impuesto sobre Sociedades. En cuanto a las personas físicas, considerando su residencia, en España deberíamos distinguir entre el Impuesto sobre la Renta de las Personas Físicas y el Impuesto a la Renta sobre la Renta de no Residentes, contenido en el RDL 5/2004, de 5 de marzo. Vale anotar que en Chile la clasificación es similar con la particularidad el impuesto a la renta de no residentes, se encuentra anidado dentro de la única ley de renta, llevando el extraño nombre de Impuesto Adicional.

El Impuesto sobre la Renta de las Personas Físicas es un tributo de carácter personal y directo que grava, porque grava las rentas obtenidas en cabeza del contribuyente. En cuanto a los principios, la propia ley establece que se rige por los principios de igualdad, generalidad y progresividad, la renta de las personas físicas de acuerdo con su naturaleza y sus circunstancias personales y familiares.

A diferencia de la LIS, en el IRPF encontramos una definición de renta, en el art. 2 IRPF, que la entiende "como la totalidad de sus rendimientos, ganancias y pérdidas patrimoniales y las imputaciones de renta que se establezcan por la ley”. Definición que es concordante con lo que venimos entendiendo por renta, en el sentido que es un concepto neto, es decir, de ingresos menos gastos.

\footnotetext{
${ }^{751}$ La Ley 35/2006, de 28 de noviembre, ha tenido sucesivas modificaciones, la última por Ley 22/2013, de 23 de diciembre. Disponible en Internet en: https://www.boe.es/diario_boe/txt.php?id=BOE-A-2006-20764\#analisis. (10 Abr 2014).
} 
El período de imposición será el año natural, devengándose el impuesto el 31 de diciembre de cada año, sin perjuicio de las excepciones que establece la propia Ley. La imputación de ingresos se prevé sobre base de "devengado"752 por regla general, permitiendo el uso del criterio del "percibido" 753 , en los casos que correspondan a las Reglas Especiales, establecidas en el art. 14.2 IRPF.

El sujeto pasivo del impuesto, lo encontramos regulado en el art. 8 IRPF, que señala como tal a "[1]as personas físicas que tengan su residencia habitual en territorio español". El sujeto pasivo debe ser residente en territorio español y estará sometido a imposición por las rentas sobre el principio de renta mundial.

En ciertos casos, la Ley obliga a un sujeto pasivo a consolidar sus rentas con las de otro contribuyente, produciendo una suerte de fusión de sujetos pasivos, es el caso de la "transparencia fiscal, que se produce, cuando en el caso de ciertas sociedades, el beneficio calculado según la LIS, "se imputa a cada uno de los socios, integrándose con el resto de las rentas de éstos, aun cuando tales beneficios no hayan sido objeto de distribución" ${ }^{, 754}$. Esta figura debemos tenerla presente porque se aplicará a las sociedades de artistas y deportistas y a los derechos de imagen, que son parte de nuestro estudio posterior.

La base imposible está sancionada en los arts. 15 y sgtes. IRPF, constituida por "el importe de la renta del contribuyente (...)"755, según la Ley. La base imponible es la renta disponible del contribuyente, por lo que es necesario partir por "delimitar e integrar las rentas que, puesto que resultan de la deducción de una serie de gastos, pueden calificarse como netas y después restar el denominado mínimo vital”756. La determinación de la renta gravable y la consiguiente base imponible, se hace conforme lo dispone el Capítulo II, de la Ley del IRPF, que se hace cargo de: los rendimientos del trabajo, capital, capital inmobiliario, capital mobiliario, actividades económicas, ganancias y pérdidas patrimoniales, transmisiones título lucrativo, ganancias patrimoniales no justificadas, gastos deducibles y reducciones. La norma busca hacerse

${ }^{752}$ MARTÍN QUERALT. Ob. supra cit. p. 571. El autor define devengado como: “(...) esto es, al momento en que nace el derecho a percibirlos o a exigirlos, con independencia del momento en que unos y otros se hacen efectivos".

${ }^{753}$ Esto es, cuando efectivamente se han cobrado.

${ }_{754}$ Ob. supra cit., p. 557.

755 Art. 15 Ley 35/2006, IRPF.

${ }^{756}$ Ob. supra cit., p. 558. 
cargo de la totalidad de los ingresos y descontar aquellos gastos que resultan adecuados para producirlos.

La cuantificación de los componentes de la base imponible se realiza por estimación directa como regla general, lógicamente, ante inconsistencias la administración tiene la alternativa de recurrir al método indirecto, de conformidad a la Ley 58/2003, de 17 de diciembre, General Tributaria. Por excepción, ciertos rendimientos se determinan por el método de estimación objetiva.

Integración y compensación de rentas. Determinada la base imponible, la Ley obliga a efectuar la integración y compensación entre rendimientos y pérdidas, pero no permite una fusión total de los rendimientos sino que los clasifica según lo que denomina base imponible general y base imponible del ahorro ${ }^{757}$.

La base liquidable. En el caso del IRPF, por efecto de la integración y compensación de rentas, requiere se dividida en dos tipos diferentes, la base liquidable general y la del ahorro. La particularidad es que la base liquidable general puede ser compensada con futuras bases positivas, de la misma naturaleza por un período de cuatro años siguientes.

El IRPF es un impuesto compartido entre el Estado y las CCAA, por lo que el tipo impositivo se divide entre lo que corresponde a unos y otros. En todo caso, el impuesto es progresivo y actualmente la suma de la escala estatal más autonómica resulta en porcentajes entre el 24.75 por ciento a 56 por ciento en Cataluña.

La deuda tributaria, se genera después de aplicar las deducciones en cuota a que haya derecho. Al respecto hay que considerar que las circunstancias personales y familiares del contribuyente han sido consideradas para el cálculo de la base imposible, por lo que, las deducciones que puedan caber a estas alturas no deben ser significativas.

Finalmente, el IRPF al igual que el IS hace referencia a normas sobre la gestión del impuesto.

${ }^{757}$ Arts. 47 y sgtes., Ley 35/2066 IRPF. 
En cuanto a la propiedad intelectual se refiere, existen sólo cuatro referencias expresas en la Ley 35/2006 sobre Impuesto a la Renta de las Personas Física (IRPF): en el art. 17. 2. d) ${ }^{758}$, que considera rendimientos del trabajo los provenientes de la elaboración de obras literarias, artísticas o científicas, siempre que se ceda el derecho a su explotación; art. 25. 4. a), que clasifica, bajo ciertos requisitos, a los rendimientos de la propiedad intelectual e industrial como provenientes del capital mobiliario; art. 101. 3, que fija en un 19\% el importe de los pagos a cuenta por los rendimientos procedentes derivados de la elaboración de obras literarias, artísticas o científicas, siempre que se ceda el derecho a su explotación; y, art. 101. 9. IRPF, que fija en un 19\% el importe de los pagos a cuenta por los rendimientos procedentes de la propiedad intelectual e industrial.

Si seguimos el esquema que utilizamos al tratar el TRLIS sólo deberíamos concentrarnos en las disposiciones que hemos citado, no obstante, estimamos que atendida la estructura del IRPF español, que es sustancialmente diferente del caso chileno, puesto que distingue entre los diferentes tipos de rentas imputables al contribuyente persona natural, es el momento para poder ilustrar sobre las diferentes formas que pueden tomar los rendimientos de la propiedad intelectual, lo que hará que normalmente estén gravados con el impuesto en su calidad de activo susceptible de generar rentas o visto desde el punto de vista jurídico como bien inmaterial.

Como es sabido, en la Ley del IRPF las rentas gravables, pueden provenir de rendimientos o de incrementos de patrimonio ${ }^{759}$. A su vez, los rendimientos pueden tener su origen en el trabajo, capital o actividades económicas, con lo que se configuran cuatro fuentes de rendimientos, lo curioso es que la propiedad intelectual puede generar rendimiento bajo todas estas formas, de ahí que resulte interesante detenernos en característica, tal como haremos seguidamente.

\subsubsection{La propiedad intelectual como rendimiento del trabajo}

Cuando LÓPEZ ESPADAFOR ${ }^{760}$ afirma que no puede haber rentas del trabajo con motivo de la propiedad industrial está en lo cierto y no podemos desconocer la verdad de su afirmación, no obstante limitada al contexto en que se efectúa parece ser

\footnotetext{
${ }^{758}$ Ley 35/2006, de 28 de noviembre, del Impuesto sobre la Renta de las Personas Físicas (IRPF).

${ }^{759}$ LÓPEZ. Ob. supra cit., p. 84.

${ }^{760}$ LÓPEZ. Ob. supra cit., p. 98.
} 
una afirmación bastante más estrecha de lo que realmente es. En efecto, en la realidad española, el art. 15. 1. de la Ley de Patentes ${ }^{761}$, bajo el título de Invenciones Laborales, se traslada la propiedad del invento al empleador, cuando ha sido creado por un trabajador en el contexto de una relación de trabajo, cuyo objetivo es la actividad investigativa explícita o implícitamente; en este sentido, la ocupación del trabajador y su contraprestación o salario, estarán siempre gravados con el impuesto al trabajo y la patente al radicarse en el empleador no puede ser para el trabajador objeto de rendimiento alguno, puesto que no estará en su patrimonio. Sin embargo, teóricamente, creemos que la distinción que se debe efectuar es más amplia, aun cuando, en cualquier caso, tendrá los mismos resultados.

Independiente de la legislación, las alternativas que se pueden dar a propósito de la creación de propiedad intelectual en el contexto de una relación de trabajo, son que la creación sea de propiedad: del empleador (que será lo común); del trabajador; de ambos; de un tercero; o, en proporciones para alguno de ellos, bajo régimen de comunidad.

Si la propiedad se radica en el empleador, la solución de LÓPEZ ESPADAFOR, de estimar que el trabajador recibe su renta del trabajo por su desempeño laboral, sin que tenga nada que ver la propiedad de la creación, es indiscutida, porque materialmente nunca llega al trabajador derecho alguno de propiedad intelectual sobre su creación.

En el evento que la propiedad se radique en el trabajador, la situación varía, porque difícilmente podríamos pensar es una relación laborar, aquella en que el trabajador trabaja para sí mismo, puesto que el pago carecería de objeto y causa, siendo una donación. En este contexto, tampoco podría sostenerse que la propiedad intelectual nació de la relación laboral, que jamás existió.

De otro lado, asumiendo la hipótesis de estimar que una parte de la propiedad intelectual es del empleador y otra del trabajador, de todas formas debemos concluir que la renta viene de la actividad laboral, pagada en parte en especie (la proporción que le

${ }^{761}$ Ley 11/1986, de 11 de marzo, Ley de Patentes. 
corresponde de la propiedad intelectual) ${ }^{762}$ y en dinero (la remuneración), de manera que tampoco hay un rendimiento del trabajo personal derivado de la propiedad intelectual.

Finalmente, en el evento extraño, pero posible, que se pacte que la propiedad intelectual será de un tercero, esta acción lucrativa la habrá hecho el trabajador a cambio de su remuneración vinculada al contrato de trabajo, por lo que la conclusión no cambia.

Ahora bien, desde el punto de vista de la propiedad intelectual, la creación se puede dar en el contexto de una relación laboral, entendida como la vinculación del trabajo bajo subordinación y dependencia, pero también podría suceder que no exista tal relación, sino que la actividad creativa se emprenda por encargo, en este caso, mucho tiene que ver con la organización que haya asumido el creador, puesto que podría generar rentas del trabajo o de actividades económicas. En ese orden de ideas, los rendimientos derivados de la actividad creativa para un tercero, serán normalmente calificados como rendimientos de actividades económicas, toda vez que será el creador, quien por cuenta propia organice su trabajo personal y capital o los medios de producción y de recursos humanos o de uno de ambos, con la finalidad de intervenir en la producción de bienes inmateriales ${ }^{763}$, tales son los bienes que constituyen la propiedad intelectual.

Por excepción en el caso de las obras literarias, artísticas y científicas, cuyo derecho de explotación se haya cedido, el art. 17. 2. d) IRPF, estimo que los rendimientos de la elaboración de estas creaciones, bajo la condición señalada, corresponden a rentas del trabajo, por lo que nada cabría argumentar al respecto, salvo advertir que sin existir esta norma, en el evento de haber una relación laboral, la solución sería la misma atendido lo que explicamos supra, de manera que la disposición tiene sentido cuando no exista una relación laboral.

En atención a lo expuesto, es curioso que el art. 17. 3 IRPF ponga cuidado en aclarar que no obstante que los rendimientos derivados de la elaboración de obras literarias, artísticas o científicas en los casos que se haya cedido el derecho de

\footnotetext{
${ }^{762}$ En este caso la parte de la remuneración que se paga en especie, es decir la propiedad intelectual, tendrá que valorarse conforma al art. 42 y sgtes. de la Ley del IRPF, pero su origen no varía en la medida que sigue siendo el trabajo el que crea propiedad industrial, no es la propiedad industrial la que crea rendimientos del trabajo.

${ }^{763}$ Art. 27. 1 IRPF.
} 
explotación deben ser considerados como rentas del trabajo, cuando supongan la ordenación por cuenta propia de medios de producción y de recursos humanos o de uno de ambos, con la finalidad de intervenir en la producción o distribución de bienes o servicios, se calificarán como rendimientos de actividades económicas, puesto que es la misma conclusión a la que debe llegarse de la aplicación sistemática de los art. 17.2. d) y 27 de la Ley del IRPF, tal como lo demostramos supra.

Por último, en lo que dice relación con los pagos a cuenta, en el caso que los rendimientos sean considerados rentas del trabajo, es decir, nacidos de una relación laboral, ya sabemos que no existe tal obligación. Cuando se trate de rendimientos procedentes de la elaboración de obras literarias, artísticas o científicas, siempre que se ceda el derecho a su explotación, los pagos a cuenta se deben efectuar con tasa de un $19 \%{ }^{764}$. En los demás casos, es decir: rendimientos provenientes de la elaboración de obras literarias, artísticas o científicas, sin ceder los derechos de explotación; rendimientos de otros derechos propiedad intelectual que no sean los mencionados; y, rendimientos de la propiedad industrial, la tasa para los pagos a cuenta también es de $19 \%{ }^{765}$.

\subsubsection{La propiedad intelectual como capital mobiliario}

El Art. 25. 4. a) de la Ley del IRPF, es la base para establecer una distinción entre cuando los rendimientos de la propiedad intelectual se vinculan a capitales mobiliarios o a actividades económicas. Verdaderamente, el artículo es bastante confuso, puesto que señala que se entenderán rendimientos del capital mobiliario, "Los procedentes de la propiedad intelectual cuando el contribuyente no sea el autor y los procedentes de la propiedad industrial, que no se encuentre afecta a actividades económicas realizadas por el contribuyente" ${ }^{\$ 766}$, de manera que, del tenor literal de la norma, se desprende que distingue entre la propiedad intelectual e industrial, exigiendo para que sus rendimientos sean considerados como de capitales mobiliarios, en el primer caso que el contribuyente no sea el autor y en el segundo, que no se encuentre afecto a actividades económicas. A efectos de tener en claro la hipótesis fáctica que estamos analizando, vale tener presente que podría tratarse de un sujeto que recibe a la propiedad intelectual por herencia, de manera que sin ser su creador posee sus derechos

\footnotetext{
${ }^{764}$ Art. 101. 3 de la Ley del IRPF.

765 Art. 101. 9. de la Ley del IRPF

${ }^{766}$ Art. 25. 4. a) de la Ley del IRPF.
} 
patrimoniales y también cuando alguien adquiere la propiedad intelectual, ya sea de su autor o de un tercero y la explota ${ }^{767}$.

Según nuestro análisis, lo lógico es entender, tal como vimos supra, que en la medida que la propiedad intelectual se produzca bajo el amparo de una relación laboral, estaremos frente a rendimientos del trabajo y cuando nazca como consecuencia del trabajo y esfuerzo individual de una persona, podrá ser un rendimiento de actividades económicas, en el momento que se cumplan con los requisitos de organización de trabajo y capital (conforme el art. 27 IRPF) o que el creador decida comercializar la propiedad intelectual en sí misma o sus rendimientos y también, puede dar origen a rendimientos del capital mobiliario, cuando quién obtiene provecho de ella no es el autor o creador, puesto que de serlo estaremos en alguno de los dos casos anteriores.

Bajo el análisis anterior, no es claro por qué la Ley del IRPF, para atribuir a las rentas de la propiedad intelectual la calidad de rendimientos de capitales mobiliarios, distingue entre propiedad intelectual propiamente tal y propiedad industrial, exigiendo en el primer caso que el contribuyente no sea el autor y en el segundo que no se encuentre afecto a actividades económicas. El dilema, LÓPEZ ESPADAFOR ${ }^{768}$ lo soluciona diciendo: "Téngase en cuenta que el caso de la propiedad intelectual es un supuesto paralelo al de la propiedad industrial, de forma que a las ganancias procedentes de ambas se les debe dar una solución similar", de donde desprende que, para que a las ganancias de la propiedad intelectual se les dé el tratamiento de capitales mobiliarios, es necesario que no se encuentren afectos a una actividad económica y que el sujeto pasivo no sea el autor. Compartimos la solución que da el autor citado, al exigir copulativamente ambos requisitos a la propiedad intelectual e industrial, sin embargo pensamos que a la misma conclusión se puede llegar por un camino más técnico que no implique fundarse en la condición que la propiedad intelectual e industrial sean supuestos paralelos, ya que normalmente lo serán, pero podrían existir matices. Así las cosas, bastaba con las observaciones que hicimos supra sobre su creación y explotación en el marco de una relación laboral o de actividades económicas, para advertir que lo dispuesto por el art. 23. 4. a) IRPF, no es contradictorio con lo que concluimos, sino que solamente confuso.

\footnotetext{
${ }^{767}$ Ejemplos extraídos de LÓPEZ. Ob. supra cit., p. 87.

${ }^{768}$ Ob. supra cit., p. 86.
} 
Así pues, en el caso de la propiedad intelectual propiamente tal, las posibilidades son que nazca de la creación del contribuyente o que la adquiera. Si la crea, las alternativas son que lo haga en el marco de una relación laboral generando rendimientos del trabajo, salvo la cesión de los derechos de explotación, tal como vimos más arriba o que la produzca directamente fuera de una actividad económica o dentro de ella. Fuera de una actividad económica no habrá renta gravable, salvo que la comercialice, en cuyo caso estaremos frente a una actividad económica. De otra parte, si la creación es en el contexto de una actividad económica, sus rendimientos serán subsumidos como una ganancia más dentro de esta actividad, por lo que la solución no varía.

Para el caso que el contribuyente adquiera la propiedad intelectual propiamente tal, tenemos que lo puede hacer en el marco de una actividad económica, hipótesis en que el rendimiento será parte de su actividad o sin tener una actividad económica relacionada, circunstancia en que el rendimiento podrá ser una ganancia patrimonial o un rendimiento de capitales mobiliarios, según la forma de explotación, de manera que el hecho que el art. 25. 4. a) IRPF, disponga que estaremos frente a un rendimiento de capital mobiliario cuando el contribuyente no sea el autor, es algo que podría no haberse dicho y la solución sería la misma, salvo en el caso que la explotación de la propiedad intelectual haya producido para el adquirente un incremento patrimonial, puesto que en ese caso, el artículo se presta para pensar que al rendimiento se le debería tener como proveniente de capitales mobiliarios y no como incremento patrimonial $^{769}$.

En cuanto a la propiedad industrial, el análisis es el mismo que el anterior, ya que las posibilidades son que nazca de la creación del contribuyente o que la adquiera. Si la crea, puede hacerlo en el marco de una relación laboral generando rendimientos del trabajo o producirla directamente fuera de una actividad económica o dentro de ella. Fuera de una actividad económica no habrá renta gravable, salvo que la comercialice, en cuyo caso estaremos frente a una actividad económica. Si la creación se da en el contexto de una actividad económica, sus rendimientos serán subsumidos como una ganancia más dentro de esta actividad, por lo que la solución no varía.

${ }^{769}$ Esta hipótesis nos limitamos a plantearla, pero no la defendimos, puesto que creemos que lo que debe decidir el asunto es la naturaleza de la operación y no una norma que no es del todo clara. De suerte que, donde haya incremento patrimonial se debe resolver como tal y no por la vía de pensar que hay un rendimiento de capitales mobiliarios, puesto que su naturaleza es diferente. 
Supuesto que el sujeto pasivo adquiera la propiedad industrial, lo puede hacer en el marco de una actividad económica, hipótesis en que el rendimiento será parte de su actividad o sin tener una actividad económica relacionada, circunstancia en que el rendimiento podrá ser una ganancia patrimonial o un rendimiento de capitales mobiliarios, según la forma de explotación, de manera que el hecho que el art. 23. 4. a) IRPF, disponga que estaremos frente a un rendimiento de capital mobiliario cuando los rendimientos no se encuentren afectos a una actividad económica realizada por el contribuyente, es igual que en el caso anterior, algo que podría no haberse dicho y la solución sería la misma, salvo en el caso que la explotación de la propiedad intelectual haya producido para el adquirente un incremento patrimonial, puesto que en esa hipótesis, el artículo se presta para pensar que al rendimiento se le debería tener como proveniente de capitales mobiliarios y no como incremento patrimonial ${ }^{770}$.

\subsubsection{La propiedad intelectual como rendimiento de actividades económicas}

Tal como venimos analizando, la propiedad intelectual puede ser adquirida o producida por el sujeto pasivo. Si la adquiere y obtiene rendimientos de ello, en el marco de su actividad profesional o económica, claramente es un rendimiento de esa actividad, conforme al art. 27 IRPF, ya sea que obtenga una ganancia por su comercialización como puede suceder en un comerciante de arte o marcas, o que obtenga una renta por el otorgamiento de licencias a terceros.

Para el caso que el contribuyente sea el autor o creador y no lo sea en el marco de su actividad profesional o económica, estimamos que hay dos posibles alternativas, un caso es que hecha la creación decida no explotarla, de manera que no habrá renta alguna, sólo el disfrute moral que le proporciona su creación y el otro, es que decida su explotación, ya sea para venderla o licenciarla, supuesto en el que creemos se transforma automáticamente en una actividad económica, donde está organizando su trabajo personal o capital o ambos, para la obtención de la renta, por lo que su tributación debería mantenerse al amparo del régimen de los rendimientos de actividades económicas $^{771}$.

\footnotetext{
${ }^{770} \mathrm{Al}$ igual que el caso anterior y por las mismas razones, esta hipótesis nos limitamos a plantearla, pero no la defendimos.

771 En este punto discrepamos con LÓPEZ ESPADAFOR, Ob. supra cit., p. 88, quien piensa que "al no estar afectos los derechos de forma exclusiva (...) a la actividad empresarial o profesional del sujeto
} 


\subsection{La propiedad intelectual en el IVA}

La Ley 37/1992, de 28 de diciembre, Impuesto sobre el Valor Añadido, se refiere expresamente a la propiedad intelectual en cinco oportunidades a saber: art. 11. 2. $4^{\circ}$, que viene a considerar prestación de servicios para efectos de IVA, "Las cesiones y concesiones de derechos de autor, licencias, patentes, marcas de fábrica y comerciales y demás derechos de propiedad intelectual e industrial"; art. 20. Uno. 26, que declara exentos de IVA, a "[1]os servicios profesionales, incluidos aquéllos cuya contraprestación consista en derechos de autor, prestados por artistas plásticos. Escritores, colaboradores literarios, gráficos y fotográficos de periódicos y revistas, compositores musicales, autores de obras teatrales y de argumento, adaptación, guion y diálogos de las obras audiovisuales, traductores y adaptadores" ${ }^{\$ 72}$; art. 50, que define como exentas del impuesto, "las importaciones de marcas, modelos o diseños, así como de los expedientes relativos a la solicitud de derechos de propiedad intelectual o industrial destinados a los organismos competentes para tramitarlos"; art. 69. Uno. $2^{\circ}$. a), que entiende prestados en el territorio de aplicación del impuesto, los servicios de “cesiones y concesiones de derechos de autor, patentes, licencias, marcas de fábrica o comerciales y los demás derechos de propiedad intelectual o industrial, así como de cualquiera otros derechos similares", cuando el destinatario sea un empresario o profesional y radique en el citado territorio la sede de su actividad económica o tenga en el mismo un establecimiento permanente o, en su defecto, el lugar de su domicilio o residencia habitual.

\subsubsection{El hecho imponible del IVA y la propiedad intelectual}

La Ley 37/1992 no menciona a la propiedad intelectual o a las transacciones que puedan efectuarse sobre ellas como hecho gravado del IVA, lo que no implica que no pueda constituir un hecho gravado, tal como hemos reiterado a lo largo de nuestro

pasivo, por lo que éste obtenga por la concesión de licencias de explotación a terceros, tendrá que computar un rendimiento de capital mobiliario".

772 Desde el período tributario que inicia el 1 de enero de 2014, se derogó el art. 20. 1. N $\mathrm{N}^{\circ} 27$, que se refería a "[l]as entregas de obras de arte y bienes análogos que no se destinen normalmente a uso industrial, cuando se efectúen por sus autores o por personas que actúen en nombre y por cuenta de ellos. En este número se comprenden los siguientes bienes: a) Las pinturas. dibujos y pinturas al pastel, incluidas las copias, realizadas totalmente a mano, con exclusión de los artículos manufacturados decorados a mano y de los dibujos industriales. b) Las litografías, grabados y estampas firmadas y numeradas por el artista y obtenidas por medio de piedras litográficas, planchas u otras superficies grabadas, totalmente ejecutadas a mano. c) Las obras originales de arte estatuario y escultórico, con exclusión de las reproducciones en serie de las obras de artesanía de carácter comercial". 
estudio, la propiedad intelectual en cuanto bien inmaterial puede ser un activo empresarial, un objeto transable y como tal, hecho gravado de impuestos, en esa medida se comprende dentro del hecho imponible previsto en el art. 4. Uno, LIVA ${ }^{773}$, en cuanto deja sujetas al impuesto "las entregas de bienes y prestaciones de servicios realizadas en el ámbito espacial del impuesto por empresarios o profesionales a título oneroso, con carácter de habitual u ocasional, en el desarrollo de su actividad empresarial o profesional, incluso si se efectúan en favor de los propios socios, asociados, miembros o partícipes de las entidades que las realicen".

Lo fundamental dentro de la descripción del hecho imponible, en este caso, tal como anota expresamente LÓPEZ ESPADAFOR ${ }^{774}$ y se desprende de lo dicho por TRULL I AHUIR ${ }^{775}$, son dos cuestiones: el elemento material del hecho imponible y el componente subjetivo relativo al sujeto pasivo.

En cuanto al elemento material del hecho imponible, lo constituye la entrega de bienes y prestaciones de servicios a título oneroso, entendiéndose por entrega de bienes "la transmisión del poder de disposición sobre bienes corporales" propiedad intelectual puede ser objeto de transmisión de los derechos de disposición que sobre ella se ejercen; sin embargo, su naturaleza jurídica es de bien incorporal, con lo que queda completamente al margen de ser considerada para una posible "entrega de bienes", en el sentido de la LIVA, que únicamente se refiere a bienes corporales. No sucede lo mismo al analizar qué entiende la LIVA por "prestación de servicios", ya que el art. 11. Uno. LIVA diseña un verdadero cajón de sastre, donde cabe todo lo que no sea "entrega de bienes", en este sentido, al decir que prestación de servicios es toda operación "que no tenga la consideración de entrega, adquisición intracomunitaria o importación de bienes", alcanza a las operaciones sobre bienes incorporales, de manera que una interpretación sistemática de las normas, hace imposible sacarle el quite al gravamen del IVA en las transacciones sobre la propiedad intelectual. Por lo demás, si la conclusión no hubiese quedado clara, el propio art. 11 . Dos. $4^{\circ}$, expresamente califica de servicio: "Las cesiones y concesiones de derechos de autor, licencias, patentes,

\footnotetext{
${ }^{773}$ Ley del IVA. En referencia a la Ley 37/1992.

${ }^{774}$ LÓPEZ. Ob. Cit., pp. 123.

${ }^{775}$ TRULL I AHUIR, JOAN, y otros. La investigación y el desarrollo tecnológico ante el Impuesto sobre el Valor Añadido, Impuestos. Revista de Doctrina, Legislación y Jurisprudencia, Tomo I, 1999, pp. 255.

${ }^{776}$ ART. 8. Uno. LIVA.
} 
marcas de fábrica y comerciales y demás derechos de propiedad intelectual e industrial”.

El componente subjetivo al que hemos hecho referencia, implica determinar quién será empresario o profesional a efectos de la LIVA. La Ley 37/1992, regula casos específicos como las sociedades mercantiles que serán empresarias o profesionales, sin embargo, para nuestros fines, debemos centrar nuestra atención en dos de los supuestos más amplios que define la norma, tales son: las personas o entidades que realicen actividades empresariales o profesionales que impliquen la ordenación por cuenta propia de factores de producción materiales y humanos o de uno de ellos, con la finalidad de intervenir en la producción o distribución de bienes o servicios ${ }^{777}$ 778; y, aquellos que "realicen una o varias entregas de bienes o prestaciones de servicios que supongan la explotación de un bien corporal o incorporal con el fin de obtener ingresos continuados en el tiempo".

Para conocer el tratamiento que debemos dar a la propiedad intelectual, no es necesario partir de los mismos presupuestos que utilizamos en el impuesto sobre sociedades, ya que, en este caso, elemento diferenciador no es la calidad de autor o creador, sino que la condición de empresario o profesional. Así pues, en el evento que la propiedad intelectual se enmarque dentro de las actividades normales de un contribuyente profesional (por ejemplo: es ingeniero y se dedica a la investigación) o empresario (el sujeto pasivo tiene una empresa de I+D), caerá dentro del concepto base de actividades empresariales o profesionales, que implica "la ordenación por cuenta propia de los factores de producción material y humanos o de uno de ellos, con la finalidad de intervenir en la producción y distribución de bienes y servicios" ${ }^{\text {"779 }}$, por lo que estará afecto a IVA, ya sea que transfiera la totalidad de sus derechos sobre la propiedad intelectual o que conceda una licencia sobre la misma.

También puede suceder que el sujeto pasivo, no tenga naturalmente la calidad de profesional o empresario para efectos del IVA, como pudiese ser una persona cualquiera que pinta un cuadro o desarrolla un invento, en cuyo caso no cumplirá con el supuesto

\footnotetext{
${ }^{777}$ El art. 5. Dos. LIVA, especifica que: "En particular, tienen esta consideración las actividades extractivas, de fabricación, comercio y prestación de servicios, incluidas las de artesanía, agrícolas, forestales, ganaderas, pesqueras, de construcción, mineras y el ejercicio de profesiones liberales y artísticas".

${ }^{778}$ Esta definición nace de la unión de los numerales Uno. a) y Dos. del art. 5 LIVA.

${ }^{779}$ Art. 5. Dos. LIVA.
} 
del hecho imponible del art. 4 LIVA, ya que la prestación sobre la propiedad intelectual no será efectuada por un empresario o profesional; sin embargo, este supuesto de no sujeción sólo permitirá la no tributación de la enajenación de la propiedad, puesto que en el evento que el sujeto pasivo decida no vender y explotar su propiedad intelectual vía licencia u otro modo que le reporte una renta periódica, se tratará de una entrega de bienes o prestación de servicios, de un bien incorporal, con el fin de obtener ingresos continuados en el tiempo, actividad que calza con el hecho imponible del art. 5. Uno. c) LIVA, resultando afecta la operación.

\subsubsection{Exenciones en favor de la propiedad intelectual propiamente tal}

El art. 20 LIVA, diseña un impresionante listado de exenciones al IVA, que al mirarlo hace pensar que existen más actividades exentas que gravadas, haciéndose cargo de nuestra materia, en el mismo artículo, apartado Uno, numeral 26.

El art. 376 de la Directiva 2006/112/CE del Consejo, relativa al sistema común del Impuesto sobre el Valor Añadido ${ }^{780}$, vigente desde 2007, vino a derogar la Directiva 77/388/CEE y permitió a España "seguir eximiendo las prestaciones de servicios suministradas por los autores que figuran en el punto 2) de la parte B del Anexo X y a las operaciones que figuran en los puntos 11) y 12) de la parte B del Anexo X, en las condiciones que existían en dicho Estado miembro del 1 de enero de 1993”. A partir de la autorización dada por la normativa comunitaria, la Ley del IVA, se ha limitado a incorporar en el art. 20. Uno. $26^{\circ}$, el texto de la misma exención que existía en la Disposición Adicional Tercera de la Ley 22/1987, sobre Propiedad Intelectual, donde a nuestro juicio, es su ubicación más apropiada, toda vez que es una exención a la Ley del IVA.

La disposición del número 26 de que hablamos, parte abarcando un espectro muy amplio, pues deja exentos del impuesto a todos los "servicios profesionales", sin embargo inmediatamente se arrepiente de tanta generosidad y al otorgar la exención a los derechos de autor, entra en una regulación de detalle, cuya sola lectura hace pensar

${ }^{780}$ La Directiva es de 28 de noviembre de 2006, publicada en el DO L 347, de 11 de diciembre de 2006. 
que muy pocos y en contadas ocasiones, serán los beneficiados ${ }^{781}$; más aún, da la idea que esto se presta para más confusión que beneficios.

No debemos perder de vista que las operaciones sobre la propiedad intelectual, normalmente estarán gravadas con IVA, en calidad de prestación de servicios, aun cuando se trate de la cesión de los derechos de autor, tal como vimos supra. En esa medida, el punto de partida para nuestro análisis es que estamos frente a un hecho gravado con el impuesto, debiendo cumplirse con todas las obligaciones formales del tributo, sólo que su pago está liberado en virtud de una exención.

La exención consiste en no gravar con IVA a los servicios profesionales cuya contraprestación consista en derechos de autor, prestados por artistas plásticos, escritores, colaboradores literarios, gráficos y fotográficos de periódicos y revistas, compositores musicales, autores de obras teatrales y de argumento, adaptación, guion y diálogos de las obras audiovisuales, traductores y adaptadores, de manera que como primera aproximación debemos advertir que no todos los autores están beneficiados, a modo de ejemplo, el software se protege por derecho de autor y el desarrollador es autor y no está beneficiado con la norma.

En todo caso, más que esta circunstancia anecdótica lo que afectará la aplicación práctica de la disposición es la interpretación de la administración tributaria, seguramente dispuesta a resguardar la recaudación por sobre los fines de la norma. Así las cosas, el sujeto pasivo debe ser autor, por lo que debemos recurrir al RDL 1/2006 que fija el texto refundido de la Ley de Propiedad Intelectual, cuyo art. 5 señala como autor a "la personal natural que crea una obra literaria, artística o científica". La Ley de Propiedad Intelectual considera que se puede ser autor de cualquier tipo de obra, es decir de una producción relativa a las ciencias, la literatura o el arte, sin embargo, la disposición tributaria no se extiende a la autoría sobre todas las creaciones, sino que a aquellas que específicamente ha querido beneficiar.

Desde otro punto de vista, también podemos ver lo restrictivo de la norma y de lo que será su aplicación, al advertir que el propio art. 5, antes anotado, permite que las

\footnotetext{
${ }^{781}$ Los servicios profesionales, incluidos aquéllos cuya contraprestación consista en derechos de autor, prestados por artistas plásticos, escritores, colaboradores literarios, gráficos y fotográficos de periódicos y revistas, compositores musicales, autores de obras teatrales y de argumento, adaptación, guion y diálogos de las obras audiovisuales, traductores y adaptadores.
} 
personas jurídicas puedan ser autores en determinados casos, no obstante la administración tributaria, tal como veremos más adelante, se esmera en intentar demostrar que la exención sólo es aplicable a personas naturales. En el mismo sentido, el art. 11 de la Ley de Propiedad Intelectual, considera autores no solamente a los creadores de obras originales sino también a quienes realizan obras a partir de otras ya existentes, tal es el caso de las traducciones, adaptaciones, actualizaciones y otros.

El asunto es cuando menos espinudo, puesto que el catálogo de qué puede ser considerado obra a efectos del derecho de autor es muy amplio, comprende conferencias, discursos, lecciones, memorias, comentarios, coreográficas, pantomimas, adaptaciones radiales, periódicos, revistas, fotografías, proyectos, bocetos y maquetas arquitectónicas y los sistemas de elaboración de mapas, esferas geográficas o armilares, etc., para sólo mencionar algunas que no solemos recordar. Así también, el concepto de autor, no responde únicamente al creador con aura de genio, del que brota la creación por inspiración divina, sino que en muchas ocasiones se atribuye a verdaderos empresarios, como sucede en la industria de las obras audiovisuales. Estas consideraciones, nos hacen pensar en la concurrencia del principio de igualdad ante la ley y en la obligación de que los tributos y con ellos las exenciones, deban estar fundados en antecedentes objetivos no discriminatorios, puesto que la voluntad del legislador español de favorecer a ciertos autores por determinadas obras, difícilmente aprobará esos parámetros.

Además de las restricciones puestas por el legislador en la exención que nos ocupa, la Dirección General de Tributos ha ido recortando aún más su contenido ${ }^{782}$, tal como queda claro de los comentarios que proliferan en Internet, tal como advierten JPB Asesores, Economistas y Abogados, quienes exponen que la DGT niega la exención "a las prestaciones efectuadas por personas jurídicas u otro tipo de entidades o personas distintas de los autores (por ejemplo, herederos), ya que la propiedad intelectual sólo corresponde a los autores" ${ }^{\text {"783 }}$. En el mismo sentido encontramos información publicada

\footnotetext{
${ }^{782}$ Sobre este asunto, MARIZA CASTELO, comenta: "Por último, la interpretación de esta norma en la práctica por la Agencia Tributaria es restrictiva hasta límites insospechados, habiendo sido además actividad común la apertura de inspecciones al gremio periodístico, a la busca de actividades realizadas para medio radiofónico o televisivo aplicando la exención, o lo contrario, es decir, la facturación indiscriminada con IVA", Apuntes sobre la exención de IVA para autores y periodistas, LegalArte, 2001. Disponible en Internet en: http://www.literaturas.com/Documentos1.htm (10 Jul 2013).

783 JPB Asesores. Economistas y Abogados. Disponible en Internet en:
} 
por una editorial, que al comentar una Consulta Vinculante, de una entidad pública que poseía los derechos de la propiedad intelectual sobre un fondo de imágenes y de edición de libros y preguntaba si al cederlos onerosamente a un grupo editorial, estaría gravada con IVA; se le contestó: "están sujetas y no exentas del Impuesto sobre el Valor Añadido las prestaciones de servicios objeto de consulta consistentes en la cesión de los derechos de la propiedad intelectual de un fondo de imágenes y de edición de libros objeto de consulta, efectuadas por el Ente público consultante"784. De nuestra parte, encontramos la respuesta a la Consulta Vinculante, AF 1134-09, donde una persona física que realiza traducción de artículos para revistas, cuyo cliente es una universidad española, consulta sobre sus servicios de traducción, la DGT contesta que las prestaciones están sujetas al impuesto, aun cuando el traductor sea una persona física, "en cuanto dicha traducción no supone una aportación personal y distinta de la obra preexistente", estableciendo también que esta exención supone "la actuación profesional de los citados autores, ya que el objetivo de dicha exención es el de fomentar la creación cultural, no así el tráfico mercantil derivado de la misma". Bajo estas fórmulas, la DGT vació de contenido a la Ley de Propiedad Intelectual y a la uniformidad de la doctrina, que reconocen derechos de autor a los traductores.

El criterio de la DGT que parece solamente como restrictivo, si lo pensamos un poco más afondo, tiene profundas consecuencias. En el caso del derecho de autor, sucede que la mayor parte de las veces no son ellos quienes recaudan sus beneficios sino que personas jurídicas, son las entidades de gestión colectiva de los derechos de autor, que toman su representación y la tarea de cobro y recaudación, por lo que la exención puede hacerse inmediatamente ilusoria o al menos va en directo perjuicio de los autores más pequeños que no tienen otra alternativa que valerse de los servicios de las entidades de gestión de derechos ${ }^{785}$.

http://www.jpbasesores.com/index.php/es/observatorio-fiscal/153-la-cesion-de-derechos-de-autoriexento-del-iva (10 Jul 2013).

784 Consulta Vinculante DGT, de 22 de abril de 2010. THOMSON REUTERS. Disponible en Internet en: http://portaljuridico.lexnova.es/doctrinaadministrativa/JURIDICO /47955/consulta-vinculante-dgt-de22-de-abril-de-2010-iva-cursos-de-formacion-sujecion-exencion-de (10 Jul 2013).

785 Sobre este asunto, CASTELO, escribe: "Se produce entonces la extraña situación siguiente: la entidad de gestión perceptora viene obligada a facturar con IVA por el total, siendo correcto en lo referido a su porcentaje de derechos o descuento de administración, así como en el caso de que proceda el reparto a personas jurídicas o herederos de autores fallecidos, pero no en el del autor vivo, quien no facturará a la entidad con IVA, lo que sí harán los anteriores”. Ob. supra cit. Disponible en Internet el: http://www.literaturas.com/Documentos1.htm (1 Jul 2013). 
En definitiva la comparación entre la redacción de la norma y la práctica de la DGT, dan con una disposición arbitraria, que consigue desvirtuar la supuesta buena voluntad del legislador para crear una norma cuya bondad es más que dudosa ${ }^{786}$. La disposición, por una parte, discrimina en razón del lugar de trabajo, por ejemplo: los "fotógrafos" deben trabajar para "periódicos y revistas"787, para tener derecho a la deducción; pero, ¿Qué pasaría si lo hicieran para una editorial? Lo propio sucede con los autores de obras teatrales y de argumento, adaptación, guion y diálogos, puesto que se les exige que lo sean para "obras audiovisuales", para tener derecho a la exención.

De contrario, a intérpretes, artistas, directores y técnicos que sean personas físicas, así como a los productores de películas que se exhiban en salas de espectáculos y a los organizadores de obras tanto teatrales como musicales, se les gravará con el impuesto con un tipo de 21 por ciento.

Por otra parte, tal como vimos antes, si bien la disposición parece querer beneficiar a los autores, deja fuera a varios como: directores de cine o audiovisuales, coreógrafos o autores de programas de computación.

Finalmente, la ley también discrimina al enumerar las obras, ya que no toda la actividad creativa está necesariamente protegida como obra en el sentido de la Ley de Propiedad Intelectual, de manera que muchas creaciones estarán excluidas, por lo que siguiendo a MARISA CASTELO ${ }^{788}$, podemos recordar que entre "obras fotográficas" y "meras fotografías", sólo las primeras son obras protegidas por derecho de autor.

\subsubsection{El curioso artículo 50 de la Ley del IVA}

El art. 50 LIVA, señala: "Estarán exentas del impuesto las importaciones de marcas, modelos o diseños, así como de los expedientes relativos a la solicitud de derechos de propiedad intelectual o industrial destinados a los organismos competentes para tramitarlos".

La disposición literalmente está dejando exenta de impuesto la importación de una marca, modelo, diseño y de los expedientes destinados a los organismos de registro.

\footnotetext{
${ }^{786}$ Según palabras de CASTELO. Ob. supra cit.

787 Art. 20. Uno. 26 LIVA.

${ }^{788}$ Ob. supra cit.
} 
Para LÓPEZ ESPADAFOR, la norma no puede estar hablando de importación, porque en el régimen del IVA, tal como vimos, la propiedad intelectual por su carácter de bien inmaterial se reconduce a servicios y no a las importaciones ${ }^{789}$. Con lo que podríamos estar de acuerdo, si no creyésemos que la ubicación de la cesión de la propiedad intelectual como un servicio, no es más que una ficción del legislador español, de la que puede arrepentirse en cualquier momento, ya que, como se quiera, la propiedad intelectual es un bien como cualquier otro. Por otra parte, si lo vemos desde el punto de vista de nuestro estudio y comparamos la realidad jurídica chilena con la española, la importación puede darse perfectamente, porque en Chile la cesión no es más que la forma de hacer la tradición de los bienes incorporales, de manera que, el título que hace operar el modo de adquirir puede ser cualquiera como la compraventa, nacional o internacional.

En otras palabras, en Chile nadie dudaría que la cesión de la propiedad intelectual no es un servicio, sino que una transacción sobre mercaderías, de manera que podría ser una compraventa internacional hecha en Chile y después, cumplido el contrato con la cesión internacional de los derechos de propiedad intelectual, léase por ejemplo, una marca. Así las cosas, ¿Por qué no podría entonces el legislador español estar viendo a la propiedad intelectual como un bien importable? Observemos que el Capítulo III, Importaciones de bienes, de la Ley del IVA, no exige que el objeto importado sea un bien corporal, como si lo hace con el hecho gravado básico, de ser así, la adquisición internacional de marcas, modelos y diseños puede ser una importación y tiene sentido la exención; no obstante nacerá con ella una pregunta, que parece perseguirnos: ¿Por qué están beneficiados marcas, modelos y diseños y no otros títulos de propiedad industrial?, ello asumiendo que la propiedad intelectual tiene una exención propia en el art. 20. Uno. $26^{\circ}$ LIVA, y la tuvo en el mismo lugar número $27^{\circ}$.

LÓPEZ ESPADAFOR encuentra explicación al art. 50, vinculándolo únicamente a los expedientes de propiedad intelectual e industrial ${ }^{790}$. Para él, la importación de la propiedad intelectual en tanto servicio está gravada y los expedientes son accesorios a esta prestación de servicios, por lo que, el impuesto está vinculado a la operación principal. En otras palabras, al cobrar IVA a los expedientes se les estaría cobrando el impuesto dos veces, una en tanto forman parte de la importación de la

\footnotetext{
${ }^{789}$ LÓPEZ. Ob. supra cit., p. 136.

790 Ob. supra cit., p. 136.
} 
propiedad intelectual, otra de manera autónoma. A nuestro parecer, la explicación es un intento desesperado por encontrar sentido al artículo, puesto que el supuesto indudable del ingreso de los expedientes es para su registro, de manera que ello supone únicamente el acceso ideológico de la información, efectuado por el mismo titular original de la invención quien busca registrar a su nombre, sin que pueda existir allí, importación alguna.

Así las cosas, nos parece más lógico pensar que simplemente estamos frente a una exención para la importación de marcas, modelos o diseños y de una especificación con ropaje de exención cuando el artículo dice que estarán exentos del impuesto los expedientes destinados al registro. Creemos que funda nuestra posición, dos consideraciones adicionales, una es que a contrario sensu, siguiendo la tesis de LÓPEZ ESPADAFOR, los expedientes judiciales por un exhorto internacional estarían gravados con IVA, en tanto importación de papel y la otra, es que en materia de propiedad intelectual la información para el registro normalmente fluye a través de medios electrónicos, lo que además, haría a la norma desajustada de la realidad.

\subsubsection{La regla sobre localización}

La disposición que menciona expresamente a la propiedad intelectual en materia de localización es el art. 69. Uno. $2^{\circ}$. a) de la LIVA, que entiende prestados en España, los servicios de cesiones y concesiones de derechos de autor, patentes, licencias, marcas de fábrica o comerciales y los demás derechos de propiedad intelectual o industrial, cuando el destinatario sea un empresario o profesional y radique en España la sede de su actividad económica, o tenga un establecimiento permanente o, en su defecto, el lugar de su domicilio.

Aunque hemos dicho que nos referiremos solamente a las normas que hagan expresa referencia a la propiedad intelectual y además, que no entraremos al análisis de las operaciones intracomunitarias en materia de IVA, porque implicaría desviar nuestra atención del centro de nuestro estudio, hemos creído necesario cerrar este punto, redondeando la situación de las normas de localización, referentes a operaciones con países no comunitarios.

Puede tener aplicación en esta materia el art. 68 LIVA, ya que en el evento que el destinatario en España no sea empresario o profesional, no se aplicaría la disposición 
de localización del art. 69. Uno. $2^{\circ}$. a), sino que el art. 68, ambos de la Ley del IVA, resultando que la operación no quedaría localizada en España y por tanto, resultaría no gravada con el tributo $^{791}$.

En el caso que los derechos de propiedad intelectual son transmitidos desde España al extranjero, cabe aplicar la disposición general del art. 69. Dos. LIVA, que no considera realizados en territorio español, algunas prestaciones de servicios, lo que es coherente con el tratamiento de servicios que hemos analizado da la Ley del IVA a la propiedad intelectual. En consecuencia en estos casos, conforme a lo que es usual en materia de IVA, la suerte del impuesto será decidida en el país de destino.

\section{En el ámbito chileno}

A diferencia de lo que vimos al hablar de los impuestos en España, en el caso chileno, toda la imposición directa se encuentra bajo el amparo de una normativa única, el Decreto Ley N ${ }^{\circ} 824$ sobre Impuesto a la Renta ${ }^{792}$, de 1974, donde están integrados el impuesto a las personas físicas, sociedades y extranjeros. Por su parte, la tributación indirecta se concentra el Decreto Ley $\mathrm{N}^{\circ}$ 825, sobre Impuesto al Valor Agregado, también de 1974. Recordemos, que anticipamos que en septiembre de 2014 ha habido el Chile una profunda reforma tributaria, que ha dejado en la tributación a la renta subsistiendo dos sistema uno donde se integran totalmente los tributos a nivel de empresa y persona natural (designado como sistema de "renta atribuida") y, otro, donde en apariencia se integran parcialmente, pero que en definitiva consiste también en una integración total, con la posibilidad de postergar el pago del impuesto a nivel de persona natural, pagando con posterioridad a una tipo más alta (llamado sistema "parcialmente integrado). Ahora bien, en el sistema español, para conocer la tributación de la propiedad intelectual, hay que diferenciar entre la naturaleza de quien recibe la renta (persona jurídica o persona natural); en Chile, hay que distinguir por la naturaleza de la renta: si proviene de régimen general o de la propiedad intelectual, pues según eso tiene un tratamiento preferente.

Al igual que el estudio que enfrentamos de la legislación española, veremos las referencias específicas a la propiedad intelectual en la normativa tributaria, no obstante ello, debemos considerar que la legislación tributaria común estará siempre presente,

\footnotetext{
${ }^{791}$ Ob. supra cit., p. 132.

${ }^{792}$ Texto accesible en Internet en: http://www.leychile.cl/Navegar?idNorma=6368 (10 Jun 2013).
} 
aplicándose plenamente sus normas en todos aquellos casos en que no exista una regla especial al respecto, de suerte que, las utilidades o beneficios obtenidos con la explotación de una obra, invento o marca tributarán conforme a las reglas generales de la Ley de la Renta, en defecto de normas especiales. En esa medida, sólo nos detendremos en disposiciones generales, cuando lo creamos indispensable para destacar un efecto muy significativo que involucra a la propiedad intelectual.

\section{1. $\quad$ Decreto Ley $\mathbf{N}^{\circ}$ 824, Ley de Impuesto a la Renta}

En Chile no existe una ley de impuesto a la renta para las personas físicas, otra para las personas jurídicas y otra para los extranjeros, el impuesto a la renta es único y está integrado, de manera que los rendimientos de empresa automáticamente reciben como crédito lo que han pagado a ese nivel, al ser retirados de la empresa por una persona natural. Hasta septiembre de 2014, antes de que las utilidades sean retiradas, el pago de impuesto era un verdadero entero a cuenta, que se registra en un libro especial llamado Fondo de Utilidades Tributables, también conocido como FUT ${ }^{793}$. En otras palabras, el impuesto a la renta se concretaba a nivel de persona natural, la única excepción son los contribuyentes extranjeros, que deben tributar por las remesas y se les otorga el crédito por el impuesto pagado a nivel de empresa en Chile, ya sean personas naturales o jurídicas. A partir de septiembre de 2014, se establece una reforma tributaria ${ }^{794}$, en que el sistema si bien se mantiene integrado, en el sentido que los impuestos a nivel de empresa siguen siendo un entero a cuenta, para el impuesto personal, conocido como Global Complementario, presenta una variación fundamental, que consiste en la eliminación del FUT. Desde ahora, la tributación a la renta se saldará cada año, sin posibilidad de postergación; así pues, la ley entiende retiradas las utilidades de la empresa aunque ello no se haya hecho materialmente, obligando a colacionarlas a nivel de impuesto Global Complementario al final de cada período impositivo. Es decir, atribuye las rentas a los socios, independiente del hecho material

\footnotetext{
${ }^{793}$ En Chile existe muy poca literatura sobre impuestos, normalmente todo lo que se puede encontrar es la ley y las circulares de la administración tributaria, llamada Servicio de Impuestos Internos (SII). Respecto del FUT sucede lo propio, por lo que una de las pocas obras sobre la materia, es de: SALORT, VICENTE. Manual Operativo Tributario, Edimatri, Ediciones Tributarias y Laborales Aplicadas SA, cuya edición de noviembre y diciembre de 2002, abordan en extenso la operación del FUT. Actualmente existe un proyecto de ley en trámite para eliminar el FUT e incorporar otras reformas al sistema tributario chileno. Boletín $\mathrm{N}^{\circ}$ 9290-05, de 02 de abril de 2014. Disponible en Internet en: www.bcn.cl (15 Abr 2014).

${ }^{794}$ La reforma tributaria integra puede encontrarse en: http://www.senado.cl/appsenado/templates/tramitacion/index.php\# (15 Sep 2014).
} 
de haberlas retirado, de ahí su nombre de "renta atribuida". Junto a este sistema, se diseñó otro alternativo, que permite la postergación de la tributación a nivel de persona, pero asumiendo tasas de gravámenes más altas; otra forma de verlo, es que subsiste el FUT con tasas que lo desincentivan.

\subsubsection{Ingresos renta y no renta en el DL $N^{\circ} 824$}

La legislación de la renta chilena, tiene la particularidad de detenerse a enumerar lo que no es, es decir, hace un catálogo de lo que son "ingresos no renta", claro está que como las incongruencias no pueden ser propiedad de la legislación tributaria española, el legislador chileno también tiene vocación para confundir y no todo lo que enumera como "no renta", son verdaderos hechos no gravados, tal como pasamos a explicar.

Para entender el contexto y por qué legislador chileno se preocupa de enumerar lo que no es, es decir, los hechos que no constituyen renta, nos valdremos de lo que recuerda FIGUEROA VELASCO ${ }^{795}$, quien comenta que en la primera Ley de Renta $\mathrm{N}^{\circ}$ 3.996, de 1924, no se definió que se entendía por renta, modificaciones posteriores, específicamente la Ley $\mathrm{N}^{\circ} 8.419$, establecieron que se consideraría como aumento de capital y no como renta, el mayor valor que sobre el precio de adquisición obtuviere una persona al enajenar o transferir un bien raíz, acciones, bonos y otros valores mobiliarios, salvo que los ganara una persona que hiciera de la adquisición y enajenación de dichos bienes, su profesión habitual. Esto dio pie a que los contribuyentes discutieran que se entendía por renta (que resultaba gravado) y por aumento de capital (que quedaba exento), agregaban que "era condición esencial del concepto de renta, que hubiere una cosa que rindiere utilidades o beneficios o de la que pudiere cobrarse algo y que este rendimiento fuere periódico". Como se entiende, la cantidad de rendimientos que escapaban al concepto de renta, eran muchos, tales como: herencias, donaciones, mayor valor obtenido por la enajenación no habitual de marcas, derechos de llaves, patentes, venta de negocios, establecimientos de comercio, cuotas o participaciones sociales, etc.

Lógicamente el fisco sostenía la posición contraria, puesto que a su juicio el art. 13 de la Ley $\mathrm{N}^{\circ} 8.419$ "gravaba no sólo las rentas, sino también los beneficios y utilidades, cualquiera fuere su origen, naturaleza o denominación, por lo que la ley tributaria en realidad prescindía de que hubiere o no enriquecimiento efectivo, o

795 FIGUEROA VELASCO, PATRICIO. Manual de derecho tributario. Ley de impuesto a la renta. Selección Manuales Jurídicos, Editorial Jurídica de Chile, 1989, pp. 13 y sgtes. 
aumento sustancial de patrimonio o que el producto o fruto fuere el rendimiento de una cosa".

Los tribunales fueron completamente vacilantes sobre el asunto, generando más incertidumbre que soluciones, por lo que la salida al asunto, como siempre sucede en derecho tributario, vino impuesta por ley. Así, la Ley $\mathrm{N}^{\circ} 15.564$, de 1964, que junto a instaurar una ley de renta completamente nueva, zanjó el asunto estableciendo un concepto de renta tan amplio, que sería imposible controvertir que algún rendimiento fuese renta, como contra partida, la propia ley se vio obligada a intentar definir que no es renta, conformando lo que en derecho chileno se conoce como los hechos "no renta", algunos de los cuales son verdaderos supuestos de no sujeción, pero otros son casos de tipo reducido, exenciones, reducciones estructurales, etc. La definición amplia a que hacemos referencia se contiene, actualmente, en el artículo $2^{\circ} .1$ del DL $\mathrm{N}^{\circ} 824$, que dice, se entiende por renta: "los ingresos que constituyan utilidades o beneficios que rinda una cosa o actividad y todos los beneficios, utilidades e incrementos de patrimonio que se perciban o devenguen, cualquiera que sea su naturaleza, origen o denominación" ${ }^{, 796}$. De todas formas, cabe tener presente que los hechos exentos propiamente tales, también existen y se les cataloga como tales ${ }^{797}$.

\subsubsection{El régimen de tributación especial de la propiedad intelectual hasta septiembre de 2014}

La reforma de septiembre de 2014, tal como hemos explicado, trajo cambios a todo el sistema tributario y la propiedad intelectual no fue la excepción, claro está que las cosas no quedaron más claras que antes, sino que cuando menos igual de confusas. Ahora bien, finalmente lo interesante de nuestro trabajo es ver cuáles son las alternativas de tributación que posee la propiedad intelectual, conforme a su propia naturaleza jurídica y plasticidad intrínseca, bajo distintos sistemas jurídicos, de ahí, que hemos decidido mantener las explicaciones del régimen vigente hasta septiembre de 2014 y adicionar las novedades que aparecen con la reforma, esto permite ver nuestro objeto de análisis desde diferentes prismas y contribuye al crisol de posibilidades que otorga su tributación.

\footnotetext{
${ }^{796}$ Sobre el concepto de renta, puede verse: MASSONE PARODI, PEDRO. El impuesto a la renta. Edeval, Valparaíso, Chile, 1996, pp. 66 y sgtes.

${ }^{797}$ El Art. 39 de la Ley de Renta, DL N 824, contiene un listado de hechos exentos.
} 
En lo pertinente del artículo 17 del DL N ${ }^{\circ} 824^{798}$, Ley de la Renta, vigente hasta septiembre de $2014^{799}$, establece: "No constituye renta (...), No $\mathrm{N}^{\circ}$. El mayor valor, incluido el reajuste del saldo de precio, obtenido en las siguientes operaciones, sin perjuicio de lo dispuesto en el artículo 18. (...) Letra e): La enajenación del derecho de propiedad intelectual o industrial, en caso de que dicha enajenación sea efectuada por el inventor o autor" $" 800$.

Seguidamente, el inciso segundo del art. 17, $\mathrm{N}^{\circ} 8$, refiriéndose a la letra e) citada, señala: "No constituye renta sólo aquella parte del mayor valor que se obtenga hasta la concurrencia de la cantidad que resulte de aplicar al valor de adquisición del bien respectivo el porcentaje de variación experimentado por el índice de precios al consumidor en el período comprendido entre el último día del mes anterior al de la adquisición y el último día del mes anterior al de la enajenación, todo ello sin perjuicio de lo dispuesto en el artículo 18. Por fecha de enajenación se entenderá la del respectivo contrato, instrumento u operación".

Para completar el panorama, el inciso tercero, del art. 17, $\mathrm{N}^{\circ} 8$, antes citado, indica: "La parte del mayor valor que exceda de la cantidad referida en el inciso anterior se gravará con el Impuesto de Primera Categoría en el carácter de impuesto único a la renta, a menos que operen las normas sobre habitualidad a que se refiere el artículo $18^{\circ}$. Estarán exentas de este impuesto las cantidades obtenidas por personas que no estén obligadas a declarar su renta efectiva en la Primera Categoría y siempre que su monto no exceda a diez unidades tributarias mensuales por cada mes, cuando el impuesto deba retenerse y de diez unidades tributarias anuales al efectuarse la declaración anual, ambos casos en el conjunto de las rentas señaladas. Para los efectos de efectuar la citada declaración anual, serán aplicables las normas sobre reajustabilidad que se indica en el $\mathrm{N}^{\circ} 4$ del artículo 33".

\footnotetext{
${ }^{798}$ Recordemos que en el caso chileno, la expresión "decreto ley", se refiere a los instrumentos normativos por medio de los cuales han gobernado las autoridades de facto a lo largo de la historia del país. Durante el régimen liderado por el General Augusto Pinochet, se dictaron más de 3600 decretos leyes, los que posteriormente mantuvieron su vigencia, reconociéndoseles rango de ley ordinaria.

${ }^{799}$ Cabe hacer notar, que hasta septiembre de 2014, cuando escribo sobre la reforma, la disposición no ha sido promulgada ni publicada en el Diario Oficio, por ello no tiene número de ley, sin embargo, se trata de una ley aprobada por el Congreso, de manera que sólo faltan los trámites formales para su nacimiento a la vida del derecho.

${ }^{800}$ Art. $17, \mathrm{~N}^{\circ} 8$, letra e), DL $\mathrm{N}^{\circ} 824$.
} 
El análisis de la disposición transcrita, muestra que junto a otros, como el art. $17.20^{\circ}$ del mismo DL $\mathrm{N}^{\circ} 824$, constituyen un verdadero régimen especial de tributación para la propiedad intelectual en general, en la medida que establece hipótesis en que la propiedad intelectual será un ingreso no renta, un ingreso renta de régimen común o un ingreso renta gravado con un impuesto único a la renta, esto significa, tal como su nombre lo indica, que será el único impuesto a la renta que pagarán estos beneficios.

Por otra parte, a pesar de tratarse de un régimen especial de tributación, al igual que todo el sistema, está integrado en una ley única, por lo que no cabe hacer ninguna distinción como las que tendríamos que hacer en el derecho español, por ejemplo: respecto a si las rentas se atribuyen a un contribuyente que tribute por rentas del trabajo, profesionales o bajo el impuesto de sociedades, etc.

\subsubsection{Enajenación como verbo rector del régimen especial de la propiedad intelectual}

El art. 17, $\left.\mathrm{N}^{\circ} 8, \mathrm{e}\right)$, de la Ley de la Renta, configura el hecho no renta, sobre la base del verbo "enajenar", que implica hacer ajeno, es decir, traspasar el dominio. Este asunto que resulta tan obvio, hace necesario hacer una detención para explicar que en Chile, la combinación de los artículos $576^{801}$ y $583^{802}$ del Código Civil, ha llevado, unánimemente a sostener, que los derechos reales y personales son bienes incorporales, apropiables y perfectamente transables ${ }^{803}$. De manera que, la propiedad intelectual en cualquiera de sus formas, es un objeto y su disposición siempre y sin duda, será tratada como actuaciones sobre bienes, por lo que no podría darse una solución como la asimilación a servicios, que se hace de la propiedad intelectual en España, para efectos de gravarla con IVA.

En función de esa conceptualización de la propiedad intelectual y del hecho que en el derecho chileno, de los contratos solamente pueden nacer derechos personales, la cesión de los bienes incorporales, se ha entendido como el mecanismo para hacer la

${ }^{801}$ El art. 576, del Código Civil, dice: "Las cosas incorporales son derechos reales o personales".

${ }^{802}$ El art. 583, del Código Civil, dice: "Sobre las cosas incorporales hay también una especie de propiedad".

${ }^{803}$ Sobre este asunto puede verse ALESSANDRI RODRÍGUEZ, ARTURO y OTRO. Curso de derecho civil, Editorial Nacimiento, Santiago, Chile, 1957, pp. 44 y sgtes y 440 y sgtes. 
tradición de los mismos ${ }^{804}$, desligándola de cualquier atributo contractual. En otra palabras, en Chile los derechos de propiedad intelectual pueden venderse, donarse, arrendarse, etc., y la cesión es la manera de cumplir la obligación de transferencia que nació a causa de un contrato ${ }^{805}$.

\subsubsection{Cuatro formas de tributar de la propiedad intelectual en el art. 17 de la Ley de la Renta}

A propósito del art. 17, $\left.\mathrm{N}^{\circ} 8, \mathrm{e}\right)$, el Servicio de Impuestos Internos ha distinguido $^{806}$, acertadamente a nuestro juicio, tres alternativas de tributación a la renta para la propiedad intelectual, a saber: como ingreso no constitutivo de renta; impuesto único a la renta; y, rentas del trabajo. Ahora bien, el caso analizado por el SII dice relación con un contribuyente persona natural que obtiene regalías de una editorial, por lo que, si quisiéramos ver el asunto desde una perspectiva teórica, tendríamos que incluir otras hipótesis de tributación, como cuando quien recibe las rentas es el autor o creador empresario unipersonal o empresa.

\section{III.3.1.2.2.1 Ingreso no constitutivo de renta}

El art. 17, $\mathrm{N}^{\circ} 8$, letra e), del DL $\mathrm{N}^{\circ} 824$, debe ser leído en conjunto con el $\mathrm{N}^{\circ} 20$, del mismo artículo, que considera como no renta, la "constitución de la propiedad intelectual (...), sin perjuicio de los beneficios que se obtengan" de ella. La norma cae un poco en lo absurdo, puesto que la "constitución" de la propiedad intelectual sólo puede ser entendida como la creación o el registro de la misma, resulta ser que en ninguna de dichas acciones hay propiamente una renta y en el evento de haberlo, mientras no se explote, por el hecho de la creación y su consiguiente titularidad, su valor jamás podría determinarse, ya que estaría constituido únicamente por el disfrute que dan a su autor o creador. En otras palabras, implicaría pensar que al escribir un poema, puede existir una tasación del disfrute que éste otorga a su autor. Por cierto que

${ }^{804}$ En este sentido: Ob. supra cit., pp. 424 y sgtes. También puede verse, por ejemplo: ORREGO ACUÑA, JUAN ANDRÉS. La cesión de derechos. Disponible en Internet en: www.juanandresorrego.cl (10 Jul 2013).

805 Si bien la descripción que hacemos del asunto no se discute en derecho nacional, también hay que tener en cuenta que por una cuestión de costumbre, no de técnica jurídica, es frecuente encontrar contratos de "cesión de derechos"; sin embargo, esos contratos son entendidos como "venta de derechos" y la cesión es la manera de hacer la tradición de los mismos. En el mismo sentido, es frecuente que para evitar suspicacias, se encuentre en los contratos, la siguiente redacción: "Que, por este acto, Pedro vende, cede y transfiere a Diego (...)".

${ }^{806}$ Oficio SII N ${ }^{\circ} 1.906$, de 04 de julio de 1996. En Chile no existen las consultas vinculantes, por lo que el SII normalmente contesta los requerimientos de los contribuyentes a través de oficios. 
encuadrando la creación como un invento patentable financiado con gastos soportados por una empresa, podemos estimar un valor, incluso sería posible rechazar estos gastos, desde el punto de vista fiscal, si se efectúan en un invento que no sirve a la empresa, pero lo que no puede exigirse, es que se esté obligado a explotar el invento o a generar rentas por su intermedio.

El asunto es recogido por el SII, que entiende, el acto de "constituir dicha propiedad", como sinónimo de formar, establecer, instituir, es decir, cualquier acción que conduzca a la creación, excluyendo aquellas que pudiesen implicar la explotación o enajenación de la misma. Entonces, bajo el supuesto de que se trate de la constitución de la propiedad intelectual, el incremento patrimonial que implica la constitución de dicha propiedad sería un ingreso no renta ${ }^{807}$.

Sobre el punto bajo análisis resta, únicamente, preguntarnos si al hablar de “propiedad intelectual” el art. 17, $\mathrm{N}^{\circ} 20$, del DL $\mathrm{N}^{\circ} 825$, se está refiriendo al género propiedad intelectual (intelectual e industrial) o a la propiedad intelectual propiamente tal. Al comparar el numeral $8^{\circ}$, letra e), antes citado, con el numeral $20^{\circ}$, también aludido previamente, jurídicamente cabe el argumento que diría: si el legislador habló de propiedad industrial e intelectual en el numeral $8^{\circ}$, letra e) y un poco más adelante en el mismo artículo, se refirió sólo a la propiedad intelectual, es porque en este último caso sólo se comprende la propiedad intelectual propiamente tal. No obstante, tal como analizamos latamente en su oportunidad, en el sistema chileno está tan internalizado el uso de la expresión propiedad intelectual como género, que sumado ello, a las consideraciones que hicimos supra, sobre el despropósito que implicaba gravar con renta la constitución de la propiedad intelectual en general, hacen muy difícil pensar que pudiese entenderse que en el numeral $20^{\circ}$, la expresión "propiedad intelectual" no esté tomada como el género que involucra a la propiedad intelectual propiamente tal y a la propiedad industrial.

${ }^{807}$ Sobre el asunto, dice el punto 3. del Oficio SII N ${ }^{\circ}$ 1.906, de 04 de julio de 1996, antes citado: "Ahora bien, si la renta se genera en la constitución de la propiedad intelectual, entendido el acto de 'constituir dicha propiedad', como sinónimo de formar, establecer, instituir, etc., excluyéndose de ella, por lo tanto, cualquier otra forma de acción distinta de esta como podría ser la explotación o enajenación de la misma, para los efectos tributarios el incremento patrimonial que implica la constitución de dicha propiedad constituye un ingreso no afecto a impuesto, conforme a lo previsto por el no. 20 del artículo 17 de la ley del ramo, sin que se comprenda en la referida liberación tributaria los ingresos provenientes de la explotación de la propiedad intelectual, ya que la misma norma legal en comento, en su parte final, expresamente señala que la calidad de ingreso no constitutivo de renta de la constitución de la propiedad intelectual, es sin perjuicio de los beneficios que se obtengan de dicho bien". 


\section{III.3.1.2.2.2 Impuesto único a la renta}

Una vez constituido el derecho de propiedad intelectual, ya sea por su creación misma o por su registro, corresponde analizar que sucede si este se hace ajeno, ya sea por venta u otro título traslaticio de dominio. La lectura correlativa del art. 17, hasta el $\mathrm{N}^{\circ}$ 8, letra e), parece indicar que no constituye renta "la enajenación" del derecho de propiedad industrial, efectuada por el inventor o creador. Sin embargo, el legislador en el artículo citado opta por el método más confuso de regulación que pudo concebir, puesto que en el mismo art. 17, inciso tercero, altera la norma anterior, gravando con el impuesto de primera categoría ${ }^{808}$ en carácter de único a la renta, los rendimientos señalados. De suerte que, los rendimientos de la enajenación del derecho de propiedad intelectual efectuada por el inventor o creador, no constituyen un ingreso no renta, como parece indicarlo el artículo 17, sino una renta gravada con impuesto de primera ${ }^{809}$ categoría $^{810}$ en carácter de único ${ }^{811}$. En este mismo sentido se pronuncian CONTRERAS HUGO Y GONZÁLEZ LEONEL ${ }^{812}$.

Analizando el fondo de la disposición podemos ver que se trata de una norma concebida de manera muy amplia, claramente con fines promocionales, puesto que concede la ventaja de tributar con una tasa menor a todos los autores o creadores por los réditos obtenidos de la enajenación de sus creaciones, sin distinción de ninguna especie, por lo que sus efectos se extenderá a todo el elenco de creaciones protegidas por la Ley 17.336 sobre Derecho de Autor y a todos los objetos protegidos por la Ley 19.039 sobre Propiedad Industrial, gran diferencia con las disposiciones que analizamos en el derecho español, que se encontraban plenas de disquisiciones que terminaron por sembrarnos la duda sobre sus reales objetivos.

${ }^{808}$ En la Ley de la Renta chilena, actualmente, existen dos categorías, primera categoría para las rentas de cualquier tipo de empresa, ya sea que se obtengan como persona jurídica o natural; y, segunda categoría, para las rentas del trabajo, ya sea bajo régimen de vinculación laboral (impuesto único al trabajo) o como ejercicio libre.

${ }^{809}$ Sobre el asunto, dice el punto 4. del Oficio SII N ${ }^{\circ}$ 1.906, de 04 de julio de 1996, antes citado: "Si las rentas provienen de la enajenación de la propiedad intelectual, entendiéndose esta como la cesión del dominio de la misma a un tercero, sin que su autor pueda seguir explotándola, la tributación de las citadas rentas se encuentra radicada en la letra e) del no. 8 del artículo 17 de la ley del ramo, norma que señala que no constituye renta el mayor valor, incluido el reajuste del saldo de precio, obtenido en la enajenación del derecho de propiedad intelectual o industrial, en caso que dicha enajenación sea efectuada por el inventor o autor (...)".

${ }^{810}$ La tasa actual del impuesto de primera categoría es de $20 \%$.

${ }^{811}$ La referencia a ser un impuesto "único a la renta", implica que será el único tributo a la renta que se debe pagar, es decir, que no se integra junto a los demás tributos a la renta para ningún efecto.

812 CONTRERAS HUGO Y GONZÁLEZ LEONEL. Curso práctico de impuesto a la renta, Edit. Cepet, Santiago, Chile, 1996, p. 57 


\section{III.3.1.2.2.3 Renta del trabajo}

La tercera alternativa se presenta cuando las rentas provienen ya no de la enajenación, ni de la constitución de la propiedad intelectual, sino de su explotación efectuada por el propio autor o creador que no es empresa, es lo que típicamente llamaríamos regalías. En este caso, para el SII se trataría de rentas del trabajo, que en derecho chileno corresponden a rentas de "segunda categoría" provenientes del ejercicio de una ocupación lucrativa, afectándose con el impuesto a la renta en esa calidad ${ }^{813}$, debiendo dar boletas de honorario y además cumplir con el Impuesto Global Complementario, tal como advierten CONTRERAS HUGO Y GONZÁLEZ LEONEL $^{814}$.

\section{III.3.1.2.2.4 Quien recibe las rentas es el autor o creador empresario unipersonal o empresa}

A pesar del esfuerzo sistematizador que hace el SII, existe un caso que no abordó, es el que se presenta cuando el autor o creador que recibe las regalías, es una empresa o un empresario unipersonal, para efectos tributarios. El régimen especial que venimos analizando favorece al autor o creador, pero únicamente respecto de la constitución y de la enajenación, no así respecto de la explotación de la propiedad intelectual, hipótesis en la que queda sometido al régimen normal de tributación. Así las cosas, el autor o creador que tribute en primera categoría (empresa), estará afecto al impuesto con tasa normal de 20 por ciento, cuyo importe es crédito para el Impuesto

${ }^{813}$ Derivado de la circunstancia que hemos venido explicando, en el sentido que en Chile los impuestos a la renta están integrados, la gran distinción que debe hacerse para conocer la tributación de una persona es si obtiene rentas del trabajo o de empresa. En el primer caso, está sujeto a una tasa progresiva de cero a cuarenta por ciento y en el segundo a una tasa fija de veinte por ciento. Ahora bien, como los impuestos están integrados a fin de año se produce la "tributación real" que únicamente opera respecto de las personas naturales e implica que se colacionan todos sus ingresos en una cuenta única, al amparo de lo que se conoce como Impuesto Global Complementario, que al final del día es el real y único impuesto a la renta. De manera que, si se trata de una empresa o empresario, los dineros que su dueño, accionista, el propio empresario, etc., haya retirado de la empresa para su consumo, se sumarán a cualquier otro que posea en el Impuesto Global Complementario y se considerará como pago a cuenta (en Chile se dice como "crédito") el veinte por ciento pagado a nivel de empresa. Lo anterior, es lo que hace que en el caso del autor que obtiene regalías de la editorial, se le considere sujeto al impuesto global complementario y justifica que el Oficio SII $\mathrm{N}^{\circ} 1.906$, que venimos citando, diga: "y de acuerdo a la clasificación de la renta (de la segunda categoría), las personas pagadoras de los ingresos, cuando se traten de aquellas indicadas en el $\mathrm{N}^{\circ} 2$ del artículo 74 de la ley de la renta, estarán obligadas a efectuar la retención de impuesto del $10 \%$ que dispone dicha norma, declarándola dentro del plazo que señala el artículo 78 de la citada ley; retención que el beneficiario del ingreso podrá invocarla como abono a sus impuestos anuales a la renta a declarar al termino del ejercicio, debidamente actualizada, en los términos previstos por el artículo 75 de la ley del ramo".

${ }^{814}$ Ob. supra cit., p. 57 
Global Complementario, tal como relatan CONTRERAS HUGO Y GONZÁLEZ LEONEL $^{815}$.

\subsubsection{Otras particularidades del régimen previsto en el art. 17 de la Ley de la Renta}

Anteriormente hicimos presente lo confusa que era la redacción del art. 17 del DL $\mathrm{N}^{\circ} 824$, que venimos analizando, lo que se manifiesta a lo largo de todo su texto, habiendo dado origen a múltiples dificultades interpretativas, ya sea porque en algún caso efectivamente establece un régimen especial de tributación o porque en otros, aparenta crearlo. Esto nos obliga a detenernos en dos tópicos especiales y posteriormente haremos un resumen de la situación.

\section{III.3.1.2.3.1 Habitualidad}

Continuando con el análisis del art. 17, tantas veces citado, en el $\mathrm{N}^{\circ} 8$, párrafo tercero, podemos leer: “(...) se gravará con el impuesto de primera categoría en el carácter de impuesto único a la renta, a menos que operen las normas de habitualidad a que se refiere el artículo 18 ".

La norma parece estar diciéndonos: si usted es habitual en este tipo de operaciones, entonces no tendrá el beneficio de pagar el impuesto de primera categoría en carácter de único, sino que deberá tributar conforme a lo establecido en el artículo 18 de la ley de la Renta y esto parece ser aplicable a la propiedad intelectual que está en el art. $17, \mathrm{~N}^{\circ} 8$, párrafo primero. Es decir, un autor o creador que hace de la creación, invención y desarrollo de tecnología su actividad habitual estaría alcanzado por el artículo 18 , consecuentemente, afecto a la tributación normal, es decir, sin obtener el beneficio del art. $17 \mathrm{~N}^{\circ} 8$.

Como se aprecia, el desarrollo del tema hasta aquí parece razonable, no obstante ello, al leer el artículo 18 detenidamente, nos encontramos con que no se refiere al art. $17 \mathrm{~N}^{\circ} 8$ letra e), que es el caso del autor o creador que enajena su derecho. Por ello, estimamos que debe prevalecer la norma especial que exime de impuesto al contribuyente, ya que está diseñada en términos generales, si el legislador quisiese hacer excepción de ella, debería hacerlo actuando expresamente.

${ }^{815}$ Ob., supra cit., p. 57. 
Se concluye entonces, que la tributación que afecta a la enajenación de los derechos de propiedad intelectual, efectuados por su creador o inventor, es la de impuesto de primera categoría en carácter de único, independientemente de la habitualidad.

\section{III.3.1.2.3.2 Mayor valor tributable}

Nuevamente el art. 17 encierra sorpresas, puesto que el $\mathrm{N}^{\circ} 8$, párrafo segundo, dice: “En los casos señalados en las letras a), c), d), e) ${ }^{816}$, h) y j), no constituirá renta sólo aquella parte del mayor valor que se obtenga hasta la concurrencia de la cantidad que resulte de aplicar al valor de adquisición del bien respectivo, el porcentaje de variación experimentado por el índice de Precios al Consumidor en el período comprendido entre el último día del mes anterior a la adquisición y el último día del mes anterior al de la enajenación, todo ello sin perjuicio de lo dispuesto en el artículo 18 $(\ldots)$ ".

Como este artículo habla de "no renta", pareciera decir que se confirma lo dispuesto por el artículo $17 \mathrm{~N}^{\circ} 8$ letra e), en el sentido de que aquí hay un ingreso no renta. Nada más alejado de la realidad, simplemente está dejando al margen de la tributación el reajuste del valor de costo o adquisición de la propiedad industrial, es decir está reconociendo la existencia de la inflación, evitando que el contribuyente pague impuestos sobre el mayor valor nominal que pudo haber experimentado la propiedad debido a la inflación, pero que lógicamente no constituye ninguna utilidad, sino que simplemente la actualización a tiempo presente de los costos de sus derechos de propiedad. Por otra parte, ello no tiene nada de extraño, ya que la regla general en el derecho chileno, es evitar el pago de impuestos derivado del aparente mayor valor de los bienes nacido de la inflación.

\section{III.3.1.2.3.3 Resumen}

Conforme a lo anterior, el mayor valor originado en la enajenación de los derechos de propiedad intelectual o industrial tributará como sigue:

${ }^{816}$ Recordemos que en la letra e) es donde está el beneficio de la tributación con tasa de impuesto único a la renta, para la propiedad intelectual. 
- Si la enajenación la realiza el autor o creador, se encuentra afecto al Impuesto de Primera Categoría como impuesto único, con tasa de 20\%, sin importar la habitualidad del contribuyente.

- Cuando la enajenación la realiza el autor o creador, que no está obligado a declarar su renta efectiva en Primera Categoría y el mayor valor no exceda de diez unidades tributarias mensuales en caso de retención del impuesto, o diez unidades tributarias anuales al momento de la declaración anual, se encuentra exento de todo impuesto.

- Si la enajenación la realiza quien no es autor o creador, pagará los impuestos normales de la ley de la renta, es decir: Primera Categoría y Global Complementario, según sea el caso. A todo evento, el mayor valor derivado del reajuste del valor de costo o adquisición, por aplicación de la variación del índice de precios al consumidor entre el último día del mes anterior a la adquisición y el último día del mes anterior al de la enajenación, no constituirá renta.

Lógicamente, se entiende que la tributación se aplicará en cada caso, sobre el mayor valor obtenido en la operación, debiendo considerarse como tal, el monto de la enajenación, deducido el valor de costo, reajustado por la variación del índice de precios al consumidor, entre el último día del mes anterior al momento del desembolso ${ }^{817}$ y el último día del mes anterior al de la enajenación.

\subsubsection{El régimen de tributación especial de la propiedad intelectual desde septiembre de 2014}

En lo pertinente del artículo $17 \mathrm{~N}^{\circ} 8$ del DL No 824818, Ley de la Renta, vigente desde septiembre de 2014819, establece: "Las enajenaciones a que se refiere el presente

${ }^{817}$ Hablamos de desembolso, ya que la expresión resulta más comprensible, en la medida que en el evento de ser el enajenante el autor o creador, tendrá derecho a imputar como costo el valor de los insumos adquiridos para desarrollar el invento, reajustados en la forma indicada, desde la fecha de su respectiva adquisición. De otra parte, si el enajenante no es el autor o creador, tendrá derecho a imputar como costo el valor de adquisición del respectivo derecho, también reajustado en la forma indicada, desde la fecha de adquisición.

${ }^{818}$ Recordemos que en el caso chileno, la expresión "decreto ley", se refiere a los instrumentos normativos por medio de los cuales han gobernado las autoridades de facto a lo largo de la historia del país. Durante el régimen liderado por el General Augusto Pinochet, se dictaron más de 3600 decretos leyes, los que posteriormente mantuvieron su vigencia, reconociéndoseles rango de ley ordinaria.

819 Cabe hacer notar, que hasta septiembre de 2014, cuando escribo sobre la reforma, la disposición no ha sido promulgada ni publicada en el Diario Oficio, por ello no tiene número de ley, sin embargo, se trata de una ley aprobada por el Congreso, de manera que sólo faltan los trámites formales para su nacimiento a la vida del derecho. 
número se regirán por las siguientes reglas: ... e) Enajenación del derecho de propiedad intelectual o industrial. No constituye renta el mayor valor obtenido en su enajenación, siempre que el enajenante sea el respectivo inventor o autor".

A pesar de haberse reformado la norma, en lo esencial, las afirmaciones que hicimos en el sentido que constituye un verdadero régimen especial de tributación para la propiedad intelectual, se mantienen, con la diferencia que ahora no existe la tributación exenta básica por menos de diez unidades tributarias anuales y además, desapareció el régimen de impuesto único a la renta, existiendo solamente la posibilidad de estar frente a un hecho no renta y al régimen tributación normal. Lo que no cambió, es la necesidad de hacer esfuerzos interpretativos para encontrar el régimen tributario real, puesto que, en el inciso segundo del $\mathrm{N}^{\circ} 8$, del artículo 17, de que estamos hablando, se establece que cuando se trate de un contribuyente que determine el impuesto de primera categoría sobre rentas efectivas, deberá tributar con los impuestos normales de la ley de la renta; de manera que, en ese caso, el ingreso no renta de la letra e), del $\mathrm{N}^{\circ} 8$ del artículo 17, se vuelve letra muerta, para pasar al régimen general de tributación.

\subsubsection{Enajenación como verbo rector del régimen especial de la propiedad intelectual}

En el art. 17, $\mathrm{N}^{\circ}$ 8, e), de la Ley de la Renta, el legislador no innovó, manteniendo el verbo rector "enajenar", de manera que las observaciones que hicimos en su oportunidad, se mantienen plenamente vigentes.

\subsubsection{Tres formas de tributar de la propiedad intelectual en el art. 17 de la Ley de la Renta}

La modificación más importante después de la reforma de septiembre de 2014, ha sido la eliminación de la posibilidad de tributar con un impuesto único a la renta, que dejaba salda toda la tributación por las rentas afectas a ese sistema. De manera que, a partir de la fecha señalada, las posibilidades se reducen a tres, dos de ellas definidas claramente por el legislador y la tercera deducida por aplicación de las normas generales. 


\section{III.3.1.3.2.1 Ingreso no constitutivo de renta}

Ya dijimos que el art. 17, $\mathrm{N}^{\circ}$ 8, letra e), del DL $\mathrm{N}^{\circ}$ 824, debe ser leído en conjunto con el $\mathrm{N}^{\circ} 20$, del mismo artículo, que considera como no renta, la "constitución de la propiedad intelectual (...), sin perjuicio de los beneficios que se obtengan" de ella. Estas disposiciones y su interrelación no fueron alteradas por la reforma, de manera que mantenemos los comentarios que sobre ellas hicimos supra, puesto que conservan plenamente su vigencia.

\section{III.3.1.3.2.2 Desaparecimiento del impuesto único a la renta}

Previamente vimos como el legislador antes de septiembre de 2014, declaraba la enajenación de la propiedad intelectual como un hecho no renta, sin embargo, verdaderamente lo que había era el establecimiento de un impuesto único a la renta, con tipo fijo, cuyo pago agotaba la tributación asociada. La rareza del asunto, es que la reforma tributaria se hizo para recaudar más impuestos y eliminar exenciones, pero en la especie, al eliminar la disposición del mismo art. 17, inciso tercero, que gravaba con impuesto único a las rentas del artículo 17 letra e), produjo el efecto de consolidar la tributación como no renta.

Sobre este punto, en el "Mensaje de S.E. la Presidenta de la Republica con el que inicia un proyecto de ley de reforma tributaria que modifica el sistema de tributación de la renta e introduce diversos ajustes en el sistema tributario", $\mathrm{N}^{\circ}$ 24-362, de uno de abril de $2014^{820}$, nada se dice específicamente y tampoco pudimos encontrar antecedentes en la discusión legislativa, sino que por el contrario, todos los antecedentes dicen que los objetivos de la reforma son aumentar la recaudación y eliminar exenciones, de manera que, al menos en este punto, la solución va en contra de lo propuesto.

Considerando lo anterior, no nos atrevemos a mantener la afirmación que antes hicimos, en el sentido que se trata de "una norma concebida de manera muy amplia, claramente con fines promocionales, puesto que concede la ventaja de tributar con una tasa menor a todos los autores o creadores por los réditos obtenidos de la enajenación de sus creaciones", no por su tenor literal, que creemos se mantiene apuntado en ese

\footnotetext{
${ }^{820}$ Disponible en: http://www.senado.cl/appsenado/templates/tramitacion/index.php\# (15 Sep 2014).
} 
sentido, sino en tanto cuanto, dudamos de la conciencia real del legislador de haber querido actuar como lo hizo.

\section{III.3.1.3.2.3 Régimen normal de tributación}

El nuevo inciso tercero del $\mathrm{N}^{\circ}$ 8, del artículo 17 de la Ley de la Renta, establece: "Cuando las operaciones a que se refiere este número [donde se incluyen las del $17 \mathrm{~N}^{\circ} 8$, letra e), de que venimos hablando] sean realizadas por contribuyentes que determinen el impuesto de primera categoría sobre rentas efectivas, el total del mayor valor a que se refiere este número constituirá renta, gravándose conforme a las reglas del Título II, con los impuestos de primera categoría y global complementario o adicional, según corresponda, sobre la base de la renta percibida o devengada, de acuerdo al régimen de tributación al que se encuentre sujeto. En estos casos, los valores de adquisición se reajustarán aplicando las normas del artículo 41, cuando el contribuyente respectivo se encuentre obligado a aplicar dichas normas".

La aplicación de esta norma desvanece parte del ingreso no renta creado por el artículo $17 \mathrm{~N}^{\circ} 8$, letra e), que venimos analizando, puesto que pasa al régimen general los rendimientos de la propiedad intelectual e industrial obtenidos por contribuyentes sujetos a renta efectiva, independientemente de que sean o no el autor o creador.

\section{III.3.1.3.2.4 Renta del trabajo}

La tercera alternativa, tal como analizamos previamente, no viene de las normas citadas, sino que de la aplicación del sistema general de tributación, se presenta cuando existe una explotación de la propiedad intelectual o industrial por vía de regalías. En este caso, si se trata de una persona natural, tal como vimos, para el SII se serían rentas del trabajo, clasificadas en Chile como de "segunda categoría" provenientes del ejercicio de una ocupación lucrativa, afectándose con el impuesto a la renta en esa calidad. En el caso de ser una empresa la que efectúa la explotación, no cabe duda que aplicará el régimen general, tributando con primera categoría a nivel de empresa y con Global Complementario o Adicional a nivel del contribuyente final, lo que resulta equivalente al caso que analizamos supra, cuando quien recibe las rentas es el autor o creador empresario unipersonal o empresa. 


\subsubsection{Resumen}

La nueva legislación simplifica la tributación de los rendimientos de la propiedad intelectual e industrial, no obstante no estamos seguros por completo si esto fue el objetivo del legislador.

Conforme venimos analizando, la tributación sería la siguiente:

- Simple creación. Ingreso no renta. Nunca está sujeta a impuesto.

- Enajenación efectuada por un contribuyente con renta efectiva. Régimen normal de tributación con primera categoría e impuesto Global Complementario o Adicional a nivel de contribuyente final;

- Enajenación efectuada por un contribuyente sin renta efectiva, que además es el autor o creador. No renta.

- Enajenación efectuada por un contribuyente sin renta efectiva, que no es el autor o creador. Si está sujeto a tributación de empresas (primera categoría) tributa conforme al régimen normal de tributación. Si está sujeto a tributación de personas naturales (segunda categoría), le corresponde pagar sus impuestos a nivel de Global Complementario o Adicional, según sea residente o no.

- Explotación vía royalties. Régimen normal de tributación. Es decir, si está sujeto a tributación de empresas (primera categoría) tributa conforme al régimen normal de tributación. Si está sujeto a tributación de personas naturales (segunda categoría), le corresponde pagar sus impuestos a nivel de Global Complementario o Adicional, según sea residente o no.

\subsubsection{El régimen normal de tributación y la propiedad intelectual}

Como hemos visto supra antes y después de la reforma de septiembre de 2014, ha existido y subsiste un régimen especial de tributación de la propiedad intelectual, que se extiende a su enajenación por el autor o creador, al mayor valor que se pueda producir por su constitución, de manera que, fuera de los casos especiales, cuando se obtengan rentas por la explotación de la propiedad intelectual, no hay razón para dudar que deban estar sometidas al régimen normal de tributación, por lo que, tal como también vimos: si el autor o creador es una empresa o empresario unipersonal, sobre la diferencia entre costo y precio de venta, se gravará con el impuesto de primera 
categoría $^{821}$ y con el Global Complementario. Si el autor o creador es una persona natural que no tributa como empresa, sobre la diferencia entre costo y precio de venta, se gravará con el impuesto de Segunda Categoría ${ }^{822}$ y con el Global Complementario ${ }^{823}$.

Bajo el régimen general de tributación, el legislador se detuvo a regular algunas cuestiones que le parecieron relevantes en materia de propiedad intelectual, que analizaremos, a las que dedicaremos nuestra atención en los subtítulos siguientes.

\subsubsection{Localización}

En el art. $10^{\circ}$ de DL $\mathrm{N}^{\circ} 824^{824}$, encontramos una disposición expresa que se refiere a la localización de los rendimientos de la propiedad intelectual, la norma es muy escueta, pero a la vez es clara, al establecer que son rentas de fuentes chilena, las regalías, los derechos por el uso de marcas y otras prestaciones análogas derivadas de la explotación en Chile de la propiedad industrial e intelectual.

La disposición a pesar de partir con ejemplos bastantes restringidos, finalmente es de una amplitud total, puesto que sitúa en Chile a la totalidad de los rendimientos por la explotación de la propiedad intelectual e industrial, lo que conforme al derecho nacional incluye cualquier beneficio derivado de creaciones intelectuales.

\subsubsection{Gastos necesarios para producir la renta}

En derecho tributario siempre ha existido y probablemente nunca dejará de existir una interacción entre el estado y los contribuyentes, uno intentando aumentar la recaudación, los otros viendo la forma de disminuir su propia carga tributaria. Ahora bien, probablemente donde más claramente lo vemos, es a propósito de los gastos necesarios para producir la renta ${ }^{825}$.

${ }^{821}$ Actualmente con tasa de $20 \%$, previsto que suba a 25 y $27 \%$, según se opte por el régimen con renta atribuida o parcialmente integrado, en el año 2017. Conforme a la reforma de septiembre de 2014.

${ }^{822}$ Actualmente con tasa progresiva de 0 a $40 \%$. Previsto que varíe de 0 a $35 \%$ o 0 a $44 \%$ según se opte por el régimen con renta atribuida o parcialmente integrado, en el año 2017. Conforme a la reforma de septiembre de 2014.

${ }^{823} \mathrm{Si}$ el contribuyente no posee rentas de Segunda Categoría, corresponde aplicar derechamente el Global Complementario. La tasa actual del Global Complementario es progresiva de 0 a $40 \%$.

${ }^{824}$ Esta disposición no fue modificada por la reforma de septiembre de 2014.

${ }^{825}$ Entendemos por gastos necesarios para producir la renta, aquéllos que el legislador permite al contribuyente considerar como gastos de su negocio, con el consiguiente efecto de rebajar la utilidad afecta a impuesto. 
De las cuatro oportunidades que la Ley de la Renta se refiere a la propiedad intelectual, para: establecer su localización, crear casos de ingresos no renta, regular la tributación de los no residentes y normar sobre los gastos necesarios para producir la renta, sólo en este último caso separa a la propiedad industrial y el software, de la intelectual propiamente tal. Al parecer, el legislador chileno únicamente entiende que se pueden producir gastos en la propiedad industrial y el software ${ }^{826}$, es como si solamente a éstos los considerara originados dentro de la dinámica de empresa y respecto del resto de los derechos de propiedad intelectual, pensase que nacen exclusivamente de la genialidad inventiva, ausentes de dispensa económica en su creación.

Conforme el legislador organizó las cosas, la propiedad industrial y el software fueron objeto del establecimiento de una norma de anti-elusión ${ }^{827}$, establecida por la Ley $\mathrm{N}^{\circ} 19.506$, de julio de 1997, que puso límites a los pagos efectuados por los contribuyentes al extranjero, como contraprestación por derechos de propiedad industrial y software. Con la norma citada, en la actualidad, es posible distinguir tres hipótesis para los gastos necesarios para producir la renta y la propiedad industrial: desembolsos en que ha incurrido la empresa en la investigación científica y tecnológica; desembolsos consistentes en pagos por el uso de marcas y patentes en Chile y en el extranjero; y, desembolsos relacionados con los costos directos y la compra de derechos de Propiedad Industrial.

\section{III.3.1.4.2.1 Desembolsos en que ha incurrido la empresa en la investigación científica y tecnológica}

La Ley $\mathrm{N}^{\mathrm{o}} 18.775$, incorporó el número $11^{828}$, al art. $31^{829}$ de la Ley de la Renta $^{830}$. Esto fue necesario ya que, del contexto de la Ley de la Renta, no resultaba del todo claro que los gastos incurridos por las empresas en la investigación científica y tecnológica podían deducirse de la renta bruta para los efectos de la aplicación del impuesto de primera categoría, cuando dichos desembolsos se relacionaran con ingresos que se generarían en ejercicios futuros, o bien, cuando simplemente la empresa

${ }^{826}$ Conforme a la Ley $\mathrm{N}^{\circ} 17.336$, sobre Derecho de Autor, el software en Chile es propiedad intelectual.

${ }^{827}$ Norma de control es el nombre que reciben en Chile, disposiciones cuya conformidad con los principios del derecho tributario normalmente está en duda y que nace del celo de la administración tributaria que pretende evitar algo que a su juicio es foco de evasión o elusión.

${ }^{828}$ Esta disposición no fue modificada por la reforma de septiembre de 2014.

${ }^{829}$ Recordemos que el ART. $31^{\circ}$ se refiere a los gastos necesarios para producir la renta.

${ }^{830}$ Ley $\mathrm{N}^{\circ} 18.775$, art. $1^{\circ}, \mathrm{N}^{\circ} 6$, letra b), de 14 de enero de 1989, incorporó el número 11 al artículo $31^{\circ}$ de la Ley de la Renta. 
abandonaba el proyecto de investigación, por no ser conveniente su implementación o continuar con su desarrollo. En virtud de lo anterior, fue necesario que se estableciera expresamente en la Ley de la Renta el tratamiento tributario aplicable a los desembolsos incurridos por los conceptos antes señalados ${ }^{831}$.

Es así como el artículo 31 de la Ley de la renta establece: "Especialmente procederá la deducción de los siguientes gastos, en cuanto se relacionan con el giro del negocio:" (...) " $\mathrm{N}^{\mathrm{o}} 11$. Los gastos incurridos en la investigación científica y tecnológica en interés de la empresa aun cuando no sean necesarios para producir la renta bruta del ejercicio, pudiendo ser deducidos en el mismo período en que se pagaron o adeudaron o hasta en seis ejercicios comerciales consecutivos". De esta manera, se establecer un régimen de libertad de amortización cuyo contenido es mucho más amplio que en el caso español, puesto que permite rebajar los gastos incurridos en la investigación científica y tecnológica en interés de la empresa, sin exigir que sean necesarios para la producción de la renta, sino que solamente sean en interés de la empresa, e incluso, cuando dichos desembolsos no sean necesarios para producir la renta del ejercicio.

La libertad de amortización está dada por la posibilidad de opción del contribuyente, para rebajarlos en el mismo ejercicio en que se pagaron o adeudaron, o bien, traspasarse a resultado, en uno, dos, tres, hasta un máximo de seis ejercicios comerciales consecutivos.

A todo evento, es necesario destacar que el Servicio de Impuesto Internos ha establecido, que para que proceda esta rebaja en los términos antes previstos, deben cumplirse, además, todas aquellas condiciones que exige sobre la materia el inciso primero del art. $31^{\circ}$, es decir, son considerados un gasto más, de aquellos necesarios para producir la renta.

Hasta aquí el problema del art. $31 \mathrm{~N}^{0} 11$, parecería agotado, no obstante ello, en este instante se plantean las preguntas más interesantes, por cuanto el legislador no definió que se entiende por "ciencia y tecnología en interés de la empresa", cuestión a la que nos dedicaremos desde el próximo párrafo.

${ }^{831}$ Circular No 11/89, de 27 de enero de 1989. 
El oficio $N^{o} 3826$ de 21 de septiembre de 1992 del Servicio de Impuestos Internos, establece que para que opere la rebaja que autoriza el art. $31 \mathrm{~N}^{0} 11$ de la Ley de Renta, deben cumplirse los siguientes requisitos básicos: que se trate de gastos incurridos en la investigación científica y tecnológica, y que hayan sido desembolsados en interés de la empresa. Seguidamente, haciéndose cargo del primer requisito, dice: "[e]n cuanto al primer requisito, teniendo presente que el legislador no ha definido la expresión 'investigación científica y tecnológica' a que se alude, y de conformidad al principio básico en materia de hermenéutica civil consagrado en el Artículo $20^{\circ}$ del Código Civil, recurriendo a las definiciones que sobre el particular contiene el Diccionario de la Real Academia Española, por 'investigación científica' debe entenderse aquella que persigue la obtención de un conocimiento cierto de las cosas por sus principios y causas, y por 'investigación tecnológica' aquella encaminada a obtener un conocimiento propio de un oficio mecánico o arte industrial".

Transcribimos el oficio del SII, que es el único que ha habido hasta la fecha, porque de cierta manera, es tan básico el conocimiento que parece tener sus redactores sobre la materia, que se ven casi obligados a recurrir al diccionario para definir el contenido de lo legislado, no decimos que ello no sea posible, más aún como herramienta hermenéutica es perfectamente procedente, sin embargo habiendo analizado previamente, a propósito de la legislación española, el contenido de la $\mathrm{I}+\mathrm{D}+\mathrm{i}$, siendo conscientes de la extensión y complejidad de la materia, a nuestro juicio, la salida de la administración tributaria chilena raya en la ingenuidad.

Estimamos que el SII se equivoca al aplicar la norma del art. 20 del Código Civil $^{832}$, puesto que debió usar el art. 21 del mismo cuerpo legal, que haciéndose cargo de las palabras técnicas de toda ciencia o arte, manda a considerar el significado de quienes profesan la misma ciencia o arte. De haber seguido este criterio el SII, habría considerado la opinión de expertos en innovación o al menos en propiedad intelectual y habría llegado a un conceptualización del asunto más próxima, por ejemplo, a la

${ }^{832}$ El art. 20 del Código Civil chileno, señala: "Las palabras de la ley se entenderán en su sentido natural y obvio, según el uso general de las mismas palabras; pero cuando el legislador las haya definido expresamente para ciertas materias, se les dará en éstas su significado legal".

El art. 21 del Código Civil chileno, dice: "Las palabras técnicas de toda ciencia o arte se tomarán en el sentido que les den los que profesan la misma ciencia o arte; a menos que aparezca claramente que se han tomado en sentido diverso". 
definición de tecnología de la OMPI ${ }^{833}$, para quien tecnología "se refiere a productos finales de investigación y desarrollo científico, presentados en forma de invenciones y conocimientos especializados que se utilizan como instrumentos o procedimientos para crear productos y servicios nuevos o mejorados destinados a satisfacer mejor las necesidades del mercado" $" 834$.

El análisis de las definiciones anotadas muestra diferencias fundamentales en la conceptualización que se hace de las ideas, puesto que la definición de la OMPI es armoniosa con la conceptualización de la $\mathrm{I}+\mathrm{D}+\mathrm{i}$ como instrumento de desarrollo económico y con la protección que recibe en el contexto de la propiedad intelectual, asumiendo en el centro del asunto, la existencia de: "invenciones y conocimientos especializados", destinados a crear "productos y servicios nuevos o mejorados" para satisfacer necesidades de mercado, características que dan cuenta de la $\mathrm{I}+\mathrm{D}+\mathrm{i}$ tal como la hemos venido estudiando y que están ausentes en la visión del SII y de la Real Academia de la Lengua Española.

Un poco más preciso sobre el contenido que ha querido definir el legislador en la materia, es la exigencia de novedad que hace el Oficio 3826, antes citado, al establecer que si un "estudio "no persigue la obtención de un conocimiento nuevo derivado de una investigación científica o tecnológica', sino que es producto de un conocimiento preexistente de orden técnico como lo es la ingeniería civil y la arquitectura, tales desembolsos no reúnen los requisitos básicos que exige el $\mathrm{N}^{\circ} 11$ del Artículo $31^{\circ}$ de la Ley de la Renta, para ser aceptados como gastos necesarios para producir la renta". Esta apreciación es ratificada por el SII Oficio $\mathrm{N}^{\circ} 3489 / 95$, de 22 de noviembre de 1995, donde rechaza un proyecto, estableciendo que "no persigue la obtención de un conocimiento nuevo derivado de una investigación científica o tecnológica, sino que son producto de un conocimiento preexistente de orden técnico, como lo es la Ingeniería Civil y la Arquitectura”.

El organismo fiscalizador razona sobre la idea, que el artículo $31 \mathrm{~N}^{\mathrm{o}} 11$ se refiere a un conocimiento nuevo, por lo que se confirma la impropiedad de usar como definición la dada por la Real Academia de la Lengua Española que no contempla este

${ }^{833}$ OMPI es el acrónimo de Organización Mundial de la Propiedad Intelectual.

${ }^{834}$ OMPI. Intercambiar valor. Negociación de acuerdos de tecnología. Disponible en Internet en: http://www.wipo. int/export/sites/ www/sme/es/documents/pdf/technology licensing.pdf $\left(\begin{array}{ll}10 & \mathrm{Jul}\end{array}\right.$ 2013). 
requisito. Sin embargo, nuestro mayor problema no deriva de esta sutileza interpretativa, sino del hecho que, la exigencia establecida por los oficios comentados es determinante en términos que la investigación debe perseguir la obtención de un "conocimiento nuevo derivado de una investigación científica o tecnológica". Es decir, el SII hace presente la exigencia de la novedad, pero no la define y lo que es más grave, del contexto de los oficios parece exigir la novedad como un concepto coloquial, en términos de requerir en todo invento una novedad universal y absoluta, en consecuencia que sabemos que el concepto de novedad para la $\mathrm{I}+\mathrm{D}+\mathrm{i}$, tiene un contenido propio $\mathrm{y}$ específico, que es mucho menos riguroso que la sola exigencia de "un conocimiento nuevo". Ahora bien, desde la perspectiva de la legislación chilena, la definición de novedad en términos absolutos se aproxima más a uno de los requisitos sustantivos de patentes $^{835}$, pero no tenemos evidencia que el legislador tributario haya querido beneficiar exclusivamente a los desarrollos patentables con la norma que analizamos, por el contrario de su tenor literal se refiere a los "gastos incurridos en la investigación científica y tecnológica", sin distinguir.

El SII a la expresión "ciencia y tecnología", como objeto de la norma, le exige la obtención de un conocimiento "nuevo", requisito que la ley no contempla y además, le impone un contenido que no parece ser armónico con las necesidades de la investigación científica y tecnológica, particularmente si convenimos que la disposición del $31 \mathrm{~N}^{\circ} 11$ de la Ley de la Renta, está destinada a las actividades de I+D+i. La indefinición de contenidos, como es natural, impedirá una interpretación armónica y pacífica de las normas jurídicas, en los diferentes planos en que es necesario que se expresen, lo que da origen a preguntas como qué sucederá con aquellos gastos, relacionados con una invención que no busca un conocimiento nuevo en concepto del organismo fiscalizador, no obstante ser perfectamente registrable para la propiedad industrial y por tanto protegible en concepto del legislador. Bajo la visión del SII no gozarán del amparo del artículo $31 \mathrm{~N}^{\mathrm{o}} 11$, de la Ley de la Renta, sin embargo constituye un conocimiento al cual el Estado otorga su máxima protección concediendo una patente de invención para la explotación exclusiva de la tecnología.

${ }^{835}$ El art. 33 de la Ley $\mathrm{N}^{\circ} 19.039$, define que: "Una invención se considera nueva cuando no existe con anterioridad en el estado de la técnica. El estado de la técnica comprenderá todo lo que haya sido divulgado o hecho accesible al público, en cualquier lugar del mundo, mediante una publicación en forma tangible, la venta o comercialización, el uso o cualquier otro medio, antes de la fecha de presentación de la solicitud de patente en Chile". 
El problema no se termina al establecer que entendemos errónea la interpretación del Servicio de Impuestos Internos, en tanto deja fuera del artículo $31 \mathrm{~N}^{\mathrm{o}}$ 11 de la Ley de la Renta, gastos que naturalmente deberían estarlo, continúa al momento de determinar cuál es el tratamiento que deben tener estos gastos, en el evento de seguir la tesis del organismo administrador. La conclusión cae por su propio peso, el mismo tratamiento de aquellos gastos que no deben estar en el artículo $31 \mathrm{~N}^{\circ} 11$ de la Ley de la Renta (es decir, que no son gastos aceptados como necesarios para producir la renta), pero que tampoco reciben el tratamiento de gastos rechazados (aquellos que deben sumarse a la base imponible por corresponder a expensas que nada tiene que ver con el giro o porque van en beneficio directo del empresario y no del negocio). Un ejemplo concreto lo encontramos en el Oficio $\mathrm{N}^{\circ} 3498$, de 22 de noviembre de 1995, que dictaminó que los gastos efectuados por la empresa forestal en el desarrollo de un estudio de factibilidad de un proyecto urbanístico, no reunía los requisitos básicos que exige el $N^{\circ} 11$ del art. 31 de la Ley de la Renta, para ser deducidos, resolviendo que las "cantidades debían activarse y rebajarse de los propios ingresos que genere en el futuro dicho proyecto de factibilidad".

Estamos frente a gastos que no son del giro, no es el problema saber si poseen novedad o no. Simplemente, se trata de gastos que no son del giro y por ello parecerían ser gastos rechazados, no obstante el SII, consciente en que puedan ser activados y rebajarlos de los ingresos futuros que estos mismos gastos generen.

La mecánica para manejarlos es fácil de entender, lo complicado es saber por qué el Servicio de Impuestos Internos les dio este tratamiento. Sólo existen dos caminos los entendió como gastos de organización y puesta en marcha de un nuevo negocio, ya que les hizo aplicable el artículo $41 \mathrm{~N}^{\circ} 7$ de la Ley de Impuesto a la Renta que se refiere al tema y por eso activarlos en vez de declararlos como gasto rechazado por no ser del giro o se trataría de gastos no son del giro de la empresa y por lo tanto son un gasto rechazado. En esta alternativa, existiría una impropiedad en la visión del Servicio de Impuestos Internos al permitir mantenerlos activados. Desde nuestra perspectiva, la primera posición es la correcta, ya que la investigación realizada en una nueva área de negocios será un activo para la empresa, transformándose en una inversión para el futuro negocio, de suerte que si éste se concreta se podrá seguir el camino normal de toda empresa e imputar dichos desembolsos a las utilidades que el proyecto genere. 
No obstante lo anterior, otro problema se presenta si es que el nuevo negocio no da frutos o la investigación fracasa, puesto que esos gastos permanecerán activados indefinidamente, hasta que sea cierto que el nuevo negocio nunca rendirá utilidades, en cuyo caso procederá su castigo cargándolo a resultado. Posteriormente, recibirían el tratamiento de un agregado a la renta líquida imponible por disposición del artículo 33 $\mathrm{N}^{\mathrm{o}}$ 1, letra g), de la Ley de la Renta.

\section{III.3.1.4.2.2 Desembolsos consistentes en pagos por el uso o transferencia en Chile y en el extranjero}

El pago por el uso o transferencia de la propiedad intelectual en Chile, no está sujeto a ninguna norma especial, salvo las reglas generales sobre tasación de operaciones contenidas en los artículos 63 y 64 del Código Tributario.

No sucede lo mismo con los pagos efectuados al extranjero, respecto de los cuales cualquier suma pagada o abonada en cuenta, sin deducción alguna, relacionada con los derechos de propiedad intelectual que la ley señala, estarán afecto a las restricciones que prevé la ley. La limitación está contenida en el art. $31 \mathrm{~N}^{\circ} 12^{836}$ de la Ley de la Renta, disposición que establece una remisión al art. $59^{837}$ inciso primero de la misma ley, para fijar el objeto de su contenido ${ }^{838}$, que consiste en patentes de invención,

${ }^{836}$ Esta disposición no fue modificada por la reforma de septiembre de 2014.

${ }^{837}$ Esta disposición no fue modificada por la reforma de septiembre de 2014.

${ }^{838}$ El artículo 59 es una confusa norma establecida en el contexto del impuesto adicional, que corresponde al impuesto sobre la renta de no residentes. El inciso primero, a pesar de su extensión, sólo se refiere a la propiedad industrial y al software, tal como queda de manifiesto de su lectura, ya que dice: "Se aplicará un impuesto de 30\% sobre el total de las cantidades pagadas o abonadas en cuenta, sin deducción alguna, a personas sin domicilio ni residencia en el país, por el uso, goce o explotación de marcas, patentes, fórmulas y otras prestaciones similares, sea que consistan en regalías o cualquier forma de remuneración, excluyéndose las cantidades que correspondan a pago de bienes corporales internados en el país hasta un costo generalmente aceptado. Con todo, la tasa de impuesto aplicable se reducirá a $15 \%$ respecto de las cantidades que correspondan al uso, goce o explotación de patentes de invención, de modelos de utilidad, de dibujos y diseños industriales, de esquemas de trazado o topografías de circuitos integrados, y de nuevas variedades vegetales, de acuerdo a las definiciones y especificaciones contenidas en la Ley de Propiedad Industrial y en la Ley que Regula Derechos de Obtentores de Nuevas Variedades Vegetales, según corresponda. Asimismo, se gravarán con tasa de $15 \%$ las cantidades correspondientes al uso, goce o explotación de programas computacionales, entendiéndose por tales el conjunto de instrucciones para ser usados directa o indirectamente en un computador o procesador, a fin de efectuar u obtener un determinado proceso o resultado, contenidos en cassette, diskette, disco, cinta magnética u otro soporte material o medio, de acuerdo con la definición o especificaciones contempladas en la Ley Sobre Propiedad Intelectual, salvo que las cantidades se paguen o abonen en cuenta por el uso de programas computacionales estándar, entendiéndose por tales aquellos en que los derechos que se transfieren se limitan a los necesarios para permitir el uso del mismo, y no su explotación comercial, ni su reproducción o modificación con cualquier otro fin que no sea habilitarlo para su uso, en cuyo caso estarán exentas de este impuesto. En el caso de que ciertas regalías y asesorías sean calificadas de improductivas o prescindibles para el desarrollo económico del país, el Presidente de la República, previo informe de 
modelos de utilidad, marcas, fórmulas y otras prestaciones similares, dibujos y diseños industriales, esquemas de trazado o topografías de circuitos integrados, nuevas variedades vegetales y software. $\mathrm{Al}$ igual que casos anteriores, la técnica legislativa no puede ser más confusa, puesto que simplemente se está poniendo un límite a las erogaciones relacionadas con ciertos derechos y en vez de enumerarlos, la ley se remite a otro artículo, donde aparece un elenco disperso de derechos de propiedad intelectual. Ahora bien, difícilmente sabremos por qué el legislador optó por esta vía, puesto que habría sido suficiente con referirse a la propiedad industrial y habría incluido a todos los derechos enumerados y a las variedades vegetales, sólo habría necesitado una remisión especial al software que es propiedad intelectual, de la misma manera, se levanta inmediatamente la duda sobre qué sucede con el resto de los derechos de propiedad intelectual. Obviamente no será muy frecuente que una empresa pueda justificar como gasto necesario para producir la renta la compra de un cuadro de un artista plástico, lo que no quita que para cierto tipo de industrias, como la cinematográfica, radio, televisión, etc., el pago por contenidos protegidos por propiedad intelectual pueda ser también una vía para trasladar utilidades al exterior, hipótesis que parece no importar al legislador chileno.

En consecuencia, sabemos que la propiedad intelectual en general y especialmente la propiedad industrial, ha sido usada como mecanismo para transferir utilidades bajo la forma de pagos por royalties, derechos o la simple venta, contabilizando estas erogaciones como gastos de la empresa a un precio mucho mayor que el de mercado y es lo que motiva la norma en análisis, desarrollada por diferentes circulares y oficios del SII, abordando diferentes aspectos de la misma, que pasamos a analizar en adelante:

la Corporación de Fomento de la Producción y del Comité Ejecutivo del Banco Central de Chile, podrá elevar la tasa de este impuesto hasta el $80 \%$. No obstante, la tasa de impuesto aplicable será de $30 \%$ cuando acreedor o beneficiario de las regalías o remuneraciones se encuentren constituidos, domiciliados o residentes en alguno de los países que formen parte la lista a que se refiere el artículo $41^{\circ} \mathrm{D}$, o bien, cuando posean o participen en $10 \%$ o más del capital o de las utilidades del pagador o deudor, así como en el caso que se encuentren bajo un socio o accionista común que, directa o indirectamente, posea o participe en un $10 \%$ o más del capital o de las utilidades de uno u otro. El contribuyente local obligado a retener el impuesto deberá acreditar estas circunstancias y efectuar una declaración jurada, en la forma y plazo que establezca el Servicio de Impuestos Internos mediante resolución". 
- Limite a los pagos efectuados al extranjero ${ }^{839}$. Los pagos por los conceptos señalados supra, se aceptarán como gasto sólo hasta un monto máximo equivalente al $4 \%$ de los ingresos anuales por ventas o servicios del giro ordinario de la empresa, percibidos o devengados durante el ejercicio comercial respectivo, independientemente si dichos desembolsos han incidido o no en el costo de los bienes o servicios que constituyen los ingresos brutos del giro de la empresa $^{840}$.

El objetivo de la regulación es bastante claro, evitar que por la vía de pagos originados en derechos los ítems que antes señalamos, las empresas transfieran a sus matrices o relacionadas, utilidades que debían pagar impuesto adicional $^{841}$, rebajando artificialmente el resultado de la empresa, al pagar un precio superior al del mercado amparados en lo difícil que resulta la tasación de estas operaciones.

No obstante lo anterior, el mismo art. $31 \mathrm{~N}^{\circ} 12$ de la Ley de la Renta, prevé ciertos casos en que el referido límite del cuatro por ciento no es aplicable: cuando en el ejercicio comercial respectivo, entre el contribuyente y el beneficiario del pago no exista o no haya existido una relación directa o indirecta en el capital, control o administración de uno u otro ${ }^{842}$; y, tampoco se aplicará el límite del cuatro por ciento, cuando en el país del domicilio del

${ }^{839}$ El asunto fue tratado por la Circular SII No 61-97, de 15 de octubre de 1997.

${ }^{840}$ La Circular definió que entiende por ingresos del giro del contribuyente, diciendo que son: "todos aquéllos que provienen de la actividad habitual o normal que realiza según su objeto social, vale decir, en términos contable financiero los ingresos provenientes de la enajenación de su activo realizable, excluyendo de dichos ingresos todos aquellos que sean extraordinarios o esporádicos, como ser, los originados en ventas del activo inmovilizado, en inversiones en capitales mobiliarios, ganancias de capital, etc., en la medida que sean ajenos al giro comercial que caracteriza a la empresa".

${ }^{841}$ El impuesto adicional es el impuesto chileno a las rentas de no residentes y está subsumido dentro de la Ley de la Renta.

${ }^{842}$ Para estos efectos, se entenderá que existe relación directa o indirecta en el capital, control o administración de una u otra empresa cuando se den los presupuestos descritos en los artículos 86 y 87 de la Ley No 18.046 (ley de Sociedades Anónimas) y en el artículo 97 de la Ley No 18.045 (ley sobre Mercado de Valores), que el SII hace extensivos a los contribuyentes individuales y a cualquier tipo de sociedad.

Asimismo, aun cuando el control puede ser una consecuencia de la tenencia de acciones o derechos, la disposición que se analiza está referida también a una situación de pluralidad de propietarios, en la que además se tiene poder para realizar determinadas actuaciones, por lo que, en la misma forma se considerará que existe relación cuando se presenten las circunstancias señaladas en el artículo 98 de la Ley $\mathrm{N}^{\circ} 18.045^{842}$. 
beneficiario o perceptor de la renta, ésta se grave con impuestos a la renta con tasa igual o superior a un 30 por ciento $^{843}$.

Monto sobre el cual se aplica el límite ${ }^{844}$. El art. $31 \mathrm{~N}^{\circ} 12$, que venimos analizando, no es del todo claro en precisar, qué pagos y por cuáles montos, se encontrarán comprendidos dentro del límite del cuatro por ciento para remesar al extranjero, al efecto, en el inciso final, se lee: "Para determinar si los montos pagados por los conceptos indicados en el inciso primero de este número se encuentran o no dentro del límite allí indicado, deberán sumarse en primer lugar todos los pagos que resulten de lo dispuesto en los incisos segundo y tercero. Los restantes pagos se sumarán a continuación de aquéllos", resulta ser que en los incisos segundo y tercero se encuentran todos los pagos que si se afectan al límite, en consecuencia, lo que está diciendo la norma es que sólo podré efectuar remesas afectas al límite del $4 \%$ en la medida que no haya hecho remesas no sujetas al referido límite o por el saldo de aquellas ${ }^{845}$.

${ }^{843}$ En estos casos, el Ministerio de Hacienda, de oficio o a petición de los interesados, establecerá mediante Decreto Supremo dictado al efecto, la lista de los países que se encuentren en la situación antes comentada.

${ }^{844} \mathrm{El}$ asunto fue tratado por la Circular SII No 61-97, de 15 de octubre de 1997.

${ }^{845}$ La Circular SII N ${ }^{\circ} 61$ de 1997, grafica con un ejemplo:

\begin{tabular}{||l|l||}
\hline ANTECEDENTES. & \\
\hline 1) Monto anual de ventas y servicios del giro de la empresa, sin reajuste. & $\$ 200.000 .000$ \\
\hline $\begin{array}{l}\text { 2) Total pagos efectuados al exterior por los conceptos a que se refiere el inciso } \\
\text { primero del artículo 59 de la Ley de la Renta, sin reajuste. }\end{array}$ & 17.000 .000 \\
\hline $\begin{array}{l}\text { 3) Pagos anuales por los conceptos antes indicados que no quedan sujetos al límite del } \\
\text { 4\%, por no existir relación directa o indirecta entre la empresa pagadora de la renta } \\
\text { y el beneficiario de la misma, sin reajuste. }\end{array}$ & 3.000 .000 \\
\hline $\begin{array}{l}\text { 4) Pagos anuales por los conceptos antes señalados que no quedan sujetos al límite del } \\
\text { 4\%, por estar las rentas afectas en el exterior a un impuesto superior o igual a un } \\
\text { 30\%, sin reajuste. }\end{array}$ & 2.000 .000 \\
\hline $\begin{array}{l}\text { 5) Pagos anuales por los conceptos antes señalados que quedan sujetos al límite del 4\% } \\
\text { por no cumplir las condiciones anteriores, sin reajuste. }\end{array}$ & $\$ 12.000 .000$ \\
\hline DESARROLLO & \\
\hline $\begin{array}{l}\text { 1) Determinación límite del 4\% Monto anual nominal de ventas y servicios: } \$ \\
\text { 200.000.000 x 4\%. }\end{array}$ & 83.000 .000 \\
\hline Imputación de pagos al límite del 4\%. Monto límite. & $\$ 8.000 .000$ \\
\hline Menos :a) Pagos no afectos al límite del 4\%, por no existir relación. & $\$(3.000 .000)$ \\
\hline b) Pagos no afectos al límite del 4\% por estar afectos a impuestos en el exterior. & $\$(2.000 .000)$ \\
\hline Subtotal & $\$ 3.000 .000$ \\
\hline c) Pagos restantes afectos al límite del 4\%. & $\$(12.000 .000)$ \\
\hline Exceso no aceptado como gasto tributario. & $\$(9.000 .000)$ \\
\hline
\end{tabular}

En el caso del ejemplo planteado, sólo se aceptará como gasto por concepto de los desembolsos sujetos al límite del $4 \%$ a que se refiere el inciso primero del artículo 59 de la ley, la suma de \$ 3.000.000, equivalente al saldo del límite del $4 \%$ que ha quedado después de imputar los desembolsos no sujetos al referido límite. 
- Cantidades remesadas que superan el límite ${ }^{846}$. Debemos considerar que pasa, si se remesan cantidades que superan el límite del cuatro por ciento. Lógicamente, no existe inconveniente jurídico para pagar al exterior cantidades que superen estos límites, pero constituirán un gasto rechazado de aquéllos a que se refiere el art. $33 \mathrm{~N}^{\mathrm{o}} 1$ de la Ley de la Renta, y por lo tanto, deberán agregarse al resultado del balance (utilidad o pérdida), debidamente reajustados cuando se trate de un desembolso efectivo, para los efectos de su afectación con el impuesto de primera categoría. Para los fines de determinar a qué mes del período comercial corresponden los excesos de gastos determinados y su respectivo agregado reajustado a la renta líquida imponible del impuesto de primera categoría, se utilizará el método FIFO (primero en entrar, primero en salir ), vale decir, al saldo del límite del 4\% (descontado previamente del monto total de dicho límite los gastos no sujetos a dicha regulación), se le imputarán los primeros gastos incurridos en el ejercicio por los conceptos a que se refiere el inciso primero del artículo 59 de la ley, de acuerdo a la fecha en que éstos fueron desembolsados o adeudados, hasta cubrir dicho saldo, y los gastos restantes o la parte de ellos que resulten de la citada imputación, cuando se trate de desembolsos efectivos, quedarán sujetos a la reajustabilidad dispuesta en el $\mathrm{N}^{\mathrm{o}} 3$ del art. 33 de la Ley de la Renta.

Como un último asunto, tenemos que hacer presente que la norma que hemos venido analizando fija límites a los gestos que se pueden pagar por los conceptos que se establecen en el inciso primero del art. 59 de la Ley de la Renta, pero ello no significa que haya generado una categoría diferente de gastos, es decir, estos gastos además de estar sujetos al límite, deben cumplir con todos los requisitos y condiciones que contempla la Ley de la Renta para estimar que un gasto es aceptado (art. 31 de la Ley de la Renta), de otra forma tendrán el carácter de gastos rechazados, gravándose con el impuesto establecido en el artículo 21 de la Ley de Impuesto a la Renta.

- Obligación de presentar declaración jurada ante el SII ${ }^{847}$. Dispuso el SII que dentro de los dos meses siguientes al término del ejercicio comercial respectivo, debe confeccionarse en duplicado una declaración jurada simple y presentarse en

${ }^{846} \mathrm{El}$ asunto fue tratado por la Circular SII No 61-97, de 15 de octubre de 1997.

${ }^{847} \mathrm{El}$ asunto fue regulado por la Circular SII N 91, de 15 de octubre de 1997. 
la dirección regional correspondiente, en la cual se señale expresamente que en dicho ejercicio no ha existido la relación, con las personas a las que se les haya hecho pagos en el extranjero por los conceptos del art. 59 inciso primero de la Ley de la Renta.

A nuestro entender, el SII ha excedido sus facultades de interpretación de la ley tributaria, al exigir que la mencionada declaración jurada deba presentarse en la dirección regional correspondiente al domicilio del contribuyente, puesto que la Ley de la Renta, sólo obliga al contribuyente a confeccionar la declaración y guardarla para una eventual fiscalización ${ }^{848}$. Mientras la ley se conforma con la formulación y conservación de la declaración, el SII exige oficiosamente una gestión adicional.

- Existencia de dos ítems separados en el art. $31 \mathrm{~N}^{\circ} 12$ de la Ley de la Renta ${ }^{849}$. Un contribuyente presentó una consulta, puesto que a su juicio, en la norma citada, existían dos ítems de objetos sometidos a tributación que no se mesclaban. Entendía el contribuyente que por una parte deberían considerarse los gastos pagados a contribuyentes sin domicilio ni residencia en Chile, con los que la empresa tuviese relación, los que quedaban sometidos al límite del cuatro por ciento; y, por otra parte, aquéllos que no poseían esta característica y que como tales, no se encontraban sujetos al límite indicado. La posición del contribuyente al separar los dos rubros los gastos, es bastante razonable desde el tenor literal de la norma, sin embargo, produce un efecto beneficioso para el contribuyente, puesto que sólo un grupo de los gastos queda sujeto al límite y el otro no, de ahí que el SII se apresuró en interpretar la disposición del modo más conveniente al fisco.

El SII respondió manteniendo su postura original, el sentido que el límite opera de manera conjunta para todos los gastos, posición que compartimos, puesto que

${ }^{848}$ El art. $31 \mathrm{~N}^{\circ} 12$ de la Ley de la Renta, en lo que respecta, señala lo siguiente: “(...) el contribuyente o su representante legal deberá formular una declaración jurada en la que señale que en dicho ejercicio no ha existido la relación indicada. Esta declaración deberá conservarse con los antecedentes de la respectiva declaración anual de impuesto a la renta, para ser presentada al Servicio de Impuestos Internos cuando éste lo requiera".

${ }^{849}$ Después de dictada la Circular $\mathrm{N}^{\circ} 61$, de 1997, antes citada, puesto que un contribuyente planteó que en el art. $31 \mathrm{~N}^{\circ} 12$ existían dos ítems perfectamente diferenciables y que corrían por caminos separados, lo que resultaba en una forma de tributar distinta de la que normaba la Circular $\mathrm{N}^{\circ} 61$. Al respecto, el SII emitió el Oficio $\mathrm{N}^{\circ} 2268$, de 26 de agosto de 1998, sobre la materia. 
el art. $31 \mathrm{~N}^{\mathrm{o}} 12$ de la Ley de Impuesto a la Renta, no distingue al regular sobre la materia y más aún ordena sumar todos los pagos efectuados ${ }^{850}$. De manera que no cabe duda, que cualquiera sea la hipótesis de pagos efectuados al extranjero, deberán colacionarse todos, para el cálculo del cuatro por ciento ${ }^{851}$.

- Condicionalidad de la norma del art. 31 No 12 de la Ley de Impuesto a la Renta. La disposición que venimos analizando no opera siempre, sino que está sujeta a la condición de que entre el contribuyente y el beneficiario del pago haya existido algún tipo de relación. Así las cosas, de existir pagos efectuados al extranjero de aquellos a que se refiere el art. 59 inciso primero de la Ley de la Renta, que se hagan a un relacionado y a un no relacionado en el mismo período, deben considerarse la totalidad de los pagos, para el cálculo del límite del cuatro por ciento, tal como hemos analizado supra. La disposición es aplicable en el evento de existir pagos a un relacionado, a un relacionado y a un no relacionado,

${ }^{850}$ Dice el art. $31 \mathrm{~N}^{\circ} 12$, de la Ley de la Renta, en lo pertinente: "Para determinar si los montos pagados por los conceptos indicados en el inciso primero de este número se encuentran o no dentro del límite allí indicado, deberán sumarse en primer lugar todos los pagos que resulten de lo dispuesto en los incisos segundo y tercero. Los restantes pagos se sumarán a continuación de aquéllos".

${ }^{851}$ Un ejemplo puede ayudar a aclarar el asunto:

\begin{tabular}{||l|l||}
\hline 1) Ingresos totales por ventas del giro. & $\$ 100.000 .000$. \\
\hline $\begin{array}{l}\text { 2) Tope pagos efectuados al exterior por uso de marcas y patentes a un relacionado, } \\
4 \% .\end{array}$ & $\$ 4.000 .000$. \\
\hline 3) Pagos al exterior por uso de marcas a relacionados. & $\$ 3.000 .000$. \\
\hline $\begin{array}{l}\text { 4) Pagos al exterior por uso de marcas a no relacionados y beneficiarios de países con } \\
\text { impuesto igual o superior a 30\%. }\end{array}$ & $\$ 5.000 .000$. \\
\hline
\end{tabular}

En el ejemplo, los gastos no sujetos al tope superan al cuatro por ciento, pero como se aceptan sin tope, los cinco millones constituyen gasto aceptado. En consecuencia, los tres millones pagados a relacionados, constituyen gasto rechazado.

En el siguiente ejemplo, moveremos los gastos aumentando a los relacionados y disminuyendo a los no relacionados:

\begin{tabular}{|l|l|}
\hline 1$)$ Ingresos totales por ventas del giro. & $\$ 100.000 .000$.
\end{tabular}

2) Tope pagos efectuados al exterior por uso de marcas y patentes a un relacionado, $\$ 4.000 .000$. $4 \%$.

\begin{tabular}{|l|l}
\hline 3$)$ Pagos al exterior por uso de marcas a relacionados. & $\$ 5.000 .000$.
\end{tabular}

4) Pagos al exterior por uso de marcas a no relacionados y beneficiarios de países con $\$ 3.000 .000$. impuesto igual o superior a $30 \%$

El resultado cambia, no obstante el monto los gastos es el mismo. Los gastos no sujetos al tope serán los primeros en imputarse y consecuentemente se aceptan completamente. Seguidamente imputaremos los gastos pagados a relacionados, es decir los cinco millones, pero de ellos sólo se aceptará el monto que falta para llegar al tope (si ya imputamos tres millones, nos resta uno), es decir, un millón.

En conclusión, en este caso tenemos cuatro millones aceptados y cuatro rechazados, a diferencia del caso anterior, en que tenía cinco millones aceptados y tres rechazados. 
pero es improcedente cuando los pagos se efectúan únicamente a un no relacionado, puesto que en ese caso no existe límite del cuatro por ciento ${ }^{852}$.

\subsubsection{El impuesto adicional}

Ya hemos explicado en varias oportunidades que en Chile, todos los impuestos a la renta se encuentran integrados no sólo jurídicamente puesto que están alojados al amparo de una única ley de impuesto a la renta, sino que también financieramente operan de manera conjunta, actuando en dos niveles, uno de empresa y el otro de persona natural. La verdad es que al final del día se pueden producir los mismos resultados que con un sistema en que los impuestos estén separados, todo dependerá de los tipos aplicados y de la relación que se defina en los diferentes niveles de tributación. A modo de ejemplo, si a nivel del IS la carga tributaria es de un 20 por ciento y no se paga IRPF por las cantidades hasta que se retiren, la situación será bien parecida a la chilena hasta antes de la reforma de septiembre de 2014, vigente el FUT o después de la reforma con el llamado "régimen parcialmente integrado".

De todas formas, en Chile, la carga tributaria definitiva se soporta a nivel de persona natural, quienes concentran la totalidad de sus ingresos en el Impuesto Global Complementario $^{853}$ (esto antes y después de la reforma de septiembre de 2014), instancia en que el tributo soportado a nivel de empresa, es considerado íntegramente un pago a cuenta de los impuestos definitivos que a cada contribuyente corresponda. El hecho de que la carga tributaria se soporte finalmente por las personas naturales tiene una excepción en el impuesto a la renta de no residentes, que toma el nombre de Impuesto Adicional ${ }^{854}$, en el sentido que se pagará el tributo por cualquier cantidad que se remese o ponga a cuenta, independientemente que él no residente sea un contribuyente empresa o persona natural, para efectos de la Ley de la Renta.

El Impuesto Adicional se ubica ente los artículos 58 a 64 de la Ley de la Renta, gravando con una tasa de $35 \%$ a las personas sin domicilio ni residencia en Chile, por la totalidad de las remesas o cantidades abonadas en cuenta, sin deducción alguna, que perciban desde Chile.

\footnotetext{
${ }^{852}$ Específicamente dice el art. $31 \mathrm{~N}^{\circ} 12$ : "El límite establecido en el inciso anterior no se aplicará cuando en el ejercicio respectivo, entre el contribuyente y el beneficiario del pago no exista o no haya existido relación directa o indirecta".

${ }^{853}$ Contreras. Ob. supra cit., pp. 459 y sgtes. Massone. Ob. supra cit., pp. 122 y sgtes.

${ }^{854}$ Obs. supra cit., pp. 505 y sgtes. y pp. 122 y sgtes, respectivamente.
} 
En lo que a nuestro estudio se refiere, el impuesto adicional posee una regulación expresa para la propiedad intelectual, en el artículo 59 de la Ley de la Renta, donde cabe alojar para efectos impositivos, los pagos realizados al extranjero a propósito de derechos de propiedad intelectual.

\subsubsection{El hecho gravado con impuesto adicional}

Al impuesto adicional, tal como explicamos supra, grava todas las rentas de fuente chilena, obtenidas por no residentes, sin embargo para nuestro estudio son relevantes solamente las rentas vinculadas a la propiedad intelectual, por lo que nos concentramos en el art. 59 incisos primero, segundo y tercero ${ }^{855}$, que expresamente se refieren a ella y en un par de disposiciones más, que están estrechamente vinculadas en cuanto abordan las asesorías que pueden estar relacionadas a la propiedad intelectual.

El art. 59 inciso primero de la Ley de la Renta ${ }^{856}$, en lo que a nuestro estudio interesa, grava con el impuesto adicional, a las cantidades pagadas o abonadas en cuenta, a personas sin domicilio ni residencia en el país, por el uso, goce o explotación de una serie de bienes intangibles (según detalla), que específicamente son derechos de propiedad intelectual.

Son sujetos pasivos para los fines del impuesto adicional, tal como señala LEONEL CONTRERAS ${ }^{857}$, todas las personas naturales o jurídicas, incluyendo a aquellas entidades que posean personalidad jurídica, pero sean sujetos de impuestos ${ }^{858}$, que no tengan domicilio ni residencia en el país, cualquiera que sea su cualidad o naturaleza jurídica ${ }^{859}$.

En lo que a la determinación de la base imponible se refiere, tal como suele suceder en este tipo de impuesto, las cantidades que se gravan con el tributo, están constituidas por cualquier suma que se paguen o abonen en cuenta a las personas indicadas precedentemente, teniendo solamente derecho a deducir, el impuesto de Primera Categoría soportado durante el año, las pérdidas por operaciones de capitales

${ }^{855}$ Estas disposiciones no fue modificada por la reforma de septiembre de 2014.

${ }^{856}$ Según su texto actual, modificado por última vez por la Ley $\mathrm{N}^{\circ} 18.343$, de 2009 , que "Modifica distintos cuerpos legales con el objeto de mejorar las condiciones de financiamiento para personas y empresas".

${ }^{857}$ CONTRERAS. Ob. supra cit., p. 505.

${ }^{858}$ Como pueden ser comunidades o sociedades de hecho.

${ }^{859}$ Como vemos el sujeto pasivo es el mismo que en España grava el Impuesto a la Renta de No Residentes. 
mobiliarios y en ciertas enajenaciones y el impuesto territorial pagado durante el año, según explica LEONEL CONTRERAS ${ }^{860}$.

El objeto del hecho gravado, es decir, la causa del pago debe estar en el uso, goce o explotación de los derechos que se enumeran en el art. 59, inciso primero, de la Ley de la Renta. Como la propiedad intelectual es un bien más en el derecho chileno, las facultades de usar y gozar no representan problema interpretativo, en cuanto se aplicarán los artículos 582 y siguientes del Código Civil, donde el uso corresponde a la facultad de servirse personalmente de aquello de que se es dueño y el goce consiste en poder permitir el goce por un tercero, ya sea de manera remunerada o no. Claro está, que en el caso del uso, la hipótesis de renta en el contexto del impuesto adicional es un poco más rebuscada, no obstante hay casos, porque por ejemplo en Chile la propiedad intelectual puede estar siendo explotada por un establecimiento permanente que hace pagos a su matriz.

Lo que realmente complica un poco más es la explotación de la propiedad intelectual como supuesto gravado, ya que sabemos que sus rendimientos pueden obtenerse de su enajenación o de permitir su uso a un tercero (licencias), acciones que tendremos que suponer son las que ha querido comprender el legislador al hablar de explotación.

\subsubsection{La propiedad intelectual como objeto del hecho gravado del art. 59}

Tal como venimos analizando son los rendimientos de ciertos derechos de propiedad intelectual los que están gravados con el impuesto, sin embargo la ley no fue clara al definirlos, generando un verdadero crucigrama cuya solución no ha sido revelada por el SII.

Lo primero que deberíamos advertir, es que, tal como vimos al analizar la perspectiva constitucional de la propiedad intelectual en Chile, debemos tener claro que el asunto se reduce a un esquema muy básico, donde la propiedad intelectual abarca a la propiedad intelectual propiamente tal $^{861}$ y a la propiedad industrial ${ }^{862}$, de manera que para referirse a ellas como objeto de un hecho gravado es suficiente con hablar de

\footnotetext{
${ }^{860}$ Ob. supra cit., p. 504.

${ }^{861}$ Regulada por la Ley $N^{\circ} 17.336$, de 1970, sobre Propiedad Intelectual, que no obstante de propiedad intelectual sólo tiene el título porque en todo su contenido prefiere la expresión derecho de autor.

${ }^{862}$ Regulada por la Ley $\mathrm{N}^{\circ} 19.039$, de 1991, sobre Propiedad Industrial.
} 
derecho de autor o propiedad intelectual y de propiedad industrial. Esta opción bastante simple atendida la realidad nacional no gustó al legislador que optó por una vía más intrincada.

La regulación del artículo 59 de la Ley de la Renta, nos permite identificar los siguientes grupos de derechos de propiedad intelectual, cuyos rendimientos por su uso, goce o explotación, sea que consistan en regalías o cualquier forma de remuneración, constituyen hecho gravado del impuesto adicional ${ }^{863}$ :

a) Marcas, patentes, fórmulas y otras prestaciones similares, que pagaran una tasa de 30 por ciento;

b) Patentes de invención, modelos de utilidad, dibujos y diseños industriales, esquemas de trazado o topografías de circuitos integrados y nuevas variedades vegetales, que están gravadas con tasa de 15 por ciento;

c) Programas computacionales, entendiéndose por tales el conjunto de instrucciones para ser usados directa o indirectamente en un computador o procesador, a fin de efectuar $\mathrm{u}$ obtener un determinado proceso o resultado, contenidos en casete, diskette, disco, cinta magnética u otro soporte material o medio, a los que afecta una tasa de 15 por ciento;

d) Programas computacionales estándar, que son aquellos en que los derechos que se transfieren se limitan a los necesarios para permitir el uso del mismo, y no su explotación comercial, ni su reproducción o modificación con cualquier otro fin que no sea habilitarlo para su uso, que estarán exentos;

e) Proyecciones de cine y televisión tributarán con tasa de 35 por ciento, salvo que se trate de remuneraciones provenientes del trabajo o habilidad de personas, recibidas por personas naturales, que hayan desarrollado en Chile actividades científicas, técnicas, culturales o deportivas, que tributarán con tasa de 20 por ciento;

f) El uso de derechos de edición o de autor, que estarán afectos a una tasa de 15 por ciento;

g) Otras rentas de propiedad intelectual, deberían tributar con la norma residual y gravarse con un 35 por ciento.

${ }^{863}$ Ob. supra cit., pp. 513 y sgtes., puede verse un cuadro sinóptico sobre los sujetos obligados, bases tributables y retenciones. 


\subsubsection{Indefinición sobre titularidad, dominio o derecho sobre los derechos de propiedad intelectual}

Hemos analizado que en el art. 59 de la Ley de la Renta, existe un elenco de derechos sobre los cuales se asume existe la posibilidad de obtener rendimientos. En el mismo sentido, parece razonable entender que la ley ha estado pensando en un titular o dueño de esos derechos y en una explotación de los mismos que le reporta beneficios, ya sea que se aproveche personalmente de ellos o porque permite su utilización por terceros a cambio de un pago. Sin embargo, en ninguna parte la norma distingue o exige que quien recibe el pago sea el dueño o tenga derecho siquiera a recibir alguna remuneración por algún derecho de propiedad intelectual. Como está planteado el artículo, no existe inconveniente en pagar a Juan, por el uso de una patente de propiedad de Pedro. Tampoco habría problema en pagar a Juan, por "una prestación similar" 864 , que implique una asesoría para la explotación de la patente de Pedro.

La ausencia de preocupación de la norma, respecto de quién está legitimado a recibir un pago o remuneración, conlleva facilitar la utilización de las tasas rebajadas como mecanismo para transferir utilidades y revela que el legislador no tenía para nada claro lo que estaba buscando. Recordemos que el objetivo declarado de la rebaja de tasas, fue facilitar el ingreso de tecnología y de ahí cabrían mil preguntas, como: ¿Qué tipo de tecnología? ¿Para ser utilizada en qué etapa del proceso de $\mathrm{I}+\mathrm{D}+\mathrm{i}$ ? ¿Da lo mismo que se trate de una tecnología obsoleta? ¿Qué relevancia puede tener que esté o no patentada? ¿Puede beneficiarse de la tasa reducida una tecnología que es del dominio público? ¿Qué teoría sobre el desarrollo económico es en la que se confió o se tuvo en mente a la hora de elaborar la norma? ¿Cuánto se consideró la matriz productiva del país para el diseño?, etc.

Junto a lo anterior debemos asumir que los objetivos declarados de la norma a que hemos hecho referencia no han cambiado, desde el momento que la reforma de septiembre de 2014, era el momento propicio para mejorar la disposición, que superó el vaivén legislativo, sin dificultades.

Lo que más preocupa, es que la simplicidad casi ingenua del diseño normativo y de las resoluciones del SII, revelan la falta de un análisis sistémico, la ausencia de un

${ }^{864}$ Descripción de uno de los hechos gravados, efectuada por el Art. 59, inciso primero, de la Ley de la Renta. 
patrón que permita deducir cuál fue el criterio que se utilizó para la construcción de la figura legal, que se muestra como una regulación improvisada, movida por el slogan que la tecnología impulsa la economía, pero sin un perfil claro de lo que en definitiva se busca.

Para ilustrar sobre lo que estamos hablando, nos detendremos solamente en la referencia del art. 59, inciso primero, al uso de marcas, patentes, formulas y otras prestaciones similares. El uso de marcas, patentes y formulas, es fácil de conceptualizar, pero no por ello deja de tener algunos matices.

En la especie, será lógico efectuar pagos ya sea en Chile o al extranjero, respecto de un contribuyente que necesita utilizar ciertos derechos de propiedad industrial que no le pertenecen y son de legítima propiedad de un tercero, a contrario sensu, no será aceptable que se pague por un derecho que pertenece al propio contribuyente o cuyo uso es del dominio público.

La complejidad que se puede dar a propósito de la titularidad de derechos de propiedad intelectual, particularmente de propiedad industrial puesto que están sometidos a regímenes de registro nacional, son muchas, lo que hace que el asunto sea teóricamente difícil de abordar, volviéndose más difícil aún, cuando se carece de una conformación argumental que permita conocer las directrices que orientaron al legislador. Con la estructura que posee actualmente la norma, podríamos llegar al absurdo de aplicar la tasa rebajada a un pago por algo que es del dominio público, por ejemplo: una remesa por el uso de una patente que sólo está registrada en su país de origen, porque en Chile es del dominio público ${ }^{865}$. ¿Qué sucedería si el pago se efectuase por un derecho para producir paracetamol? ${ }^{866}$, o ¿Qué pasaría si las remesas al extranjero se hicieran por el pago de licencias correspondientes a una patente caducada, anulada o no registrada? ${ }^{867}$

\footnotetext{
${ }^{865}$ Lógicamente que la realidad tiene matices y el pago podría hacerse por know how, asesoría técnica relativas a la tecnología que protege la patente, para poder exportar a determinados países donde la tecnología si está protegida, etc. Lo que hemos querido destacar dramatizando los ejemplos, es la falta de prolijidad del legislador para regular el asunto.

${ }^{866}$ Que está en el dominio público hace muchos años.

${ }^{867}$ La idea del ejemplo es que como no existe registro o este ha caducado, el conocimiento por el que se paga es del dominio público y posible de usar por cualquier persona.
} 
Algo parecido a lo que venimos exponiendo, en el sentido de la indefinición del legislador, es lo que dice relación con los pagos relativos a "fórmulas" y "otras prestaciones similares". Cuanto la norma habla de "fórmulas", tal vez se refiere a fórmulas industriales capaces de desarrollar un quehacer industrial dentro de la empresa. Por su lado, cuando indica "otras prestaciones similares", seguramente está exigiendo que digan relación a una forma de desarrollar una tecnología, de implementar un procedimiento industrial o de incorporar un determinado know how a un producto o servicio. Todo ello sería aceptable, más aún podríamos decir que están fuera del concepto de "fórmulas" y "otras prestaciones similares", las asesorías o fórmulas administrativas, meramente matemáticas, estadísticas, $u$ otras que no guarden relación con un saber técnico objeto de la propiedad industrial. Sin embargo, todo ello no pasa de ser especulación, ya que tal como latamente hemos expuesto, no tenemos en el tenor literal del art. 59, en su historia, ni en pronunciamientos de la administración tributaria o de los Tribunales de Justicia, opiniones que nos permitan asegurar cuál es la opción que tomó el legislador de turno.

\subsubsection{Las sobretasas en el art. 59}

En la historia de la Ley $\mathrm{N}^{\circ} 19.506^{868}$, no queda duda del interés del legislador por reducir la tasa de impuesto adicional para favorecer la transferencia tecnológica desde el exterior, lo que efectivamente hace. Junto a ello, también toma precauciones, para "evitar remesas encubiertas de utilidades con tasa inferior" ${ }^{\text {" }}$.

Así pues, para evitar que los pagos efectuados a tasas reducidas previstos para la transferencia de tecnología, sean usados para remesar utilidades que de otra forma serían afectas con la tasa normal del impuesto adicional (o cualquiera otra superior), disminuyendo así el pago de los impuestos correspondientes, "la tasa reducida no se aplicará en los casos en que los pagos se efectúen a personas relacionadas o que operan desde paraísos fiscales o regímenes fiscales preferenciales nocivos" ${ }^{\$ 770}$.

En resumidas cuentas, la tasa reducida de impuesto de 15 por ciento, que correspondería aplicar en los casos del inciso primero del art. $59^{871}$ DL $\mathrm{N}^{\circ} 824$, se eleva

\footnotetext{
${ }^{868}$ Historia de la Ley $\mathrm{N}^{\circ} 18.506$. Ob. cit., p. 9.

${ }^{869}$ Ob. supra cit., p. 9.

${ }^{870}$ Ob. supra cit., p. 10.

${ }^{871}$ Conforme a la clasificación que hicimos supra, correspondería a: “ b) Patentes de invención, modelos de utilidad, dibujos y diseños industriales, esquemas de trazado o topografías de circuitos integrados y
} 
a un 30 por ciento, cuando los acreedores o beneficiarios en el extranjero, se encuentren en alguna de estas circunstancias: estén constituidos, domiciliados o residan en algún país calificado, conforme a la ley, como paraíso fiscal; o, posean o participen en un 10 por ciento o más del capital o de las utilidades del pagador o deudor chileno, o se encuentren bajo un socio o accionista común que, directa o indirectamente, posea o participe en un 10 por ciento o más del capital o de las utilidades de uno u otro ${ }^{872}$.

La norma parece muy razonable, sin embargo a nuestro entender, deja en evidencia que es posible evitar su cumpliendo, efectuando la misma conducta que restringe al amparo de otros derecho de propiedad intelectual, puesto que en el propio art. 59, tantas veces citado, existen proyecciones de cine y televisión cuando se trate de remuneraciones provenientes del trabajo o habilidad de personas, recibidas por personas naturales, que hayan desarrollado en Chile actividades científicas, técnicas, culturales o deportivas que tributan con tasa de 20 por ciento y los pagos por el uso de derechos de edición o de autor, que están afectos a una tasa de 15 por ciento. Las dos son tasas inferiores al 30 por ciento, que corresponde en el evento de aplicar la norma de resguardo, por lo que serán útiles para efectuar la misma operación que el legislador pretendió evitar dos incisos antes en el mismo art. 59.

A los contribuyentes pagadores de las rentas de la propiedad intelectual, que se encuentren en la situación del inciso primero del art. 59, esto es afectados por una sobretasa, se les impone la obligación de presentar una declaración jurada dentro de los dos meses siguientes al término del ejercicio comercial en el cual pagaron, abonaron en cuenta, pusieron a disposición del interesado o remesaron al exterior las rentas respectivas.

\subsubsection{Retención y pago del impuesto}

De acuerdo al art. $74 \mathrm{~N}^{\circ} 4$ de la Ley de la Renta, quienes paguen las rentas que se remesen al extranjero por derechos de propiedad intelectual, estarán obligados a retener y pagar lo que por impuesto adicional corresponda. Es decir, el contribuyente

nuevas variedades vegetales, que están gravadas con tasa de $15 \%$ " y "c) Programas computacionales, entendiéndose por tales el conjunto de instrucciones para ser usados directa o indirectamente en un computador o procesador, a fin de efectuar u obtener un determinado proceso o resultado, contenidos en cassette, diskette, disco, cinta magnética u otro soporte material o medio, a los que afectas una tasa de $15 \%$ ".

${ }^{872}$ Más información puede verse en la Circular SII N 8, de 02 de febrero de 2007. 
ubicado en Chile, es quien se encuentra en la obligación de retener el impuesto por las rentas remesadas al extranjero y enterarlo en arcas fiscales. Se trata de una norma que cambia el sujeto del impuesto, ya que de otra forma la dificultad del SII para perseguir a contribuyentes extranjeros, dificultaría su cobro. Esta es la misma razón, por la cual generalmente, estos derechos son pactados en forma neta por el contribuyente extranjero, de suerte que, para él el impuesto no es un costo porque es asumido por el contribuyente nacional, lo que en Chile se hace con total tranquilidad, porque nunca el SII ha exigido el incremento del impuesto en la base imponible en esos casos y no es una situación prevista en la ley.

Quien efectúa la retención estará además obligado según el artículo 78 de la Ley de Impuesto a la Renta, a enterar en arcas fiscales, dentro de los primeros doce días de cada mes, el impuesto retenido en el mes inmediatamente anterior.

\subsubsection{El rol de las asesorías y el art. 59}

La Historia de la Ley $\mathrm{N}^{\circ} 20.154$, de 2007, revela que uno de sus objetivos fue reducir a 5 por ciento, la tasa de impuesto adicional, aplicable a las remuneraciones pagadas por trabajos de ingeniería o técnicos, servicios profesionales o técnicos prestados en Chile o en el exterior. Se trataba de facilitar la contratación de servicios especializados, de una "persona o entidad conocedora de una ciencia o técnica a través de un consejo, informe o plano"873.

Para los fines indicados, se eliminaron las asesorías del inciso primero del art. 59 y se trasladaron, bajo una nueva redacción, al inciso cuarto del $\mathrm{N}^{\circ} 2$ del art. $59^{874}$ de la Ley de la Renta. La tasa del impuesto adicional se redujo a un 15 por ciento ${ }^{875}$.

Respecto de las asesorías, la ley tomó la precaución de gravarlas con una sobretasa de 20 por ciento, en las mismas condiciones que a los derechos de propiedad industrial que previamente hemos analizado, esto es cuando entre el pagador y el

${ }^{873}$ Ob. supra cit., p. 9.

${ }^{874}$ Disposición no modificada por la reforma de septiembre de 2014.

${ }^{875}$ Especificando sobre el asunto, la Circular $\mathrm{N}^{\circ}$ 8, sobre: "Instrucciones sobre modificaciones introducidas a los artículos 59 y 60 de la ley de la renta por la ley n ${ }^{\circ} 20.154$, de 2007”, antes citada, señala: "En efecto, tal disposición preceptúa que las remuneraciones pagadas a personas naturales o jurídicas, sin domicilio ni residencia en el país, por concepto de trabajos de ingeniería o técnicos o por servicios profesionales o técnicos que una persona o entidad conocedora de una ciencia o técnica presta a través de un consejo, informe o plano, se afectarán con una tasa de impuesto Adicional de $15 \%$, sea que tales servicios se presten en Chile o en el extranjero". 
prestador del servicio existe relación o cuando están involucrados paraísos fiscales. Sin embargo, la especificación que hace la norma, sobre qué debe entenderse por una asesoría, al establecer que corresponde a "un consejo, informe o plazo, sea que se preste en Chile o el extranjero", levanta de plano, todas las dudas que analizamos supra, respecto a qué relación tienen que tener estas asesorías con un conocimiento protegible por propiedad intelectual u otra forma de protección, con el estado tecnológico de quien las requiere, etc., cuestiones todas que se encuentran en la más absoluta nebulosa, tanto desde el punto de vista normativo como jurisprudencial.

\subsubsection{Algunas conclusiones sobre el artículo 59}

Las complejidades que pueden advertirse en el artículo 59 que analizamos, dan pie para hacer algunas precisiones que analizamos seguidamente.

\section{III.3.1.5.7.1 Confusión del Art. 59 al hablar de patentes}

Un asunto evidente es que en la clasificación que hemos realizado sobre los derechos de propiedad intelectual, tal como los ordena el art. 59 de la Ley de la Renta, las "patentes" están repetidas. Efectivamente, en un caso están gravadas las "patentes" con el 30 por ciento y en el otro las "patentes de invención" por el 15 por ciento.

En el sistema jurídico chileno, la expresión "patente" es usada de manera coloquial, para referirse al pago de ciertos derechos o impuestos municipales, como el permiso de circulación de los automóviles, el impuesto por actividades económicas y otros. Además, es usada por la ley de Propiedad Industrial para referirse a las Patentes de Invención ${ }^{876}$ donde expresamente se definen. No hay más ocasiones en que el derecho chileno use esta expresión.

Ahora bien, en el contexto que está usada la expresión "patente" es claramente referida como un bien capaz de producir rendimientos que son gravados por el impuesto adicional, de manera que es imposible que se esté tratando de las "patentes" relacionadas con derechos o impuestos municipales. La única acepción de la expresión "patente" que cabe en el tejido del art. 59, es la de patentes de invención. Es decir, derechos de propiedad industrial, por los cuales se está pagando un rédito o producto que se grava con el impuesto adicional.

${ }^{876}$ El Art. 31 de la Ley 19.039 sobre Propiedad Industrial, define que "se entiende por patente el derecho exclusivo que concede el Estado para la protección de una invención”. 
El asunto que subyace hasta el momento, es a qué quiso referirse el legislador al dividir en dos incisos el gravamen y en un caso aplicar una tasa de 30 por ciento y en el otro 15 por ciento. Oficialmente el SII no ha dicho nada al respecto. Es claro, que comparada con la tasa general del impuesto adicional de 35 por ciento, la propiedad intelectual tiene un tratamiento preferente que va desde el 30 por ciento a la exención, a pesar de ello, subsiste la duda sobre qué criterio usó el legislador para establecer una tasa u otra.

Un criterio que habría parecido razonable es dividir entre aquellos activos de propiedad industrial vinculados a la $\mathrm{I}+\mathrm{D}+\mathrm{i}$ y los demás, de manera de beneficiar aquellos que tendrán un mayor efecto beneficioso para la economía. Esta postura habría justificado dejar las marcas comerciales en el primer grupo, gravadas con la tasa más alta y en el segundo los demás; sin embargo, junto a las marcas, también gravadas con tasa del 30 por ciento, aparecen las "patentes, fórmulas y otras prestaciones similares", con lo que el asunto se vuelve en un sinfín de cuestiones que en nada aclaran, ya que no se puede encontrar explicación: al motivo por el cuál aparecen las marcas junto a las patentes; a la razón por qué las patentes están gravadas con tasa de $30 \%$ y en el párrafo siguiente las patentes de invención (que son lo mismo) con tasa de 15\%; a la pregunta sobre si las fórmulas a que se refiere el artículo son ecuaciones matemáticas, recetas, deben o no estar vinculadas o formar parte de derechos de propiedad industrial, en el evento de estarlo, tributan al 30 por ciento o pueden formar parte de las patentes de invención del inciso siguiente y tributar a 15 por ciento; si las prestaciones similares, deben ser similares a marcas, patentes, fórmulas, etc.

La Historia de la Ley $20.154^{877}$, que modifica el art. 59, citado, para dejarlo de la manera que ahora lo estudiamos, avala nuestra teoría, en el sentido que en el mensaje presidencial que dio origen la ley indicada, expresamente se declara que busca responder a la "necesidad de disminuir el impuesto adicional relacionado con la transferencia tecnológica desde el exterior”, es por ello, que mediante una disminución

\footnotetext{
${ }^{877}$ Disponible en Internet en: http://www.leychile.cl/Consulta/portada hl?tipo norma=XX1\&nro ley=20154\&anio=2013 ( 15 Jul 2013).
} 
del impuesto adicional, "se pretende facilitar el acceso a procesos tecnológicos de punta provenientes del exterior" $"$.878.

A pesar de la claridad de la Historia de la ley, del texto normativo, literalmente, lo único que resulta indiscutido, es que los pagos por marcas están gravados con tasa del 30 por ciento, porque los restantes conceptos que enumeramos previamente y que el art. 59 grava con tasa de 30 por ciento, de una u otra manera, básicamente por lo impreciso de la descripción normativa, podrán ser reconducidos a alguno de los derechos de propiedad industrial gravados en el mismo artículo con tasa de 15 por ciento.

Desde el punto de vista del derecho tributario, se ve con bastante claridad, que ante tal incordio normativo la solución no puede perjudicar al contribuyente y que la administración tributaria deberá conformarse con una tributación al 15 por ciento, al menos en el caso de las patentes de invención, no obstante la creatividad del lado fiscal es fructífera, por lo que de no haber una corrección a nivel legislativo, lo más probable es que el asunto se resuelva por los Tribunales de Justicia.

\section{III.3.1.5.7.2 Redundancia del art. 59 al hablar de derechos de edición}

Semejante al problema que acabamos de analizar en el punto precedente, es el que se presenta con los derechos de edición y de autor. Conforme a la clasificación que expusimos supra, obtenida del propio art. 59, los derechos de autor ${ }^{879}$ en general, por el uso, goce o explotación, deberán tributar con la tasa del 35 por ciento, por excepción los programas de computación pagan una tasa de 15 por ciento, salvo los programas estándar que estarían exentos; y, las proyecciones de cine y televisión cuando se trate de remuneraciones provenientes del trabajo o habilidad de personas, recibidas por personas naturales, que hayan desarrollado en Chile actividades científicas, técnicas, culturales o deportivas, pagarán un 20 por ciento. Sin embargo, el inciso tercero del art. 59, se

\footnotetext{
${ }^{878}$ El mensaje presidencial que consta en la Historia de la Ley $\mathrm{N}^{\circ} 20.154$, expresamente señala: "En primer lugar, se propone disminuir a $15 \%$ la tasa del Impuesto Adicional previsto en la Ley sobre Impuesto a la Renta, que grava las cantidades pagadas por el uso, goce o explotación de patentes de invención, modelos de utilidad, dibujos y diseños industriales, esquemas de trazado o topografías de circuitos integrados, nuevas variedades vegetales y programas computacionales, toda vez que estas actividades implican una transferencia de conocimiento desde el exterior, incrementando la adopción y adaptación de nuevos productos y procedimientos, así como la incorporación de nuevos conocimientos. Adicionalmente, esta medida pretende convertirse en un impulso al desarrollo de nuestra industria de software".

879 Sinónimo de propiedad intelectual propiamente tal, conforme a la legislación chilena.
} 
detiene para decir que las cantidades que se paguen por el "uso" de derechos de autor, les afectará una tasa de 15 por ciento.

La reducción de tasa al derecho de autor genera muchos problemas interpretativos, de inicio, ya analizamos que al hablar de "uso", en el derecho chileno nos estamos refiriendo a la facultad de usar, propia del dominio, y explicamos, que determinar la existencia de renta en el contexto de la explotación personal, a los fines del impuesto adicional, es bastante difícil ${ }^{880}$. Por ello, el verbo "usar" parece más bien estarse utilizando en un sentido coloquial, que involucra permitir el uso a un tercero ${ }^{881}$, lo que desde el punto de vista de la propiedad intelectual sería equivalente a cualquier explotación que no implique su enajenación.

De ser la anterior la interpretación correcta, el derecho de autor estaría gravado con tasa de 15 por ciento, lo que hace detenerse a observar que por su parte los programas computacionales están protegidos por derecho de autor, en consecuencia, qué sentido tiene especificar que están gravados con un 15 por ciento, si estaban gravados con un 15 por ciento, por ser derecho de autor. Tal vez, se consideró al programa computacional desde su perspectiva de mercancía, más que de derecho de autor.

De otra parte, así como el legislador parece olvidar que los programas de computación se protegen por derecho de autor, también olvidó que los contratos de edición ${ }^{882}$ no son más que una forma que tienen el autor de permitir la explotación de su obra por un tercero, por lo que, al final del día, son derecho de autor puro y duro. En consecuencia, qué sentido tiene que el inciso tercero del art. 59, antes citado, diga que "las cantidades que se paguen por el uso de derechos de edición o de autor", cuando habría dicho lo mismo, diciendo: "por el uso de derechos de autor".

En este caso, a diferencia de lo que sucede con el caso de las patentes, que analizamos antes, donde la Historia de la Ley es bastante clara, no existe historia disponible para aclarar la disposición, de ahí que la inventiva del SII se ha puesto en

\footnotetext{
${ }^{880}$ Pusimos con único ejemplo, el hecho que la propiedad intelectual estuviese siendo explotada por un establecimiento permanente que hace pagos a su matriz.

881 Técnicamente la facultad de goce.

${ }^{882}$ El Art. 48 de la Ley $\mathrm{N}^{\circ} 19.336$ sobre Propiedad Intelectual, define el contrato de edición, de la siguiente manera: "Por el contrato de edición el titular del derecho de autor entrega o promete entregar una obra al editor y éste se obliga a publicarla, a su costa y en su propio beneficio, mediante su impresión gráfica y distribución, y a pagar una remuneración al autor".
} 
marcha y pronunciándose a propósito de remesas por concepto de derechos de autor por ejecuciones musicales, definió que estos pagos se encontraban dentro de la parte del art. 59, que grava las cantidades pagadas o abonadas en cuenta por el uso, goce o explotación de "marcas, patentes, fórmulas y otras prestaciones similares". Es decir, como los pagos por derechos de autor, claramente no son marcas, patentes ni fórmulas, significa, para el SII, que son "otras prestaciones similares".

No requiere argumentación definir que la única motivación para esta decisión es aplicar la tasa más alta posible, puesto que no existe ningún argumento de texto ni lógica que permita semejante conclusión. Ahora bien, el problema más grave, es que fundados en esta interpretación, queda derogado el inciso tercero del art. 59, que grava con un 15 por ciento, las cantidades que se paguen por el uso de derechos de autor, puesto que estarían comprendidos en la frase "otras prestaciones similares"

Finalmente, debemos hacer presente que el SII ha intentado aclarar estos problemas, publicando una tabla explicativa del impuesto adicional ${ }^{884}$, sin embargo lejos de dar luces sobre el asunto, simplemente se limita a copiar el art. 59, dividiéndolo en líneas, por lo que al no abordar nada de fondo, el intento es de total inutilidad, tanto es así, que al referirse a patentes, soluciona el problema con dos títulos "Marcas, patentes" y "Patentes de invención", demostrando que no conocen la diferencia, inexistente por lo demás, entre ambos supuestos institutos disímiles. Además, al referirse a los derechos de autor utiliza el título "Derechos de edición", señalando que comprende: "Cantidades pagadas por el uso de derechos de edición o de autor de libros", en consecuencia que en ninguna parte el art. 59 hace sinónimos los derecho de edición y de autor, ni menos limita el derecho de autor a "autor de libros". En definitiva, la confusión de conceptos es total.

\subsubsection{Beneficios tributarios para actividades de $I+D$}

Actualmente, en Chile, al igual que en España, tal vez nadie dude que la I+D produce efectos beneficiosos para la economía, resultando una actividad digna de estimular, no obstante, por alguna razón, nuestros legisladores parecen estar siempre diez, veinte o más años, atrás de la realidad teórica y empírica en cualquier materia. En

\footnotetext{
883 Oficio SII N 214, de 25 de enero de 2008. Disponible en Internet en: www.sii.cl (15 Jul 2014).

${ }^{884}$ Disponible en Internet en:

http://www.sii.cl/portales/inversionistas/imp_chile/impuesto_adicional.htm (15 Jul 2014).
} 
el caso de los beneficios tributarios por I+D, estando disponible toda una evolución de más de 30 años sobre la materia, con innumerables ejemplos y análisis, incluso en nuestro propio idioma ${ }^{885}$ y también en inglés, el asunto se aborda tímidamente, con criterios de fondo que parecen no estar al día en el conocimiento teórico existente sobre la estructura de la investigación, desarrollo e innovación y además, produciendo una carga burocrática, que a veces hace dudar si los costos de ésta no llevarán a un juego de suma cero a las cuentas agregadas del sistema.

Al presente, existen básicamente dos mecanismos de estímulo tributario para $\mathrm{I}+\mathrm{D}$, uno vinculado a donaciones y el otro que consiste en una rebaja al impuesto a las empresas $^{886}$.

\subsubsection{Beneficios tributarios para donaciones por $\mathbf{I}+\mathbf{D}$}

Ley $\mathrm{N}^{\circ} 18.681$, de 1987, se titula de la siguiente manera: Establece Normas Complementarias de Administración Financiera, de Incidencia Presupuestaria y Personal, sin embargo, en el ámbito tributario se le llamó “de Franquicias Tributarias para el Desarrollo Científico y Tecnológico” ${ }^{\text {} 87}$.

La ley citada, en su Art. 69, contempló por primera vez una franquicia tributaria para las empresas y contribuyentes del impuesto global complementario, que efectúen donaciones a los organismos que se señalan y bajo las condiciones que se indicarán más adelante.

La idea del legislador chileno, si bien fue y es útil, no parece tener una línea teórica muy claramente delimitada en favor de la innovación y el desarrollo, ya que parece simplemente querer sacarse de encima el peso de intervenir y ni siquiera acepta que el esfuerzo innovativo sea asumido por los particulares, lo que queremos decir, es que fue incapaz de crear un sistema que permitiese a los particulares asumir por si mismos sus proyectos creativos, sino que únicamente favoreció la acción benéfica derivada de donaciones.

${ }^{885}$ Nos referimos a la historia de los incentivos tributarios por $\mathrm{I}+\mathrm{D}+\mathrm{i}$ en España, que analizamos anteriormente.

${ }^{886}$ Impuesto de Primera Categoría.

${ }^{887}$ Para reglamentar esta ley, el SII emitió la Circular No 24, de 07 de mayo de 1993. Disponible en Internet en: www.sii.cl (15 Jul 2013). 
El diseño legislativo favorece a personas que deseen donar para efectos de $\mathrm{I}+\mathrm{D}+\mathrm{i}$. A efectos de tener derecho al beneficio tributario, existen requisitos para los donantes, donatarios y para el destino de los dineros donados.

\section{III.3.1.7.1.1 Quiénes pueden ser donantes}

Para efectos del beneficio en estudio, pueden ser donantes: aquellos contribuyentes de primera categoría (empresas o personas naturales que tributen como empresa) que declaren sus rentas efectivas mediante contabilidad completa ${ }^{888}$; quienes siendo de la primera categoría que declaren sus rentas efectivas mediante contabilidad simplificada; los que estando afectos al impuesto Global Complementario que declaren rentas efectivas.

Por tanto, quedan al margen de la posibilidad de ser donantes, los contribuyentes de la primera categoría que declaren rentas presuntas o que estén afectos a impuesto único o sustitutivo de dicha categoría y quienes siendo contribuyentes de global complementario no declaren rentas efectivas.

\section{III.3.1.7.1.2 Quiénes pueden ser donatarios}

En cuanto a los donatarios, únicamente pueden serlo universidades estatales o particulares reconocidos por el Estado, o institutos profesionales estatales o particulares reconocidos por el Estado. No es un objetivo de nuestro estudio evaluar la aplicación práctica que hasta la fecha ha tenido el beneficio que analizamos, a pesar de ello, no requiere ningún estudio darse cuenta que tiene una extensión muy limitada y que parte de un lugar muy distante del que teóricamente, en la actualidad y también en 1987, cuando se dicta la Ley, se estima debe tener la I+D+i en la economía.

En efecto, antes, analizamos latamente como es que, actualmente, se entiende que la innovación es un proceso que opera en todo el ámbito económico, no son sólo las innovaciones rupturistas, de alta tecnología o aquellas que requiere complejos desafíos científicos, más aún lo fundamental es la actitud innovadora y la capacidad de las empresas para producir pequeños, pero sostenidos y constantes cambios ${ }^{889}$. De

${ }^{888}$ Quedan incluidos aquellos contribuyentes de la primera categoría que estando afectos a renta presunta, optan por declarar renta efectiva mediante contabilidad completa.

889 Al respecto pueden verse: FERNÁNDEZ DE CÓRDOVA, RAFAEL GUITIÁN. Innovación tecnológica $I+D$. Dikinson, Madrid, 1997, pp. 11 y sgtes.; JAIME ABOITES Y MANUEL SORIA. Innovación, propiedad intelectual y estrategias tecnológicas. La experiencia de la economía 
contrario, la norma en análisis solamente beneficia a lo que parece ser alta investigación liderada por universidades e institutos. De otra parte, también vale la pena advertir, que la investigación por la cual se ha recibido la donación, no tiene por qué ser beneficiosa para la industria o actividad que hace la donación, claro está que normalmente existirá algún convenio o acuerdo entre el donante y el donatario para aprovechar los beneficios de la investigación, pero lo que llama la atención es que esto no fue un elemento a considerar por la norma.

\section{III.3.1.7.1.3 Objeto de la donación}

Los montos donados deberán consistir únicamente en dinero efectivo. Las donaciones recibidas en función del beneficio tributario de la Ley $\mathrm{N}^{\circ} 18.681$, deben destinarse a alguna de las actividades que menciona el art. 69, de la ley citada. Se trata de una descripción muy amplia, que nuevamente deja en evidencia la superficialidad con que el legislador chileno maneja el asunto. En efecto, las actividades que pueden ser beneficiadas son las siguientes: adquisición de inmuebles destinados a la docencia, investigación o extensión de las actividades desarrolladas por dichas instituciones; adquisición de equipamiento para impartir docencia o realizar investigación; readecuación de infraestructura para apoyar el perfeccionamiento académico; $y$, proyectos de investigación en general.

Si se observa con detenimiento el objeto que pueden tener las donaciones, se aprecia que más que promocionar la actividades de $\mathrm{I}+\mathrm{D}+\mathrm{i}$, se beneficia a universidades e institutos, en apoyo de la actividad docente, independiente de que se efectúen acciones de $\mathrm{I}+\mathrm{D}+\mathrm{i}$. Solamente el último ítem beneficiado, que corresponde a los proyectos de investigación en general, implican una vinculación directa con la innovación, aunque, como se advierte es tan amplia la redacción que será difícil poder aconsejar sobre cuál es su contenido.

mexicana. Universidad Autónoma Metropolitana, México D.F., 1999, pp. 17 y sgtes.; y, THOMAS L. FRIEDMAN. Tradición versus innovación. Buscar el equilibrio en la era de la globalización, Atlantida, Madrid, 1999. En este caso, aunque es un análisis muy novelado de la situación y todo el libro se refiere a la innovación, es interesante el planteamiento del autor y muy vinculado a nuestro tema, desde la página 249 en adelante. 


\section{III.3.1.7.1.4 Beneficio tributario}

Los contribuyentes que realicen donaciones en los términos indicados y a las instituciones mencionadas, tendrán derecho a un beneficio tributario que opera de la siguiente manera:

- Hasta el 50\% de lo donado, actualizado según establece la ley ${ }^{890}$, es considerado crédito $^{891}$ contra el impuesto a la renta de Primera Categoría o del impuesto Global Complementario, según corresponda ${ }^{892}$;

- Existe un tope anual de $14.000 \mathrm{UTM}^{893}$;

- El crédito utilizable en cada ejercicio no puede exceder del monto de los impuestos determinados, sin embargo el exceso es acumulable para los ejercicios siguientes;

- Aquella parte que es usada como crédito contra el impuesto, no pude ser usada como gasto necesario para producir la renta, de manera que si se ha cargado a resultados, deberá reversarse la operación a efectos fiscales, dentro del proceso conocido como renta líquida imponible.

- Respecto al 50 por ciento restante que no da derecho al crédito y al exceso por sobre las 14.000 UTM, deberá aplicarse lo dispuesto en el art. $31 \mathrm{~N}^{\circ} 7$ de la Ley de la Renta, esto es, que no podrá exceder del 2 por ciento de la renta líquida imponible o el 1,6 o/oo del capital propio de la empresa al término del ejercicio.

\section{III.3.1.7.1.5 Propiedad intelectual}

Ya vimos que gran parte del esfuerzo innovativo se radica en manos del altruismo de empresarios que decidan donar, sin embargo, desde el punto de vista de la propiedad intelectual, específicamente desde la idea de constituir derechos de propiedad industrial y software, que son las áreas donde más frecuentemente se darán los avances de interés para la empresa, debemos observar que la ley no impide radicar la propiedad del conocimiento adquirido en manos del donante o aplicar estos conocimientos para el desarrollo o implementación de una tecnología usada por el donante, lo que es una gran ventaja, porque permite trasladar la totalidad de los beneficios económicos del

\footnotetext{
${ }^{890}$ En la Ley de Impuesto a la Renta, el Art. 95 establece un mecanismo de actualización de aplicación general.

891 Que sea un crédito implica que descuenta, como un pago a cuenta, pero no existe derecho a devolución, en el evento que exceda del monto del impuesto a pagar.

${ }^{892}$ Previamente se deducen las contribuciones de bienes raíces.

${ }^{893}$ Unidades Tributarias Mensuales. Actualmente, alrededor de US\$80.
} 
desarrollo a quien hizo el gasto, quien por otro lado, contribuye casi sin quererlo al desarrollo de conocimiento y know-how en la universidad o instituto que trabajaron para su beneficio.

\subsubsection{Beneficios tributarios para inversión privada en I+D}

A través de la Ley $\mathrm{N}^{\circ}$ 20.241, de 19 de enero de 2008, que Establece un Inventivo Tributario a la Inversión Privada en Investigación y Desarrollo, se incorpora en el derecho chileno, un incentivo tributario destinado directamente a estimular la inversión privada en $\mathrm{I}+\mathrm{D}$. Para el mensaje presidencial del proyecto de ley, "viene a complementar los esfuerzos que está efectuando el país para consolidar un sistema coherente de incentivos específicos a la investigación y desarrollo (I+D). En particular, éste apunta a incentivar un mayor esfuerzo del sector privado que, de acuerdo a comparaciones internacionales, es el que se encuentra más rezagado en esta materia” ${ }^{\circledR 94}$.

Con esta Ley se pretendía no solamente abordar la baja inversión privada en $\mathrm{I}+\mathrm{D}$, sino también potenciar el vínculo entre el mundo de la investigación y el productivo. Por otro lado, se trata de una idea limitada en el tiempo puesto que, al menos en teoría, la ley tendrá una duración limitada de diez años.

De entrada al análisis, podemos ver confirmado lo que venimos diciendo en el sentido que el legislador chileno suele estar diez o veinte años atrás en estas materias y parece no indagar las experiencias internacionales antes de legislar, puesto que, le habría bastado mirar a España, donde ni siquiera tiene que traducir, para haber visto una experiencia de treinta años en la materia. En efecto, lo primero que llama la atención es lo tardío de la regulación, ya hemos visto como los beneficios de la innovación y el desarrollo vienen siendo investigados, al menos desde los años cuarenta y además, ya existían experiencias bien desarrolladas de estímulos fiscales sobre la materia, desde los años $70 \mathrm{~s}^{895}$.

De otra parte, tal como venimos majaderamente repitiendo, el entendimiento que revela el legislador del asunto, nuevamente lo muestra alejado de los desarrollos de la

${ }^{894}$ Historia de la Ley $N^{\circ} 20.241$, de 19 de enero de 2008, que Establece un Inventivo Tributario a la Inversión Privada en Investigación y Desarrollo, pp. 5 y siguiente. Disponible en Internet en: www.bcn.cl (18 Jul 2013).

895 Hemos puesto como referente los años 70 , no obstante haber experiencias anteriores, porque la Ley del Impuesto sobre Sociedades de 1978, fue el punto de partida de nuestra investigación, de ahí que podamos afirmar que en ese momento ya existía un beneficio suficientemente desarrollado como tal. 
teoría económica, puesto que al pensar en estimular únicamente la investigación en centros de investigación avanzada, como universidades o entidades ad hoc, de entrada desconoce los beneficios de la investigación efectuada al interior de los aparatos productivos, que son quienes mejor conocerán sus necesidades y el área de investigación en que trabajarán y también, pasa por alto, los beneficios que pueden producir las mejoras incrementales. En una palabra, tal como se concibió originalmente, este beneficio resulta elitista y discriminatorio, establecido no en beneficio de la innovación y el desarrollo, como principios generales y poseedores de externalidades positivas, sino como un privilegio en favor de una determinada área productiva, tal es universidades y centros de investigación, capaz de favorecer únicamente a empresas grandes que pueden externalizar la investigación.

En lo más práctico, la ingenuidad del legislador se ve reflejada en la idea de ponerle un límite temporal en el tiempo, le habría bastado con ver la experiencia española, para darse cuenta lo difícil que es desinstalar estos mecanismos de la economía.

De todas formas, con cierta ironía, tenemos que reconocer que el legislador chileno si aprendió la lección del español, puesto que a cuatro años de su implementación, por medio de la Ley $\mathrm{N}^{\circ}$ 20.670, de 06 de marzo de 2012, vino a modificar la Ley $\mathrm{N}^{\circ}$ 20.241. Esperemos que el animus innovandi tenga, al menos, inspiración de mejoría, tal como se aprecia en las innumerables modificaciones que ha sufrido el sistema español.

\section{III.3.1.7.2.1 Control versus burocracia}

Cuando hablamos de $\mathrm{I}+\mathrm{D}+\mathrm{i}$, si bien la financiación siempre es indispensable, el riesgo intrínseco a estas actividades, hace que tome un rol fundamental, de ahí que, un asunto que no puede escapar a nuestra atención es la clásica opción "por la financiación pública, generadora de mayor igualdad y burocracia (Europa), o por la financiación privada (Estados Unidos y Japón), tan eficaz como generadora de desigualdades" ${ }^{\text {} 896,}$ puesto que el legislador nacional opta por un sistema compartido, que en apariencia parece ser una opción ecléctica, que sin asumir mayor riesgo, se decide por el camino intermedio. Sin embargo, el sistema creado se presenta acompañado de un aparataje

${ }^{896}$ GONZÁLEZ, EUSEBIO y CHAMORRO, JOSÉ ANTONIO. Ob. Cit., pp. 84. 
administrativo que difícilmente lo haría útil, de hecho, en el año 2008, conforme al diseño original, para tener acceso al beneficio se necesitaba una evaluación y aprobación previa de $\mathrm{CORFO}^{897}$, lo que sin duda fue una de las razones, por las que la modificación del año 2012, incorpora como alternativa la posibilidad de iniciar un proyecto y obtener la aprobación posterior, lo que si bien mantiene el halo de desconfianza $^{898}$ que se refleja en la institucionalidad creada, al menos facilita la operatividad del sistema.

Una segunda complejidad que acarrea la excesiva burocratización viene dada por una cuestión estructural, tal es que el sistema únicamente favorece a quienes tiene una gran capacidad administrativa, produciendo desigualdades entre los posibles innovadores, puesto que sólo tendrán la capacidad de acceder a los beneficios, quienes tengan grandes estructuras administrativas. De manera que, se viene a favorecer a quienes tengan más capital e infraestructura y la capacidad de invertir no sólo en la investigación en sí misma, sino que en la elaboración de un proyecto previo a la investigación, destinado a cumplir con los requisitos, siempre crecientes, que exige la administración. De manera que, el centro del asunto no es el beneficio de las empresas más innovadoras. En la práctica se ha generado un grupo de operadores intermedios que para quienes carecen de experiencia en el sistema, resultan ser la única forma de acceder al beneficio, puesto que son quienes tienen el know-how en la elaboración de un proyecto aceptable por CORFO.

Vistas las cosas como las hemos descrito, no parece que se estén protegiendo valores como la igualdad, interés público o bienestar general ${ }^{899}$, sino más bien la protección de ciertos grupos y de un determinado tipo de investigación e innovación de alto nivel, que no necesariamente es la que se ajusta a la realidad de nuestra economía. En otras palabras, aquellos empresarios que requieren de mejoras incrementales e innovaciones menores en sus procesos productivos no tienen acceso a beneficios estatales.

\footnotetext{
${ }^{897}$ CORFO es el acrónimo de Corporación de Fomento de la Producción, entidad pública que tiene por objeto estimular la producción en Chile.

${ }^{898}$ Desconfianza en el sentido que para acceder al beneficio hay que pasar por el control previo de la administración y no existe posibilidad de la actividad autónoma del contribuyente, aunque éste cumpla con todos los requisitos sustantivos de la ley.

${ }^{899}$ Ob. supra cit., p. 86. En cuanto principios que deben presidir la construcción de beneficios tributarios.
} 
La intención declarada al crear el sistema fue minimizar los "espacios de discrecionalidad administrativa y se relajan las restricciones de montos" $" 900$ y plazos que actualmente existen en los fondos concursables. A nuestro entender, el modelo dista mucho de lograr su objetivo. Si se buscaba evitar la discrecionalidad, un sistema de consultas vinculantes cumple con ese objetivo, con el componente adicional de entregar una decisión uniforme, pública y aplicable a todos los contribuyentes, en contra partida a un sistema de aprobación previa que es completamente incierto hasta su aprobación y perfectamente variable entre un proyecto y otro.

\section{III.3.1.7.2.2 Descripción del beneficio}

El sistema funciona bajo la idea de establecer la posibilidad de rebajar impuestos por las sumas invertidas en proyectos de I+D. Intervienen en él, obviamente, los contribuyentes, los centros de investigación, CORFO y entidades que prestan servicios. Los proyecto de I+D cuyo valor supere las 100 UTM pueden postular al beneficio, es decir, no se trata de un sistema autogestionado por el contribuyente, siempre requiere la intervención de CORFO, lo que genera una fuerte concentración en la capital del país.

Teniendo un proyecto ${ }^{901}$, para saber si califica como I+D, no será suficiente con revisar qué ha pasado con proyectos anteriores o estudiar las consultas vinculantes previas (puesto que no existen), sino que siempre será necesario certificarlo ante CORFO, para lo cual existen dos vías: la primera consiste notificar a CORFO la intención de acogerse a la ley, comenzar el proyecto y en paralelo impulsar el proceso de certificación; o, certificar el proyecto antes de su inicio ${ }^{902}$. Sólo un proyecto certificado puede acceder al beneficio.

El sistema en su versión del año 2008, únicamente permitía acceder al beneficio a través de contratar con un centro de investigación ${ }^{903}$, desde la modificación del año 2012, es posible efectuar investigaciones dentro de la propia empresa, lo que nos parece un avance más que significativo, en función de ajustar al beneficio a principios de igualdad y no discriminación. A consecuencia de esta modificación, actualmente se

\footnotetext{
${ }^{900}$ Historia de la Ley $\mathrm{N}^{\circ}$ 20.241. Ob. Cit., p. 9.

${ }^{901}$ La necesidad de tener un proyecto que presentar a la autoridad, implica que cada vez más será necesaria la participación de terceros que se especializan en los requerimientos que impone el aparato estatal, lo que a nuestro entender es una de las debilidades del sistema.

902 Debemos reconocer que afortunadamente los plazos de certificación han sido de entre 40 a 60 días, lo que es estándar muy aceptable.

${ }^{903}$ Los centros de investigación se conocen como CI.
} 
habla de investigación "intramuros" y "extramuros" dependiendo de si la investigación se hace en la empresa o se encarga a un tercero.

CORFO es la entidad que registra a los $\mathrm{CI}^{904}$, quienes postulan presentando una serie de antecedentes y cuya incorporación al registro se resuelve por resolución fundada $^{905}$. La incorporación de un CI es resuelta por un comité formado por cinco miembros: dos de CORFO, dos designados por la Corporación Nacional de Ciencia y Tecnología y uno por el Ministro de Economía. Cada año los CI deben informar sobre cualquier cambio en los antecedentes que les permitieron registrarse, y una declaración jurada que los antecedentes son fidedignos. Además, el CI debe pagar un arancel, que CORFO puede fijar, sin exceder del 50 por ciento de los costos totales del procedimiento de acreditación para un CI.

Todos los contratos de que se suscriban entre los contribuyentes con derecho al beneficio y los CI registrados, deben ser autorizador por $\mathrm{CORFO}^{906}$, sin importar que un contrato pudiese, por ejemplo, ser la consecuencia natural de otro anterior.

${ }^{904}$ La excesiva burocratización del sistema, ya puede verse en el mensaje presidencial de la Ley 20.241, que a propósito de la acreditación de los CI, señala: "La acreditación de los centros de investigación interesados será entregada por la Corporación de Fomento de la Producción (CORFO), luego de que ésta verifique que aquellos cumplen con las condiciones mínimas formales establecidas al efecto y que posean, entre otros, la capacidad técnica para llevar a cabo las labores de investigación o desarrollo que se le encarguen. Los centros de investigación elegibles para los efectos de la acreditación serán aquellos que dependan de alguna universidad, o estén constituidos como personas jurídicas, con o sin fines de lucro, cuyo único objeto sea la realización de labores de investigación o desarrollo. Además, tendrán que cumplir con los requerimientos establecidos en el Reglamento de Acreditación que será dictado en el marco del presente proyecto de ley".

905 Los requisitos para los CI, están en el art. 2 de la Ley y son:

- Contar en el país, con organización y medios, tanto personales como materiales, suficientes para realizar actividades de investigación y desarrollo;

- Estar ejerciendo actividades de investigación básica, aplicada o de desarrollo tecnológico, durante, al menos, los 24 meses anteriores a la solicitud de inscripción en el Registro;

- Poseer sistemas de administración financiero-contable adecuados para realizar seguimientos a contratos investigación y desarrollo sujetos a las disposiciones de esta ley;

- Presentar una declaración jurada, firmada por el representante, en la que éste declare que los antecedentes entregados a CORFO para efectos de obtener la inscripción en el Registro, sean auténticos, fidedignos, veraces y que están plenamente vigentes a la fecha de su presentación.

906 Otro ejemplo de la excesiva burocratización del sistema, lo vemos en el mensaje presidencial de la Ley 20.241, que sobre el asunto dice: "Por su parte, los contratos que los contribuyentes celebren con los centros de investigación así acreditados deberán ser revisados y certificados por CORFO, entidad que sancionará que el objeto del contrato corresponde efectivamente a la realización, por parte del centro de investigación acreditado, de actividades de investigación o desarrollo en el ámbito de su competencia. De esta forma, para poder acceder al beneficio de que trata este proyecto de ley, es imprescindible que los contratos celebrados con los centros de investigación acreditados al efecto, hayan sido certificados por CORFO.

CORFO fiscalizará la correcta ejecución y cumplimiento de los contratos a los que se refiere el proyecto de ley, para lo cual podrá solicitar, tanto de los contribuyentes como de los centros de 
Existe una norma de transparencia que impide que exista relación entre el contribuyente beneficiado y el centro de investigación, norma que tenía sentido cuando la investigación únicamente podía producirse extramuros, pero desde que se implementó el sistema intramuros, parece absurdo exigirlo, ya que, desde el momento en que la investigación la puede efectuar el propio contribuyente, no puede existir una vinculación más estrecha con un centro de investigación.

\section{III.3.1.7.2.3 Investigación y desarrollo}

El legislador estableció una definición de qué entiende por investigación y desarrollo, no obstante olvidó a la innovación. La ausencia de una definición de innovación podría no ser relevante, en la medida que su contenido conceptual estuviese, pero no lo está. Se requiere un sistema que distinguiese entre investigación, desarrollo e innovación, como partes de un sistema de innovación que dé cabida desde las pequeñas mejoras incrementales a cambios técnicos rupturistas. Así las cosas, lo que preocupa, es que para el legislador chileno el asunto se agota en investigación y desarrollo, tal como él las define, desatendiendo una visión de sistema, lo que lleva, tal como hemos repetido, a una innegable discriminación en favor de concentraciones empresariales, en este caso destinada a monopolizar la investigación.

La modificación de 2012, tal como aclara POLANCO ZAMORA ${ }^{907}$, vino a detallar la definición de investigación para dejar en claro que el concepto comprende tanto la investigación básica como la aplicada. Aclaración que si bien se agradece, también merece un cometario en el sentido que poco serviría un beneficio tributario que sólo beneficie a una de ellas, así pues, desde el punto de vista jurídico no podría encontrarse justificación para la distinción. Desde la perspectiva de la interpretación de la ley tributaria, ante la ausencia de distinción por el legislador, no cabía al intérprete distinguir, en consecuencia, a nuestro juicio, la aclaración era innecesaria y únicamente revela la existencia de dudas básicas entre quienes operan el sistema.

investigación, la información que estime necesaria al efecto, guardando desde luego la debida confidencialidad respecto de los contratos que conozca".

907 POLANCO ZAMORA, GONZALO. Reporte tributario. Centro de Estudios Tributarios de la Universidad de Chile. Disponible en Internet en: http://www.cetuchile.cl/index.php?option $=$ com content\&view $=$ category\&layout $=$ blog\&id=83\&Itemi $\underline{\mathrm{d}=160}(25 \mathrm{Jul} 2013)$. 
Para el legislador del 2012, investigación básica es "aquella que consiste en trabajos experimentales o teóricos que se emprenden principalmente para obtener nuevos conocimientos acerca de los fundamentos de los fenómenos y hechos observables, con prescindencia de si tienen una aplicación o utilización determinada"908 y la investigación aplicada, consiste en "trabajos originales realizados para adquirir nuevos conocimientos; sin embargo, está dirigida fundamentalmente hacia un objetivo práctico específico" $"$ 909.

En cuanto al concepto de desarrollo, la ley hace sinónimos al "desarrollo experimental" y al "desarrollo", estableciendo que "consiste en trabajos sistemáticos que aprovechan los conocimientos existentes obtenidos de la investigación y/o la experiencia, y está dirigido a la producción de nuevos materiales, productos o dispositivos; a la puesta en marcha de nuevos procesos, sistemas y servicios, o a la mejora sustancial de los ya existentes. Asimismo, se comprende el desarrollo de programas informáticos, siempre que dicho desarrollo dé lugar a mayor conocimiento con el objetivo de resolver en forma sistemática una incertidumbre científica o tecnológica o permita generar un mejoramiento sustancial e innovador en algún proceso, producto y/o servicio" ${ }^{, 10}$.

El art. 1 de la Ley 20.241, también establece un catálogo de las actividades que no se consideran actividades de investigación o desarrollo, tales son:

- Pruebas y evaluaciones, una vez que un prototipo se transforma en un material, producto o proceso comercializable, que tengan como fin inmediato su inserción en el mercado;

- Las mejoras, adaptaciones y análisis de carácter rutinario, repetitivo o menor aplicadas en materiales, productos, servicios o procesos, aunque en ellos se utilice tecnología;

- Modificaciones estéticas o menores de aplicaciones ya existentes para diferenciarlas de otras;

- Los cambios periódicos o de temporada de materiales, productos o procesos;

- La promoción de aquello que sea resultado de investigación o desarrollo;

908 Art. $1^{\circ}$ de la Ley $N^{\circ} 20.241$.

909 Art. $1^{\circ}$ de la Ley $N^{\circ} 20.241$.

${ }^{910}$ Art. $1^{\circ}$ de la Ley $N^{\circ} 20.241$. 
- La adquisición de propiedad intelectual o industrial cuando ésta consista en el objeto principal de las labores de investigación o desarrollo; y,

- La realización o contratación de estudios de mercado y de comercialización.

Hablando de este tema POLANCO ZAMORA ${ }^{911}$, recuerda algo que nos parece casi una contradicción total, puesto que en la redacción del año 2008 de la ley en comento, se excluían del beneficio los gastos vinculados a la adquisición de la propiedad intelectual o industrial que derivaran de la investigación. Actualmente, sólo se excluye cuando la adquisición de la propiedad intelectual, sea el objeto principal de la investigación y desarrollo, lo que resulta razonable, porque el aporte al conocimiento está en la investigación y el desarrollo, no en la constitución de propiedad intelectual en sí misma, de manera que la propiedad intelectual no puede llegar a existir sin la $\mathrm{I}+\mathrm{D}^{912}$.

Compartimos con POLANCO ZAMORA cuando sostiene que la norma atentaba en contra de los esfuerzos de investigación aplicada, puesto que excluye del beneficio tributario a los gastos vinculados al mecanismo de protección de la propia investigación.

\section{III.3.1.7.2.4 Contribuyentes beneficiados}

Tienen acceso al beneficio, únicamente los contribuyentes de primera categoría que declaren su renta efectiva determinada según contabilidad completa, circunstancia que parece ser aceptada en Chile y no prestarse para discusión alguna, puesto que revisada la Historia de la Ley, únicamente hay una referencia a la posibilidad de extender el beneficio a los contribuyentes de primera categoría que tributen conforme a contabilidad simplificada ${ }^{913}$, proposición que no tuvo ninguna acogida, de manera que se dio por aceptado que el beneficio únicamente debe otorgarse a contribuyentes de primera categoría que tributen con contabilidad completa. Pues bien, a nuestro entender el sistema también es discriminatorio desde esa perspectiva, ya que deja fuera a cualquier otro tipo de contribuyente, como pudiesen ser quienes tributen mediante

911 Ob. supra cit.

912 Conforme a la actual redacción del art. $1^{\circ}$ de la Ley $\mathrm{N}^{\circ} 20.241$, se incluyen dentro del beneficio a los gastos vinculados con las "actividades necesarias para la constitución de los derechos de propiedad intelectual, industrial y de obtentores vegetales, incluyendo los servicios profesionales involucrados en el proceso de obtención de los derechos y registros, informes periciales, defensas ante eventuales oposiciones y costos de publicaciones asociadas, podrán ser objeto del beneficio tributario establecido en esta ley, en la medida que éstas se deriven de los resultados obtenidos de proyectos y contratos de Investigación y Desarrollo debidamente certificados por la "CORFO", al amparo de la presente ley".

${ }^{913}$ Historia de la Ley $\mathrm{N}^{\circ} 20.241$. Ob. Cit., pp. 60. 
contabilidad simplificada, los de renta presunta, de segunda categoría, los afectos al impuesto global complementario o adicional y, los contribuyentes acogidos al régimen simplificado del artículo 14 ter de la Ley de la Renta.

Según nuestro punto de vista, es una discriminación arbitraria el distinguir en función del régimen tributario de un sujeto pasivo, cuando el mismo no conlleva ninguna variación en sus condiciones objetivas. Los elementos válidos para diferenciar son aquellos vinculados a la necesidad y beneficios de la investigación. En consecuencia, desde la perspectiva descrita, el beneficio en estudio es también discriminatorio en favor de determinados contribuyentes, donde cuentan necesariamente las empresas más grandes, que siempre estarán en primera categoría con contabilidad completa.

\section{III.3.1.7.2.5 Conformación del beneficio}

El beneficio consiste en un crédito contra el impuesto de primera categoría del 35 por ciento sobre el monto invertido en $\mathrm{I}+\mathrm{D}$, debidamente certificado por CORFO. Además, el contribuyente podrá rebajar como gasto necesario para producir la renta el monto que no haya sido utilizado como crédito contra el pago del impuesto de primera categoría, es decir el 65 por ciento restante, independiente de que el proyecto de I+D no se relacione con el giro de la empresa. No deben considerarse para efectos de los cálculos del beneficio, los montos que provengan de financiamiento estatal ${ }^{914}$.

En caso de producirse un remanente de crédito, éste no dará derecho a devolución, pero podrá imputarse, en forma reajustada, al impuesto de primera categoría que corresponda pagar durante los ejercicios posteriores.

\footnotetext{
${ }^{914}$ Un ejemplo muy simple de cómo opera el sistema, lo encontramos en Internet en:

http://www.asiel.cl/portal/productos-y-servicios/ingenieria-y-desarrollo-de-software/item/95financiami ento-con-franquicia-tributaria-ley-id.html ( 27 Jul 2013)

\begin{tabular}{|l|l|l|}
\hline \hline Operación & Ítem & Monto \\
\hline+ & Ingresos operacionales & $\$ 75.000 .000 .-$ \\
\hline- & Costos operacionales & $\$ 38.000 .000 .-$ \\
\hline- & Gastos aceptados en I+D (65\%) & $\$ 6.500 .000 .-$ \\
\hline$=$ & Utilidades antes de impuestos & $\$ 30.500 .000 .-$ \\
\hline- & Impuesto a la renta (20\%) & $\$ 6.100 .000 .-$ \\
\hline- & Crédito por I+D (35\%) & $\$ 3.500 .000 .-$ \\
\hline$=$ & Cuota a pagar & $\$ 2.600 .000 .-$ \\
\hline
\end{tabular}
}


El monto total anual del crédito, tuvo originalmente dos límites, por una parte, no podía exceder de un 15 por ciento del ingreso bruto anual, determinado según el art 29 de la Ley de la Renta, ni tampoco de 5.000 UTM de acuerdo al valor de dicha unidad al término del ejercicio. Desde el año 2012, el sistema fue modificado y se caracteriza por poseer los siguientes requisitos:

- El monto mínimo para acceder al beneficio es un proyecto de 100 UTM;

- Por lo menos el 50 por ciento del proyecto, recursos humanos y subcontrataciones, deben corresponder a gastos por actividades que se lleven a cabo dentro del territorio nacional ${ }^{915}$;

- El tope del crédito tributario (35 por ciento) es de 15.000 UTM. Este tope considera todos los proyectos de una empresa que hayan sido certificados y ejecutados en el período;

- El arancel de CORFO es de 10 UTM, que se paga al momento de solicitar la certificación independiente del resultado de la certificación;

- Es posible formar conjuntos de empresa para postular al beneficio;

- El incentivo tributario no excluye a otros subsidios públicos.

\subsubsection{El impuesto al valor agregado}

El Decreto Ley $\mathrm{N}^{\circ} 825$, de 31 de diciembre de 1974, sobre Impuesto a las Ventas y Servicios, que corresponde a la ley del IVA en Chile, no se hace cargo de la propiedad intelectual propiamente tal, ni de la propiedad industrial, en cuanto género, sino que únicamente de ciertos derechos de propiedad industrial.

El art. $8^{\circ}$, letra h), del DL $N^{\circ} 825$, dice: "El impuesto de este Título afecta a las Ventas y Servicios" "Para estos efectos serán consideradas también como ventas y servicios, según corresponda" (...), letra h): "El arrendamiento, subarrendamiento o cualquier otra forma de cesión del uso o goce temporal de marcas, patentes de invención, procedimientos o fórmulas industriales y otras prestaciones similares".

Cabe entonces hacerse la pregunta sobre: ¿Por qué el legislador chileno es tan selectivo a la hora de gravar con IVA a la propiedad intelectual? La respuesta debemos

\footnotetext{
915 Este límite nos hace recordar lo que sucedió en España donde una norma semejante no aprobó los estándares del Tratado de la Unión Europea, siendo declarada como contraria al Tratado, por el Tribunal Europeo.
} 
buscarla en la estructura del IVA en Chile, puesto que básicamente grava a las ventas y no a los servicios que son alcanzados sólo por excepción. Bajo este esquema, las transacciones que comúnmente se dan sobre la propiedad intelectual no se ajustan a los hechos gravados básicos de IVA, que son dos: "hecho gravado básico de venta" y "hecho gravado básico servicio".

En cuanto al hecho gravado básico venta, en la Ley del IVA se exige que la cosa objeto de la transacción sea un bien corporal ${ }^{916}$, requisito que claramente no cumple la propiedad intelectual en ninguna de sus formas, puesto que siempre es un bien incorporal.

Revisado el hecho gravado básico servicio, vemos que para el DL $\mathrm{N}^{\circ} 825$, no son todos los servicios gravables con IVA, sino que ciertos y determinados servicios, que por remisión se encuentran enumerados en los números 3 y 4, del art. 20 de la Ley de Impuesto a la Renta ${ }^{917}$, donde no figura ningún derecho de propiedad intelectual ni manifestación del mismo.

Atendido lo anterior, para gravar con IVA a los derechos de propiedad industrial el legislador sólo podía definir un hecho gravado especial, cuestión que hizo en el art. $8^{\circ}$, letra h), del DL $\mathrm{N}^{\circ} 825$, generando un hecho gravado especial asimilado a servicio. Efectivamente se trata de un hecho asimilado a servicio, por cuanto lo que está gravado es "el arrendamiento, subarrendamiento o cualquier otra forma de cesión del uso o goce temporal"918. Es decir, lo que gravó el legislador son los rendimientos de la explotación

${ }^{916}$ El Art. $2^{\circ}, \mathrm{N}^{\circ} 1^{\circ}$ del DL $\mathrm{N}^{\circ} 825$, entiende "Por 'venta', toda convención independiente de la designación que le den las partes, que sirva para transferir a título oneroso el dominio de bienes corporales muebles, bienes corporales inmuebles de propiedad de una empresa constructora construidos totalmente por ella o que en parte hayan sido construidos por un tercero para ella, de una cuota de dominio sobre dichos bienes o de derechos reales constituidos sobre ellos, como, asimismo, todo acto o contrato que conduzca al mismo fin o que la presente ley equipare a venta".

${ }^{917}$ El art. $20 \mathrm{~N}^{\circ} 3$ y $4^{\circ}$ de la Ley de la Renta, señala: " $3^{\circ}$.- Las rentas de la industria, del comercio, de la minería y de la explotación de riquezas del mar y demás actividades extractivas, compañías aéreas, de seguros, de los bancos, asociaciones de ahorro y préstamos, sociedades administradoras de fondos mutuos, sociedades de inversión o capitalización, de empresas financieras y otras de actividad análoga, constructora, periodísticas, publicitarias, de radiodifusión, televisión, procesamiento automático de datos y telecomunicaciones"; " $4^{\circ}$.- Las rentas obtenidas por corredores, sean titulados o no, sin perjuicio de lo que al respecto dispone el $\mathrm{N}^{\mathrm{o}} 2$ del artículo 42, comisionistas con oficina establecida, martilleros, agentes de aduana, embarcadores y otros que intervengan en el comercio marítimo, portuario y aduanero, y agentes de seguro que no sean personas naturales; colegios, academias e institutos de enseñanza particular y otros establecimientos particulares de este género; clínicas, hospitales, laboratorios y otros establecimientos análogos particulares y empresas de diversión y esparcimiento".

${ }^{918}$ Art. $8^{\circ}$, letra h), del DL N 825. 
de la propiedad intelectual conservando su dominio, lo que típicamente conocemos como licencias, de manera que no gravó la transferencia de la propiedad intelectual.

Tal como advertimos, no son los rendimientos de cualquier derecho de propiedad intelectual los que están gravados, sino que únicamente de algunos derechos de propiedad industrial, tales son: marcas, patentes de invención, procedimientos o fórmulas industriales y otras prestaciones similares.

Desde el punto vista del análisis del hecho gravado básico de venta, se conforma lo que venimos diciendo, en el sentido que la transferencia de marcas, patentes de invención, procedimientos o fórmulas industriales y otras prestaciones similares, no está gravada con IVA. Así pues, para la Ley del IVA, se entiende por "venta", toda convención independiente de la designación que le den las partes, que sirva para transferir a título oneroso "el dominio de bienes corporales muebles" y todos los derechos gravados son bienes incorporales, por lo que atendida su propia naturaleza quedan excluidos del hecho gravado básico de venta.

La norma en estudio, simplemente grava el uso temporal de determinados derechos de propiedad industrial por un tercero distinto de su dueño. Si recordamos que los atributos del dominio son usar, gozar y disponer, vemos que la norma grava el uso y goce de estos derechos por un tercero, más no su disposición (implicaría una cesión permanente del uso), hecho este último, que si bien no es alcanzado por la Ley de IVA, perfectamente lo es por la Ley de Renta.

\subsubsection{Necesidad de registro de la propiedad intelectual para fines impositivos}

Bajo este título se pretende determinar, si las normas tributarias referentes a la propiedad intelectual en Chile, rigen solamente para los derechos debidamente registrados o extienden su ámbito de aplicación a todas las formas registrales o no. De partida, debemos descartar el asunto respecto de la propiedad intelectual propiamente tal, puesto que ella no necesita del reconocimiento registral para tener existencia jurídica, por lo que sería absurdo que el legislador tributario desconociera esta realidad para exigir registros, sin embargo no cabe duda de la utilidad que será contar con un registro, cuando ello es procedente, para efectos de demostrar la existencia de los derechos objeto de tributación. 
Conforme a lo anterior, nos queda únicamente analizar la situación de la propiedad industrial, donde el registro, si bien no puede considerarse como constitutivo del derecho que protege, es sin dudas, un elemento fundamental, puesto que da cuenta de la existencia de protección jurídica para el derecho registrado.

Creemos que a lo largo de nuestro trabajo hemos demostrado que la propiedad industrial tiene por objeto amparar las creaciones del intelecto humano y que la legislación a su respecto no pretende proteger al primero que obtiene un registro, sino al verdadero creador. Confirmación irrefutable de lo anterior, es la posibilidad del creador de demandar la nulidad de los privilegios industriales concedidos a quien no es su inventor o autor, alternativa jurídica que existe en Chile, España y todos los países parte del Convenio de la Unión de París. Así las cosas, es claro que el carácter de propietario de un derecho de propiedad industrial no deriva de la existencia de un privilegio industrial debidamente registrado en una oficina nacional o en las correspondientes oficinas a nivel internacional. En ese mismo orden de ideas, las normas de impuestos relativas al tema no exigen registro o declaración alguna de autoridad para estimar que se está frente a un derecho de propiedad industrial, al efecto, por ejemplo, el art. 17, $\mathrm{N}^{\circ}$ 8, letra e), de la Ley de la Renta, se refiere a la "enajenación del derecho de propiedad intelectual o industrial, en caso que dicha enajenación sea efectuada por el inventor o autor ", sin dar importancia a la existencia de registro de ninguna especie.

Sin duda que el verdadero problema puede ser determinar quién es el verdadero creador o inventor de un derecho de propiedad industrial, pero una vez determinado, queda sujeto a las leyes tributarias sobre el tema, independiente del registro. La determinación de quién es el verdadero creador o inventor parece del todo compleja, ya que es imposible ingresar al interior de las personas para saber quien tuvo primero una idea, sin embargo, si es posible determinar quién ha sido el primero en desarrollar un invento, utilizar una marca o explotar un derecho, cuestión que normalmente nos llevará a su verdadero creador.

Para ejemplificar sobre el problema, hemos analizado un par de ejemplos extremos. En un caso, pensamos en un restaurante llamado "La mejor comida catalana", correspondería a una marca irregistrable por descriptiva y carente de distintividad ${ }^{919}$. No

919 En Chile vulneraría el art. 20, letra e), de la Ley $N^{\circ}$ 19.039. En España, estaría afectado por el artículo $5^{\circ}$ b, de la Ley 17/2001, de 7 de diciembre, de Marcas. 
obstante, su creador ha invertido dinero en publicitar y afamar la marca, de suerte que podría ser la más afamada cadena de restoranes de un país. La marca financieramente constituiría un activo de la empresa y tendría un costo representado por sus gastos de creación y promoción; jurídicamente, se trata de un derecho de propiedad industrial extrarregistral. En esa medida, su venta estaría afecta a impuesto en Chile, al igual que 1 lo estaría en España de producirse allá la transacción. El costo de venta sería el valor contable y como utilidad, la diferencia entre éste y el precio de venta. Más aún, en el contexto de una cadena de restaurantes, sería un ingreso corriente del giro.

La existencia de derechos de propiedad industrial extrarregistrales es una realidad en el mundo entero, no obstante no siempre es conocida, de hecho, a modo de ejemplo, podemos ver como el Oficio SII, $N^{\circ} 144$, de diciembre de 1994, exige para autorizar la eliminación de un activo correspondiente a una marca comercial que el contribuyente acredite que "el valor de la marca comercial corresponde a una inversión efectiva y, además, pruebe que ha dejado de ser útil para la empresa mediante una certificación otorgada por la autoridad competente que declare que no ha sido renovada, o que ha sido caducada o abandonada en conformidad a las normas de la Ley $\mathrm{N}^{\mathrm{o}}$ 19.039". En el caso de un signo extrarregistral o de derechos sobre una patente registrada en el extranjero y no en Chile, por tanto no sujeto a las normas de la Ley $\mathrm{N}^{\circ}$ 19.039, conforme a lo dispuesto por el SII, jamás podría procederse al castigo o eliminación contable de los derechos, aunque su titular hubiese perdido un juicio reivindicatorio al respecto. Una disposición como la que pretende establecer por oficio el SII, sería posible para los derechos registrados, pero no respecto de los que tiene existencia extrarregistral. Tal como lo plantea el SII, desconocer el hecho que por no estar registrado un derecho de propiedad industrial no deja de ser un activo de la empresa, por el contrario, puede ser uno de los más preciados, con un costo económico y tributario perfectamente demostrable.

Otro ejemplo llevado al límite lo encontramos con una tienda de retail, "Homecenter". La marca ha recibido el reconocimiento de ser famosa y notoria y actualmente está registrada, pero por largo tiempo su registro fue sistemáticamente rechazado por la oficina chilena de propiedad industrial, por estimarla descriptiva de la cobertura que posee, tal es: artículos para el hogar. Mientras no estuvo registrada la marca era famosa y notoria, no obstante no tener registro. 
En algún momento Homedepot, el gigante del retail de los Estados Unidos quiso instalarse en Chile, supongamos que para entrar al país compra la marca Homecenter, no para usarla, sino que para evitar que la use la competencia, para ello, pacta que Homecenter puede continuar el giro, pero con otra marca. Para que funcione el ejemplo, además, llega a Chile El Corte Inglés, que no tiene contrato alguno que lo vincule con Homedepot, lo que unido al hecho que la marca Homecenter no está registrada, lo lleva a decidir usar la marca Homecenter. A poco andar, la marca comienza a ser usada por El Corte Inglés, que con grandes inversiones en publicidad logra posicionarse en el mercado usando el signo Homecenter. En este caso, la marca Homcenter comprada como resguardo por Homedepot, perdió su valor para Homedepot, porque la compraron como una estrategia para evitar que otro la use y eso no sucedió, desde el momento que El Corte Inglés la usa válidamente. En este caso, la marca es perfectamente un activo para ambas empresas (Homedepot y El Corte Inglés), pero en el caso de Homedepot ha perdido completamente su valor, de manera que no se ve inconveniente para que fuese castigada como activo, no obstante jamás podrá obtenerse el certificado que pretende el SII.

En el mismo orden de ideas puede suceder que, una empresa decida no registrar un invento, a fin de mantenerlo en secreto y evitar que pase al dominio público una vez terminado el período de protección. Si este conocimiento se filtra de la empresa y llega a manos de la competencia perderá completamente su valor económico y la empresa tributariamente no podrá jamás reconocer esta pérdida, porque no podrá obtener certificado alguno de la autoridad.

No obstante lo anterior, el oficio citado establece: "En la generalidad de los casos, una marca comercial representa una inversión, pero si con el devenir del tiempo pierde su valor económico, no representando ninguna inversión para su propietario, deberá castigarse su valor, de acuerdo a lo establecido en el artículo 31 de la Ley de la Renta". Este párrafo, representa la idea principal dentro del oficio, es decir, la posibilidad de castigar la inversión correspondiente a un derecho de propiedad industrial cuando ha perdido su valor económico, lo que nos parece acertado. Sin embargo, el problema se presenta cuando el SII pierde la perspectiva al intentar controlar esta operación, para ello exigió el correspondiente certificado de autoridad, olvidando que la naturaleza de la propiedad industrial permite que exista bajo otras formas que no 
constituyen registro, y como consecuencia, no puede obtenerse una declaración de autoridad que dé cuenta de la pérdida del valor económico de estos derechos. 


\section{VINCULACIÓN ENTRE ESPAÑA Y CHILE. ESPECIAL REFERENCIA AL ARTÍCULO XII DEL MODELO DE CONVENIO DE DOBLE IMPOSICIÓN DE LA OCDE}

\section{Introducción}

Hasta este momento, nuestro estudio ha consistido en la descripción de las normas que se refieren a la tributación de la propiedad intelectual tanto en Chile como en España, consideraciones que sin duda son útiles, sin embargo una cuestión relevante para nuestro estudio es también, cómo se relacionan estas dos jurisdicciones tributarias, respecto de la propiedad intelectual. No se trata del concepto de propiedad intelectual en sí mismo o de su naturaleza jurídica, sino de entrar a una definición más precisa y a la vez más práctica de la tributación del objeto de nuestro estudio, de manera que, buscamos poder deslindar entre los posibles conceptos y alternativas de negocios involucrados y sus alternativas de tributación, como por ejemplo: definir que incidencia tiene que se haga la cesión de los derechos de explotación versus la venta de los mismos o qué implicancia tiene estar frente al know-how o asistencia técnica, etc. Todo ello, con el objeto de establecer la tributación que corresponde a la distinta calificación jurídica que puede asumir una determinada situación de hecho y las consecuencias que se derivan en uno u otro país. Ahora bien, los límites que puede tener el estudio que acometemos son infinitos, en la medida que la creación humana no tienen límites y a su vez, es el motor de la propiedad intelectual, el objeto de nuestro estudio.

De poder dimensionar una medida para la creación humana, deberíamos también considerar todas las posibles alternativas de negocios que se pueden dar sobre estas creaciones, lo que haría crecer todos los parámetros; no obstante aquello, creemos que siempre será un aporte analizar la conexión entre las dos jurisdicciones que hemos analizado, de manera que permita acercar a colores de realidad, el análisis abstracto que hemos venido realizando.

Que los rendimientos de la propiedad intelectual sean constitutivos de renta, no es algo que debiera asombrar, puesto que naturalmente lo serán, no obstante, es frecuente que atendida la naturaleza de la fuente productora de estos rendimientos exista para ellos un régimen diferente. Así pues, tuvimos oportunidad de ver, que tanto en España como en Chile, los derechos de autor gozan de un régimen preferente, atendidas motivaciones de difusión de la cultura, y por su lado, el sistema de patentes se ve 
beneficiado con mecanismos promocionales y de estímulo, fundados en consideraciones de beneficio económico para la comunidad, todo lo cual, suele perfilar un régimen variopinto en la tributación respectiva.

Así pues, en propiedad intelectual lo que puede partir como una simple asesoría, puede llevar a involucrar cánones, una prestación de servicios o incluso rendimientos empresariales, y un poco más allá, también caben preguntas curiosas, si definimos que la asesoría es para una empresa de transporte aéreo o de contenedores, etc. En síntesis, no buscamos dramatizar, sino que dejar en claro que como cuestión metodológica, a fin de poder dar límites a nuestro estudio, hemos tomado como base de comparación entre Chile y España, el artículo 12 del MC OCDE, de manera que el análisis lo haremos a la luz de esta disposición y del convenio suscrito entre las dos naciones.

Para dar forma a lo que venimos diciendo, en este capítulo, primero desarrollaremos un ejemplo práctico, por cierto que sobre la base de supuestos muy simples, con el único objeto de graficar cuál es el común denominador económico del estudio y dimensionar su incidencia en el asunto, seguidamente analizaremos el artículo $12 \mathrm{MC}$ OCDE y finalmente, nos haremos cargo del tratado suscrito entre España y Chile, a fin de entregar el contenido conceptual para nuestro trabajo.

\section{Ejemplo sobre alternativas de tributación de una licencia en Chile y España}

El objetivo de trabajar un ejemplo es mostrar gráficamente las preguntas que motivaron nuestro estudio y hacer más práctica nuestra investigación. En este orden de ideas, consideramos la tributación bajo una única jurisdicción tributaria (tributación nacional normal) y bajo más de una jurisdicción (doble tributación internacional ${ }^{920}$ ), en escenarios con y sin normas para evitar la doble imposición. Tal como venimos anticipando, se trata de un ejemplo muy simplificado, puesto que sería imposible abordar todas las situaciones de hecho bajo las cuales se pueden producir o explotar rendimientos de la propiedad intelectual.

En nuestro caso de laboratorio, primero analizaremos la situación de un contribuye residente fiscal en España y luego de uno residente fiscal en Chile, en ambos casos los supuestos serán los mismos.

${ }^{920}$ Como es lógico el centro de nuestra atención será la doble tributación internacional entre Chile y España, revisando otras alternativas sólo de manera accidental. 


\subsection{Contribuyente residente fiscal en España}

Hemos ideado un ciudadano español (Paco), persona natural, que desarrolló una máquina en el garaje de su casa. Se trata de dos dispositivos que ubicados en una posición remota el uno del otro, permiten transportar energía eléctrica hasta una distancia de $500 \mathrm{kms}$, sin cables y sin pérdida de energía en el transporte. Los costes totales del desarrollo fueron $€ 500$. Paco ha registrado la invención en España ${ }^{921}$ y en Chile ${ }^{922}$. Paco no quiere preocuparse de la construcción o comercialización de los dispositivos, ni de nada que tenga que ver con la explotación comercial de la invención, de manera que solamente está dispuesto a licenciar la tecnología para que otros construyan los aparatos y los vendan, como consecuencia de ello, podemos saber que no tendrá ningún otro coste en el futuro asociado a su invención, salvo las anualidades de la patente $\mathrm{u}$ otros desarrollos que puedan dar origen a nuevas invenciones.

Así las cosas, analizaremos algunas alternativas que posee Paco para la explotación de su invención, al respecto, veremos qué pasa si:

a) Otorga una licencia por un año a una empresa española, que le pagará un canon o regalía de $€ 10.000$ por año.

b) Otorga una licencia por un año a una empresa chilena, residente fiscal en Chile, que le pagará un canon o regalía de $€ 10.000$ por año.

c) Otorga una licencia por un año a una empresa extranjera ubicada en Paraguay, residente fiscal en Paraguay, que le pagará un canon o regalía de $€ 10.000$ por año.

Por otra parte, veremos qué pasa si Paco aporta la patente a una sociedad de responsabilidad limitada, creada con su mujer e hijos (mayores de edad).

\subsubsection{Otorga licencias como persona natural}

En la primera hipótesis que nos hemos puesto, Paco decide licenciar los derechos sobre su patente, en su calidad de persona natural. En los dos supuestos planteados, vamos a considerar que Paco no va a llevar a cabo la ordenación por cuenta propia de los factores de producción con la finalidad de intervenir en la producción o

921 OEPM Oficina Española de Patentes y Marcas.

922 INAPI Instituto Nacional de la Propiedad Industrial. 
distribución de la maquinaria (en cuyo caso, tributaría como rendimientos de actividades económicas).

La situación sería como sigue:

a) Si Paco otorga una licencia por un año a una empresa española, que le pagará un canon o regalía de $€ 10.000$ por año, el impuesto que se devenga es el IRPF, que conforme al artículo 25.4 de la Ley 35/2006, de 28 de noviembre, del Impuesto sobre la Renta de las Personas, tendrá la consideración de rendimiento de capital mobiliario y quedará gravado en el impuesto en la base imponible del ahorro a un tipo del 19\% sobre los primeros 6.000 euros y el resto (4.000 euros en este ejemplo) al 21\%. Para nuestro ejemplo, suponiendo que Paco no tiene otros ingresos, el coste fiscal ascendería a 1.980 euros, que resultaría un tipo medio efectivo de gravamen del 19,8\%. Además, este tipo de rendimientos no tienen derecho a deducir los gastos necesarios para su obtención, si bien podrían reducirse en un $40 \%$ si se hubieran generado en un periodo superior a dos años (artículo 26 de la Ley del IRPF). Aquí obviamente no hay ningún problema de doble imposición.

b) Si Paco opta por entregar una licencia por un año a una empresa chilena, residente fiscal en Chile, que le pagará un canon o regalía de $€ 10.000$ por año, la situación anterior cambia, básicamente porque se comprometen dos jurisdicciones tributarias sobre el mismo canon. En efecto la sociedad chilena, pagará los $€ 10.000$, monto sobre el cual deberá retener la tasa del impuesto Adicional ${ }^{923}$. Como ya explicamos antes en el desarrollo de nuestro estudio, existe una confusión del legislador chileno en el artículo 59 de la Ley de la Renta (impuesto Adicional), puesto que aplica al mismo hecho gravado, tal es patentes, una tasa de 30\% y a reglón seguido la cambia por un $15 \%{ }^{924}$. Afortunadamente para Paco, el problema no se le presentará porque conforme al artículo 12, 2. b) del Convenio entre Chile y España ${ }^{925}$, la tasa de retención

\footnotetext{
${ }^{923}$ Impuesto Adicional es el nombre que recibe el impuesto a la renta de no residentes. Debe su nombre a que está "adicionado" dentro de la ley de la renta.

${ }^{924}$ Este problema lo tratamos en detalle al hablar del impuesto Adicional, en el punto 3.1.4.4.

${ }^{925}$ El nombre oficial del convenio es: "Convenio entre el Reino de España y la República de Chile para evitar la doble imposición y prevenir la evasión fiscal en materia de impuestos sobre la renta y sobre el patrimonio". El documento fue firmado por las autoridades competentes el día 7 de Julio de 2003 en Madrid y fue publicado en el Diario Oficial del 24 de enero de 2004. El Convenio entró en vigor el 22 de diciembre de 2003 y se aplica con respecto a los impuestos sobre las rentas que se obtengan y a las cantidades que se paguen, abonen en cuenta, se pongan a disposición o se contabilicen como gasto, a partir del 1 de enero del año 2004.
} 
en fuente está limitada al 10\%. De manera que Paco recibirá la suma de $€ 9.000$ netos, después de haberle retenido 1.000 euros el pagador en Chile.

En España, Paco deberá declarar en su declaración del IRPF el importe total del canon como rendimientos de capital mobiliario, es decir, los 10.000 euros al igual que en el supuesto anterior, tributando al 19 y $21 \%$ sobre este importe. Por otra parte, Paco tendrá derecho aplicar Deducción por Doble Imposición Internacional (regulada en el artículo 80 de la Ley del IRPF) por los $€ 1.000$ de impuestos pagados en Chile. Así, la normativa española le permite deducirse de la cuota líquida la menor de las cantidades siguientes:

1) El importe efectivo de lo satisfecho en Chile, esto es, $€ 1.000$.

2) El resultado de aplicar el tipo medio efectivo de gravamen a la parte de la base liquidable gravada en el extranjero. En este caso, vimos que el tipo medio efectivo de gravamen para Paco era del 19,8\%, que aplicado sobre los 10.000 euros resulta un importe de 1.980 euros.

Como el importe pagado en Chile resulta menor que el de aplicar la segunda regla, será ese el importe (€1.000) el que podrá deducirse de la cuota. Así, Paco deberá pagar en España un importe de 1.980 euros, resultado de aplicar los tipos de gravamen de las rentas del ahorro sobre el canon, menos 1.000 euros que podrá deducirse en cuota, evitando así la doble imposición entre ambos países. De ahí derivaría para Paco una tributación en Chile de 1.000 euros y una tributación en España de 980 euros, con lo cual habría tenido la misma presión fiscal que si hubiera cedido su patente a una persona o entidad española.

c) Otorga una licencia por un año a una empresa extranjera ubicada en Paraguay, residente fiscal en Paraguay ${ }^{926}$, que le pagará un canon o regalía de $€ 10.000$ por año. Sobre el monto del pago la empresa retendrá la suma de $€ 1.500$ con tasa del $15 \%$, según se establece en el artículo 20 de la Ley $N^{\circ}$ 2421/04, de Reordenamiento

${ }^{926}$ Entre España y Paraguay no hay convenio de doble imposición, así que aplican propiamente las normas de tributación nacional de cada país. 
Administrativo y de Adecuación Fiscal del Paraguay ${ }^{927}$. De manera que Paco recibirá la suma de $€ 8.500$ netos después de haber pagado impuestos en Paraguay.

Al igual que en el segundo supuesto, en España Paco deberá declarar en su declaración del IRPF el importe total del canon como rendimientos de capital mobiliario, es decir, los 10.000 euros, tributando al 19 y $21 \%$ sobre este importe, si bien tendrá derecho aplicar Deducción por Doble Imposición Internacional (regulada en el artículo 80 de la Ley del IRPF) por los $€ 1.500$ de impuestos pagados en Paraguay. Así, la normativa española le permite deducirse de la cuota líquida al menos las cantidades siguientes:

1) El importe efectivo de lo satisfecho en Paraguay, esto es, 1.500 euros

2) El resultado de aplicar el tipo medio efectivo de gravamen a la parte de la base liquidable gravada en el extranjero. En este caso, vimos que el tipo medio efectivo de gravamen para Paco era del 19,8\%, que aplicado sobre los 10.000 euros resulta un importe de 1.980 euros.

Como el importe pagado en Paraguay resulta menor que el de aplicar la segunda regla, será ese el importe (1.500 euros) el que podrá deducirse de la cuota. Así, Paco deberá pagar en España un importe de 1.980 euros, resultado de aplicar los tipos de gravamen de las rentas del ahorro sobre el canon, menos 1.500 euros que podrá deducirse en cuota, evitando así la doble imposición entre ambos países. De ahí derivaría para Paco una tributación en Paraguay de 1.500 euros y una tributación en

${ }^{927}$ El artículo 20 de la Ley N 2421/04, establece: “Art. 20.- Tasas.

1) La tasa general del Impuesto será del $20 \%$ (veinte por ciento) para el primer año de vigencia de la presente Ley y del 10\% (diez por ciento) a partir del segundo año, sobre las utilidades.

2) Cuando las utilidades fueren distribuidas, se aplicará adicionalmente la tasa del 5\% (cinco por ciento) a partir del segundo año de la vigencia de la presente Ley, sobre los importes netos acreditados o pagados, el que fuere anterior, a los dueños, socios o accionistas. Las utilidades destinadas a la cuenta de reserva legal, o a reservas facultativas o a capitalización no estarán sujetas al impuesto establecido en este numeral.

3) La casa matriz, sus socios o accionistas, domiciliados en el exterior deberán pagar el impuesto correspondiente a las utilidades o dividendos acreditadas por las sucursales, agencias o establecimientos situados en el país, aplicando la tasa del 15\% (quince por ciento) sobre los importes netos acreditados, pagados o remesados, de ellos el que fuere anterior. Las utilidades destinadas a la cuenta de reserva legal, a reservas facultativas o a capitalización no estarán sujetas al impuesto establecido en este numeral.

4) Las personas domiciliadas o entidades constituidas en el exterior con o sin sucursal, agencia o establecimiento situados en el país determinarán el impuesto aplicando la suma de las tasas previstas en los numerales 1), 2) y 3) sobre las rentas obtenidas, independientemente de las mencionadas agencias, sucursales o establecimientos". 
España de 480 euros, con lo cual habría tenido la misma presión fiscal que si hubiera cedido su patente a una persona o entidad española o chilena.

Tal como opera la norma española, Paco sólo aumentará su presión fiscal real, cuando el tipo que le corresponda en España sea inferior a la retención efectuada en el extranjero.

\subsubsection{Otorga licencias como sociedad de responsabilidad limitada}

En la segunda hipótesis que nos hemos puesto, Paco ha cedido todos los derechos sobre la patente a Paco y familia SRL, que actualmente es titular de la patente, por lo que las licencias son otorgadas por esa persona jurídica. El aporte de la patente se valorizó en su costo de $€ 500$, su mujer aportó $€ 300$ en efectivo y cada uno de sus dos hijos $€ 100$, quedando la participación de cada quien en un 50,30, 10 y 10 por ciento, respectivamente.

En España, la aportación de una patente a una sociedad deberá realizarse por su valor de mercado atendiendo a lo dispuesto en el artículo 37.1.d de la Ley del IRPF, por lo que se pondría de manifiesto en sede de la persona física aportante (en este caso, Paco) una ganancia patrimonial por la diferencia entre el valor de adquisición (500 euros) y el valor de mercado de la patente (para nuestro ejemplo hemos considerado un valor de mercado de 50.000 euros), quedando gravada entre el 19 y el $21 \%$, resultando una cuota de 10.275 euros.

Para esta alternativa analizaremos las mismas hipótesis de inversión que como persona natural. El ejemplo queda de la siguiente manera:

a) Si Paco y familia SRL otorga una licencia por un año a una empresa española, que le pagará un canon o regalía de $€ 10.000$ por año, el impuesto que se devenga es el Impuesto de Sociedades (IS), que conforme a la Disposición Adicional Octava del Real Decreto Legislativo 4/2004, de 5 de marzo, por el que se aprueba el Texto Refundido de la Ley del Impuesto sobre Sociedades, actualmente gravado al tipo general del 30\%. Para nuestro ejemplo, suponiendo que Paco y familia SRL no tiene otros ingresos, a fin de año habrá reconocido como gasto solamente la tasa de transferencia de la patente desde Paco a la empresa, tanto en Chile como en España y los gastos del agente de 
propiedad industrial, que para nuestro ejemplo los suponemos en $€ 1.000$, de manera que la utilidad líquida para efectos de impuestos será de $€ 9.000$.

En España los derechos de propiedad industrial se consideran activos intangibles y pueden amortizarse anualmente si su vida útil tiene un límite temporal. En este caso, al ser una patente con un límite temporal, debemos contemplar un gasto de amortización del $10 \%$ anual del valor de la patente, esto es, 5.000 euros. Por todo ello, la liquidación del impuesto sería como sigue:

\begin{tabular}{|l|l|}
\hline Ingresos & 10.000 euros \\
\hline Gastos & $(1.000)$ euros \\
\hline Amortización & $(5.000)$ euros \\
\hline Base Imponible & 4.000 euros \\
\hline Tipo de gravamen & $30 \%$ \\
\hline Cuota íntegra & 1.200 euros \\
\hline Beneficios después de impuestos & 2.800 euros \\
\hline
\end{tabular}

Posteriormente, pueden darse dos alternativas, (i) que las utilidades no sean retiradas de la empresa y sean utilizadas en investigación y gastos de la propia empresa, en cuyo caso, no habrá una nueva imposición que atender. Y (ii) otra posibilidad es que la sociedad reparta los beneficios a los socios, quienes las deberían declarar en sus propias declaraciones del IRPF, quedando la tributación como sigue, según el tramo de impuesto que correspondería a cada quien: Paco retiró un 50\% de las utilidades por $€$ 1.400, tributando 266 euros; a su mujer se le entregó el 30\% de las utilidades (840 euros), por lo que le corresponde una de 159,60 euros; y cada uno de sus hijos ${ }^{928}$ recibió un $10 \%$ del beneficio (280 euros), teniendo que tributar en su IRPF por 53,20 euros.

En este último supuesto, no cabe la posibilidad de que los socios personas físicas apliquen ningún tipo de mecanismo para evitar la doble imposición, si bien en España la normativa prevé una exención individual de 1.500 euros anuales (artículo 7.y de la Ley del IRPF), por lo que si Paco y su familia no hubieran recibido más dividendos que los obtenidos por esta sociedad, quedarían exentos de tributación al no alcanzar en ningún caso el límite cuantitativo. Así pues, aquí hay una gran diferencia con Chile, antes y después de la reforma de septiembre de 2014, puesto que en Chile, siempre el impuesto pagado a nivel de sociedad es un pago a cuenta del impuesto personal.

\footnotetext{
${ }^{928}$ Hemos supuesto que los hijos son mayores de edad y no tienen otros ingresos.
} 
b) Si Paco y familia SRL otorga una licencia por un año a una empresa chilena, residente fiscal en Chile, que le pagará un canon o regalía de $€ 10.000$ por año, la situación anterior cambia, básicamente porque se comprometen dos jurisdicciones tributarias sobre el mismo canon. En efecto la sociedad chilena, pagará los $€ 10.000$, monto sobre el cual deberá retener la tasa del impuesto Adicional ${ }^{929}$, cuyo tipo, según hemos visto está limitado en la fuente al 10\%, conforme al artículo 12, 2. b) del convenio de doble imposición entre Chile y España ${ }^{930}$. De manera que Paco y familia SRL recibirá la suma neta de $€ 9.000$. Sin embargo, el importe que deberá reconocer en su declaración del IS es el importe total, es decir, los 10.000 euros. Contando con que no posee otros ingresos, deberán descontar los gastos y la amortización, quedando la base imponible igual que en el caso anterior, es decir, 4.000 euros. El tipo sería del $30 \%$, como hemos apuntado anteriormente, quedando una cuota de 1.200 euros. Por su parte los $€ 1.000$ pagados en Chile, se podrán deducir de la cuota resultante en concepto de deducción por doble imposición internacional (artículo 31 del TRLIS), de manera que se neutralizaría la doble imposición producida por las dos jurisdicciones fiscales. A este respecto, no podemos pasar por alto, lo que ya vimos, en el sentido que la normativa española permite deducir de la cuota íntegra la menor de las cantidades siguientes:

- El importe del impuesto efectivamente satisfecho en el extranjero (1.000 euros)

- El importe de la cuota íntegra que hubiese resultado de haber obtenido las rentas en territorio español. En este sentido, debe tenerse en cuenta que hay que computar los ingresos y los gastos según la normativa contable y fiscal vigente en España (como veremos a continuación, el impuesto ascendería a 1.200 euros). Así, la liquidación sería como sigue:

\begin{tabular}{|l|l|}
\hline Ingresos & 10.000 euros \\
\hline Gastos & $(1.000)$ euros \\
\hline Amortización & $(5.000)$ euros \\
\hline Base Imponible & 4.000 euros \\
\hline Tipo de gravamen & $30 \%$ \\
\hline Cuota íntegra & 1.200 euros \\
\hline Deducción Doble Imposición & -1.000 euros \\
\hline Cuota líquida & $\frac{200 \text { euros }}{2.800 \text { euros }}$ \\
\hline Beneficios después de impuestos & 2.800 \\
\hline
\end{tabular}

\footnotetext{
${ }^{929}$ Ver nota anterior.

${ }^{930}$ Ver nota anterior.
} 
Posteriormente, al igual que en caso anterior, pueden darse dos alternativas, (i) que las utilidades no sean retiradas de la empresa y sean utilizadas en investigación y gastos de la propia empresa, en cuyo caso, no habrá una nueva imposición que atender. Y (ii) otra posibilidad es que la sociedad reparta los beneficios a los socios, quienes las deberían declarar en sus propias declaraciones del IRPF, quedando la tributación, según los tramos que afectan a cada quien, como sigue: Paco retiró un $50 \%$ de las utilidades por $€ 1.400$, tributando 266 euros; a su mujer se le entregó el 30\% de las utilidades ( 840 euros), por lo que le corresponde una de 159,60 euros; y cada uno de sus hijos ${ }^{931}$ recibió un $10 \%$ del beneficio (280 euros), teniendo que tributar en su IRPF por 53,20 euros.

c) La última alternativa que hemos querido explorar es que la licencia por un año se otorga a una empresa extranjera ubicada en Paraguay, residente fiscal en Paraguay ${ }^{932}$, país con el que España no tiene suscrito convenio para evitar la doble imposición, que le pagará un canon o regalía de $€ 10.000$ por año. Sobre el monto del pago la empresa retendrá la suma de $€ 1.500$ con tasa del $15 \%$, según se establece en el artículo 20 de la Ley $\mathrm{N}^{\circ}$ 2421/04, de Reordenamiento Administrativo y de Adecuación Fiscal del Paraguay $^{933}$. De manera que Paco y familia SRL recibirá la suma neta de $€ 8.500$, Sin embargo, el importe que deberá reconocer en su declaración del IS es el importe total, es decir, los 10.000 euros. Contando con que no posee otros ingresos, deberán descontar los gastos y la amortización, quedando la base imponible igual que en el caso anterior, es decir, 4.000 euros. El tipo sería del 30\%, como hemos apuntado anteriormente, quedando una cuota de 1.200 euros. Por su parte los $€ 1.500$ pagados en Paraguay, se podrán deducir de la cuota resultante en concepto de deducción por doble imposición internacional (artículo 31 del TRLIS), con las limitaciones que vimos en el ejemplo anterior. En esta ocasión, el impuesto pagado en Paraguay sería superior a la cantidad que se debería haber pagado en España, por lo que no podrá deducirse la totalidad. Así, la liquidación sería como sigue:

\begin{tabular}{|l|l|}
\hline Ingresos & 10.000 euros \\
\hline Gastos & $(1.000)$ euros \\
\hline Amortización & $(5.000)$ euros \\
\hline Base Imponible & 4.000 euros \\
\hline Tipo de gravamen & $30 \%$ \\
\hline Cuota íntegra & 1.200 euros \\
\hline
\end{tabular}

\footnotetext{
${ }^{931}$ Hemos supuesto que los hijos son mayores de edad y no tienen otros ingresos.

${ }^{932}$ Ver nota anterior.

933 Ver nota anterior.
} 


\begin{tabular}{|l|l|}
\hline Deducción Doble Imposición & $(1.200)$ euros \\
\hline Cuota líquida & 0 euros \\
\hline Beneficios después de impuestos & 2.500 euros \\
\hline
\end{tabular}

Posteriormente, al igual que en caso anterior, pueden darse dos alternativas, (i) que las utilidades no sean retiradas de la empresa y sean utilizadas en investigación y gastos de la propia empresa, en cuyo caso, no habrá una nueva imposición que atender. Y (ii) otra posibilidad es que la sociedad reparta los beneficios a los socios, quienes las deberían declarar en sus propias declaraciones del IRPF, quedando la tributación, según el tramo que afecte a cada quien, como sigue: Paco retiró un 50\% de las utilidades por $€$ 1.250, tributando 237,50 euros; a su mujer se le entregó el 30\% de las utilidades (750 euros), por lo que le corresponde una de 142,5 euros; y cada uno de sus hijos ${ }^{934}$ recibió un $10 \%$ del beneficio ( 250 euros), teniendo que tributar en su IRPF por 47,50 euros.

En ninguno de los supuestos anteriores, hemos tenido en consideración la posibilidad de aplicar la reducción del $60 \%$ de la renta procedente de la cesión de la patente recogida en el artículo 23 del TRLIS, ya que se incumple uno de los requisitos esenciales, y es que la sociedad no habría sido la creadora del invento.

Asimismo, tampoco hemos contemplado la posibilidad de aplicar la deducción por actividades de investigación y desarrollo e innovación tecnológica recogida en el artículo 35 del TRLIS por la adquisición de la patente, ya que la norma excluye a aquellos casos en los que la adquisición se haya realizado a una persona vinculada, como es nuestro caso.

\subsection{Contribuyente residente fiscal en Chile}

Los supuestos en este caso son los mismos que en el anterior, solamente cambiamos la residencia fiscal y la localización del sujeto de nuestro ejemplo, así las cosas, se trata de un ciudadano chileno (Caupolicán), persona natural, que desarrolló una máquina en el garaje de su casa. Son dos dispositivos que ubicados en una posición remota el uno del otro, permiten transportar energía eléctrica hasta una distancia de $500 \mathrm{kms}$, sin cables y sin pérdida de energía en el transporte. Los costos totales del desarrollo fueron $\$ 500.000$ (pesos chilenos). Caupolicán ha registrado la invención en España y en Chile, no quiere preocuparse de la construcción o comercialización de los

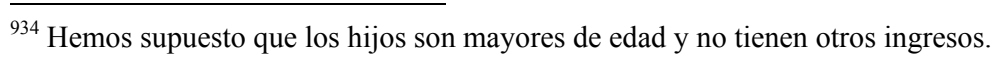


dispositivos, ni de nada que tenga que ver con la explotación comercial de la invención, de manera que solamente está dispuesto a licenciar la tecnología para que otros construyan los aparatos y los vendan, como consecuencia de ello, podemos saber que no tendrá ningún otro coste en el futuro asociado a su invención, salvo las anualidades de la patente $\mathrm{u}$ otros desarrollos que puedan dar origen a nuevas invenciones.

En Chile debemos hacer una primera distinción, puesto que no está del todo claro si las rentas por cánones de una patente estarían obligadas a tributar como rentas empresariales o personales. La LIR, divide las rentas en dos grandes grupos, que llama "Categorías" "935, en la Primera Categoría ubica a las rentas del capital y de las empresas comerciales, industriales, mineras y $\operatorname{otras}^{936}$ y la Segunda Categoría considera a las rentas del trabajo ${ }^{937}$. Normalmente encontramos a estas rentas bajo la estructura de

${ }^{935}$ Ver Preguntas Frecuentes del SII. Disponible en Internet en: http://www.sii.cl/preguntas frecuentes/renta/001 002 1711.htm (15 Jul 2013).

936 El artículo 20 de la LIR, señala: "Establécese un impuesto de $20 \%$ que podrá ser imputado a los impuestos global complementario y adicional de acuerdo con las normas de los artículos $56, \mathrm{~N}^{\mathrm{o}} 3 \mathrm{y}$ 63. Este impuesto se determinará, recaudará y pagará sobre:

$1^{\circ}$.- La renta de los bienes raíces en conformidad a las normas siguientes $(\ldots)$

$2^{\circ}$.- Las rentas de capitales mobiliarios consistentes en intereses, pensiones o cualesquiera otros productos derivados del dominio, posesión o tenencia a título precario de cualquiera clase de capitales mobiliarios, sea cual fuere su denominación, y que no estén expresamente exceptuados, incluyéndose las rentas que provengan de:

a) Bonos y debentures o títulos de crédito (...);

b) Créditos de cualquier clase, incluso los resultantes de operaciones de bolsas de comercio;

c) Los dividendos y demás beneficios derivados del dominio, posesión o tenencia a cualquier título de acciones de sociedades anónimas extranjeras, que no desarrollen actividades en el país, percibidos por personas domiciliadas o residentes en Chile;

d) Depósitos en dinero, ya sea a la vista o a plazo;

e) Cauciones en dinero;

f) Contratos de renta vitalicia, y

g) Instrumentos de deuda de oferta pública a que se refiere el artículo 104, las que se gravarán cuando se hayan devengado. (...)

$3^{\circ}$.- Las rentas de la industria, del comercio, de la minería y de la explotación de riquezas del mar y demás actividades extractivas, compañías aéreas, de seguros, de los bancos, asociaciones de ahorro y préstamos, sociedades administradoras de fondos mutuos, sociedades de inversión o capitalización, de empresas financieras y otras de actividad análoga, constructora, periodísticas, publicitarias, de radiodifusión, televisión, procesamiento automático de datos y telecomunicaciones.

$4^{\circ}$.- Las rentas obtenidas por corredores, sean titulados o no, sin perjuicio de lo que al respecto dispone el $\mathrm{N}^{\circ} 2$ del artículo 42, comisionistas con oficina establecida, martilleros, agentes de aduana, embarcadores y otros que intervengan en el comercio marítimo, portuario y aduanero, y agentes de seguro que no sean personas naturales; colegios, academias e institutos de enseñanza particular y otros establecimientos particulares de este género; clínicas, hospitales, laboratorios y otros establecimientos análogos particulares y empresas de diversión y esparcimiento.

$5^{\circ}$.- Todas las rentas, cualquiera que fuera su origen, naturaleza o denominación, cuya imposición no esté establecida expresamente en otra categoría ni se encuentren exentas.

$6^{\circ}$.- Los premios de lotería (...)".

937 El artículo 42 de la LIR, señala: "Se aplicará, calculará y cobrará un impuesto en conformidad a lo dispuesto en el artículo 43, sobre las siguientes rentas:

$1^{\circ}$.- Sueldos, sobresueldos, salarios, premios, dietas, gratificaciones, participaciones y cualesquiera otras asimilaciones y asignaciones que aumenten la remuneración pagada por servicios personales, 
contribuyentes de la primera categoría, actuando como empresas, puesto que será una opción más conveniente al permitir contabilidad, lo que incluye depreciación, imputación de gastos, etc. La base imposible resultante estará sometida a una tasa de $20 \%{ }^{938}$ y lo más destacable era hasta septiembre de 2014 la posibilidad de llevar FUT $^{939}$.

En la LIR, además de los impuestos por categorías, existe un segundo nivel de tributación, al que sólo están sometidas las personas naturales, es el impuesto del Título III de la LIR, Del Impuesto Global Complementario ${ }^{940}$. Bajo estos dos niveles de tributación, el segundo nivel se activa solamente cuando el contribuyente de primera categoría retira la utilidad de la empresa y se la lleva para su consumo personal, activando el llamado Impuesto Global Complementario ${ }^{941}$, que grava las rentas de las personas naturales bajo la idea de concentrar en un único impuesto la totalidad de sus

montepíos y pensiones, exceptuadas las imposiciones obligatorias que se destinen a la formación de fondos de previsión y retiro, y las cantidades percibidas por concepto de gastos de representación. (...) $2^{\circ}$.- Ingresos provenientes del ejercicio de las profesiones liberales o de cualquiera otra profesión u ocupación lucrativa no comprendida en la primera categoría ni en el número anterior, incluyéndose los obtenidos por los auxiliares de la administración de justicia por los derechos que conforme a la ley obtienen del público, los obtenidos por los corredores que sean personas naturales y cuyas rentas provengan exclusivamente de su trabajo o actuación personal, sin que empleen capital, y los obtenidos por sociedades de profesionales que presten exclusivamente servicios o asesorías profesionales.

Para los efectos del inciso anterior se entenderá por "ocupación lucrativa" la actividad ejercida en forma independiente por personas naturales y en la cual predomine el trabajo personal basado en el conocimiento de una ciencia, arte, oficio o técnica por sobre el empleo de maquinarias, herramientas, equipos u otros bienes de capital. (...)".

938 Art. 20, DL N 824, de 1974, Ley de la Renta.

939 Tal como hemos explicado antes, en el régimen vigente hasta septiembre de 2014 en Chile, la tributación de quienes lleven renta efectiva permitía la postergación de los impuestos personales, registrando las utilidades en un registro que se denomina FUT. El FUT es el Fondo de Utilidades Tributables (decimos es y no era, porque permanece vigente hasta quienes tengan FUT lo consuman totalmente), básicamente consiste en un registro de las utilidades producidas a nivel de empresa (entendiendo por tal, toda organización que no sea persona natural y que tribute según renta efectiva) y de los impuestos que estas empresas han pagado a ese nivel. Si el empresario no retira los dineros de la empresa la tributación se agota con la tasa pagada a ese nivel y la tributación del empresario queda en suspenso. Sólo cuando el empresario retire estas utilidades, se produce la rebaja del FUT y ese retiro es asumido como una utilidad retirada que va al impuesto del empresario persona natural, donde opera una tasa progresiva del 0 al $40 \%$, hasta septiembre de 2014 y llegará a unos tipos de 0 a $35 \%$ después de la reforma, teniendo siempre derecho a acreditar contra su impuesto personal, aquel pagado a nivel de empresa. Lo característico del FUT es que como representa la integración tributaria, puede dar lugar a la devolución del impuesto pagado a nivel de empresa, si es que a nivel de persona natural resulta afecto a una tasa menor. Además, debe hacerse presente que el FUT no prescribe jamás, de manera que las pérdidas pueden compensarse indefinidamente hacia el futuro. Tal como también explicamos previamente, después de la reforma de septiembre de 2014, existen dos sistemas uno de ellos llamado de "renta atribuida" y el otro "sistema parcialmente integrado", en esencia ambos mantiene la integración del impuesto a la renta entre empresa y personas naturales, radicando el impuesto a nivel de persona natural, con la diferencia que en el modelo parcialmente integrado, el monto de lo considerado como pago a cuenta no es la totalidad del impuesto pagado a nivel de empresa.

940 Art. 52 y sgtes. de la LIR.

941 Comúnmente conocido como "global". 
rentas, con una tasa progresiva de 0 a $40 \%$. La particularidad del sistema es que los impuestos pagados a nivel de categoría, son siempre crédito contra el impuesto del Global Complementario, así, el efecto significativo se produce considerando las rentas de la primera categoría, puesto que su tipo es fijo a $20 \%$, resultando entonces que comparado con el impuesto Global Complementario puede ser mayor o menor, si el impuesto Global Complementario tributa a una tipo mayor, el contribuyente deberá pagar la diferencia entre el 20\% pagado y el tipo definitivo; si el tipo es menor, tendrá derecho a devolución de la diferencia. En cambio, el tipo del impuesto de segunda categoría está calzado con el del Global Complementario, por lo que salvo la adición de otras rentas, no habrá diferencia en la carga tributaria.

La duda sobre si las rentas provenientes de un royalty debiesen ser tributadas en primera o segunda categoría, surgen porque en ninguna parte en el artículo 20, ni en el 42 de la LIR, se hace referencia expresa a estas rentas, las que según los antecedentes de nuestro ejemplo, podrían ser parte del artículo $20 \mathrm{~N}^{\circ} 5$ de la LIR, que señala: "Todas las rentas, cualquiera que fuera su origen, naturaleza o denominación, cuya imposición no esté establecida expresamente en otra categoría ni se encuentren exentas", y también podrían considerarse en el artículo $42 \mathrm{~N}^{\circ} 2$ de la LIR, al someter a su imperio los: "[i]ngresos provenientes del ejercicio de las profesiones liberales o de cualquiera otra profesión u ocupación lucrativa no comprendida en la primera categoría ni en el número anterior (...) se entenderá por "ocupación lucrativa" la actividad ejercida en forma independiente por personas naturales y en la cual predomine el trabajo personal basado en el conocimiento de una ciencia, arte, oficio o técnica por sobre el empleo de maquinarias, herramientas, equipos u otros bienes de capital”.

Como sabemos, Caupolicán desarrolló su invento en el garaje de su casa, básicamente fundado en los conocimientos de su ciencia, arte u oficio, lo que daría lugar a clasificar las rentas de la patente obtenida con ese esfuerzo en la segunda categoría, conforme al artículo $42 \mathrm{~N}^{\circ} 2$ de la LIR; sin embargo, también es sostenible que debiese aplicarse el artículo $20 \mathrm{~N}^{\circ} 5$, en cuanto conforma un cajón de sastre en el que caben todas las rentas no especificadas en otra parte, cuyo es el caso de los royalties, hipótesis en la que debería tributar en primera categoría.

Al fin y al cabo, como no es una cuestión que sea útil para nuestro estudio, puesto que sólo queremos mostrar las diferencias numéricas que pueden dar las distintas 
calificaciones que se dé a la renta, la discusión lejos de ser un problema, contribuye a nuestros objetivos, de manera que ejemplificaremos considerando a Caupolicán como persona natural, tributando en primera y segunda categoría.

Para hacer comparable nuestro ejemplo, pondremos a Caupolicán ante las mismas hipótesis de hecho que sometimos a Paco.

\subsubsection{Otorga licencias como persona natural}

En una primera hipótesis Caupolicán decide licenciar los derechos sobre su patente, en su calidad de persona natural, para lo cual, analizamos:

a) Si Caupolicán otorga una licencia por un año a una empresa chilena, que le pagará un canon o regalía de $\$ 10.000 .000$ por año, el impuesto que se devenga es el Impuesto a la Renta ${ }^{942}$, tal como explicamos la duda se plantea sobre si deberá tributar en primera o en segunda categoría, por lo que haremos el ejemplo, considerando ambas hipótesis:

\begin{tabular}{|c|c|c|}
\hline Ítem & Primera Categoría & Segunda Categoría \\
\hline $\begin{array}{l}\text { Renta, consistente en el valor } \\
\text { del canon de la licencia }\end{array}$ & $\$ 10.000 .000 .-$ & $\$ 10.000 .000 .-$ \\
\hline Gasto aceptado por la ley & $\$ 500.000 .-$ & No aplica en este momento \\
\hline Base imponible & $\$ 9.500 .000 .-$ & $\$ 10.000 .000 .-$ \\
\hline $\begin{array}{l}\text { Impuesto de primera categoría. } \\
\text { Tipo } 20 \%\end{array}$ & $\$ 1.900 .000 .-$ & No hay \\
\hline Saldo FUT & $\begin{array}{l}\text { Utilidad por } \$ 7.600 .000 \text {, con } \\
\text { un crédito del } 20 \% \text { por } \$ \\
1.900 .000 .-\end{array}$ & No hay \\
\hline \multicolumn{3}{|c|}{ Impuesto Global Complementario } \\
\hline $\begin{array}{l}\text { Aplica el impuesto global } \\
\text { complementario en abril de } \\
\text { cada año }\end{array}$ & Al retirar la utilidad & $\begin{array}{l}\text { Siempre se consideran retiradas } \\
\text { las utilidades }\end{array}$ \\
\hline Gastos & $\begin{array}{l}\text { No procede porque ya se } \\
\text { descontaron a nivel de } \\
\text { primera categoría }\end{array}$ & $\begin{array}{l}\text { Tiene derecho a gastos presuntos } \\
\text { por un } 30 \%{ }^{943} \text {. } \$ 3.000 .000 \text {.- }\end{array}$ \\
\hline Base imponible & $\begin{array}{l}\text { Debe incrementar el impuesto } \\
\text { pagado por la renta en } \\
\text { primera categoría } \\
\$ 9.500 .000 .-\end{array}$ & $\begin{array}{l}\text { No debe incrementar porque no } \\
\text { ha pagado nada hasta el } \\
\text { momento } \\
\$ 7.000 .000 \text {.- }\end{array}$ \\
\hline $\begin{array}{l}\text { Tasa según tabla progresiva del } \\
\text { impuesto } \\
\text { complementario }\end{array}$ & $4 \%$ & $4 \%$ \\
\hline Carga tributaria, calculado & $\$ 115.797 . .^{944}$ & $\$ 15.797 . .^{945}$ \\
\hline
\end{tabular}

942 Recordemos que en Chile el impuesto a la Renta está contenido de manera integrada en una ley única, el DL N 824, de 1973.

${ }^{943}$ Para el año tributario 2014, tienen un tope de \$ 6.605.064.- 


\begin{tabular}{|c|c|c|}
\hline según valores al año 2014 & & \\
\hline $\begin{array}{l}\text { Impuesto pagado a nivel de } \\
\text { primera categoría con derecho } \\
\text { a devolución }\end{array}$ & $\$ 1.800 .000 .-$ & No hay \\
\hline 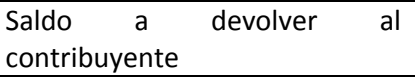 & \$1.684.203.- & No hay \\
\hline $\begin{array}{l}\text { Líquido obtenido después de } \\
\text { impuestos }\end{array}$ & \$9.384.023.- & \$9.484.023.- \\
\hline
\end{tabular}

b) Si Caupolicán opta por entregar una licencia por un año a una empresa española, residente fiscal en España, que le pagará un canon o regalía en euros, por el equivalente a $\$ 10.000 .000$, sobre ese monto deberá retener la tasa del Impuesto a la Renta de no Residentes, considerando que conforme al artículo 12, 2. b) del Convenio entre Chile y España, la tasa de retención en fuente está limitada al 10\%. De manera que Caupolicán recibirá la suma de $\$ 9.000 .000$.

\begin{tabular}{|c|c|c|}
\hline Ítem & Primera Categoría & Segunda Categoría \\
\hline $\begin{array}{l}\text { Renta, consistente en el valor } \\
\text { del canon de la licencia }\end{array}$ & $\$ 9.000 .000 .-$ & $\$ 10.000 .000 .-$ \\
\hline Gasto aceptado por la ley & $\$ 500.000 .-$ & No aplica \\
\hline Base imponible & $\$ 8.500 .000 .-$ & No aplica \\
\hline $\begin{array}{l}\text { Incremento impuesto retenido } \\
\text { en el extranjero }\end{array}$ & $\$ 1.000 .000 .-$ & No aplica \\
\hline Renta líquida & $\$ 9.500 .000 .-$ & No aplica \\
\hline $\begin{array}{l}\text { Impuesto de primera categoría. } \\
\text { Tipo } 20 \%\end{array}$ & $\$ 1.900 .000 .-$ & No hay \\
\hline $\begin{array}{l}\text { Crédito contra el impuesto de } \\
\text { primera categoría, por } \\
\text { impuesto soportado en el } \\
\text { extranjero }^{947} \text {. }\end{array}$ & $\$ 1.000 .000$. & $\begin{array}{l}\text { No hay porque no aplica el } \\
\text { impuesto de primera categoría y } \\
\text { el crédito está solamente } \\
\text { previsto para el impuesto de } \\
\text { primera categoría }\end{array}$ \\
\hline A pagar & $\$ 900.000 .-$ & \\
\hline Saldo FUT & $\begin{array}{l}\text { Utilidad por } \$ 7.600 .000 \text {, con } \\
\text { un crédito con derecho a } \\
\text { devolución de } \$ 900.000 \text {.- }\end{array}$ & No hay \\
\hline \multicolumn{3}{|c|}{ Impuesto Global Complementario } \\
\hline $\begin{array}{l}\text { Aplica el global complementario } \\
\text { en abril de cada año }\end{array}$ & Al retirar la utilidad & $\begin{array}{l}\text { Siempre se consideran retiradas } \\
\text { las utilidades }\end{array}$ \\
\hline
\end{tabular}

944 Cabe advertir que el impuesto no es de \$ 380.000, como podría parecer a primera vista, al multiplicar los siete millones de pesos por el cuatro por ciento, lo que sucede es que como la tasa es progresiva, debe aplicarse una rebaja de $\$ 264.202$, para compensar la parte de la renta que se enmarca dentro del mínimo exento.

945 Cabe advertir que el impuesto no es de $\$ 280.000$, como podría parecer a primera vista, al multiplicar los siete millones de pesos por el cuatro por ciento, lo que sucede es que como la tasa es progresiva, debe aplicarse una rebaja de $\$ 264.202$, para compensar la parte de la renta que se enmarca dentro del mínimo exento.

946 Art. 41 A, letra C, LIR.

947 Art. 41 A, letra C, números 3 y 4 de la LIR. La característica de este crédito es que si no se puede aprovechar completamente un año, también es llevado al FUT y se puede utilizar en los años siguientes. 


\begin{tabular}{|c|c|c|}
\hline Gastos & $\begin{array}{l}\text { No procede porque ya se } \\
\text { descontaron a nivel de } \\
\text { primera categoría }\end{array}$ & $\begin{array}{l}\text { Tiene derecho a gastos presuntos } \\
\text { por un } 30 \%{ }^{948} . \$ 3.000 .000 \text {.- }\end{array}$ \\
\hline Base imponible & $\begin{array}{l}\text { Debe incrementar el impuesto } \\
\text { pagado por la renta en } \\
\text { primera categoría } \\
\$ 9.500 .000 .-\end{array}$ & $\begin{array}{l}\text { No debe incrementar porque no } \\
\text { ha pagado nada hasta el } \\
\text { momento } \\
\$ 7.000 .000 \text {.- }\end{array}$ \\
\hline $\begin{array}{l}\text { Tasa según tabla progresiva del } \\
\text { impuesto } \\
\text { complementario }\end{array}$ & $4 \%$ & $4 \%$ \\
\hline $\begin{array}{l}\text { Carga tributaria, calculado } \\
\text { según valores al año } 2014\end{array}$ & $\$ 115.797 . .^{949}$ & $\$ 15.797 . .^{950}$ \\
\hline $\begin{array}{l}\text { Impuesto pagado a nivel de } \\
\text { primera categoría con derecho } \\
\text { a devolución }\end{array}$ & $\$ 900.000 .-$ & $\begin{array}{l}\text { No hay crédito por el impuesto } \\
\text { pagado en el extranjero porque } \\
\text { en el caso de los royalties está } \\
\text { previsto solamente para ser } \\
\text { deducido del impuesto de } \\
\text { primera categoría, conforme al } \\
\text { artículo } 41 \text { A, letra C, número } 3 \\
\text { de la LIR }\end{array}$ \\
\hline 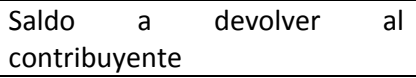 & $\$ 784.203 .-$ & No hay \\
\hline $\begin{array}{l}\text { Líquido obtenido después de } \\
\text { impuestos }\end{array}$ & \$8.384.203.- & $\$ 8.484 .023 .-$ \\
\hline
\end{tabular}

Llama la atención en esta comparación como es que el crédito por impuestos pagados en el extranjero, en el caso de los royalties, sólo pueda acreditarse contra los impuestos de primera categoría, lo que obligará a los contribuyentes a organizarse como empresa aportando sus activos a ella, para asegurar que la naturaleza de las rentas sea entendida como del artículo $20 \mathrm{~N}^{\circ} 5$ y por tanto, tributar en primera categoría. En el caso en estudio, los números no muestran la diferencia significativa que se puede dar al no tener el derecho al crédito por impuestos pagados en el extranjero, básicamente porque el bajo monto de los ingresos hace que el contribuyente quede en un tipo mínimo de tributación, pero bastará que sus ingresos aumenten y lo trasladen a tasas superiores al 10\%, para que comience a notarse la mayor carga impositiva que sufrirá aquél contribuyente que tributa en segunda categoría sin derecho al crédito versus el de primera categoría que si lo tendrá.

948 Para el año tributario 2014, tienen un tope de $\$ 6.605 .064$.-

949 Cabe advertir que el impuesto no es de $\$ 380.000$, como podría parecer a primera vista, al multiplicar los siete millones de pesos por el cuatro por ciento, lo que sucede es que como la tasa es progresiva, debe aplicarse una rebaja de $\$ 264.202$, para compensar la parte de la renta que se enmarca dentro del mínimo exento.

950 Cabe advertir que el impuesto no es de $\$ 280.000$, como podría parecer a primera vista, al multiplicar los siete millones de pesos por el cuatro por ciento, lo que sucede es que como la tasa es progresiva, debe aplicarse una rebaja de $\$ 264.202$, para compensar la parte de la renta que se enmarca dentro del mínimo exento. 
c) Otorga una licencia por un año a una empresa extranjera ubicada en Paraguay, residente fiscal en Paraguay ${ }^{951}$, que le pagará un canon o regalía en pesos chilenos de $\$$ 10.000.000 por año. Sobre el monto del pago, la empresa retendrá la suma de $\$$ 1.500.000, a un tipo de 15\%, según se establece en el artículo 20 de la Ley № 2421/04, de Reordenamiento Administrativo y de Adecuación Fiscal del Paraguay ${ }^{952}$. Curiosamente este porcentaje es el mismo que correspondería aplicar en virtud del artículo 12, 2 del Convenio entre Chile y Paraguay ${ }^{953}$, puesto que el tipo de retención en fuente está limitada al 15\%. De manera que Caupolicán recibirá la suma de \$ 8.500.000.

\begin{tabular}{|l|l|l|}
\hline Ítem & Primera Categoría & Segunda Categoría \\
\hline $\begin{array}{l}\text { Renta, consistente en el valor } \\
\text { del canon de la licencia }\end{array}$ & $\$ 8.500 .000 .-$ & $\$ 10.000 .000$ - $^{-}$ \\
\hline Gasto aceptado por la ley & $\$ 500.000 .-$ & No aplica \\
\hline Base imponible & $\$ 8.000 .000 .-$ & No aplica \\
\hline $\begin{array}{l}\text { Incremento impuesto retenido } \\
\text { en el extranjero }\end{array}$ & $\$ 1.500 .000 .-$ & No aplica \\
\hline Renta líquida & $\$ 9.500 .000 .-$ & No aplica \\
\hline $\begin{array}{l}\text { Impuesto de primera categoría. } \\
\text { Tipo 20\% }\end{array}$ & $\$ 1.900 .000 .-$ & No hay \\
\hline
\end{tabular}

${ }^{951}$ Entre Chile y Paraguay hay convenio de doble imposición, denominado "Convenio entre la República de Chile y la República del Paraguay para evitar la doble imposición y para prevenir la evasión fiscal en relación al impuesto a la renta y al patrimonio y su protocolo". El tratado fue firmado por las autoridades competentes el 30 de agosto de 2005, en Santiago, y publicado en el Diario Oficial del 2 de octubre de 2008. El convenio entró en vigor el 26 de agosto de 2008 y se aplica con respecto a los impuestos sobre las rentas que se obtengan y a las cantidades que se paguen, abonen en cuenta, se pongan a disposición o se contabilicen como gasto, a partir del $1^{\circ}$ de enero de 2009.

952 El artículo 20 de la Ley $\mathrm{N}^{\circ} 2421 / 04$, establece: “Art. 20.- Tasas.

1) La tasa general del Impuesto será del $20 \%$ (veinte por ciento) para el primer año de vigencia de la presente Ley y del 10\% (diez por ciento) a partir del segundo año, sobre las utilidades.

2) Cuando las utilidades fueren distribuidas, se aplicará adicionalmente la tasa del 5\% (cinco por ciento) a partir del segundo año de la vigencia de la presente Ley, sobre los importes netos acreditados o pagados, el que fuere anterior, a los dueños, socios o accionistas. Las utilidades destinadas a la cuenta de reserva legal, o a reservas facultativas o a capitalización no estarán sujetas al impuesto establecido en este numeral.

3) La casa matriz, sus socios o accionistas, domiciliados en el exterior deberán pagar el impuesto correspondiente a las utilidades o dividendos acreditadas por las sucursales, agencias o establecimientos situados en el país, aplicando la tasa del 15\% (quince por ciento) sobre los importes netos acreditados, pagados o remesados, de ellos el que fuere anterior. Las utilidades destinadas a la cuenta de reserva legal, a reservas facultativas o a capitalización no estarán sujetas al impuesto establecido en este numeral.

4) Las personas domiciliadas o entidades constituidas en el exterior con o sin sucursal, agencia o establecimiento situados en el país determinarán el impuesto aplicando la suma de las tasas previstas en los numerales 1), 2) y 3) sobre las rentas obtenidas, independientemente de las mencionadas agencias, sucursales o establecimientos".

953 El artículo 12 del Convenio, en lo pertinente señala: "Las regalías procedentes de un Estado Contratante y pagadas a un residente del otro Estado Contratante pueden someterse a imposición en ese otro Estado.

2. Sin embargo, estas regalías pueden también someterse a imposición en el Estado Contratante del que procedan y de acuerdo con la legislación de este Estado, pero si el beneficiario efectivo es residente del otro Estado Contratante, el impuesto así exigido no puede exceder de 15 por ciento del importe bruto de las regalías".

954 Art. 41 A, letra C, LIR. 


\begin{tabular}{|c|c|c|}
\hline $\begin{array}{l}\text { Crédito contra el impuesto de } \\
\text { primera categoría, por } \\
\text { impuesto soportado en el } \\
\text { extranjero }^{955} \text {. }\end{array}$ & $\$ 1.500 .000 .-$ & $\begin{array}{l}\text { No hay porque no aplica el } \\
\text { impuesto de primera categoría } \\
\text { y el crédito está solamente } \\
\text { previsto para el impuesto de } \\
\text { primera categoría }\end{array}$ \\
\hline A pagar & $\$ 400.000 .-$ & \\
\hline Saldo FUT & $\begin{array}{l}\text { Utilidad por } \$ 7.600 .000 \text {, con un } \\
\text { crédito con derecho a } \\
\text { devolución de } \$ 400.000 .-\end{array}$ & No hay \\
\hline \multicolumn{3}{|c|}{ Impuesto Global Complementario } \\
\hline $\begin{array}{l}\text { Aplica el global complementario } \\
\text { en abril de cada año }\end{array}$ & Al retirar la utilidad & $\begin{array}{l}\text { Siempre se consideran retiradas } \\
\text { las utilidades }\end{array}$ \\
\hline Gastos & $\begin{array}{l}\text { No procede porque ya se } \\
\text { descontaron a nivel de primera } \\
\text { categoría }\end{array}$ & $\begin{array}{l}\text { Tiene derecho a gastos } \\
\text { presuntos por un } 30 \%{ }^{956} \text {. } \$ \\
3.000 .000 \text {.- }\end{array}$ \\
\hline Base imponible & $\begin{array}{l}\text { Debe incrementar el impuesto } \\
\text { pagado por la renta en primera } \\
\text { categoría } \\
\$ 9.500 .000 .-\end{array}$ & $\begin{array}{l}\text { No debe incrementar porque } \\
\text { no ha pagado nada hasta el } \\
\text { momento } \\
\$ 7.000 .000 \text {.- }\end{array}$ \\
\hline $\begin{array}{l}\text { Tasa según tabla progresiva del } \\
\text { impuesto global } \\
\text { complementario }\end{array}$ & $4 \%$ & $4 \%$ \\
\hline $\begin{array}{l}\text { Carga tributaria, calculado } \\
\text { según valores al año } 2014\end{array}$ & $\$ 115.797 . .^{957}$ & $\$ 15.797 .-^{958}$ \\
\hline $\begin{array}{l}\text { Impuesto pagado a nivel de } \\
\text { primera categoría con derecho } \\
\text { a devolución }\end{array}$ & $\$ 400.000 .-$ & $\begin{array}{l}\text { No hay crédito por el impuesto } \\
\text { pagado en el extranjero porque } \\
\text { en el caso de los royalties está } \\
\text { previsto solamente para ser } \\
\text { deducido del impuesto de } \\
\text { primera categoría, conforme al } \\
\text { artículo } 41 \mathrm{~A} \text {, letra C, número } 3 \\
\text { de la LIR }\end{array}$ \\
\hline 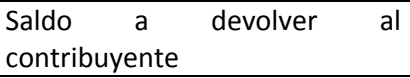 & \$284.203.- & No hay \\
\hline $\begin{array}{l}\text { Líquido obtenido después de } \\
\text { impuestos }\end{array}$ & $\$ 7.884 .203 .-$ & $\$ 7.984 .023 .-$ \\
\hline
\end{tabular}

Como se aprecia la diferencia con el caso anterior no es muy significativa, radicándose básicamente en el mayor impuesto que se soportará por la retención en Paraguay, claro está, que en todo caso, se demuestra cómo es que aumentando la tasa

955 Art. 41 A, letra C, números 3 y 4 de la LIR. La característica de este crédito es que si no se puede aprovechar completamente un año, también es llevado al FUT y se puede utilizar en los años siguientes.

956 Para el año tributario 2014, tienen un tope de \$ 6.605.064.-

957 Cabe advertir que el impuesto no es de $\$ 380.000$, como podría parecer a primera vista, al multiplicar los siete millones de pesos por el cuatro por ciento, lo que sucede es que como la tasa es progresiva, debe aplicarse una rebaja de $\$ 264.202$, para compensar la parte de la renta que se enmarca dentro del mínimo exento.

958 Cabe advertir que el impuesto no es de \$280.000, como podría parecer a primera vista, al multiplicar los siete millones de pesos por el cuatro por ciento, lo que sucede es que como la tasa es progresiva, debe aplicarse una rebaja de $\$ 264.202$, para compensar la parte de la renta que se enmarca dentro del mínimo exento. 
impositiva en el extranjero, inmediatamente se refleja en la utilidad líquida de la operación.

\subsubsection{Otorga licencias como sociedad de responsabilidad limitada}

Nos corresponde analizar la situación de Caupolicán, cuando ha cedido todos los derechos sobre la patente a Caupolicán y Familia Inversiones Limitada ${ }^{959}$ o CFI Ltda, que actualmente es titular de la patente, por lo que las licencias son otorgadas por esa persona jurídica. El aporte de la patente se valorizó en su costo de $\$ 500.000$, su mujer aportó $\$ 300.000$ en efectivo y cada uno de sus dos hijos $\$ 100.000$, quedando la participación de cada quien en un 50, 30, 10 y 10 por ciento, respectivamente. Los gastos de la sociedad son de $\$ 500.000$ y están representados por el coste que significó el traspaso de las patentes a nombre de la sociedad en Chile y España, por concepto de tasas de transferencia y honorarios de agentes.

En este caso, toda vez que la sociedad CFI Ltda, es contribuyente de primera categoría conforme al artículo $20 \mathrm{~N}^{\circ} 3$ de la LIR, donde están las rentas de la industria y el comercio, no cabe la duda sobre si debe tributar en primera o segunda categoría, de manera que la tributación será equivalente a la que hemos analizado para Caupolicán persona natural tributando en primera categoría, por lo que sería inútil y repetitivo copiar nuevamente lo ya dicho, de manera que nos limitaremos a las particularidades que se dan, especialmente, por el hecho que la sociedad posee varios socios personas naturales, lo que permite atomizar el impuesto global complementario al recibir las rentas en cabeza de cada uno de los socios de manera parcial.

Analizaremos las mismas hipótesis de inversión que como persona natural. El ejemplo queda de la siguiente manera:

a) Si CFI Ltda., otorga una licencia por un año a una empresa chilena, que le pagará un canon o regalía de $\$ 10.000 .000$ por año, el impuesto que se devenga es el impuesto a la Renta y su tributación a nivel de primera categoría es idéntica al caso de Caupolicán persona natural tributando en primera categoría. A ese nivel la única diferencia es que el costo de $\$ 500.000$ del desarrollo del invento no puede ser aprovechado por la sociedad porque ella no incurrió en él, y tampoco es costo la

${ }^{959}$ En Chile las SRL se identifican agregando la palabra "limitada" o la abreviación "Ltda.". 
adquisición de la patente porque fue un aporte así que corresponde a capital, sin embargo, matemáticamente el resultado es idéntico, en la medida que posee gastos por $\$$ 500.000 , representados por los gastos de transferencia de las patentes.

Las diferencias más significativas las encontramos en el impuesto Global Complementario, puesto que tal como advertimos previamente, éste será atomizado en la medida que las utilidades son repartidas entre varios contribuyentes. Cabe hacer presente que hasta la reforma de septiembre de 2014, mientras no se retiren las utilidades la tributación termina a nivel de primera categoría, sólo en el año que aquellas se retiren se devenga el impuesto Global Complementario. Desde septiembre de 2014, tal como latamente hemos explicado, desaparece el FUT, lo que obliga a tributar por la totalidad de las utilidades ${ }^{960}$.

Asumiendo que en el año respectivo se retiró la totalidad de las utilidades de la empresa por los socios, cada uno de ellos deberá presentar su propia declaración de impuestos, quedando la tributación como sigue:

\begin{tabular}{|c|c|}
\hline Ítem & Primera Categoría \\
\hline $\begin{array}{l}\text { Renta, consistente en el valor del canon de la } \\
\text { licencia }\end{array}$ & $\$ 10.000 .000 .-$ \\
\hline Gasto aceptado por la ley & $\$ 500.000 .-$ \\
\hline Base imponible & \$9.500.000.- \\
\hline Impuesto de primera categoría. Tipo $20 \%$ & $\$ 1.900 .000 .-$ \\
\hline Saldo FUT & $\begin{array}{l}\text { Utilidad por } \$ 7.600 .000 \text {, con un crédito del } 20 \% \\
\text { por } \$ 1.900 .000 .-\end{array}$ \\
\hline \multicolumn{2}{|c|}{ Impuesto Global Complementario } \\
\hline $\begin{array}{l}\text { Aplica el impuesto global complementario en } \\
\text { abril de cada año }\end{array}$ & Al retirar la utilidad \\
\hline Gastos & $\begin{array}{l}\text { No procede porque ya se descontaron a nivel de } \\
\text { primera categoría }\end{array}$ \\
\hline $\begin{array}{l}\text { Base imponible, determinada por el retiro en la } \\
\text { proporción de cada socio, la que tiene asociado } \\
\text { un crédito por el impuesto pagado a nivel de } \\
\text { primera categoría }\end{array}$ & $\begin{array}{l}\text { Caupolicán: } \$ 3.800 .000 \text {, con crédito de } \$ \\
950.000 .- \\
\text { Mujer: } \$ 2.280 .000 \text {, con crédito de } \$ 570.000 .- \\
\text { Hijos: } \$ 760.000 \text {, con crédito de } \$ 190.000 \text {, cada } \\
\text { uno. }\end{array}$ \\
\hline $\begin{array}{l}\text { A la base imponible debe agregarse el } \\
\text { incremento del impuesto pagado en primera } \\
\text { categoría }\end{array}$ & $\begin{array}{l}\text { Caupolicán: } \$ 4.750 .000 \text {, con crédito de } \$ \\
950.000 .- \\
\text { Mujer: } \$ 2.850 .000 \text {, con crédito de } \$ 570.000 .- \\
\text { Hijos: } \$ 950.000 \text {, con crédito de } \$ 190.000 \text {, cada } \\
\text { uno. }\end{array}$ \\
\hline $\begin{array}{l}\text { Tasa según tabla progresiva del impuesto Global } \\
\text { Complementario }\end{array}$ & $\begin{array}{l}0 \% \\
\text { El mínimo exento para el año } 2014 \text { es de } \$\end{array}$ \\
\hline
\end{tabular}

960 Salvo que se opte por el régimen parcialmente integrado, en cuyo caso, tal como venimos diciendo la tributación aumenta, derivado del hecho que no se considerará como pago a cuenta en el impuesto personal, sino un porcentaje del impuesto pagado a nivel de empresa. 


\begin{tabular}{|l|l|}
\hline & $6.605 .064 .-$ \\
\hline $\begin{array}{l}\text { Carga tributaria, calculada para cada socio según } \\
\text { valores al año } 2014\end{array}$ & $\$ 0 .{ }^{961}$ \\
\hline $\begin{array}{l}\text { Impuesto pagado a nivel de primera categoría } \\
\text { con derecho a devolución }\end{array}$ & $\$ 1.900 .000 .-$ \\
\hline Saldo a devolver los contribuyentes & $\begin{array}{l}\text { Caupolicán: } 950.000 .- \\
\text { Mujer: } 570.000 .- \\
\text { Hijos: } \$ 190.000, \text { cada uno. }\end{array}$ \\
\hline Líquido obtenido después de impuestos & $\$ 9.500 .000 .-$ \\
\hline
\end{tabular}

Como se aprecia, el efecto de la integración de los tributos en el sistema chileno, produce que al quedar cada uno de los socios bajo el mínimo exento, tienen derecho a la devolución de lo que esa renta ha pagado a nivel de empresa. En otras palabras, en esta hipótesis la tributación resultó ser cero. Después de la reforma de septiembre de 2014, para nuestro ejemplo no hay variación, salvo que el contribuyente opte por el sistema parcialmente integrado, en cuyo caso, cuando haga el retiro en el futuro, no tendrá derecho a considerar como pago a cuenta la totalidad de lo pagado a nivel de empresa, sino que solamente un porcentaje de aquello.

b) Si CFI Ltda, otorga una licencia por un año a una empresa española, residente fiscal en España, que le pagará un canon o regalía en euros, por el equivalente \$10.000.000 por año, al igual que en los casos anteriores, en la mecánica del impuesto no hay variaciones, sin embargo si se produce una diferencia significativa a la hora de solicitar la devolución del impuesto pagado a nivel de primera categoría, puesto que no se permitirá el reintegro de la cuota pagada en España, quedando el ejemplo, en lo que respecta, como sigue:

\begin{tabular}{|c|c|}
\hline \multicolumn{2}{|c|}{ Impuesto Global Complementario } \\
\hline $\begin{array}{l}\text { Aplica el impuesto global complementario en } \\
\text { abril de cada año }\end{array}$ & Al retirar la utilidad \\
\hline Gastos & $\begin{array}{l}\text { No procede porque ya se descontaron a nivel de } \\
\text { primera categoría }\end{array}$ \\
\hline $\begin{array}{l}\text { Impuesto pagado en Chile con derecho a } \\
\text { devolución, anotado en el FUT }\end{array}$ & $\$ 900.000 .-$ \\
\hline $\begin{array}{l}\text { Base imponible, determinada por el retiro en la } \\
\text { proporción de cada socio, la que tiene asociado } \\
\text { un crédito por el impuesto pagado a nivel de } \\
\text { primera categoría con derecho a devolución }\end{array}$ & $\begin{array}{l}\text { Caupolicán: } \$ 3.800 .000 \text {, con crédito de } \$ \\
450.000 .- \\
\text { Mujer: } \$ 2.280 .000 \text {, con crédito de } \$ 270.000 \text {.- } \\
\text { Hijos: } \$ 760.000 \text {, con crédito de } \$ 90.000 \text {, cada } \\
\text { uno. }\end{array}$ \\
\hline $\begin{array}{l}\text { A la base imponible debe agregarse el } \\
\text { incremento del impuesto pagado en primera }\end{array}$ & $\begin{array}{l}\text { Caupolicán: \$ 4.750.000, con crédito de \$ } \\
\text { 950.000.- }\end{array}$ \\
\hline
\end{tabular}

${ }^{961}$ Cabe advertir que el impuesto no es de $\$ 380.000$, como podría parecer a primera vista, al multiplicar los siete millones de pesos por el cuatro por ciento, lo que sucede es que como la tasa es progresiva, debe aplicarse una rebaja de $\$ 264.202$, para compensar la parte de la renta que se enmarca dentro del mínimo exento. 


\begin{tabular}{|c|c|}
\hline categoría & $\begin{array}{l}\text { Mujer: } \$ 2.850 .000 \text {, con crédito de } \$ 570.000 .- \\
\text { Hijos: } \$ 950.000 \text {, con crédito de } \$ 190.000 \text {, cada } \\
\text { uno. }\end{array}$ \\
\hline $\begin{array}{l}\text { Tasa según tabla progresiva del impuesto global } \\
\text { complementario }\end{array}$ & $\begin{array}{l}0 \% \\
\text { El mínimo exento para el año } 2014 \text { es de } \$ \\
6.605 .064 .-\end{array}$ \\
\hline $\begin{array}{l}\text { Carga tributaria, calculada para cada socio según } \\
\text { valores al año } 2014\end{array}$ & \$ $0 .-^{962}$ \\
\hline $\begin{array}{l}\text { Impuesto pagado a nivel de primera categoría } \\
\text { con derecho a devolución }\end{array}$ & $\$ 900.000 .-$ \\
\hline Saldo a devolver los contribuyentes & $\begin{array}{l}\text { Caupolicán: } 450.000 .- \\
\text { Mujer: } 270.000 .- \\
\text { Hijos: } \$ 90.000, \text { cada uno. }\end{array}$ \\
\hline Líquido obtenido después de impuestos & $\$ 8.500 .000 .-$ \\
\hline
\end{tabular}

En este caso, al igual que en el anterior no hubo lugar a tributación en Chile, no obstante la diferencia es que el contribuyente soportó el impuesto pagado en España.

c) La última alternativa que analizamos previamente corresponde a la situación en que se entrega la licencia a una empresa extranjera ubicada en Paraguay, residente fiscal en Paraguay ${ }^{963}$. En este caso, la única variación con el caso anterior es que la retención en Paraguay será de un $15 \%$, manteniéndose todas las demás condiciones iguales, por lo que no creemos que sea necesario repetir lo ya dicho.

\section{Cánones y la doble imposición}

El ejemplo que hemos analizado previamente, pone de manifiesto un fenómeno que se dará con mucha frecuencia en la tributación de cánones, tal es la doble imposición interna e internacional. Efectivamente, los derechos de propiedad intelectual, por sus características, son especialmente propicios a generar rentas en diferentes niveles de las actividad económica, ya que bien pueden crearse a nivel de personas naturales, como serán el autor, creador o inventor y también a nivel de empresas, donde podemos encontrar desde industrias de la entretención y la investigación, hasta desarrollos y hallazgos accidentales dentro de un proceso creativo o productivo, por lo que pueden dar lugar a situaciones de doble imposición económica y jurídica, nacional e internacional ${ }^{964}$. Así pues, en los ejemplos vimos, particularmente

962 Cabe advertir que el impuesto no es de $\$ 380.000$, como podría parecer a primera vista, al multiplicar los siete millones de pesos por el cuatro por ciento, lo que sucede es que como la tasa es progresiva, debe aplicarse una rebaja de $\$ 264.202$, para compensar la parte de la renta que se enmarca dentro del mínimo exento.

963 Ver nota anterior.

964 LÓPEZ ESPADAFOR, CARLOS MARÍA. La Doble Imposición Interna. Lex Nova. Valladolid, 1999. La doble imposición interna puede ser un fenómeno fácil de encontrar en la propiedad 
cuando la titularidad de la patente se trasladó a manos de una sociedad, la renta estuvo constituida por un flujo económico único, producido por la licencia ${ }^{965}$, específicamente por el pago de los royalties, no obstante debió tributar en Chile y España y en manos de la sociedad y de los socios, según fuese el caso ${ }^{966}$, de manera que es un desafío permanente el intentar armonizarlos.

Cuando los derechos de propiedad intelectual están en manos de una persona jurídica, podemos ejemplificar muy fácilmente para ver la doble imposición económica interna. En efecto, suponiendo la titularidad de una patente por una sociedad que recibe una renta producto de cánones, este flujo económico deberá volver a enfrentar un impuesto a nivel de las personas naturales socias, de manera que podría darse un escenario como el siguiente:

\begin{tabular}{|l|r|}
\hline Sociedad & 100 \\
\hline Canon o royalty & 80 \\
\hline Base tributable ( 100 menos gastos por 20) & 28 \\
\hline Impuesto Sociedades Tasa 35\% & 52 \\
\hline Líquido obtenido después de impuestos (80-28) & 52 \\
\hline Distribución de toda la renta a los socios & 14 \\
\hline IRPF Tasa (supuesta) 27\% & 42 \\
\hline Carga tributaria total & 38 \\
\hline Líquido obtenido después de impuestos por la persona natural & $52.5 \%$ \\
\hline Tasa efectiva aplicada & \\
\hline
\end{tabular}

Globalmente visto no cabe duda sobre el mayor gravamen que implica un sistema que no tiene mecanismos para evitar la doble imposición, no obstante matemáticamente, al fin del día, el asunto se reduce a una cuestión de tasas y no de etapas de imposición, puesto que puede existir imposición en variados niveles y si el total de tasas aplicados es bajo, la carga tributaria igualmente lo será, pero no es ese el problema, sino que las condiciones de igualdad que deben presidir al tributo y que se distorsionan cuando el impuesto se aplica en cascada sobre una misma renta, sin considerar los tributos pagados previamente. Así pues, si de matemática se trata, la

intelectual, por ejemplo, cuando la titularidad de la propiedad intelectual y sus rendimientos se radica en una empresa. El libro contiene un excelente análisis sobre la doble imposición interna. Págs. 58 y sgtes.

965 Con un monto que supusimos en $€ 10.000$ o $\$ 10.000 .000$, según el caso. Se trata de números arbitrarios, que no representan una proporción de cambio.

${ }^{966}$ La doble imposición, particularmente la económica, se presenta en todos los sistemas de renta y se enfrenta con diferentes métodos, esa es una de las razones que explican el FUT en el sistema chileno y en el Impuesto de Sociedades español encontramos variados sistemas para reducirla, tales como el Título VI, Capítulo II, "Deducciones para Evitar la Doble Imposición”, artículos 28 y sgtes, de la Ley 43/1995, del Impuesto sobre Sociedades, los artículos 66 y sgtes. de la Ley 40/1998, actual Ley reguladora del IRPF o el artículo 32, de la Ley 20/1990 sobre Régimen Fiscal de las Cooperativas. 
situación puede ser fácilmente más gravosa que la descrita, puesto que bastaría exigir al contribuyente persona natural, que tuviese como retirado el impuesto pagado a nivel de la sociedad para el sólo efecto de la progresión de la tasa que le afecte, en cuyo caso el tipo final que le afectaría sería necesariamente mayor ${ }^{967}$.

Cuando vemos el asunto desde la perspectiva internacional e involucramos a más de una jurisdicción tributaria, los problemas de doble imposición, que al amparo del derecho interno podían pasar desapercibidos, se hacen evidentes, puesto que la sola circunstancia de existir dos poderes tributarios concurrentes sobre una misma renta, da lugar a la doble imposición, elevando las dificultades para su eliminación, puesto que la armonización ya no es una cuestión de un único poder tributario, sino que de uno o más Estados.

El mismo ejemplo que venimos exponiendo, en el plano internacional implica que la invención se produce en el país A y la licencia se otorga a un país B, de manera que el flujo económico se produce desde B que paga las rentas por la licencia hasta A que las recibe, dando lugar a una situación como la siguiente:

\begin{tabular}{|c|c|}
\hline País B. Fuente. Licenciatario. ${ }^{968}$ & País A. Residencia. Titular de la patente. \\
\hline \multicolumn{2}{|l|}{ Renta por licencia por: 100.- } \\
\hline \multirow{4}{*}{$\begin{array}{l}\text { Remesa al País A: } 80 \text {. Conformada por los } 100 \\
\text { menos el impuesto soportado en residencia de } \\
20 \text { (Tasa supuesta de } 20 \% \text { ). }\end{array}$} & $\begin{array}{l}\text { Recepción de la renta por la licencia, por el } \\
\text { titular de la patente en el país A, por: 80.- }\end{array}$ \\
\hline & $\begin{array}{l}\text { Para este país, la renta es de } 100, \text { puesto que es } \\
\text { la renta por la licencia, por lo que normalmente } \\
\text { obligará al contribuyente a hacer lo siguiente: } \\
\text { - } \quad \text { Renta por licencia: } 80 .- \\
\text { - } \quad \text { Más impuesto pagado en el extranjero: } \\
\text { - } 20 .- \\
\text { - Renta tributable: } 100 .-\end{array}$ \\
\hline & Tipo: $40 \%$ \\
\hline & Impuesto en país A: 40 (100*40\%) \\
\hline \multicolumn{2}{|l|}{ Carga total tributaria: $60(20+40)$} \\
\hline \multicolumn{2}{|c|}{$\begin{array}{l}\text { En este caso, respecto de las } 20 \text { que se pagaron como impuesto en el país } B \text {, existe doble } \\
\text { imposición, porque volvieron a formar parte de la base imponible en el país } A \text {. }\end{array}$} \\
\hline
\end{tabular}

${ }^{967}$ Para nuestro ejemplo, podría suceder que el contribuyente persona natural tuviese que considerar retirados los 52 que efectivamente retiró y además el impuesto pagado a nivel de empresa por 28 unidades. Es decir, podría la ley exigir que para efectos de IRPF, considerara retirados toda la renta producida en la sociedad, por un total de 80. En ese caso, sin duda el contribuyente se desplazaría en su impuesto personal (puesto que la tabla normalmente es progresiva). De manera que, tendría que tributar sobre las 52 unidades con tipo más alto, es decir mayor que el 27\%, lo que lógicamente conlleva un aumento de la carga impositiva.

${ }^{968}$ Ejemplo basado en otro propuesto por GONZÁLEZ, ALEX y ORMEÑO RODRIGO. Renta Neta de Fuente Extranjera. Tributación en un Mundo Globalizado. Disponible en Internet en: http://www.cetuchile.cl/images/docs/64-97.pdf (15 Jul 2013). 
Ésta es la alternativa más gravosa, puesto que bajo esta hipótesis, los dos Estados involucrados (países A y B), se han limitado a tomar el monto consolidado de la renta, para aplicar su poder tributario sin ninguna consideración sobre el hecho que otra potestad tributaria se está ejerciendo sobre ella.

Así pues, aunque implica reiterar lo evidente, es ocasión de recordar las dificultades que para el comercio internacional, implicaría mantener a raja tabla una estructura como la que estamos analizando, la sola circunstancia de enfrentar a tipos tributarios cercanos al treinta por ciento en cada Estado, elevaría la carga tributaria por sobre el sesenta por ciento, desincentivando el intercambio internacional ${ }^{969}$, es por ello que los países, ya sea unilateral o bilateralmente se empeñen en reducir estos perniciosos efectos. Por nuestra parte, no estamos tratando de analizar todos los diferentes mecanismos para reducir la doble imposición internacional, menos cuando lo han hecho otros antes con excelente acierto ${ }^{970}$, sino que simplemente graficar a groso modo, los derroteros por los cuales deberán transitar los rendimientos calificados como cánones en un contexto de doble imposición internacional. Fundados en estas consideraciones, el paso siguiente es observar cómo funcionan los mecanismos para evitar la doble imposición internacional. Partiremos con un ejemplo que trata un mecanismo unilateral y posteriormente uno bilateral.

Nuestro ejemplo con un país que ha tomado la medida unilateral de acreditar el impuesto soportado en el extranjero, resultaría de la siguiente manera:

\begin{tabular}{|l|l|}
\hline País B. Fuente. Licenciatario. $^{971}$ & País A. Residencia. Titular de la patente. \\
\hline Renta por licencia por: $100 .-$ & \\
\hline Remesa al extranjero: 80. Conformada por los & $\begin{array}{l}\text { Recepción de la renta por la licencia, por el } \\
\text { titular de la patente en el país A, por: 80.- } \\
100 \text { menos el impuesto soportado en residencia } \\
\text { de } 20 \text { (Tasa supuesta de 20\%). }\end{array}$ \\
\hline
\end{tabular}

${ }^{969}$ CAMPOS B., ADOLFO. Doble Tributación Internacional. Título V. Efectos de la Doble Imposición sobre el Comercio Internacional. Disponible en Internet en: http://www.legalinfo-panama.com/php/pfp.php3?doc=/articulos/articulos 27b.htm (15 Jul 2013).

970 Al respecto, puede verse, entre otros: HORTALÁ VALLVÉ, JOAN. Comentarios a la Red española de Convenios de Doble Imposición. Cánones. Regalías. Mecanismos para evitar la doble imposición. Thomson-Aranzadi. Cizur Menor, Navara, 1999, pp. 671 y sgtes; CAMPOS, ADOLFO. Doble Tributación Internacional. Disponible en Internet en:

http://www.legalinfo-panama.com/php/pfp.php3?doc=/articulos/articulos_27b.htm (15 Ago 2013); y, RUBIO GUERRERO, JUAN JOSÉ. En Manual de Fiscalidad Internacional. Tema 2. Los principios básicos de la fiscalidad internacional y la doble imposición internacional. Instituto de Estudios Fiscales, Escuela de Hacienda Pública. Ministerio de Hacienda, 2001, pp. 41 y sgtes.

${ }^{971}$ Ejemplo basado en otro propuesto por GONZÁLEZ, ALEX y ORMEÑO RODRIGO. Renta Neta de Fuente Extranjera. Tributación en un Mundo Globalizado. Disponible en Internet en: http://www.cetuchile.cl/images/docs/64-97.pdf (15 Ago 2013). 


\begin{tabular}{|c|c|}
\hline & $\begin{array}{l}\text { Para este país, la renta sería de } 80^{972} \text {, monto al } \\
\text { que probablemente se le deberá incrementar la } \\
\text { tasa de impuesto que habría soportado esa } \\
\text { renta de obtenerse en el país de destino (país A) } \\
\text { (tasa supuesta de } 17 \% \text { ), resultando entonces: } \\
\quad \text { - Renta por licencia: } 80 \text {. } \\
\text { - Incremento: } 16,3 .(80 * 0.204819)^{973} \\
\text { - Renta tributable: } 96,3 \text {. }\end{array}$ \\
\hline & Tipo: $17 \%$ \\
\hline & Impuesto en país A: $16,3(96,3 * 17 \%)$ \\
\hline & $\begin{array}{l}\text { Crédito por impuesto pagado en el país } B \text {, } \\
\text { corresponde al tope del impuesto que debería } \\
\text { haber pagado en el país } A \text {, es decir: } 16,3^{974} \text {. }\end{array}$ \\
\hline & $\begin{array}{l}\text { Total a pagar: } 16,3 \text { de impuesto, menos } 16,3 \text { de } \\
\text { crédito. Es decir, total a pagar: } 0 .\end{array}$ \\
\hline \multicolumn{2}{|c|}{ Carga total tributaria: 20 , que se soportaron únicamente en el país B. } \\
\hline \multicolumn{2}{|c|}{$\begin{array}{l}\text { En este caso, no existe doble imposición, porque se soportó una única tributación en el país B. Este } \\
\text { efecto, se produjo porque el país A, renunció voluntariamente a su potestad para cobrar impuesto, } \\
\text { por la vía de otorgar un crédito equivalente al impuesto que debía soportarse bajo su legislación. }\end{array}$} \\
\hline & $\begin{array}{l}\text { De existir un segundo nivel de tributación, por } \\
\text { ejemplo, porque esta renta la recibió una } \\
\text { empresa y después es distribuida a personas } \\
\text { naturales, puede suceder algo como lo } \\
\text { siguiente: } \\
\text { - Base imponible persona natural: } 80 \\
\quad \text { más el Incremento de } 16,3 \text {. Total: } \\
\text { 96,3.- } \\
\text { - Tipo impositivo a nivel de persona } \\
\text { - } \text { natural: } 40 \% \\
\text { - Meta tributaria: } 38,5(96,3 * 40 \%) \\
\text { - } \text { M pagar: } 22,2 .-\end{array}$ \\
\hline \multicolumn{2}{|c|}{ Carga total tributaria: 42,2 (20 pagados en el país $B+22,2$ pagados en el país A) } \\
\hline \multicolumn{2}{|c|}{$\begin{array}{l}\text { En este caso, como se aprecia, únicamente existe doble imposición sobre las } 3.7 \text { unidades, } \\
\text { respecto de las cuales no operó el crédito en el país A, porque el impuesto era de } 17 \% \text { y no de } 20 \% \\
\text { como en el país B. Con ello, se redujo considerablemente la doble imposición, quedando reducida } \\
\text { a } 42,2 \text {, en comparación con los } 60 \text {, en la hipótesis que no existía ningún mecanismo atenuador, no } \\
\text { obstante se trabajó casi con las mismas tasas. }\end{array}$} \\
\hline
\end{tabular}

${ }^{972}$ En este punto las alternativas son variadas, podría considerarse como renta, entre otras, las 100 unidades como en el caso anterior, las 80 unidades más el impuesto soportado en el extranjero o las 80 unidades más la tasa de impuesto que debió soportar en destino (utilizamos esta alternativa en el ejemplo porque nos parece la de más ordinaria ocurrencia).

973 El factor 0.204819, es el que permite determinar el monto que sumado a la base de las 80 U. resultará en una cantidad tal, que cuando se aplique el impuesto con tasa de $17 \%$, la base imposible vuelva a ser exactamente $80 \mathrm{U}$. Se obtiene de dividir 17 por 83 . Lógicamente, este guarismo varía en función de la tasa impositiva con la que se esté trabajando.

${ }^{974}$ Teóricamente un sistema propone que se incremente la renta según la tasa del país de la fuente y se otorgue este monto como crédito, pero ello puede producir subsidiar al país de la fuente, cuando la tasa del país de la fuente es mayor que la del país de destino, tal como sucede en el ejemplo. Por ello, preferimos ejemplificar con un caso de más normar ocurrencia, en donde el incremento y el crédito respectivo estarán limitados por la tasa menor entre país de fuente y destino. 
No debemos olvidar que este ejercicio es simplemente un ejemplo, para mostrar el efecto de las medidas unilaterales, pero los mecanismos a través de los cuales los estados pueden actuar unilateralmente son múltiples y variados.

En la alternativa en la cual existe un convenio de doble imposición entre los dos estados involucrados, nuestro ejemplo, funcionaría de la siguiente manera:

\begin{tabular}{|c|c|}
\hline País B. Fuente. Licenciatario. ${ }^{975}$ & País A. Residencia. Titular de la patente. \\
\hline \multicolumn{2}{|l|}{ Renta por licencia por: $100 .-$} \\
\hline \multirow[t]{6}{*}{$\begin{array}{l}\text { Remesa al extranjero: } 90 \text {. Conformada por los } 100 \\
\text { menos el impuesto soportado en residencia de } 10 . \\
\text { (Tasa supuesta de 10\%, porque conforme al } \\
\text { convenio el estado de la fuente limitó su capacidad } \\
\text { tributaria hasta ese monto) }\end{array}$} & $\begin{array}{l}\text { Recepción de la renta por la licencia, por el } \\
\text { titular de la patente en el país A, por: 90.- }\end{array}$ \\
\hline & $\begin{array}{l}\text { Para este país, la renta sería de } 90^{976} \text {, monto al } \\
\text { que se incrementa la tasa de impuesto que } \\
\text { habría soportado esa renta de obtenerse en el } \\
\text { país de destino }{ }^{977} \text { (país A) (tasa supuesta de } \\
17 \% \text { ), con tope del impuesto pagado en el país } \\
\text { de la fuente (país A, tasa } 10 \% \text { ), resultando } \\
\text { entonces: } \\
\quad \text { - Renta por licencia: } 90 . \\
\text { - Incremento: } 10 .\left(90^{*} 1.11\right)^{978} \\
\text { - Renta tributable: } 100 \mathrm{U} \text {. }\end{array}$ \\
\hline & Tipo: $17 \%$. \\
\hline & Impuesto en país A: 17 (100*17\%) \\
\hline & $\begin{array}{l}\text { Crédito por impuesto pagado en el país } B \text {, } \\
\text { corresponde al impuesto que debería haber } \\
\text { pagado en el país } A \text {, con tope del impuesto } \\
\text { pagado en } B(10 \%) \text {, es decir: } 10^{979} \text {. }\end{array}$ \\
\hline & $\begin{array}{l}\text { Total a pagar: } 17 \text { de impuesto, menos } 10 \text {, de } \\
\text { crédito. Es decir, total a pagar: } 7 \text {. }\end{array}$ \\
\hline \multicolumn{2}{|c|}{$\begin{array}{l}\text { Carga total tributaria: } 17 \text { que en este caso, se divide entre el país A y el B. Donde } 10 \text { son recibidos por } \\
\text { B y } 7 \text { por A. }\end{array}$} \\
\hline
\end{tabular}

975 Ejemplo basado en otro propuesto por GONZÁLEZ, ALEX y ORMEÑO RODRIGO. Renta Neta de Fuente Extranjera. Tributación en un Mundo Globalizado. Disponible en Internet en: http://www.cetuchile.cl/images/docs/64-97.pdf (15 Ago 2013).

976 En este punto las alternativas son variadas, podría considerarse como renta las 100 unidades como en el caso anterior, la 80 unidades, las 80 unidades más el impuesto soportado en el extranjero o las 80 unidades más la tasa de impuesto que debió soportar en destino (utilizamos esta alternativa en el ejemplo porque nos parece la de más ordinaria ocurrencia).

977 Ya sabemos que en este punto las alternativas son variadas, pero este es el sistema que arbitrariamente hemos escogido para nuestro ejemplo, por lo que, para hacer los ejemplos comparables debemos mantenerlo.

${ }^{978}$ El factor 1.11, es el que permite determinar el monto que sumado a la base de las 90 U. resultará en una cantidad tal, que cuando se aplique el impuesto con tasa de $10 \%$, la base imposible vuelva a ser exactamente 90 U. Se obtiene de dividir 10 por 90. Lógicamente, este guarismo varía en función de la tasa impositiva con la que se esté trabajando.

979 En este caso al igual que en el anterior, puede observarse como es necesario que el incremento tenga como límite la tasa del impuesto pagado en fuente, porque como el tipo en destino es mayor, si se otorga un crédito con una tasa mayor en país de destino estará beneficiando al país de la fuente. 


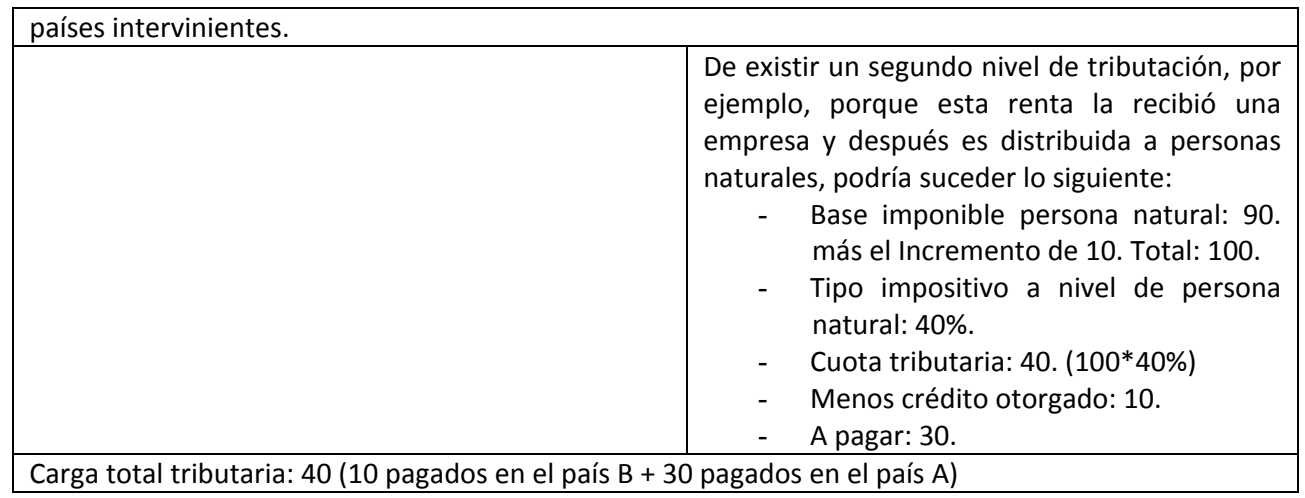

\subsection{Cánones y regalías en el modelo de convenio OCDE}

\subsubsection{Introducción}

Hasta este momento los problemas de doble imposición parecen reducirse a una cuestión de tasas, lo que sin duda es una variable, tal como hemos demostrado precedentemente, obviamente que mientras menor sea la tasa impositiva final, en directa proporción desaparecerá la atención que reciba el asunto, eso desde una perspectiva meramente matemática. Sin embargo, la dimensión jurídica del asunto nos enfrenta a preguntas vinculadas a la justicia de cada instituto y particularmente, a la coherencia conceptual que soporta el gravamen de una determinada manifestación de capacidad contributiva, en este caso, la propiedad intelectual. Ahora bien, el elemento de conexión entre los países de nuestro estudio es básicamente el tratado para reducir la doble imposición suscrito entre ellos, donde la propiedad intelectual no es tratada como tal, sino que puede estar subsumida dentro de las calificaciones de renta que el propio tratado hace, especialmente en el artículo 12 del Convenio Chile-España. Por lo anterior, considerando lo que venimos exponiendo sobre lo difícil de establecer los límites para nuestro trabajo, no concentraremos en el referido artículo 12 y su equivalente en el MC OCDE.

Los cánones en el MC OCDE, hablando nuevamente desde el punto de vista matemático, tienen una regulación bastante simple, se trata de dejar la competencia para gravarlos en uno $\mathrm{u}$ otro Estado contratante o de dividirla en función de una alícuota pactada ad hoc; será un cinco, seis, diez o el porcentaje que se quiera y siempre el resultado será un mero cálculo aritmético. No obstante aquello, el debate real estará en determinar qué rendimientos serán los que queden bajo esta simple regla matemática, de ahí emana la necesidad de determinar qué se entiende por canon, misión compleja por 
dos razones: por una parte, por las difusas fronteras del concepto y por otra, porque a veces es difícil definir qué es aquello que no es canon, que puede corresponder a una renta de artista o deportista, rentas del trabajo, ganancias de capital, incluso a un beneficio empresarial $^{980}$.

El artículo 12.1 del MC OCDE es distinto de los artículos que podemos encontrar en los convenios que firman España y Chile, porque el MC OCDE atribuye a la residencia la jurisdicción sobre los cánones y España y Chile buscan una tributación, al menos compartida, aunque como países importadores de tecnología, debieran preferir que fuese exclusiva en la fuente. Con ello, la realidad es que el artículo 12 es muy semejante al 11 del MC OCDE. El porcentaje de retención de tributación del canon en la fuente, que han pactado tanto Chile como España varía entre 3 a 20 por ciento, pero lo habitual es encontrarlo en 5 o 10 por ciento de retención.

\subsubsection{Armonización entre la definición de canon del Estado de la fuente y el convenio}

Al igual que cualquiera de las rentas comprendidas en el MC OCDE, no podemos pasar por alto, que lo primero que se debe hacer cuando se está frente al pago de un canon, es comprobar si efectivamente está sujeto a imposición en el Estado de la fuente, puesto que sólo de ser así, corresponde aplicar el convenio de doble imposición. En el evento de no estar gravado en fuente, nada tiene que hacer el convenio y la competencia para gravarlo es completamente del Estado de residencia ${ }^{981}$. Sin embargo, una renta que internamente está gravada, puede suceder que no tenga una calificación armonizada entre el derecho interno y el tratado, cuestión a la que los cánones son especialmente sensibles dada la efusión de emociones que despierta su contenido, como hemos tenido oportunidad de apreciar largamente.

${ }^{980}$ Esta es, a nuestro juicio, la renta cuya diferenciación con los cánones es teleológicamente más compleja, resultando una distinción bastante imaginaria.

981 BUITRAGO DÍAZ, ESPERANZA. El concepto de cánones y/o regalías en los convenios para evitar la doble Tributación sobre la Renta. Wolters Kluwer. Valencia, España, 2007 pp. 37 y sgtes. Indirectamente se refiere al tema SERRANO, cuando describe un método para la aplicación de los CDI, partiendo de la base que para su aplicación debe existir un impuesto nacional, ver: SERRANO ANTÓN, FERNANDO. Principios básicos de la fiscalidad internacional y los convenios para evitar la doble imposición internacional: historia, tipos, fines, estructura y aplicación. En Fiscalidad Internacional. Obra dirigida por SERRANO ANTÓN, FERNANDO. Editorial CEF, Madrid, 2013, pp. 300 y sgtes. 
A modo de ejemplo de las desavenencias que se producen en este ámbito, parece oportuno recordar el caso que oímos en clases del profesor MARTIN JIMÉNEZ ${ }^{982}$. Con motivo de la adecuación de la legislación española a la Directiva Comunitaria relativa a los intereses, se introdujo en el IRNR una definición en el art. 13.1.f.3 ${ }^{\circ}$, que dice: “Tienen la consideración de cánones o regalías las cantidades de cualquier clase pagadas por el uso, o la concesión de uso de: derechos sobre obras literarias, artísticas o científicas incluidas las películas cinematográficas. Patentes, marcas de fábrica o de comercio, dibujos y modelos planos formulas o procedimientos secretos. Derechos sobre programas informáticos. Informaciones relativas a experiencias industriales, comerciales o científicas. Derechos personales susceptibles de cesión, tales como derecho de imagen. Equipos industriales, comerciales o científicos. Cualquier derecho similar a los anteriores. En particular, tienen esta consideración las cantidades pagadas por el uso o la concesión de uso de los derechos amparados por el texto refundido de la Ley de Propiedad Intelectual, aprobado por Real Decreto Legislativo 1/1996, de 12 de abril, la Ley 11/1986, de 20 de marzo, de Patentes, y la Ley 17/2001, de 7 de diciembre, de Marcas".

La definición anotada parte estrechando el concepto a aquello que específicamente señala, pero la referencia final a "cualquier derecho similar a los anteriores", llena de desconcierto, puesto que frente a lo rugoso de los bordes del concepto de canon, el legislador parece empeñado en mantener la incertidumbre. En fin, debemos detener la atención en los derechos de imagen, que hacen una aparición triunfal. Así pues, con un claro afán de garantizar la retención en la fuente de los pagos hechos a artistas y deportistas, el IRNR se esmeró en tratar de decir: "yo me aseguro que se quede algo de esa renta en España", sin embargo, donde empezó la solución, nació el problema, puesto que el MC OCDE no incluye a los derecho de imagen, en su definición de canon. Es decir, como los acuerdos de doble imposición priman sobre la ley interna, respecto de aquellos países con los que exista convenio, los derechos de imagen no serán cánones, en consecuencia no tendrán asegurada la retención en la fuente que normalmente pacta España en sus convenios, más aún pueden llegar a ser

\footnotetext{
${ }^{982}$ El asunto es tratado por el profesor MARTÍN JIMÉNEZ, ADOLFO, en La tributación de los cánones o regalías. En Comentarios a los convenios para evitar la doble imposición y prevenir la evasión fiscal, concluidos por España. Obra coordinada por RUIZ GARCÍA, JOSÉ RAMÓN y CALDERÓN CARRERO, JOSÉ MANUEL, Fundación Pedro Barrié de la Maza, Instituto de Estudios Económicos de Galicia, 2004, pp. 982 y sgtes.
} 
considerados como rentas empresariales y con ello eliminar la retención en la fuente. De manera que, el cambio de definición en la ley interna no produce efecto respecto de una definición autónoma del convenio, por lo que el bautismo efectuado por el legislador español no puede ser bendecido, y si al ir al convenio de doble imposición, puede verse que se trata de derechos imagen, a efectos del convenio recibirán la calificación de tal, resultando considerados como beneficio empresarial o renta de actividades deportivas, si queremos calificarlo como tal, pero no serán canon en ningún caso.

El problema que hemos descrito tiene otro extremo, puesto que puede suceder que la definición interna de canon sea más restringida que la definición del convenio. Hemos mencionado como los países importadores de tecnología, tienden a ensanchar la definición de canon porque su interés es que tributen en la fuente, o al menos se retenga una parte de sus rendimientos en fuente, entonces mientras más ancha sea la definición de canon, mayores son los potenciales ingresos. De esta manera, es posible encontrar convenios como España-Brasil o España-Grecia, donde la definición de canon incluye no solamente los conceptos habituales relativos a la propiedad intelectual, sino que se extiende a otros pagos por servicios de asistencia técnica, es decir se desprende de la idea de ceder un intangible, gravando una simple prestación de servicio. El efecto de la ampliación del concepto de canon en el convenio puede ser inesperado. Observemos que la primera regla en la materia, manda revisar la ley interna para determinar si la renta está gravada y sólo después de ello iré al convenio. Siguiendo esta lógica, en España están sujetos a imposición los cánones o regalías, pero ya vimos que la definición de cánones no incorpora a la asistencia técnica, de manera que tendremos que ver si la legislación interna grava a estos servicios, allí encontraremos como punto de conexión al artículo 13.1.b ${ }^{983}$ del TRLIRNR, que grava los servicios de asistencia técnica, "cuando se trate de prestaciones de servicios realizadas en territorio español".

983 Art. 13, 1.b) TRLIRNR: "Las rentas de actividades o explotaciones económicas realizadas sin mediación de establecimiento permanente situado en territorio español, cuando no resulte de aplicación otro párrafo de este artículo, en los siguientes casos:

1. Cuando las actividades económicas sean realizadas en territorio español. No se considerarán obtenidos en territorio español los rendimientos derivados de la instalación o montaje de maquinaria o instalaciones procedentes del extranjero cuando tales operaciones se realicen por el proveedor de la maquinaria o instalaciones, y su importe no exceda del 20 por ciento del precio de adquisición de dichos elementos.

2. ${ }^{\circ}$ Cuando se trate de prestaciones de servicios utilizadas en territorio español, en particular las referidas a la realización de estudios, proyectos, asistencia técnica o apoyo a la gestión. Se entenderán utilizadas en territorio español aquellas que sirvan a actividades económicas realizadas en territorio español o se refieran a bienes situados en éste. Cuando tales prestaciones sirvan parcialmente a actividades económicas realizadas en territorio español, se considerarán obtenidas en España sólo por la parte que sirva a la actividad desarrollada en España (...)". 
Para completar el caso, pensemos que la sociedad española recibe las prestaciones desde USA, las utiliza en la mitad ella y en la otra mitad una filial suya ubicada en un tercer país. Las consecuencias serían que si la prestación fuese canon a efectos del convenio, el cien por ciento de los pagos tendrían retención en fuente, sin embargo, como son servicios, sólo está gravada aquella parte que se prestó en España, es decir, el cincuenta por ciento de la prestación y en consecuencia sólo debe retenerse por ello.

En conclusión, como consecuencia del hecho que antes de entrar al convenio debe la renta respectiva estar gravada por la legislación interna, si la definición del convenio es más restringida que la legislación interna ${ }^{984}$, no se asegura la retención en fuente, por el contrario, se limita la aplicación del convenio que no se aplicará a esas rentas. Por el otro lado, si la definición del convenio es más amplia que la legislación interna ${ }^{985}$, sujetando a tributación determinadas rentas que en la legislación interna no lo están -por ejemplo, define como cánones determinados servicios de asistencia técnicaesto tampoco asegura la retención en fuente para todos esos servicios, eso sólo significa que debe acudirse a la legislación del Estado de la fuente y sólo si allí están sometidos a gravamen, quedarán sujetos a retención en conformidad al convenio, si no los grava, no cabe aplicar el convenio y no hay retención, puesto que el convenio no crea obligaciones tributarias $^{986}$.

\subsubsection{La competencia tributaria}

Los convenios de doble imposición funcionan sobre la base de producir el reparto de la competencia para gravar las rentas entre los Estados contratantes, asunto que a propósito de los cánones toma tintes muy claros en favor y en contra de los países productores e importadores de tecnología ${ }^{987}$. En efecto, a los países exportadores de tecnología les interesará el gravamen en residencia y a los importadores en fuente, de ahí la marcada tendencia en favor de una u otra posición, según quien haya redactado el modelo de convenio, a modo de ejemplo: el MC OCDE cede en favor de los países

\footnotetext{
${ }_{984}^{98}$ No considera canon algo que la legislación interna considera como tal.

${ }^{985}$ Considera canon algo que la legislación interna no considera como tal.

${ }^{986}$ Sobre las relaciones entre los CDI y el derecho interno, no puede dejarse de ver: CALDERÓN CARRERO, JOSÉ MANUEL. La Doble Imposición Internacional en los Convenios de Doble Imposición y en la Unión Europea. Editorial Aranzadi, Pamplona, 1997, pp. 43 y sgtes.

987 TOVILLAS MORÁN, JOSÉ MARÍA. Estudio del Modelo de Convenio sobre Renta y Patrimonio de la OCDE de 1992. Marcial Pons, Madrid, 1996, pp. 91 y sgtes.
} 
exportadores y el de la Comunidades Andinas en beneficio de los importadores ${ }^{988}$, en clara consonancia con quienes respaldan a cada una de esas agrupaciones, exportadores e importadores de tecnología, respectivamente.

La OCDE busca que los cánones tributen sólo en residencia y eso es lo que hace el modelo en artículo 12 cuando señala: "Las regalías de un Estado contratante y cuyo beneficiario efectivo es un residente de otro Estado contratante sólo pueden someterse a imposición en ese otro Estado". Esta regla es igual a la de beneficios empresariales, de manera que no se ve mucho sentido al artículo, sin embargo lo tiene, puesto que en la práctica los Estados no renuncian completamente a su competencia tributaria sobre las regalías y pactan una retención en fuente, tal como da cuenta por separado las experiencias de España ${ }^{989}$ y Chile y tal como lo hace el convenio suscrito entre ambos países.

La estrategia que ha seguido la OCDE para disminuir la retención de los países importadores de tecnología que someten a retención en la fuente los cánones, ha sido pasar rentas de los cánones al art. 7 de los beneficios empresariales. Así, si revisamos en el tiempo el MC OCDE, nos vamos a encontrar con que en el año 1992 la OCDE suprime del concepto de cánones la cesión de equipos industriales, comerciales y científicos; es decir, en el MC OCDE el pago por el arrendamiento de un bien generaba cánones hasta el año 1992. A partir del año 1992, esa frase se suprime y pasa a beneficio empresarial. A la vez por la vía de los Comentarios al MC OCDE se va ligando esa definición de canon, porque también en el año 1992, se añade una referencia y se aclara la tributación de los programas de ordenador, excluyendo de tributación en la fuente de determinadas operaciones.

\subsubsection{Cánones y su relación con otras rentas en los MC}

Resulta un planteamiento tautológico intentar determinar que debe hacerse primero, si deslindar otras rentas para llegar a la definición de cánones o al analizar la

\footnotetext{
${ }^{988}$ Este es probablemente uno de los asuntos más tratados todas las publicaciones que se refieren a cánones o royalties. A modo de ejemplo, puede consultarse: BUITRAGO. Ob. Cit., pp. 383 y sgtes; GARCÍA-MORENO, MARÍA PASTOR. Los Convenios de Doble Imposición. En Fiscalidad Internacional. Obra dirigida por SERRANO ANTÓN, FERNANDO. Editorial CEF, Madrid, 2013, pp. 78. 300 y sgtes; CALDERÓN. Ob. supra cit., pp. 193 y sgtes; CARMONA FERNÁNDEZ, NÉSTOR. La Fiscalidad de los Cánones en el Impuesto sobre la Renta de no Residentes. ICE. Nuevas Tendencias en Economía y Fiscalidad Internacional No 825, Septiembre-Octubre 2005, pp. 135 y sgtes.

989 España únicamente no tiene retención en fuente, en los convenios suscritos con Hungría y Bulgaria.
} 
definición de cánones, deslindar otras rentas, ante la duda, simplemente abordaremos el asunto desde sus dos perspectivas. Por ahora, lo que tenemos que tener claro, es cuándo hay que aplicar el artículo 12 del MC OCDE y excluir ya algunos supuestos que directamente nos llevan a otros artículos.

\subsubsection{Rentas del artículo 6 del MC OCDE. Rentas de inmuebles}

Los pagos por la cesión recursos naturales donde se entrega una contraprestación al derecho a la actividad extractiva, ya sea que se hagan en retribución de concesiones administrativas sobre minas u otra forma, nunca generarán canon, sino que estaremos en el ámbito de aplicación del artículo 6 del MC OCDE, por lo que será irrelevante que se le llame canon al pago. Lo mismo puede darse con el pago por una concesión marítima. Cualquier pago por la explotación de recursos naturales o bienes raíces, habitualmente no generará canon ${ }^{990}$.

\subsubsection{Rentas de los artículos 7, 10 y 11 del MC OCDE. Establecimiento permanente, dividendos e intereses}

El artículo 7.7 del MC OCDE establece una regla de prioridad donde las rentas que son calificadas bajo otros preceptos del convenio, a la vez son excluidas del artículo $7^{991}$, lo que unido al artículo 12 del MC OCDE, nos permite afirmar que cuando se paga un canon a una empresa -naturalmente por una renta que pueda ser calificada como canon- queda sellado el destino de la norma que se aplica, con independencia que el pago recibido se encuentre dentro de la actividad económica habitual de la empresa. Puede tratarse de una empresa completamente dedicada a la investigación, siendo la cesión de patentes su actividad habitual y ese rendimiento seguirá siendo canon, no mutará a beneficios empresariales. Es decir, el artículo 12 tiene prioridad sobre el artículo 7 y cuando una renta es susceptible de ser calificada como canon, tendremos que acudir a él directamente y no al artículo 7, salvo que exista un establecimiento permanente de la empresa en el Estado de la fuente ${ }^{992}$, es decir la existencia de un establecimiento permanente en el Estado de la fuente, unido a la vinculación del activo

${ }^{990}$ En este sentido se pronuncia BUITRAGO. Ob. supra cit., p. 397.

${ }^{991}$ En este sentido CALDERÓN CARRERO, JOSÉ MANUEL. La tributación de los beneficios empresariales. En Comentarios a los convenios para evitar la doble imposición y prevenir la evasión fiscal, concluidos por España. Obra coordinada por RUIZ GARCÍA, JOSÉ RAMÓN y CALDERÓN CARRERO, JOSE MANUEL, Fundación Pedro Barrié de la Maza, Instituto de Estudios Económicos de Galicia, 2004, pp. 488 y sgtes.

992 Esta es una situación prácticamente idéntica a los artículos 10 y 11 MC OCDE, que también son prioritarios respecto del artículo $7 \mathrm{MC}$ OCDE. 
por el que se pagan los cánones al establecimiento permanente, hace que éstos se atribuyan al establecimiento permanente y no a la casa central.

Los dividendos e intereses regulados en los artículos 10 y 11 del MC OCDE sólo pueden confundirse con los cánones por su naturaleza de intangibles, por lo que normalmente no habrá confusión, salvo cuando se trate de contratos mixtos o cuando los intereses sean parte del financiamiento, por lo que no parecen ser un foco de conflicto a la hora de diferenciarlos.

\subsubsection{Rentas del artículo 13. Ganancias de capital}

El artículo 13 del MC OCDE discurre sobre una base radicalmente distinta del artículo 12 sobre cánones, desde el momento que "el artículo 13 exige que la ganancia derive de una enajenación de un bien -o derecho- mientras que el concepto de canon toma como referente la remuneración del uso, la cesión de uso o la concesión de uso de los derechos afectados" $" 993$.

En el caso de los cánones, al ser bienes incorporales, muchas veces los límites entre la sola cesión del uso y la transferencia de la totalidad del dominio, no siempre se dan con las notas de pureza que podría esperarse, pudiendo encontrar casos en que determinar la melodía es tarea de agudo oído, ya sea porque aquello que se designa como cesión de uso, tiene todos los acordes de transferencia de dominio o al revés, porque lo que aspiró a sonar como dominio en manos de un tercero, son melodías de uso. Al respecto no es difícil ejemplificar, podemos ver casos en que una licencia por tiempo indefinido, sujeta a un pago único y en la cual el licenciante no retiene para si ningún derecho, claramente posee acordes de enajenación; por otro lado, la venta de una patente, con una cláusula de retroventa obligatoria a plazo por un monto muy bajo y donde el precio consiste en un porcentaje de las ventas de los artículos producidos con la patente, se sintoniza con un canon y la cesión del uso, no con un título traslaticio de dominio $^{994}$, aunque también podemos encontrar casos extremos, como la posición de los

993 GARCÍA PRATS, ALFREDO. La tributación de las ganancias del capital. En Comentarios a los convenios para evitar la doble imposición y prevenir la evasión fiscal, concluidos por España. Obra coordinada por RUIZ GARCÍA, JOSÉ RAMÓN y CALDERÓN CARRERO, JOSÉ MANUEL, Fundación Pedro Barrié de la Maza, Instituto de Estudios Económicos de Galicia, 2004, pp. 488 y sgtes.

${ }^{994}$ Casos de difícil definición vinculados a licencias pueden verse en BUITRAGO. Ob. supra cit., p. 78. 
tribunales españoles que, tal como cuenta BUITRAGO DÍAZ ${ }^{995}$, se han negado a estimar que sea posible celebrar un contrato de venta sobre el know-how.

La manera de determinar cuándo se está frente a una transferencia o a la cesión del uso, para BUITRAGO DÍAZ ${ }^{996}$ implica una problemática que "suele ubicarse en dos extremos: una calificación conforme a lo previsto en el ordenamiento jurídico, especialmente el civil, o conforme a una consideración económica"997, lo que da cuenta de lo variopinto de las soluciones que se han propuesto, sin embargo, nosotros nos acoplamos a la propuesta de la autora que venimos citando, que apoyada en el derecho civil, plantea que "toda enajenación conlleva el derecho de uso y disposición, y al contrario, la facultad exclusiva de uso no conlleva la de disposición del bien por parte del licenciatario"

Lo que a nosotros interesa es dejar cimentado que las ganancias de capital del artículo 13 del MC OCDE se originan en la transferencia de derechos y los cánones del artículo 12 se hacen cargo de las retribuciones por el uso, así pues, cualquiera sea el velo que cubra sus formas, debe buscarse la diferencia en esa característica nuclear.

\subsubsection{Rentas del artículo 15 MC OCDE. Rentas del trabajo}

Puede ser visto como una perogrullada decir que la relación entre las rentas del trabajo y los cánones no se da a propósito del derecho de uso, puesto que el trabajo podrá emplearse o consumirse, pero no usarse, al menos no en el sentido de un atributo propietario. La vinculación entre las rentas de los artículos 12 y 15 del MC OCDE vienen dada teniendo en cuenta que, habitualmente, la invención la lleva a cabo un trabajador de la empresa, quien recibirá una remuneración por esta actividad. Habrá que atender a la normativa de la propiedad intelectual y laboral para saber cuál es el régimen jurídico exacto y básicamente, dónde radica la legislación la atribución propietaria, para encontrar resultados variados. En propiedad industrial encontramos las llamadas "invenciones en servicio", que normalmente entregan la propiedad al empleador, pero también hay casos en que la solución pasa por una atribución compartida. En el derecho

\footnotetext{
995 Ob. supra cit. p. 70.

996 Ob. supra cit. p. 54

${ }^{997}$ Las alternativas para definirlo son variadas, no se trata de una cuestión pacífica, por lo que nos limitamos a plantear el asunto, ya que su análisis implicaría alejarnos del centro de nuestra investigación.

998 Ob. supra cit., p. 73.
} 
de autor y copyright la solución es también semejante, con la particularidad que allí, el reconocimiento de los derechos morales permanece siempre en manos del autor. De manera que, si se paga al trabajador sueldos para que invente o cree, estaremos frente a rentas del trabajo. Si en el contexto de la relación laboral se realiza un pago adicional porque se quiere remunerar esa invención o conceder derechos al trabajador sobre la invención, podrían generarse cánones también, por lo que, no debe enfrentarse el asunto con criterios preestablecidos.

La legislación sobre propiedad industrial, habitualmente, atribuye los derechos sobre invenciones laborales al empleador, es el caso de España ${ }^{999}$ y Chile ${ }^{1000}$. Una solución equivalente encontramos en el caso del derecho de autor en España ${ }^{1001} \mathrm{y}$ Chile $^{1002}$. Luego, los pagos que se hagan serán normalmente rentas del trabajo, lo que no quita que puedan no serlo, como en el evento que el inventor sea codueño de la invención. Si se trata pagos que haga una sociedad al trabajador que está desarrollando una actividad en otro Estado contratante, esos pagos normalmente serán rentas del trabajo y no cánones.

\subsubsection{Artículo 17 del MC OCDE. Artistas y deportistas}

Entre los cánones y las rentas de artistas y deportistas del artículo 17 del MC OCDE, también se pueden plantear problemas, porque habitualmente en el caso de artistas, la actuación en el territorio de otro Estado, no sólo conlleva un pago por su actuación, sino que obtienen una serie de rendimientos adicionales que no están vinculados exactamente a la actuación, como por ejemplo: cuando el artista tiene registrado su nombre como marca cuya explotación licencia con el objeto de rotular artículos. Hay también que pensar que se puede pagar al artista porque actúe y al mismo tiempo se gravará la actuación, luego se transmitirá en TV, se venderá el video con la actuación o la música, etc.

999 Así lo permite el artículo 15 de la Ley 11/1986, de 20 de marzo, de Patentes.

1000 Expresamente lo acepta el artículo 68 de la Ley N ${ }^{\circ} 19.039$, sobre Propiedad Industrial.

1001 En la ley española de Propiedad Intelectual, encontramos que es posible la transferencia, bajo el título Transmisión de derechos del autor asalariado, en el artículo 51 del Real Decreto Legislativo 1/1996, de 12 de abril, por el que se aprueba el texto refundido de la Ley de Propiedad Intelectual.

1002 En Chile, en el caso de la ley de Derechos de Autor, si bien no hay una referencia expresa a la titularidad como en el caso de las patentes, el artículo 7, de la ley $\mathrm{N}^{\circ} 17.336$, sobre Derechos de Autor, reconoce expresamente la posibilidad de ser titular derivado de los derechos patrimoniales, con lo cual está definido que los derechos del autor pueden ser transferidos a su empleador, cuando es contratado para crear. 
La distinción entre el artículo 12 y 17 del MC OCDE, estará marcada porque en el último, los pagos siempre estarán vinculados a la actuación en sí misma ${ }^{1003}$ en calidad de "artista del espectáculo o deportista"1004; es decir, por el hecho de salir al escenario y realizar la actuación o cumplir con el compromiso deportivo, en definitiva la ejecución de la actividad artística o deportiva ${ }^{1005}$. De esta manera, otros pagos vinculados al uso de la propiedad intelectual o industrial, más que a la ejecución específica que realiza en el Estado de la fuente, por cualquiera concepto, tales como: explotación de marca, ventas de grabaciones y otros, encontrarán cobijo bajo el concepto de cánones ${ }^{1006}$.

Especial atención merece en este punto el llamado derecho a la imagen, que JIMÉNEZ COMPAIRED ${ }^{1007}$, sintetiza diciendo que "es la representación de la figura humana en forma visible y reconocible; que es una manifestación esencial de la personalidad, puesto que constituye uno de los elementos fundamentales de la proyección externa de la persona; y que realiza las funciones de individuar e identificar a la persona". Seguidamente recuerda, que el artículo 18 de la Constitución Española garantiza el derecho a la propia imagen, conjuntamente con el derecho a la intimidad y el honor, los que se desarrollan en la "Ley Orgánica 1/1982, de 5 de mayo, de protección civil del derecho al honor, a la intimidad personal y familiar y a la propia imagen" ${ }^{\prime 1008}$. En el derecho chileno no existe una referencia expresa al derecho a la imagen, se le suele elevar a rango constitucional al amparo del artículo $19 \mathrm{~N}^{\circ} 4$ de la $\mathrm{CPR}$, donde la Constitución declara proteger "El respeto y protección a la vida privada y a la honra de la persona y su familia" ${ }^{1009}$, sin embargo, ese amparo muestra el derecho

1003 Exigencia que queda clara de la lectura de los Comentarios al artículo 17 del MC OCDE.

1004 GARCÍA. Ob. supra cit. p. 846.

1005 Muchos ejemplos sobre casos que implican rentas de artistas y deportistas a los efectos del artículo 17 MC OCDE, pueden encontrarse en: Ob. supra cit. pp. 846 y sgtes.

1006 No obstante, no faltan los pronunciamientos que no aceptan la diferenciación que hemos hecho, a modo de ejemplo, HERNÁNDEZ GALANTE, JAVIER. Fiscalidad de artistas y deportistas. Aspectos internacionales. En Fiscalidad Internacional. Obra dirigida por SERRANO ANTÓN, FERNANDO. Editorial CEF, Madrid, 2013, p. 956, recuerda como la STS de 28 de enero de 2011, en el Recurso de Casación núm. 3213/2007, asimila los pagos realizados como contraprestación por la cesión del uso de la marca con el nombre del jugador a los pagos en contraprestación de la cesión del uso de los derechos de imagen, a los efectos de tenerlos en cuenta para la aplicación del límite artículo 92.1 y 2 de la LIRPF, que establece un régimen especial de imputación para este tipo de rentas.

1007 JIMÉNEZ COMPAIRED, ISMAEL. El régimen tributario de la explotación comercial de la propia imagen. Marcial Pons, Madrid, 2001, pp. 27 y sgtes., citando a AZURMENDI ADARRAGA.

1008 Ob. supra cit. p. 27.

1009 En este sentido, ANGUITA RAMÍREZ, PEDRO. La protección civil del derecho a la propia imagen, honra y diva privada ante la jurisprudencia. Obstáculos normativos para una reparación adecuada. Disponible en Internet en: http://www.udp.cl/facultades_carreras/derecho/pub_derecho_privado.asp (15 Ago 2013). 
a la imagen en su perfil relacionado con el derecho a la intimidad, más que en su perspectiva patrimonial, por ello, creemos que mejor cobijo se encuentra siguiendo a SILVA BASCUÑAN ${ }^{1010}$, quien sostiene que todos los derechos inherentes a la persona humana están incorporados y protegidos por la Constitución aun cuando no se hayan mencionado expresamente, lo que a nuestro juicio se confirma con la lectura del artículo $5^{\circ}$ de la CPR, que reconoce como límite a la soberanía "el respeto a los derechos esenciales que emanan de la naturaleza humana", lo que supone la existencia de ellos de manera anterior y superior al Estado.

De todas formas, lo importante es establecer que más allá de que el derecho a la imagen sea elevado a nivel legal o constitucional, se le concibe como un derecho de la naturaleza humana o vinculada a los derechos de la personalidad, poseedor de un aspecto patrimonial que le permite ser objeto de actos jurídicos y generar rentas; ya sea que lo haga vinculado al valor publicitario de la imagen, por su capacidad para ser objeto de contratos, porque se le asimile a derechos de propiedad intelectual particularmente marcas- u otra razón. "Sea lo que sea, el componente patrimonial de la imagen, su cualificación como objeto de explotación comercial, existe. Las manifestaciones de riqueza vinculadas a la misma atraen inmediatamente los apetitos fiscales: las transmisiones, cesiones o licencias de uso que se puedan producir; los ingresos y gastos generados en los diferentes agentes económicos; yendo más lejos su propia valoración patrimonial”"1011.

\subsubsection{Otras rentas en el MC OCDE}

Las creaciones del intelecto humano cruzan transversalmente todas las ciencias y también todas las actividades del ser humano, por lo que muy probablemente encontremos vinculación de los cánones con cualquier otro tipo de renta concebida por el MC OCDE, como por ejemplo, las pensiones del artículo 18 o las rentas de estudiantes del artículo 19, pudiendo encontrar casos que se presten a discusión como una invención se puede dar en el contexto de trabajos efectuados por estudiantes o cosas parecidas, lo que muestra que los cánones nunca serán una materia con fronteras definidas.

1010 SILVA BASCUÑAN, ALEJANDRO. Tratado de derecho constitucional. Editorial Jurídica de Chile, Santiago, 1997, p. 136.

1011 JIMÉNEZ. Ob. supra cit. p. 32. 


\subsubsection{Análisis del concepto de canon o regalía}

En el art. 12.2 del MC OCDE, encontramos la definición de regalías, al señalar: "El término "regalías", en el sentido de este artículo, significa las cantidades de cualquier clase pagadas por el uso, o la concesión de uso, de derechos de autor sobre obras literarias, artísticas o científicas, incluidas las películas cinematográficas, de patentes, marcas, diseños o modelos, planos, fórmulas o procedimientos secretos, o por informaciones relativas a experiencias industriales, comerciales o científicas". ${ }^{1012}$

Como reflexiones generales sobre la definición, debemos recordar que hemos tomado como referente aquella dada por el MC OCDE, pero no es la única que existe y tampoco es la única que circula en el contexto internacional, de hecho cada uno de los modelos de convenios posee la propia ${ }^{1013}$, diferente de la otra, aunque manteniendo elementos comunes que están siempre presentes, como la inclusión de la propiedad intelectual e industrial y sus rendimientos.

Tal como hemos visto, la definición es autónoma respecto de la legislación interna ${ }^{1014}$, en el sentido que aunque ella se esmere por ampliar su cobertura, como lo hace el TRLIRNR con los derechos de imagen, que están comprendidos dentro de la legislación española como cánones, no forman parte del artículo 12, 2 MC OCDE y por tanto, no tributan bajo su amparo a efectos del convenio.

Dentro de la definición, tal como tendremos oportunidad de ver, se amalgaman una serie de rentas cuyo común denominador es difícil de definir, los orígenes de este problema lo hemos tratado a lo largo de nuestro estudio, se remontan a la propia concepción de la propiedad intelectual y su contenido, aún no definido a escala

1012 En su momento abordamos el problema de encontrar uniformidad sobre si se debe usar la expresión canon, regalía, royalty u otra, por lo que entendemos que el lector tiene claro que los términos los entendemos sinónimos.

1013 Una exposición sobre las diferentes definiciones de regalía en los modelos de convenio, puede encontrarse en GARCÍA HEREDIA, ALEJANDRO. Fiscalidad internacional de los cánones: derechos de autor, propiedad industrial y know-how. Lex Nova, Valladolid, 2007, pp. 56 y sgtes.

1014 Aunque compartimos la idea que la definición del convenio es autónoma respecto de la del derecho interno, esto no quiere decir que no tengan vinculación, lo que queda bastante claro al oír a VÁZQUEZ DEL REY VILLANUEVA, ANTONIO. Sobre el concepto cánones o "royalties". Jurisprudencia Tributaria, Aranzadi, 2002, Vol. 2, p. 2307, quien escribe: "En principio, la existencia de un concepto interno parece carecer de relevancia a efectos de la interpretación y aplicación de los Convenios de Doble Imposición, en la medida en que cada convenio incorpora su propio concepto que, básicamente responde a las pautas del Modelo de Convenio de la OCDE. Sin embargo, esto no es del todo cierto porque la noción que aparece en el convenio se integra de una serie de términos que no aparecen definidos en aquella sede. Es el caso, por ejemplo, de la expresión $<$ derechos de autor sobre obras literarias, artísticas y científicas $>$ ". 
planetaria y a la génesis del MC OCDE y al hecho de haber sido desarrollado en un contexto multilateral de países exportadores de tecnología, quienes buscan la tributación de las regalías en residencia, sin embargo en el mercado global sus clientes son países importadores de tecnología que pretenden la tributación en fuente. Ante esta contraposición de intereses, vemos un artículo heterogéneo ${ }^{1015}$, que sufre los avatares de las transacciones que sin duda se han llevado adelante para acordar un texto, de manera que vuelve a ser verdad aquel paradigma que dice: si bien las transacciones son buenas en política, confunden al derecho.

BUITRAGO DÍAZ hace un intento por clasificar los elementos de la definición, estableciendo, que "en general comprende: 1) pagos efectuados como contraprestación; 2) por el uso o derecho a usar; 3) un listado de bienes o derechos"1016. En el mismo sentido, la autora da cuenta de la falta de acuerdo entre la doctrina, en los intentos de encontrar un denominador común para los elementos de la definición, ejemplificando con MORGENTHALER, quien estima que se trata de un listado de bienes o derecho, en contraposición con GARCÍA PRATS, que considera que la nota característica es el uso o la cesión del uso. Por su parte, la autora levanta una tercera teoría, indicando que existe un elemento común caracterizado por "la posición de privilegio de que goza quien faculta el uso a un tercero".

En nuestra opinión, no existe una verdadera razón basal del artículo, sino que obedece a la transacción política sobre su contenido, de manera que intentar encontrar una eadem ratio unificadora fundada en principios jurídicos es un esfuerzo improductivo, puesto que probablemente su utilidad más significativa sería como recurso para apoyar la analogía como elemento interpretativo, cuestión que tampoco desbordará en utilidad, desde el momento que a pesar de los esfuerzos de EZIO VANONI ${ }^{1017}$, la aplicación de la analogía en derecho tributario, sigue siendo discutida $^{1018}$ y aún en el evento de ser aceptada ${ }^{1019}$, requiere apoyarse en un contexto

1015 La caracterización como heterogéneo ya fue hecha por GARCÍA PRATS, ALFREDO. Los cánones en los Convenios de Doble Imposición y su tributación, Revista General de Derecho $N^{\circ} 579$, diciembre de 1992, p. 1176.

1016 BUITRAGO. Ob. supra cit. p. 32.

1017 VANONI, EZIO. Naturaleza e interpretación de las leyes tributarias, Dott A. Giuffre, Milan, Italia, 1961, pp. 337 y sgtes.

1018 De hecho en el contexto español, ni el legislador consigue ponerse de acuerdo con sí mismo, sobre el grado de utilidad que permitirá a la analogía; así pues, no será difícil convenir que el artículo 23.3 de la LGT, hoy artículo 14 de la Ley 58/2003, que establece que no se admitirá la analogía para 
jurídico coherente he indubitado, "con un grado de afinidad tal que puede afirmarse que se encuentra en la misma ratio jurídica que inspira la norma formulada"1020 ${ }^{\text {, condiciones }}$ que no reúnen las ratios jurídicas que hemos analizado. Así las cosas, parece más útil reconocer la realidad y asumir que muchos de los bienes descritos en la definición no tienen una vinculación, de manera que, la justificación para unos no siempre servirá para los otros, como puede suceder entre los pagos por derechos de autor y la utilización de equipos científicos. En estas circunstancias, se apega más a la realidad pensar que pueden existir en la definición grupos de bienes que tienen una justificación común, en vez de buscar una razón omnicomprensiva y única, puesto que de otra manera, trabajar sobre supuestos falsos llevará a conclusiones erradas.

\subsubsection{Elementos característicos de la definición del artículo 12.2 MC OCDE}

En la definición del artículo 12. $2 \mathrm{MC}$ OCDE hay tres elementos ${ }^{1021}$ que deben estar presentes para conformar una regalía a los efectos del convenio, son:

a) Que se trate de los bienes que se enumeran en la definición. En consecuencia el acto jurídico generador del canon ${ }^{1022}$, debe tener por objeto uno de los intangibles que se mencionan en la definición ${ }^{1023}$. El sustantivo "bienes" lo hemos considerado como género, puesto que el concepto de canon se mueve en el terreno de los bienes inmateriales o específicamente de los derechos intangibles, la excepción viene dada por aquellos casos en que se incluye la cesión de equipos industriales, comerciales o científicos.

extender más allá de sus términos estrictos del ámbito del hecho imponible de las exenciones o bonificaciones, es un poco como decir: "ni lo uno, ni lo otro, sino todo lo contrario".

1019 Como sucede en el derecho español, desde la incorporación de la expresión "cualquier derecho similar a los anteriores", a la definición de cánones o regalías contenida en el artículo 13.1.f) $3^{\circ}$ de la TRLIRNR y como también pasa en aquellos convenios que incluyen expresiones como "derechos análogos" o "derechos similares", para dejar abierta la posibilidad de integrar los cánones con otros rendimientos semejantes. Sobre los casos y la forma como se acepta la analogía a propósito de las regalías, puede verse a BUITRAGO. Ob. supra cit., pp. 102 y sgtes.

1020 VANONI. Ob. supra cit., pág. 338.

1021 En este mismo sentido podemos ver a MARTÍN. Ob. supra cit., p. 683 y sgtes. Los mismos requisitos analiza BUITRAGO. Ob. supra cit., pp. 31 y sgtes.

1022 Normalmente la licencia.

1023 DELGADO PACHECO, ABELARDO. En Capítulo XV. El régimen de los cánones en la fiscalidad internacional: cuestiones especialmente debatidas en España. Obra dirigida por SERRANO ANTON, FERNANDO. Fiscalidad Internacional. CEF, Madrid, 2013, p. 715. 
b) Que exista de una autorización del uso o derecho a usar. GARCÍA HEREDIA $^{1024}$ explica que la expresión "uso o la concesión del uso" que utiliza el MC OCDE, define la naturaleza jurídica de la transacción que dará lugar a las regalías. En efecto, tal como tuvimos oportunidad de analizar, lo característico es que una persona que tiene una posición de privilegio o poder sobre un bien (normalmente un intangible) permite el uso de un bien ${ }^{1025}$ a un tercero, conservando el titular su posición de privilegio o poder ${ }^{1026}$.

Llama la atención que se use la expresión "uso" y seguidamente "la concesión del uso", puesto que parece ser lo mismo, para el autor citado, ello se explica por la amplitud que quiso darse al concepto, de manera que abarcara los usos pasados y los que se puedan efectuar en el futuro, de la manera más amplia posible, lo que es coincidente con los comentarios que hace al respecto MARTÍN JIMÉNEZ ${ }^{1027}$, para quien "la formulación amplia del título jurídico, igualmente, abarcaría los supuestos en los que, existiendo la concesión de uso del bien o derecho, el concesionario no hace un uso efectico del mismo (...) tampoco es relevante que el bien o derecho esté registrado como propiedad industrial o intelectual". Reforzando la idea de la amplitud que puede considerar el pago, aunque siempre vinculado al uso, los comentarios al artículo 12 del MC OCDE, dejan en claro que las retribuciones indemnizatorias por el uso ilegal también deben ser consideradas como un pago por el uso. Por su lado BUITRAGO DÍAZ ${ }^{1028}$ advierte sobre los pagos por el no uso, tales como licencias exclusivas y prohibición de competencia, puesto que las administraciones tributarias de los Estados Unidos de Norteamérica y Suiza, se han pronunciado en el sentido que no se engloban dentro de la definición, pero varios tratados los contemplan como cánones, como es el caso de Nueva Zelanda y Filipinas y Australia con diversos países, por lo que concordamos con la autora, que no es una materia sobre la cual pueda darse una opinión generalizada.

1024 GARCÍA HEREDIA. Ob. Cit. páginas 33 y sgtes.

1025 Normalmente incorporal como una marca o patente, pero también puede ser corporal como los equipos científicos y técnicos.

1026 En vez de hablar de una posición de privilegio o poder, podríamos haber hablado derechamente de dominio, pero no quisimos hacerlo para no enmarañarnos en la discusión que tuvimos oportunidad de analizar en su momento, sobre si respecto de los bienes inmateriales existe o no un verdadero dominio y cuáles son las facultades de éste.

1027 MARTÍN. Ob. supra cit. p. 684.

1028 BUITRAGO. Ob. supra cit. pp. 120 y 121. 
La diferenciación entre la cesión del uso y la transferencia del bien en sí mismo, puede ser muy opaca, tal como analizamos en su momento, por ejemplo, con ciertas licencias con cláusulas desbordantes de derechos en favor del licenciatario. En lo concreto, hay que distinguir si se trata de una licencia o de la venta de un derecho, diferencia por cierto perfectamente posible, de suerte que, según las características del contrato vamos a encontrarnos en el artículo 12 o 13 del MC OCDE.

c) Que haya un pago o remuneración ${ }^{1029}$. La existencia de un pago o remuneración es el tercer elemento de los cánones, simplemente se trata de que debe haber una contraprestación, excluyéndose las cesiones gratuitas. No obstante, MARTÍN JIMÉNEZ ${ }^{1030}$ agudamente advierte, que nada impide que se considere dentro del artículo 12 del MC OCDE, una presunción o ficción de pago de la legislación interna, como puede pasar por ejemplo, con las reglas sobre partes vinculadas.

El pago, obviamente, debe ser por el uso o cesión del uso, por lo que también aquí será necesario estar atentos a una suerte de realistic test ${ }^{1031}$, puesto que bajo la forma de una licencia podría estarse ocultando una compraventa a plazo o bajo un pago con acciones podría estar oculta una ganancia de capital $^{1032}$.

El tipo de remuneración es irrelevante, no importa que sea fija o variable, vinculada a la rentabilidad del licenciatario, en especie, de contado, a plazo, etc., siempre será canon, tal como dejan en claro los comentarios al MC OCDE.

\subsubsection{Derechos y bienes específicos de la definición de regalía}

Para definir el contenido exacto que ha querido comprender un convenio dentro del concepto de canon, se requerirá siempre de un esfuerzo interpretativo, por simple que éste sea, para ello compartimos con GARCÍA HEREDIA ${ }^{1033}$, que debe distinguirse entre aquellos términos definidos por el tratado y los que no lo están, "para estos últimos es necesario acudir a las reglas generales de interpretación de la CVDT y a la regla especial de interpretación de los CDI" prevista en el artículo 3.1 del MC OCDE.

1029 Un análisis exhaustivo de los pagos como elementos de los cánones, se puede encontrar en Ob. supra cit., pp. 33 y sgtes.

1030 MARTÍN. Ob. supra cit., pp. 685.

1031 Según BUITRAGO. Ob. supra cit., p. 78, es la denominación que recibe la doctrina norteamericana que busca determinar el verdadero contenido de un contrato para definir su tributación.

1032 Sobre el pago con acciones, puede verse: Ob. supra cit. p. 45.

1033 Ob. supra cit. p. 83. 
Los cánones son un concepto definido en el MC, sin embargo ello lejos de solucionar el problema lo agrava, puesto que "hay una indefinición de cada uno de los elementos que lo integran”"1034, lo que obliga a su análisis particular y pormenorizado.

Por lo anterior, para definir completamente qué se entiende por canon, iniciaremos el análisis de la definición buscando los derechos y bienes a que se refiere, para lo cual, como introducción haremos una clasificación y después entraremos al análisis específico. Siguiendo a GARCÍA HEREDIA ${ }^{1035}$, proponemos una clasificación que identificar las fuentes generadoras de cánones bajo dos criterios, un criterio de género $^{1036}$, es decir, aquellas fuentes que contienen otras especies y un criterio de importancia jurídica, entendido como aquellos supuestos que son más singulares o se han prestado para más debate jurídico. Nuestro objetivo si bien es académico, es más bien pedagógico, puesto que organizar las cosas de esta manera, permite un acercamiento al tema más gradual, partiendo de lo más fácil y explicable a lo más complejo. Bajo estas premisas, pensamos en la siguiente ordenación:

a) Propiedad intelectual, que el MC OCDE, derechamente llama "de derechos de autor sobre obras literarias, artísticas o científicas, incluidas las películas cinematográficas";

b) Propiedad industrial, donde se incluyen "patentes, diseños o modelos, planos, fórmulas o procedimientos secretos";

c) Know-how, que se refiere a "informaciones relativas a experiencias industriales, comerciales o científicas";

d) Equipos industriales, comerciales o científicos. Este tipo de bienes estuvieron tradicionalmente incluidos en el artículo 12 del MC OCDE, pero fueron eliminados en la versión de 1992, puesto que se pensó que este tipo de equipos no se condecía con la definición de canon ${ }^{1037}$. Sin embargo, no puede pasarse por alto, porque estos equipos están incluidos en convenios firmados antes de 1992 y lo seguirán estando en muchos convenios futuros, puesto que su eliminación implica para los países renunciar al gravamen en fuente.

\footnotetext{
1034 Ob. supra cit. p. 84.

1035 Ob. supra cit., pp. 39 y sgtes.

1036 Otra clasificación es hecha por FERNÁNDEZ DE PEDRO, FRANCISCO. Fiscalidad de los no residentes en España (IV): Rentas obtenidas sin establecimiento permanente. En Manual de fiscalidad internacional. Dirigido por CORDÓN EZQUERRO, TEODORO. IEF, Madrid, 2001, pp. 233 y sgtes.

1037 Con lo cual, la noción de regalía se acercó mucho más a la idea de intangible exclusivamente.
} 
e) Prestaciones de servicios. En los comentarios al artículo 12 del MC OCDE, queda claro que las prestaciones de servicios no se incluyen dentro del concepto de know-how, que era el único lugar donde podrían haber estado los servicios, sin embargo también encontraremos convenios que incluyan determinadas prestaciones de servicios, vinculadas a los bienes o derechos antes mencionados;

f) Supuestos confusos o de difícil calificación. En este caso nos referimos a ciertos casos limítrofes donde normalmente existirá confusión para poder determinar si estamos o no frente a un bien o derecho objeto de canon. Es el caso de determinados contratos suscritos por artistas y deportistas, por ejemplo, cuando usan su nombre como marca comercial; contratos complejos, donde se hacen aportes a investigación y desarrollo, a cambio de una determinada participación en la invención; pactos de percepción líquida de cánones, como cuando se contrata que el pago será un monto fijo y que la retención que impone el Estado de la fuente será de cargo del licenciatario, se plantea la duda sobre cuál es la naturaleza jurídica de ese pago retención, por llamarlo descriptivamente; contratos de franquicia; y, pagos por derechos de imagen, entre otros.

\subsubsection{Derechos de autor}

La definición del artículo 12.2 del MC OCDE incluye dentro de las regalías a los "derechos de autor sobre obras literarias, artísticas o científicas", lo que de entrada da fe, del hecho que la definición no resuelve el problema de qué se entiende por cánones, puesto que al optar por definir a través de un listado de bienes y derechos, el problema interpretativo mutó, desde la necesidad de interpretar la definición a definir el contenido de cada uno de los bienes y derechos que componen la propia definición. En consecuencia, la pregunta que cabe es: ¿qué se entiende por "derechos de autor sobre obras literarias, artísticas o científicas? Al respecto, tuvimos oportunidad de analizar el contenido del derecho de autor tanto en Chile como en España, definiendo que aunque con una nomenclatura diferente, en ambos países por derechos de autor se entiende propiedad intelectual, con los matices que a ella se da, en cada caso.

Relacionando lo que venimos estudiando, en el sentido de la autonomía de la definición de cánones del MC y sobre la interpretación de los CDI, cabe preguntarse cuál es la manera de dar contenido a la "propiedad intelectual" a que se refiere el MC al hablar de "derechos de autor". De partida, el MC ni sus comentarios ofrecen una 
definición o explicación, pareciendo asumir un entendimiento armónico de cuál es su contenido, lo que no es así, de hecho ni siquiera hay uniformidad respecto de la relación entre propiedad intelectual y copyright, cuestión por demás sabida, que no requiere análisis. En este sentido, compartimos lo propuesto por MARTÍN HEREDIA ${ }^{1038}$, en el sentido que no puede usarse la definición del Convenio Multilateral UNESCO/OMPI para la Eliminación de la Doble Imposición en materia de cánones derivados de derechos de autor, para interpretar la norma que nos ocupa, a lo que agregamos que tampoco puede usarse la definición de otro tratado internacional, puesto que el TDI tendrá que interpretarse conforme al derecho de los Estados contratantes (artículo 3.2 del MC OCDE) o apelando a su contexto (en aplicación de la CVDT), pero nada tienen que hacer terceros tratados.

Siguiendo el propio MC OCDE, convenimos con MARTÍN HEREDIA ${ }^{1039}$ que la respuesta se deberá encontrar en el derecho interno del Estado de la fuente, partiendo por el derecho tributario y siguiendo por el resto ${ }^{1040}$, en cuyo caso, las preguntas serán múltiples, puesto que cada país ha dotado de contenido a la propiedad intelectual con un sustrato más o menos equivalente, pero a la vez con grandes diferencias, baste recordar que a la luz de la expresión genérica "derecho de autor" podremos encontrar al derecho de autor como especie y también al copyright y bajo este último, cohabitan otros derechos que para el sistema continental son los derechos conexos.

Así las cosas, habrá que ver en el Estado que corresponda a la fuente, qué tipos de obras son protegidas por el derecho de autor y hasta donde se extienden los derechos que ese Estado garantiza, además, obviamente, de definir cuáles de ellos pueden ser cedidos. Estimamos que un sustrato común en esta materia son los derechos de explotación, reproducción, distribución, comunicación pública, puesta a disposición y transformación, en el sentido que la mayoría de los sistemas de una u otra forma los garantizan y que todos ellos, usualmente, pueden ser cedidos.

Con definir un sustrato común en los derechos básicos del derecho de autor y copyright, no hemos conseguido salvar todas las dudas, ni menos dotar completamente de contenido a la frase "por el uso, o la concesión del uso, de derechos de autor sobre

1038 MARTÍN. Ob. supra cit., p. 685.

1039 MARTÍN. Ob. supra cit., p. 686.

1040 No hablamos de la legislación mercantil, porque la propiedad intelectual no siempre se cobija bajo el derecho mercantil, de hecho en Chile, es parte del Derecho Civil. 
obras literarias, artísticas o científicas”, puesto que cabrá preguntarse, que sucede, con los derechos conexos. Los comentarios al MC OCDE no se hacen cargo de la distinción. MARTÍN HEREDIA ${ }^{1041}$ opta por apoyarse en el 3.2 del MC OCDE, aplicar la legislación española sobre derecho de autor, donde los derechos conexos son parte del derecho de autor y por tanto, quedan incluidos en la definición. BUITRAGO DÍAZ ${ }^{1042}$ utilizando un razonamiento por exclusión, sostiene "la falta de inclusión de los pagos por derechos conexos en el artículo de cánones o regalías de los CDI no se deduce que el uso o derecho a usar una obra protegida por Derecho de autor por el titular de un derecho conexo esté fuera de su ámbito”. CEBALLOS DELGADO ${ }^{1043} \sin$ dar mayores explicaciones, estima que una interpretación literal, niega en la definición de regalía aquellas rentas percibidas por artistas, intérpretes y ejecutantes, pero de contrario, las acepta cuando medie un contrato de representación, entendiendo por tal aquél en que el autor de una obra autoriza a un empresario para su ejecución pública, estipulando que las regalías se paguen en favor del artista o interprete "con base en la venta de los ejemplares gravados".

Otros autores, no obstante referirse específicamente a la propiedad intelectual, simplemente omiten el problema y no hacen mención de los derechos conexos ${ }^{1044}$.

En nuestra opinión, si bien el derecho de la propiedad intelectual dista mucho de estar armonizado a escala mundial, no conocemos otra área de la ciencia jurídica, donde exista mayor cantidad de tratados multilaterales, con más antigüedad y con mayor extensión sustantiva, de manera que, es un hecho público y notorio que existe un cierto sustrato común y que en el mundo entero se reconocen los conceptos de derechos de autor, copyright y propiedad industrial. De lo anterior, se deriva una cierta estandarización de los mismos y si bien podrá discutirse si el software debe protegerse por derecho de autor, patente, ambos o un tercer sistema, y también puede discutirse si el derecho de los productores de audiovisuales es un derecho de autor o un conexo, entre muchas otras cosas, conjuntamente tendrá que convenirse que al escritor de un libro se le reconoce como autor en todas partes del mundo y al cantante como intérprete,

1041 Ob. supra cit., p. 686.

1042 BUITRAGO. Ob. supra cit., p. 194.

1043 CEBALLOS DELGADO, JOSÉ MIGUEL. Estudio comparativo del concepto de regalías contenido en los modelos de convenio para evitar la doble imposición y su alcance en materia de propiedad intelectual, p. 14. Disponible en Internet en: www.usergioarboleda.edu.co (10 Mar 2014).

1044 Es el caso de CARMONA, CORDÓN. Obs. supra cit. 
de manera que, al igual como hemos postulado frente a otros problemas, más que buscar la gran solución dogmática al tema, creemos que en principio a los derechos conexos no se les puede negar su espacio dentro del derecho de autor, no obstante, que la cuestión debe resolverse en definitiva analizándose en función de cada caso, sin duda partiendo de la legislación del Estado de la fuente y teniendo en cuenta el contrato específico que se busca calificar, donde no debe perderse de vista que lo que se debe buscar es la posibilidad de uso por un tercero del derecho en cuestión, manteniendo quien recibe la renta la titularidad del mismo.

\subsubsection{Propiedad industrial}

La propiedad industrial está incluida en la definición al hablar de "patentes, marcas, diseños o modelos, planos, fórmulas o procedimientos secretos" y también al decir: "informaciones relativas a experiencias industriales, comerciales o científicas".

Tal como advierte GARCÍA HEREDIA ${ }^{1045}$, en opinión que compartimos, "la parte del concepto de canon que, supuestamente, se refiere a la propiedad industrial, se encuentran también referencias que aluden a la propiedad intelectual e, incluso, algunas de ellas, al know-how ${ }^{1046}$, lo que es claro que patentes y marcas están dentro de la propiedad industrial, diseños o modelos, planos, fórmulas o procedimientos secretos e informaciones relativas a experiencias industriales, comerciales o científicas, pueden estar bajo una clasificación amplia de propiedad industrial y no estarlo bajo una visión estricta. En el mismo sentido, hay otros institutos que no están mencionados y que también pueden estar bajo un alero amplio, tales como: modelos de utilidad, dibujos textiles, nombre comercial, topografías de circuitos integrados, denominaciones de origen e indicaciones geográficas, por sólo mencionar algunos.

En nuestra opinión, en la búsqueda de argumentos en esta materia, se puede llegar a cualquier parte, como MARTÍN HEREDIA ${ }^{1047}$ quien estima de utilidad la referencia a "diseños o modelos", puesto que como en España no están específicamente en la ley de patente, con su inclusión se deja claro que generan cánones, opinión que no refutamos, pero por otro lado, también podría pensarse que la referencia es mala, puesto

\footnotetext{
1045 GARCÍA. Ob. supra cit. p. 257.

1046 Eso suponiendo que sabemos dónde clasificar el know-how dentro de la propiedad intelectual en general, lo que por cierto, es otro problema.

1047 MARTÍN. Ob. supra cit., p. 713.
} 
que da cabida al argumento a contrario sensu, por medio del cual se podría sostener que todos aquellas categorías normalmente incluidas en la propiedad industrial y que no están mencionadas, no generan cánones. BOKOBO MOICHE ${ }^{1048}$ en otro extremo, se conforma con referirse a las leyes españolas de patentes, diseños industriales y marcas, para conferir contenido al asunto. Por nuestra parte, la solución es la misma que en el caso del derecho de autor, en el sentido que existe una conciencia relativamente uniforme a nivel mundial de qué involucra la propiedad industrial, más allá, de determinados matices o institutos que reciben protección en algunos países y en otros no, por lo que no caben interpretaciones restrictivas, sino que al amparo del artículo tienen lugar todas las rentas provenientes de la explotación económica del uso, de derechos reconocidos por el Estado, para proteger tanto la actividad innovadora como mercantil, mediante el otorgamiento de derechos de comercialización exclusivos, ejercibles erga omnes, ya sea con el objeto de asegurar la producción o la identificación en exclusiva de productos y servicios ofrecidos en el mercado.

Sin que sea relevante que el artículo 12 del MC OCDE, se haya limitado a ejemplificar con algunos de sus institutos más característicos ${ }^{1049}$. En este sentido, vuelve a ser verdad, que la idea central del artículo no son tanto los derechos que menciona, sino que la posibilidad de permitir el uso de los mismos por un tercero manteniendo la titularidad del éste en quien faculta ese uso.

\subsubsection{Know-how}

Describir el know-how siempre es una tarea difícil, puesto que se trata de una idea implantada desde el common law al derecho continental, llegando a ser un préstamo $^{1050}$, de manera que se trata de la misma palabra en inglés y español, es decir, posee el mismo contenido en un idioma que en el otro; así por ejemplo, se dificulta pensar que en España o Chile, alguien pensase hacer un contrato "para la transferencia

1048 BOKOBO MOICHE, M SUSANA. Los convenios de doble imposición sobre la renta y el patrimonio: Interpretación y calificación, Crónica Tributaria $\mathrm{N}^{\circ} 114,2005$, p. 59.

1049 A igual conclusión llega BUITRAGO. Ob. supra cit., p. 124. Quien abordando el tema desde el punto de vista de marcas, estima que la extensión a otros institutos no mencionados en el artículo 12 del MC OCDE es una interpretación extensiva perfectamente posible y no un caso de interpretación analógica.

1050 Sobre préstamos y calcos, puede verse a CASAS TELLO, SONIA. Calcos lingüísticos y fraseológicos en el lenguaje audiovisual: el caso de Pulp Fiction. Jornadas de Foment de la Investigació. Universitat Jaume I. Disponible en Internet en: http://www.uji.es/bin/publ/edicions/jfi3/calcos.pdf (10 Sep 2014). 
del conocimiento experimental", sino que derechamente harían un contrato para la transferencia del know-how.

Para MARTÍN JIMÉNEZ ${ }^{1051}$ para dar contenido al know-how los comentarios al MC OCDE, aceptan la definición de la Association des Bureaux pour la Protection de la Propieté Industrielle, para quienes "el know-how es el conjunto no divulgado de informaciones técnicas, patentables o no, que son necesarias para la reproducción industrial, directamente y en las mismas condiciones, de un producto o de un procedimiento; procediendo de la experiencia, el know-how es el complemento de lo que un industrial no puede saber por el solo examen del producto y el mero conocimiento del progreso de la técnica”.

Vale tomar en cuenta que el know-how no es el contrato, sino que el conocimiento que una persona se compromete a transferir ${ }^{1052}$. De manera que tratándose de un contrato innominado nada impediría que se le llamase como acabamos de proponer, "contrato de transferencias de conocimiento experimental"; sin embargo, conforme a las dificultades prácticas que ya ha enfrentado en know-how, vaya quien a saber cuáles otras acarrearía semejante bautismo, aunque su contenido fuese estricta y perfectamente know-how. Sea como fuere, lo característico del know-how, cuestión en la que existe bastante consenso ${ }^{1053}$, es que se trata de informaciones técnicas no divulgadas, que se han mantenido en reserva, procedente del conocimiento práctico y no es obtenible directamente del arte, susceptible de patentar o no y que otorga un aporte a la implementación de un proceso o elaboración de un producto.

El know-how es uno de los temas sobre los que más se extienden los comentarios al MC OCDE, de manera que son de mucha utilidad para entender la real extensión del concepto. En concordancia con lo que venimos exponiendo, los comentarios al MC OCDE, incorporan en la noción de know-how todos los elementos característicos que anotamos supra, tal como podemos ver si los leemos detenidamente ${ }^{1054}$ : "La expresión 'pagos [...] por informaciones relativas a experiencias industriales, comerciales o

1051 MARTÍN. Ob. supra cit., p. 713.

1052 Sobre este asunto puede verse a GARCÍA HEREDIA. Ob. supra cit., pp. 261 y sgtes.

1053 En este sentido puede verse a MARTÍN. Ob. supra cit., pp. 713 y sgtes; GARCÍA HEREDIA. Ob. supra cit., pp. 261 y sgtes; BUITRAGO. Ob. supra cit., pp. 271 y sgtes; BOKOBO. Ob. supra cit., pp. 62 y sgtes; entre otros.

1054 Entre paréntesis pondremos nuestros comentarios, para demostrar donde están los elementos teóricos del know-how. 
científicas' (existencia de informaciones técnicas) se utiliza en el contexto de la transmisión de cierta información no patentada (puede ser patentable, pero debe estar patentada) y que, por lo general, no recae en el ámbito de otras categorías de derechos sobre la propiedad intelectual (si recae en otra categoría de propiedad intelectual será objeto de ella y no de know-how). Normalmente se trata de información de carácter industrial, comercial o científico, nacida de experiencias previas (debe venir del conocimiento práctico y no del arte), que tiene aplicaciones prácticas en la explotación de una empresa, y de cuya comunicación puede derivarse un beneficio económico (debe ser un aporte)".

Con estos datos característicos, tendremos los elementos para identificar un conocimiento específico, que es el objeto de lo que llamamos know-how y que puede ser transmitido del que lo posee a otra persona, volviéndose el objeto de un contrato.

Lógicamente que uno de los temas fundamentales del know-how es deslindarlo de su figura más próxima, la prestación de servicios, toda vez que la transferencia del know-how implica una prestación de servicios, será muy fácil confundir a ambos y es de donde se ha derivado la mayor parte de litigios, que han hecho saltar a la fama de la tributación internacional a este instituto. Por ello, el MC se esmera en decir, que no conforma know-how, la información obtenida de experiencias obtenidas como resultado de la prestación de servicios para el pagador y se hace cargo de ciertos indicios para demostrar su existencia, a saber: el cedente no interviene en el uso que el cesionario haga del conocimiento y no garantiza el resultado; no se trata de hacer aquello que usualmente se hace en una profesión, es decir, no es una prestación de servicios profesionales; existe el compromiso de mantener la confidencialidad de la información, porque no es pública y no se puede obtener del arte existente; los conocimientos son transferidos al cesionario, no se trata de que sólo se permita su uso; generalmente, el proveedor hará muy poco, de acuerdo con el contrato, además de aportar la información disponible o reproducir el material existente, puesto que no se contrata la ejecución per se, sino que el aporte de conocimiento.

Para cerrar el asunto, el MC cambia de estrategia, haciendo una delimitación negativa, para mostrar casos de prestación de servicios que no constituyen know-how, tales como: servicios de posventa; servicios prestados por un vendedor en el marco de la garantía debida al comprador; listados de clientes potenciales, cuando tales listados se 
confeccionen específicamente para el pagador con información de carácter público ${ }^{1055}$; los dictámenes emitidos por un ingeniero, un abogado o un experto contable; y, las asesorías prestadas por vía electrónica, vinculadas a una base de datos para solucionar problemas $^{1056}$.

La dedicación que ponen los comentarios al MC OCDE en el know-how, atendida su preponderancia y extensión, por sí solos hablan de una especial preocupación, lo que viniendo del contexto multilateral de la OCDE supone la atención de muchos Estados partes, afirmación que se ve corroborada en el caso español, donde parecen sobrar los casos y las resoluciones en uno u otro sentido, por lo que no puede pasarse por alto el llamado caso "Opel Corsa", puesto que dio origen a una serie de sentencias que terminaron por fijar una discutida jurisprudencia.

Si bien, este caso permite escribir el capítulo de un libro sobre la materia ${ }^{1057}$, solamente nos detendremos en una afirmación que no compartimos y que dice relación con que para el TS español, el know-how no puede ser objeto de venta y por tanto, tampoco de una transferencia dominical. Las razones del TS para esto, las resume GARCÍA HEREDIA ${ }^{1058}$, bajo cinco puntos, sin embargo tres de los argumentos se refieren al caso concreto y además, efectivamente conducen a la conclusión de que se estaba frente a cánones, de manera que, lo que discutimos no es la conclusión en el caso, sino la afirmación genérica sobre la imposibilidad de vender el know-how. Los argumentos genéricos para estimar que el know-how no es vendible, son que la compraventa no es posible porque no se puede garantizar la posesión pacífica y tranquila al comprador, tal como exige el artículo 1474 del Código Civil Español y que al ser el know-how un bien incorporal, no puede cumplir con el mandato de constar en un título, tal como previene el artículo 1464 del código citado. Desde nuestra perspectiva y compartiendo con el autor mencionado, estos argumentos son falsos, desde el momento en que se puede garantizar la posesión pacífica del know-how, puesto que encuentra protección en el derecho de la competencia desleal, en el secreto

1055 Aclara el MC OCDE: “sin embargo, la remuneración por un listado confidencial de clientes a los que el perceptor de la remuneración ha suministrado un producto o servicio concreto, sí constituiría una remuneración por conocimientos prácticos -know- how- dado que estaría relacionada con la experiencia comercial de este en sus relaciones con tales clientes".

1056 Especifican los comentarios al MC OCDE, que se trata del trouble-shooting, "como puede ser una base de datos que proporciona información no confidencial, en respuesta a preguntas frecuentes o a problemas comunes que se plantean a menudo a los usuarios de aplicaciones informáticas".

1057 Como efectivamente lo hizo con extraordinaria claridad, GARCÍA. Ob. supra cit., p. 284 y sgtes.

1058 Ob. supra cit., pp. 294 y sgtes. 
empresarial y en el propio Código Civil, por la ley del contrato, que permitirá exigir el cumplimiento de la obligación pactada o la indemnización de perjuicios. En cuanto a que deba constar en un instrumento, además de ser un requisito falso, puesto que ni siquiera el contrato que contenga la transferencia tiene obligación de constar por escrito, si se tienen la necesidad de exigirlo, basta que se ponga por escrito y el propio contrato servirá de constancia. En nuestra opinión el know-how, aunque completamente abstracto e inmaterial, desde el momento que presta una utilidad al hombre y tiene un valor, puede ser objeto de transferencia dominical, para ello, el contrato antecedente por fuerza será la compraventa y no otro. Ahora bien, lo que se transferirá será eso “know-how” y no otra cosa, lo que queremos decir, es que se transferirá con todas sus virtudes y vicios, por lo que no puede del hecho de ser un instituto cuya protección pudiese ser débil, desprenderse su imposibilidad de ser transferido, del mismo modo que no podría quien compra A, esperar recibir B, tampoco se le puede exigir al know-how ser más de lo que es, como requisito para hacerlo transferible.

\subsubsection{Equipos industriales, comerciales y científicos}

En los modelos de CDI versiones de 1963 y 1977, se califican como cánones los pagos por "el uso o la cesión del uso de equipos industriales, comerciales y científicos", desapareciendo en la versión de 1992.

El mayor coste que significaba la retención en fuente y la pérdida de dinamismo que implicaba para el arriendo internacional de maquinarias ${ }^{1059}$, fue uno de los antecedentes para que el Comité de Asuntos Fiscales de la OCDE, propusiera la eliminación de las rentas procedentes de la cesión del uso de equipos industriales, comerciales y científicos del concepto de regalías ${ }^{1060}$, aunque también se razona sobre la base de la influencia de los países industrializados, en la medida que su eliminación como regalías, descarta la retención en la fuente y traslada su tributación

1059 Sobre este punto, MARTÍN. Ob. supra cit., pp. 726 y sgte., explica: "El gravamen en la fuente de los pagos por cesión de equipos muy probablemente genera doble imposición pues el Estado de la fuente aplicará los tipos impositivos sobre el montante bruto pagado, y este impuesto no será deducido íntegramente del impuesto a pagar en el Estado de residencia, debido a que en este Estado el arrendador puede deducir gastos (v.gr. amortizaciones, gastos de financiación) que harán que la cuota del impuesto a pagar se reduzca notablemente en comparación con el impuesto debido en el Estado de la fuente".

1060 De esto dan cuenta GARCÍA HEREDIA. Ob. Cit., pp. 325. 
exclusivamente a residencia, normalmente en calidad de beneficios empresariales ${ }^{1061}$. Sea como fuere, son los propios comentarios al MC OCDE, los que señalan: "Mientras la definición del término "regalías", en el Proyecto del Convenio de 1963 y en el Modelo de Convenio de 1977, comprendía los pagos "por el uso o la concesión de uso de un equipo industrial, comercial o científico", la mención a dichos pagos en esta definición ha sido suprimida. Habida cuenta de la naturaleza de las rentas procedentes del arrendamiento de equipos industriales, comerciales o científicos, incluyendo las rentas procedentes del arrendamiento de contenedores, el Comité de Asuntos Fiscales ha decidido excluir estas rentas de la definición de regalías y, en consecuencia, del campo de aplicación del artículo 12, a fin de asegurar que dichas rentas estén comprendidas dentro de las disposiciones referentes a la imposición de los beneficios de las empresas y de las actividades profesionales comprendidas en los artículos 5 y 7”.

A pesar de lo anterior, muchos estados formularon reservas a la eliminación y continúan incluyendo la cesión del uso de estos bienes, como parte de la definición de regalía, de manera que actualmente, tenemos a la OCDE que "considera estas rentas como beneficios empresariales y, por otro, muchos Estados continúan incluyendo en el concepto de canon esta clase de pagos" ${ } 1062$.

\subsubsection{Prestaciones de servicios de asistencia técnica}

Tal como hemos venidos analizando, es claro que el concepto de canon no involucra prestaciones de servicios de asistencia técnica, ni de otros, no obstante la relación con los cánones se da a propósito de los primeros. Pues bien, los comentarios al MC OCDE dejan en claro que es así, sin embargo algunos países se han reservado el derecho a "gravar en la fuente, como regalías, las rentas procedentes del arrendamiento - leasing - de equipos industriales, comerciales o científicos o de contenedores, así como las rentas procedentes de la asistencia técnica en conexión con el uso o la concesión de uso de tales equipos y contenedores" ${ }^{1063}$. Cuando la reserva se plantea, surgen una serie de dudas respecto de la asistencia técnica, siendo la fundamental si todos los pagos relativos a asistencia técnica serán per se calificados como cánones o sólo aquellos vinculados bienes y derechos que naturalmente generan cánones. Desde

1061 En este sentido MARTÍN. Ob. supra cit., pp. 726 y sgtes. y BUITRAGO. OB. supra cit., pp. 268 y sgtes.

1062 GARCÍA HEREDIA. Ob. supra cit., p. 326.

1063 Hasta la versión de 2010 del MC OCDE, esta reserva era hecha también por España, actualmente sólo la mantiene Portugal, bajo el parágrafo 43.1 de los comentarios al artículo 12. 
nuestra perspectiva, creemos que hay una pureza dogmática bastante clara en las regalías en función de que corresponden al pago por el uso de intangibles, de manera que, si bien entendemos los tirones que hay de cada interesado en cada renta, léase cada uno de los estados que renuncia o gana la tributación de ellas en virtud de un convenio, la forma de conseguir los objetivos de los CDI es manteniendo su coherencia, por lo que, creemos que debe darse una interpretación apegada a esa naturaleza a la reserva que comentamos y únicamente permitir la consideración como cánones de aquellos servicios vinculados a bienes o derechos naturalmente generadores de ellos ${ }^{1064}$.

\subsubsection{Supuestos confusos o de difícil calificación}

Movidos por la misma justificación pedagógica de que hablamos antes, cuando decidimos incorporar un subtítulo sobre casos confusos o de difícil calificación, no fue pensando en crear más fuentes genéricas de cánones, que las que hemos visto, lo que sucede es que nos pareció que al explicar juntos todos los casos, vinculados a una determinada fuente de cánones, se pierde la pureza dogmática de aquella, tras una maraña de hipótesis y conclusiones: así por ejemplo, al hablar de la propiedad intelectual como fuente de cánones, podríamos haber abordado el caso del software, las traducciones, las películas cinematográficas, etc., lo que a nuestro juicio, lejos de aclarar, podría confundir. De manera que, teniendo claro el contenido básico de cada fuente, estimamos sería más fácil analizar los casos difusos.

Los supuestos confusos o de difícil calificación los analizaremos desde ahora.

\section{IV.3.1.7.6.1 Programas de ordenador}

Probablemente el mejor lugar para hablar de programas de ordenador habría sido bajo el título de derechos de autor, puesto que la protección a éstos se otorga, normalmente, al menos vía derecho de autor o copyright; sin embargo, su tributación a las luz de los CDI se ha prestado para tantos matices, que tal como advertimos, no quisimos complicar las explicaciones.

En el supuesto de los programas de ordenador, lo primero que debería decirse es que es un fenómeno que no nace con el MC OCDE, obviamente porque por aquellos años, los programas de ordenador tenían muy poca o nula importancia. En los

1064 En el mismo sentido, aunque fundado en diferentes argumentos, se pronuncia GARCÍA HEREDIA. Ob. supra cit., pp. 314 y sgtes. 
comentarios al MC OCDE de 1977 no aparecen, sino que lo hacen en la versión de 1992, que modifican los párrafos 12 a 17 donde se trata por primera vez el tema, posteriormente se han mantenido y sufrido ciertas modificaciones ${ }^{1065}$.

En cuanto a la regulación que hace el MC OCDE, podemos comentar que no se refiere específicamente a ellos en el texto del artículo 12, por lo que deben entenderse incluidos en la frase "derechos de autor sobre obras literarias, artísticas o científicas", lo que es aceptable en España y Chile. Lo que sabemos de los programas de ordenador, nace de los comentarios al MC OCDE, en los párrafos que señalamos previamente, donde se establecen ciertas reglas generales a modo de principios, que podríamos resumir como sigue: la necesidad de atender a la sustancia del contrato, de manera que sólo existirán cánones en aquellos casos en que se ceda el uso de derechos de autos sobre las obras ${ }^{1066}$; la ausencia de cánones cuando los derechos que se otorgan solamente permiten al usuario la utilización del programa (shrink wrapped software license) ${ }^{1067}$; la irrelevancia de la forma, es decir, no importa la forma de transmisión del programa de ordenador para su tributación ${ }^{1068}$; la irrelevancia del pago, en el sentido que éste puede ser hecho por cualquier medio o modalidad ${ }^{1069}$; la ausencia de cánones cuando exista la transferencia plena del derecho de autor ${ }^{1070}$; en los contratos mixtos, cuando sea posible, debe descomponerse atendiendo a la naturaleza de las rentas, sino estarse a lo principal. ${ }^{1071}$

España, tal como recuerda MARTÍN JIMÉNEZ, ${ }^{1072}$ en su calidad de país importador de tecnología ha intentado mantener lo más ancho posible el concepto de canon para asegurar la recaudación en fuente, para ello partió por hacer una observación a los Comentarios del artículo 12 del MC OCDE, que se radicó en el parágrafo 28 de los Comentarios, en ella, España no se aleja de la idea central que la cesión del uso de los derechos de autor sobre los programas de ordenador conlleva cánones, principio que

1065 Ello según MARTÍN JIMÉNEZ. Ob. supra cit., pp. 692 y sgtes. También puede encontrarse detalladamente tratados los programas de ordenador en las obras de BUITRAGO y GARCÍA HEREDIA que hemos citado antes. En el mismo sentido un artículo del profesor GARCÍA HEREDIA. Los programas de ordenador en los convenios de doble imposición. Contabilidad y Tributación, $\mathrm{N}^{\circ} 268$, julio de 2005 , pp. 55 y sgtes.

1066 Parágrafos 8.2, 8.4, 14.2, 14.3 y 14.4 Comentarios al MC OCDE.

1067 Parágrafo 14 Comentarios al MC OCDE.

1068 Parágrafo 14.1 Comentarios al MC OCDE.

1069 Lo entendemos en el mismo parágrafo 14.1 Comentarios al MC OCDE.

1070 Parágrafo 15 Comentarios al MC OCDE.

1071 Parágrafo 17 Comentarios al MC OCDE.

1072 MARTÍN. Ob. supra cit., p. 696. 
comparte, pero si lo hace en cuanto consideran que permitir el uso por un tercero de los programas de ordenador ${ }^{1073}$, también implica cánones, noción que los Comentarios rechazan claramente. De manera que, en la posición inicial de España, el concepto de cánones involucra la cesión de los derechos de autor sobre los programas, como también la cesión del uso de los programas en sí mismos. Desde este punto de partida inicial, España ha transitado por un camino con variaciones normativas y jurisprudenciales en uno y otro sentido ${ }^{1074}$, “que presenta dos peculiaridades notables: en primer lugar, esa evolución ha sido conducida a través de la doctrina de la DGT, la cual ha utilizado como soporte normativo las observaciones españolas al MC OCDE; en segundo lugar, aunque al parecer a contrapelo, ha implicado "recortar el ámbito de aplicación de la soberanía fiscal española"1075.

Actualmente las observaciones españolas se radican en el parágrafo 28 de los Comentarios al MC OCDE, al decir: "España, México y Portugal no se adhieren a la interpretación que figura en los párrafos 14, 14.4, 15, 16 y 17.1 a 17.4. España, México y Portugal estiman que los pagos relativos a las aplicaciones informáticas - software se encuentran dentro del ámbito de aplicación del artículo cuando se transfiere solamente una parte de los derechos sobre el programa, tanto si los pagos se efectúan en contraprestación de la utilización de un derecho de autor sobre una aplicación software - para su explotación comercial (excepto los pagos por el derecho de distribución de copias de aplicaciones informáticas estandarizadas que no comporte el derecho de adaptación al cliente ni el de reproducción), como si los mismos corresponden a una aplicación - software - adquirida para uso empresarial o profesional del comprador, siendo, en este último caso, aplicaciones - software- no absolutamente estándares sino adaptadas de algún modo para el adquirente".

1073 Aquí está el matiz más interesante en este tema, puesto que una cosa es ceder el uso de los derechos de autor, es decir de las atribuciones que le asisten al autor en tanto tal, como son los derechos de reproducción, distribución, modificación, comunicación al público o puesta a disposición, de manera que sea otro el que pueda explotar comercialmente la obra, en este caso, el programa de ordenador y otra cosa, es permitir el uso de la obra por un tercero, en cuyo caso no se está cediendo derecho de autor alguno, por se está ejerciendo, al comercializar la obra para que la utilice un tercero. Es el mismo caso de la venta de un libro, que cuando se compra en una librería se adquiere el derecho a "usar" (leer) la obra, pero no se tiene a derecho de autor alguno. De ahí que sea distinto hablar de "ceder el uso del derecho de derechos de autor sobre un programa de ordenador" a "ceder el uso de un programa de ordenador".

1074 Al respecto pueden verse a MARTÍN, BUITRAGO, GARCÍA y DELGADO, en las obras citadas. Vale la pena advertir, que de profundizarse en el tema, debe partirse por GARCÍA, quien posee una pluma desbordante en claridad y pedagogía.

DELGADO. Ob. supra cit., p. 764. 
DELGADO PACHECO ${ }^{1076}$ nos aporta un resumen de la posición española en nuestros días, resumiéndolo en cinco puntos:

- Adquisición de copias de programas estándar para su reventa: no constituyen cánones. Lo que es concordante con el MC OCDE;

- Adquisición de copias de programas estándar para su uso personal o empresarial por el propio adquirente sin revenderlos o cederlos de ningún modo a un tercero: originan un beneficio empresarial. También es armónico con el MC OCDE;

- Adquisición de programas estándar para su explotación, adaptación o reproducción: da origen a cánones. En este caso, se aparta del MC OCDE;

- Adquisición del uso de programas específicos para su explotación: los pagos serán cánones. Igual que en el caso anterior, se aparta de MC OCDE;

- Adquisición del uso de programas específicos o adaptados de cualquier modo al cliente para su propio uso: la renta será un canon. Nuevamente, la solución es diferente al MC OCDE.

No puede el lector decirnos que no le advertimos que los programas de ordenador eran fuente de muchos "misterios", pues bien, otro asunto lo encontramos en el Convenio España-USA, donde se prevén distintos tipos de retención en función de la naturaleza del derecho de autor cedido: en el caso del derechos sobre obras literarias y artísticas el convenio establece un tipo reducido de retención en la fuente de 3\%; para las obras científicas se incrementa un poco la retención llegando al 5\%; y, existe una disposición residual para otras obras de un 10\%. Así las cosas, al momento de aplicar el convenio, no era necesario ser muy despierto para darse cuenta que el "misterio" intentaría ser revelado por la industria sosteniendo que los programas de ordenador eran obras literarias y por tanto tributan al $3 \%$ y por la administración tributaria, proclamando la imposibilidad de clasificar a los programas de ordenador, que necesariamente debían ser subsumidos en la disposición residual y retener un $10 \%$. La solución de los tribunales es que dieron la razón a las empresas informáticas y equipararon los pagos por cesión de programas de ordenador a las obras literarias o

1076 Ob. supra cit., p. 765. 
artísticas, ni siquiera consideraron las obras científicas. Tanto la AN como el TS dieron la razón a $\mathrm{IBM}^{1077}$ que era la empresa involucrada ${ }^{1078}$.

\section{IV.3.1.7.6.2 Derechos conexos ${ }^{1079}$}

Como sabemos los derecho conexos, vecinos o afines, como quiera llamárseles, están relacionados con el derecho de autor, pero no alcanzan su misma jerarquía, sucede un poco con la relación entre patentes y otros como modelos de utilidad, son derechos que obedecen a una misma naturaleza y justificación, no obstante protegen esfuerzos creativos de distinto nivel y por ello, reciben un respaldo jurídico diferenciado. Explica GARCÍA HEREDIA ${ }^{1080}$ que los derechos conexos o afines, no protegen a la obra o creación en sí misma, sino que se vinculan a "productos" o "elementos" que nacen o pueden tener origen a propósito de la utilización de las obras, al respecto propone un ejemplo, al sugerir: "pensemos en una película y en la retransmisión de un espectáculo deportivo o artístico. La película se considera una obra audiovisual protegida por los derechos de autor, mientras que la retransmisión del partido de fútbol se configura como una grabación audiovisual ${ }^{1081}$ protegida por los derechos afines".

Pueden ser titulares de derechos conexos, entre otros, artistas y ejecutantes de diferentes tipos de obras, sin embargo para nuestros efectos, nos interesa destacar que existe un cierto paralelismo entre las obras protegidas por el derecho de autor y por los derechos conexos; así por ejemplo, tendremos de un lado la obras audiovisuales y sonoras (como una película o una canción) protegidas por el derecho de autor y por otro lado, las grabaciones audiovisuales y fonogramas (como la grabación del partido y la fijación sonora de una interpretación) amparados por un derecho conexo. Esta distinción

1077 Como contrapartida se modificó la legislación interna en la definición de canon del TRIRNR que sitúa a los programas de ordenador en un lugar distinto de las obras literarias, artísticas y científicas. Lo que al parecer se pretende por el legislador español es influir en esta doctrina de los tribunales, porque al separar en la legislación las obras literarias, artísticas y científicas, de los programas de ordenador, tal vez no podrá interpretarse la cesión de los programas de ordenador como cesión de obras literarias, al menos a efectos del convenios de doble imposición España - USA.

1078 Un análisis en detalle con extractos de la jurisprudencia, puede verse en MARTÍN JIMÉNEZ, Ob. supra cit., pp. 705 y sgtes.

1079 Al igual que el caso de los programas de ordenador, el lugar para tratar lo que sucede con los derechos conexos, atendida su naturaleza, debió haber sido junto al derecho de autor, pero no lo hicimos solamente para no contaminar las explicaciones que dimos para el derecho de autor.

1080 GARCÍA. Ob. supra cit., pp. 220.

1081 La diferencia fundamental es que en la película (derecho de autor) la actividad creativa es total, desde el guion, la organización de las escenas, etc.; en cambio, en la retransmisión del partido de fútbol (derecho afín) la actividad creativa se limita probablemente a la organización de las cámaras, los acercamientos y poco más, por ello da lugar a una grabación audiovisual protegida por un derecho conexo o afín. 
es el origen de la discordia, puesto que los CDI suelen dejar en claro que los cánones provienen de la cesión de los derechos de autor, sin aclarar si por derechos de autor entienden, en sentido amplio, a éstos más los derechos conexos o por el contrario, si se la expresión se usa en un sentido restringido que sólo incluye al derecho de autor propiamente tal. Las consecuencias son evidentes, si dentro del concepto no se incluye a los derechos conexos los pagos por las grabaciones audiovisuales y fonogramas no darán origen a cánones, sino que a beneficios empresariales o servicios, según sea el caso. En el contexto Español, como era de esperar, el TEAC y la DGT, no distinguen "considerando cánones tanto las rentas de unas como de otras, siempre que estemos ante una cesión de uso de las mismas y no ante una transmisión en propiedad"1082, aun cuando, la AN ha estimado que la cesión de uso de los derechos conexos no conlleva cánones, al no tratarse de un derecho de autor.

La solución definitiva tiene mucho que ver con lo que se diga en cada CDI, a modo de ejemplo, recordemos que el MC OCDE en el artículo 12, respecto de los derechos afines o conexos, sólo se dice: "incluidas las películas cinematográficas", que tal como venimos analizando calzan más bien bajo la protección del derecho de autor, es decir, iluminados únicamente por el artículo 12, podría resultar que los derechos conexos no estén ahí y jamás generen cánones. En el otro extremo, una obra audiovisual puede generar a la vez derechos de autor y conexos, como la grabación de una obra de teatro $^{1083}$, donde coexistirá el derecho de autor sobre la obra y el afín sobre la grabación de la misma.

\section{IV.3.1.7.6.3 Traducciones}

En el caso de las traducciones, hay que ser muy cuidadoso, porque no siempre es claro cuándo los pagos efectuados a un traductor situado en otro Estado generan cánones y cuándo pagos por servicios específicos. Se debe tener en cuenta, que determinadas traducciones pueden ser consideradas como obras derivadas, pero otras no.

Tal como parece ser una constante en esta materia, la jurisprudencia no es uniforme, no obstante MARTÍN JIMÉNEZ ${ }^{1084}$ resume lo establecido por las

1082 Ob. supra cit., p. 226.

1083 Ejemplo propuesto por GARCÍA. Ob. supra cit., p. 221.

1084 MARTÍN. Ob. supra cit., p. 688. 
Resoluciones de la DGR de 29 de junio de $2001^{1085}$, distinguiendo: entre los pagos por traducciones que generarán cánones, lo que se producirá cuando exista la cesión de uso de un derecho de autor; y aquellos que no dan lugar regalías, que se producen en tres casos: cuando existe la transmisión dominical de los derechos de autor; cuando la traducción es técnica y por lo tanto no hay labor creativa ni derecho de autor comprometido; y, cuando la traducción no recae sobre una obra literaria, artística o científica.

\section{IV.3.1.7.6.4 Emisiones de televisión, imágenes, noticias y programas en general}

Cuando se trata de señales de televisión, imágenes, noticas y programas en general, también hay casos especialmente polémicos porque es muy difícil saber cuándo estamos frente a rendimientos de la actividad empresarial o servicios y cánones, siendo la administración tributaria fácilmente seducida a estimar todo lo que se relacione con la industria audiovisual como canon.

La distinción entre aquellos casos en que estos servicios cuentan como tales, debiendo ser calificados como prestaciones de servicios independientes o como beneficios empresariales y cuándo deben ser considerados realmente cánones, se ha encontrado en diferentes criterios. A decir de MARTÍN JIMÉNEZ ${ }^{1086}$ para el TEAC "dan lugar a un canon cuando la entidad cedente se reserva los derechos de autor sobre el objeto cedido" y para la AN la línea divisoria "se encuentra en la participación del intelecto en la obra cedida y no en la mera cesión o locación de los correspondientes servicios técnicos". Otro autor ha visto que la jurisprudencia "se apoya en la distinción que existe en los CDI entre las rentas denominadas cánones y las prestaciones de servicios y en que para que exista un canon es necesario que se cedan derechos de autor" 1087

En conclusión, podemos ver cánones cuando el cedente realiza una cierta aportación intelectual a la obra, es decir hay canon si lo que se cede es un programa ya elaborado, puesto que en la elaboración del programa habrá un aporte creativo. Por el contrario, en el caso de simples imágenes, sin elaborar el programa completo o sin

1085 Disponibles en la página web de la AEAT.

1086 Ob. supra cit., p. 689.

1087 GARCÍA HEREDIA. Ob. supra cit., p. 229. 
editar, se aproxima más a un rendimiento empresarial, porque habría una simple captura de la imagen, carente de aporte creativo.

Los casos abundan, estimándose que no dan lugar regalías: el servicio de ondas hertzianas vía satélite; ${ }^{1088}$ transformación de guiones cinematográficos en soporte fílmico; ${ }^{1089}$ servicios de mezcla y masterización; ${ }^{1090}$ servicios de asesoramiento y consultoría audiovisual ${ }^{1091}$; cesión por una entidad holandesa del derecho a la redifusión en directo los combates de boxeo, tanto en directo como en diferido ${ }^{1092}$. Entre los casos que sin dan lugar a regalías, encontramos la distribución por cintas de video de los partidos de la liga italiana de fútbol ${ }^{1093}$; y, la cesión de los derechos de emisión de los Premios Oscar, que se hace a través de la entrega de una copia, conservando el cedente los derechos de autor y cediendo solamente una licencia.

\section{IV.3.1.7.6.5 Bases de datos}

Las bases de datos, de alguna manera son receptoras de todas las diferencias de que hemos venido hablando, puesto que por un lado les pesan las discusiones sobre la calificación de los programas de ordenador y por otro, el hecho de estar protegidas por derechos de autor.

En España y en Chile las bases de datos se encuentran protegidas en la ley de propiedad intelectual, claro que se debe precisar que su amparo se extiende a la estructura de la obra en cuanto considera una cierta disposición y colocación de sus contenidos, pero no se extiende a los contenidos. De todas formas, esta relación con el derecho de autor, unida al hecho que normalmente son usadas para prestar un servicio y a la posición siempre expansiva del concepto de canon de la administración tributaria española, hace que en España no siempre se oiga la posición de los Comentarios al MC OCDE, que en el parágrafo 11.4, estiman que las bases de datos deben ser tratadas como prestación o rendimientos empresariales y es ahí donde radica la dificultad para su calificación.

\footnotetext{
1088 Trata con detalle este caso BUITRAGO. Ob. supra cit., pp. 229 y sgtes.

1089 Vid. RTEAC 10 de julio de 1996 (JT 1996/1224)

1090 Vid. RDGT 14 de junio de 2005 (V 1094/05)

1091 Vid. RDGT 06 de junio de 2005 (V 1008-05)

1092 Ejemplo en MARTÍN JIMÉNEZ. Ob. supra cit., p. 690.

1093 Se ha visto labor creativa en la creación de las cintas en contra posición a la transmisión en directo que no la tendría y generaría rendimiento empresariales.
} 
El uso de la base de datos, puede requerir la utilización de un software (provisto por el prestador del servicio) y de un ordenador ${ }^{1094}$, y es aquí donde algunos pronunciamientos del $\mathrm{TEAC}^{1095}$ han optado por entender que hay cánones, puesto que se está cediendo el uso del programa de ordenador, posición que no compartimos, porque, más allá de vulnerar el parágrafo 11.6 de los Comentarios al MC OCDE, se pasa a llevar un principio basal del derecho, tal es que lo accesorio sigue la suerte de lo principal y porque en ese caso, el programa de ordenador es sólo un medio para la producción de la renta gravable, pero no es de él de donde se genera ni la riqueza, ni el servicio por el que se cobra.

\section{IV.3.1.7.6.6 Diseños, modelos, dibujos industriales, topografías de circuitos integrados y otros derechos de propiedad industrial}

En general bajo el título propuesto queremos hablar de diseños, modelos, dibujos industriales, diseños textiles, topografías de circuitos integrados, variedades vegetales, marcas tridimensionales, marcas sonoras y cualquier otro derecho de propiedad industrial no mencionado en el artículo 12 del MC OCDE. Aunque ya hablamos del tema, por lo que el lector conoce nuestra posición y los motivos que nos llevan a sostener que en tanto se trate de intangibles, se transfiera su uso y no se produzca una cesión dominical, estamos ante cánones, quisimos detenernos, puesto que habiendo analizado lo que sucede con los derecho afines o conexos, tal vez valga la pena advertir que la situación es más o menos la misma, en la medida que se trata en general de derechos de menor jerarquía, incardinados al amparo de los hermanos mayores llamados derechos de patentes y marcas, por lo que las razones que dimos en ese momento, las tenemos por repetidas ahora.

La situación es un poco diferente sólo respecto de los diseños y modelos, puesto que aparecen especialmente mencionados en el artículo 12 del MC OCDE, de manera que ellos han sido bendecidos con el llamado de los cánones; sin embargo, esta bendición ¿podría llegar a ser una condena para los demás derechos de propiedad industrial no mencionados? En efecto, el argumento salta a la vista, si de los hermanos menores de las patentes sólo se mencionó a diseños y modelos, esto quiere decir que el resto no genera cánones. Creemos que eso no pasa de ser una posición argumentativa,

\footnotetext{
1094 También puede ser muy claramente un servicio como cuando la base de datos se utiliza para entregar información telefónica, sin embargo, ese no será un caso difícil de calificar.

1095 Ob. supra cit., p. 691, cita la Resolución de 23 de julio de 1997 (JT 1997/1187).
} 
pero errada, puesto una solución debe buscarse en razones de fondo como las que explicamos en su momento y no en mera dialéctica, de suerte que hace más sentido entender el llamado a modelos y diseños como ejemplos, que como exclusiones.

\section{IV.3.1.7.6.7 Acuerdos de I+D}

Dos empresas llegan a un acuerdo para financiar una investigación, que puede consistir en un porcentaje de la propiedad, un usufructo, una licencia, etc., ${ }^{1096}$ claro está que se trata de empresas situadas en distintos países. Lógicamente, el objetivo es tener una participación en los resultados de la investigación, es decir, en la patente que se genere. La pregunta es: ¿cómo se deben tratar estos pagos, en relación a esos acuerdos de contribución y distribuciones de costes y beneficios? En principio, los pagos no son cánones, podrán ser renta empresarial del artículo 7 del MC OCDE, salvo que estén encubriendo una cesión por el uso de bienes y derechos contemplados en el artículo 12.

La OCDE ${ }^{1097}$ estima que si desde el inicio del acuerdo de reparto de costes, cada partícipe tiene un "interés esencial" en el mismo y la posibilidad de explotar sus resultados a título de dueño y no de licenciatario, usuario u otro título de mera tenencia, las contribuciones no se distinguen de los pagos por la adquisición de un bien material y por lo tanto, no deben ser tratadas como cánones ${ }^{1098}$. Por su parte el TEAC ${ }^{1099}$ rechazó la calificación de cánones de los aportes de una sociedad española en el contexto del CDI España-EE.UU, por estimar que las contribuciones por gatos de I+D no pueden dar lugar a canon por no existir contraprestación, puesto que por su propia naturaleza el proyecto hace imposible la adquisición de una tecnología que no existe, que se va a crear y puede suceder que jamás llegue a existir ${ }^{100}$.

1096 Un ejemplo semejante es el caso de una empresa que realiza una aportación económica a otra para contribuir a la grabación de una telenovela, a cambio de una participación en los beneficios resultantes de la explotación de la misma. En nuestra opinión, si la aportación da derecho a la explotación de derechos de autor sobre dicha telenovela, tendrán la calificación de cánones; en cambio, si la explotación la hace la empresa aportada y la aportante sólo recibe una participación de las utilidades, no estaríamos frente a cánones, porque la renta no tiene origen en la explotación de ningún derecho de autor de titularidad del aportante. GARCÍA HEREDIA. Ob. supra cit., p. 230.

En las llamadas "Líneas maestras de la OCDE para las Administraciones tributarias y las multinacionales en materia de precios de transferencia", capítulo VIII del documento de 1998. Citado por MARTÍN JIMÉNEZ. Ob. supra cit., p. 724.

1098 Ob. supra cit., p. 724.

1099 Resolución del TEAC de 22 de octubre de 1997. Citado por MARTíN JIMÉNEZ. Ob. supra cit., p. 725.

1100 Discrepa con este criterio MARTÍN JIMÉNEZ. Ob. supra cit., p. 726 y lo comparte GARCÍA HEREDIA. Ob. supra cit., p. 51. En nuestra opinión, el criterio es acertado, ya que no se debe 
En este tema parece importante cerrar haciendo presente que no debe llevar a error el hecho que los acuerdos de I+D operen sobre una tecnología que existiría más adelante, no puede llevar al absurdo de pensar que se está haciendo un pago por anticipado de esa tecnología para obtener un derecho de dominio o de uso sobre la misma, puesto que no es claro si la tecnología llegará a existir y en el evento de nacer, tampoco se sabe si será exitosa, ni muchos menos su valor. En otras palabras, el esfuerzo innovador, tal como sucede en la mayoría de los casos, puede ser pérdida pura, en cuyo caso se estará tributando por la pérdida. De manera que compartimos cuando se dice que no se deben confundir dos pagos diferentes: "por un lado, la aportación o financiación para el desarrollo de una determinada tecnología, y por otro, la posibilidad de que dicha tecnología, una vez lograda, sea cedida a cambio de una nueva retribución que sí pudiera ser calificada como canon"1101 ${ }^{\text {. CARMONA FERNÁNDEZ }}{ }^{1102}$ interpreta la visión de la DGT de una manera mucho más estricta, cuando anota: "La doctrina administrativa sostiene en esta materia un criterio notablemente estricto: si la tecnología o propiedad intelectual obtenidas como resultado de los trabajos de investigación y desarrollo, constituyen derechos de propiedad de la entidad no residente y no de la entidad residente aportante de las contribuciones, los pagos en cuestión constituyen la contrapartida del derecho a su utilización y deben ser calificados como cánones, aunque dicha contrapartida se haga efectiva de forma anticipada a la utilización de los derechos".

Cuando hablamos de I+D o I+D+i o I+D+i+e, siempre el objeto es el mismo, la innovación, por lo que debemos asumir el riesgo que ello implica, la incertidumbre que se presenta no sólo respecto de la posibilidad de lograr el resultado técnico, sino que también el éxito económico que permita el desarrollo de la tecnología, es el compañero inseparable de cualquier proyecto de innovación, por ello, recuerdo de mis años vinculado al derecho de patentes, cuántos genios locos y no tan locos he visto desfilar por las oficinas de patentes, todos con el sueño de una invención capaz de producir rendimientos de manera mágica y desenfrenada. Creo que el llamado a las administraciones tributarias es, cuando menos, esperar a que exista para riqueza antes de gravarla y a no dificultar los esfuerzos creativos.

confundir el control con lo sustantivo, en el mismo sentido, por atender a lo accesorio podría sostenerse que la retención injustificada en la fuente para proyecto de $\mathrm{I}+\mathrm{D}$ es una carga ilegítima al esfuerzo innovador que perjudica a la sociedad en su conjunto.

1101 GARCÍA. Ob. supra cit., p. 51.

1102 CARMONA. Ob. supra cit., p. 142. 


\section{IV.3.1.7.6.8 Leasing y renting}

El leasing es ante todo un contrato en el que intervienen tres partes, una que es el dueño de los bienes que se darán en arrendamiento, otra que es la que financia la operación y una tercera que es quien recibirá los bienes, lo que no significa que las tres partes estén relacionadas entre sí, sino que, podríamos decir, que el contrato se cumple por etapas, puesto que quien financia primero adquirirá los bienes y luego los arrendará, funcionando como un intermediario. La transferencia desde el dueño, tenedor original de los bienes, no representa dificultades, puesto que el traspaso es dominical, no es más que una compra de bienes, que de ser internacional, será sólo una importación. La segunda operación es la que representa variantes a la hora de su calificación, puesto que mientras sea un arrendamiento, los pagos serán cánones -lógicamente en aquellos CDI que hayan mantenido la cláusula sobre equipos industriales, comerciales o científicoscomo normalmente es el caso de España, pero al momento de ejercer la opción de compra, entra a tallar el dominio y con ello, desaparecen los cánones ${ }^{1103}$.

Desde el punto de vista de los CDI debemos encontrar un ajuste para estas rentas y allí, podemos ver tres posiciones en función de la naturaleza jurídica que se atribuya al leasing: de entender el leasing como un arriendo de equipos industriales, comerciales o científicos, nada que decir, estamos frente a cánones; bajo la idea que se trata de una compraventa, no habrán cánones, sino que ante ganancias de capital o beneficios empresariales; y, finalmente, la consideración como un contrato de financiación, nos pone frente a rentas de servicios personales independientes o beneficios empresariales $^{1104}$.

La OCDE no tiene actualmente comentarios sobre este punto, de ahí que GARCÍA HEREDIA utilice aquellos que existían para el artículo 12 del MC OCDE, de donde desprende que aquellas cuotas que corresponden al arrendamiento serán cánones y las que formen parte del precio por la opción de compra, puedan caer dentro de los artículos 7, 13 o 21, apreciación que compartimos, básicamente, porque tanto en Chile como en España, el leasing ha sido objeto de una legislación ad hoc que ha reconocido el arraigo en su seno de esta doble naturaleza de arriendo y compraventa, configuración normativa que no se puede soslayar.

1103 Sobre el asunto puede verse BUITRAGO. Ob. supra cit., p. 99.

1104 En esto hemos seguido a GARCÍA HEREDIA. Ob. supra cit., p. 335. 
El renting estimamos presenta menos problemas, puesto que al final del día es un arriendo en que el arrendador se hacer cargo de la mantención y los seguros, obviamente, para entrar al tema de los cánones debe tratarse de una operación internacional y además tratarse de un CDI que incorpore la cláusula de equipos industriales, comerciales y científicos. Desde esa perspectiva y asumiendo entonces que está presente el requisito de la cesión del uso, nada cabe que agregar, estamos frente a cánones. Sin embargo, lo interesante de levantar el tema del renting es un asunto que también involucra al leasing, referente a la pregunta sobre ¿qué sucede si los bienes cedidos no pueden ser clasificados como industriales, comerciales o científicos? El RTEAC de 04 de abril de 2003 (JT 2003/1286), se pronunció en un caso de arrendamiento de vehículos por una empresa española, para el uso particular de sus trabajadores, a una empresa portuguesa, atribuyendo a los pagos el carácter de beneficios empresariales ${ }^{1105}$, lo que parece acorde con lo que venimos exponiendo.

\section{IV.3.1.7.6.9 Productos digitales}

Los productos digitales fueron motivo de gran desconcierto y objeto de las más peregrinas teorías sobre la forma de recibirlos en los CDI, en su momento alimentaron creativas teorías sobre el fin de la historia y el inicio de un nuevo DTI, nada fue más alejado de la realidad, los principios existentes demostraron resistir los embates de la tecnología y actualmente han dado origen a los parágrafos 17.1 a 17.4 de los Comentarios al art. 12 del MC OCDE, que hacen aplicables los mismos principios que estudiamos a propósito de los programas de ordenador a los productos digitales, tales como imágenes, sonido o texto, ${ }^{1106}$ donde, para "determinar si los pagos

1105 Ejemplo tomado de GARCÍA HEREDIA. Ob. supra cit., p. 337.

1106 En estos parágrafos se señala:

- 17.1: "Los principios enunciados anteriormente en lo que respecta a los pagos de aplicaciones informáticas - software payments - son igualmente aplicables a las operaciones de otros tipos de productos digitales como las imágenes, los sonidos o el texto. El desarrollo del comercio electrónico ha multiplicado el número de estas operaciones. Para determinar si los pagos correspondientes constituyen o no regalías, la principal cuestión que ha de abordarse es el motivo esencial por el que se paga.";

- 17.2: "En ciertos países, la legislación aplicable establece que las operaciones que permiten al cliente descargar en su computadora productos digitales pueden dar lugar a que el citado cliente utilice los derechos de autor (el copyright), por ejemplo, porque puedan hacer una o más copias en su computadora del contenido digital en virtud del contrato suscrito. Cuando el pago constituye esencialmente la remuneración de algo distinto al uso o la cesión de uso del derecho de autor (como la adquisición de otros tipos de derechos, datos o servicios contractuales) y que el uso del citado derecho de autor se limita al uso de los derechos necesarios para la descarga, el almacenamiento y el manejo en la computadora, red u otro medio de almacenamiento, ejecución o visualización del cliente, dicha utilización del derecho de autor no debe afectar al análisis de la naturaleza del pago a los efectos de aplicar la definición de <regalías>"; 
correspondientes constituyen o no regalías, la principal cuestión que ha de abordarse es el motivo esencial por el que se paga".

Trasladando los principios de los programas de computación, tal como proponen los Comentarios, aunque deberíamos convenir que sin los Comentarios llegaríamos a la misma conclusión, se puede advertir que si la operación consiste en la adquisición para uso personal o profesional, es decir no comercial, la situación es equivalente a la compra de un bien físico como un libro o de una licencia de las que llamamos shrink wrapped software license, por lo que no habrá lugar a canon alguno porque no se transfiere ningún derecho de autor, aunque haya que hacer una copia digital del producto adquirido. Estaremos entonces frente a beneficios empresariales del artículo 7 del MC OCDE.

En el otro extremo, si la transacción tiene por objeto ceder el uso del derecho de autor para una explotación del mismo, como cuando se adquiere la música para incorporarla a una película, habrá cánones ${ }^{1107}$.

\section{IV.3.1.7.6.10 Empresas de navegación marítima o aérea}

Debemos recordar que hay un artículo especial que regula la tributación de las empresas de navegación marítima por aguas interiores y aéreas. De manera que, estas

- 17.3: "Tal es el caso de las operaciones que permiten al cliente (que puede ser una empresa) descargar en la computadora productos digitales -aplicaciones informáticas - software-, imágenes, sonidos, o texto- para su propio uso o disfrute. En esas operaciones, el pago se realiza básicamente a cambio de adquirir datos transmitidos en forma de señal digital, y por lo tanto, no corresponde a regalías y se rige por el artículo 7 o por el 13 según el caso. En la medida que el acto de copiar la señal digital en el disco duro o cualquier otro soporte para archivar del cliente implica que este último utiliza derechos de autor conforme a la legislación pertinente y las disposiciones contractuales aplicables, esta reproducción o copia es sólo el medio a través del cual se captura y almacena la señal digital. Dicha utilización de los derechos de autor no es importante a efectos de la clasificación porque no se corresponde con lo que el pago remunera esencialmente (es decir, la adquisición de datos transmitidos bajo la forma de una señal digital), que constituye el factor determinante a efectos de la definición de regalías. Tampoco habría fundamento en asimilar los pagos de dichas operaciones a "regalías" si, en virtud de la legislación y las disposiciones aplicables, la creación de una copia es considerada como uso del derecho de autor por parte del proveedor en lugar del cliente"; $y$,

- 17.4: "En cambio, cuando el pago constituye esencialmente la remuneración de la cesión del derecho a utilizar un derecho de autor inherente a un producto digital que es descargado informáticamente con esa finalidad, las operaciones correspondientes dan lugar a regalías. Ese es el caso, por ejemplo, de un editor que paga por adquirir el derecho a reproducir una imagen sujeta a derecho de autor que descargará electrónicamente para que aparezca en la portada de un libro que está produciendo. En esta operación, el pago constituye esencialmente la remuneración de la adquisición del derecho a usar el derecho de autor inherente al producto digital -es decir, el derecho a reproducir y distribuir la imagen- y no únicamente la adquisición del contenido digital”.

En este sentido GARCÍA HEREDIA. Ob. supra cit., pp. 159 y sgtes. 
empresas si tienen buques o aviones, por las rentas que generen en la explotación comercial de los mismos, por regla general, no irán al artículo 7, ni al 12 MC OCDE.

Hasta aquí, todo es bastante claro, sin embargo la delimitación del espectro de aplicación del artículo 8 la dan los Comentarios, que excluyen de su aplicación "los beneficios del arrendamiento de buques o aeronaves o casco desnudo, salvo que constituyan una fuente ocasional de renta para una empresa dedicada a la explotación internacional de buques y aeronaves". Es decir, claramente el artículo está separando la explotación comercial referente al negocio del transporte marítimo y aéreo, de otro negocio, el de arrendamiento de bienes, que sin duda tienen naturalezas bastante diferentes, de donde se deriva la pregunta sobre cómo se clasifican estas rentas. En primer lugar debe deslindarse que la norma está hecha para empresas dedicadas a la explotación de buques o aeronaves en tráfico internacional, ${ }^{1108}$ puesto que si es una empresa dedicada solamente al arrendamiento o corretaje de naves y aeronaves, no estaremos en el artículo 8, probablemente en el 7, pero no en el 8.

Asumido lo anterior, si se trata del arrendamiento a casco desnudo de una nave o aeronave y el CDI posee la cláusula sobre el uso de equipos industriales, comerciales y científicos, estaremos frente a cánones, de no ser así, se tratará de rendimientos empresariales. La excepción viene dada en los propios comentarios, que mantienen la tributación en el artículo 8, cuando el arrendamiento constituye una actividad ocasional $^{1109}$.

En conclusión, como en todos los casos que venimos viendo, va a depender en gran medida del contrato y de la forma de explotación real de la nave.

\subsubsection{El artículo 12.3 MC OCDE}

El artículo 12.3 del MC OCDE, se encuentra vinculado con el artículo 7, ya desde los comentarios al artículo 7.7 del MC OCDE, cuyo parágrafo 35, dice que se aplicará el artículo 7, a las rentas que corresponda según el artículo 12.3 del MC OCDE. En definitiva, se trata de mantener la regla de atribución de las rentas al establecimiento permanente, "si el beneficiario efectivo de las regalías, residente de un Estado contratante, realiza en el Estado contratante del que proceden las regalías una actividad

1108 Conforme al artículo 8.1 del MC OCDE.

1109 En este sentido GARCÍA HEREDIA. Ob. supra cit., pp. 339 y sgtes. 
empresarial por medio de un establecimiento permanente situado allí, y si el bien o el derecho por el que se pagan las regalías está vinculado efectivamente a dicho establecimiento permanente".

En todo caso, el Comentario al apartado 3, se apura en decir, que no se trata de un caso de aplicación del principio de la vis atractiva del establecimiento permanente, sino que del principio de la vinculación efectiva, que impone que los cánones sean atribuidos al establecimiento permanente cuando se deban en conexión con derechos o propiedades que forman parte del activo del establecimiento o se encuentren vinculados con él.

Probablemente lo más conflictivo en este caso sea determinar cuándo un bien se encuentra vinculado con el establecimiento permanente, claro está, que si se trata de bienes corporales que se poseen en propiedad la vinculación es bastante clara, pero cuando se trata de intangibles como la propiedad intelectual, es muy difícil pensar en que se podrían desafectar de la noción de pertenecer a la empresa en su conjunto, asignándolos en exclusiva al establecimiento permanente, puesto que, por su naturaleza se trata de un activo que es perfectamente posible que sea asignado, explotado y de interés simultáneo para la casa matriz y para el establecimiento permanente.

\subsubsection{El artículo 12.4 del MC OCDE. Una norma de control}

El artículo 12 del MC OCDE, repite la misma regulación que en el caso de intereses y dividendos. Se trata de una disposición específica en relación al artículo 9 del MC OCDE, para regular la posible existencia de pagos excesivos entre empresas vinculadas, con el objeto de reducir artificialmente su tributación en fuente.

Se pretende prevenir que se pueden inflar los pagos de cánones para crear gasto deducible en un Estado y un mayor rendimiento en otro. Así, podrían trasladarse los rendimientos de una jurisdicción a otras. En la medida que haya un pago superior al de mercado, por el exceso, el Estado de la fuente puede aplicar su legislación interna sin respetar los límites impuestos por el tratado.

Los requisitos para que opere la norma, son la existencia de "una relación especial" entre el pagador de los cánones y el beneficiario efectivo o entre ambos y cualquier otra persona. La expresión como se aprecia es extraordinariamente amplia, a 
nuestro juicio, tanto lo es que queda en los márgenes de la arbitrariedad y atenta contra la seguridad jurídica, no obstante las explicaciones de MARTÍN JIMÉNEZ ${ }^{1110}$ sobre su utilidad, puesto que permite incluir allí institutos que se escaparían de la regla del artículo 9 del MC OCDE, tales como los trust, las relaciones tipo conduit / back to back, en la que existe un tercero no vinculado entre partes vinculadas. El otro requisito para que tenga aplicación la norma es evidente, debe haber un canon.

\subsubsection{Regla de la fuente}

El MC OCDE tiene la curiosidad de que no tiene regla para determinar la fuente de los cánones y es así porque atribuye la jurisdicción en exclusiva sobre los cánones al Estado de la residencia. En otros convenios de doble imposición, especialmente los que siguen el modelo de tributación compartida entre la fuente y la residencia, una regla relativa a la fuente puede ser de utilidad. En el caso de los cánones, lógicamente la fuente se fijará en el Estado en que se encuentre el pagador, salvo que el canon se vincule al establecimiento permanente situado en otro Estado.

\subsubsection{La base imponible}

Todo el tiempo hemos hablado de la retención en la fuente, pero sobre qué monto cabe hacer la mentada retención en fuente. El MC no dice nada al respecto y es obvio porque parte de la base la tributación exclusiva en la residencia. La respuesta vamos a tener que buscarla específicamente en los CDI en que las partes hayan pactado la tributación compartida, donde las soluciones pueden ser muy variadas, puesto que están en juego los mismos intereses económicos de los Estados contratantes, que los han llevado a pactar la tributación compartida por sobre el modelo propuesto por la OCDE, así, por ejemplo, permitir la reducción de gastos del monto de lo cánones, reducirá automáticamente la recaudación en fuente ${ }^{1111}$.

Lo que vemos particularmente en los tratados celebrados por España es la expresión "importe bruto", ${ }^{1112}$ es decir, sin ningún tipo de deducción de gastos. Se aplica sobre la cuantía integra del pago, ese es el monto sobre el que tengo que aplicar el tipo de retención que prevé el convenio específico.

1110 MARTÍN. Ob. Cit., pp. 737.

1111 Sobre esta materia puede verse a GARCÍA HEREDIA. Ob. supra cit., pp. 103 y sgtes.

1112 Según MARTÍN JIMÉNEZ. Ob. supra cit., p. 671. 
Un asunto que se genera con la retención a cuenta, dice relación con los pagos libres de impuestos. Es decir, al fin y al cabo al receptor del canon le interesa recibir un monto tal que le permita solventar sus gastos, obtener utilidad y pagar sus impuestos en residencia, para ello es razonable que pacte un precio fijo que le signifique un monto determinado en su cuenta o en otras palabras, que todos los impuestos y gastos asociados a ese pago, sean asumidos por el pagador del canon. Si esto es así, el cesionario deberá hacer un cálculo matemático para que la base imponible sea una cantidad tal, que descontada la retención en fuente, resulta una cantidad líquida equivalente al monto del canon acordado con el cesionario. Matemáticamente el cálculo es simple, pero jurídicamente implica que entre el monto originalmente pactado y el efectivamente pagado hay una diferencia, sobre la que podría no haberse tributado. Este será un tema que resolver, porque por ejemplo, pensemos en la cesión de una patente, que incluye una cláusula libre de impuestos, puede suceder que somos un país importador de tecnología, por un lado nos estamos quedando con parte de la recaudación, pero por otra estamos elevando el costo de la tecnología, será como hacerse trampa en el solitario. Las posibles respuestas son dos: añadir o no el importe del impuesto a la base imponible o "monto bruto", lo que deberán resolver los Estados según sus necesidades.

Otra cuestión que puede plantearse es: ¿cuándo debe hacerse el pago? Eso es competencia del Estado desde el que se realiza el pago, es decir el Estado donde hay que hacer esta retención y no varía en nada el hecho que a quien se pague sea directamente el beneficiario efectivo o un intermediario, puesto que desde el punto de vista del estado de la fuente, ese es el momento de la puesta a disposición.

\subsubsection{Los llamados cánones culturales}

Es posible encontrar que en determinados CDI algunos cánones están exentos de retención en la fuente, se trata de los pagos por la cesión de uso de obras literarias y artísticas, el llamado "canon cultural"1113. Se trata de fomentar el intercambio cultural, por ejemplo: permitir que las partituras sobre una obra musical de un determinado autor se reproduzcan en un concierto en otro Estado, una obra de teatro, etc. Claro está que no por ser "culturales" estarán libres de controversia, sólo pensando un poco saltan los

1113 Encontramos casos entre España y Cuba, Francia, México, Polonia, entre otros. Según MARTíN JIMÉNEZ. Ob. supra cit., pp. 670. 
ejemplos: una fotografía puede ser incluida dentro como una obra artística y estar exenta de tributación de la fuente por canon cultural, pero según la modalidad de envío de la fotografía, si se rebela, se pone en un sobre y se envía: ¿Hay allí canon cultural? Y, si la mando en un soporte magnético, ¿Podría cambiar su calidad de canon por su calidad de bien digital? No viene al caso hacernos cargo ahora de la casuística, lo que hemos querido destacar lo delicado que es alterar el entramado de bienes, derechos y calificaciones que regulan la interrelación de los cánones, de ahí la importancia de intentar tener una claridad dogmática sobre la base del asunto.

\subsubsection{El rol de la cláusula de nación más favorecida}

Algunos CDI, no todos, incluyen cláusulas de nación más favorecida, que son especialmente relevantes en el caso de los cánones, dos casos españoles son Brasil e India. La cláusula de la nación más favorecida, normalmente se incorpora en protocolos adicionales en una cláusula específica que establece que si uno de los Estados contratantes, después de la firma de este convenio firmara un CDI más favorable con otro país, los tipos más favorables del otro CDI se trasladan al que tiene la cláusula de nación más favorecida.

España tiene experiencia en la materia, el caso que más nos llama la atención es el de Brasil, que incluso fue ajustado reduciendo los tipos para llevarlos al estándar del CDI entre España y Japón, que siendo posterior, tenía unos tipos más beneficiosos.

Ahora bien, los CDI si bien no modifican la legislación interna de los países contratantes, se promulgan como leyes de los países que los suscriben, por lo que, estimamos que en el evento que los países no tengan la diligencia de armonizarlos, siendo ley interna de los países, en el evento de suscribirse un CDI con un tercer país en condiciones más favorable, la cláusula de NMF podría ser invocada directamente por el contribuyente afectado, en su calidad de ley interna, sin tener que recurrir a normativa de derecho internacional.

\subsection{Los cánones en derecho comunitario}

El derecho comunitario no debiera ser relevante para nuestro estudio, puesto que no impone obligaciones a España con terceros Estados no partes de la UE, como es el caso de Chile, sin embargo, existiendo una Directiva sobre la materia que analizamos y 
dada la importancia de estas normas en el contexto comunitario, al menos quisimos dar noticias de su existencia. Se trata de la Directiva 2003/49/CE, de 03 de junio, relativa al régimen común aplicable a los pagos de intereses y cánones efectuados entre sociedades asociadas en Estados miembros ${ }^{1114}$.

Lo que pudiera interesarnos de una Directiva es cómo afecta el derecho interno y si esto puede incidir en las relaciones de España con terceros Estados. Pues bien, a diferencia de los CDI la Directiva "sí califica las rentas y establece un régimen fiscal para las mismas, obligando a que todos los Estados miembros recojan una exención en la fuente para los cánones"1115. En otras palabras, la definición de canon para la Directiva es obligatoria para el derecho interno, pero como la establecida en los CDI no lo es, lo que sucede es un simple cambio en la normativa nacional de España, que no afecta sus tratados suscritos con otros Estados ${ }^{1116}$.

Otro efecto que puede plantear la Directiva es la relación entre Estados miembros de la UE que han suscrito CDI entre ellos. A esos efectos, podemos ver dos hipótesis, si se trata de un caso en que el CDI considera generadores de cánones bienes o derechos que la Directiva no considera, como sucede con la asistencia técnica (que no está en la definición de canon de la Directiva), entonces el Estado de la fuente podrá seguir aplicando el CDI y no estará obligado a declarar la exención en fuente, al menos no en cumplimiento de la Directiva. Por otra parte, si sucede al revés, es decir, la Directiva considera generador de canon a un bien o derecho regulado por el CDI, como pueden ser los derechos de autor, el estado de la fuente deberá aplicar la Directiva y declarar la exención, no obstante haya pactado una retención limitada en el CDI.

\subsection{El modelo de convenio de la ONU}

\subsubsection{Introducción}

En San Francisco EE.UU. el 26 de junio de 1945 en San Francisco, al terminar la Conferencia de las Naciones Unidas sobre Organización Internacional, se firmó la Carta de las Naciones Unidas, que entró en vigor el 24 de octubre del mismo año, dando

1114 Publicada en el DOCE L 157, de 26 de junio de 2003.

1115 GARCÍA HEREDIA. Ob. supra cit., p. 71.

1116 Lógicamente que estamos hablando de una consecuencia directa sobre el CDI, porque ya vimos los casos en que la definición de canon del derecho interno es más amplia o más restringida que la del CDI y las consecuencias que ello trae. 
nacimiento a lo que conocemos como Organización de las Naciones Unidas o simplemente ONU. En el artículo 1, párrafo 3 de la Carta de las Naciones Unidas, se declara como propósito de las Naciones Unidas, “[r]ealizar la cooperación internacional en la solución de problemas internacionales de carácter económico, social, cultural o humanitario (...)".

Al amparo de estos objetivos, existe dentro de las Naciones Unidas el Departamento de Asuntos Económicos y Sociales, que en 1963 creó un Grupo de Expertos, denominado Grupo de Expertos sobre Acuerdos Fiscales entre Estados desarrollados y Estados en desarrollo, constituido por representantes de los respectivos Estados, pero que actuaban personalmente, sin representar a sus países. En 1980, tomaron el nombre de Grupo Ad Hoc de Expertos sobre Cooperación en Materia Tributaria, conformado por diez miembros de administraciones tributarias de países desarrollados y quince de países en desarrollo y economías en transición. De este grupo, desde 2004 denominado Comité de Expertos sobre Cooperación Internacional en Materia Tributaria, nación el Modelo de Convenio de la ONU de 1980, "elaborado para vencer la resistencia de algunos Estados a entrar en la dinámica negociadora y signataria de convenios fiscales para eliminar la doble imposición, por entender que resultaban lesivos para sus intereses"

Explica GARCÍA PRATS ${ }^{1118}$, que “[e]l Modelo de la ONU nació como complemento al Modelo de la OCDE para adaptarse a las específicas exigencias de los países en desarrollo, y ha experimentado un proceso de convergencia con el Modelo de Convenio de la OCDE”, opinión que implícitamente comparte GARCÍA HEREDIA ${ }^{1119}$, al comentar: "ambos modelos son muy similares, hasta el punto de que el MC ONU ha llegado a transcribir literalmente muchos de los artículos y Comentarios de la OCDE". Por su parte, las Naciones Unidas declaran expresamente esta convergencia, sin hacer ninguna declamación de originalidad ${ }^{1120}$.

1117 GARCÍA PRATS, FRANCISCO. Los modelos de convenio, sus principios rectores y su influencia sobre los convenios de doble imposición, Crónica Tributaria, N 133/2009, 2009, p. 105.

1118 Ob. supra cit., p. 105.

1119 GARCÍA. Ob. supra cit., p. 59.

$1120 \mathrm{Al}$ respecto puede leerse en la página web de la ONU: "El objetivo particular del Modelo de Naciones Unidas es facilitar la entrada de tratados fiscales bilaterales de los países en desarrollo, lo que contribuiría a la consecución de sus objetivos de desarrollo. Las similitudes entre los modelos de la ONU y la OCDE reflejan la importancia de lograr la coherencia, mientras que las áreas más 
A pesar de la convergencia que se describe para ambos modelos, que por lo demás es muy cierta en lo sustantivo, la diferencia manifiesta entre ellos es la preeminencia que confiere a la tributación en la fuente, por sobre la tributación en residencia, cuestión especialmente notoria respecto de los cánones. Efectivamente, esta vocación de tributación en la fuente, busca beneficiar a los países consumidores de tecnología, lo que está en perfecta armonía con los objetivos del MC ONU, que por lo demás, son abiertamente declarados por las Naciones Unidas, que a propósito de la última actualización del Modelo, efectuada en 2011, expresan : "El Modelo de Naciones Unidas en general, mantiene una mayor proporción de ingresos fiscales para el 'Estado de origen', el país donde la actividad de inversión o de otro tipo se lleva a cabo. Mientras que el modelo de la OCDE mantiene una mayor participación al 'Estado de residencia', el país del inversionista, empresario. Por lo tanto, el Modelo de Naciones Unidas normalmente permite más derechos de imposición a los países en desarrollo sobre los ingresos generados por las inversiones extranjeras en estos países" ${ }^{\text {"121 }}$.

No debemos perder de vista que el MC ONU "se elaboró tomando como punto de partida el Modelo de Convenio de la OCDE al que se realizaron las adaptaciones pertinentes", ${ }^{1122}$ de manera que en lo sustancial y particularmente en lo conceptual, en cuanto a cánones atañe, son iguales, lo que permite tener claro que es innecesario volver a analizar por completo el MC ONU y que sólo vale la pena concentrarse en las principales diferencias.

\subsubsection{Principales diferencias entre el MC ONU y OCDE}

Para establecer las diferencias entre el MC ONU y OCDE, viene en nuestra ayuda GARCÍA PRATS, ${ }^{1123}$ quien partiendo de la similitud de los principios básicos que articulan ambos modelos, divide las diferencias entre ellos en dos grandes grupos. Por una parte, están las que podríamos llamar diferencias de forma, donde encontramos: que los órganos encargados de la elaboración de los modelos son muy distintos, puesto que el MC OCDE se elabora por el Comité de Asuntos Fiscales de la OCDE, es decir

importantes de divergencia refleja membresías y prioridades diferentes de las dos organizaciones". Disponible en Internet en:

http://www.un.org/es/development/desa/news/administration/doble-tributacion.html (10 Abr 2014).

1123 GARCÍA. Ob. supra cit., p. 113. 
por un órgano dependiente de ella; en cambio, el MC ONU se desarrolla por el Comité de Asuntos Fiscales de la ONU, compuesto por representantes de Estados desarrollados y en desarrollo, con la particularidad que actúan en virtud de su capacidad personal y no como mandatarios de un Estado; y, que el MC OCDE se publica sólo en inglés y francés, a diferencia del MC ONU que se publica en los seis idiomas de la ONU.

Por otro lado, tenemos las diferencias que podemos identificar como sustantivas, es decir, que tienen que ver con el fondo de la materia regulada por los convenios, en donde, en "líneas generales, las grandes diferencias se encuentran en la regulación de la tributación de los servicios, con la inclusión de dos preceptos específicos -artículo 14 y 5.3.b-, en menor medida en el concepto de establecimiento permanente, también en el concepto y reparto de competencias tributarias sobre los cánones, así como en la cláusula residual del Modelo"1124. Claro está que nuestro interés no es relevar todas las diferencias entre ambos sino que solamente las que tengan que ver con los cánones, donde se distinguen por un diferente reparto de la competencia tributaria, una definición de cánones con más o menos elementos y la adición de una regla que se refiere a la fuente de los cánones ${ }^{1125}$.

\subsubsection{Diferencias específicas en el tratamiento de los cánones entre el MC ONU y OCDE}

Es precisamente respecto de cánones o regalías donde las diferencias entre el MC ONU y el MC OCDE se pueden observar más claramente. Ya hemos hecho presente como es que el MC ONU no pretende ocultar su vocación de protector de los países en desarrollo y menos adelantados, de manera que vista las cosas desde esa dimensión, considerando además que el conocimiento y la tecnología son piezas clave para el desarrollo económico, que el vehículo jurídico para su protección y difusión se llama propiedad intelectual y que sus rendimientos económicos provienen principalmente de los cánones o regalías, la preponderancia del asunto toma ribetes de eje central.

1124 GARCÍA. Ob. supra cit., p. 113.

1125 En cuanto a las diferencias en el artículo 12 sobre los cánones, el propio MC ONU, el párrafo 1, de los Comentarios al mismo artículo, señala: "El artículo 12 de la Convención modelo de las Naciones Unidas reproduce las disposiciones del artículo 12 de la Convención modelo de la OCDE, con las siguientes excepciones: primera, modificaciones de fondo en los párrafos 1 y 3 ; segunda, la adición de dos nuevos párrafos 2 y 5 , con el resultado de que los números de los párrafos de la Convención modelo de las Naciones Unidas son distintos de los de la Convención modelo de la OCDE; y tercera, un ajuste de redacción en el párrafo 4". 
El MC ONU gira el centro de la distribución de la competencia tributaria desde la tributación en residencia, propia del MC OCDE, planteando la tributación compartida, entre el Estado de residencia y de la fuente -basado en un modelo de tributación limitada en fuente con un tope negociable. Es decir, a la luz del MC ONU los cánones deben tributar un monto (según un tipo que se negociará en cada convenio) en residencia -retenido y pagado por el licenciatario- y por el saldo que recibe efectivamente el licenciante, deben tributar nuevamente en fuente -enterado por el licenciatario.

Por alguna extraña razón, que desconozco, normalmente percibo una especial dificultad en explicar a las personas que no siempre el tipo de un impuesto será lo determinante, parece ser que la noción de un porcentaje alto, desencadena temores y tribulaciones con una certeza de ecuación matemática, en consecuencia que una aparentemente discreta reformulación del hecho gravado o de la composición de la base, puede producir efectos algorítmicos comparados con el desplazamiento del tipo. La razón de exponer estas ideas viene enlazada con la vocación de protección a los países en desarrollo que postula el MC ONU, puesto que cuando se trata de vocaciones, no puede dejar de verse también la presencia de los países industrializado en las Naciones Unidas, y su propia vocación de resguardo, de ahí que la estrategia más eficiente para trasladar rendimientos desde la fuente a la residencia, no sea la negociación del tipo, sino que la redefinición de la competencia tributaria por la vía de la reformulación del contenido de los cánones, que es precisamente lo que ha hecho el MC OCDE, al procurar reducir el contenido de la noción de canon, trasladándolo a rendimientos empresariales. En este sentido GRACÍA PRATS, escribe: “el MCOCDE planteó en 1992 una revisión del concepto de cánones, reduciéndolo, al excluir del mismo las rentas derivadas del uso o la concesión del uso de equipos industriales comerciales o científicos, reconduciendo las mismas al ámbito de los rendimientos empresariales, bajo la influencia del artículo 7 del Modelo de Convenio"1126. De aquí entonces nace una segunda diferencia entre los modelos de convenio, mientras el MC ONU incluye las rentas derivadas del uso o la concesión del uso de equipos industriales comerciales o científicos como parte de los cánones, para el MC OCDE forman parte de los rendimientos empresariales del artículo 7.

1126 Ob. supra cit., p. 120. 
Otra diferencia es la mayor preponderancia que pone el MC ONU en la industria cinematográfica, ya que no habla solamente de "las películas cinematográficas", sino que agrega a "las películas o cintas utilizadas para su difusión por radio o televisión", de esta adición del MC ONU, CEBALLOS DELGADO ${ }^{1127}$ al parecer deduce una mayor presencia de los intangibles derivados, tales como los derechos conexos, perspectiva que no compartimos, puesto que tal como analizamos en su momento, para nosotros la definición es enunciativa.

El MC ONU es más extensivo en la búsqueda de radicar las rentas en fuente, no sólo al atribuir las rentas percibidas en el Estado de la fuente, sino que también al incorporar el concepto de centro fijo, haciendo aplicables a él, las disposiciones del artículo 14 que pervive en el $\mathrm{MC}$ ONU (recordemos que fue derogado en el $\mathrm{MC}$ OCDE), produciendo el efecto de tributación en fuente.

La última diferencia destacable ya tuvimos oportunidad de analizarla previamente, se encuentra en el parágrafo 5. del art. 12 del MC ONU, que establece una regla sobre la procedencia de los cánones, lo que no puede llamar a sorpresa, desde el momento que el Modelo opta por la tributación compartida.

\subsection{Cuadro comparativo entre los modelos ONU y OCDE versus el convenio España-Chile}

Junto a las diferencias que hemos anotado entre los MC ONU y OCDE, para enfrentar la comparación con lo que se pactó en el caso del Convenio entre España y Chile, es útil ver los textos de manera simultánea, por ello, el siguiente cuadro:

\begin{tabular}{|c|c|c|}
\hline MC OCDE & MC ONU & io ESPAÑA-CHILE \\
\hline ARTÍCULC & $\begin{array}{llll}\text { Artículo } & 12 & \text { CÁNONES } & 0 \\
\text { REGALÍAS } & & & \\
\end{array}$ & $\begin{array}{lll}\text { Artículo } & 12 & \text { CÁNONES } \\
\text { REGALÍAS } & & \\
\end{array}$ \\
\hline $\begin{array}{l}\text { 1. Las regalías procedentes de } \\
\text { un Estado contratante y cuyo } \\
\text { beneficiario efectivo es un } \\
\text { residente del otro Estado } \\
\text { contratante sólo pueden } \\
\text { someterse a imposición en ese } \\
\text { otro Estado. }\end{array}$ & $\begin{array}{l}\text { 1. Los cánones procedentes de } \\
\text { un Estado contratante pagados } \\
\text { a un residente de otro Estado } \\
\text { contratante podrán someterse a } \\
\text { imposición en este último } \\
\text { Estado. }\end{array}$ & $\begin{array}{l}\text { 1. Los cánones o regalías } \\
\text { procedentes de un Estado } \\
\text { Contratante y pagadas a un } \\
\text { residente del otro Estado } \\
\text { Contratante pueden someterse } \\
\text { a imposición en ese otro Estado. }\end{array}$ \\
\hline & 2. Sin embargo, esos cánones & 2. Sin embargo, estos cánones o \\
\hline
\end{tabular}

1127 El autor plantea el asunto siguiendo a CATALINA HOYOS. CEBALLOS. Ob. supra cit., p. 14.

1128 Donde es posible, subrayamos las diferencias que posee el Convenio España-Chile con los modelos ONU y OCDE. 


\begin{tabular}{|c|c|c|}
\hline & $\begin{array}{l}\text { también podrán someterse a } \\
\text { imposición en el Estado } \\
\text { contratante del que procedan y } \\
\text { de acuerdo con la legislación de } \\
\text { este Estado, pero si el } \\
\text { propietario beneficiario de los } \\
\text { cánones es residente del otro } \\
\text { Estado contratante, el impuesto } \\
\text { así exigido no podrá exceder del } \\
\% \text { (el porcentaje se } \\
\text { determinará mediante } \\
\text { negociaciones bilaterales) del } \\
\text { importe bruto de los cánones. } \\
\text { Las autoridades competentes de } \\
\text { los Estados contratantes } \\
\text { determinarán de mutuo } \\
\text { acuerdo la forma de aplicar este } \\
\text { límite. }\end{array}$ & $\begin{array}{l}\text { regalías pueden también } \\
\text { someterse a imposición en el } \\
\text { Estado Contratante del que } \\
\text { procedan y de acuerdo con la } \\
\text { legislación de este Estado, pero } \\
\text { si el beneficiario efectivo es } \\
\text { residente del otro Estado } \\
\text { Contratante, el impuesto así } \\
\text { exigido no podrá exceder de: } \\
\text { a) por ciento del importe } \\
\text { bruto de esos cánones o regalías } \\
\text { pagados por el uso o el derecho } \\
\text { al uso de equipos industriales, } \\
\underline{\text { comerciales o científicos; }} \\
\text { b) } 10 \text { por ciento del importe } \\
\underline{\text { bruto de esos cánones o regalías }} \\
\text { en todos los demás casos. }\end{array}$ \\
\hline $\begin{array}{l}\text { 2. El término "regalías", en el } \\
\text { sentido de este artículo, } \\
\text { significa las cantidades de } \\
\text { cualquier clase pagadas por el } \\
\text { uso, o la concesión de uso, de } \\
\text { derechos de autor sobre obras } \\
\text { literarias, artísticas o } \\
\text { científicas, incluidas las } \\
\text { películas cinematográficas, de } \\
\text { patentes, marcas, diseños o } \\
\text { modelos, planos, fórmulas o } \\
\text { procedimientos secretos, o por } \\
\text { informaciones relativas a } \\
\text { experiencias industriales, } \\
\text { comerciales o científicas. }\end{array}$ & $\begin{array}{l}\text { 3. El término "cánones" } \\
\text { empleado en este artículo } \\
\text { comprende las cantidades de } \\
\text { cualquier caso pagadas por el } \\
\text { uso o la concesión de uso de } \\
\text { derechos de autor sobre las } \\
\text { obras literarias, artísticas o } \\
\text { científicas, incluidas las películas } \\
\text { cinematográficas y las películas } \\
\text { o cintas utilizadas para su } \\
\text { difusión por radio o televisión, } \\
\text { de patentes, marcas de fábrica o } \\
\text { de comercio, dibujos o modelos, } \\
\text { planos, fórmulas o } \\
\text { procedimientos secretos, así } \\
\text { como por el uso o la concesión } \\
\text { de uso de equipos industriales, } \\
\text { comerciales o científicos, y las } \\
\text { cantidades pagadas por } \\
\text { informaciones relativas a } \\
\text { experiencias industriales, } \\
\text { comerciales o científicas. }\end{array}$ & $\begin{array}{l}\text { 3. Los términos "cánones" o } \\
\text { "regalías" empleados en este } \\
\text { artículo significan las cantidades } \\
\text { de cualquier clase pagadas por } \\
\text { el uso, o el derecho al uso, de } \\
\text { derechos de autor sobre obras } \\
\text { literarias, artísticas o científicas, } \\
\text { incluidas las películas } \\
\text { cinematográficas o películas, } \\
\text { cintas y otros medios de } \\
\text { reproducción de la imagen y el } \\
\text { sonido, de patentes, marcas de } \\
\text { fábrica o de comercio, dibujos o } \\
\text { modelos, planos, fórmulas o } \\
\text { procedimientos secretos u otra } \\
\text { propiedad intangible, por } \\
\text { informaciones relativas a } \\
\text { experiencias industriales, } \\
\text { comerciales o científicas o por el } \\
\text { uso o derecho al uso, de equipos } \\
\text { industriales, comerciales o } \\
\text { científicos. }\end{array}$ \\
\hline $\begin{array}{l}\text { 3. Las disposiciones del } \\
\text { apartado } 1 \text { no son aplicables si } \\
\text { el beneficiario efectivo de las } \\
\text { regalías, residente de un } \\
\text { Estado contratante, realiza en } \\
\text { el Estado contratante del que } \\
\text { proceden las regalías una } \\
\text { actividad empresarial por } \\
\text { medio de un establecimiento } \\
\text { permanente situado allí, y si el } \\
\text { bien o el derecho por el que se } \\
\text { pagan las regalías está } \\
\text { vinculado efectivamente a } \\
\text { dicho establecimiento } \\
\text { permanente. En tal caso son } \\
\text { aplicables las disposiciones del }\end{array}$ & $\begin{array}{l}\text { 4. Las disposiciones de los } \\
\text { párrafos } 1 \text { y } 2 \text { no se aplicarán si } \\
\text { el propietario beneficiario de los } \\
\text { cánones, residente en un Estado } \\
\text { contratante, realiza operacio- } \\
\text { nes comerciales en el otro } \\
\text { Estado contratante del que } \\
\text { procedan los cánones, por } \\
\text { medio de un establecimiento } \\
\text { permanente situado en él, o } \\
\text { presta en ese otro Estado } \\
\text { servicios personales } \\
\text { independientes desde un centro } \\
\text { fijo situado en él, y el derecho o } \\
\text { propiedad por el que se paguen } \\
\text { los cánones está vinculado }\end{array}$ & $\begin{array}{l}\text { 4. Las disposiciones de los } \\
\text { párrafos } 1 \text { y } 2 \text { de este artículo, } \\
\text { no son aplicables si el } \\
\text { beneficiario efectivo de los } \\
\text { cánones o regalías, residente de } \\
\text { un Estado Contratante, realiza } \\
\text { en el otro Estado Contratante } \\
\text { del que proceden los cánones o } \\
\text { regalías, una actividad } \\
\text { empresarial por medio de un } \\
\text { establecimiento permanente } \\
\text { situado en ese otro Estado, y el } \\
\text { derecho o bien por el que se } \\
\text { pagan los cánones o regalías } \\
\text { está vinculado efectivamente a } \\
\text { dicho establecimiento }\end{array}$ \\
\hline
\end{tabular}




\begin{tabular}{|c|c|c|}
\hline artículo 7. & $\begin{array}{l}\text { efectivamente con a) ese } \\
\text { establecimiento permanente o } \\
\text { centro fijo, o con b) las } \\
\text { actividades comerciales } \\
\text { mencionadas en el apartado c) } \\
\text { del párrafo } 1 \text { del artículo } 7 \text {. En } \\
\text { tales casos se aplicarán las } \\
\text { disposiciones del artículo } 7 \text { o del } \\
\text { artículo } 14 \text {, según corresponda. }\end{array}$ & $\begin{array}{l}\text { permanente. En tal caso serán } \\
\text { aplicables las disposiciones del } \\
\text { artículo } 7 .\end{array}$ \\
\hline & $\begin{array}{l}\text { 5. Los cánones se considerarán } \\
\text { procedentes de un Estado } \\
\text { contratante cuan- do el deudor } \\
\text { sea un residente de ese Estado. } \\
\text { Sin embargo, cuando el deudor } \\
\text { de los cánones, sea o no } \\
\text { residente en un Estado } \\
\text { contratante, tenga en un Estado } \\
\text { contratante un establecimiento } \\
\text { permanente o un centro fijo en } \\
\text { relación con el cual se haya } \\
\text { contraído la obligación de pagar } \\
\text { los cánones y este } \\
\text { establecimiento o centro fijo } \\
\text { soporte el pago de los mismos, } \\
\text { los cánones se considerarán } \\
\text { procedentes del Estado en que } \\
\text { esté situado el establecimiento } \\
\text { permanente o centro fijo. }\end{array}$ & $\begin{array}{l}\text { 5. Los cánones o regalías se } \\
\text { considerarán procedentes de un } \\
\text { Estado Contratante cuando el } \\
\text { deudor sea un residente de ese } \\
\text { Estado. Sin embargo, cuando } \\
\text { quien paga los cánones o } \\
\text { regalías, sea o no residente de } \\
\text { un Estado Contratante, tenga en } \\
\text { un Estado Contratante un } \\
\text { establecimiento en relación con } \\
\text { el cual se haya contraído la } \\
\text { obligación de pago de los } \\
\text { cánones o regalías y que soporte } \\
\text { la carga de los mismos, dichos } \\
\text { cánones o regalías se } \\
\text { considerarán procedentes del } \\
\text { Estado Contratante donde esté } \\
\text { situado el establecimiento } \\
\text { permanente. }\end{array}$ \\
\hline $\begin{array}{l}\text { 4. Cuando, por las relaciones } \\
\text { especiales existentes entre el } \\
\text { deudor y el beneficiario } \\
\text { efectivo o por las que uno y } \\
\text { otro mantengan con terceros, } \\
\text { el importe de las regalías, } \\
\text { habida cuenta del uso, derecho } \\
\text { o información por los que se } \\
\text { pagan, exceda del que habrían } \\
\text { convenido el deudor y el } \\
\text { beneficiario efectivo en } \\
\text { ausencia de tales relaciones, } \\
\text { las disposiciones de este } \\
\text { artículo no se aplicarán más } \\
\text { que a este último importe. En } \\
\text { tal caso la cuantía en exceso } \\
\text { podrá someterse a imposición } \\
\text { de acuerdo con la legislación } \\
\text { de cada Estado contratante, } \\
\text { teniendo en cuenta las demás } \\
\text { disposiciones del presente } \\
\text { Convenio }\end{array}$ & $\begin{array}{l}\text { 6. Cuando, por las relaciones } \\
\text { especiales existentes entre el } \\
\text { deudor y el propietario } \\
\text { beneficiario o entre ambos y } \\
\text { cualquier otra persona, el } \\
\text { importe de los cánones, habida } \\
\text { cuenta del uso, derecho o } \\
\text { información por el que se } \\
\text { paguen, exceda del importe que } \\
\text { habría sido acordado por el } \\
\text { deudor y el propietario } \\
\text { beneficiario en ausencia de tales } \\
\text { relaciones, las disposiciones de } \\
\text { este artículo no se aplicarán más } \\
\text { que a este último importe. En tal } \\
\text { caso, el exceso podrá someterse } \\
\text { a imposición de acuerdo con la } \\
\text { legislación de cada Estado } \\
\text { contratante, teniendo en cuenta } \\
\text { las demás disposiciones de la } \\
\text { presente Convención. }\end{array}$ & $\begin{array}{l}\text { 6. Cuando, por razón de las } \\
\text { relaciones especiales existentes } \\
\text { entre el deudor y el beneficiario } \\
\text { efectivo, o de las que uno y otro } \\
\text { mantengan con terceros, el } \\
\text { importe de los cánones o } \\
\text { regalías, habida cuenta del uso, } \\
\text { derecho o información por los } \\
\text { que se pagan, exceda del que } \\
\text { habrían convenido el deudor y } \\
\text { el beneficiario efectivo en } \\
\text { ausencia de tales relaciones, las } \\
\text { disposiciones de este artículo } \\
\text { no se aplicarán más que a este } \\
\text { último importe. En tal caso, la } \\
\text { cuantía en exceso podrá } \\
\text { someterse a imposición de } \\
\text { acuerdo con la legislación de } \\
\text { cada Estado Contratante, } \\
\text { teniendo en cuenta las demás } \\
\text { disposiciones del presente } \\
\text { Convenio". }\end{array}$ \\
\hline
\end{tabular}




\subsection{El convenio de doble imposición entre España y Chile}

\subsubsection{Introducción}

El "Convenio entre el Reino de España y la República de Chile para evitar la doble imposición y prevenir la evasión fiscal en materia de impuestos sobre la renta y sobre el patrimonio", firmado el 7 de julio de 2003 en Madrid, entró en vigencia a partir del 1 de enero del año 2004, constituye el documento con el que creemos corresponde cerrar nuestro estudio, puesto que es el tratado vigente sobre la materia suscrito entre España y Chile.

En lo que a nosotros interesa, es decir, cánones o regalías, tal como podría haberse previsto, se aleja del MC OCDE, asumiendo casi a la letra el MC ONU, optando por una alternativa de tributación compartida con retención en la fuente.

El estudio del CDI España-Chile, probablemente podría haber sido el centro de nuestro trabajo, pero los resultados creemos que habrían sido peores, puesto que para llegar a comprenderlo en su integridad, tendríamos que haber hecho referencias y análisis por separado, que probablemente, a poco andar, el CDI España-Chile habría sido muy difícil de distinguir, perdido tras un telón de explicaciones y análisis, de manera que, eso justificó nuestra idea de ubicarlo al final y es la razón por la que, intentaremos hacer solamente los comentarios que nos parezcan fundamentales, centrándonos en aquellas cosas que difieren de los modelos que hemos analizado, puesto que en las demás, tal como hemos ensayado, nos encontramos en una base de relativa uniformidad que hace innecesario repetir lo estudiado.

\subsubsection{El artículo 12. Cánones o regalías}

\subsubsection{1. $\quad$ El texto}

El artículo 12 se refiere a los cánones o regalías y se ubica en perfecta simetría con los MC OCDE y ONU, que tratan el tema en el artículo 12, lo que claramente no es una coincidencia, ni parece ser nada destacable, de antemano sabemos que los convenios se suscriben bajo esos modelos.

El texto es el siguiente:

“Artículo 12 CÁNONES O REGALÍAS 
1. Los cánones o regalías procedentes de un Estado Contratante y pagadas a un residente del otro Estado Contratante pueden someterse a imposición en ese otro Estado.

2. Sin embargo, estos cánones o regalías pueden también someterse a imposición en el Estado Contratante del que procedan y de acuerdo con la legislación de este Estado, pero si el beneficiario efectivo es residente del otro Estado Contratante, el impuesto así exigido no podrá exceder de:

a) 5 por ciento del importe bruto de esos cánones o regalías pagados por el uso o el derecho al uso de equipos industriales, comerciales o científicos;

b) 10 por ciento del importe bruto de esos cánones o regalías en todos los demás casos.

3. Los términos "cánones" o "regalías" empleados en este artículo significan las cantidades de cualquier clase pagadas por el uso, o el derecho al uso, de derechos de autor sobre obras literarias, artísticas o científicas, incluidas las películas cinematográficas o películas, cintas y otros medios de reproducción de la imagen y el sonido, de patentes, marcas de fábrica o de comercio, dibujos o modelos, planos, fórmulas o procedimientos secretos $u$ otra propiedad intangible, por informaciones relativas a experiencias industriales, comerciales o científicas o por el uso o derecho al uso, de equipos industriales, comerciales o científicos.

4. Las disposiciones de los párrafos 1 y 2 de este artículo, no son aplicables si el beneficiario efectivo de los cánones o regalías, residente de un Estado Contratante, realiza en el otro Estado Contratante del que proceden los cánones o regalías, una actividad empresarial por medio de un establecimiento permanente situado en ese otro Estado, y el derecho o bien por el que se pagan los cánones o regalías está vinculado efectivamente a dicho establecimiento permanente. En tal caso serán aplicables las disposiciones del artículo 7.

5. Los cánones o regalías se considerarán procedentes de un Estado Contratante cuando el deudor sea un residente de ese Estado. Sin embargo, cuando quien paga los cánones o regalías, sea o no residente de un Estado Contratante, tenga en un Estado Contratante un establecimiento en relación con el cual se haya contraído la obligación de pago de los cánones o regalías y que soporte la carga de los mismos, dichos cánones o regalías se 
considerarán procedentes del Estado Contratante donde esté situado el establecimiento permanente.

6. Cuando, por razón de las relaciones especiales existentes entre el deudor y el beneficiario efectivo, o de las que uno y otro mantengan con terceros, el importe de los cánones o regalías, habida cuenta del uso, derecho o información por los que se pagan, exceda del que habrían convenido el deudor y el beneficiario efectivo en ausencia de tales relaciones, las disposiciones de este artículo no se aplicarán más que a este último importe. En tal caso, la cuantía en exceso podrá someterse a imposición de acuerdo con la legislación de cada Estado Contratante, teniendo en cuenta las demás disposiciones del presente Convenio".

Al finalizar el texto bajo el título Protocolo, encontramos el parágrafo X, que señala:

“Ad. artículos 10, 11 y 12.

Las disposiciones de los artículos 10, 11 y 12 no se aplicarán si el propósito principal o uno de los principales propósitos de cualquier persona vinculada con la creación o atribución del derecho o crédito en relación con el cual los dividendos, los intereses o los cánones o regalías se paguen, sea el de obtener los beneficios de esos artículos mediante tal creación o atribución.”.

\subsubsection{El título del artículo 12}

Ya en la denominación del artículo 12 del CDI España-Chile vemos un matiz, puesto que no se refiere únicamente a regalías, como los hace el MC OCDE, sino que se sigue al MC ONU hablando de “cánones o regalías". Sabemos que las palabras son sinónimas, el problema es que ninguna de ellas está definida en el derecho chileno vinculada a la propiedad intelectual. En el caso de los cánones, la particularidad es que corresponde a la designación para rentas periódicas que se usa en el arrendamiento, usufructo y censo, entre otras ${ }^{1129}$; sin embargo, respecto de las regalías el silencio es absoluto. En esa medida, para Chile es innocuo utilizar uno u otro concepto, pero evita

1129 La referencia a cánones está en el Código Civil chileno, en los artículos 647, 796, 1559, 1594 y 2022 y siguientes en el contrato de Censo. 
confusiones o mal interpretaciones el usar ambos, aun cuando cabría hacer presente que en Chile, al menos coloquialmente, el término más utilizado es el préstamo "royalty".

\subsubsection{Atribución de jurisdicción}

El CDI España-Chile opta por repartir la jurisdicción tributaria sobre los cánones entre ambos países, lo que resulta completamente claro en los números 1 y 2 del artículo 12, cuando establecen: "Los cánones o regalías procedentes de un Estado Contratante y pagadas a un residente del otro Estado Contratante pueden someterse a imposición en ese otro Estado", "Sin embargo, estos cánones o regalías pueden también someterse a imposición en el Estado Contratante del que procedan y de acuerdo con la legislación de este Estado".

Esta solución es esperable atendida la calidad de país importador de tecnología de Chile, sin embargo, en este caso, la posición relativa de España es de exportador de tecnología, por lo que era esperable que se sintiera más cómoda con una solución al estilo del MC OCDE ${ }^{1130}$.

\subsubsection{Límite de retención en fuente}

El CDI establece dos límites para el gravamen en fuente, un caso de excepción aplicable sólo en el caso de los pagos por el uso o el derecho al uso de equipos industriales, comerciales o científicos, limitado al 5 por ciento del importe bruto; y el otro, la norma residual, que pasa a ser el tipo general, del 10 por ciento del importe bruto en todos los demás casos.

En este punto llaman la atención dos asuntos vinculados al uso de equipos industriales, comerciales o científicos, por una parte el hecho que el CDI se refiera a ellos, puesto que era esperable que España, tal como vimos, desde su posición relativa de exportador de tecnología, no quisiera incluir este ítem; y por otra, la tasa reducida al 5 por ciento, puesto que es el único caso de tipo inferior a 10 por ciento en todo el

1130 A modo de ejemplo, en el informe presentado por el Embajador Chileno ante la Cámara de Bilbao, en el año 2011, podemos ver como las importaciones desde España a Chile, consideran, principalmente: maquinarias y aparatos mecánicos y eléctricos, vehículos, aeronaves, vehículos espaciales, aeronaves y demás productos industriales. Por parte de Chile, las exportaciones a España se concentran en commodities, minerales sin elaborar y productos agrícolas, todo lo que da cuenta de una típica relación de país industrializado versus país en desarrollo. El informe está disponible en Internet en: http://www.camarabilbao.com/ccb/contenidos.downloadatt.action?id=8764571 (15 Abr 2014). 
convenio. Como es habitual en los CDI y también en los TLC, no tenemos una explicación oficial de las motivaciones exactas que se tuvieron para llegar a una solución u otra; sin embargo, en este caso, desde la perspectiva, se ve muy claramente una transacción entre la pretensión de Chile de incluir a los pagos por el uso o el derecho al uso de equipos industriales, comerciales o científicos y la aspiración de España de sacarlos, encontrando el equilibrio una vez asumida la decisión de incorporarlos, justo en la mitad del tipo pactado como régimen general ${ }^{1131}$.

\subsubsection{Bienes y derechos específicos en la definición de cánones o regalías}

En la definición se conserva el elemento central que caracteriza a los cánones, tal es su necesaria asociación con los pagos por "el uso o el derecho al uso", lo que es muy importante, puesto que de otra manera, probablemente estaríamos frente a cualquier cosa menos a cánones.

En cuanto a los bienes específicos que se incluyen en la definición y por tanto generadores de cánones, basalmente están todos aquellos que figuran en los $\mathrm{MC} \mathrm{OCDE}$ y ONU que hemos analizado, de manera que a lo dicho para ellos nos remitimos. Sin embargo, además se agregan: las películas, cintas y otros medios de reproducción de la imagen y el sonido; marcas de fábrica o de comercio; otra propiedad intangible; y, los equipos industriales, comerciales o científicos.

Respecto de las películas y otros medios de reproducción de la imagen y el sonido $^{1132}$, estimamos que es una adición acertada, probablemente innecesaria, porque de todas maneras estarían comprendidos, pero al menos nos libera de las discusiones que conocimos sobre si son generadores de cánones o no. En otro sentido, de paso, estimamos que la especificación hecha aviva las posibles polémicas sobre los bienes digitales y los derechos conexos, puesto que se presta para argumentar que si el CDI hubiese querido incluirlos por qué no lo hizo, razonamiento tan usado que suele no convencer a nadie, pero que en el caso específico, tiene bastante sentido. En conclusión probablemente, deberíamos decir: "mucho ayuda lo que poco estorba". De todas formas, no conocemos experiencia empírica hasta el momento, sobre este punto.

\footnotetext{
1131 Desgraciadamente no se han publicado, al menos en Chile, explicaciones sobre las razones para negociar en uno u otro sentido.

1132 En especial la adición de estas referencias está tratada por MARTíN. Ob. Cit., pp. 688.
} 
La referencias a marcas de fábrica o de comercio es una especificación que si bien sigue al MC ONU, es completamente innecesaria, puesto que se trata de un distingo obsoleto que en Chile ni siquiera se conoce y en España no tiene sentido, puesto que al hablar de "marcas" se involucra a ambas. Vemos aquí una sutileza que nuevamente demuestra lo peligroso que puede llegar a ser apartarse de los estándares conocidos, puesto que el modelo que más se ajustaba a la realidad de ambos Estado era el MC OCDE.

Al hablar de "otra propiedad intangible" el artículo usa el diseño, que comentamos en su momento, permite dejar abierta la redacción para extender su aplicación a otros activo o derechos inmateriales no enumerados, claro está que eso mirándolo con buenas intenciones, puesto que hablar de "propiedad intangible" no deja de involucrar una serie de contrasentidos. De partida, la propiedad en sí misma es un intangible, puesto que es un derecho, que puede recaer sobre bienes tangibles e intangibles, es otra cosa, pero en sí misma, la propiedad es un intangible. De esta manera, leída literalmente la frase, el adjetivo intangible calificando al derecho de propiedad, no tiene sentido, sólo podría tenerlo si se estuviese refiriendo a otro derecho de propiedad, como pudiese ser la minera, indígena, etc., lo que parece atentar contra una interpretación sistemática del Convenio.

En otro sentido, si la frase buscaba referirse a "otra propiedad sobre otros intangibles", tampoco se gana mucho en contenido, puesto que no es la propiedad sobre los intangibles el objeto de cánones, sino que el uso o derecho de uso.

En consecuencia, el sentido de la frase que da más contenido y resulta más armónico a una interpretación lógica y sistemática, es el que se refiere al pago por el uso de otros bienes o derechos intangibles, dejando una redacción abierta, donde habría cabida para aportar claridad, por ejemplo, respecto de los casos que conocimos como supuestos confusos o de difícil calificación y otros derechos de propiedad intelectual, tales como: diseños textiles, topografías de circuitos integrados, etc.

A todo evento no deja de sorprendernos la incorporación de este segmento, porque enfrenta frontalmente nuestra teoría sobre la concepción global del Convenio España-Chile, puesto que se trata de una norma que conocidamente cede en beneficio 
de los países importadores de tecnología, al ampliar el contenido de la noción de cánones.

En cuanto a la referencia a los equipos industriales, comerciales o científicos, la analizamos en su momento, únicamente cabe pensar que ante las posiciones contrapuestas que pueden tener los países frente a ella, es un buen ejemplo de salida a la hora de negociar. Por otra parte, atendida la incorporación de los equipos industriales, comerciales o científicos, podríamos haber esperado que también se incorporara la asistencia técnica, pero no hay referencia alguna a la materia.

En cuanto a los bienes y derechos que están tal cual en el MC OCDE, es del caso recordar respecto del derecho de autor, know-how y de cualquier otro bien incorporal, lo que analizamos en su momento respecto del régimen de propiedad en Chile, puesto que en el derecho chileno no existe ningún problema en comprar o vender ningún bien incorporal, salvo que su enajenación esté prohibida por la ley ${ }^{1133}$, con la particularidad que desde la compraventa no es posible llegar al dominio, sino que se requiere que opere un modo de adquirir, normalmente, la tradición para los bienes corporales y la cesión para los bienes incorporales. En este sentido, habrán dos conclusiones que tener presente, por una parte deberá tenerse en cuenta que la expresión "cesión" que utiliza el número 2 del artículo 12, está tomada en el sentido de permitir el uso y no como modo de adquirir de los bienes incorporales; y por otra parte, que en el derecho chileno no se pueden dar las discusiones que existen en el derecho español sobre la imposibilidad de vender el know-how o las implicancias de la cesión del derecho de autor.

En lo que dice relación con las patentes y otros títulos de propiedad industrial, tales como diseños textiles, topografías de circuitos integrados y otros similares, también debe considerarse que en Chile se encuentran todos anidados bajo una única ley de propiedad industrial ${ }^{1134}$, lo que unido a la expresión que ya comentamos "otra propiedad intangible", lleva a concluir, que todos los derechos de propiedad industrial están incorporados en la definición como potenciales generadores de cánones. En esa medida, la discusión que analizamos en su momento, sobre la extensión de la definición a estos derechos, en Chile tiene cabida respecto de las variedades vegetales, puesto que

1133 Como sucede con ciertos artículos religiosos, los bienes embargados, los bienes públicos, etc.

1134 Ley $N^{\circ} 19.039$, sobre Propiedad Industrial. 
son el único derecho regulado en una ley autónoma ${ }^{135}$ y con relación a algunos institutos no protegidos como las marcas tridimensionales y olfativas.

En cuanto a los programas de ordenador, llama la atención que siendo un tema con tanto conflicto subyacente en España no esté incorporado en el CDI, ni para dejar claro que está incorporado, ni tampoco para incorporar la reserva que España suele hacer al MC OCDE, que analizamos supra. Esta particularidad sirve para confirmar que desde el punto de vista de un CDI entre España y Chile, el rol de España es claramente de proveedor y el de Chile de importador de tecnología. Al fin y al cabo, estamos frente a uno de los misterios de la propiedad intelectual, irónicamente hablando, puesto que habiendo dos modelos cuyas tendencias son tan marcadas, creemos que en la aplicación práctica, en el caso del Convenio España-Chile, no se asumió solemnemente ni el uno, ni el otro.

\subsubsection{Relación con el establecimiento permanente}

En el parágrafo 4, del artículo 12, se establece que en el evento que el beneficiario efectivo de los cánones realice en el Estado de la fuente sus actividades por medio de un establecimiento permanente y el derecho por el que se pagan los cánones o regalías está vinculado a ese EP, deja de aplicarse la alternativa de la tributación compartida y pasan a atribuirse estos cánones al EP, tributando como una renta de aquél, en función del artículo 7.

En Chile sucedería que esas rentas deberían pagar a nivel del EP el impuesto de Primera Categoría, a un porcentaje de 20 por ciento y al momento de remesar estaría gravado con impuesto Adicional a un tipo de 35 por ciento, con crédito del 20 por ciento previamente pagado ${ }^{1136}$. Lógicamente, la tributación se vuelve más cara en la fuente, pero al estar dentro del EP gana la alternativa de deducir los gastos asociados a la producción del canon, alternativa que no posee bajo la tributación del artículo 12.

En todo caso la norma no tiene nada de particular, puesto que no es más que una aplicación del principio de la vis atractiva del EP.

1135 Ley N ${ }^{\circ}$ 19.342, que Regula Derechos de Obtentores de Nuevas Variedades Vegetales.

1136 Recordemos que desde la reforma de septiembre de 2014, con el desaparecimiento del FUT, el pago del impuesto adicional se produce en cada período tributario hayan o no habido remesas. 


\subsubsection{Determinación del Estado de procedencia}

En la lógica del modelo OCDE con la atribución de la competencia tributaria al Estado de residencia, es innecesaria una norma que exija que para beneficiarse del tipo reducido los cánones deben provenir del Estado de la fuente. En cambio, bajo el prisma del MC ONU considerando la tributación compartida, es necesaria la incorporación de una norma sobre la determinación del Estado de precedencia, por ello, el Convenio España-Chile toma en consideración esta variable en el parágrafo quinto del artículo 12, al definir que los cánones se entenderán procedentes del Estado de la fuente cuando el deudor sea un residente de ese Estado. En otras palabras opta por el criterio de la residencia.

La excepción se produce cuando quien paga los cánones tenga un EP en un Estado contratante - en cuyo favor se paguen los cánones y que además sea el que efectivamente soporta su carga económica- dichos cánones se entenderán procedentes del Estado en que esté situado el EP y en función de eso estarán o no dentro de los límites del art. 12.

\subsubsection{Algunas cuestiones pendientes}

Toda vez que muchos de los problemas que presenta la noción de cánones han sido objeto de largos debate y tratamiento, podría haber sido la oportunidad de dejar, sino zanjados, al menos, aclarados algunos conceptos, como: ¿cuál es el importe bruto? En el caso chileno la LIR utiliza la expresión, "pagado o abonado en cuenta”, ¿es éste el importe bruto?; o, ¿qué es "creación o atribución?, se refiere a la creación artificial de cánones o de la propiedad intelectual en sí misma. Son temas que dejamos planteados para futuros estudios.

\subsubsection{Disposiciones antielusión}

El Convenio España-Chile, repite las disposiciones antielusión del 12. 4 del MC OCDE y 12.6 del MC ONU, por lo que a ese respecto nos remitimos a lo que vimos en su momento.

Lo particular es que el Convenio España-Chile, considera un Protocolo donde incorpora una norma antielusión ${ }^{1137}$ que adaptándola a la situación de los cánones

1137 La disposición dice así: "IX” "Ad. artículos 10, 11 y 12" 
quedaría como sigue: "Las disposiciones relativa a cánones no se aplicarán si el propósito principal o uno de los principales propósitos de cualquier persona vinculada con la creación o atribución del derecho en relación con el cual los cánones o regalías se paguen, sea el de obtener los beneficios de esos artículos mediante tal creación o atribución".

La regla anotada, a nuestro juicio, es suficientemente ambigua al no definir qué quiso decir con creación o atribución y a la vez, suficientemente confusa, como para no llegar a ser aplicada jamás. De todas formas, creemos que con esfuerzo, busca decir que cada uno de los estados contratantes podrá gravar la totalidad de la renta sin las limitaciones que impone el CDI, cuando se cumplan los siguientes requisitos:

- Que, exista una persona vinculada a la creación o atribución de titularidad del derecho o bien generador de cánones. Aquí podrían caber hasta los agentes y abogados de propiedad industrial;

- Que, el derecho o bien creado por la persona vinculada sea el que motiva los cánones;

- Que, el propósito principal o uno de los propósitos principales de la creación del derecho o bien, sea el obtener los beneficios de estos artículos mediante la creación o atribución. Es decir, el origen de la propiedad intelectual debe ser para aprovecharse de las ventajas del artículo. Además debe tratarse de uno de los propósitos principales, lo que impone la dificultad de saber cuándo un propósito es principal.

En otras palabras, parece ser que la disposición busca atacar la simulación como medio para a través de la creación de derechos o su traspaso a terceros, generar artificialmente el pago de cánones con el ánimo de beneficiarse del CDI. Estimamos que ya bastantes disposiciones generales antielusión poseen los CDI, como para complicar el asunto con una disposición tan peculiar ${ }^{1138}$, que finalmente no es claro si servirá para evitar la elusión o apoyarla, al crear una redacción inentendible.

"Las disposiciones de los artículos 10, 11 y 12 no se aplicarán si el propósito principal o uno de los principales propósitos de cualquier persona vinculada con la creación o atribución del derecho o crédito en relación con el cual los dividendos, los intereses o los cánones o regalías se paguen, sea el de obtener los beneficios de esos artículos mediante tal creación o atribución".

1138 En palabras de DELGADO. Ob. supra cit., p. 742. 


\subsubsection{La cláusula de la nación más favorecida}

El Convenio Chile-España tuvo algunos efectos que van más allá del interés exclusivo de las partes, a consecuencia de la cláusula NMF. En efecto, en algunos convenios, tales como los celebrados por Chile con Canadá, México, Corea, Ecuador, Noruega y Polonia, se incluyó la cláusula de la nación más favorecida, que implica para Chile que en el evento de acordar un tipo de retención más bajo para los cánones con un tercer Estado debe también favorecer a aquél con el que pactó la cláusula de NMF.

Esta condición se cumplió con la entrada en vigencia del Convenio EspañaChile, que contempló tasas máximas de retención en la fuente para intereses y cánones inferiores a las contempladas en los convenios indicados.

Lo llamativo en este caso no es la cláusula NMF, sino que el SII dictó oficiosamente la Circular $\mathrm{N}^{\circ}$ 08, de 26 de enero de 2005, haciéndose cargo del asunto y disponiendo la retención a los tipos inferiores para todos los convenios involucrados, una actitud bastante desconcertante para una administración tributaria, más aún considerando las discusiones que hemos tenido oportunidad de conocer sobre la recepción de los convenios de doble imposición en el derecho interno, a lo que cabría agregar que conforme al artículo $5^{\circ}$, inciso segundo de la Constitución Política de la República, Chile reconoce el monismo como solución a la integración de los tratados internacionales al derecho interno, únicamente en lo que se refiere a los derechos esenciales que emanan de la persona humana, ${ }^{1139}$ de manera que siendo esencialmente dualista, incluso puede discutirse que el SII tenga la facultad de rebajar el tipo y no haya debido hacerse a través de una ley expresa de implementación. Este punto ha sido motivo de intenso debate interno en Chile, particularmente en lo que dice relación con los tratados sobre propiedad intelectual e industrial, pero su estudio escapa a los límites de nuestro estudio.

1139 Art. $5^{\circ}$, inciso segundo, CPR: "El ejercicio de la soberanía reconoce como limitación el respeto a los derechos esenciales que emanan de la naturaleza humana. Es deber de los órganos del Estado respetar y promover tales derechos, garantizados por esta Constitución, así como por los tratados internacionales ratificados por Chile y que se encuentren vigentes". 


\section{CONCLUSIONES}

1. En el derecho comparado, la naturaleza jurídica de la propiedad intelectual no está definida de manera uniforme, sino que coexisten las más variadas teorías sobre su origen y su justificación jurídica. Algunas concepciones más tradicionales han sido superadas por visiones posteriores, como sucede con aquella posición que la entiende como un privilegio; no obstante, los más variopintos puntos de vista subsisten hasta nuestros días, entendiéndola como verdadera propiedad, propiedad especial, monopolio, derecho humano, derechos de la personalidad y como un elemento de la noción que entiende a la investigación, innovación y desarrollo como bases del crecimiento económico, entre otras.

2. En los tratados internacionales sobre propiedad intelectual, tales como el Convenio de la Unión de París y el Convenio de Berna, aunque no expresamente, también está presente esa dispersión sobre su naturaleza jurídica. En efecto, no se trata de que algunos de ellos le atribuyan una naturaleza jurídica y los demás otra, sino que realmente es un asunto que estos instrumentos no abordan, precisamente por tratarse de una materia sobre la que no es posible llegar a un consenso internacional.

En el plano fiscal internacional, sucede lo mismo, el artículo 12 del MC OCDE evita referirse a las rentas de la propiedad intelectual de manera general, soslayando la indefinición del contenido que esto puede involucrar. Así pues, se refiere a su objeto como "cánones" o "regalías", que define optando por una solución pragmática, catalogando cada una de las fuentes materiales de renta como "las cantidades de cualquier clase pagadas por el uso, o el derecho al uso, de derechos de autor sobre obras literarias, artísticas o científicas, incluidas las películas cinematográficas o películas, cintas y otros medios de reproducción de la imagen y el sonido, de patentes, marcas de fábrica o de comercio, dibujos o modelos, planos, fórmulas o procedimientos secretos $\mathrm{u}$ otra propiedad intangible, por informaciones relativas a experiencias industriales, comerciales o 
científicas o por el uso o derecho al uso, de equipos industriales, comerciales o científicos".

Comparando el ordenamiento español y chileno también se observa una divergencia en la conceptualización de la naturaleza jurídica de la propiedad intelectual, perfilándose como una especie de propiedad civil en el sistema chileno y un derecho autónomo en el derecho español. A nivel constitucional, en la regulación española la presencia de la propiedad intelectual está en diferentes artículos siempre tras un velo que exige un esfuerzo interpretativo para encontrar su figura, interactuando con otros derechos como la propiedad, la libre creación y producción, y aquellos que se yerguen como límite o contrapeso, de ahí que haya sido una preocupación de la jurisprudencia, encontrar el balance y armonía entre todos ellos. En el caso chileno, también la propiedad intelectual reconoce límite en los demás derechos garantizados por la Constitución, con una diferencia fundamental, la declaración de constituir un derecho de propiedad a lo largo de la historia constitucional chilena es expresa e indubitada, lo que le otorga un perfil potente y reforzado en comparación con la realidad española, aunque no podemos olvidar que la última modificación constitucional al introducir la libertad de crear y difundir las artes, se aproximó al modelo Español.

3. La economía utiliza un concepto de propiedad con un contenido diferente del jurídico, puesto que consiste en la posibilidad, amparada por el derecho, de excluir a otros en la utilización de un bien; sin embargo, siendo una perspectiva distinta, revela un sustrato común con la noción jurídica, en tanto poder sobre una cosa que faculta para disponer de ella conforme a la ley. Así, es precisamente el poder que otorga la ley sobre una cosa, lo que permite excluir de su uso a terceros, demostrando una vinculación fáctica entre el punto de vista jurídico y económico.

Al revisar la evolución de la ciencia económica, pudimos apreciar como se ha ido trabajando sobre el rol del avance técnico en la economía, hasta llegar al estado actual, donde es indubitado el influjo benéfico de la innovación en el crecimiento económico, así pues, hoy en día puede discutirse la forma o grados 
de la influencia, pero no el hecho de existir un aporte beneficioso del avance técnico en la economía. El traslado de esta constatación de la ciencia económica al derecho es manifiesto en nuestro estudio, cuando hablamos de propiedad intelectual y particularmente de propiedad industrial.

4. El diseño de las leyes de propiedad intelectual al menos en los últimos cien años en España y Chile, ha estado marcado por la influencia de las ideas que venimos hablando. Siempre en el mensaje de la ley sobre propiedad intelectual o en su historia, se hace referencia expresa y se pone como una motivación determinante los beneficios que trae el avance técnico y la debida protección de la propiedad intelectual, idea que resulta ser el centro gravitacional en la creación de beneficios tributarios para la $\mathrm{I}+\mathrm{D}+\mathrm{i}$, tal como tuvimos oportunidad de ver al analizar las sendas estructuras de estímulo fiscal que han existido en Chile y España desde mediados de los años setenta hasta la fecha.

La dinámica de esta interacción recíproca se manifiesta: en la economía, por la influencia en el comportamiento de los agentes económicos que se produce por las leyes que regulan a la propiedad intelectual y especialmente, en cuanto se establecen gravámenes, incentivos tributarios y subsidios; y, en el derecho, por la consideración de los principios y conocimientos que ha aportado la economía al momento de legislar. Tan fuerte es esta dependencia, que ha dado origen a postular una nueva disciplina, el Análisis Económico del Derecho, que encuentra su más preciado objeto de estudio -donde sus premisas se cumplen sin lugar a dudas- en nuestra materia de estudio, la propiedad intelectual y su tributación. Efectivamente, pudimos constatar que los aumentos en los grados de protección de la propiedad intelectual se justifican a nivel nacional e internacional a través de los beneficios que el avance técnico y la producción cultural generan en la comunidad; en contraposición, se postula que débiles estándares de protección ralentizan el avance y condenan a los países a la pobreza y subdesarrollo. Asimismo, la implementación de subsidios, beneficios y hasta premios es frecuente, siempre con el objeto de estimular el avance técnico, baste recordar el ejemplo citado, sobre el hecho que Felipe II, el Prudente, ofreció 10.000 coronas para quien desarrollara un invento que permitiera medir la navegación en alta mar. 
En conclusión, cuando de tributación de la propiedad intelectual se habla, quien pretenda que el análisis jurídico puede hacerse solamente fundado en principios y dogmas clásicos del derecho estará en un error, puesto que la influencia de la economía ha perfilado su regulación jurídica al menos desde el Convenio de la Unión de París de 1883.

5. Si bien los rendimientos de la propiedad intelectual pueden someterse a tributación conforme a las reglas generales de la leyes sobre la renta de España y Chile, ciertos aspectos derivados de las dificultades que conlleva su valoración y su propia condición de intangible, hacen propicia la creación de normas específicas, para aquellos temas de mayor sensibilidad a la hora de determinar la utilidad gravable, tales como: amortización, imputación de gastos, determinación de costo de adquisición y venta, lo que no pasa desapercibido para los legisladores español y chileno, aunque con soluciones y justificaciones diversas. En el caso de España, se observa una legislación mucho más desarrollada, que se hace cargo de temas en detalle, como la amortización para la cual define requisitos y establece diferentes sistemas; en cambio, en Chile, el temor a una menor recaudación, lleva a negar la posibilidad de amortizar, permitiendo solamente efectuar una imputación de gasto cuando la propiedad intelectual ha caducado y perdido completamente su valor.

No obstante lo anterior, la regulación más frondosa se crea, a nuestro juicio, por la influencia de las conclusiones aportadas por la economía sobre los beneficios del avance técnico, es eso lo que motiva el diseño de un régimen jurídico de beneficio claramente definido. Instituciones como el patent box, minoraciones asociadas a actividades de $\mathrm{I}+\mathrm{D}+\mathrm{i}$, tasas reducidas o la conformación de supuestos de no sujeción para autores y creadores de propiedad intelectual, se han justificado en el aporte que estas actividades generan a la sociedad en su conjunto, tanto en España como en Chile.

6. Asumir que el avance técnico beneficia a la economía, no implica que se conozca la forma ni la proporción en que éste influye, de manera que el diseño tanto en España como en Chile de sendos mecanismos de estímulo, anidados en 
beneficios impositivos para $\mathrm{I}+\mathrm{D}+\mathrm{i}$, muestra, tal como tuvimos oportunidad de analizar, el frenético vaivén de cambios y más cambios que han enfrentado estos beneficios tributarios en uno y otro país. Sin reparos los legisladores proclaman la certeza de la idea que estimular el avance técnico es beneficioso, como motivación para el establecimiento de beneficios tributarios; no obstante, de la misma manera, frente a la incertidumbre de sus efectos, observamos cómo les modifican una y otra vez. Así pues, tuvimos oportunidad de analizar cómo la justificación de los continuos cambios no está dada por errores jurídicos, indefinición en la redacción, antinomias, vacíos legales, ni otras consideraciones jurídicas, tampoco por modelos matemáticos precisos -ya que no existencapaces de medir la incidencia del avance técnico en una economía determinada, sino que por consideraciones macroeconómicas tomadas como antecedentes generales de la economía del país. Es decir, tanto en España como en Chile, los cambios no se justifican en la evidencia empírica demostrada, sino en la afirmación teórica de la economía sobre los beneficios del avance técnico.

7. Hemos observado los continuos cambios en la tributación de la propiedad intelectual, especialmente en lo que respecta a $\mathrm{I}+\mathrm{D}+\mathrm{i}$ y al Capítulo $12 \mathrm{MC}$ OCDE, que llegamos a calificarlos de vertiginosos. Consideramos que la justificación jurídica de la propiedad intelectual en España y Chile casi no ha cambiado. Si se quiere podrá no estar del todo definida, pero la indefinición se ha mantenido siempre en los mismos límites, lo cual nos lleva a concluir que no es allí donde pueden encontrar explicación las sucesivas modificaciones de la legislación tributaria sobre la materia. Así las cosas, es precisamente la incidencia de la economía, desde el punto de vista teórico o derivado de apreciaciones y mediciones prácticas, la razón que impulsa los sucesivos cambios, en una relación dinámica con el avance en el conocimiento económico, donde la norma jurídica, manteniendo su naturaleza, se presta para reconocer los avances en la ciencia económica, aceptando el rediseño constante de mecanismos de estímulo y favor, y a la vez, es el vehículo para consolidar acuerdos, transacciones y encuentros que la sociedad nacional e internacional busca en un momento determinado, si no, baste con mirar el MC OCDE y MC ONU, en tanto cada uno de ellos representa intereses diversos respecto de los cánones. En el mismo sentido, pudimos estudiar como la interpretación 
dinámica del MC OCDE, impulsa cambios incluso en su texto, trasladando al arrendamiento de maquinarias y equipos desde el artículo 12 al 7 del MC OCDE, variación que busca satisfacer los intereses de países productores de tecnología y que por lo mismo, los países importadores no comparten. Asimismo, en el Tratado de Doble Imposición entre España y Chile, vimos claramente una transacción en el tipo impositivo para equipos industriales, comerciales y científicos.

8. Desde el punto de vista fiscal, los rendimientos de la propiedad intelectual podrían ser sometidos a tributación tanto en el plano nacional como internacional recurriendo a las normas generales sobre la renta, con algunas especificaciones como vimos antes, sin necesidad de una regulación específica. Tanto en España como en Chile, bastaría con constatar que se trata de bienes inmateriales y que en algunos casos las rentas provienen de su arrendamiento y en otros de su enajenación. Sobre esa base, los flujos provenientes de la propiedad intelectual que encajen en la definición de renta de cada Estado tienen sellado su destino obligados a contribuir. No obstante lo anterior, tal como muestra nuestro estudio, tanto en el plano nacional como internacional se constata una regulación especial.

En el ámbito nacional, en el caso de España, la regulación especial de la propiedad intelectual viene principalmente por el desarrollo de mecanismos de estímulo a la $\mathrm{I}+\mathrm{D}+\mathrm{i}$, que en Chile también se han instalado aunque con efectos mucho más limitados. Junto a ello, en Chile es posible observar un tratamiento preferente a través de la conformación de supuestos de no sujeción o tipos rebajados, en beneficio de los autores o creadores de propiedad intelectual.

En el ámbito internacional, en el contexto del MC OCDE que une a España y Chile, los rendimientos de la propiedad intelectual tributarían de todas formas si no existiera el artículo 12 del MC OCDE, que se refiere a ellos, puesto que serían absorbidos por otros artículos del Convenio, de manera que, los países han optado por una alternativa que privilegia la regulación específica. 
Desde el punto de vista tributario, la razón de esta regulación pormenorizada, no la podemos encontrar en la naturaleza jurídica de la propiedad intelectual, en la medida que, al fin y al cabo, cualquiera que fuese la naturaleza jurídica ella, de entre las muchas que analizamos en su momento, siempre estaríamos frente a un rendimiento y como tal a una renta gravable. Tanto es así, que bajo diferentes concepciones sobre la naturaleza jurídica de la propiedad intelectual, tanto en España como en Chile está sometida al pago del impuesto a la renta. Tampoco parecen justificación suficiente para una regulación de detalle, los problemas de deslinde sobre su tributación, que se dan a propósito de determinados bienes de propiedad intelectual, como los productos digitales, las shrink wrap licences, el know how o respecto de la asistencia técnica y otros servicios, puesto que son casos puntuales de indefinición, como los que se pueden dar en cualquier otra área. De manera que, conforme a nuestro estudio, estimamos que aquí nuevamente subyace la conceptualización económica sobre la importancia del avance técnico en la economía, lo que se refleja en el establecimiento de beneficios en su favor y la protección de los autores y creadores, en el plano del derecho interno.

En el mismo sentido anterior, en el ámbito internacional, España y Chile comparten la vocación por adoptar un modelo donde al amparo de artículo 12 del MC OCDE, cohabitan servicios, propiedad intelectual e incluso arrendamiento de maquinaria y equipos, lo que lleva a concluir que la naturaleza jurídica no fue lo importante a la hora negociar el tratado, sino que el reparto de las rentas, lo que en sí mismo no conlleva ninguna novedad, puesto que ese es el objeto del MC OCDE; sin embargo, para nuestro estudio confirma que a la hora de establecer el diseño de la tributación de la propiedad intelectual, su naturaleza jurídica no es relevante, sino que pesan más las consideraciones de orden económico que jurídico.

9. En contraposición a la escasa relevancia que tiene la naturaleza jurídica de la propiedad intelectual en el diseño normativo de su tributación, sí es relevante al aplicar las normas tributarias que definen su imposición, así pues, la calificación jurídica de un determinado instituto es determinante a la hora de establecer su imposición. En efecto, la opción por la que normalmente se decantan los 
Estados, tanto en el plano interno como internacional, de no considerar a la propiedad intelectual como un tipo de bienes inmateriales genérico productor de rentas, si no que de detallar cada uno los bienes, derechos, actos o contratos que estando vinculados a la propiedad intelectual tributaran bajo su rótulo -tal como vimos sucede en España y Chile- hace que muchas veces sea difícil encontrar las fronteras entre una y otra fuente de renta, lo que puede incidir en su clasificación y con ello en su tributación. Lo ejemplos no se hacen esperar, donde encontramos casos como: la búsqueda de los deslindes entre servicios, know how, asesoría técnica y patentes; lo que estudiamos al ver figuras indefinidas como las ondas hertzianas; los derroteros de la tributación del know how en el caso Opel; o, el uso de las expresiones "cánones o regalías" en el CDI EspañaChile, a pesar que en Chile estas palabras no están definidas en ningún texto legislativo, con un contenido que las vincule a la propiedad intelectual.

De manera que, resulta paradójico que la naturaleza jurídica de la propiedad intelectual y la definición estricta de sus límites, que al momento de la creación de la norma no es una cuestión relevante, se vuelva esencial al aplicarla. En este sentido, podemos rememorar el caso que no pudimos resolver del artículo 59 de la LIR, que grava las "patentes" con un tipo de 30 por ciento y seguidamente las "patentes de invención" con 15 por ciento. Claramente el legislador no tomó en cuenta la naturaleza jurídica de las "patentes" en tanto derechos de propiedad industrial, puesto que no advirtió que en esa rama del derecho "patentes" y "patentes de invención" son sinónimos. Ahora bien, lo paradójico resulta del hecho que será precisamente esta constatación -que produce el problema- el apoyo más sólido que tendrá el juez a la hora de resolver, puesto que no le puede caber duda, que simplemente se trata de términos sinónimos, que será estéril buscar diferencias entre ellos, de manera que debe buscar la solución partiendo de la base que está ante una contradicción. En el ámbito español, encontramos el insólito caso del artículo 50 LIVA, que declara exenta de IVA la importación de los expedientes destinados a los organismos de registro de una marca, modelo o diseño, en consecuencia que no existe importación, ni exportación de expedientes para el registro de estos derechos de propiedad intelectual. 
10. Tal vez ninguna rama del derecho tributario esté desvinculada de la economía, de hecho es del fenómeno económico de donde se obtienen los recursos que sustentan la tributación y a la vez, la incidencia de la tributación en la economía es la motivación para usarle de manera instrumental con el fin de intervenir en la economía. Sin embargo, a nuestro juicio, pudimos constatar que la tributación de la propiedad intelectual tiene una vinculación diferente, más fuerte, enraizada en la justificación de la protección de la propiedad intelectual, su regulación jurídica y su consideración como elemento promotor de la economía, que se trasladan al derecho tributario rematando el diseño de su tributación, característica que observamos en la regulación especial de la amortización, imputación de gastos, tipos reducidos, supuestos de no sujeción y mecanismos de beneficio y estímulo en general en el plano interno y en el reparto de ingresos por fuente de rentas en el contexto internacional, donde siempre están presentes la dimensión jurídica y económica de la propiedad intelectual. 


\section{BIBLIOGRAFÍA}

ABOITES, JAIME Y MANUEL SORIA. Innovación, propiedad intelectual y estrategias tecnológicas. La experiencia de la economía mexicana. Universidad Autónoma Metropolitana. México D.F. 1999.

ADAMES PÉREZ, JANET. La propiedad intelectual como derecho fundamental, Gaceta $\quad 2009 . \quad$ Judicial, Disponible en http://www.adopi.org.do/index.php?option=com_content\&view=article\&id=82:1 a-propiedad-intelectual-como-derecho-fundamental\&catid=43: articulos-deinteres\&Itemid $=76$ ( 02 Abr 2013).

ADAMO, S. L'eliminazione dell' appendice fiscale: riflessi sull' attendibilità del bilancio di esercizio. Rivista dei Dottori Commercialisti, núm. 4. 1995.

ALCAZAR VARÓ, ENRIQUE y otro. Diccionario de Términos Jurídicos InglésEspañol. Editorial Ariel, Barcelona, 1993.

AlChiAn, A y DEMSETZ. H. El Paradigma de los Derechos de Apropiación. Hacienda Pública Española, № 68. 1981.

ALESSANDRI RODRÍGUEZ, ARTURO; SOMARRIVA U, MANUEL; y, VODANOVIC H, ANTONIO. Tratado de los derechos reales. Editorial Jurídica de Chile. Tomo I. 1993.

ALLISTAIR, CHRISTOPHER. Innovation + Incentives: VCs Find Partner in Quebec. Venture Capital Journal, Wellesley Hills. 2002.

ÁLVAREZ VILLAMARÍN, JOSÉ CARLOS. La deducción para inversiones en $I+D$ en el impuesto sobre sociedades: alternativas de reforma. Revista de Derecho Financiero y de Hacienda Pública, Vol. 43, Nº 225 (226). 1993.

ANGUITA RAMÍREZ, PEDRO. La protección civil del derecho a la propia imagen, honra y diva privada ante la jurisprudencia. Obstáculos normativos para una reparación adecuada. Disponible en Internet en: http://www.udp.cl/facultades_carreras/derecho/pub_derecho_privado.asp $\quad(15$ Ago 2013).

ARROYO ZAPATERO, LUIS y GARCÍA RIVAS, NICOLAS. Protección penal de la propiedad intelectual, en Estudios de derecho penal económico. Colección Estudios, Universidad de Castilla-La Mancha. 1994. 
ASCARELLI, TULIO. Teoría de la concorrenza dei beni inmateriali. Milan. 1956. Traducido por VERDERA Y TUELLS, EVELIO y SUÁREZ-LLANOS GÓMEZ, LUIS, en obra homónima, Ed. Bosh, Barcelona. 1970.

AZCARATE, G. Ensayo sobre la Historia de la Propiedad Intelectual Ed. Imprenta de Legislación, 1880.

AZEVEDO, ADALBERTO. El nacimiento de la tecnología relacionado con la ciencia. Disponible en Internet en: http://www.slideshare.net/ProfessorAdalbertozevedo/ freeman1974123 (10 Abr 2013).

BAYONA SAÉZ, CRISTINA y otros. Motivaciones Empresariales para Cooperar en I+D: Un Análisis Empírico con Empresas Españolas. Documento de Trabajo, $\mathrm{n}^{\circ}$ 36. Departamento de Gestión de Empresas. Universidad Pública de Navarra. 1999.

BERCOVITZ RODRÍGUEZ-CANO, R. Introducción a la regulación de los Derechos de autor. Cuadernos de Derecho Judicial, CGPJ. 1995.

BERCOVITZ RODRÍGUEZ-CANO, RODRIGO (Coordinador). Manual de Propiedad Intelectual. Tirant Lo Blanch. Valencia, 2001.

BILLINGS, B.A., ANTHONY and other. Would H.R. 463 Improve The Competitiveness of U.S. R\&D Tax Incentives?. Tax Notes, Vol. № 99, number 10. 2003.

BLOOM, NICHOLAS and others. How Has Tax Affected the Changing Cost of R\&D? Evidence from Eight Countries. The Institute for Fiscal Studies, Working Paper Series, $N^{\circ}$ 9. 1997.

BLOOM, NICHOLAS and others. Do R\&D Tax Credit Work? Evidence From a Panel of Countries 1979 - 1994. Institute for Fiscal Studies and University College London. 1999.

BLOOM, NICHOLAS and others. Do R\&D Tax Credit Work? Evidence From a Panel of Countries 1979 - 1997. Journal of Public Economics. Vol. 85. 2002.

BOKOBO MOICHE, M SUSANA. Los convenios de doble imposición sobre la renta y el patrimonio: Interpretación y calificación, Crónica Tributaria $\mathrm{N}^{\circ}$ 114. 2005.

BONET SÁNCHEZ, MARÍA PILAR. Los Incentivos Fiscales a la $I+D+i$ en el Impuesto sobre Sociedades. Revista Valenciana de Economía y Hacienda, № 5. 2002. 
BRAÑA, JAVIER y otros. El Estado y el cambio tecnológico en la industrialización tardía. Un análisis del caso español. Fondo de Cultura Económica, México D.F., 1984, Ediciones F.C.E. España. 1984.

BROWN, CHUCK. Reforma Fiscal e Incentivos: Un Estudio Práctico del Reino Unido. Cuestiones Claves sobre la Reforma Fiscal. CEDRIC SANDFORD. Instituto de Estudios Fiscales. Madrid. 1997.

BUITRAGO DÍAZ, ESPERANZA. El concepto de cánones y/o regalías en los convenios para evitar la doble Tributación sobre la Renta. Wolters Kluwer. Valencia. España. 2007.

CAGO RODRÍGUEZ, ALBERTO. De los incentivos fiscales a las actividades de $I+D$. Hacienda Pública Española. Monografías N² 2. 1992.

GAGO RODRÍGUEZ, ALBERTO. Imposición e innovación tecnológica: la reforma de los incentivos fiscales a las actividades de $I+D$, Hacienda Pública Española, Monografías $N^{\circ}$ 2/1992. 1992.

CALDERÓN CARRERO, JOSÉ MANUEL. La Doble Imposición Internacional en los Convenios de Doble Imposición y en la Unión Europea. Editorial Aranzadi. Pamplona. 1997.

CALDERÓN CARRERO, JOSÉ MANUEL. La tributación de los beneficios empresariales. En Comentarios a los convenios para evitar la doble imposición y prevenir la evasión fiscal, concluidos por España. Obra coordinada por RUIZ GARCÍA, JOSÉ RAMÓN y CALDERÓN CARRERO, JOSÉ MANUEL, Fundación Pedro Barrié de la Maza, Instituto de Estudios Económicos de Galicia. 2004.

CÁMARA ÁGUILA, MARÍA DEL PILAR. El derecho moral de autor. Comares, Granada. 1998.

CAMPOS B., ADOLFO. Doble Tributación Internacional. Título V. Efectos de la Doble Imposición sobre el Comercio Internacional. Disponible en Internet en: http://www.legalinfo-panama.com/php/pfp.php3?doc=/articulos/articulos_27b. htm (15 Jul 2013).

CANAVAL PALACIOS, JUAN PABLO. Manual de Propiedad Intelectual, Edit. Universidad del Rosario. Bogotá. 2008.

CARMONA FERNÁNDEZ, NÉSTOR. La Fiscalidad de los Cánones en el Impuesto sobre la Renta de no Residentes. ICE. Nuevas Tendencias en Economía y Fiscalidad Internacional $N^{\circ} 825.2005$. 
CARVAJAL M., JUAN CARLOS. Evolución de la propiedad intelectual, Instituto Tecnológico de Costa Rica. Disponible en www.tec-digital.itcr.ac.cr (10 Feb 2014).

CASAS TELLO, SONIA. Calcos lingüísticos y fraseológicos en el lenguaje audiovisual: el caso de Pulp Fiction. Jornadas de Foment de la Investigació. Universitat Jaume I. Disponible en Internet en: http://www.uji.es/bin/publ/edicions/jfi3/calcos.pdf (10 Sep 2014).

CASTELO, MARISA. Apuntes sobre la exención de IVA para autores y periodistas. LegalArte. 2001.

CASTRO BONILLA, ALEJANDRA. La protección constitucional del derecho de autor en España, Noticias Jurídicas, diciembre de 2002. Disponible en internet en: http://noticias.juridicas.com/articulos/05-Derecho\%20Constitucional/200212275512281010243310.html (20 Abr 2013).

CEBALlOS DELGADO, JOSÉ MIGUEL. Estudio comparativo del concepto de regalías contenido en los modelos de convenio para evitar la doble imposición y su alcance en materia de propiedad intelectual, p. 14. Disponible en Internet en: www.usergioarboleda.edu.co (10 Mar 2014).

COLAO SÁNCHEZ, PEDRO. La "amortización” del inmovilizado inmaterial en el Impuesto sobre Sociedades: algunas cuestiones. Revista Impuestos $\mathrm{N}^{\circ} 21$. Madrid. 1993.

CONTRERAS HUGO Y GONZÁLEZ LEONEL. Curso práctico de impuesto a la renta, Edit. Cepet. Santiago. Chile. 1996.

COSÍN OCHAITA, RAFAEL. El nuevo régimen fiscal de las actividades de investigación y desarrollo. Gaceta Fiscal N 144, 1996.

CORTÉS GIRÓ, VICENTE. Derecho de Propiedad Intelectual. Editorial Marfil. Alcoy. 1957

CLARO SOLAR, LUIS. Explicaciones de derecho civil chileno y comparado. Tomo VI. Edit. Roma. Chile. 1930.

CREMADES, JAVIER. Aspectos constitucionales del derecho de autor. Diario La Ley, Sección Doctrina. Ref - 126. Tomo 2. Editorial La Ley.1996.

CHACÓN, JACINTO. Exposición razonada. Estudio comparativo del Código Civil Chileno. Imprenta Nacional. Santiago de Chile. 1890.

CHAPMAN, AUDREY. La propiedad intelectual como derecho humano. Boletín de Derecho de Autor, Volumen XXXV N 3, julio-septiembre de 2001, Ediciones 
UNESCO. Disponible en Internet http://unesdoc.unesco.org/images/0012/001255/125505s.pdf (30 Mar 2013).

CHICO Y ORTÍZ, JOSÉ MARÍA. Principios y Problemas de la Propiedad Intelectual. Revista General de Legislación y Jurisprudencia. Vol 89. ํㅜ 3.

DANVILA Y COLLADO, MANUEL. La propiedad intelectual: Legislación española y extranjera. Imprenta de la Correspondencia de España, 1882. Digitalizado en 2010.

DESANTES GUANTER, JOSÉ MARÍA. El derecho de autor en la Constitución española de 1978. Cuadernos constitucionales de la Cátedra Fadrique Furió Ceriol, ISSN 1133-7087, $\mathrm{N}^{\mathrm{o}}$ 3. 1993. Disponible en Internet en: http://dialnet.unirioja.es/servlet/articulo?codigo=229791 (12 Abr 2013).

DESANTE GUANTER, J. La información como derecho. Ed. Nacional. Madrid. 1974.

DÍEZ-PICAZO y GULLÓN, ANTONIO. Sistema de derecho civil. Vol III, Tecnos. 2000.

DÍEZ-PICAZO, LUIS. Fundamentos del derecho civil patrimonial, VI, Derechos Reales. Civitas Colección. 2012.

D' JESÚS PÉREZ, ANTONIO JOSÉ. Fundamentos de un sistema de gestión colectiva de derechos reprográficos. Universidad de los Andes, Facultad de Ciencias Jurídicas y Políticas. Postgrado de Especialización en Propiedad Intelectual. Mérida. Venezuela. 2001. Disponible en Internet en: http://tesis.ula.ve/postgrado/tde arquivos/80/TDE-2012-06-11T04:38:19Z2258/Publico/ (30 Mar. 2013).

EVANGELIO LLORCA, RAQUEL. El encargo de obra intelectual. Dykinson. 2006.

FERNÁNDEZ DE CÓRDOVA, RAFAEL GUITIÁN. Innovación tecnológica I+D. Dikinson. Madrid. 1997.

FERNÁNDEZ DE SOTO BLASS, MARÍA LUISA. Practicum del Derecho Tributario Español. Edit. Dykinson. Madrid. 2005

FERNÁNDEZ IPARRAGUIRRE, JOSÉ LUIS y CASADO MAYORDOMO, MANUEL. Contabilidad financiera para directivos. ESIC Editorial. Madrid. 2008.

FERNÁNDEZ DE PEDRO, FRANCISCO. Fiscalidad de los no residentes en España (IV): Rentas obtenidas sin establecimiento permanente. En Manual de fiscalidad internacional. Dirigido por CORDÓN EZQUERRO, TEODORO. IEF. Madrid. 2001. 
FIGUEROA VELASCO, PATRICIO. Manual de derecho tributario. Ley de impuesto a la renta. Selección Manuales Jurídicos. Editorial Jurídica de Chile. 1989.

FREEMAN, CHRISTOPHER. Economics of Thecnical Change. En Trade, Growth and Technical Change. Editado por Daniel Archibugi y Jonathan Michie, publicado por Cambridge University Press. 1998.

FREEMAN CHRISTOPHER. La teoría económica de la innovación industrial. Alianza Editorial. 1974.

FREEMAN, CHRISTOPHER. The Economics of Industrial Innovation. Routledge, Tercera Edición. 1997.

FREEMAN, CHRISTOPHER. The Economics of Technical Change. Archibugi D. \& J. Michie (eds.), Cambridge University Press, 1998.

FRIEDMAN, THOMAS. Tradición versus innovación. Buscar el equilibrio en la era de la globalización. Atlantida. Madrid. 1999.

GALENDE DEL CANTO, JESÚS. La Fiscalidad de los Gastos de Investigación y Desarrollo: Situación Actual y Propuestas de Reforma. Revista de Contabilidad y Tributación, editorial Estudios Financieros, No 151. 1995.

GARCÍA GARRIDO, MANUEL. Diccionario de Jurisprudencia. Romana Dykinson. Madrid. 2000.

GARCÍA HEREDIA, ALEJANDRO. Fiscalidad internacional de los cánones: derechos de autor, propiedad industrial y know-how. Lex Nova. Valladolid. 2007.

GARCÍA HEREDIA, ALEJANDRO. Los programas de ordenador en los convenios de doble imposición. Contabilidad y Tributación, $\mathrm{N}^{\circ} 268.2005$.

GARCÍA LÓPEZ, DANIEL. Aproximación crítica a la propiedad intelectual: la cultura como valor para la democracia. Revista Telemática de Filosofía del Derecho, $\mathrm{N}^{\text {o }}$ 10. 2006/2007. ISSN 1575-7382. Disponible en Internet en: www.filosofiayderecho.com/rtfd (30 Mar 2013).

GARCÍA-MORENO, MARÍA PASTOR. Los Convenios de Doble Imposición. En Fiscalidad Internacional. Obra dirigida por SERRANO ANTÓN, FERNANDO. Editorial CEF. Madrid. 2013.

GARCÍA PRATS, FRANCISCO. La tributación de las ganancias del capital. En Comentarios a los convenios para evitar la doble imposición y prevenir la evasión fiscal, concluidos por España. Obra coordinada por RUIZ GARCÍA, 
JOSÉ RAMÓN y CALDERÓN CARRERO, JOSÉ MANUEL, Fundación Pedro Barrié de la Maza, Instituto de Estudios Económicos de Galicia. 2004.

GARCÍA PRATS, FRANCISCO. Los cánones en los Convenios de Doble Imposición y su tributación, Revista General de Derecho № 579. Diciembre de 1992.

GARCÍA PRATS, FRANCISCO. Los modelos de convenio, sus principios rectores y su influencia sobre los convenios de doble imposición. Crónica Tributaria, № 133. 2009.

GARCÍA-ROSADO GONZÁLEZ, BEGOÑA. Impuesto sobre sociedades: Guía. Edit. CISS. 2008.

GAY SALUDAS, JOSÉ MARÍA. El Inmovilizado Inmaterial en el Contexto del Nuevo Impuesto sobre Sociedades: Normas de Valorización "versus" Normas Contables. Revista del Profesional de Contabiliad. Técnica Contable. 1995.

GIERKE, OTTO. Deutsches Privatrechts. Leipzig. Munich. 1936.

GIL GÓMEZ, HERMENEGILDO y PORTILlA SOGORB, JOSÉ. En Economía, Contabilidad y Finanzas. De la Universidad Politécnica de Valencia. 2001.

GÓMEZ DIÉZ, JUSTO JOSÉ. La propiedad intelectual y el artículo 20.1 b) de la Constitución española. Revista de la Facultad de Derecho de la Universidad Complutense. Anuario $\mathrm{N}^{\circ} 84$.

GOMEZ URANGA, MIKEL; SÁNCHEZ PADRÓN, MIGUEL y DE LA PUERTA, ENRIQUE. El cambio tecnológico hacia el nuevo milenio. Debates y nuevas teorías. Economía Crítica. Madrid. 1992.

GONZÁlEZ, ALEX y ORMEÑO RODRIGO. Renta Neta de Fuente Extranjera. Tributación en un Mundo Globalizado. Disponible en Internet en: http://www.cetuchile.cl/images/docs/64-97.pdf (15 Jul 2013).

GONZÁLEZ, EUSEBIO y CHAMORRO JOSÉ ANTONIO. Incentivos Fiscales a las Actividades de I+D en Defensa. Ceseden n ${ }^{\circ} 280$ - Ministerio de Defensa. 2003.

GONZÁLEZ GONZÁLEZ, LOURDES. Régimen Fiscal de las Actividades de Investigación y Desarrollo. Impuestos. Revista de Doctrina, Legislación y Jurisprudencia, tomo $\mathrm{n}^{\circ}$ II. 1998.

GONZÁLEZ GONZÁLEZ, MARÍA JOSÉ. Los gastos de investigación y desarrollo en el impuesto sobre sociedades. El Real Decreto $N^{\circ} 1.622 / 1922$. Carta Tributaria, Monografías, $\mathrm{N}^{\circ}$ 179. 1993.

GONZÁLEZ ORTIZ, DIEGO. Correcciones de valor: pérdidas de valor de elementos patrimoniales y provisión para riesgos y gastos, Universitat Jaume I. Castellón. 
Disponible en Internet en: http://www.uji.es/bin/publ/edicions/s47.pdf (15 May 2013).

GONZÁLEZ POVEDA. Impuesto sobre Sociedades. Ediciones Pirámide SA. Madrid. 1988.

HEIJS, JOOST. Política Tecnológica e Innovación. Consejo Económico y Social (CES), Madrid, 2000.

HERNÁNDEZ GALANTE, JAVIER. Fiscalidad de artistas y deportistas. Aspectos internacionales. En Fiscalidad Internacional. Obra dirigida por SERRANO ANTÓN, FERNANDO. Editorial CEF. Madrid. 2013.

HERNAZ MARTÍN, ANTONIO. Estudio Contable y Fiscal de las Amortizaciones. aceta Fiscal no 158, 1997.

HIDALGO CAPITÁN, LUIS ANTONIO. El pensamiento económico sobre el desarrollo. De los mercantilistas al PNUD. Universidad de Huelva, 1998. Disponible en Internet en: http://www.uhu.es/antonio.hidalgo/documentos/pesd.pdf. (12 Abr 2013).

HORTAlÁ VALLVÉ, JOAN. Comentarios a la Red española de Convenios de Doble Imposición. Cánones. Regalías. Mecanismos para evitar la doble imposición. Thomson-Aranzadi. Cizur Menor. Navara. 1999.

HUNEEUS ZEGERS, JORGE. La Constitución ante el Congreso (sobre la Constitución de 1833). Publicada en Chile, entre 1879 y 1880.

HYWEL G. JONES. Introducción a las teorías modernas del crecimiento económico. Antoni Bosch. Barcelona. 1979.

JENSEN, HENRI. Derechos intelectuales: de los autores, artistas, productores de fonogramas. Editorial Jurídica de Chile. 1970.

JIMÉNEZ COMPAIRED, ISMAEL. El régimen tributario de la explotación comercial de la propia imagen. Marcial Pons. Madrid. 2001.

KANT, IMMANUEL. Principios metafísicos del derecho. Edit. Américalee. Buenos Aires. Argentina.

LABATUT SERER, GREGORIO. Deducibilidad fiscal del fondo de comercio en los ejercicios 2012 y 2013, en el caso de sociedades y empresario individual. Disponible en Internet en: http://gregoriolabatut.blogcanalprofesional.es/deducibilidad-fiscal-del-fondo-decomercio-en-los-ejercios-2012-y-2013-en-el-caso-de-sociedades-y-empresarioindividual/ (2 May 2013). 
LACRUZ BERDEJO, JOSÉ LUIS. Elementos de derecho civil: Derechos reales. Dykinson. Madrid. 2003.

LANDAU, RALPH. How Competitiveness can be Achieved: Fostering Economic Growth and Productivity. Technology and Economics. Washington. 1991.

LANDES, WILLIAM M. y POSNER, RICHARD A. La estructura económica del derecho de propiedad intelectual e industrial. Traducción de SÁNCHEZ ÁlVAREZ, VÍCTOR MANUEL. Fundación Cultural del Notariado. Madrid. 2006.

LARRAGUIBEL ZAVALA, SANTIAGO. El Derecho de Autor en la Constitución Política de la República de Chile. Revista Derecho y Jurisprudencia y Gaceta de los Tribunales, Tomo LXXX, N² 2, mayo-agosto. Edit. Jurídica de Chile. 1983.

LARRAGUIBEL ZAVALA, SANTIAGO. Tratado sobre la propiedad industrial. Editorial Jurídica Conosur. Santiago de Chile. 1995.

LATORRE, VIRGILIO. Naturaleza Jurídica de la Propiedad Intelectual. Protección Penal del Derecho de Autor. Tirant Lo Blanch. Valencia. 1994.

LATORRE, VIRGILIO. Protección penal del derecho de autor. Tirant lo Blanch. Valencia. 1994.

LHUILLERY, STÉPHANE. Problems involved in designing and implementing $R \& D$ tax incentive schemes. OCDE Working Papers Vol. IV. R\&D Tax Provisions, $\mathrm{N}^{\circ}$ 96. Paris. 1996.

LINK, ALBERT. Fiscal Measures to Promote R\&D and Innovation - Trends and Issues, en R\&D Tax Provisions. OECD Working Papers, N 96. Paris. 1996.

LÓPEZ ESPADAFOR, CARLOS MARÍA. Régimen Fiscal de la Propiedad Industrial. Tirant Lo Blanch. Madrid. 1998.

MANRESA Y NAVARRO, JOSÉ MARÍA. Comentarios al Código Civil Español. Tomo III. Madrid. 1904.

MARCO MOLINA, JUANA. La Propiedad Intelectual en la Legislación Española. Marcial Pons. Madrid. 1995.

MARCO MOLINA, JUANA. Bases históricas y filosóficas y precedentes legislativos del derecho de autor. Revista Anuario de Derecho Civil. 1994.

MARTIN ARESTI, PILAR. La Licencia Contractual de Patente. Aranzadi. Pamplona. 1997.

MARTÍN FERNÁNDEZ, JAVIER y otro. Las Actividades de Investigación y Desarrollo e Innovación Tecnológica en el Impuesto sobre Sociedades: A 
Propósito de la Reciente Doctrina Administrativa y de las Modificaciones Legislativas para el Ejercicio 2002. Quincena Fiscal, No 4. 2002.

MARTÍN JIMÉNEZ, ADOLFO, en La tributación de los cánones o regalías. En Comentarios a los convenios para evitar la doble imposición y prevenir la evasión fiscal, concluidos por España. Obra coordinada por RUIZ GARCÍA, JOSÉ RAMÓN y CALDERÓN CARRERO, JOSÉ MANUEL, Fundación Pedro Barrié de la Maza, Instituto de Estudios Económicos de Galicia. 2004.

MASSONE PARODI, PEDRO. El impuesto a la renta. Edeval. Valparaíso. Chile. 1996.

MAKHLOUF, GABRIEL. Ciot European Branch Conference. Discurso de 07 de marzo de 2003. Disponible en Internet en: http://www.oecd.org/ctp/taxtreaties/cioteuropeanbranchconference.htm (10 Feb 2014).

MINISTERIO DE ECONOMÍA Y COMPETITIVIDAD DE ESPAÑA. Deducción por proyectos de $I+D+I T$ e informes motivados, patent box y novedades. Madrid. Disponible en Internet en: http:2012i/Jornada14-062012Ministerio\%20deducciones\%20I-d.pdf 2013.

MIRÓ ROCASOLANO, PABLO. El teorema de Coase y sus implicaciones según el problema del coste social, en Contribuciones a la Economía de La Economía de Mercado, virtudes e inconvenientes. Disponible en Internet en: http://www.eumed.net/cursecon/colaboraciones/index.htm (05 Abr 2013).

MORILlO MÉNDEZ, ANTONIO. La Deducción por Gastos de Investigación, Desarrollo e Innovación Tecnológica en el Impuesto sobre Sociedades. Impuestos. Revista de Doctrina, Legislación y Juriprudencia, Tomo No II. 2001.

MORON LERMA, ESTHER. La tutela del secreto de empresa, desde una teoría general del bien jurídico, Tesis de Doctorado, Departamento de Ciencia Política y Dret Public, UAB, URN TDX-0405102-104031. 2001.

NEUMANN, MANFRED. Fiscalidad y Cambio Tecnológico. Hacienda Pública Española No 131 - 4. 1994.

OECD. R\&D Tax Provisions OECD. Working Papers, Vol. IV, No 96. 1996.

OECD. Tax Incentives for Research and Development: Trends and Issues. Trabajo conjunto CIBE, CSTP y CFA. OECD, Science Technology Instry, STI. 2002.

OLLERO TASSARA, ANDRÉS. Entre creación y propiedad el problemático carácter "fundamental" de los derechos de autor, X Jornadas de Estudio, Introducción a 
los derechos fundamentales, Dirección General del Servicio Jurídico del Estado, Ministerio de Justicia, Secretaría General Técnica, Centro de Publicaciones. España. 1988.

OTERO ESPINOZA, FRANKLIN. Concordancias y jurisprudencia del Código Civil Chileno. Casa Zamorano y Caperán. Santiago de Chile. 1920.

OTERO GARCÍA-CASTRILLÓN, CARMEN. Las Patentes en el Comercio Internacional, Edit. Dykinson. Madrid. 1997.

OVETT, DAVINIA. Propiedad intelectual y derechos humanos: ¿queda ahora clara la diferencia?, en Informe Político $N^{\circ} 3$, 3D Trade - Human Rigths - Equitable Economy, 2006. Disponible en Internet en: http://www.3dthree.org/pdf 3D/3D CDESC DDHH PI.pdf (28 Mar 2013).

PALMA MARTOS, LUIS. Teoría Económica, innovación Tecnológica y Estructuras de Mercado. Editorial de la Universidad de Sevilla. Sevilla. 1989.

PERAIRE SAUS, JUAN MIGUEL. Gastos en Investigación y Desarrollo $(I+D)$. Tribuna Fiscal No 96. 1998.

PERAIRE SAUS, JUAN MIGUEL. La Nueva Regulación de la Deducción por Gastos en I+D e Innovación Tecnológica. Revista Tributaria y Financiera, No 117. 2000.

PÉREZ BUSTAMANTE, DAVID. Fiscalidad de las Inversiones Cinematográficas en la Nueva Ley del Cine, Revista Aranzadi de Derecho del Deporte y el Entretenimiento, $\mathrm{n}^{\circ} 25,2009$. Disponible en Internet en: http://www.uria.com/es/publicaciones/articulos-juridicos.html?id=2186\& pub=Publicacion\&tipo=es $(10$ Abr 2014).

PEREZ DE CASTRO, NAZARETH. El Derecho de Propiedad sobre Obras de Arte y el Derecho de Autor al Respecto de la Obra. Actualidad Civil. Número 3. Semana 12-18. 1987.

PLAZA PENADES, JAVIER. El Derecho de Autor y su Protección en el Artículo 20,1,b) de la Constitución. Tirant Monografías, Valencia. 1997.

PLAZAS, ARCADIO. Consideraciones introductorias al derecho de autor. Revista de Derecho y Jurisprudencia, Tomo LXXVII, Editorial Jurídica de Chile. 1980.

POLANCO ZAMORA, GONZALO. Reporte tributario. Centro de Estudios Tributarios de la Universidad de Chile. Disponible en Internet en: http://www.cetuchile.cl/index.php?option=com_content\&view=category\&layout $=$ blog\&id=83\&Itemid $=160$ (25 Jul 2013). 
POSNER, RICHARD. El análisis económico del derecho. Traducción de SUAREZ, EDUARDO. Fondo de Cultura Económica, Segunda Edición. México. 2007.

PROUDHON PIERRE, JOSEPH. Les Majorats Litteraries. Paris, 1863.

RODRÍGUEZ-ARIAS BUSTAMANTE, LINO. Naturaleza jurídica de los derechos intelectuales. Revista de Derecho Privado. Madrid. 1949.

ROGUIN, ERNEST Y NAVARRO DE PALENCIA, JOSÉ MARÍA. Las reglas jurídicas: Estudio de ciencia jurídica pura. Reimp. de la Eden. de Madrid. La España Moderna. 1904.

ROMERO COLOMA, AURELIA MARÍA. La Protección Constitucional de los Derechos de los Artistas. Actualidad Administrativa. Editorial La Ley 1492. 2000.

ROSEMBUJ, TULIO. Intangibles. La fiscalidad del capital intelectual. El Fisco, Barcelona. 2003.

ROSEMBUJ, TUlio. La Patente de Invención. El Fisco. Revista Mensual de Información Tributaria No 148, Barcelona. Diciembre 2008 - enero 2009.

ROSEMBUJ, TULIO. El Programa Informático. El Fisco. Revista Mensual de Información Tributaria $\mathrm{N}^{\circ} 146$, octubre 2008.

ROSEMBUJ, TULIO. El derecho de Autor. El Fisco. Revista Mensual de Información Tributaria $\mathrm{N}^{\circ} 147$, noviembre 2008.

ROSEMBUJ, TULIO. Derecho Fical Internacional. El Fisco. Barcelona. 2001.

ROUBIER, M. P. Le Droit de le propieté industrielle. Ed. Sirey, vol I, París. 1952.

RUIZ ZAPATERO, JOSÉ LUIS. Deducción por Actividades de Investigación Científica e Innovación Tecnológica Relacionada con el Software. Revista de Contabilidad y Tributación, Editorial Estudios Financieros, No 207. 2000.

SÁEZ DE IBARRA Y TRUEBA, IGNACIO. Los Gastos de Investigación y Desarrollo: concepto y tratamiento fiscal. Cuadernos de Formación de la Inspección de Tributos No 3. Escuela de Hacienda Pública. DL. 1988.

SAÍŹ GONZÁLEZ, PATRICIO. Invención, patentes e innovación en la España Contemporánea. Publicación de la OEPM. Madrid. 1999.

SALAZAR REYES-ZUMETA, LEONEL. Aproximación Teórica a la Naturaleza Jurídica de los Bienes Inmateriales y del Derecho de Propiedad Intelectual, Rev. Propiedad Intelectual, $\mathrm{N}^{\circ}$ 13, enero-diciembre. Mérida-Venezuela. 2010.

SALORT S., VICENTE. Manual Operativo Tributario. Ediciones Tributarias y Laborales. Santiago. Chile. 2002. 
SALUDES, FLORENTINO. Patent box, La estrategia fiscal de los activos intangibles. Presentación disponible en Internet en: www.iies.es/attachment/333494/ (30 Mar 2014).

SÁNCHEZ CHÓLIZ, JULIO. Algunas reflexiones sobre la medida del cambio tecnológico. En El cambio tecnológico hacia el nuevo mileno. Debates y nuevas teorías. Obra coordinada por MALGESINI, GRACIELA. Economía Crítica, Madrid. 1992.

SÁNCHEZ ROMÁN, J. Derecho civil común y foral. Tomo III, S.F.

SCHUMPETER, JOSEPH. Capitalismo, Socialismo y Democracia. Versión castellana por ATANASIO SÁNCHEZ. Editorial Claridad, 1946.

SCHUMPETER, JOSEPH. Ciclos Económicos. Análisis teórico, histórico y estadístico del proceso capitalista. Traducción de Jordi Pascual. Prensas Universitaras de Zaragoza. Zaragoza. 2002.

SCHUMPETER, JOSEPH. 10 Grandes economistas: de Marx a Keynes. Alianza Editorial. 1983.

SECRETARÍA GENERAL DE LA OCDE. R\&D Tax Provisions. OECD WORKING PAPERS, Vol. IV, N 96. Paris. 1996.

SERRANO ANTON, FERNANDO. Fiscalidad Internacional. CEF. Madrid. 2013.

SERRANO ANTÓN, FERNANDO. Principios básicos de la fiscalidad internacional y los convenios para evitar la doble imposición internacional: historia, tipos, fines, estructura y aplicación. En Fiscalidad Internacional. Obra dirigida por SERRANO ANTÓN, FERNANDO. Editorial CEF. Madrid. 2013.

SERRANO, YOLEIDA. Derechos Humanos y Propiedad Intelectual, Revista Razón y Palabra, $N^{\circ} 81$, noviembre 2012 - enero 2013. Disponible en Internet en: http://www.razonypalabra.org.mx/N/N81/M81/15_Serrano_M81.pdf (30 Mar 2013).

SEUBA, XAVIER. Derechos de propiedad intelectual y derechos humanos, estado de la cuestión y desarrollos recientes, Universidad Pomepeu Fabra de Barcelona. Disponible en Internet en: http://www.descweb.org/files/cap12.pdf (30 Mar 2013).

SILVA BASCUÑAN, ALEJANDRO. Tratado de derecho constitucional. Editorial Jurídica de Chile. Santiago. 1997. 
SMITH, ADAM. Investigación sobre la naturaleza y causas de la riqueza de las naciones, El Otriba, Argentina. Disponible en: http://www.amawebs.com/storage/docs/n59bb37dgon.pdf (12 Abr 2013).

SUTHERSANEN, UMA. El Derecho de Autor como Motor de la Libertad de Expresión una Perspectiva Inglesa. Derecho de Autor y Libertad de Expresión. Actas de las Jornadas de Estudio ALAI. Huygens Editorial. Barcelona. 2006.

TALL \& CUTE WORDPRESS. Citado en Curiosidades y Errores Históricos. Disponible en Internet en: www.erroreshistoricos.com/curiosidades-historicas/ciencia/621--evolucion-delconocimiento-humano-durante-los-ultimos-30000-anos.html (14 Feb 2010)

TAX INCENTIVES FOR RESEARCH AND DEVELOPMENT: TRENDS AND ISSUES. Secretary-General of the OECD. 2002.

TOBES PORTILLO, PALOMA. Incentivos Fiscales a la Investigación, Desarrollo e Innovación. Crónica Tributaria No 109. 2003.

TOBES PORTILlO, PALOMA. Incentivos Fiscales a la Investigación, Desarrollo e Innovación. Instituo de Estudios Fiscales, Documentos No 17. 2003.

TOVILLAS MORÁN, JOSÉ MARÍA. Estudio del Modelo de Convenio sobre Renta y Patrimonio de la OCDE de 1992. Marcial Pons. Madrid. 1996.

TRULL I AHUIR, JOAN B. y otros.La Investigación y el Desarrollo Tecnológico ante el Impuesto sobre el Valor Añadido. Impuestos. Revista de Doctrina, Legislación y Jurisprudencia, Tomo No I. 1999.

ULMER, E. One hundred years of the Berne Convention, International Review of Industrial Property and Copyright Law (IIC), vol 17, $\mathrm{n}^{\circ} 16,1986$.

URÍAS MARTÍNEZ, JOAQUÍN. El Derecho a la Producción y creación Literaria, Artística, Científica y Técnica. Comentarios a la Constitución Española. XXX Aniversario. Fundación Wolters Nluwer. España. 2009.

USATEGUI, JOSÉ MARÍA. Incentivos Fiscales a la Innovación. Economía Pública, No 3. 1989.

VAN REENEN, JOHN. Methodologies for evaluating the impact of $R \& D$ tax credits. R\&D Tax Provisions. OECD Vol. IV, No 96. Paris. 1996.

VANONI, EZIO. Naturaleza e interpretación de las leyes tributarias, Dott A. Giuffre. Milan. Italia. 1961.

VALVERDE Y VALVERDE. Tratado de derecho civil español. Tomo II, Ed. Cuesta. Madrid. 1910. 
VELARDE ARAMAYO, MARÍA SILVIA. Beneficios y Minoraciones en Derecho Tributario. Marcial Pons S.A. Madrid. 1997.

VELÁZQUEZ VELÁZQUEZ, SANTIAGO. Derechos humanos y derechos de propiedad intelectual, Revista Jurídica, Facultad de Ciencias Sociales y Políticas, Universidad Católica de Santiago de Guayaquil, pp. 28. Disponible en Internet en: http://www.revistajuridicaonline.com/index.php?option=com content\&task= $\underline{\text { view\&id }=501 \& \text { Itemid }=50}$ ( 30 Mar 2013).

VÁZQUEZ DEL REY VILLANUEVA, ANTONIO. Sobre el concepto cánones o “royalties”. Jurisprudencia Tributaria. Aranzadi. 2002.

VERA, ROBUSTIANO. Código Civil de la República de Chile. Tomo III, Imprenta Gutemberg. 1894.

WARDA, JACEK. Measuring the Value of R\&D Tax Provisions. R\&D Tax Provisions. OECD Working Papers, N 96. Paris.1996.

ZULOAGA VILLALÓN, ANTONIO. Derecho industrial y agrícola, explicaciones de clases revisadas por el profesor. Editorial Nascimiento. Santiago de Chile. 1943. 